


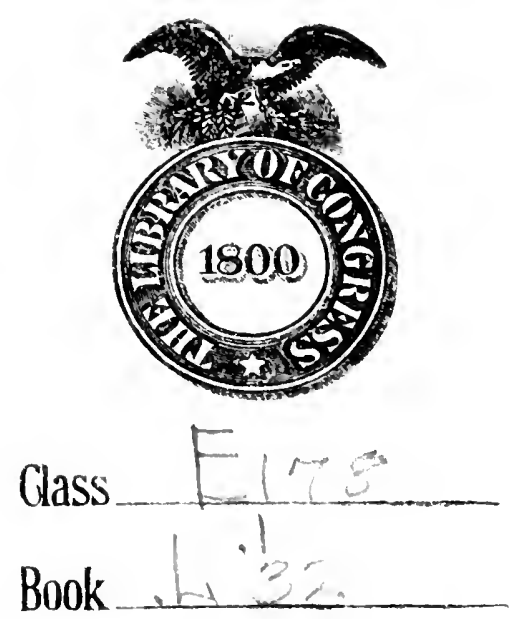

GOPYKIGHT DEROSIT 








\section{A HISTORY OF}

\section{THE UNITED STATES}

FOR SECONDARY SCHOOLS

\section{J. N. LARNED}

Author of "A History of England for the use of Schools and Acadcmies" Editor of "History for Ready Reference and Topical Reading" and "The Literature of American History"

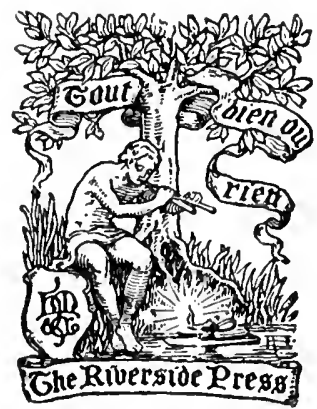

BOSTON, NEW YORK, AND CHICAGO HOUGHTON, MIFFLIN AND COMPANY The Riberside Jreso, Cambridge 


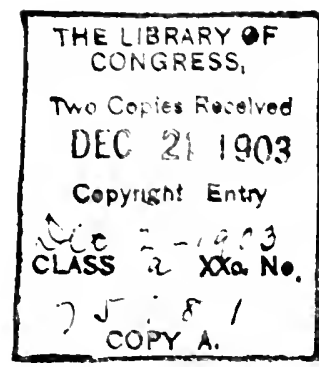

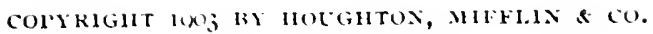

ALL RIGIITS RESLRVED

A 


\section{PREFACE.}

WhETHER the writer and the publishers of this book are justified or not in adding another to the many compends of $A$ merican history already offered to the schools is a question to be determined by the judgment of the teachers to whom it is submitted.

The book has been prepared in full accord with the views set forth in the report of "The Committee of Seven," appointed by the American Historical Association in 1896 , "to consider the subject of history in the secondary schools." Its plan assumes -

I. That American history is taught, or will be taught, in most of the secondary schools of the country, at a time when the pupils are old enough to learn, and to be interested in learning, how the circumstances and conditions of life as they find it at the present day have been brought about, through the working of influences and the movement of events in the past.

2. That those pupils have received in the lower schools some acquaintance with the romantic and delightful but not deeply instructive story of the discovery and the first explorations of the New World, and need not spend more of actual school-study on that, which is only a preface to the life-history of the United States.

It assumes, too, that most, if not all, of the teachers of 
American history in secondary schools must be in agreement with the Committee of Seven upon the fundamental principles of history-teaching, as formulated in the committee's report, - especially the following: That a "good text-book" is one "in which the sequence and relation of events can be made clear;" that "the aim of historical study in the secondary school . . . is the training of pupils, not so much in the art of historical investigation as in that of thinking historically, " that history, presented as it should be, "cultivates the judgment by leading the pupil to see the relation between cause and effect, as cause and effect appear in human affairs," - to see, in other words, "that events do not simply succeed each other in time, but that one grow's out of another, or rather out of a combination of many others;" that " unvelatid facts are of antiquarian rather than historical interest," and that there is no time in the school course for studying such facts, however interesting they may be in themselves.

This book is the product of a careful endeavor to realize these sound principles, in a presentation of American history to young minds that approach maturity and begin to be able to see meanings brought to light by a right putting of things together. The guiding aim in preparing it has been to show how continuous a procession is formed by the events that have real importance in American life ; how linked together they are by influences that reach from one to another, or by forces that work lastingly on successive generations; and by what a plain process of evolution, from its colo- 
nial beginnings, the republic of the United States has become what it is.

In pursuing this aim, the original colonies are treated, not separately, in the usual manner, but collectively, from the first, as forming already one coherent political body, made so superficially by the bond of English government, and made more substantially so by the English temper and political habit which were common to their people, and which unified them at last. Little more than what is common to their history, and what is necessary to show and explain in some degree the variations of character in them, is touched in the treatment of colonial times.

- Generally, throughout the work, the purpose of the writer has led him to be sparing rather than profuse in his selection of the things to be told. It has seemed to him better to make a free use of the limited space in so small a book for the clear unfolding of essential "sequences and relations," than to pack it with a dense collection of facts. In choosing the matter to be dealt with he has found himself in agreement again with the committee already quoted, who say in their report: "While industrial and social phases of progress should by no means be slighted, it is an absolute necessity that a course in American history should aim to give a connected narrative of political events and to record the gradual upbuilding of institutions, the slow establishment of political ideals and practices." This is unquestionably true. The political institutions of the democratic republic of the United States are fundamental to "every- 
thing else in the life of the nation? Forces and influences that arise out of the self-governing habits of the people have entered into all that they do, giving character and direction to all developments among them, all advance, all change, whether social or industrial in its field, or intellectual or moral in its work. Hence the political history of the United States is a great main stream, which forces us in our study to follow its course ; but every other stream of historical movement flows to it as a tributary, and all the expanses of the national life are opened by it to our view.

Twice in the narrative of colonial history - near the close of the seventeenth century and at the opening of the War of Independence - the writer has paused to introduce a comprehensive survey of the economic and social conditions existing in different sections of the country at those times. At the end of the work he has given a retrospective survey of similar conditions as they appear in the rapid flux of later times. These surveys, together with an Introduction, which sketches matters prior to the European settlement of regions within the territory of the United States, are not presented as numbered chapters of the book, nor printed in the type of those chapters. The intention is that teachers shall use them for reading and reference, or for regular study in the course, as they find best.

At the end of every chapter the topics of each section in it are carefully rehearsed, with numerous references to standard historical works and documentary collections, for the collateral reading and verification 
which all teachers of history require. Since the books that are accessible to students must vary in different schools, it has seemed desirable to multiply the references beyond what would otherwise be needed. By giving so wide a range to them, and by making them more than usually specific, it is believed that a feature of importance is given to the book. A full list of the works referred to, arranged alphabetically under authors' names, is placed next to the maps which precede the text. The reference to each is by the author's name only, if he is represented in the list by no more than one work; but when two or more works of the same authorship appear in the list, they are distinguished by a catch title in the reference.

Attention is invited to the numerous maps with which the book is equipped, and to the mode in which they are arranged. The larger maps, most of which will be consulted frequently, on various subjects, are placed together, at the beginning of the volume, and referred to by numbers from the text. Thus placed, in what forms an historical atlas within the book, they are found more easily, and can be used more conveniently, than if distributed here and there. Smaller maps, for the special illustration of single subjects or events, are inserted with liberality in the text.

The index to the book has been prepared with more than common care, and is designed to be especially helpful to a continuous study of all important subjects in the history which run through long periods of time. By explanatory entries such subjects are made fully and 
clearly traceable from beginning to end. The index includes also a guide to the maps, pointing out, for every place of historical interest, the map in which it appears and its position thereon.

The opinion of many teachers has concurred with the judgment of the publishers and the writer in deciding that pictorial illustrations would add little or nothing to the interest or instructive value of this book. Most of the portraits and other proper subjects that are available for historical illustration are made familiar to young people by text-books in the lower schools, and will be stale to them if repeated here. Pictures are omitted, therefore, from these pages, while maps are abundantly supplied.

Suggestions from many sources have been helpful to the writer in preparing his book; but he owes especial thanks to Mr. M. W. Richardson, junior-master of the South Boston High School, who has critically examined both the manuscript and the proofs, with great benefit to the general quality of the work; and to teachers in the Buffalo high schools, who have rendered a like service to some parts of the book.

BUfFalo, July, Igo3. 


\section{CONTENTS.}

LIST OF WORKS REFERRED TO Atlas of Historical Maps

\section{INTRODUCTION.}

Discovery and Early Exploration of America. . . . . I Europe and America in the Sixteenth Century . . . . I 2 The Aboriginal Inhabitants of North America . . . I6 Physical Features of North America and their HistoriCAL INFLUENCE.

THE COMING OF THE ENGLISH. I607-I688. CHAPTER

I. Beginnings of the Early Colonies. 1607-1660. 25

II. Political and Social Development of the Early

III. The Colonies under Charles iI. and James iI.

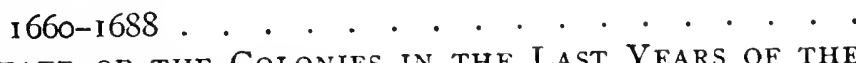
State of the Colonies in the Last Years of the Seventeenth Century . . . . . . . . . . I08

COLONIAL DEVELOPMENT. I688-I775.

IV. The Period of Strife with France. 1690-1760. . il

V. The Provocations to Revolt, I760-1775 . . . . I60

THE MAKING OF A NATION. I775-1800.

State of the Thirteen Colonies at the BeginNING OF THE WAR OF INDEPENDENCE . . . . . . I86 VI. The American Revolution and Warof IndependENCE. $1775^{-17} 8_{3}$. . . . . . . . . . . . . . 194

ViI. The United States under the Articles of ConFEDERATION. $1781-1789$. . . . . . . . . . . . . . 248

ViII. The Founding of a National Government. 1789-

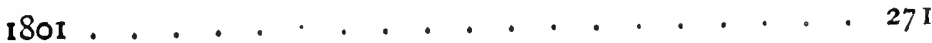


EXPANSION IN THE GREAT VALLEYS. I800-I 840.

1X. The Young Nation harassed dy Older PoWkr. 1801-1809 . . . . . . . . . . . . . . . . 306

X. SECond War with England. ISo9-18I7 . . . . . . 332

XI. AMERICAN DRMOCRACY linIDIN INDFPENDENCF. 1SI5-

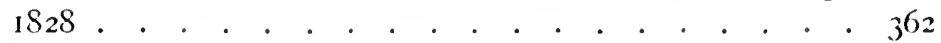

XII. THE Jackson l'ERIOD. I\$29-1 $\$ 40$. . . . . . . . 393

SECTIONAL CONTENTION. I840-1860.

Xitl. Expansion to rHe Pacific: for Free Labor or

Slave LabOR: Whicil ? $1841-1848$. . . . . . 428

XIV. The Maddening Slavery Question. 1848-1860 • 450

SECESSION, CIVII, WAR, ANI) REUNION. I860-I880.

XV. THE WAR FOR ThE UNION : ITS FIRST PERIOD-SPARing Si.avery. iS60-IS62. . . . . . . . . . . . 484

XVI. The War for the Union: its Second Period-

Striking a'T SlaverY. I862-I865 . . . . . . . 525 XViI. The Restoriad Union. I865-1880. . . . . . . 561

THE NEW ERA.

XVIII. Recent Years . . . . . . . . . . . . $58 \mathrm{I}$

Epochs of Progress and Change . . . . . . 609

\section{APPENDIX.}

A. The Constitution of the United States . . . . . . I

B. List of States . . . . . . . . . . . . . . . . 18

C. Presidential ilections : Parties, Candidates, Methods, AND VOTES . . . . . . . . . . . . . . . . . 20

D. Important Measures of the national Government . . 4 I

INDEX . . . . . . . . . . . . . . . . . . . 4 49 


\section{LIST OF MAPS.}

\section{ATLAS OF HISTORICAL MAPS.}

NUMBER

I. Map showing the Piysical, features of Greatest InfluENCE ON AMERICAN HISTORY.

II. North America: Discovery, Exploration, and Early SE'TTLEMENT, I 492-1732.

III. John SMith's Map of New ENGLAND.

IV. NORTH AMERICA IN I774.

V. New England Colonies ani) Contiguous Territory NORTHWARD, TO THE WAR OF INDEPENDENCE.

VI. Middie Colonies and Contiguous Territory northWARD, TO TIIE WAR OF INDEPENDENCE.

VII. Southern Colonies, TO THE War of Independence.

VIII. LAND Claims OF THE STATES I'RIOR TO THE CESSIONS OF I $780-1802$.

IX. The United States in 1790.

X. The Pacific Slope in I849.

XI. The United States IN I860-r86r.

XiI. Tile Civil War in the East: Fifld of the Principal Campaigns.

XiII. The Civil War in the West : Field of the Principai. Campaigns.

XIV. Slavery in the United States. Its Recessions, Extensions, and Final Extinction. I780-i 865.

XV. Continental Expansion of the United States since 1783.

XVI. Insular Expansion of the United States, i898.

XVII. Elements of the Population of the United States; THEIR GROWTH FROM I790 TO 1890.

\section{MAPS IN THE TEXT.}

PAGE

Domain of the Northern IRoquois . . . . . . . . 26 GRANT OF I606 TO THF VIRGINIA COMPANy IN ITS Two

Branches, and Grant of i6o9 to the London Company. 29 The James River Colony . . . . . . . . . . . . 3i 
First Settlement in Marilland . . . . . . . . . . . 34

The First New England Settlfiments. . . . . . . . 39

Beginnings of Connecticut . . . . . . . . . . . . 42

First Settlements on Narkagansett Bay . . . . . . . 44

Early IJutch SetTlements . . . . . . . . . . . . . 47

Early Settlements in the Carolina Grant . . . . . . $\boldsymbol{8}_{4}$

Principal Field of King William's and Queen Anne's WARS

Louisbourg the Key to the Gulf of St. Lawrence . . . I $3^{8}$

The FreNCH in the UPY'er Mississippi Valley and around THE GREat Lakes

Military Posts in the Frontier Rfgions of Northeastern New York and neighboring Canada. From Miles's History' of Canada, reproduced in Winsor's America . . . . . $\cdot$.

Plan of THE Siege of Quebec. From Miles's History of Can. ada, reproduced in Winsor's America . . . . . . . . . . 149

Boston, Lexington, Concord, ANd Vicinity . . . . . . . 195

Plan of the Battle of Bunker Hill. . . . . . . . . 20 I

The Field of War on the Hudson. . . . . . . . . . 209

The Seat of War between the Hudson and Delaware . zil

Route of Burgoyne's Invasion. . . . . . . . . . . . 213

The Seat of War in the South. . . . . . . . . . . 225

The Barbary States. . . . . . . . . . . . . . . . 3i

Niagara Frontier in iSi2-14. Reproduced, with a few adaptations, from a Gazetteer of the Province of Ufper Canada, published in 1813

WESTERN LAKE ERIE IN THE WAR OF I8IR

Maryland in the War of I8I2. . . . . . . . . . . . 349

Field of General Taylor's Campaign in Mexico . . . . 440

General Scott's Route from Vera Cruz to Mexico . . . 44I

Approaches to Washington from the North (IS6I). . 493

Field of War in West Virginia (186I-I865). . . . . . . 499

Field OF War in and aROUND Missouri and Western

KentuCKy (I861-IS65) . . . . . . . . . . . . . . 503

The Blockaded Coast (186r-1865). . . . . . . . . . 505

Hampton Roads . . . . . . . . . . . . . . . . 509

Charleston Harbor . . . . . . . . . . . . . . . 534

Track of Sherman's March to the Sea. . . . . . . . 543

Track of Sherman's March Northward From Savannah . 545

Manila Bay . . . . . . . . . . . . . . . . . . . 597

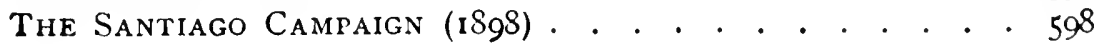




\section{LIST OF WORKS REFERRED TO.}

THE following are the works referred to in this history, either in the text or in the summaries of topics, with references for collateral reading and research, that are appended to the several chapters.

Adams, Henry. History of the United States of America during the [administrations of Thomas Jefferson and James Madison]. 9 vols. Scribners, New York. \$18.00.

John Randolph. American Statesmen Series. Houghton, Mif. flin \& Co., Boston. \$1.25.

Adams, Herber'T B. Maryland's Influence upon Land Cessions to the United States. Johns Hopkins Studies, 3d Series, No. I. Baltimore. $\$ 0.75$.

ADAMS, JoIns. Works, with a life of the author by his grandson, Charles Francis Adams. Io vols. Little, Brown \& Co., Buston. \$30.00.

Adams, Joinn Quincy. Memoirs, comprising Portions of his Diary from 1795 to 1848 . Edited by C. F. Adams. Lippincott \& Co., Philadelphia. Io vols. $\$ 5.00$ per vol.

American ArCinves: Fourth Series. Containing a documentary history of the English Colonies in North America from ... March 7 to . . J July 4, I776. 6 vols. M. St. Clair \& Peter Force, Washington.

American Historical Association. Annual Reports, i889-. Government Printing Office, Washington.

- Papers, I886-I89I. 5 vols. Putnams, New York.

American Historical Review. Macmillan, New York. Single numbers, $\$$ I.OO net.

American History Leaflets. Colonial and Constitutional. Edited by Albert Bushnell Hart and Edward Channing. Lovell \& Co., New York. Each \$o.Io.

AmEs, Fisher. Works, with a selection from his speeches and correspondence. Edited by his son. 2 vols. Little, Brown \& Co., Boston. $\$ 4.50$.

Ammen, Daniel. The Atlantic Coast. The Navy in the Civil War, II. Scribners, New York. \$I.00.

AndRews, E. BenJamin. History of the last Quarter-Century in the United States, 1870-1895. 2 vols. Scribners, New York. \$6.0o. 
Anvual Register, or a View of the History, Politics and Literature, for the Year. 1758-. London.

Arnold, Samuel G. History of Rhode Island and Providence Plantations. 2 vols. Preston \& Rounds, Providence. $\$ 7.50$ net.

A tlantic Monthly. Houghton, Mifflin \& Co., Boston. \$0.35 per copy.

Bagehot, Walter. The English Constitution and other Politicai Essays. Appleton, New York. \$2.00.

Baird, Charles W. History of the Huguenot Emigration to America. 2 vols. Dodd, Mead \& Co., New York. \$2.50 net.

Ballagh, James Curtis. White Servitude in the Colony of Virginia. Johns Hopkins Studies, Baltimore. \$0.50.

Bancroft, GEorge. History of the United States from the Discovery. Author's last revision. 6 vols. Appleton, New York. [Vol. 6 contains the History of the Formation of the Constitution, which is published also as a separate work.] \$15.00.

Bancroft, Hubert H. History of the Pacific States of North America. 27 vols. Bancroft, San Francisco. \$270.50.

Barnes, William H. History of the Thirty-ninth Congress of the United States. Harpers, New York. \$5.00.

Battles and Leaders of the Civil War. Being for the most part contributions by Union and Confederate officers, based upon "The Century War Series." Edited by Robert Underwood Johnson and Clarence Clough Buell. 4 vols. Century Co., New York. \$1 5.00 net.

Benton, Thomas H. Thirty Years' View; or a History of the Working of the American Government for Thirty Years, from $1 S_{20}$ to $1 S_{50}$. 2 vols. Appleton, New York. $\$ 6.00$.

Bishop, J. Leander. History of American Manufactures from i6o8 to 1860.2 vols. Young \& Co., Philadelphia.

Blaine, JAMEs G. Twenty Years of Congress, from Lincoln to Garfield. 2 vols. Funk \& Wagnalls Co., New York. $\$ 3.75$ per vol.

Bolles, AlberT S. Financial History of the United States. V. I : 1774-1789. V. 2: 1789-1860. V. 3: 186I-ISS5. 3 vols. Appleton, New York. V. $1, \$ 2.50 .-$ V. $2, \$ 3.50 .-$ V. $3, \$ 3.50$.

Boone, Richard G. Education in the United States. Its history. International Education Series. Appleton, New York. \$I.50.

Bourinot, J. G. Story of Canada. Story of Nations Series. Putnams, New York. \$1.50.

Brady, Cyrus 'Townsend. Commodore Paul Jones. Great Commanders Series. Appleton, New York. \$I.50 net.

Brodhead, John Romeyn. History of the State of New York. 2 vols. Harpers, New York. \$3.00.

Brooks, N. C. Complete History of the Mexican War. Gregg, Elliot \& Co., Philadelphia. 
Brooks, Phillips. Tolerance : two lectures. Dutton \& Co., New York. \$0.75.

Brown, Alexander. English Politics in Early Virginia History. Houghton, Miftlin \& Co., Boston. \$2.00.

- The First Republic in America. Houghton, Mifflin \& Co., Boston. $\$ 7.50$.

Browne, William Hand. Maryland. The History of a Palatinate. American Commonwealths Series. Houghton, Miftlin \& Co., Boston. $\$ 1.25$.

Bruce, Henry. Life of General Oglethorpe. Makers of America Series. Dodd, Mead \& Co., New York. \$1.00.

Bruce, Philip Alexander. Economic Ilistory of Virginia in the Seventeenth Century. 2 vols. Macmillan, New York. $\$ 6.00$.

Bryce, James. The American Commonwealth. 2 vols. Macmillan, London. $\$ 4.00$ net.

Burgess, John W. The Civil War and the Constitution, 1859-1865. American History Series. Scribners, New York. 2 vols. \$2.00 net.

— The Middle Period, I8I7-I860. American History Series. Scribners, New York. \$1.00 net.

- Reconstruction and the Constitution, I866-r876. American History Series. Scribners, New York. \$r.oo net.

Burke, John. History of Virginia from its Settlement to the Revolution. 3 vols. Petersburg, Va. $\$ 7.50$.

Butler, Nicholas Murray, Editor. Education in the United States. Monographs prepared for the United States Exhibit at the Paris Exposition, 1900. 2 vols. J. B. Lyon Co., Albany. \$3.50.

Cable, George W. The Negro Question. Scribners, New York. $\$ 0.75$.

- The Silent South. Scribners, New York. \$r.oo.

Carpenter, F. B. Six Months at the White House with Abraham Lincoln. The story of a picture. Hurd \& Houghton, New York.

Carrington, Henry B. Battles of the American Revolution, 1775r881. Historical and Military Criticism, with topographical illustrations. Barnes \& Co., New York. \$5.00.

- Washington, the Soldier. Scribners, New York. \$2.00.

Celebration of the Beginning of the 2D Century of the American Patent System, April, i89i. Washington.

Census Reports. Twelfth Census of the United States, taken in the year 1900. U. S. Census Office, Washington.

Century Magazine. Century Co., New York. \$o.35 per number.

Cist, Henky M. The Army of the Cumberland. Campaigns of the Civil War, VII. Scribners, New York. \$r.oo.

Clarke, James Freeman. History of the Campaign of 1812 and surrender of the Post of Detroit. [Being the second part of a volume which 
contains also "The Revolutionary Services and Civil Life of General William Hull, by his daughter, Mrs. Maria Campbell.'] Appleton, New York.

Clay, Henry. Works. Comprising his Life, Correspondence, and Speeches. Edited by Calvin Colton, with an introduction by Thomas B. Reed, and a IIistory of Tariff Legislation from is i 2 to I $\$ 96$, by William Mckinley. 7 vols. E. R. Herrick \& Co., New York. \$14.00.

Cleveland, Grover. Writings and Speeches. lidited by George F. Parker. Cassell Publishing Co., New York. \$2.50.

Conb, SANforI H. The Story of the Palatines. Putnams, New York. \$2.00.

Congrassional Directory (Official). Government Printing Office, Washington.

Cooke, John EsTen. Stonewall Jackson, a Military Biography. Appleton, New York. \$3.00.

Virginia. A History of the People. American Commonwealths Series. Houghton, Mifflin \& Co., Boston. \$1.25.

Cooley, T. M., Hiтchсоск, H., et al. Constitutional History of the United States as seen in the Development of American Law. Putnams, New York. \$2.00.

CoOper, James Fenimore. History of the Navy of the United States of America. 2 vols. Lea \& Blanchard, Philadelphia.

Coplée, Henry. General Thomas. Great Commanders Series. Appleton, New York. \$I.5O.

Cox, Jacob Dolsen. Atlanta. Campaigns of the Civil War, IX. Scribners, New York. \$i.00.

- The March to the Sea. Franklin and Nashville. Campaigns of the Civil War, X. Scribners, New York. \$I.oo.

Cox, Samuer S. Three Decades of Federal Legislation, I855-I $8 S_{5}$. Reid, Providence. \$4.50.

Cullum, George $\mathrm{W}$. Campaigns of the WVar of isi2-ISi5. James Miller, New York. \$5.00.

Curtis, Gkorge Ticknok. History of the Origin, Formation and Adoption of the Constitution of the United States. 2 vols. Harpers, New York. \$6.0o.

Cutler, Wilimam Parker, and Julia Perkins. Life, Journals and Correspondence of Rev. Manasseh Cutler, LL. D. 2 vols. Clarke \& Co., Cincinnati. $\$ 5.00$.

DAvis, Jefferson. Rise and Fall of the Confederate Goveriment. 2 vols. Appleton, New York. \$10.00.

DE Tocquevir.e. See Tocqueville.

Dexter, Mortos. Story of the Pilgrims. Congregationalist S. S. and Publishing Society, Boston and Chicago. \$0.75.

Dickinson, John. Writings, ed. by P. L. Ford. Vol. I. Hist. Soc. of Penn. 
Dix, Morgan. Memoirs of John Adams Dix. 2 vols. Harpers, New York. \$5.00.

Donaloson, Thomas. The Public Domain. Its History, with Statistics. Government Printing Office, Washington.

Doubleday, Abner. Chancellorsville and Gettysburg. Campaigns of the Civil War, VI. Scribners, New York. \$I.00.

Doyle, J. A. The English in America. Vol. I. Virginia, Maryland, and the Carolinas. Vols. 2-3. The Puritan Colonies. Longmans, London. Henry Holt, New York. \$3.50 per vol.

Drake, Samuer. Adams. Border Wars of New kngland. Scribners, New York. \$1.50.

The Making of New England, I 580-1643. Scribners, New York.

The Making of the Ohio Valley States, I660-1837. Scribners, New York. \$I.50.

The Making of Virginia and the Middle Colonies, I578-170r. Scribners, New York. \$I.50.

— The Taking of Louisbourg, 1745. Lee \& Shepard, Boston. \$0.50. Draper, Jorrn W. History of the American Civil War. 3 vols. Harpers, New York. \$10.50.

DRAPER, LYMAN C. King's Mountain and its Heroes. History of the Battle of King's Mountain, October 7, i780, and the events which led to it. Peter G. Thomson, Cincinnati.

Dunn, J. P. Indiana. A Redemption from Slavery. American Commonwealths Series. Houghton, Mifflin \& Co., Boston. \$I.25.

Eggreston, Lnward. The Beginners of a Nation. Appleton, New York. \$I.50.

The Transit of Civilization from England to America in the Seventeenth Century. Appleton, New York. \$1.50.

Elliot, Jonatilan, Editor. The Debates in the Several State Conventions on the Adoption of the Federal Constitution, as recommended by the General Convention at Philadelphia in 1787. Together with the Journal of the Federal Convention, Luther Martin's Letter, Yates's Minutes, Congressional Opinions [etc.]. 4 vols. Washington.

ElliotT, ORRIN Leshil: The Tariff Controversy in the United States, 1789-1833. Leland Stanford Junior University Monographs. Palo Alto, Cal. \$1.oo.

Ellis, George E. Puritan Age and Rule in the Colony of Massachusetts Bay, I629-1685. I Ioughton, Mifflin \& Co., Boston. \$3.50.

Federalist, Tie. A Commentary on the Constitution of the United States, by Alexander Hamilton, James Madison, and John Jay. Edited by Paul Leicester Ford. Holt, New York. \$1.75.

Fernow, Berthold. The Ohio Valley in Colonial Days. Munsells. Albany. 
Fiske, John. American Political Ideas viewed from the Standpoint of Universal History. Harpers, New York. \$1.00.

- The American Revolution. z vols. Houghton, Miftlin \& Co., Boston. \$4.00.

The Begimnings of New England. Houghton, Miftlin \& Co., Boston. \$2.00.

Civil Government in the United States considered with some Reference to its Origins. Houghton, Mifflin \& Co., Boston. \$1.00 net.

— Critical Period of American I History, 1783-1789. Houghton, Mif. thin \& Co., Boston. \$2.00.

- The Discovery of America, with some Account of Ancient America and the Spanish Conquest. 2 vols. Houghton, Mifflin \& Co., Boston. $\$ 4.00$.

— The Dutch and Quaker Colonies in America. z vols. Houghton, Mifflin \& Co., Boston. \$4.00.

- Essays, Iİistorical and Literary. 2 vols. Macmillan, New York. $\$ 4.00$ net.

— New France and New England. Houghton, Mifflin \& Co., Bos. ton. \$1.65 net.

- Old Virginia and her Neighbours. 2 vols. Iloughton, Mifflin \& Co., Boston. \$4.00.

Flick, Alexander Clariance. Loyalism in New York during the American Revolution. Columbia University I'ress. Macmillan, New York. \$2.00 net.

ForCE, M. F. From Fort I Henry to Corinth. Campaigns of the Civil War, II. Scribners, New York. \$I.oo.

FORD, PAUL LeICESTER, Editor. Pamphlets on the Constitution of the United States published during its Discussion by the People, I $7 \mathrm{~S}_{7}$ 17SS. Brooklyn.

Franklin, BENJAMN. Autobiography; edited by John Bigelow. I vol. Elia Series. Putnams, New York. \$.oo.

— Works, ed. by Jared Sparks. Io vols. Boston.

FREEMA, EDWARD A. Greater Greece and Greater Britain. Macmillan, I,ondon. \$I.OO.

Frotifncham, Richari). I History of the Siege of Boston and of the Battles of I exington, Concord, and Bunker Hill. C. C. Little and James Brown, Boston. \$3.50.

- Rise of the Republic of the United States. I,ittle, Brown \& Co., Boston. \$3. $\$ 30$.

Garinge, Samuli. Rawson. Student's History of England. Longmans, London. 3 vols. \$3.00 net.

GARRISON, WhllaM Lioyd. The Story of his Life, told by his Chil-

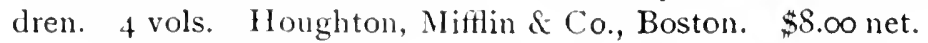

Gay, Sydvey Howakd. James Madison. American Statesmen Series. Houghton, Mifflin \& Co., Boston. \$1.25. 
Geiser, KarL Frederick. Redemptioners and Indentured Servants in the Colony and Commonwealth of Pennsylvania. Supplement to Yale Review. Vol. Io. No. 2. New Haven. \$I.50.

Grlman, Daniel C. James Monroe. American Statesmen Series. Houghton, Mifflin \& Co., Boston. \$r.25.

Gordon, Thomas F. History of Pennsylvania, to 1776 . Cary, I.ea \& Cary, Philadelphia.

Gordy, J. P. I Iistory of Political Parties in the United States. Vol. I-2. Henry Holt \& Co., New York. Title changed on the issue of vol. 2 to Political History of the United States. \$I.75 net per vol.

Grant, Ulysses S. Personal Memoirs. 2 vols. Century Co., New York. \$5.00.

Green, Jomn Richard. Short History of the English People. American Book Co., New York. \$I.2O.

Greene, Francis Vinton. General Greene. (ireat Commanders Series. Appleton, New York. \$I.50.

The Mississippi. Campaigns of the Civil War, VIII. Scribners, New York. \$I.00.

Greene, George W. Life of Nathanael Greene. 3 vols. Hurd \& Houghton, Boston. $\$ 7.50$.

- Short History of Rhode Island. J. A.\& R. A. Reid, Providence. Griffis, William Elliot. Matthew Galbraith Perry. A typical American naval officer. Iloughton, Mifflin \& Co., Boston. \$2.00.

Guizot, F. P. G. Essay on the Character and Influerice of Washington in the Revolution of the United States of America. Miller, New York.

Hall, IIenry. Ethan Allen, the Robin Hood of Vermont. Appleton, New York. \$I.OO.

Halloweir, Richard P. Quaker Invasion of Massachusetts. lloughton, Mifflin \& Co., Boston. \$1.25.

Hamilton, Aiexander. Works, edited by J. C. Hamilton. 7 vols. Charles S. Francis \& Co., New York.

Hanna, Charles $A$. The Scotch-Irish, or the Scot in North Britain, North Ireland, and North America. 2 vols. P'utnams, New York. \$1 o.oo.

Harrison, Frederic. George Washington, and other Addresses. Macmillan, New York. \$r.75 net.

HART, AlbERT Bushneld. Formation of the Union, I750-I829. Epochs of American History Series. Longmans, New York. \$r.75.

— Introduction to a Study of Federal Government. Harvard Ilistorical Monographs, 2. Gim \& Co., lioston.

- Practical Essays on $\Lambda$ merican Government. Longmans, New York. \$r.50.

Salmon Portland Chase. American Statesmen Series. Houghton, Mifflin \& Co., Boston. \$1.25. 
Hart, Alber't Busineli, Editor. American History told by Contemporaries. 4 vols. Macmillan, New York. $\$ 2.00$ per vol.

Herbert, Hilary A., AND Otilers. Why the Solid South? or Reconstruction and its Results. R. H. Woodward, Baltimore. \$I.25.

Higginson, Thomas Wentworth. Larger History of the United States, to the Close of President Jackson's Administration. Harpers, New York. \$2.00.

Hildreth, Richard. History of the United States of America. First Series, from the Iiscovery of the Continent to the Organization of the Government under the Federal Constitution. 3 vols. Second Series, from the Adoption of the Federal Constitution to the end of the Sixteenth Congress. 3 vols. Together, 6 vols. Harpers, New York. \$Iz.oo.

Hinstale, B. A. The American Government. Werner Book Co., Chicago. \$1.25 net.

- The Old Northwest. IVith a View of the 'Thirteen Colonies as Constituted by the Royal Charters. Silver, Burdett \& Co., Boston. \$1.75.

Honges, George. IVilliam Penn. Riverside Biographical Series. Iloughton, Miftlin \& Co., Boston. \$0.50 net.

Holst, H. vox. Constitutional and Political History of the United States. Translated from the German by J. J. Lalor and A. B. Mason. $S$ vols. Callaghan \& Co., Chicago. \$1 2.00 net.

- The Constitutional I aw of the United States of America. Trans. by A. B. Mason. Callaghan \& Co., Chicago. \$2.00 net.

- John Brown. I)e Wolfe, Fiske \& Co., Boston. \$1.25.

- John C. Calhoun. American Statesmen Series. Houghton, Miftlin \& Co., Boston. \$1.25.

Hosmer, JAmes K. Life of Thomas Hutchinson, Royal Governor of the Province of Massachusetts Bay. Houghton, Mifflin \& Co., Boston. $\$ 4.00$.

- Life of Young Sir Henry Vane, Governor of Massachusetts Bay and Leader of the Long Parliament. Houghton, Mifflin \& Co., Boston. $\$ 4.00$.

- Samuel Adams. American Statesmen Series. IIoughton, Mifflin \& Co., Boston. \$I.25.

$\$ 2.00$.

Short History of Anglo-Saxon Freedom, Scribners, New York.

- Short History of the Mississippi Valley. IIoughton, Mifflin \& Co., Boston. \$I.zo net.

Hubbard, William. History of the Indian Wars of New England. Ed. by Samuel G. 1)rake. 2 vols. Wroodward, Roxbury.

IIurirson, Silrley Carter. The Carolina Pirates and Colonial Commerce, r670-1740. Johns Ilopkins Studies. Baltimore. \$1.00.

Humphrers, Andrew $A$. The Virginia Campaign of ' 64 and ' 65 . The Army of the Potomac and the Army of the James. Campaigns of the Civil War, XII. Scribners. New York. \$1.00. 
Hunt, Gailinkd. Life of James Madison. Doubledlay, Page \& Co., New York: \$2.50 net.

Hutchinson, Tiromas. History of the Colony of Massachusetts Bay from ... I628 until ... I69ı. Boston.

— Same, from I69i to 1750 . Boston.

- Same, from I749 to 1774 . Murray, London.

Iles, Grorge. Flame, Electricity, and the Camera. Doubleday, Page \& Co., New York. \$2.00 net.

Interstate Commerce Commission. Annual Report on the Statistics of Railways [by Henry C. Adams]. Government Printing Office, Washington.

Irving, Whshing;on. I ife of George Washington. 5 vols. Putnams, New York. \$50.00.

James, WILliam. Naval History of Great Britain, I793-I820. 6 vols. Macmillan, New York. \$12.00.

JAY, Willinm. Review of the Causes and Consequences of the Mexican War. Mussey \& Co., Boston.

Jefferson, 'Thomas. Writings. Collected and edited by Paul Leicester Ford. Io vols. Putnams, New York. \$5.00 net.

$\$ 27.00$.

Writings. Edited by II. A. Washington. 9 vols. I ippincott.

Jevons, W. STAnley. Money and the Mechanism of Exchange. Kegan Paul, London.

Joinston, Alexander. Connecticut. A Situdy of a Commonwealth1) emocracy. American Commonwealths Series. Houghton, Mifflin \& Co., Boston. \$1.25.

- History of American Politics. 3d edition, revised and enlarged by William M. Sloane. Holt \& Co., New York. \$o.80 net.

- The United States. Its History and Constitution. Scribners, New York. \$I.00.

- Editor. Representative American Orations to illustrate American Political History. 3 vols. Putnams, New York.

KAPI, FrieInICH. Life of Frederick William von Steuben. Mason Bros., New York.

Kendal, Amos. Autobiography. Edited by his son-in-law, William Stickney. Lee \& Shepard, Boston. \$3.00.

KING, Rufus. Ohio. First Fruits of the Ordinance of 1787 . American Commonwealths Series. Houghton, Mifflin \& Co., Boston. \$I.25.

Kingsforn, Willia.. History of Canada. io vols. Rowsel \& I Iutchinson, Toronto.

KIvi.fy, D. The Independent Treasury of the United States. Crowell \& Co., New lork. \$I.50.

LALOr, JoHn J., Editor. Cyclopedia of Political Sicience, Political Economy, and of the Political IIistory of the United States. By the best 
American Writers. 3 vols. Rand, McNally \& Co., Chicago. Each, $\$ 6.00$.

LARNED, J. N. History of England for the Use of Schools and Academies. Houghton, Mifflin \& Co., Boston. \$1.25 net.

Editor. History for Ready Reference. From the best Historians, Biographers and Specialists. 6 vols. C. A. Nichols Co., Springfield, Mass.

LAuer, Paul E. Church and State in New England. Johns Hopkins Studies. Baltimore. \$0.50.

Lecky, William Edward Hartpole. History of England in the Eighteenth Century. S vols. Appleton \& Co., New York. \$20.00.

Levermore, Charles H. The Republic of New Haven. Johns Hopkins University Studies. Baltimore.

Lincoln, Abrahan. Complete Works, comprising his Speeches, Letters, State Papers, and Miscellaneous Writings. Edited by John G. Nicolay and John Hay. 2 vols. Century Co., New York. \$10.00.

LIVERMORE, MARY A. My Story of the WVar: a woman's narrative of four years' personal experience as nurse in the Union Army and in relief work. Worthington \& Co., Hartford. \$3.50.

Lodge, Henry Cabot. Alexander Hamilton. American Statesmen Series. Houghton, Miftlin \& Co., Boston. \$1.25.

- Daniel Webster. American Statesmen Series. Houghton, Mifflin \& Co., Boston. \$1.25.

- George Washington. American Statesmen Series. 2 vols. Houghton, Mifflin \& Co., Boston. \$2.50.

- Life and Letters of Cieorge Cabot. Little, Brown \& Co., Boston. $\$ 3.50$ net.

- Short History of the English Colonies in America. Harpers, New York. \$3.00.

Long, A. L. Memoirs of Robert E. Lee. His military and personal history. Stoddart \& Co., New York.

Lothrop, Thornton Kirkland. William Henry Seward. American Statesmen Series. Houghton, Mifflin \& Co., Boston. \$I.25.

LowkLl, EDWARD J. The Hessians, and other German Auxiliaries of Great Britain in the Revolutionary War. Harpers, New York. \$r.5o.

Lowell, James Russell. Among my Books. Houghton, Mifflin \& Co., Boston. Series I and 2 , each $\$ 200$.

_ Biglow Papers. Houghton, Mifflin \& Co., Boston.

Macaulay, Thomas Babington, Lord. Critical and Historical Essays. 3 vols. Houghton, Mifflin \& Co., Boston. \$6.00.

- History of England from the Accession of James II. 5 vols. Houghton, Mifflin \& Co., Boston. \$10.00.

MCCRADY, EDward. History of South Carolina. [Vol. I] under the Proprietary Government, I670-I7I9; [Vol. 2] under the Royal Govern- 
ment, I719-1776; [Vol. 3] in the Revolution, 1775-17So. Macnillan, New York. Each $\$ 3.50$ net.

McCulloch, Hugh. Men and Measures of Half a Century. Scribners, New York. \$2.50.

MacDonald, William, Editor. Select Charters and other Documents Illustrative of American History, 1606-1775; with notes. Macmillan, New York. \$2.25 net.

Editor. Seleci Documents Illustrative of the History of the United States, I776-1861. Macmillan, New York.

MacLean, J. P. Historical Account of the Settlement of Scotch Highlanders in America. Helman-Taylor Co., Cleveland. \$5.00.

MacMaster, John Bach. History of the People of the United States from the Revolution to the Civil War. 7 vols. Appleton \& Co., New York. Each \$2.50.

McPherson, Edward. Political History of the United States of America during the Great Rebellion. 2d ed. Philip \& Solomon, Washington. $\$ 5.00$.

MADISON, JAMEs. Letters and other Writings. 4 vols. Lippincotts, Philadelphia. \$16.00.

\section{York,}

_ Papers purchased by order of Congress. ${ }^{1} 3$ vols. Langley, New

Magruder, Allan B. John Marshall. American Statesmen Series. Houghton, Mifflin \& Co., Boston. \$1.25.

Mahan, A. T. The Gulf and Inland Waters. The Navy in the Civil War, III. Scribners, New York. \$I.00.

- Influence of Sea Power upon the French Revolution and Empire. 2 vols. Little, Brown \& Co., Boston. \$6.0o.

- Influence of Sea Power upon History, I660-1783. Little, Brown \& Co., Boston. \$4.00.

Marshall, John. Writings upon the Federal Constitution. Munroe \& Co., Boston.

Martineau, Harriet. Retrospect of Western Travel. 2 vols. Harpers, New York.

Massachusetts Historical Society. Collections, Boston.

Mendenhall, Thomas C. Century of Electricity. Houghton, Mifflin \& Co., Boston.

Morley, John. Walpole. English Statesmen Series. Macmillan, London. \$O.75.

Morse, John T., JR. John Adams. American Statesmen Series. Houghton, Mifflin \& Co., Boston. \$1.25.

John Quincy Adams. American Statesmen Series. Houghton, Mifflin \& Co., Boston. \$1.25.

- Benjamin Franklin. American Statesmen Series. Houghton, Mifflin \& Co., Boston. \$1.25.

I Madison's Journal of the Constitutional Convention contained in vols. 2-3. 
Morse, Johx T., JR. Thomas Jefferson. American Statesmen Series. Houghton, Mifflin \& Co., Boston. \$I.25.

— Abraham Lincoln. American Statesmen Series. 2 vols. Houghton, Mifflin \& Co., Boston. \$2.50.

National Enucational Association. Journal of Proceedings and Addresses.

NEW Yokk STATE. Documents relative to the Colonial History of the State of New York, procured in Holland, England, and France by John Romeyn Brodhead. It vols. Edited by E. B. O'Callaghan and B. Fernow. Albany.

Nichols. George Ward. Story of the Great March. Harpers, New Tork. \$I.50.

Nicolay, Joris G. The Outbreak of Rebellion. Campaigns of the Civil War, I. Scribners, New York. \$I.oo.

Nicoldy, John G., Axi Hay. Johx. Abraham Lincoln. A History. 10 vols. Century Co., New York. \$20.00.

North Alerican Review. isi6-igo3. Boston-New York. \$o.50 per number.

O'CAllaghax, E. B. History of New Netherland, or New York under the Dutch. 2 vols. Appleton \& Co., New York. \$6.00.

Olp South Leaflets. Published by the Directors of the Old South Work. Boston. \$0.05 each.

PAlfrey, Frixcis Winthrop. The Antietam and Fredericksburg Campaigns. Campaigns of the Civil War, V. Scribners, New York. $\$ 1.00$.

PAlFrey, Jom GornAy. History of New England to the Rerolution of the Seventeenth Century. 2 vols. The same, to the Revolution of the Eighteenth C'entury. I vol. The same, during the Stuart Dynasty. 2 vois. Little, Brown \& Co., Boston. \$iS.oo net.

I'ARIS, L. P. A. D'ORLEANS, Comte DE. History of the Civil War in America. 'Trans by Louis F. Tasistro. Edited by Henry Coppée. 4 vols. Coates \& Co., Philadelphia. Each $\$ 3 \cdot 50$.

Parkmax, Fraxcis. The Conspiracy of Pontiac and the Indian War after the conquest of Canada. 2 vols. Little, Brown \& Co., Boston. $\$ 3.00$.

Count Frontenac and New France under Louis XIV. Little, Brown \& Co., Boston. \$I.5O.

- Half-Century of Conflict. 2 vols. Iittle, Brown \& Co., Boston. $\$ 3.00$.

The Jesuits in North America. Little, Brown \& Co., Boston. $\$ \mathrm{I} .50$.

La Salle and the Discovery of the Great West. Little, Brown \& Co., Boston. Str.50.

Montcalm and Wolfe. 2 vols. Little, Brown \& Co., Boston. $\$ 3.00$. 
PARKMAN, Francis. The Old Régime in Canada. Little, Brown \& Co., Boston. \$1.50.

- Pioneers of France in the New World. Little, Brown \& Co., Boston. \$r.5O.

Parton, James. Life and Times of Aaron Burr. 2 vols. Houghton, Mifflin \& Co., Boston. \$5.00.

- Life of Andrew Jackson. 3 vols. Houghton, Mifflin \& Co., Boston. $\$ 7.50$.

— Life of Thomas Jefferson. Houghton, Mifflin \& Co., Boston. \$2.50.

Peck, Charles H. The Jacksonian Epoch. Harpers, New York. $\$ 2.50$.

Pellew, George. John Jay. American Statesmen Series. Houghton, Mifflin \& Co., Boston. \$1.25.

Phelan, James. History of Tennessee. Houghton, Mifflin \& Co., Boston. \$2.00.

Phisterer, Frederick. Statistical Record of the Armies of the United States. Campaigns of the Civil War, Supplementary Vol. Scribners, New York. \$I.OO.

Pittenger, Willian. Daring and Suffering. [Also rewritten and republished under varying titles: "Capturing a Locomotive," and "The Great Locomotive Chase."] Penn Pub. Co., Philadelphia. \$r.25.

Political Science Quarterly. Edited by the political science faculty of Columbia University. Ginn \& Co., Boston. \$0.50.

Pond, George, A. The Shenandoah Valley in I864. Campaigns of the Civil War, XI. Scribners, New York. \$r.co.

Poor, Henry V. Manual of the Railroads of the United States for [various years]. H. V. \& N. W. Poor, New York. \$Io.00.

Prescott, George B. Electricity and the Electric Telegraph. 8th ed., revised and enlarged. 2 vols. Appleton, New York. \$7.00.

Preston, Howard W., Editor. Documents illustrative of American History. I606-IS63. Putnams, New York. \$I.20.

Quincr, Edmuxd. Life of Josiah Quincy. Little, Brown \& Co., Boston. $\$ 3.00$ net.

Quincr, Josiah. Memoir of the Life of John Quincy Adams. S. S. Rider, Boston.

RHODE Island. Records of the Colony. Edited by J. R. Bartlett. Io vols. Providence. \$1 2.50.

Rhodes, Janes Ford. Ifistory of the United States from the Compromise of I $8_{50}$. Vols. I-4. Macmillan, New York. \$2.50 net.

Richardson, Charles F. American Literature, I607-I 885.2 vols. Putnams, New York. Each $\$ 3.00$.

Richardson, James D. A Compilation of the Messages and Papers of the Presidents, $1789-\mathbf{I} \$ 97$. Io vols. Government Printing Office, Washington. 
Rippath, Johx C. Life and Work of James A. Garfield. Jones, (incinnati.

Rives, William C'. Life and Times of James Madison. 3 vols. Little, Brown \& Co., Boston. \$I 0.50.

Roberts, Charles G. D. History of Canada. L. C. Page \& Co., Buston \$2.00 net.

Roberts, Ellis H. New York. American Commonwealths Series. 2 vols. Houghton, Miftlin \& Co., Boston. \$2.50.

Robinson, Rowland E. Vermont: A Study of Independence. American Commonwealths series. Houghton, Mifflin \& Co., Boston. $\$ 1.25$.

Ruosevelr, Theodone. Gouverneur Morris. American Statesmen Series. Houghton, Miftlin \& Co., Boston. \$1.25.

- The Naval War of ISI2. Putnams, New York. \$2.50.

— New York. Historic Towns Series. Longmans, New York. \$1.25.

- Thomas Hart Benton. American Statesmen Series. Houghton.

Mifflin \& Co., Boston. \$I.25.

- The Winning of the West. 4 vols. Putnams, New York. Each $\$ 2.50$.

Ropes, John Conmax. The Army under Pope. Campaigns of the Civil War, IV. Scribners, New York. \$1.oo.

- The Story of the Civil War. Parts I-2. [IS6I-IS62.] 2 vols. Putnams, New York. Pt. I, \$I.50; pt. 2, \$2.50.

Routledge, James. Chapters in the History of Popular Progress. I660-ISzo. Macmillan, London. I6s.

SAbine, Lorenzo. Biographical Sketches of the Loyalists of the American Revolution. 2 vols. Little, Brown \& Co., Boston. \$7.00.

SAinsbury, Wr. Noel, Editor. Calendar of State Papers [Great Britain]. Colonial Series: America and West Indies. 4 vols. London. Sargent, Nathan. Public Men and Events, from . . . ISI7 to IS 5 j. 2 vols. Lippincott, Philadelphia. \$6.0o.

Schaff, Philip. Progress of Religious Freedom. Scribners, New York. \$I.5O.

Schoolcraft, Henry R. Notes on the Iroquois. Pease $\&$ Co., Albany.

Schouler, JAMEs. History of the United States of America under the Constitution. Revised edition. 6 vols. Dodd, Mead \& Co., New York. \$I3.50.

Schurz, Carl. Abraham Lincoln. An Essay. Houghton, Mifflin \& Co., Boston. \$ٓI.5O.

L Life of Henry Clay. American Statesmen Series. 2 vols. Houghton, Mifflin \& Co.. Boston. \$2.50.

Schuyler, George IV. Colonial New York. 2 vols. Scribners, New York. \$io.00 net. 


\section{LIST OF WORKS REFERRED TO. XXVii}

Sedgwick, Ellery. Thomas Paine. Beacon Biographies Series. Small, Maynard \& Co., Boston. \$0.75.

Sefley, Sir J. R. The Expansion of England. 2d edition. Macmillan, London. 4s. 6d.

Short History of Napoleon the First. Little, Brown \& Co., Boston. $\$ 1.50$.

Seward, William H. Works. Edited by George E. Baker. New edition. 5 vols. Houghton, Mifflin \& Co., Boston. Each \$3.00.

Sharpless, IsaAc. Two Centuries of Pennsylvania History. Lippincott, Philadelphia. \$I.25 net.

Shepard, Edward M. Martin Van Buren. American Statesmen Series. Houghton, Miftlin \& Co., Boston. \$I.25.

Sherian, W. T. Memoirs, written by himself. With an appendix, bringing his life down to its closing scenes, by Hon. James G. Blaine. 2 vols. D. Appleton \& Co., New York. \$5.00.

Siebert, Wilbur H. The Underground Railroad from Slavery to Freedom. With an introduction by Albert Bushnell Hart. Macmillan, New York. \$4.00.

Simms, William Gilmore. Life of Francis Marion. Derby, New York.

Sloane, William Milligan. The French War and the Revolution. American History Series. Scribners, New York. \$I.00 net.

Smith, EDward P. Incidents of the United States Christian Commission. Lippincott, Philadelphia. \$3.00 net.

Smith, Captain John. Works, i608-i63i. Edited by Edward Arber. Birmingham.

Sirith, Goldwin. The Moral Crusader, William Lloyd Garrison. Funk \& Wagnalls, New York. \$I.00.

Soley, James Russell. The Blockade and the Cruisers. The Navy in the Civil IVar, I. Scribners, New York. \$I.OO.

Spaulding, Elbridge G. History of the Legal Tender Paper Money issued during the Great Rebellion. Buffalo.

Stanwood, Enward. History of the Presidency. Houghton, Mifflin \& Co., Boston. \$2.50.

Stevens, John Austin. Albert Gallatin. American Statesmen Series. Houghton, Mifflin \& Co., Boston. \$I.25.

Stille, Charles J. History of the United States Sanitary Commission. Lippincott, Philadelphia. \$3.50.

\section{$\$ 3.00$ net.}

Stith, IVilliam. History of the First Discovery and Settlement of Virginia. Sabin reprint, New York. $\$ 7.50$.

Stone, IVilimam L. Life of Joseph Brant (Thayendanegea), including the Border Wars of the American Revolution. 2 vols. Phinney \& Co., Buffalo. $\$ 5.00$. 
Storey, Moorfield. Charles Sumner. American Statesmen Series. Houghton, Mifflin \& Co., Boston. \$I.25.

Sumner, William Graham. Andrew Jackson as a Public Man. American Statesmen Series. Houghton, Mifflin \& Co., Boston. \$I.25.

- The Financier [Robert Morris] and the Finances of the American Revolution. 2 vols. Dodd, Mead \& Co., New York. \$5.00.

- History of American Currèncy. Holt \& Co., New York. \$3.00.

- History of Banking in the United States. [Vol. I of "History of Banking in all the Leading Nations."] Journal of Commerce, New York.

Swett, John. American Public Schools. American Book Co., New York. \$I.00 net.

TARBELL, IDA M. Life of Abraham Lincoln, drawn from original sources. 2 vols. McClure, Phillips \& Co., New York. \$5.00.

Taussig, F. W. The Silver Situation in the United States. Putnams, New York. \$0.75.

- Tariff History of the United States. A Series of Essays. 4th edition. Putnams, New York. \$1.25.

Thoreau, Henry D. A Yankee in Canada. With Anti-Slavery and Reform Papers. I. R. Osgood \& Co., Boston. \$I.5o.

Thurston, Robert H. History of the Growth of the Steam Engine. International Scientific Series. Appleton \& Co., New York. \$2.50.

Triwaites, Reuben Gold. The Colonies, I492-I750. Epoch Series. Longmans, New York. \$I.25.

Tocqueville, Alexis DE. Democracy in America. Trans. by Henry Reeve, as revised and annotated from the author's last edition by Francis Bowen. With an introduction by Daniel C. Gilman. 2 vols. Century Co., New York. \$5.00.

Tower, Charlemagne, Jr. The Marquis de Lafayette in the American Revolution. 2 vols. Lippincott, Philadelphia. \$8.00.

Treaties and Conventions Concluded between the UNited States and Other Powers since July 4, 1776 . Government Printing Office, Washington.

Trent, Willian P. Southern Statesmen of the Old Régime. Crowell \& Co., New Iork. \$2.00.

TuCker, George F. The Monroe Doctrine. A concise history of its origin and growth. George B. Reed, Boston. \$I.25 net.

Tuckermax, BAYARD. Life of General Lafayette. 2 vols. Dodd, Mead \& Co., New York. \$3.00.

Tudor, William. Life of James Otis. Wells \& Lilly, Boston.

Twitchell, Joseph Hopkins. John Winthrop. Makers of America Series. Dodd, Mead \& Co., New York. \$I.Oo.

Tyler, Moses CoIT. History of American Literature, I607-I 765 . 2 vols. Putnams, New York. Each \$2.50. 
Tylfr, Moses CoIt. Literary History of the American Revolution, 1763-1783. 2 vols. Putnams, New York. Each $\$ 3.00$.

Patrick Henry. American Statesmen Series. Houghton, Mifflin \& Co., Boston. \$1.25.

Upham, Charles Wentworth. Salem Witchcraft. 2 vols. Wiggin, Boston.

Walker, Francis A. The Making of the Nation. I783-i8i7. Scribners, New York. \$I.00 net.

Money. Holt, New York. \$2.00 net.

Walker, Williston. History of the Congregational Churches in the United States. American Church History Series. Scribners, New York. $\$ 2.00$ net.

Washington, Booker T. The Future of the Negro. Small, Maynard \& Co., Boston. \$I.5O.

Washington, George. Writings, collected and edited by Worthington Chauncey Ford. I 4 vols. Putnams, New York. \$70.00.

Watts, John. Facts of the Cotton Famine. Simpkin, Marshall \& Co., London.

Webb, Alexander S. The Peninsula. McClellan's Campaign of I862. Campaigns of the Civil War, III. Scribners, New York. \$I.00.

Webster, Daniel. Works. 6 vols. Little \& Brown, Boston. \$IS.oo.

Weeden, William B. Economic and Social History of New England. 1620-1789. 2 vols. Houghton, Mifflin \& Co., Boston. \$4.50.

Wharton, Francis. Digest of the International Law of the United States. 3 vols. Government Printing Office, Washington.

- Editor. Revolutionary Diplomatic Correspondence of the United States. 6 vols. Government Printing Office, Washington.

White, Horace. Money and Banking, illustrated by American History. Ginn \& Co., Boston. \$I.50 net.

Whiting, William. War Powers under the Constitution of the United States. $43 \mathrm{~d}$ ed. Lee \& Shepard, Boston. \$3.50.

Williams, George H. History of the Negro Race in America. 16r9-1880. Putnams, New York. \$4.00.

Wilson, Woonrow. Congressional Government. A Study in American Politics. Houghton, Mifflin \& Co., Boston. \$r.25.

- Division and Reunion, I829-I8S9. Epochs of American History. Longmans, New York. \$I.25.

Winsor, Justin. Cartier to Frontenac. 1534-1700. Houghton, Mifflin \& Co., Boston. \$4.00.

- The Mississippi Basin. The Struggle in America between the English and the French. I697-r763. Houghton, Mifflin \& Co., Boston. $\$ 4.00$.

The Westward Movement. The Colonies and the Republic west of the Alleghanies. $1763^{-1} 798$. Houghton, Mifflin \& Co., Boston. $\$ 4.00$. 
Winsor, Justin, Editor. Memorial History of Boston. 4 vols. Ticknor \& Co., Boston. \$25.00.

Editor. Narrative and Critical History of America. $S$ vols. Houghton, Mifflin \& Co., Boston. \$44.00 net.

Wormeley, Katharine PrescotT. The Other Side of War with the Army of the Potomac: Letters from the Headquarters of the U.S. Sanitary Commission during the Peninsular Campaign in Virginia in 1S62. Ticknor, Boston. 
ATLAS OF HISTORICAL MAPS 




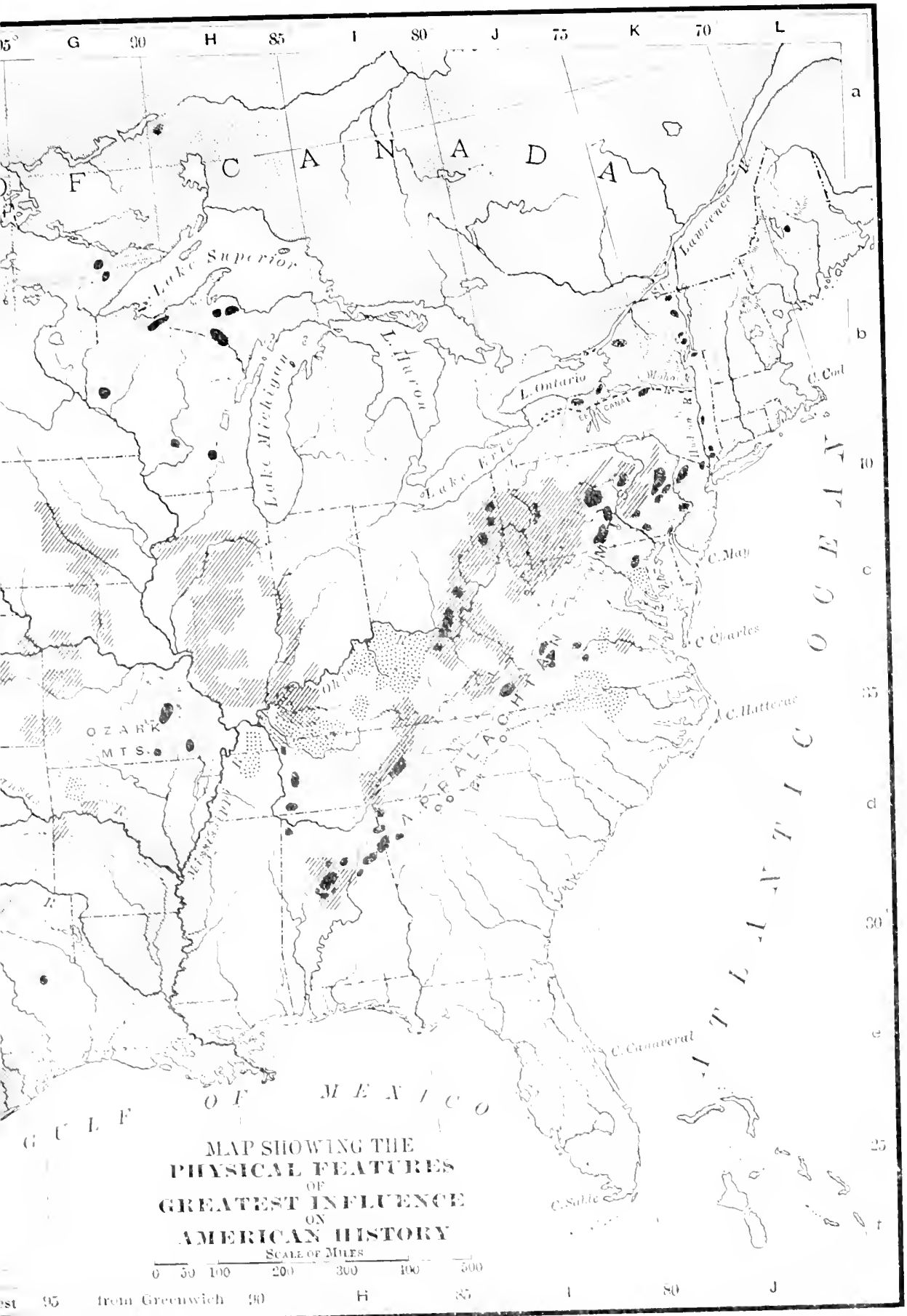






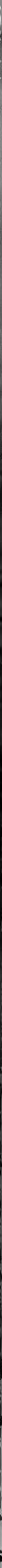




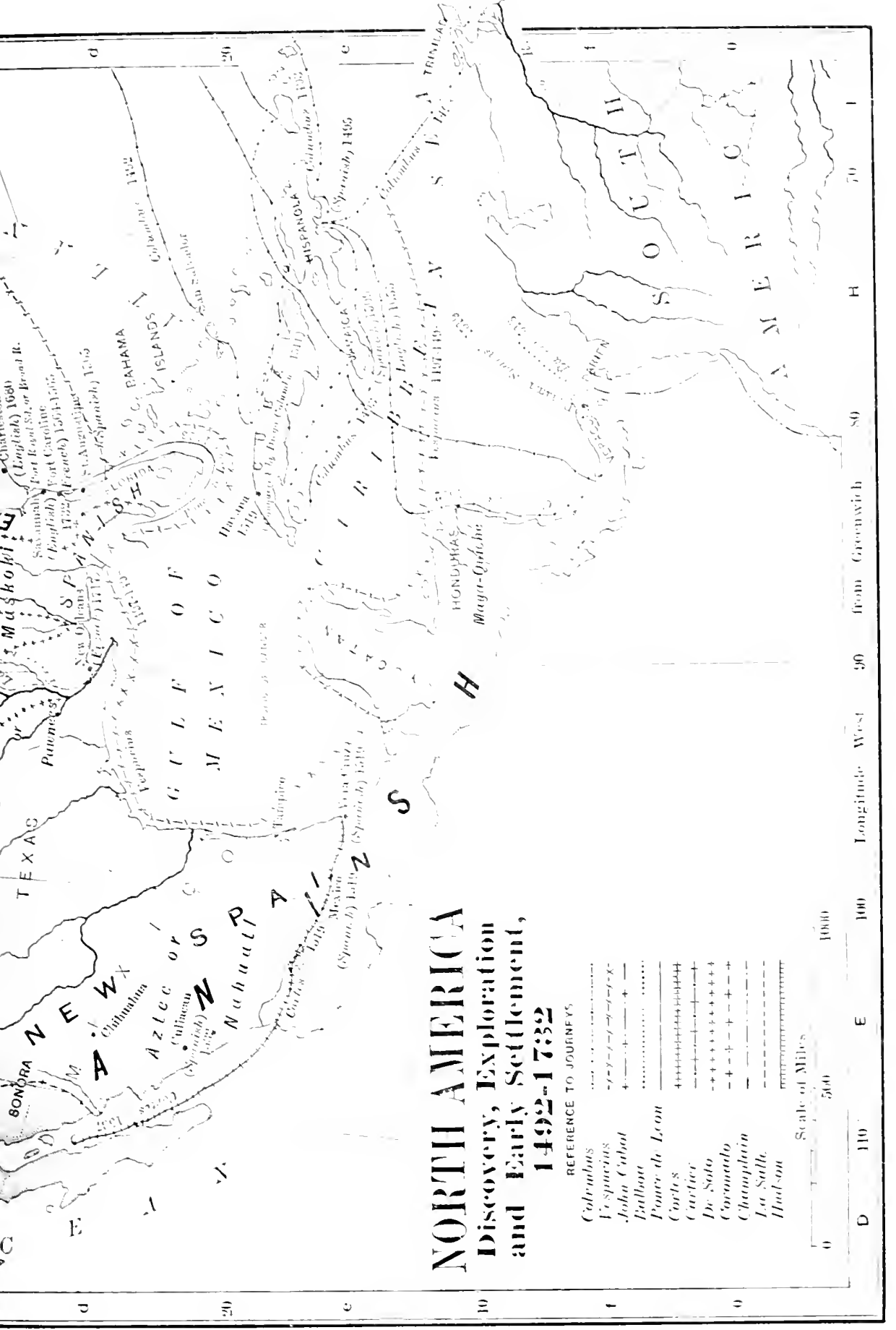






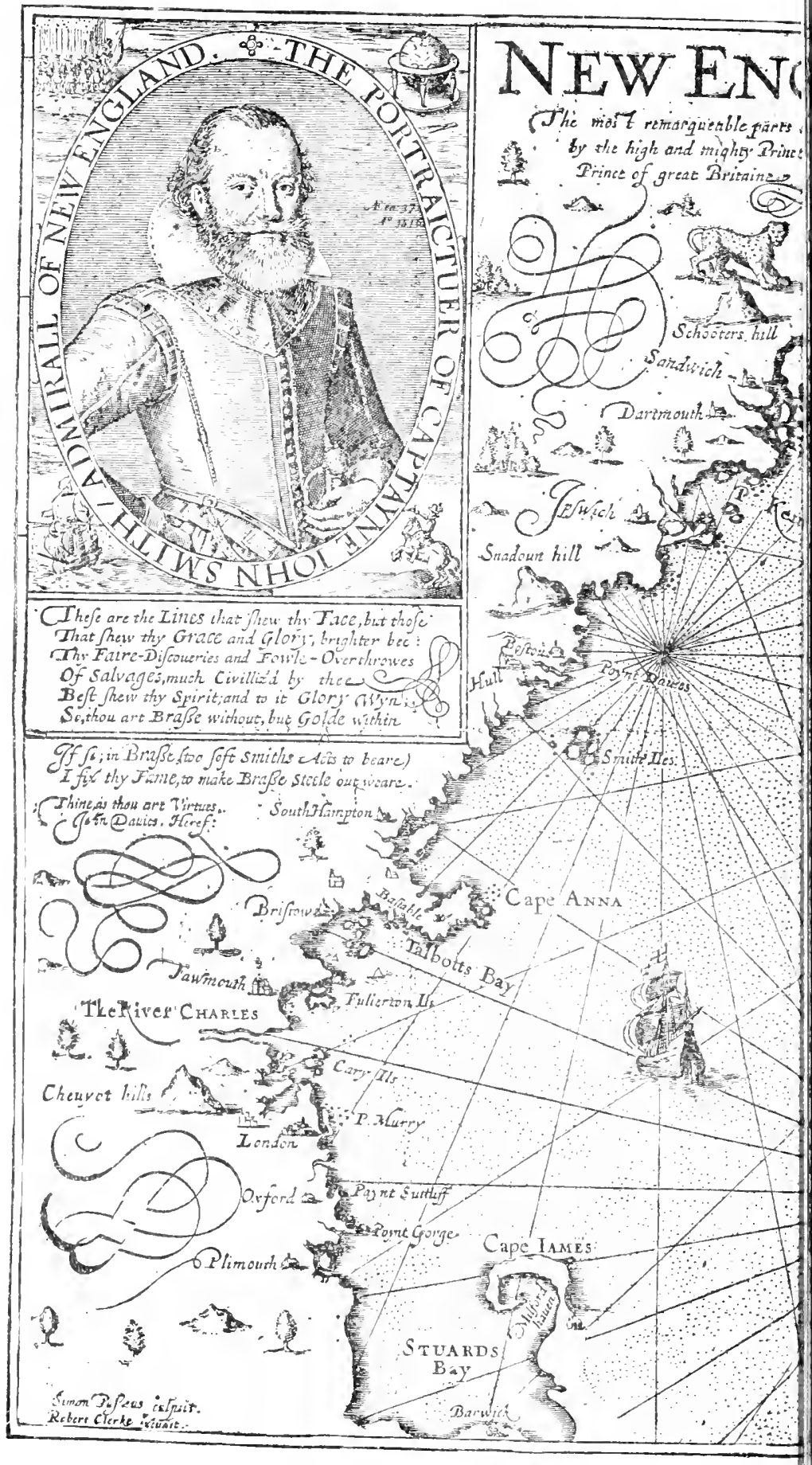

SMITH'S MAP 


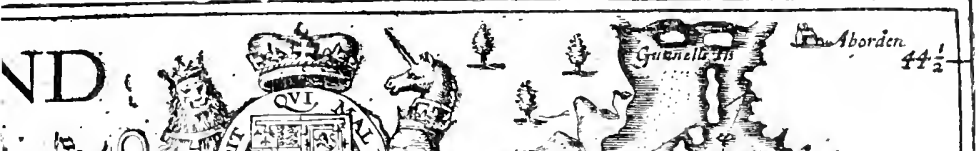
(5)

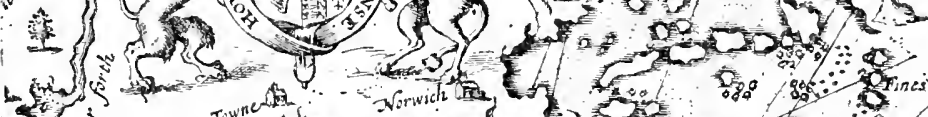

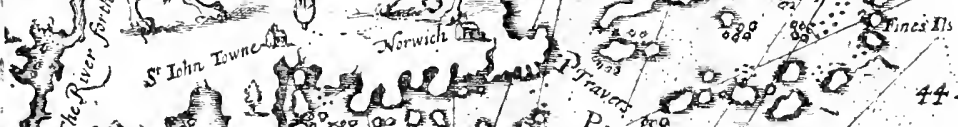

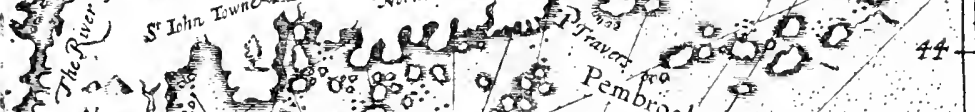

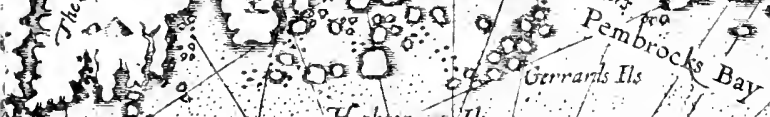

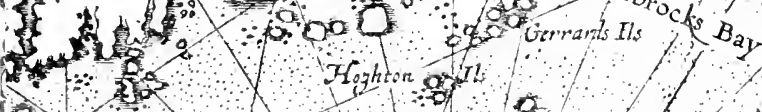

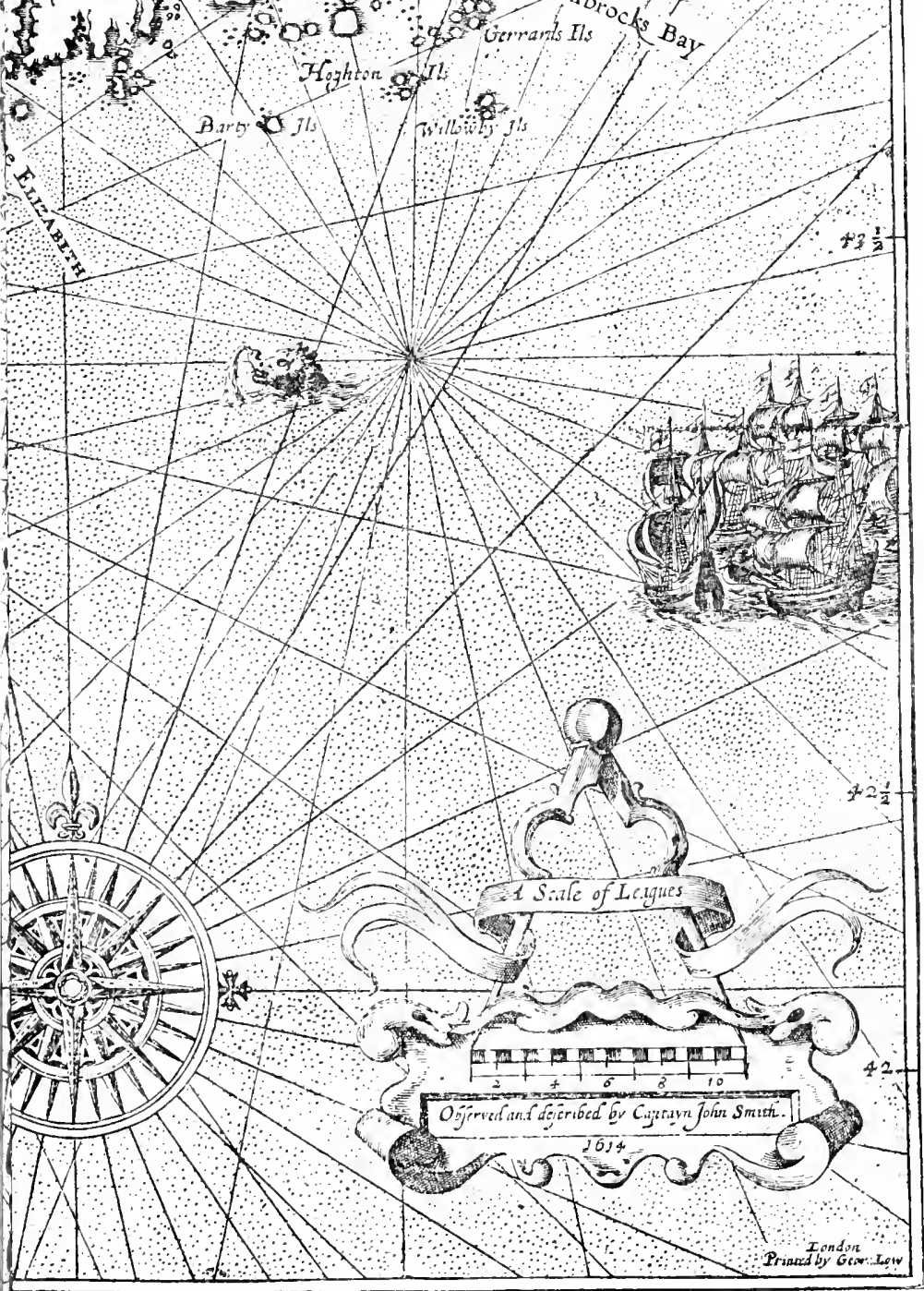

WW ENGLAND. 



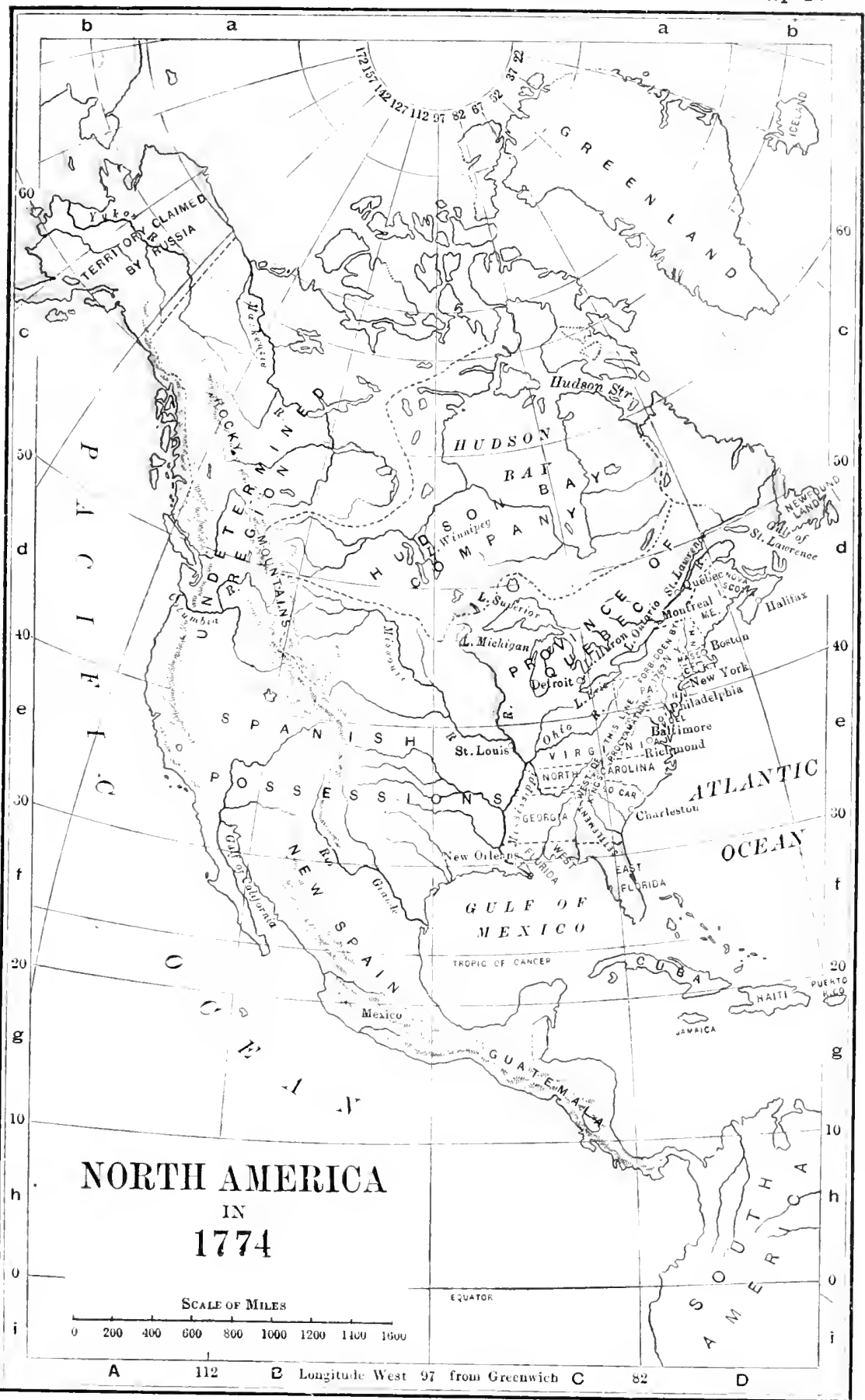






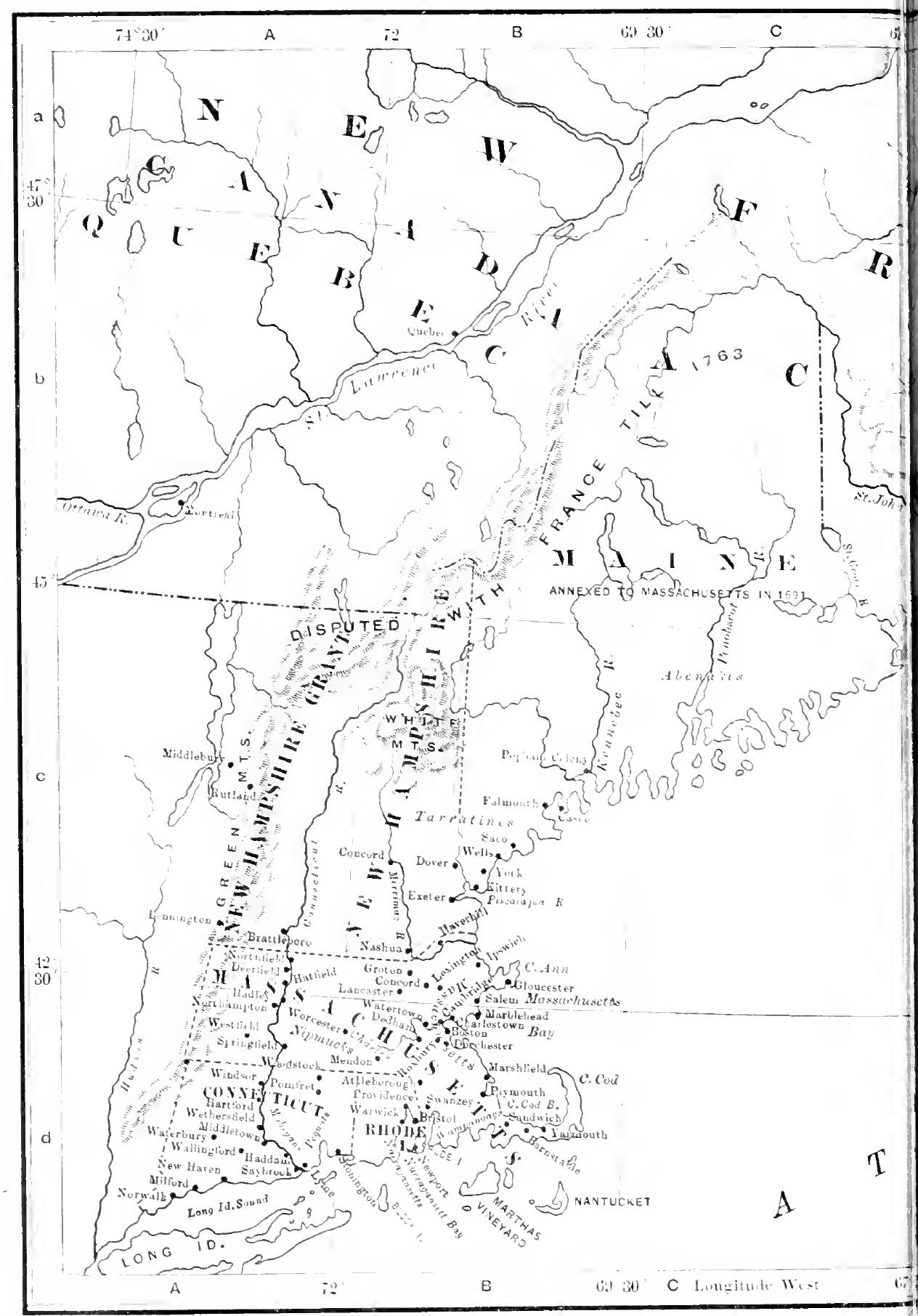





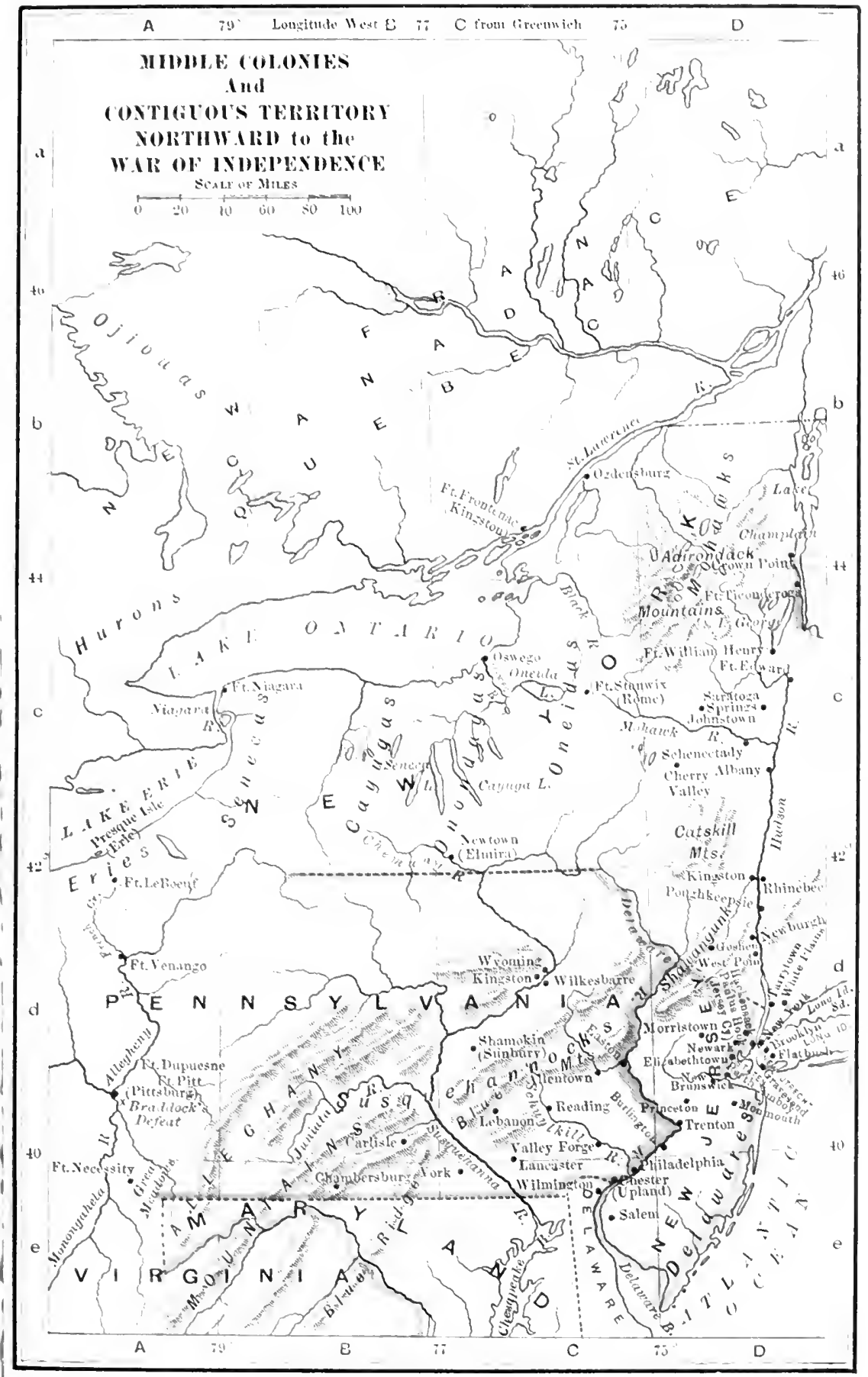





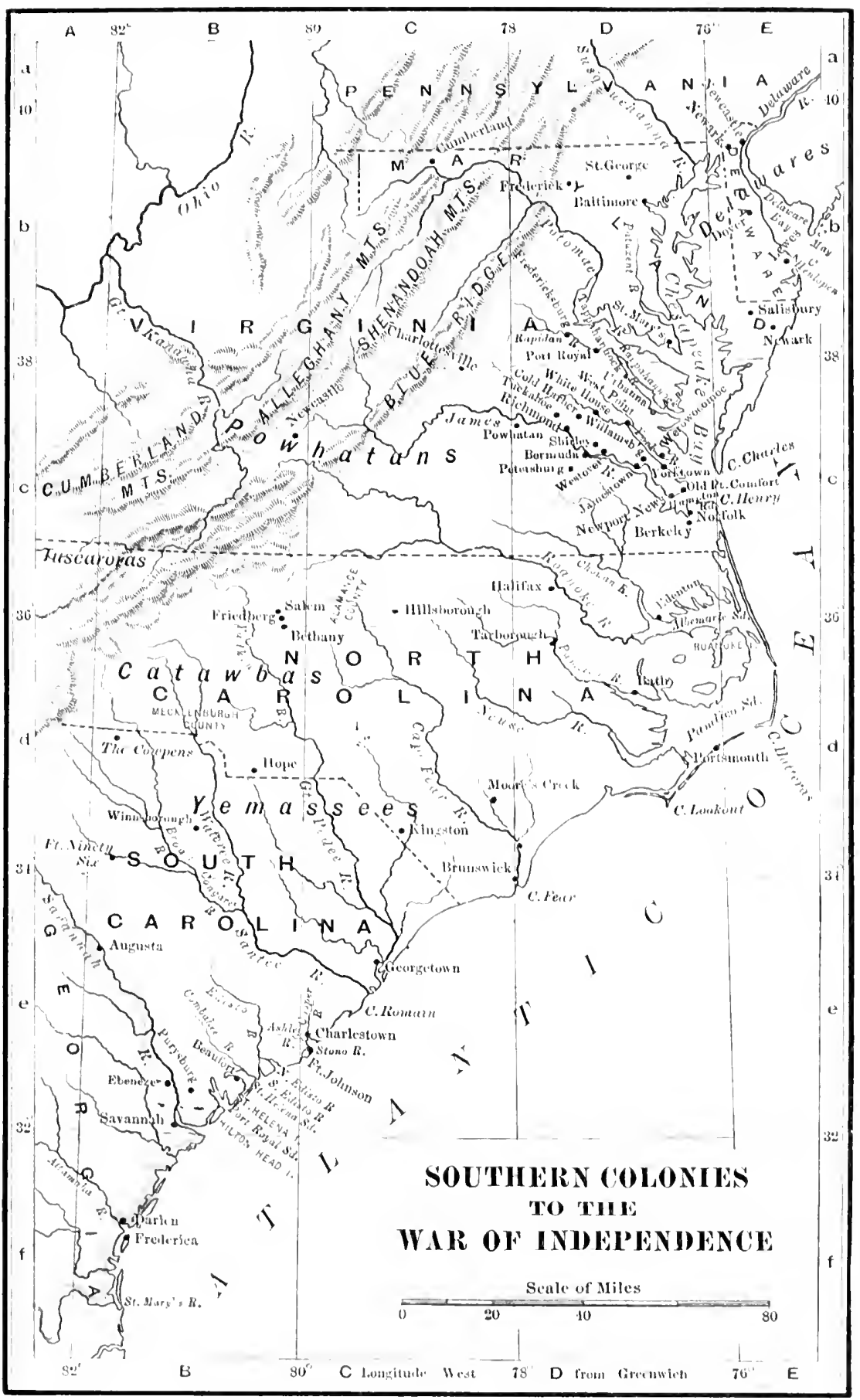





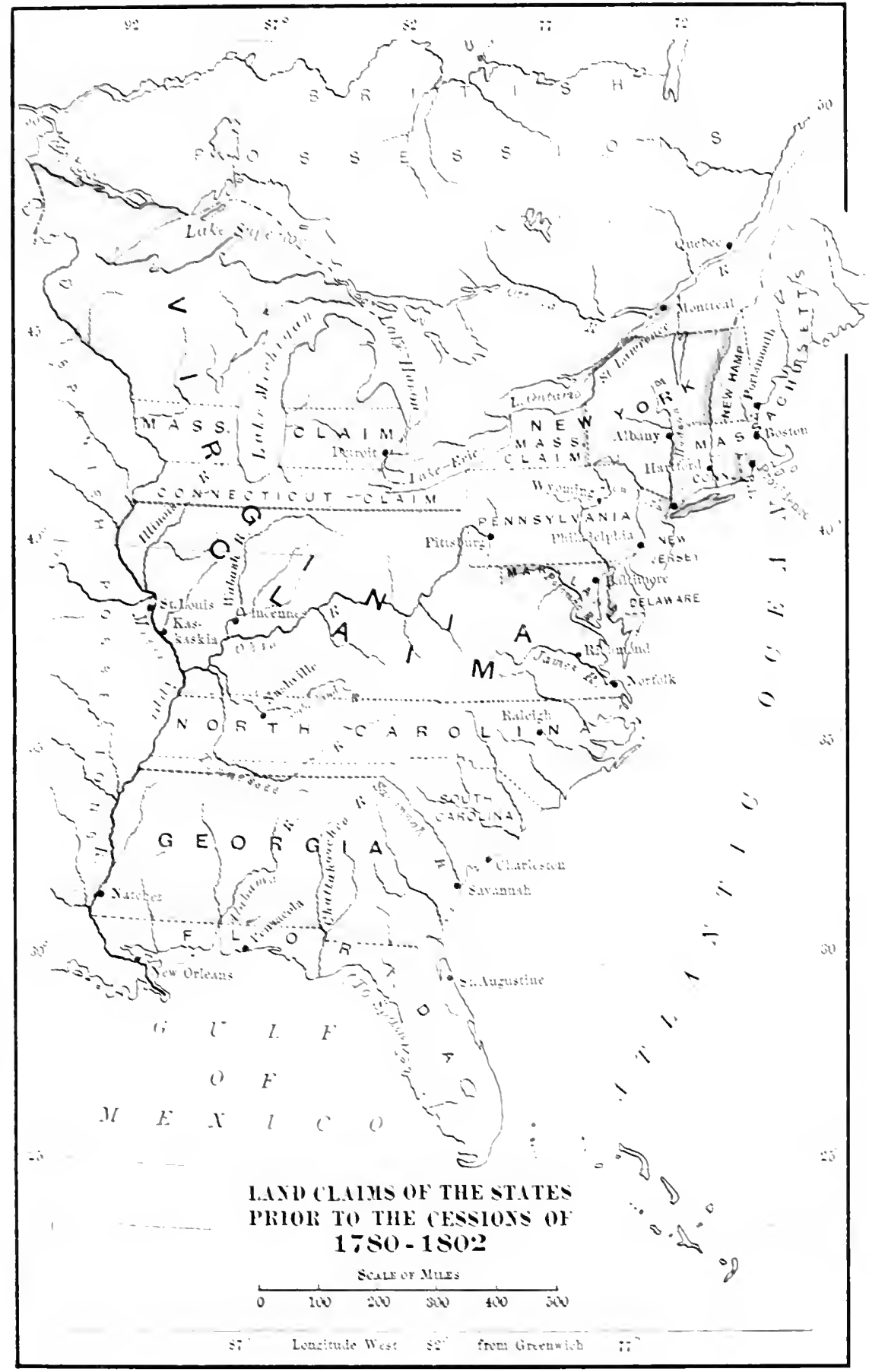



Map IX

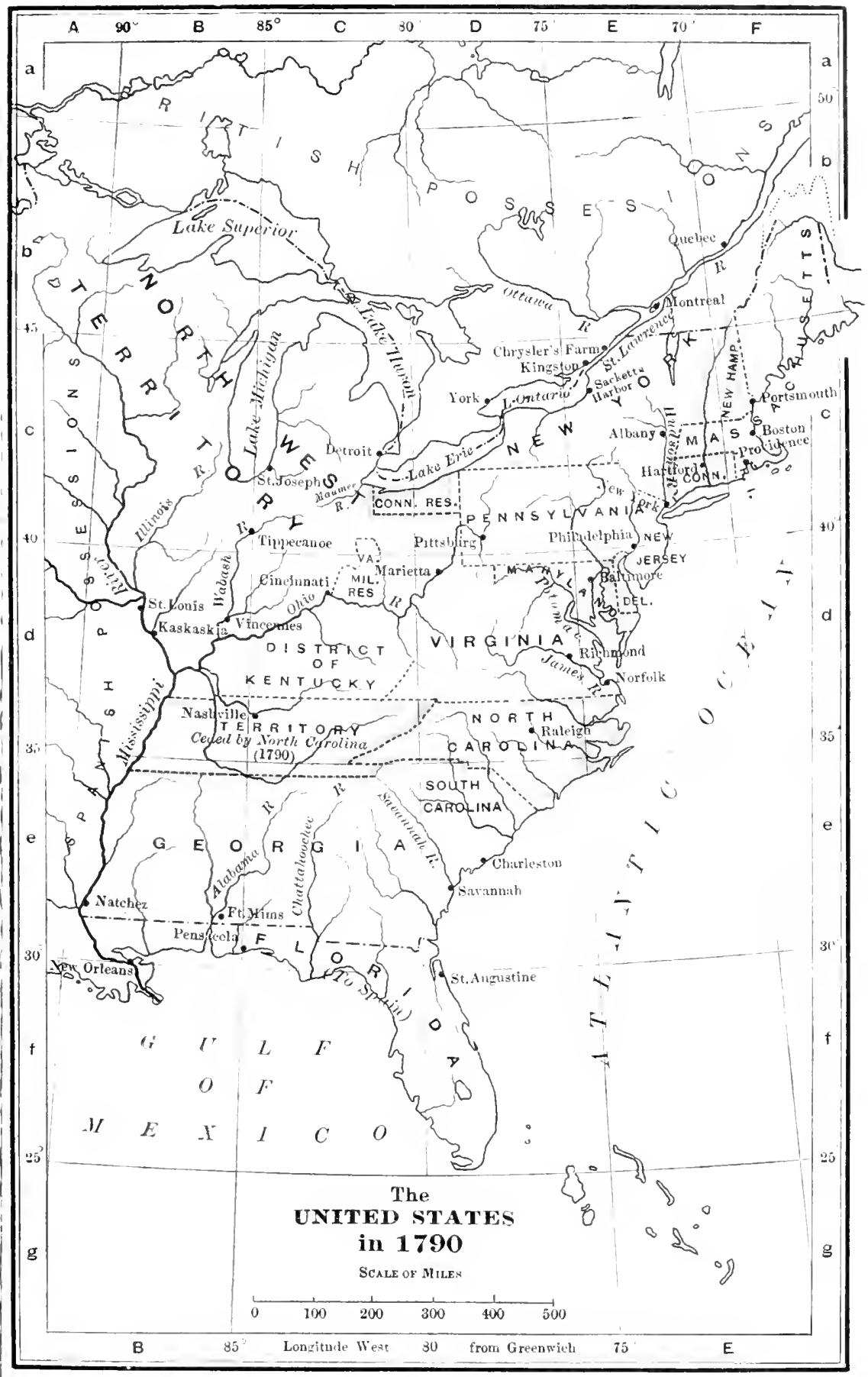



Map $\mathrm{X}$

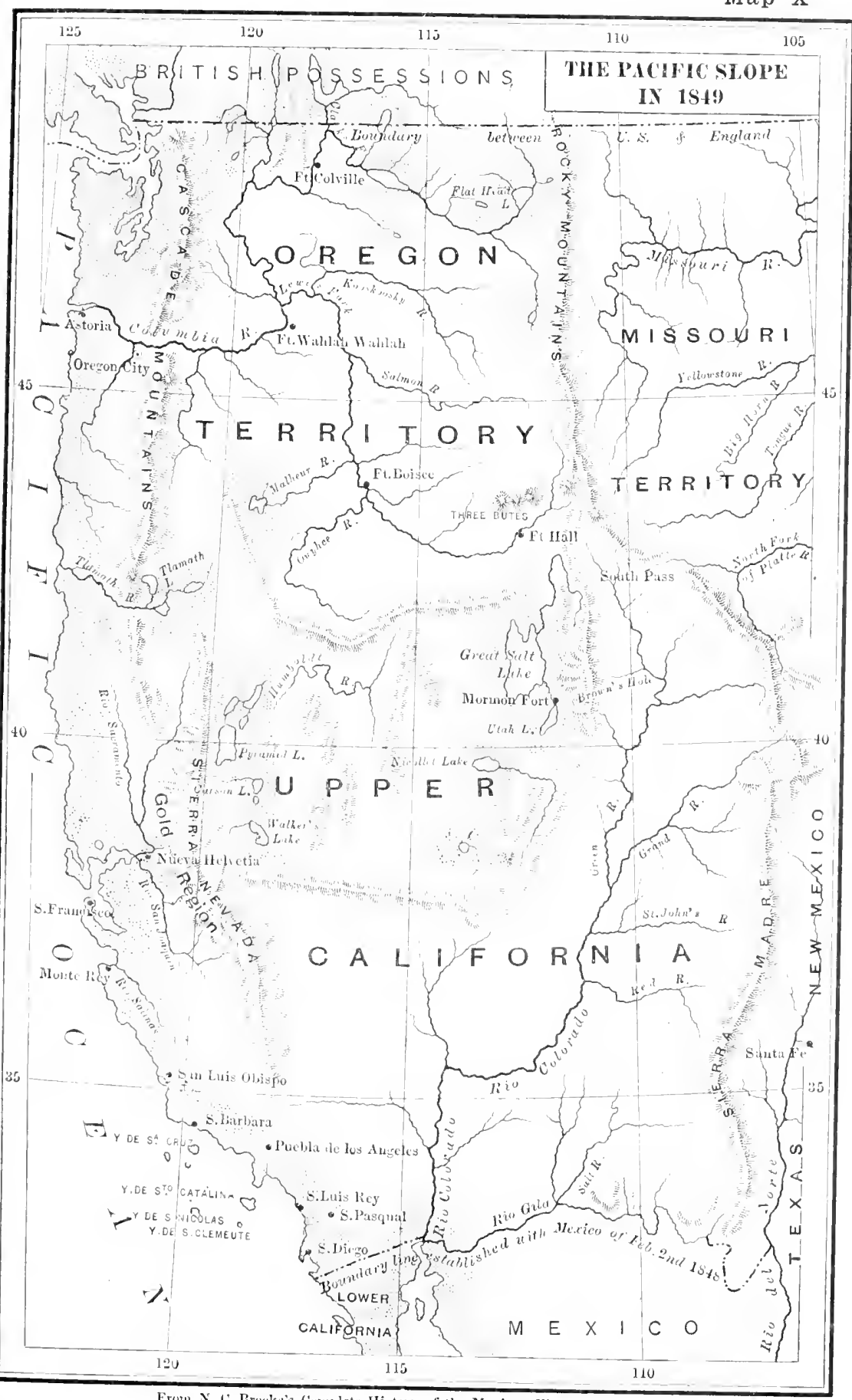

Frum X. C. Bruaks's Couplete Ulistory of the Mexican War published in 1819. 



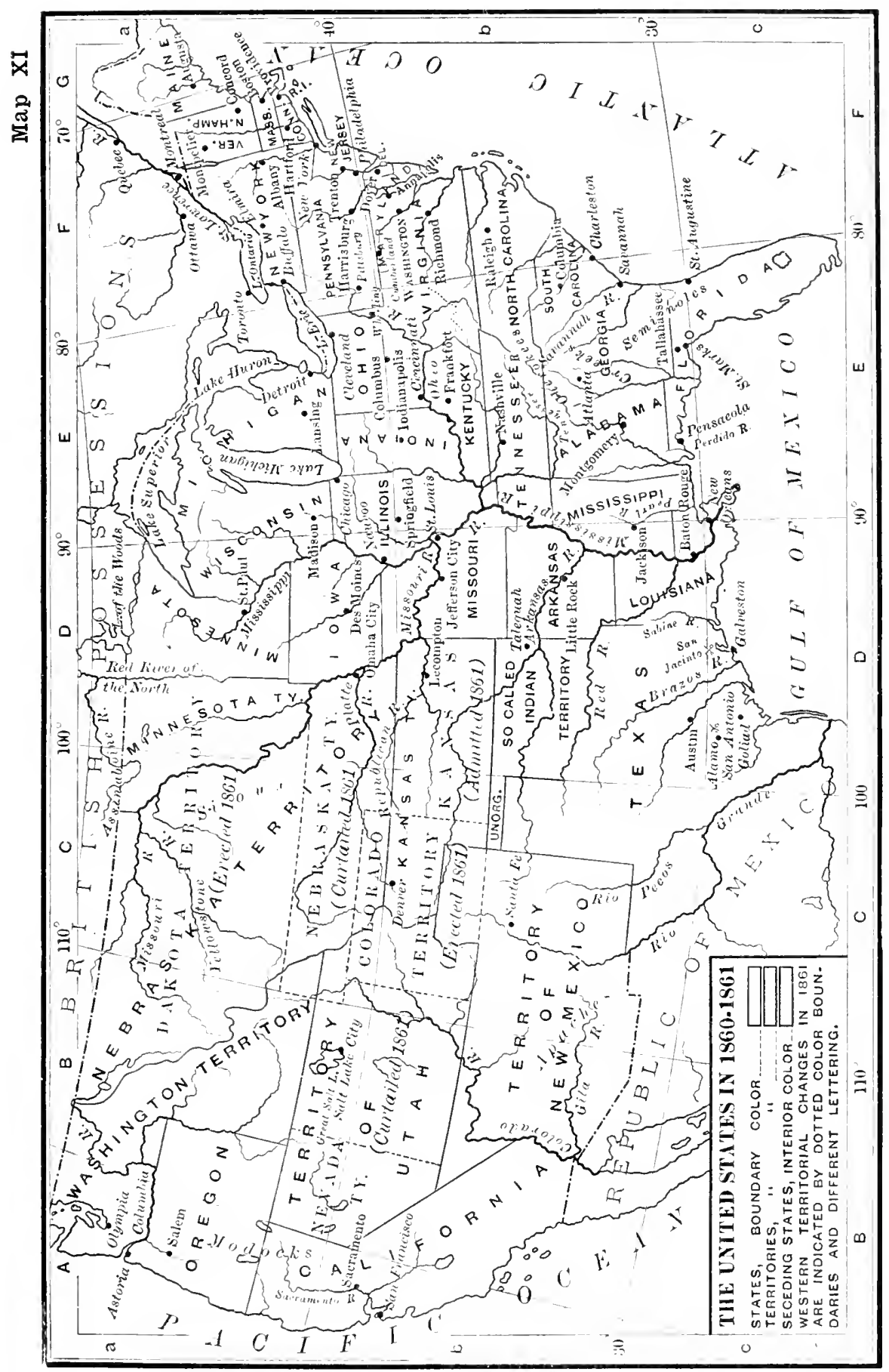



.Map XII

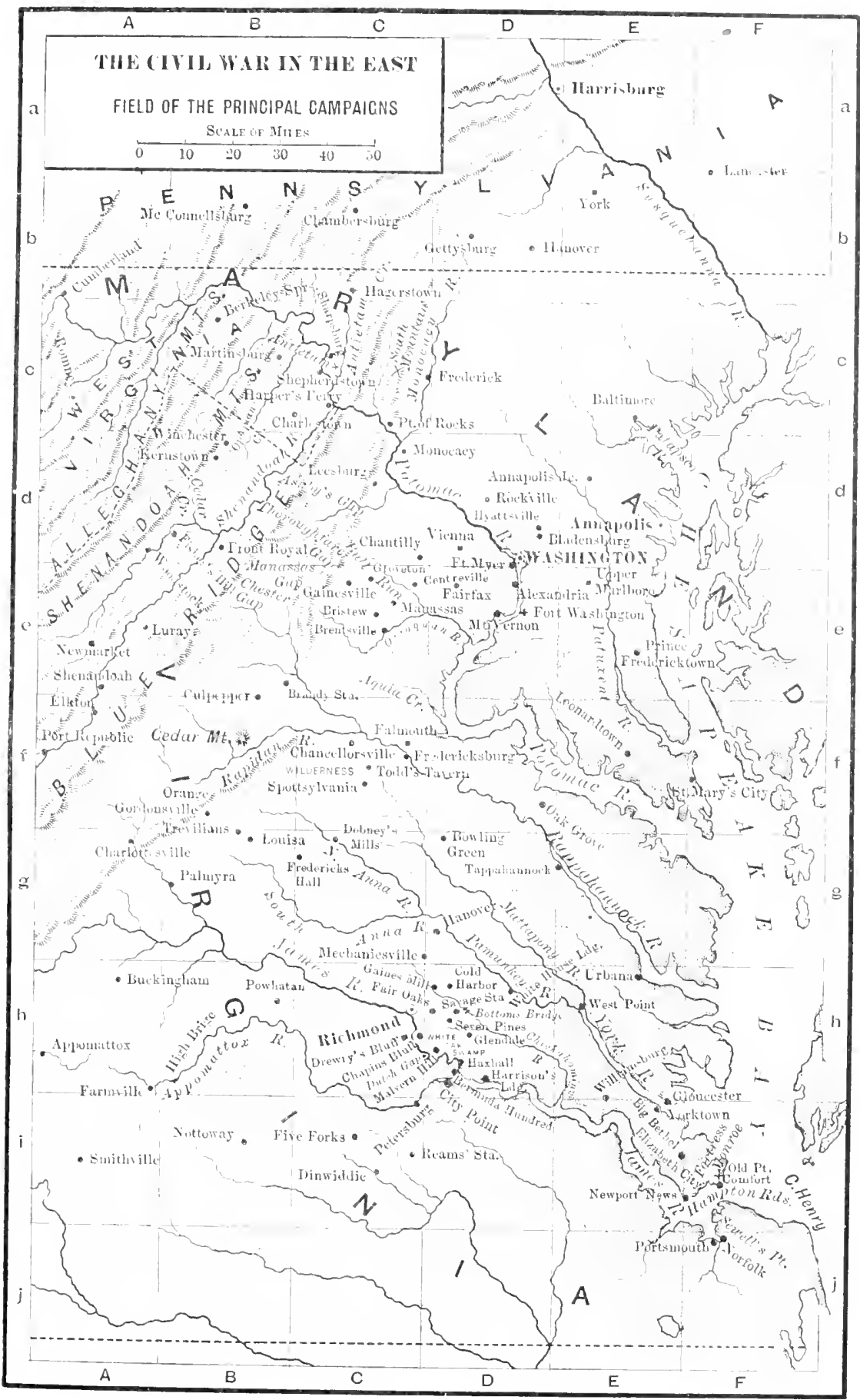






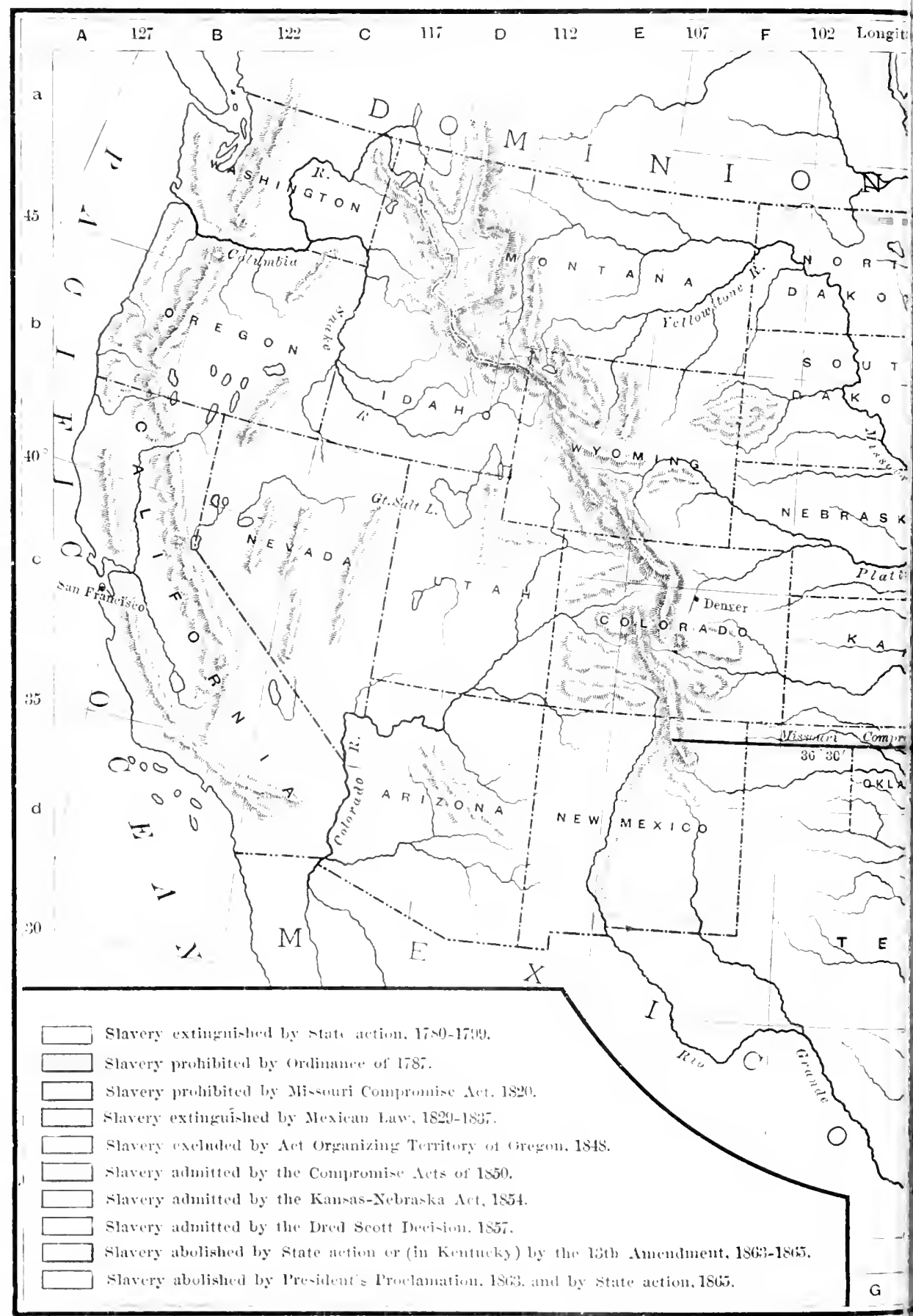




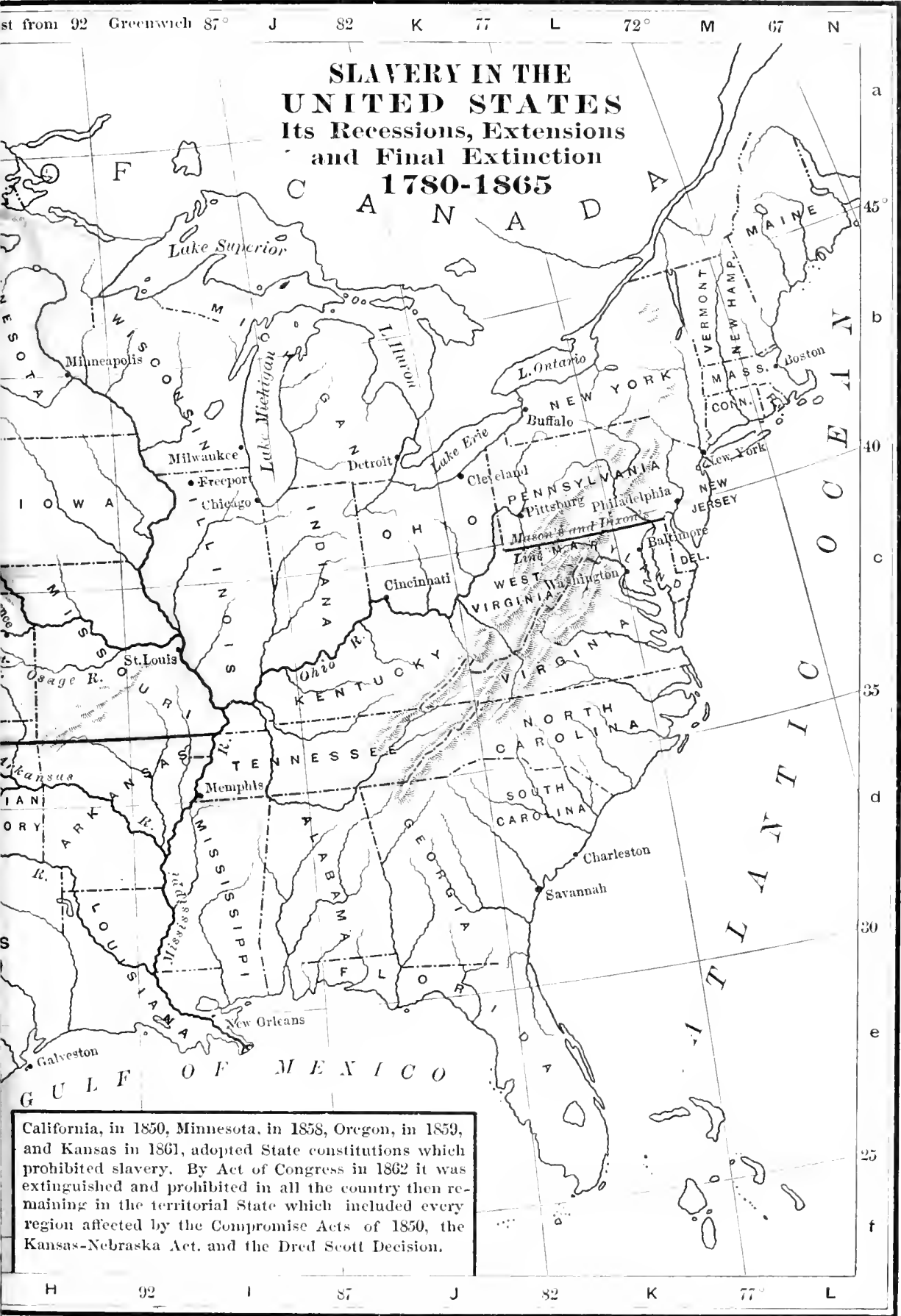






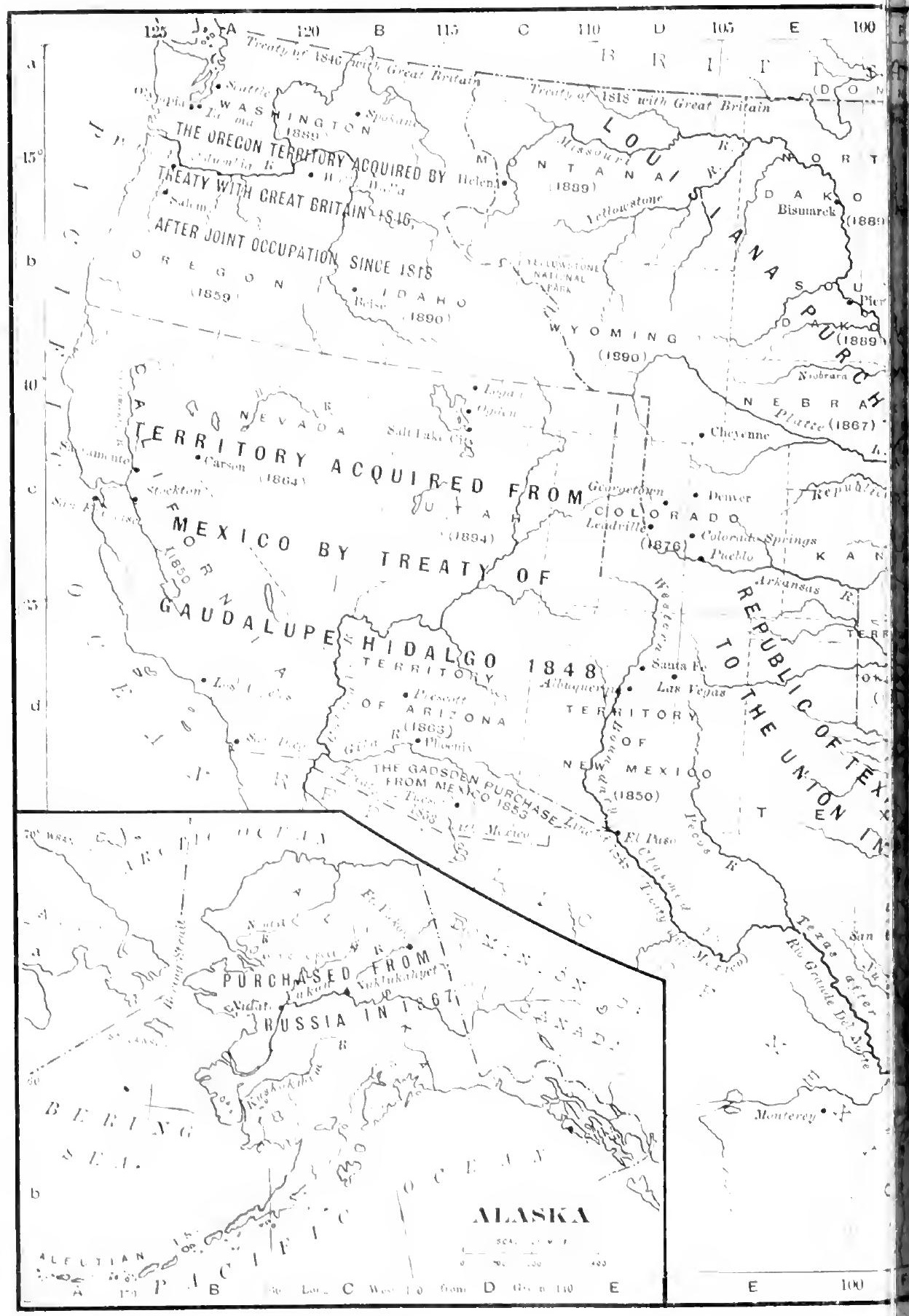





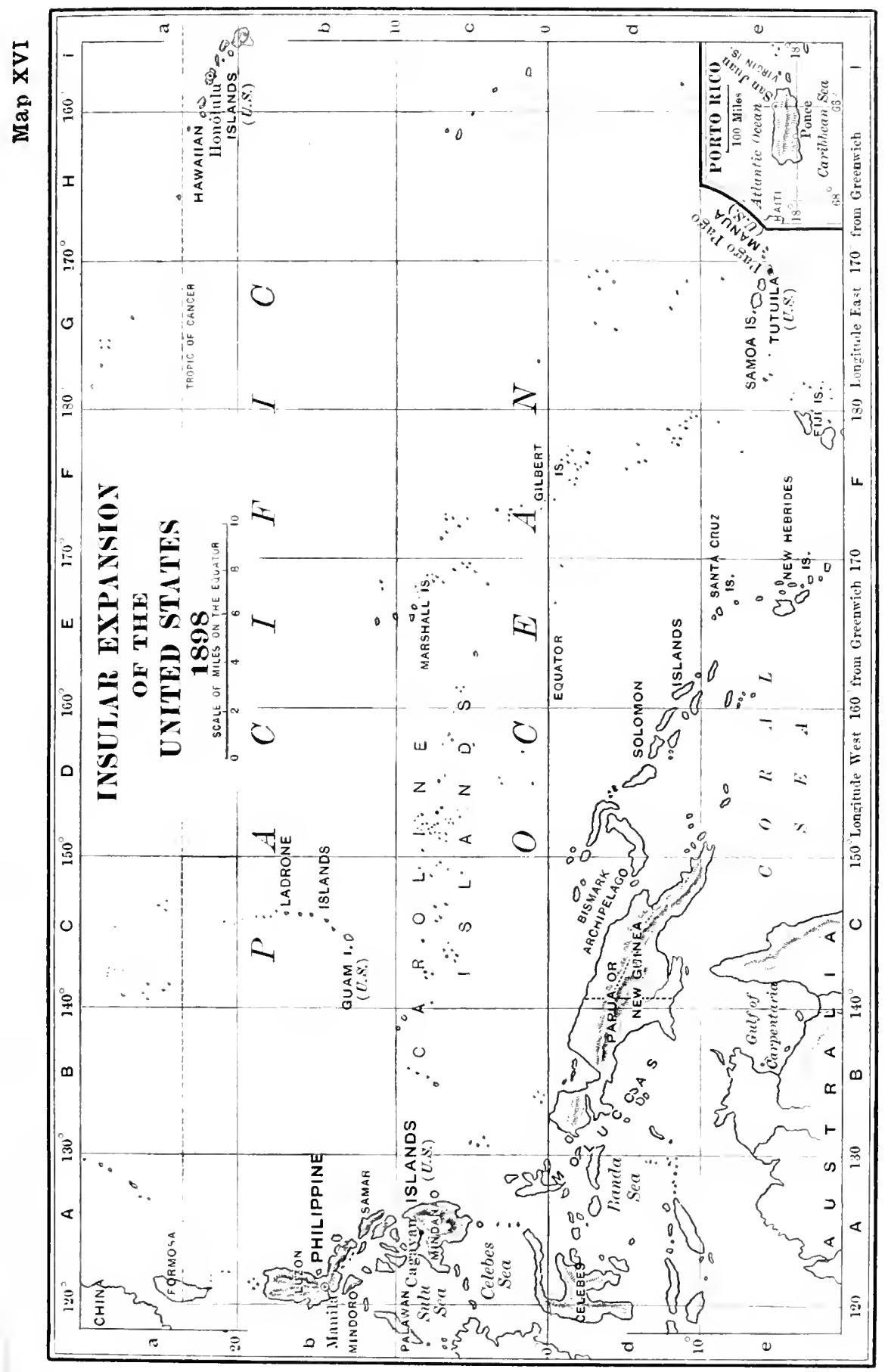



Elements of the POPUIATIOY of the

CNITED STA TES

Their growth from

1790 to 1890

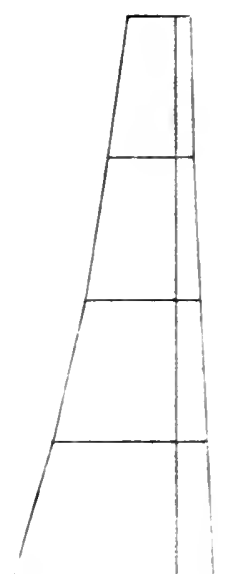

730

1800

120

225

1830

1840 



\section{HISTORY OF THE UNITED STATES.}

\section{INTRODUCTION.}

DISCOVERY AND EARLY EXPLORATION OF AMERICA.

The Voyages of the Northmen. In a certain sense it is right to credit Columbus with the discovery of America; for his voyage made the western hemisphere known to Europe, and led to its possession by peoples from the other side of the world; but he was not the first navigator from Europe who saw and touched American shores. There is no longer a doubt that bold Northmen of the tenth and eleventh centuries, who had made their way from Norway to the Orkney and Shetland islands, and then to the Faröe Islands, Iceland, and Greenland, did finally sail on toward the west and find America. The first to do this is said to have Leif been Leif Ericson, or Leif, son of Eric the Red, Ericson. whose voyage was made in the year rooo, with a single ship and a crew of thirty-five men. Others followed, and a colony was attempted, at some place which Leif had named Vinland, because he found wild grapes there, as well as good timber, which the Greenlanders and Icelanders desired. The colony failed, and further voyages beyond Greenland were given up; but the story of what had been done and seen in an unknown land survived. So far as is known, that story was not put into writing, among the "sagas," or narratives of the Icelanders, until the fourteenth century, more than three hundred years after Leif made his voyage. Historical accuracy in the saga is not, therefore, to be sup- 
posed: but many reasons exist for believing that its main statements are true.

Gionsuphical ldias in the Fiftichth (intury. If Icelanders or any others knew of a world beyond the Atlantic before Columbus made his way to it, their knowledge does not seem to have reached any in Emope who gave it thought, and it had no effect on geographical ideas. Those ideas were prepared already for the undertaking of Columbus, since many learned men. from the time of Aristotle, had believed the earth to be a globe, and that one might go westward as well as eastward to Asia, if the great ocean could be traversed, and if no other obstacles were found. In fact, the project of a royage westward, to seek the Asiatic coasts on the other side of the world, was urged on the king of Portugal by Toscanelli, a famous Italian astronomer and geographer, in 1474 , when Columbus, then in l'ortugal, most probably had his interest in the subject first roused. It is not for originating the thought of such a rovage that Columbus deserves his great fame. hut for acting on it and giring effect to it. with a courage and a resolute perseverance which nothing could defeat.

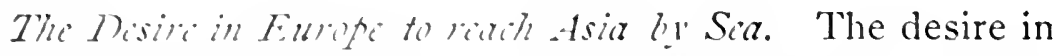
Europe to reach southern and eastern Asia, and the islands In that part of the globe. by sea, had been growing for years. China (then called Cathay). Japan (Cipango), India, and the islands south of it. were the countries out of which came a very large part of the chief luxuries of the age, such as spices. gums, precious stones. ivory, ebony, cotton fabrics, and silks. They were countries about which many fables were believed and few facts known; they were supposed to be kingdoms of measureless wealth. For centuries the grand prize of commerce - the greatest of all sources of wealth orem- had been the trade of Furope with those regions of rumd the Far bast. carried on over land-routes from the trith the Red Sea and the Persian Gulf to the Mediterranean Enst. and the Black Sea. and managed by merchants of Alexandria. Constantinople. Venice. Genoa, and other Medi- 
terranean cities. But the old Asiatic land-routes of that trade, and the whole eastern part of the Mediterranean, had fallen entirely, at last, under the control of the Turks, who capped their conquests by taking Constantinople, in $\mathbf{1} 453$. Moreover, commerce on the western Mediterranean was harassed by increasing swarms of pirates from the Parbary coasts. If a practicable ocean-route to the East did actually exist, every year added urgency to the need of its discovery and use.

But though Europe, in the last quarter of the fifteenth century, was shaking off the torpid ignorance of the Middle Ages, the spirit of enterprise was not yet easily waked. One man, in Portugal, a son of the king, had been moved by that spirit long before. This was Prince Henry, called "the Navigator," who spent his life in promoting Primre expeditions down the west African coast, to find the southern end of that continent and sail round it to Jortieg'ו'l. the lands of the East. From I4I 8 to $1_{4}{ }_{3} 3$, when he died, Prince Henry strove at this work, sending ship after ship; but the farthest point they had reached at his death was a little beyond the Gambia River, - not a fourth of the distance to the goal at which he aimed. He had trained the Portuguese, however, for tasks of ocean exploration, and they did not give them up. They pushed their voyages down the African coast, and began to think, moreover, of the practicability of reaching the samé end by a westward voyage.

The Voyares of Columbus. Maritime enterprise was at this stage in Portugal when, at some time between 1470 and 1474 , Christopher Columbus, the Genoese mariner and map-maker, came to Lisbon and found employment there. It is evident that the project of a voyage westward to the Indies took possession of his mind soon after he reached Lisbon, if it had not done so before; for he wrote to 'Toscanelli in 1474 , seeking advice and information, and received an encouraging reply. The means for carrying out his project, however, were not to be obtained in Portugal, and he went to Spain. After many years of weary effort in the two countries, he won Queen Isa- 
bella of Castile to belief in his plans. An agreement was colum- signed in the spring of 1 fo2. under which he set bus and sail from Palos on the $3 d$ of the following August, Isobrlla. with a little tleet of three small caravels, not one of which was fit for an Atlantic royage.

The ships furnished to Columbus had been taken for the expedition from unwilling owners by royal command ; debtors and criminals had been released from prison to make up some considerable part of a reluctant crew: and it is splendid proof of commanding qualities in the wreat explorer that he was able, in such circumstances, to keep mutiny suppressed for ten weeks. every day of which was changing the fears of his men into despair. Before September ended he was in extreme peril from the murderous thoughts that were working in the minds of his crew; yet his strong spirit kept them in awe until the night of the ith of October (Old Style. being the rand zoth, New Style), when a light was seen, which discor- indicated land. At two oclock next morning the ercd. land itself was in view, and at daybreak the happy explorer, with many of his companions, now penitent and admiring. Went on shore in formal state. and took possession in the name of the queen of Castile.

Columbus found himself on a small island, now known to have been one of the Bahamas: but which of those islands it was is a question in dispute. He supposed that he had arrived in the neighborhood of Cathay: and when, cruising southward, he coasted Cuba and reached Hayti, he concluded the latter to be Cipango (though he named it Espanola - Little Spain), and the former to be a part of the mainland on the Asiatic side of the world. He was puzzled by not finding the cities and the splendors he expecied. but does not seem to have been shaken in his belief. His explorations were checked on Christmas diy by the wrecking of his principal ship, and this decided him to return to spain. He reached Palos on the I 5 th of March, I 493 , after a stormy and perilous voyage.

The return was triumphant; the joy and pride in Spain 
were intense; the excitement amongst navigators and geographers, when news of what Columbus had accomplished went slowly through Europe, must have been very great; and yet nobody realized what he had

The

neves ine

Europe. done. Nobody suspected that he had found a New World. He was supposed to have reached, as he himself believed, some undetermined part of eastern Asia, which might be called vaguely " the Indies;" and the lands of his discovery were so described. It followed naturally that their inhabitants were called "Indians ;" and thus the aboriginal people of the western hemisphere received a meaningless name.

To secure and establish Spanish sovereignty over the countries which Columbus had discovered, and over further discoveries in the western ocean, an immediate application was made to the pope for such a grant as the head of the Christian church was then believed to have power to make, in disposal of heathen lands. Previous popes had made similar grants to the kings of Portugal, covering every regrion of heathendom that their ships might reach. The reigning pope, Alexander VI., now issued two bulls, or papal edicts, on the $3 \mathrm{~d}$ and 4 th of May, 1493 , vesting in the Spanish crown a like sovereignty over coun:

Grant of land by the pope. tries then or thereafter found in the western ocean, west of a meridian line drawn roo leagues west of the Azores and Cape Verde Islands, so far as such countries were not occupied already by Christian powers. Thus Portugal and Spain had papal authority for claiming all the regions of the earth which Christendom was then beginning to discover; and papal authority in those days was hard to dispute. By a treaty signed at Tordesillas, in I 494, the Spanish and Portuguese sovereigns moved the dividing meridian between their papal grants to a point 370 leagues (about I I o geographical miles) west of the Cape Verde Islands, making it, according to later computations, the meridian of $47^{\circ} 32^{\prime} 5^{6 \prime \prime}$ west of Greenwich.

To Columbus his grand discovery brought nothing but a harassed and embittered life. He returned to Hispaniola in 1493, with a fleet of seventeen ships, bearing a large party of 
eager adventurers, who expected to receive fortunes at his hands. He explored diligently for the great cities

('olum-

bus:s

sceond

'o!yage'. and rich peoples of Cipango and Cathay, and they were nowhere to be found. He discovered Jamaica and other islands, but they are him nothing that he sought. A little sold was picked up, here and there, but not much. His disappointed colonists grew angry and vindictive, and the sorely tried viceroy (so he had been commissioned) had to use his authority with a hard hand. Some of the discontented stole ships and returned to Spain, with charges against him. Then came war with the natives, already plundered and oppressed.

In the spring of 1496 Columbus returned to Spain, and was absent from America for more than two years. On the voycolume age which brought him back, in 1498 , he took a more lins's third roysuge. southerly course, and came to the island of Trinidad and the coast of South America, at the delta of the Orinoco. He saw that a river which discharged so much water as the (Orinoco must flow through a continent; but he never doubted that the continent was either Asia, or a neighbor to Asia. lying close to it on the south. He reached his colonglate in the summer. and found affairs there in worse condition than when he left. For two years he struggled with rebellion, fomented and encouraged by enemies at the Spanish court. The latter succeeded finally in having one Bobadilla

colum-

bus in sent out to inrestigate and deal with the troubles, chains.

and the powers given to that official were such that he sent Columbus home in chains. The foul indignity was somewhat repared by Queen Isabella, who gave a kind reception to the great explorer, now old and worn; but he was never restored to the viceroyalty of the lands he had added to the dominions of Castile.

He was giren, however, a small and poor fleet of four caravels. with which to make a fourth exploring royage. Colnmbuss's death. This time. sailing in May, 1502, he found the Central American coast, and examined it for some distance, attempting to establish a colony at Veragua, without 
success. In returning to Spain, which he reached in November, $1_{504}$, he suffered great hardships; and on the 20 th of May, 506 , he died.

The Rounding of Africa by the P'ortuguese. Columbus died in the belief that he had accomplished what he set out to do, reaching eastern Asia by sailing towards the west. Meantime, the Portuguese explorers had actually realized the dream of Prince Henry, and the national ambition of eighty years, having sailed round Africa into the Indian Ocean and so to Hindustan. The first of their captains to reach and pass the southern extremity of the African continent was Bartholomew Diaz, in 486 , but he did no more. In I 497-98 Vasco da Gama made the complete voyage to India, reaching Calicut, on the Malibar coast. 'This achievement had effects of more immediate impor-

Siarthol"mentw Dirre (I) Vaser, ale Gisemer. tance than those coming from what Columbus had done. It turned the rich trade of the East into a new channel and into new hands. It practically ended the sreat commercial career of Venice and other cities of the Nediterranean Sea. It seated the wider commerce of the world on the Atlantic coast of Europe, and that change had much to do with the subsequent rise of Holland and England as the leading maritime powers.

The Voyages of Fohn Cabot. Columbus was alone in the glory of his voyages to the western waters of the Atlantic until 1497. 'Then John Cabot, an Italian, residing at Pristol, England, commissioned by the English king, Henry VII., to explore the wide ocean, steered a course so straight westward that it brought him, as is now believed, to the coast of Labrador. He sighted the coast on the $24^{\text {th }}$ of June, 1497 , being the first of the fifteenth

\section{Jiscror-} rry of the Amririreme rosetiveret. century explorers to see the American mainland. In the next year he commanded a second expedition, which is believed to have reached the American crast at some point south of Labrador, and skirted it thence to Florida; but the scant records of the voyage are obscure. Until recently it was understood that this second voyage was commanded by 
Sebastian Cabot, a son of John; but research has substantially proved that John Cabot was the explorer in both years. The Cabot discovery and coasting exploration gave grounds to the English crown for claiming sovereignty over most of the North American continent, though the claim was not put forward for many years.

Tesplizs, and thi Nimbing of Ameriat. Another Italian navigator. Amerigo Vespucci (or Americus Vespucius, as his name was latinized), is believed by some historians to have coasted a long stretch of the southern part of North America in $1+97-9 S$. It is well known that Vespucius made royages to America in I 499 and I50I-02: but. in a letter that was published in Europe not long after he returned from the latter royge, lespucius gave accounts of an earlier expedition, respu- in $1497-9 S$, which he had accompanied as pilot and cius.: astronomer. His story of it led Humboldt and rmmuges. others. in later times, to believe that he had then explored Central and North American coasts from Honduras to Florida. Other historical investigators have satisfied themselves that Vespucius never made the royage in question. and that his account of it is false. We will not attempt to decide which riew is correct.

Americus Vespucius had scholarly friends in Europe who made his royages widely known. One of them, Martin Walclseemuiller, a professor of geography at St. Dié, "millwers Lorraine, in a book published in 1507 . suggester sugnes- that the continent (South American) coasted by
tim.

Tespucius in 1501-02. which he had described as ". Mundus Norus," a New World, should be named in his honor. Auerici. It was supposed to be a country quite distinct from the lands that Columbus had found, the latter being Asiatic, while Vespucius, going beyond the equator, had come upon a world that the ancients never knew. Mapmakers and globe-makers took up the suggestion, and, without any common asreement or formal action of any kind on the subject. it came to pass that the name AMERICA was fixed, first to the southern and then to the northern of the two continents of the New IVorld. 
Early Explorations and Conguests. Many years passed after the death of Columbus before the Spaniards, gold-hunting and exploring around the (julf of Mexico and the Caribbean Sea, could be shaken from the belief that they were in Asian lands and waters. Yet Vasco Nuñez de Halboa, then leader of a settlement at Jarien, crossed the mountains of the narrow isthmus in 1513 , saw the great Pacific Ocean, and waded into its waters to proclaim that he took prossession of the whole sea for the kings of

Jiscroverysof the Pracific. Castile. In the previous year, Juan Ponce de Leon explored Florida (seeking a fabled Fountain of Youth), and learned something of its extent. In I 519 Alvarez de Pineda entered the mouth of the Mississippi and was on the lower waters of the enormous stream for no less than six weeks. In the same year Hernando Cortes landed on the Mexican coast and began that rapacious con-

Pronce de Leon, Pineda, Cortes. quest of a half-civilized people, the story of which is more thrilling than any romance. Py that time it was impossible not to suspect that the mass of land which had such coast lines, such varieties of perple, and so stupendous a river, might be one that blocked the sea between Europe and Asia, and signified a larger girth to the world than geographers had been reckoning upon. Such suspicions were more than strengthened when a $f \in w$ survivors of the marvellous and terrible voyage of Magalhães (called Magellan in English speech) returned to Spain in 1522 , with news of an actual circumnavigation of the globe, - of the discovery of Magellan's straits at the southern end of Vespucius's New World; of the crossing of the great "South Sea;" of the finding of the Philip-

\section{Mregel- \\ laris voyuge roured}

the verrld. pines and the Moluccas, or Spice Islands; and of the homeward voyage thence by the Cape of Good Hope. The existence of a wide ocean between the imagined Indies and Cathay of Columbus and the real Indies and Cathay began to be un. derstood. Hut no conception was yet formed of the magnitude of the lands which lay between the Atlantic and that farther sea. The new continent was believed to have not much 
breadth, and possibly to be divided by straits, through which a search passage from ocean to ocean might be found. It for a then became the main object of exploration for the north"estpas- next hundred years to find such a "northwest passuge. sage," and, after every inlet, bay, and river mouth, south of the Arctic Circle, had been probed, the search for it went on for two more centuries in the farther north.

The French did not enter the field of exploration until I 524 , though some of their hardy fishermen had been resorting to the Newfoundland banks for a score of years, at least, before that date. It was an Italian, Verrazano, in the service rewe- of Francis I., king of France (then at war with zano. Spain), who visited some parts of the American coast in the year named above, possibly sighting the mouth of the Hudson River, and touching New England shores; but little is known of his voyage. Ten years later (I534) a French explorer, Jacques Cartier, entered the Gulf of St. Lawcurtier.
to the Pacific Ocean, or South Sea. Approaching winter drove him back, but he returned the next year and sailed up the St. Lawrence River, until stopped by the rapids, where the city of Montreal arose in after years. In I54I an attempt was made by an enterprising French nobleman, Jean Dela François de la Roque, lord of Roberval, to colonize Roque. the country discovered by Cartier, and the latter was joined with him in a patent obtained from the king. After Cartier and Roberval had each in turn passed a winter on the St. Lawrence, they abandoned their plans.

One Narraez, a Spaniard, landed an expedition of 400 men, with So horses, on the northern coast of the Gulf of Mexico, varrac: in 528 , hoping to find another such prize of empire and plunder as Cortes had won. At the end of a month of fruitless marching the party built boats and coasted to the mouth of the Mississippi, where many of them were wrecked and drowned. The remainder were cast ashore at some distance farther west, and all perished except three Spaniards and a negro, who were captured by the Indians, 
but contrived to make themselves feared as sorcerers, and were spared. For nearly eight years they wandered with the natives, until, in 1536 , they reached a Spanish outpost in Mexico, having journeyed about 2000 miles. They are supposed to have travelled through Texas and Chihuahua to northeastern Sonora. An account of their extraordinary adventures was published afterward by one Crebeza de Vrecre. of the party, Cabeza de Vaca, whose later career showed him to be no ordinary man.

Cabeza de Vaca's experience, proving the magnitude of the region north of the Mexican gulf, probably stimulated a new expedition to explore and possess it, which started from Havana, Cuba, in I539, with Fernando de Soto in command. Soto landed in western Florida, marched northward to the Savannah River, then westward, being desperately resisted by the Indians, to the Yazoo, where sissippi. he spent the winter of $x_{54} \mathrm{r}-42$. In the following spring he crossed the Mississippi, marched up its western bank to some point probably beyond the Missouri state line, and then turned back. On the return march he died. A little more than half of his men made their way to Tampico, Mexico, by river and coast.

Another expedition, resulting partly from Cabeza de Vaca's reports, and partly from other stories that were afloat at that time, started northward from Mexico, under Francisco de Coronado, in $\mathbf{I} 540$, to seek for seven wonderful cities, supposed to be hidden far away in that part of the land. An adventurous monk had seen them from a distance, in the previous year, and imagined splendors in them which did not correxist. Coronado found these "seven cities of $\mathrm{Ci}$ - mudo. bola," as they were called, and they proved to be, as is now known, the pueblos of the Zunis, in New Mexico, one of which is still occupied by the tribe. Interesting as those pueblos are, they offered nothing that Coronado desired; nor did he find anywhere the treasure that he sought, though he marched far beyond them, through Colorado, to the east of the mountains that are full of silver and gold. 
Europe and America in the Sixteenth Century.

Efficts in Europe of the late Geografhical Discoveries. The discovery of America and the finding of an ocean route from western Europe, around Africa, to the eastern seas, were events which produced extraordinary effects in the following age. 'Their new revelation of the world was a surprise to men's minds, which kindled imagination, wakened ideas, shattered many old bigotries of ignorance, emboldened both action and thought, and set a vigorous spirit of adventure and enterprise astir. By shifting the main seats of navigation and commerce from the Mediterranean to the Atlantic coast of Europe, they brought fresh races into the lead of the world's work.

The Decay of Spain. The Spaniards and Portuguese, who won possession of the new fields at first and held them for a time, were peoples of high capacity, but unfortunate circumstances were combining to bring a blight on their national life. Nine years before the voyage of Columbus, the The In- misguided piety of Queen Isabella had established quisi- the terrible tribunal of the Inquisition, which soon tion. crushed intellectual freedom in Spain. After the death of Isabella (1504) and her husband, King Ferdinand ( 1516$)$, the united Spanish crowns passed to a prince, their grandson (called Charles I. in Spain, but better known as the Emperor Charles V.), who inherited additionally the wide dominions of Austria and Burgundy, the latter including the rich provinces of the Netherlands (now Holland and

Emperor Belgium), and who was elected in 1519 to be king of the" Germany and emperor of what claimed to represent Fifth. the great empire of old Rome. Raised thus above all other sovereigns of his day in prestige and power, this imperial king was able to destroy every vestige of political freedom in Spain, and that unhappy nation went slowly to decay, under the double despotism in state and church.

It was ill fortune that led the Spaniards to those parts of America in which the precious metals were found, for the 
ruin of their country was hastened by the cruel plundering of Mexico and Peru. They could not keep the wealth of gold and silver that they gathered; it ran through their hands to enrich other people more than themselves. It paralyzed thrifty industry and substantial enterprise; it seduced and corrupted all classes; it was worse than wasted by kings and courts. The Spaniards

spain. were never colonists of their American possessions, in the proper sense of the term ; they were conquerors, - their object was not to develop, but to drain. It is more than possible, however, that if any other of the European peoples had been first to find the mines of the Aztecs and the Incas, the result would have been the same.

Rise of the Dutch. In the first years of the reign of that emperor, Charles V., who was king of Spain, the religious movement known as the Protestant Reformation was begun. He resisted it in all parts of his dominions, but it spread with rapidity almost everywhere except in Spain, where the heavy hand of the Inquisition suppressed it at once. The same dreadful engine of persecution was set to work in the Netherlands by Charles, with a different effect. Under him and his son, Philip II., the provinces so called were made to suffer many years of malignant and

\section{Plitip}

the

second. horrible oppression, until they were driven to revolt. 'Then, in their struggle for freedom, they showed a fortitude, a heroism, a vigor of spirit, that have never been surpassed. They not only won their independence in the end, but, even in the midst of their long battle with the greatest power of the age, they mastered most of the commerce of the very seas which the Spaniards and Portuguese were claiming as their own. Portugal, by falling uncler the rule of Philip II., shared the Spanish blight, and surrendered her brief control of the trade of the East to the Hollanders, or Dutch, who shared it with the English at a later day.

England and the Enorlish. - Origin of Puritans and Independents. - First Colonizing Attempts. England, at the time of the discovery of America, had just passed through a long 
series of civil wars, by which the ancient liberties of the people and the parliamentary franchises that protected them were impaired. The sovereigns (of the Tudor family) who then acquired the crown were able to create a more absolute government than the country had known before, and the second of their line, Henry VIII., became one

nefor-

mation in England. of the worst of the despots of a singularly despotic age. He opposed the Reformation with violence; but, when the pope of that day refused to annul his marriage with a queen whom he wished to discard, he forced the church in England to cast off its former allegiance to the Roman pontiff, to assume an independent character, and to acknowledge the king as its supreme head. Under his son, Edward VI., and his daughter. Elizabeth, the Church of England, thus organized independently, acquired a character much nearer to that of the Protestant or Reformed churches of the continent than Henry VIII. had desired; but it retained more of the old forms of worship than many of its clergy and lay members approved. In the time of Queen Elizabeth there grew up a strong party in the church which aimed at Rise of further changes, and this party of the Puritans, as Puritans they were styled, bore a part of great importance in dependents. the subsequent history, not of England alone, but of English colonies in America as well. A smaller religious party, called Separatists, or Independents, went further than the Puritans, withdrawing from connection with the established national church, denying the authority of government in matters of religion, and claiming the right of each Christian congregation to organize and rule itself. Some of these, too, made an important appearance in subsequent American history.

Circumstances, in the reign of Elizabeth, brought the English into conflict with Spain. Long before the conflict came to an acknowledged state of war. Spanish settlements in America and Spanish ships laden with the spoils of the New World were attacked and plundered in a more than half piratical way. It was in that lawless warfare with the Span- 
iards that the English really entered on their career of power as a maritime people; and it was then that they began to put forward their own claims to America, founded on the voyages of John Cabot, the first explorer known to have reached the North American continent and coasted its shores. The practical assertion of those claims appeared first in a royal patent issued to Sir Humphrey Gilbert, in 1578 , empowering him to occupy and colonize such territory in the New World, "not actually pos-

First Euglish attempts to forrual rolomires. sessed by any Christian prince," as he might choose to take. Sir Humphrey perished at sea, and his undertaking came to naught. He was followed in it by his younger halfbrother, Walter Raleigh (afterward Sir Walter), who spent his fortune in repeated attempts to plant an American settlement that would take root. Raleigh made a careful beginning in 1584 , when he sent out two

Sir

Wrolter Rerreighe. ships, under capable captains, to explore and choose a site. They found what pleased them on the island of Roanoke, and made a report so favorable that Raleigh, in the following year, placed a colony of 108 persons there. These people remained a single year, and then, being visited by a cruising fleet, commanded by the famous English rover, Captain Drake, they begged to be taken home. Raleigh, undiscouraged, sent a second colony to the same ground in 1587 . For three years thereafter, in consequence of the war with Spain, this settlement was reached by no ship, and when, in $\mathbf{1} 59^{\circ}$, the island was visited once more, not a vestige of the unfortunate colonists could be found. Their fate is unknown; but a surviving remnant of the Indians who were neighbor to them (the Croatans) are said to show signs even now, in their names, their language, and their bodily features, which intimate that some, at least, of the lost colonists were taken into the tribe. Raleigh's means had been exhausted, and colonizing enterprise became nearly extinct in England for a score of years. But English claims to the greater part of North America were maintained, and the whole region

Virginia. was named Virginia, in honor of the English "virgin queen." 


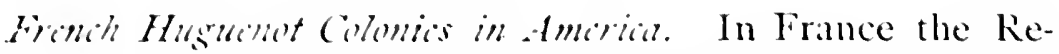
formation movement of the sixteenth century wave rise to a long series of religious civil wars between the Protestants (called Huguenots) and the (atholics. who adhered to the ancient church and its papal head. 'The latter prevailed, and the Huguenots, at difierent periods, were made to suffer severely at their hands. As a means of escape from their troubled life in France. emigration to America was recommended by Admiral coligny, the Huguenot leader, and three attempts at colonization were made, in $1555,5_{5} 62$, and 1564 . The Canada region, which France clamed as the discovery of Cartier, was barred to them, and they were forced to trespass on the clams of some other nation in secking a home. Their first undertaking was on the bay of hio de Janeiro, in coli- Brazil, where their settlement was suppressed by the gn!y sol- Portuguese. Coligny then planted a colony on Port onies. Koyal Sound, or Broad kiver. in what is now South Carolina; but it endured the hardships of the wilderness only one year. His third colony was placed on the St. John's River, in Florida, and this, the most sadly fated of all, was savagely destroyed by the spaniards (1565). who butchered every man, woman, and child, about seven hundred in all. That bloody deed gave no offence to the French govermment, but was arenged by a private citizen. Dominic de Gourgues, who recaptured the forts which the Hugnenots had built on the St. John's, and slew the Spaniards in them, to the last man.

\section{The Aboklowal Inhantants of North America.}

Stati uf the Thits athen First Known. Little or nothing is known of the life of mankind in this western hemisphere before Columbus made his memorable royage to it in 1492. Some reasonable conjectures are founded on facts learned then and since, but no actual knowledge of the aboriginal people of America prior to that time can be said to exist. Numerous tribes of a race very diffecent from any scen in 
other parts of the world were found inhabiting the two continents and the neighboring islands, and, while most of them were savage or barbarous, a few had arlvanced to the half-civilized state. These latter were bersinning a rude invention of writing by pictures mixed with signs, but they had not yet made it a means of E'rreliest linerve: let!en: Imians. preserving the records of their past. In the proper sense of the term history, the History of America bersins, therefore, with the arrival from Europe of people who practised the recording art. Behind it lies an undoubtedly lons "prehistoric" time, of which some glimpses have been obtained by a careful study of relics, remains, traditions, myths, languages, customs, and religious beliefs. These furnish facts of a kind from which much can be inferred that is protsable, but little, after all, that is not open to frequent questionings and dispute.

The tribes and confederacies of tribes found in different parts of the western continents and islands differed widely in character, in condition, and in language; but nearly all scientific men now believe that they came from one origiu op stock, and that no other stock or race had ever ex- Imdirms. isted in this part of the world. Furthermore, it seems to be a fairly well settled scientific belief that the race did not have its origin in America; but whence its ancestry came, and at how remote a time, are questions much debated, on slender grounds of fact. We will not enter the debate.

Until lately it was believed that large parts of this continent, especially in the great valley of the Mississippi, had been inhabited once by another more civilized perple, whrse imagined empire had suffered worse than the fate of Rome, being obliterated so entirely by invading barbarians that no relic remained, except a multitude of mysterirus artificial "mounds," scattered widely throughout the land. But speculation concerning those singular mounds and their builders is now silenced by the systematic and scientific study which the United States Bureau

Ho,"urls "morl merserrel breild ers. of Ethnology, organized by the government, at Washington, 
has brought to bear on the subject in recent years. It has been proved beyond doubt that the mounds in question are of no great antiquity; that they were the work of known aboriginal tribes; and that they signify no state more civilized than that in which those tribes were found. In some instances they were burial mounds; in others they were works of defence.

If the making of pottery is taken (as suggested by the late Mr. Lewis H. Morgan. in his work on "Ancient Society") for the mark of distinction between savage and barbarous peoples, the native tribes of North America were generally in the barbarous state when first known to the European world. A few would be classed as savages, but not low in the scale; a few more had risen to the rank of the half-civilized man. Not any had passed out of what is known as "the stone age" of The culture; the period, that is, in which weapons, tools, stone and other implements are made wholly or mostly of age. stone. Copper, found in its pure state and easily worked, had come into use in many parts of the continent; and even the hardening of copper into bronze, by an alloy of tin, is said to have been practised by some of the Mexican tribes, which had also learned the working of silver and gold; but, even among the latter, tools and weapons of stone remained in common use.

Many tribes, in many parts of the country, carried on some rude cultivation of the soil. Maize, or Indian corn, the one cultiva- cereal native to America, and cultivated more easily tion of than other grains, was raised extensively; other prosoil.

ducts were pumpkins, squashes, potatoes, and beans. These native articles of food were welcomed by the European settlers when they came, and have had importance in American agriculture and diet ever since. Another gift to the newcomers was tobacco, the liking for which was learned so quickly and spread so rapidly abroad that tobacco-culture soon became the most profitable industry of the New World.

In their labors and in the improvement of their modes of life the native Americans had no domesticated animals to give them help, except the llama of Peru. No beasts in the north- 
ern continent appear to have been capable of domestication, save the wolf, from the taming of which a poor species of dog had been obtained. The horse is found to have had a primitive existence in North America, but the species became extinct; the buffalo has proved practically untamable; and, in fact, the continent was singularly wanting in dumb helpers for man. Without

Lreck of domestic animirls. flocks and herds, or beasts of burden, the American race was handicapped seriously in its rise out of primitive conditions of life.

The tribes most advanced were found in Mexico, Central America, and Peru; but the state of culture among them is now known to have been much lower than formerly was supposed. The Spaniards who subjugated them misunderstood many things that they saw, and exaggerated many particulars, so that wholly wrong ideas of the native people, and of their social and political organization, were drawn from the early Spanish accounts. In Mexico, for example, they mistook a league or confecleracy of three dominant tribes for an "empire," and

Indians of Mexico and Pern. its war chief for an emperor or king. They mistook huge communal buildings, like the "pueblos" still existing in New Mexico and Arizona, - the fortress tenements of many kindred families, sometimes populated by thousands of men, women, and children, - they mistook these for palaces, and described them as evidences of royal magnificence and power.

The facts, placed now beyond doubt by recent studies, show a condition that can fairly be called half-civilization, among the Aztec or Nahuatl tribes of Mexico, the Maya-Quiché tribes of Central America, and the tribes of Peru. In agriculture and in some mechanical arts the Peruvians were the more advanced, and in their religious worship they were innocent of the human sacrifice and the cannibalism of the hideous Mexican rites; but written language, in which the Aztecs and the Mayas had made beginnings, was unknown to the Peruvian tribes. The skill of the three peoples in architecture was much beyond that found elsewhere in the New World. 
Linguistic Grouping of the Tribes. Many varieties of language were spoken by the native American tribes, most of which, still preserved among the survivors of the race, have been studied with care, especially since the formation of the Bureau of Ethnology, which directs those studies in a systematic way. The result has been to find relationships of language, or "families of speech," which classify the numerous tribes within the present territory of the United States into fifty-seven groups, the tribes in each group speaking dialects of the same tongue. These linguistic families or stocks are mostly small, more than half of the whole number being located in little districts on the Pacific coast. Some, however, were originally very large, and were spread over wide areas of the country; among such the following stood first:

r. The Algonquian stock. The many large tribes of this group were spread over the whole North Atlantic coast, as Algon- far south as North Carolina, and the whole interior quins. westward to the Mississippi (including Canada almost entire to the Rocky Mountains), excepting a region occupied by the Iroquois, or Huron-Iroquois, as described below.

2. The Iroquoian stock. The fierce, aggressive tribes of the Iroquois had forced their way into the heart of the AlgonIro- quian domain, and, when first known, were in possesquois. sion of territory covering the present State of New York (except on the lower Hudson) and most of Pennsylvania, with part of Maryland, northern Ohio, eastern Michigan, the Canadian border of lakes Huron, Erie, and Ontario, and the upper waters of the St. Lawrence River. Their footing on the St. Lawrence was not maintained. The tribe in possession of the Canadian peninsula, between lakes Ontario, Erie, and Huron, known as the Hurons or IVyandots, was Iroquoian, but at enmity with the Iroquoians south of the lakes.

In some respects, especially in political organization, the Iroquois were the most capable and the most advanced of all the natives found within the territory now covered by the United States. The five tribes (commonly called the Five Nations) of New York (Mohawks, Oneidas, Onondagas, Ca- 
yugas, Senecas) were united in a remarkable league of federal government, which might have given birth to a great Five Nadominating power, the seat and centre of an inde- tions. pendent civilization, if European intruders had not broken in upon its development when they did. According to Iroquois traditions, this league of the Five Nations (afterward made Six Nations when the Tuscaroras were taken in) had existed but a short time when Columbus and those who followed him came first to these shores. It is believed to have been formed about the middle of the fifteenth century, by Hiawatha, ${ }^{1}$ a famous chief of the Onondagas, who deserves to be ranked among the great statesmen of the world.

3. The Muskogean or Maskoki stock. This held most of the country south of the Tennessee and east of the MasMississippi, to the Atlantic and the Gulf. Its greater koki. tribes were the Creeks, the Cha'htas or Choctaws, and the Chickasaws.

4. The Siouan or Dakota family, whose large domain embraced nearly the entire western watershed of the Mississippi, from the Arkansas northward, and exSioux. tended beyond to the Saskatchewan.

5. The Caddoan or Pawnee family, whose territory was mostly south of the Siouan, in Louisiana, Pawnee. eastern Texas, and Arkansas.

6. The Shoshonean stock, the Shoshonean, Ute, and Comanche tribes of which ranged over a great part of shothe region between the Rocky Mountains and the shonean. Sierra Nevada, from northern Mexico to Oregon.

The tribes encountered by early European settlers and explorers, within the territory now embraced in the United States and Canada, were mostly those belonging to the Algonquian, Iroquoian, and Muskogean groups.

1 Traditions of Hiawatha, picked up by Schoolcraft and other writers, became mixed and confused with myths that had no reference to him, and a legend was formed on which Longfellow founded his poem. The Hiawatha of Iroquois history gave his name to the poem, but little more. 
Physical Feateres of North America aNd their HisTORICAL INFLUENCE.

Mountain ald River Sytims. Why many things happened in American history as they did can be learned by careful study of Map 1., at the begimning of this book, which shows a few of the physical features of the continent, and some effects that came from conditions of climate and soil. The conspicuous features that catch our eyes first are (r) the two systems of mountains, or of mountainous elevations of land, which lift the eastern and western sides of the continent to considerable heights above the wide stretch of its interior ground, and ( 2 ) the two mighty river systems, by which that vast interior land is drained. Between the mountain systems

tppa-

lachian ared cordilleners Moustains. - called Appalachian ${ }^{1}$ on the east and Cordilleran on the west - flows the Mississippi, gathering the stupendous volume of its waters. through countless branches, from springs in the hills of both systems, 2000 miles apart. Along the northeastern border of the valley of the Mississippi is stretched the chain of the Great Lakes, dramed to the Atlantic through the chamnel of the St. Lawrence, which skirts the enstern mountain system and passes round it at the north. These masses of highlands on the eastern and western sides of the continent, and these basins and channels of water-drainage for the great expanse of territory between them, are the bottom facts of American history. The western mountains came late into the story: the eastem had very much to do with the shaping of its earlier erents. Let us note a few particulars: -

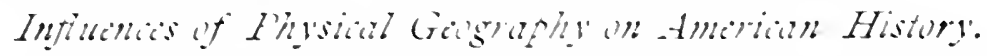

I. Because the ranges of the Appalachian system raised a considerable barrier between them and the inland country, the

1 The general name of "the Appalachian system" is given to the succession of ranges which bear local names in different sections, inclucing. for example. Cumberland Mountains, Alleghanies, Blue Ridge. South Mountains, Catskills. Adirondacks, Green Mountains, and White Mountains. 
English settlements along the Atlantic were confined for a long period to a quite narrow coast-margin of the continent, where they grew compact and strong. 'The mountains were by no means impassable, even in their wilderness state. "They were crossed by many Indian "trails," through many "gaps," traversed in early days by white trappers, hunters, ruglish and pioneers, and in our day they hardly check the "mille" speed of swift trains on a dozen lines of rail. But correst. emigration beyond the mountains, on any large scale, had to wait until the climbing footpaths of the Indian could be made into some kind of rude waron-roads, and that was a work which needed more than a century and a half. (Sce sections 72, 77, and 149.)

2. Because the St. Lawrence River runs the course that it does, and the Great Lakes of its water system lie as they do, the French, planting themselves on the lower banks of the great stream, were led by it, around and behind the mountains, into the Mississippi Valley, as naturally as the English in the same period were kept out;

Frenes in. lilie Volley. and the circumstances of the conflict in America between the two peoples were shaped by that fact. (Sce Chapter IV. and the survey preceding it.)

3. Because the long arms of the Ohio River reach into the hills of western Virginia and Pennsylvania, that stream drew the first important movement of settlers into the rheoloio great valley southwestwardly, connected them with Vull'y. the Mississippi, made their prosperity dependent on the freedom of its outlet to the Gulf of Mexico, so creating an urgent demand for the acquisition of territory controlling the whole river, and doing so soon enough to catch the rare opportunity which came to the young nation of the United States in 1803 , when the Jouisiana territory was bought from France (see section I79).

4. Because the most complete break in the Appalachian barrier is that made by the Mohawk and Hudson rivers, it followed that the first important highway of busy travel and traffic between the Atlantic and the Great Lakes and the Far 
West was opened on that route, by the building of the Erie "rimac! was thus raised to the chief place among Amerirork. can cities.

5. Because the climate and soil of large parts of the southern section of the country proved favorable to the cultivation of tobacco, cotton, and the sugar cane, which called for cheap labor, tending to agriculture on a large scale, it followed that negro slavery, existing in all the American colonies at first, became fixed in the structure of society at the South, vegro but not at the North, where the rude labor of the sluery. slave could seldom be made profitable in mechanical industries, or in the wheat-fields and corn-fields of the northern farm. Wherever slavery was profitable, self-interest resisted a growing moral sentiment against it; wherever it was not, the opposing sentiment prevailed. 'Thus, on this subject there came to be a bitter antagonism between the two sections of the country, with the terrible consequence of civil war.

6. But, because Nature had practically forbidden that the great valley of the Mississippi should be politically divided, vature and its common interests broken, the civil conflict forbade was destructive only to that which had been its "lisunion. cause. Slavery perished; the national unity of the American States was reaffirmed.

In many other particulars, events in American history have taken their course from causes that lie in the physical features of the country, or in conditions of climate and soil, or in both; but these, the more important, are enough to be cited in this place. 


\section{THE COMING OF THE ENGLISH.}

1607-1688.

\section{CHAPTER I.}

BEGINNINGS OF THE EARLY COLONIES. 1607-1660.

French Settlements. I598-1635.

1. The French in Canada and Acadia. 1598-1635. The French were earlier by a few years than the English in renewing attempts to settle themselves and establish trade within the part of the New World that they claimed. For more than half a century after Cartier's last voyage (see page 10 ) the great domain called New France ${ }^{1}$ had been treated with neglect, except by Norman and Breton fishermen, who gathered the "harvest of the sea" in the Gulf of St. Lawrence and on the Newfoundland banks. Then, in I 598 and after, under the wise rule of Henry IV., several attempts at settlement were made, promoted by various patents or grants from the king. Port Royal, One of them seated a colony at Port Royal, 1605,1610. now Annapolis, Nova Scotia, unsuccessfully in I605, but successfully in 1610 . It was established under a grant to the Sieur de Monts, which assumed to give him a territory called Acadia, extending from the 4oth degree of north latitude to the 46 th.

${ }^{1}$ Commonly signifying the whole dominion claimed by the French in North America. 
Arnong those who joined fortunes with De Monts was Samuel de Champlain, a fine character and an able man, champlain, who became the real founder of New France. 1608-1609. In I608, acting with and for De Monts, he founded a settlement at Quebec, and entered there into relations with the surrounding tribes of Indians which had wide and.lasting historical results. The Algonquins

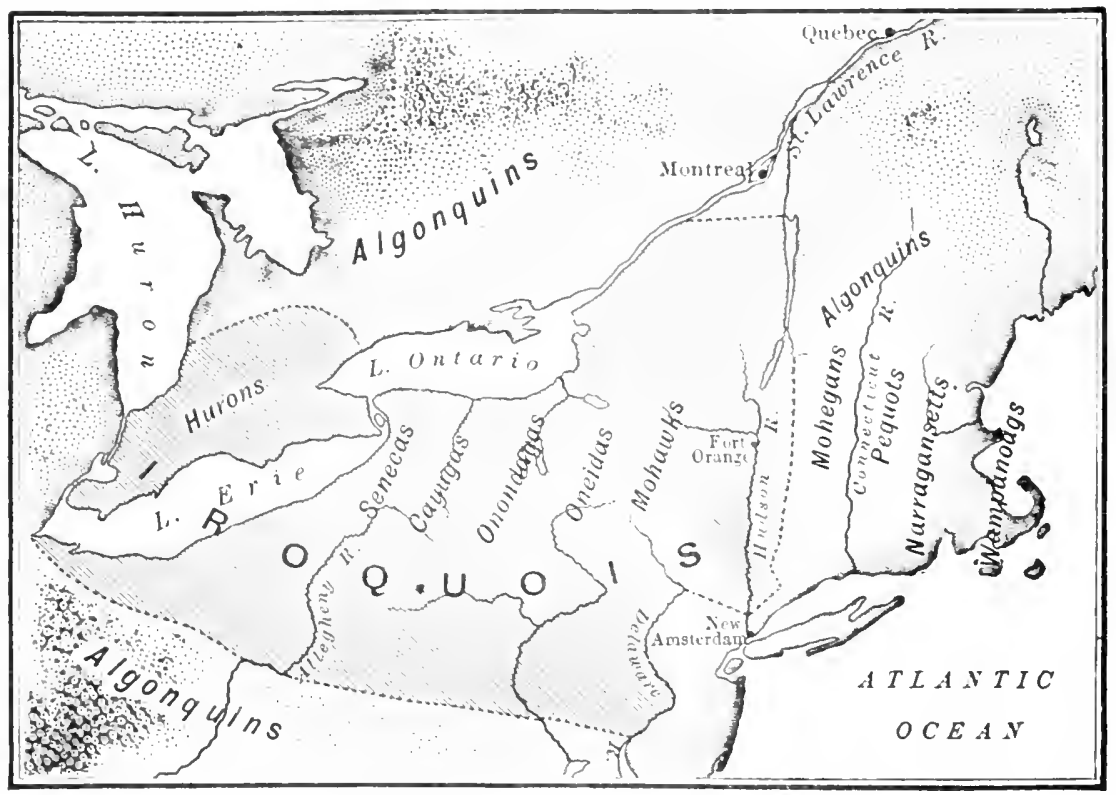

DOMAIN OF THE NORTHERN IROQUOIS.

of the St. Lawrence region were in alliance with the Hurons, immediately west of them, against the Five $\mathrm{Na}$ tions (the Iroquoian kindred of the Hurons), who occupied what is now the State of New York (see page 20). To secure the friendship of the I Iurons and Algonquins, Champlain joined their alliance, and he and his men, in r6og, took part in an invasion of the Iroquois domain, entering it by way of the lake which bears his name, and helping to defeat the warriors of the Fire Nations in a battle fought where Fort Ticonderoga was afterward 
built. Again and again in after years such attacks were repeated, until the Iroquois, the fiercest warriors on the continent, became deadly foes of the French. This placed them generally on the side of the English, when France and England came to blows in America (as will be told hereafter), and it had not a little to do with the result of that strife, - especially by having prevented the French from pushing southward, to occupy the valley of the Hudson, which they were eager to do.

2. French Fur Trade. - French Missions. Goldhunting, which had ruined so many colonizing ventures, was soon discouraged in the region that the French explored; but, in fur-trading with the Indians, they found a pursuit as alluring and almost as promising of wealth. Furs, always coveted and always high-priced in Europe, were aboundingly supplied and eagerly exchanged by the northern Indians of those days for knives, hatchets, blankets, and glittering trinkets of trifling cost. The profits of the trade were large, while the methods of it were enticing to an adventurous and rude class of men. Other attractions of the Canadian country were not strong. The resources that it offered to plain industry, in its forests and its soil, received little thought for many years, and the fur trade was the one object of interest and attention in New France. The settlements created by it were small trading stations, outside of courours de which the white population that it gave to the bois. country was mostly a wild class of coureurs de bois (forestrunners or rangers), who were the middlemen in this commerce of the woods.

The fur trade was dependent, of course, on peaceful and friendly relations between the Indians and the whites. For that reason the red men were Treatment of Indians. treated with more consideration there than elsewhere in 
America, and French conduct toward them seems favorably in contrast with that of other whites. "Spanish civilization," says Mr. Parkman the historian, "crushed the Indian: English civilization scorned and neglected him ; lirench civilization embraced and cherished him." But, so far as lrench and English were concerned, the difference, perhaps, was not so much between their civilizations as between their circumstances, which made the Indian a profitable neighbor in one case and a troublesome one in the other.

The interests of trade harmonized in this matter with the missionary spirit, which had its share everywhere Jesult among the motives of European colonization. missions. The missionary societies of the Catholic church, especially that of the jesuits, were encomaged and assisted in all ways, and they carried on among the sarages of Canada a wonderful work, with a courage, an endurance, a self-sacrifing derotion, that have never been surpassed.

Exalish Beomeings in the Sovth. 1606-1642.

3. The Virginia Company, in its Two Branches. 1606-1609. Three vorages to the New England coast between 1602 and 1605 , by kartholomew Gosnold. Martin Pring, and George Meymouth, represent all that was done by English enterprise in America for serenteen years after Raleigh wave up his personal efforts to win a footing for England in the New Morld. Then, in 1606 , a great joint stock company for the colonization of the

The first

charter, 1606 .

region called Virginia was formed and chartered by the king. James I. Its charter set the boundary of Virginia on the south at the sth parallel of latitude (near Cape Fear), and on the north at the $45^{\text {th }}$ (the northern boundary of Vermont), and gave a 
hundred miles of breadth from the coast. The company receiving this extensive grant was divided into two branches, for undertakings in two parts of the great field. The branch authorized to act in the southern division of Virginian territory, with exclusive jurisdiction from the $34^{\text {th }}$ parallel to the 38 th, had its headquarters in London, and is known usually as the London Company; the other branch, empowered to found settlements in the north between $41^{\circ}$ and $45^{\circ}$, was located in its management at Plymouth, and is spoken of as the Plymouth Company.

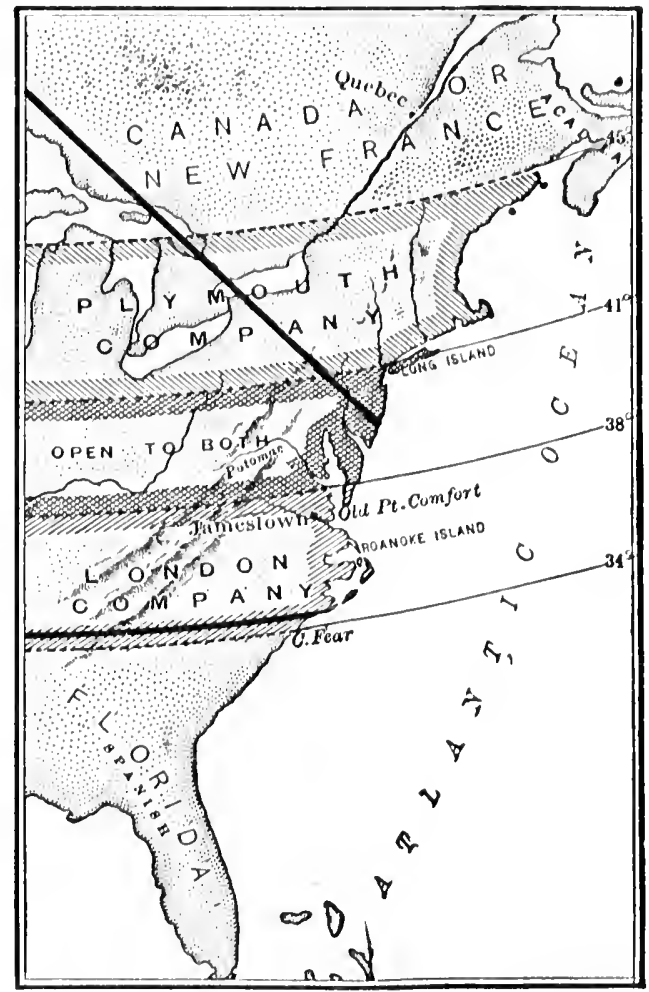

GRANT OF I606 TO TIHE VIRGINIA COMPANY IN ITS TWO BRANCHES, ANI) GRANT OF I6O9 TO THE L.ONHON COMPANY.

[Boundaries of the grant of $\mathrm{r} 606$ are shown by dotted lines; heavy black lines mark the grant of $\mathrm{I} 609$ as it was construed by the Virginians of later times, furnishing the ground of their claim to a vast territory in the Northwest.] the fields of the two companies, which was to be open to both, on terms that were expected to put them in competition for the territorial prize.

In a subsequent charter, issued in I609, the definition of the territory of the London Company was somewhat changed. This time jurisdiction was given "from sea 
to sea, west and northwest." wer a stit ot the conti-

Tie secosd clarter. 1609.

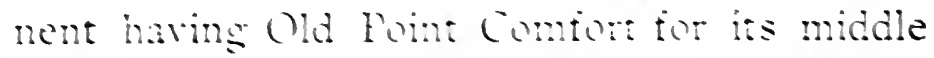
on the onst and messutus two hundred miles in cath direction theretom. The smant "irom sea to sea" will nu statio us it we remember that the continent was then suphosed to be a natow bojy of

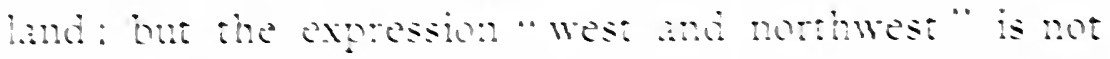

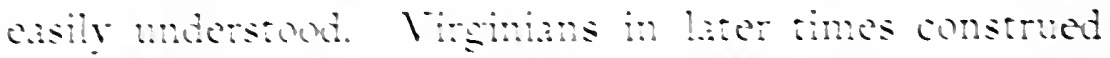

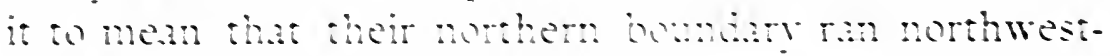

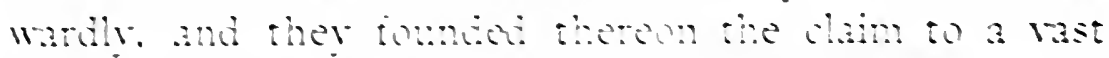

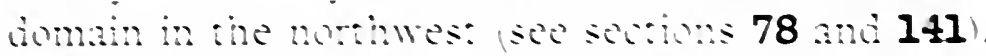

4. The James Rirer Colong of the London Branch.

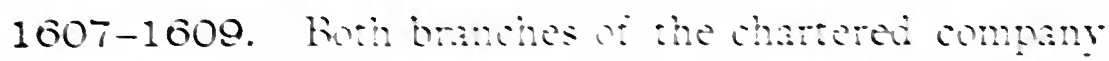

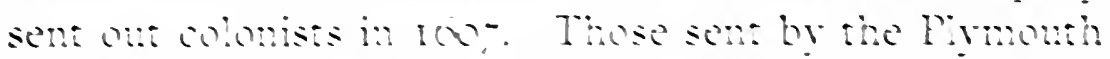

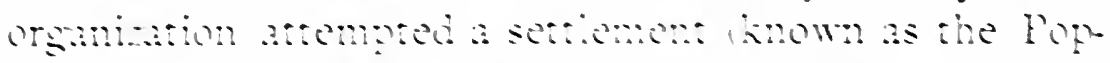

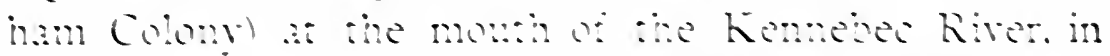

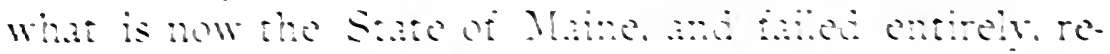

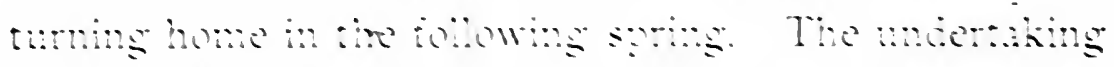

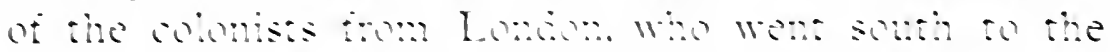

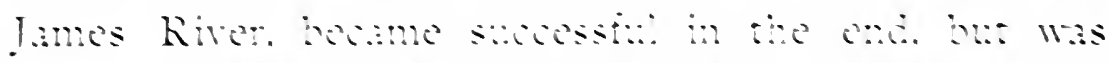

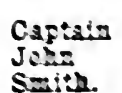

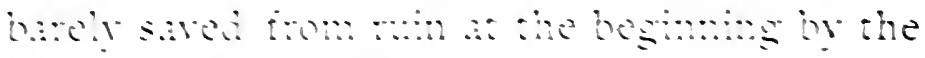

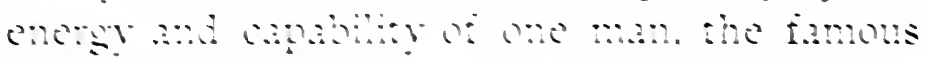

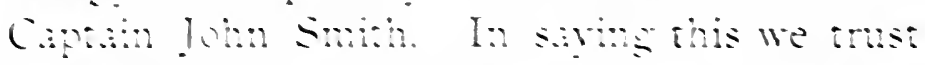

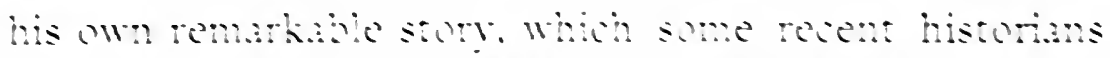

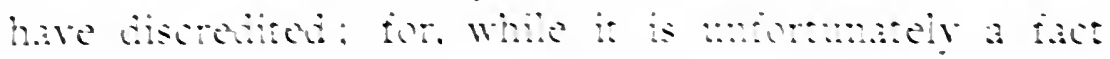

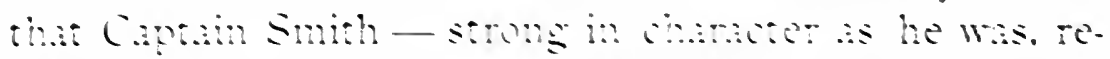

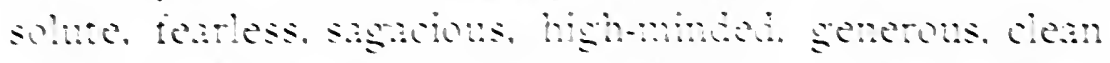

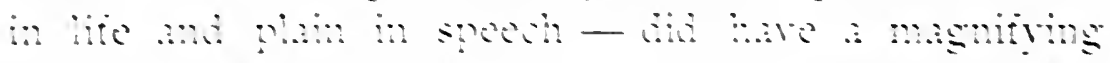

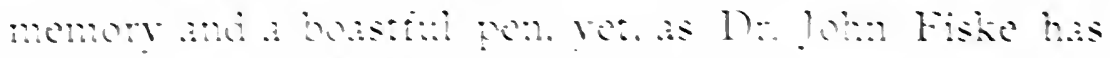

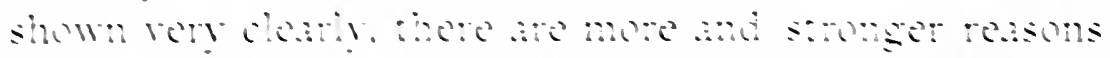

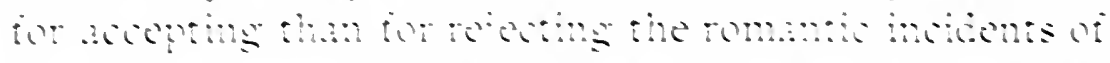

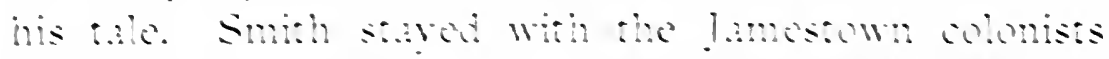

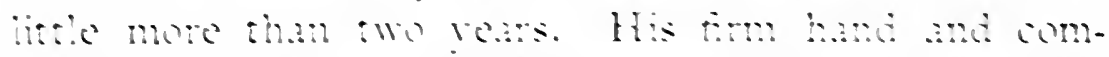

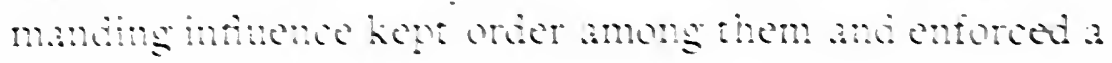


fair treatment of the neishboring Indins. on whom the thriftess whites were dependent for supplies of corn. No sooner was he gone than the sarases were prowolicd to hostility and a terrible "starring time" ensued, in the winter and spring of 1600 . when all but $(6)$ out of the 500 colonists diod.

In I don Company under-

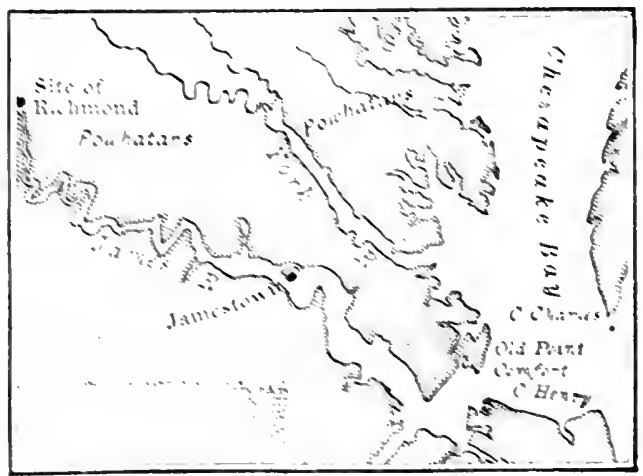

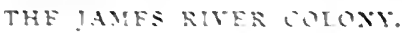
went a sueat change. being much enlarsed in numbers and strongthened in capital, having many powertul persons an? city suilds added to its membership list. The company was then made a corporation, distinet from the Hymouth Company, with a new char-

\section{Reorgan1.} zation of London Company. 1609. ter, as stated above. All the powers of soremment over the colony were rested in a supreme comeil at I ondon, whose authority was to be exerised in Virginia by a soremor responsible to nome hut itself. Fnder the autocratic goremment thus estahlished a more orderly condition of things was brought about. and the colony became able to sustain itselt.

5. Tobacco Culture. - Prosperitr. - Disaster. 1612-1624. Refore many yars the Iames River colony began to sec its way to a prosperous carede. It had found something better than sold mines, in the cultivation of an herb which, since America was Biscorered, all the world had been leaming o smoke. The natires of the West Indies taught the Spaniards. the Spaniards taught their neighbors. Kaleigh's olonists touk lessons in the 
strange fumigation from the Indians of Konoke. Drake

\section{Tobacco} picked it up. among other things in his roysmortag. ages and so the smoking of tobaco got to England and elsewhere in more than one way. It was coming to be a fashon in the eary years ot the serenteenth

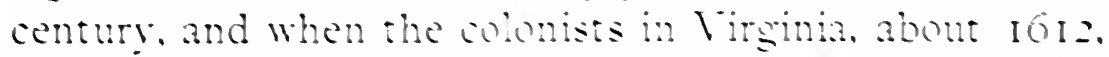
took a hint from Indin satens and found that the phant could be cultivate their crop met an eager demand.

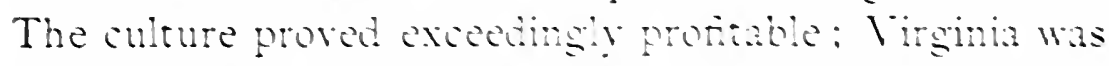
made attractive by it so a better chas of sethers than those obtained betore. and the iortmes of the colony became secure.

A change in the chanoter and riews of the London Company, even more imporant inan this change in the Reformers. Iora the contro! ot the company was won for circumstances ot the colomy was going on. In Con Corm-

Fans.

$1619-1634$ a time by a pary ut men who were leakers in

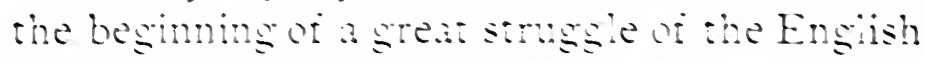
people with their hings for constimatum rights and it

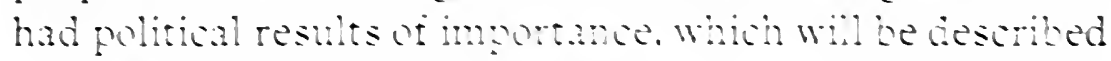
in another place lsec section 23 .

The setlements in Tirghin were now mathlying fast. spreading un and down the pensusa beween the Iames and lork rivers and in Io 2 it was estmated that the whole population mumered fox sons. For years they hat had itule trouble wath ine Inotans and they were coasing to teel any tear. The savases saw their carerodian out- lessness and were enconsoged a strike a sud3reas.
ing2. den murderous biow. which they dit on the

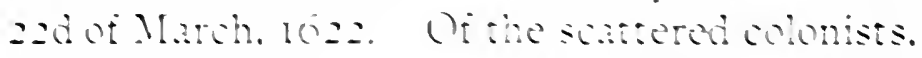

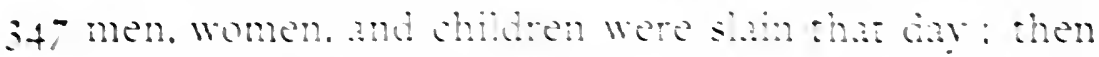

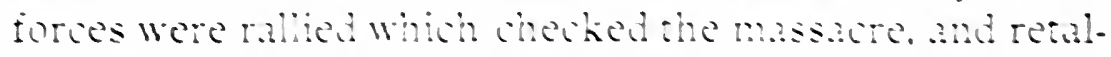
iated with a fieroness that awed the red men for a soore of years. 
The shock and the hurt to the colony from this disatster were not easily repaired. Many plantations were abandoned, many settlers returned to Engrand, ind the enemies of the company, foremost among them the king, were given a fresh ground of attack. Proceedings to rescind its charter were begun the next yeir, and by a decision of the Court of King's Bench, on the I 6 th of June, I6z4, the charter was de-

Overthrow of the London Company. clared to be "null and void." Thereupon the London Company ceased to exist, and Virginia became subject to the direct authority of the king.

6. The Founding of Maryland. 1632-1638. In I632 an extraordinary patent was issued by Charles I. (who succeeded his father, James I., in I625), conferring on Cecilius Calvert, Baron of Baltimore, the "prerogatives," the "royal rights and franchises," of sovereignty over a large part of what the Virginians considered their domain. It covered the region between the Potomac and the Delaware Bay and River, up to the 4oth parallel of north latitude, creating a principality of the kind known as "palatine" (see sect. 28). This palatinate was to be called Maryland, in honor of the queen of Charles I. It had been promised to George

Lord Baltimore's palatinate. Calvert, first Lord Baltimore, the father of Cecilius, but he died before the patent was signed, and it went to his son. Father and son had recently entered the Catholic church, and their object was to establish a place of refuge in America for people of that communion, who were cruelly treated by English laws. The elder Calvert had attempted this first, under a similar grant, in Newfoundland, but thought the climate too severe.

The settlement of Maryland was begm in the spring of ${ }^{6} \sigma_{34}$, by a company of English immigrants, both Catholic and Protestant, led by Leonard Calvert, brother 
of Cecilius, who selected their home at St. Mary's, on the river of that name. St. Mary's was then an Indian vil-

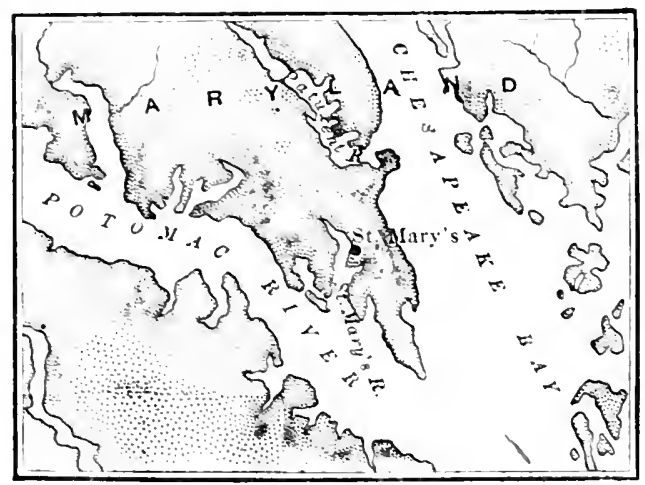

FIRST SETTLEMENT IN MARYLAND. lage, with corn-fields in fair cultivation, all of which were bought from the resident tribe, and the growing of corn received attention at once. Other immigrants followed, other settlements were founded, and the colony grew apace, Catholics and Protestants living peacefully together, equally free in their worship of God. The same religious freedom

Religious and political liberty.

was established in those same years by Roger Williams, on Narragansett Bay, but it existed nowhere else. Political liberty, also, was intended by Lord Baltimore, who planned for it with a generous mind. All the freemen of the colony were called together as early as I635, to sit in assembly with the governor (Leonard Calvert) and his council and take part in the preparation of a body of laws. In ${ }_{6} 68$ the colonists began to elect delegates to the Assembly, instead of meeting in massi, and representative government in Maryland was fairly on foot.

The early years of the Maryland colony were full of conflicts with the Virginians, who disputed its right to the territory it held, but we cannot go into the long story of those disputes. 
Beginnings of New England. I620-1642.

7. First Settlement in New England. - The Pilgrim Fathers. 1620. For several years after the abandonment of the Popham settlement on the Kennebec, little attention was given in England to the northern part of the vast territory covered by King James's grant. The first to revive interest in North Virginia, as that region was then called, was the adventurous Captain John Smith, who

Captain John Smith's survey and "Description," 1614-1616. obtained help from English merchants, in I6I4, to equip an expedition to its coast for exploration and trade. One result of the captain's careful survey was a very good map of the coast (see Map III.), which he presented to Prince Charles (afterward King Charles I.), with the suggestion that the country represented be named New England. Two years later he wrote and published "A Description of New England," in which the settlement of the region was strongly urged.

By this time the value of the fisheries, the fur trade, and the timber of New England had been learned; but, harsh in climate as the country was, and generally poor in soil, such attractions as it had were of a kind that would naturally, in that day, have drawn none but settlers of an adventurous class, like those of New France. If New England was to be populated by domestic folk, wanting homes and farms, some other inducement would be needed to bring them across the sea. Such another inducement did come into play, with powerful and memorable effects. It arose from the sore want in lingland of freedom for all religious beliefs that differed from the doctrines and forms of the established church. There was less of such freedom, in some respects, under the Stuart kings, than in Queen Elizabeth's reign; and the 
Protestant body which suffered most from the persecuting laws of the time was that of the Separatists, or Inde-

\section{The} pendents, who claimed the right of each church scrooby congregation to govern itself (see page 14). congrega-. To escape the persecution, a small society of
tion.
16020.

the Separatists, formed at Scrooby, in Nottinghamshire, left England in $\mathrm{s} 60 \mathrm{~S}$ and took refuge in Holland; but their thoughts became turned toward America, and they arranged with the London Company for a grant of land on the Delaware River, and for assistance in setThe voy- tling there. The pathetic story of the memoage of the rable voyage of these "Pilgrim Fathers" (and flower.

Sept.-Dec., 1620 . Mothers) of New England, in the leaky ship Speedwell, from Delft to Southampton, and in the Mayflower from Southampton and l'lymouth to a landing which they did not intend, in Cape Cod Bay in. stead of the Delaware River, is so familiar that it need not be repeated here.

8. The Plymouth Colony. 1620-1630. The first landing of explorers from the Mayflower, in the harbor which John Smith had named Plymouth, is beliered to have been made on Nonday, the zist of December, I620 (according to the reckoning of the New Style), though the z2d has been the amiversary long observed. It was the middle of January before the company in general left the ship. Comfortable house shelter was impossible; many had sickened in the overcrowded and long-buffeted ship; the cold was severe: food was neither plentiful nor The tirst good. The sufferings of that winter are bewinter. yond imagination, eren though we know that 44 out of 102 died before the end of March. Happily the weak settlement suffered no attacks from neighboring Indians, who are supposed to have been affrighted by a fearful pestilence which visited them three years 
before, just after they had killed two or three white fishermen on the coast. Not an Indian came near the settlement for some months; then one Samoset, who had picked up a little English from fishing ships, appeared, and intercourse with the Wampanoag tribe was opened through him. Kind treatment won the confidence of the red men, and their sachem, Massasoit, entered into an agreement of friendship which was kept unbroken for more than fifty years.

In the course of the next year the colonists received sanction from England for their occupancy of the ground on which circumstances had planted them against their will. The so-called Plymouth Company had then been reorganized and renamed as councll for "The Council for New England," and had reNew England. ceived a new patent, giving it jurisdiction over territory that spanned the continent, from the Atlantic to the Pacific, between the 4oth and 48th degrees. Its grant for the Pilgrim settlement was made to a merchant company, in trust for the colonists, who paid rent for their lands churing several years, but were able at length to buy the ground on which they lived. By heavy toil, with great hardships and privations, they gradually made themselves fairly comfortable in their new home, and were joined by a few later comers from Leyden and England; but their growth in numbers was so Slow
growth of
colony. slow that they counted no more than three hundred at the end of ten years.

In those ten years many English people engaged in fishing on the coasts of New England, and several attempts at settlement were made, with little or no result. Numerous grants were obtained from the Council for New England, by companies and individuals, and these were so carelessly or ignorantly defined that they often 
overlapped and conflicted with one another, causing: troublesome disputes in after years.

9. The Puritans in England. 1625-1630. Meantime affairs in England were taking a course which led, at the close of the period in question, to a sudden movement of Puritan emigration, so extensive that strong colonies in New England were formed. King Charles I., more despotic in disposition than even his father had been, seemed likely at that time to succeed in breaking down the resistance of his subjects and making his own will supreme. He drove Parliament from its meetingplace in I629, and for eleven years after that date the representation of the people in their government was suppressed. They were unlawfully taxed; the patriots who opposed the king were imprisoned unlawfully; the oppression became in every way intolerable: but in nothing else so much as in the king's attempt to force everybody to worship God in the mode which his own opinion approved. The views called Puritan, which have been described already (see page I4), had spread very widely by this time, and seem to have been held by a majority of the clersy and a large part of the laity of the established church. But a minority, supported by the king and the courts, were able to enforce church ceremonies which the Puritan majority abhorred. Most of those who stood up against the oppressions of the king, and strove for the constitutional rights of the people, were of the Puritan class, and were mored eren more by religious than by political feeling.

10. Emigration and Settlement of the Governor and Company of Massachusetts Bay. 1629-1637. By i6zs many Puritans were regarding their prospects in England with despair, and were looking toward America, as the Independents had done ten years before. 
A grant from the Council for New England was obtaincel by John Endicott and five others, giving them the territory from three miles north of the Merrimac River to three miles south of the Charles, with the usual stretch from sea to sea. Endicott went out that same summer, with sixty others, to take possession of the grant, and joined a little settlement already made,called Naumkeag, which then took the name of Salem and has borne it since. In I629 this scheme of colonization was broadened out. Endicott's joint stock company of six grantees became a large corporation, embracing many men of importance and wealth. Under the name of "The Governor and Company of Massa-

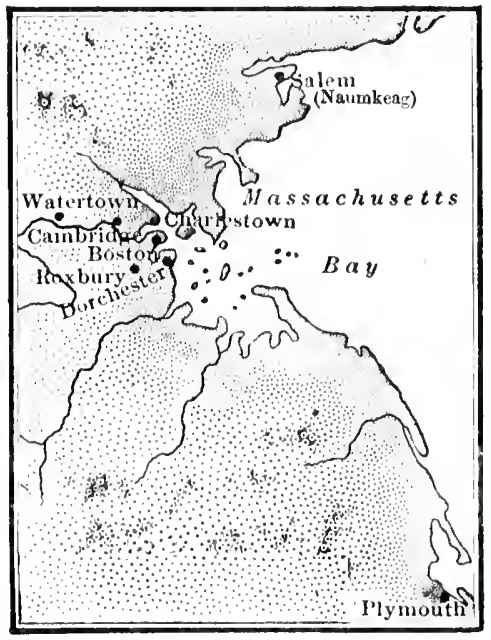

THE FIRST NFW ENGLAND SETTLEMENTS. chusetts Bay," it obtained a royal charter, drawn in such terms that, by shrewd and bold management, a degree of independence which the king had not dreamed of was secured. The company could add to its membership without limit, and its ruling body, consisting of a governor, a deputy-governor, and twelve assistants, received authority to make such laws as it might deem needful, provided only that they "be not contrary or repugnant" to the laws of England. No place in which its Removal of powers should be exercised was named, and a charter and right to transfer the charter and government to America. from England to New England was assumed. When, therefore, a large party of eight hundred Puritan colonists sailed from Yarmouth in the spring of 1630 , their 
charter, their governor (John Winthrop), and other officers, went with them to the shores of Massachusetts Bay.

This party took residence first on the northern side of Charles River, naming the place Charlestown, but soon settlement scattered, the greater number settling on the of Boston. peninsula called Shawmut, where Boston was founded and became the chief town. Others from England followed the pioneers of the Puritan migration, in such numbers that nearly 4000 are believed to have been settled, in a score of villages around Massachusetts Bay, by the year 1634 .

It was impossible for the colony to have so rapid and so prosperous a growth, and to show the political freedom that it did from the beginning, without provoking hostility in England, and its enemies were not slow to act. Controlling the Council for New England, they gave up

Hostlilty in England, the charter of that corporation, on condition that all its grants should be revoked by the king, and that New England should be parceled out afresh. Laud, the bigoted archbishop of Canterbury, was put at the head of a commission to superintend colonial affairs. The Massachusetts company was commanded to surrender its charter, and proceedings against it were begun in the English courts. But, fortunately, the conflict in England between king and parliament came then to a stage which emboldened Massachusetts to disobey the command. Thereafter, Laud and the king and all their party had enough to think of at home, and their designs against New England came to naught.

11. Enlightenment and Intolerance in the Massachusetts Colony. 1635-1647. These threatenings from England made no stay in the prosperous progress of the colony. Two very different tendencies in the character of its people, toward breadth of mind in one 
direction and narrowness in another, were being shown at this time. We have evidence of the first in the Public Latin School of Boston, opened in 1635, and in Harvard College, founded in the following year. Other public schools rose rapidly in the surrounding towns, and in 1647 the legislature

Harvard

College and public

schools,

1635-1647. of the colony, styled the "general court," enacted an ordinance which has been called with truth "the great charter of free education" in Massachusetts. "That learning may not be buried in the grave of our fathers, in church and commonwealth," it said, " the Lord assisting our endeavors, it is therefore ordered that every township in this jurisdiction, after the Lord hath increased them to the number of fifty

Ordinance of 1647. householders, shalk then forthwith appoint one within their town to teach all such children as shall resort to him to write and read."

At the same time, while sowing the seeds of free thought, by planting free schools, the Massachusetts Puritans were striving, in a narrow way, to make their own religious opinions the absolute law of their little state. Their first step in that direction was taken when all save members of their

Restriction of the franchise. churches were excluded from the "freedom" of the "body politic," - that is, from a voice and vote in public affairs (see sect. 25).

12. Secession from Massachusetts Bay. - The Founding of Connecticut. 1635-1638. Opposition to this exclusion was one, apparently, among several causes of discontent which brought about a movement of secession and emigration to the valley of the Connecticut. The movement was begun by a few pioneers in 1635 , and they were followed by a large party, led by Thomas Hooker, minister of the church at Newtown (afterward 
Cambriclge), in the next year. There were several claimants of that beautiful valley at the time. The Dutch First settle- had tried to seize it; men from Plymouth had ments. built a trading fort on the river; Lord Brooke and Lord Say and Sele, in England, held a grant which

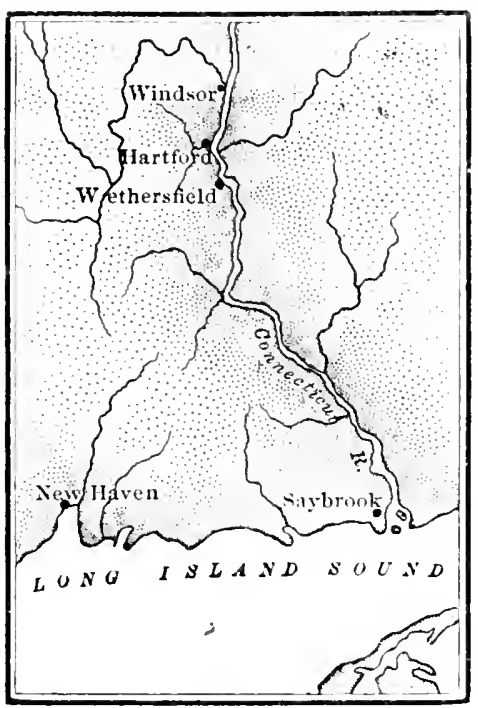

BEGINNINGS OF CONNECTICUT. covered it, and the agent of those noblemen, John Winthrop the younger, son of the Massachusetts governor, had built a fort that he called Saybrook, at the mouth of the river. At a later day the settlers from Massachusetts made terms with the holders of this grant. Their first settlements were at Windsor, Hartford, and Wethersfield, where about 800 people were living in the spring of 1637 , under a government organized more democratically than that from which

they had removed (see sect. 26).

In that year the Connecticut colony was already so strong that it bore the brunt of the first serious war in New England between the red men and the white. Some murders of white traders by Pequot Indians had been The Pequot avenged by Massachusetts with a savageness War, 1637. that enraged the tribe. Its retaliations fell mostly on the settlers in Connecticut, and, though the latter could put less than Ioo fighting men into the field, against 1000 braves, they fell upon the tribe and practically destroyed it in a brief campaign. With the help of a small company from Massachusetts and a few 
friendly Indians, they surprised the Pequots in their stronghold, hunted them down without mercy, and left but a wretched remnant, some of whom were captured and enslaved.

In the next year after the Pequot War (1638) another settlement within the later bounds of Connecticut was started, at New Haven, by a wealthy company from England, London merchants and others, colony of of the Puritain class, accompanied by their ven, 1638. minister, John Davenport. This grew very soon into a colony of several confederated towns, with a government formed on a " Fundamental Agreement," as it was styled (see sect. 26).

\section{The Founding of Providence. - Beginnings of} Rhode Island. 1636-1637. The exclusive Puritanism in Massachusetts which sent Thomas Hooker and his followers away from Charles River to a new settlement on the Connecticut was driving forth, in that same year (I636), another pastor, of even larger mind and loftier spirit, to make him the founder of still another colony, that would be in due time another American State. This was Roger Williams, who came to Boston as a young divine in $163 \mathrm{I}$. He began soon to give expression to opinions that offended the

Opinions of Rogers

Williams, Puritans in power. He contended for the perfect freedom of religious opinion ("soul-liberty," as he called it) which is common now in most parts of the world, but which few people in his day could think of as a possible thing. He held that civil governments should have nothing to do with the doctrines, ceremonies, or maintenance of any church. He denied the right of the king of England to give away lands in America, and condemned the taking of such lands without purchase from 
the Indians as a flagrant wrong. ${ }^{1} \mathrm{He}$ was beyond his age in many such views. The authorities in Boston looked upon him as a troublesome agitator, and, when he was called to a church in Salem. that approved his preaching, their hostility pursued him, until he withdrew to Plymouth, where he remained for nearly two years. Returning to his pulpit in Salem, he gave offence again to the rulers of Massachusetts Bay. In January, 1636 ,

Persecution of Roger Willams in Massachusotts. they ordered that he should be sent to England on a ship then preparing to sail ; but he escaped from them by going into the wild forest, among the Indians, whose language he had learned and whose friendship he had won. He made his way to the

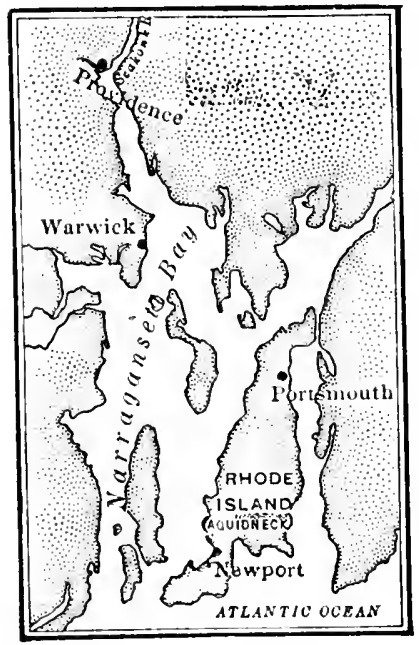

FIRST SETTLEMENTS ON NARRAGANSETT BAY. head of Narragansett Bay, where, being joined by faithful friends from Salem, he founded a settlement called Providence (see sect. 27), on ground fairly bought from the Indians, with whom a "covenant of peaceful neighborhood" was entered into and enduringly kept.

14. Mrs. Anne Hutchinson and the Antinomian Controversy. 1636-1638. In 1638 another settlement in the neighborhood of Providence was founded by another band of exiles from Massachusetts Bay. They were followers of Mrs. Anne

1 The ground first occupied by the settlers on Massachusetts Bay had not been bought from the natives; but lands acquired subsequently for the extension of the settlement are said to have been bargained and paid for. Palfrey, History of New England, iii. 137 . 
Hutchinson, a remarkable woman, who had been lecturing in Boston and causing great religious excitement by doctrines which a majority of the ministers and rulers condemned. A strong party had been won to her support, including the governor of that year, ${ }^{1}$ Sir Sir Henry Henry or Sir Harry Vane, who had lately come

\section{Vane.} from England, and who returned there the next year, to become an important actor in the momentous events of the time. The doctrines in dispute, called "Antinomian," we will not try to explain; it is enough to note the consequences of the dispute. The opponents of Mrs. Hutchinson carried the day, and she and some of her adherents were banished from the jurisdiction of Massachusetts Bay. Some went with her and her husband to the island of Aquidneck, in Narragansett Bay, which they bought from the Indians, and which got the name of Early Rhode Rhode Island, though they intended that it Island sotshould be called the Isle of Rhodes. Two set- 1638 .

tlements were formed, at Portsmouth and Newport, and a few years later $(\mathrm{I} 644-47)$ these, together with another settlement at Warwick, on Narragansett Bay, were united with that of Roger Williams in the "Colony of Providence Plantations," under a patent which Williams went to England to obtain.

Other companies of the friends and followers of Mrs. Hutchinson went northward and settled in towns which became the Exeter and Dover of New Hampshire.

15. New England in 1640. In 1642 the strife in England between king and Parliament came to an out-

1 John Winthrop had been reëlected governor each year until I634, when Thomas Dudley was chosen. In I635 John Haynes was elected; in 1636 the office was given to Vane. The next year Winthrop was returned to it and held it until 1649 , except during two years - I 64 I and I 645 . 
break of civil war. The great Puritan party had grown strong enough to feel sure of success in breaking the Decrease in tyranny of royal power, and the chief motives of emigration. emigration to New England had nearly died out. After I639 not many of that party crossed the sea. In I640 the New England population is believed to have numbered about 26,000, and it had taken root already in five of the six States formed at a later day. Even Maine, which had been granted to Sir Ferdinando Gorges, as well as New Hampshire, claimed by Captain John Mason, contained a few germs of settlement within its bounds. More than half of the whole population was in Massachusetts, where a score of towns were growing up, all in the eastern section save Springfield, on the Connecticut River. Plymouth had planted a few other towns in its neighborhood, but the total of inhabitants did not exceed 3000. Connecticut contained about the same number; the New Haven settlements somewhat less.

16. Confederation of four New England Colonies. 1643. In 1643 these four substantial colonies formed a league, or loose confederacy, called "The United Colonies of New England." The main purpose of the union was a common defence, not only against Indian enemies, but also against the Dutch settlements growing up on the Hudson and the French on the north, both of which were giving rise to some fear. The Narragansett settlements were refused admission to the league. The fact that this confederacy was formed without authority from England marks the independent, self-reliant feeling that the New England colonies had already acquired.

Dutch Settlenents. i6 IO-16 65 .

17. The Dutch on the Hudson and the Delaware. 1609-1655. The English were now securely settled in 
two widely separated parts of the American territory that they claimed, but they had lost control of the space between. The Dutch had slipped in and taken possession of the most valuable harbor on the coast, and of the two important streams then known as the North and South rivers, but afterwards named the Hudson and the Delaware. Their hold on those possessions was firm, and their title was as good as that acquired by any other European people. Though Cabot and other navigators of the sixteenth century may have looked into the noble bay of New York, it was a mariner in the service of the Dutch East India Company, Henry Hudson, who first explored the fine river which empties there and discovered the importance of the place. He did this in I609, while searching for the imagined "northwestern passage" to a sea beyond. His discovery was followed quickly by action at Amsterdam to occupy the ground. A station or factory for traffic with the Indians was estab-

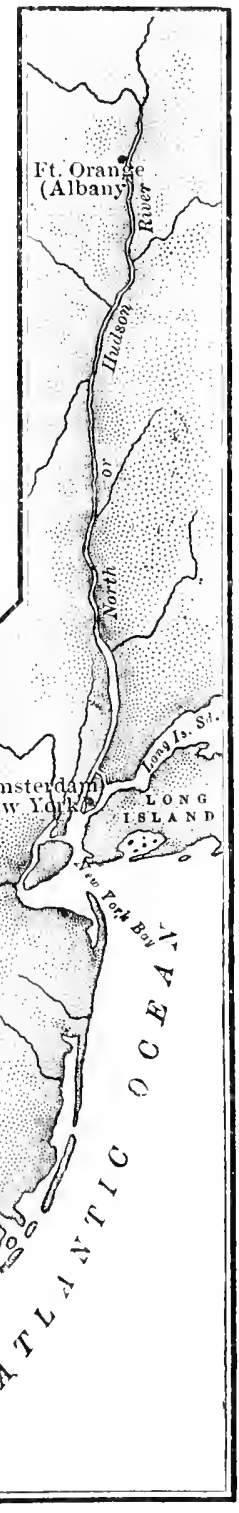

EARLY DUTCH SETTLEMEN'TS. lished on the island of Manhattan in I6ro; the neighboring coast, eastward to Cape Cod and southward to Delaware Bay, was promptly explored and mapped; the whole region was named New 
Netherland, and the company which mapped and named it received an exclusive privilege of trade from the government of Holland in $161+$. In the same year a trading Abany post called Fort Nassau was established up the Albany
founded, North River; but this was abandoned five 1619.

years later and another, called Fort (Orange, was built where the city of Albany now stands. Friendly relations with the Five Xations of the Irequois were cultivated from the first, and with hasting effect.

In 162 i the original trading company was superseded by a great corporation. styled the llest India Company; west inda chartered with "almost unlimited powers to company. colonize, govern, and defend New Netherland." 1 The new company built a fort called Fort Amsterdam on Manhattan Island, in 1623, and sent out 30 families of its serrants, who were engaged in the conduct of its trade. In that year it built, also, a fort on the Delaware (or South River), opposite the site of Philadelphia, and began the construction of another on the Comnecticut. where Hartford stands. Thus the energetic Holianders made preparations to hold the two extremitics of the territory that they clamed. On the New England side they were opposed by the Connecticut colonists, who Swedes on proved too strong for them and forced them ware Dela- back: but they established their footing on 1638-1655. the Delaware ( 653 ) after a struggle with the Swedes, who founded a settlement there. at and around liimington, in 1638 .

18. Ill Government of the Dutch Colons. In $16=6$ the company bought the island of Maniattan from the Indians, and its settlement, numed New Amsterdam, soon became a thriring seat of the fur trade - the most important outside of $\mathrm{New}$ France. Good govermment

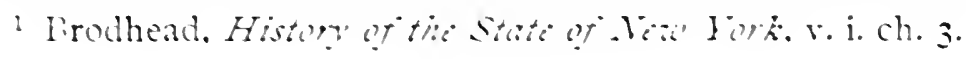


might have given the colony a brilliant career; for, looking both seaward and landward, the advantages of its position were very great. But the govermment of New Netherland was not of the kind that would build up a vigorous colonial state. For some reason the Dutch failed to carry the free spirit of their home govermment with them into the colonies they founded in other parts of the world. Even the inhabitants of the growing town of New Amsterdam had no voice in the management of their own municipal affairs for more than forty years after its settlement was begun. The governors sent out by the West India Company were autocrats, under almost no restraint. Two of them, Wouter (Walter) Van van TwllTwiller and William Kieft, who ruled the colony ler and in an important period, from $1 \sigma_{32}$ till $1 \sigma_{4} 7$, were

Kieft. 1632 -1647. men of little character or sense. The latter abused the neighboring Indians, of Algonquian tribes, with brutal recklessness, and provoked a terrible war (I64I-44). After the colony had endured his senseless tyranny for ten years, it got a hearing for its complaints and he was removed, giving place to a fiery old soldier, Peter Stuyvesant, who was more of a despot than his predecessors, but dignified his autocracy by

Peter Stuyvesant. 1647-1664. high qualities of a strong character which commanded respect. The reign of Stuyvesant lasted until the colony was taken from the Dutch.

The Colonies during the Overthrow of Monarchy in ENGLAND. 1642-1660.

19. Civil War in England. - Its Effect on the Colonies. 1642-1649. In I6 42 the conflict between the king and his party, called Cavaliers, and the luritan party of the Parliament and people, called Rountheads, came to an outbreak of civil war. This produced a con- 
fusion and weakening of government which left the colonies in practical independence for some years. Until that time the crown had exercised sole sovereignty over all colonial possessions, without any parliamentary legislation, and its right to do so had never been denied. Now, the royal authority was about to be extinguished for a period, by the result of the war, and meantime the colonies were reached by no authority that could really be enforced. In 1643 Parliament created a Board of Commissioners to superintend colonial affairs, and thus asserted its right to legislate for all the dominions of the English crown; but the Board had little power.

In 1649 the king, defeated in the war, was tried by the victorious party of his long-abused subjects, was condemned, and was put to death. A republican

\section{Common-} wealth and government was then established, for what took Protecto-

rate,

1649-1658.

the name of the Commonwealth of England;

but this existed no longer than four years. Then Oliver Cromwell, supported by the army, took the reins of government into his own hands, with the title of Lord Protector, and for the next five years he exercised an authority more dictatorial than the late king had ever claimed.

20. Substantial Independence of New England. 1642-1660. The New England colonists were natuNow Eng. rally in sympathy with the party that triumphed land during in the English civil war; but they were none war. the less disposed to gain all possible independence for themselves from the state of political confusion into which the mother country had been brought. The late king's charter to the Massachusetts colonists was supposed to furnish the ground on which they were building up a political community in the New World. Theoretically they had been his subjects, not as being 
part of the English nation, under crown and Parliament, but as being a chartered community in another dominion of the king, across the sea. Practically, their subjection to the king had been made very slight by the troubles in England which weakened his power and drew his attention away. Consequently, they had been able to act with almost the freedom of a sorereign people, from the first. Those who went away from them to the Comnecticut valley had assumed even more of self-sovereignty, when they framed a constitution for themselves (see sect. 26); and the four leading colonies were fairly stepping into political independence when they formed a federal union (see sect. 16), with

Subjection to the crown. no consent asked for or giren from the other side of the sea. This substantial independence they were determined to keep unimpaired if they could.

The attitude of New England was shown with plainness in $165 \mathrm{I}$, when Parliament demanded a surrender of the royal charter of Massachusetts, and ordered the colony to take a new one from the parlia-

Demands of Parliament. mentary commission created in 1643. No answer to the demand went from boston for more than a year: then it was given in the form of a courteous memorial, setting forth reasons why Massachusetts preferred to keep her old charter unchanged.

But the written answer of Massachusetts to Parliament did not, perhaps, express so much of her feeling of independence as was manifested in another proceeding of that same year $(1652)$. This was the setting up of a mint for the coining of silver money, to supply a pressing need of colonial trate. All

\section{A Massa-}

chusetts mint, 1652. the colonies had been suffering from the want of a standard of value and a medium of exchange. They had been forced to use the "wampum" or "peage" money 
of the Indians, made of shell beads, strung and woven

Early

money. into ornamental belts. They had likewise used beaver-skins and corn for a measure of value, and tobacco, in Virginia, was the only money known. In the palatinate of Maryland, the almost vice-royal proprietor had authority from his charter to coin money; but that, being a special attribute of sovereignty, had not been conferred upon the Governor and Company of Massachusetts Bay. They boldly took it, however, on themselves, and the "pine tree shillings" 1 which their mint began to issue might fairly be taken for an announcement that Massachusetts esteemed herself to be a practically independent state.

21. Persecution of Quakers in Massachusetts. 16561660. Massachusetts lost its able governor, John Winthrop, in I649, and John Endicott was governor for all but two of the next fifteen years. Those were years in the history of the colony on which a barbarous persecution of the pure and peaceful Christian sect called Friends or Quakers has left a black stain. The Quakers were disciples of George Fox, then preaching in Eng. land. They were required by their belief to "testify,"

\section{Rude ways}

of the Quakers. without regard to consequences, against many things in churches and governments, and to do it very often in rude and provoking ways. No punishment - death least of all - could keep them from the doing of this duty, as they conceived it to be. They were going forth from England at this time to preach their doctrines in many parts of the world, and they suffered persecution in many places, but nowhere else so unmercifully as in Massachusetts, which their

1 So called from the figure of a pine tree, stamped on the face of the coin, with the name of the colony, in one of its old forms, "Masathusets," circled round it. 
first missionaries reached in 1656 . That year they were only imprisoned and banished. The next year, under a special law, they suffered whipping, in addition, and sometimes the cutting of their ears. When those penalties failed to keep them out of Bos-

Persecution in New England. ton, the magistrates and clergy persuaded the General Court to pass a law (1658) inflicting death. Under that dreadful law, in 1659 and I660, three men and one woman were hanged. Then public feeling put a stop to the horrible work. The lesser punishments went on for some years, but no more of the dauntless Quakers were put to death. In the milder fashion they suffered persecution in all the New England colonies except Rhode Island, which was true to the tolerant principles of Roger Williams and refused to join in hunting them down.

22. Virginia and Maryland during and after the English Civil War. 1642-1657. In Virginia, during and after the English civil war, the prevalent feeling was in sympathy with the cause of the king. For three years after the execution of King Charles, an unsubmissive royalist governor, Sir William Berkeley, held his ground at Jamestown, undisturbed. It was not until I652 that Parliament sent over a fleet, with commissioners, who seated a new governor in Berkeley's place, leaving the colonial government otherwise untouched. In the next year the Lord Protector Cromwell grasped authority in England, and the Cavalier colony was discreetly submissive to his rule.

Maryland was more disturbed than Virginia by the strife in England, becoming the scene of a fierce struggle for several years. In the beginning its proprietor, Lord Baltimore, espoused the king's cause. Later, he cultivated the good-will of the opposite party, appointing a Protestant gentleman, William Stone, to be governor, 
and embodying a great enlargement of the policy of

The Toleration Act, 1649 . religious toleration in a famous act which he drew up, and which was passed by the Maryland Assembly in 1649 . In 1652 the same parliamentary commissioners who displaced Governor Berkeley in Virginia entered Maryland and annulled the authority of its palatine lord. With the help of the Puritan new settlers in Maryland (see sect. $3 \mathbf{l}$ ), they deposed Governor Stone, set up a provisional government, and filled a new Assembly with Puritans, by not allowing Catholics to vote or to hold seats. The body thus made up was so shameless as to alter the Toleration Act of 1649 , by excepting " popery, prelacy [that is, episcopacy], and licentiousness of opinion" from the beliefs and practices that should be free. A state of fierce civil war in the colony ensued, in which the Puritans triumphed (1655); but Cromwell frowned on their proceedings, and they were forced in the end (1657) to come to terms with Lord Baltimore. His government, and with it the Toleration Act of 1649 , was restored.

In 1658 Cromwell died, and a state of things followed in England which made the people willing to restore their ancient monarchy, by calling the late king's elder son from exile and seating him on the throne (I660).

\section{TOPICS AND SLGGESTED READING AND RESEARCH.}

\section{The French in Canada and Acadia.}

TOPICS AND REFERENCES.

I. Beginnings of French settlement. 2. The territory called Acadia. Parkman, Pioneirs, chs. ii.-v.; Winsor, America, ir. 135-145: Winsor, (irtic), ch. iv.; Bourinot, ch. v.; Roberts, IS-22.

3. Champlain. - His Indian alliance and its lasting consequences. Parkman, Pantics, chs, ii.-iv..ix.-xvii.; Winsor. America, iv. ch. iii.; Winsor, Carticr, chs. v.-rii.; Higginson, 127-1 36 : Bourinot, chs. vi.-viii.: Roberts. $22-+5$. 


\section{The French Fur Trade. - French Missions.}

Topics AND REFERENCES.

r. Importance of the fur trade. 2. Character of the white population that it attracted. 3. French treatment of the Indians as affected by the fur trade. Parkman, Old Résime, 303-3 I 5 ; Bourinot, ch. xii.; Weeden, i. I 29; Thwaites, I7-19, 4S-49.

4. French missions and missionaries in America. Parkman, Jesuits; Winsor, America, iv. ch. vi.; Winsor, Cartier, r29-16r ; Bourinot, ch. ix.; Higginson, r 20-1 27.

\section{The Virginia Company in its Two Branches.}

TOPICS AND REFERENCES.

r. Three early voyages to the New England coast. 2. Chartering of the Virginia Company (text in MacDonald, i. I I-I 7 ; Preston, 1-13). 3. Boundaries of the region called Virginia. 4. Division of the territory between two branches of the company. Fiske, Old Va., i. 55-67; Doyle, i. 134-149; Fisher, 30-34; Thwaites, 65-69.

5. Change in grant to the branch called the London Company (text in MacDonald, i. II-I7; Preston, I4-2I). 6. Doubtful description of its new boundary. 7. Claims founded on it by Virginians in later times. See references in sections 78 and I4I.

RESEARCH. - Which of the present States of the American Union were covered or partly covered by the first grant to the Virginia Company? On what ground could the European nations which first "discovered" different parts of the American continent, already inhabited by red men, assume a right to take possession of them?

\section{The James River Colony of the London Branch.}

\section{Topics AND References.}

1. Failure of the Popham settlement on the Kennebec. Palfrey, i. $83-85 ;$ Fiske, Old Va., i. 70, 7 I.

2. The James River colony of the London Company. 3. Services and character of Captain John Smith. - Credibility of his story. John Smith, Horks, 305-488; Stith, 42-107; A. Brown, First Republic, preface; Fiske, Old Va., i. 7I-79, So-I 43, I 5 I-I 59 ; Doyle, i. I49-166; Higginson, I4I-151; Hart, Contemp's, i. 209-218. 
4. Change in the London Company. - Its powers of government over the colony. Doyle, i. 167-I77; Fiske, Old Va., i. I 44$1+7$.

RESEARCH. - The fate of Jamestown, the first settlement in Virginia.

\section{Tobacco Culture. - Prosperity. - Disaster.}

TopICS AND REFERENCES.

I. I'rosperity on James River resulting from tobacco culture. Bruce, i. 51, 52, 160-165, 210-212, 254, 255. 262-270; Fiske, Old la., i. 174-177; Hart, Contemp's, i. 2S8-291, 307-310; Eggleston, Bisinners, s4-86.

2. Important political change in the London Company. See references in section 23 .

3. Spread of settlements between James and York rivers. 4. Murderous outbreak of Indians. 5. Overthrow of the charter of the London Company. Fiske. Old Va., i. IS9, I90, 20I-222; Hart, Contempis, i. $225-233$.

Research. - Spanish influence at the English court against the

London Company. Fiske, Old Va., i. 194-196. - With what kings dicl the English people carry on the struggle for constitutional rights that is referred to in this section?

\section{The Founding of Maryland.}

TOPICS AND REFERENCES.

I. Crant to Lord Baltimore of territory taken from Virginia (text in Preston, 63-77; MacDonald, i. 53-59).

2. His "palatine" principality. See references in section 28.

3. Object of Lord Baltimore in obtaining the grant. 4. Beginning of the settlement of Maryland. 5. Religious and political freedom in the Maryland colony. W. H. Browne, ch. ii. ; Fiske, Old l'a., i. 265-275; Doyle, i. 367-3S7; Lodge, Short Hist., 93Ioo; Drake, Making la., 66-79; Fisher, 6z-67.

RESEARCH. - The harsh treatment of Catholics in England at this period. Eggleston, Besinners, 236-239. 


\section{First Settlement in New England. - The Pilgrim Fathers.}

Topics AND References.

I. Mapping and naming of New England by Captain John Smith. Winsor, America, iii. I 79, I80; Fiske, Beginnings, 77-79; Palfrey, i. 92-98; Hart, Contempis, i. 3r3-3r8; O. S. Leaf., I2 I.

2. The influence which brought colonists to the region. 3. $\mathrm{Mi}$ gration of the "Pilgrim Fathers." 4. Their religious denomination and its claims. Palfrey, i. I26-163; Winsor, America, iii. chs. vii.-viii.. Walker, chs. i.-iii.; Dexter, chs. i.-xvi.; Fiske, Beginnings, 70-77, 79-82; Eggleston, Beginners, I4I-I 8 I ; Doyle, ii. I468; Hart, Contemp's, i. I67-170, 340-348.

\section{The Plymouth Colony.}

Topics AND REFERENCES.

I. Sufferings and trials of the Pilgrim settlement. 2. Their relations with the Indians. 3. Creation of the Council for New England (text in MacDonald, i. 23-33).

4. Its grant of land to the Pilgrim colony (text in MacDonald, i. $5 \mathrm{I}-53)$.

5. Slow growth of the colony. Palfrey, i. chs. v.-vi.; Dexter, chs. xvii.-xxv. ; Fiske, Beginnings, 82-87 ; Hart, Contemp's, i. 349-359. Research. - Other attempts at settlement in New England between 1620 and 1630. Palfrey, i. ch. vi.; Drake, Making N.E., I04-I4I. In what circumstances was the Plymouth branch of the Virginia Company reorganized and rechartered, as the Coun. cil for New England? Fisher, 84-85.

\section{The Puritans in England.}

TOPICS AND REFERENCES.

r. Despotic attempts of Charles I. in England. 2. Spreading of the views called "Puritan." Green, ch. viii. sects. I and 5 ; Winsor, America, iii. ch. vii.; Walker, 76-94; Palfrey, i. ch. vii. ; Eggleston, Beginners, 192-196; Larned, England, 379-384.

RESEARCH. - What is an "established church"? - Is there any such church in the United States? - Is there now an established church in England? - Did the distinction between Puritans and Independents, in their church organization, disappear after the former came to New England? Walker, ch. iv. 


\section{Emigration and Settlement of the Governor and Company of Massachusetts Bay.}

TOPICS ANd References.

I. Cause of the emigration. Green, ch. viii. sect. 4.

2. Grant of territory to John Endicott and others. - Endicott's settlement. 3. Chartering of "The Governor and Company of Massachusetts Bay." Remarkable degree of independence secured (text in MacDonald, i. 37-42; Preston, 36-61 ; O. S. Leaf., 7.) 4. Transfer of the charter and government to New England. Ellis, ch. vii.; Fiske, Beginnings, 92-104, and Civil Gov't, 146-148; Winsor, Boston, i. I 5I-I 59; Palfrey, i. 283-329; Doyle, ii. ch. iii. ; Hart, Cont'mp's, i. 366-372; Fisher, IOI-IO3, Io8-I I 2.

5. Rapid rise of settlements on Massachusetts Bay. 6. Demands for the surrender of the charter. Twitchell, chs. v.-x.; Fisher, I 20-1 23.

Research. - Other grants by the Council for New England, to Mason, Gorges, and others. Doyle, ii. ch. vii.; text in MacDonald, i. 36, 37, 50, 5 I.

\section{Enlightenment and Intolerance in the Massachu- setís Colony.}

TOPICS AND REFERENCES.

I. The planting of schools and founding of Harvard College. Fiske, Beginnings, Iro-I I ; Palfrey, i. 548-549; Hart, Contemp's, i. $467-472$.

2. Restriction of political rights to church members. Walker, 9S-I00, I25-I2S ; Ellis, ch. vi. ; Fiske, Beginnings, I08-109, 247252 ; Palfrey, i. 344-348, 383-389: Hart, Contemp's, 330-333, 393396.

\section{Secession from Massachusetts Bay. - The Found- ing of Connecticut.}

Topics AND References.

I. Migration of Thomas Hooker and his followers to the Connecticut. 2. Rival claimants of the Connecticut Valley. 3. The Pequot Indian War. 4. The New Haven settlement. - Its "Fundamental Agreement" (text in MacDonald, i. 67-72). Johnston, Connectiut, I7-20, 69-7t; Fiske, Beginnings, 122-127, 134-136; 
Doyle, ii. ch. v., Eggleston, Beginners, 3 I 6-325; Hart, Contemp's, i. 410-415, 439-444; Hubbard, ii. 5-38. See, also, references in sect. 26.

\section{The Founding of Providence. - Beginnings of Rhode Island.}

TOPICS AND REFERENCES.

I. 'The broad views and tolerant spirit of Roger Williams. 2. His persecution in Massachusetts. 3. The founding of Providence Plantation. 4. The buying of lands from the Indians. Arnold, i. chs. i.-iv.; Ellis, ch. viii.; Walker, I29-136; Fiske, Beginnings, II4-116; Hart, Contemp's, i. 402-406;O. S. Leaf., 54 .

Research. - The Character of Roger Williams. Eggleston, Beginners, 30I-306. - Other early advocates of religious toleration. Brooks, 38-46. - Later development of religious freedom. Schaff; Lauer, ch. iii.

\section{Mrs. Anne Hutchinson. - The Antinomian Con- troversy.}

Topics And References.

I. Banishment of Mrs. Hutchinson and her followers. 2. Settlement on the island of Aquidneck. - Other settlements on Narragansett Bay. 3. Origin of the name of Rhode Island. 4. Patent to the "Colony of Providence Plantations" (text in MacDonald, i. 91-93). 5. New Hampshire settlements. Arnold, i. chs. ii., v.vii.; Hosmer, Vane, 47-So ; Palfrey, i. ch. xii.; Ellis, ch. ix.; Eggleston, Beginners, 329-34I ; Fiske, Beginnings, I I6-I20; Twitchell, chs. xi.-xii. ; Hart, Contemp's, i. 3S2-3S7, 397-40 I.

RESEARCH. - The subsequent political career of Vane in England.

Hosmer, Vane.

\section{New England in 1640.}

Topics AND REFERENCES.

r. Outbreak of civil war in England. 2. Ending of Puritan emigration. 3. Extent and distribution of population in New England. Fiske, Beginnings, I37-I 39. 


\section{Confederation of Four New England Colonies.}

TOPICS AND REFERENCES.

I. Confederation of the four leading New England colonies (text in Preston, 85-95; MacDonald, i. 94-IOI). 2. Purpose of the union, and its significance. Fiske, Beginnings, I 55-I60; Palfrey, i. 623-634; Doyle, ii. 224-3I6; Frothingham, Rise of the Rep., 33-49; Hart, Contemp's, i. 447-454.

\section{The Dutch on the Hudson and the Delaware.}

TOPICS AND REFERENCES.

I. Position acquired by the Dutch. 2. Their title to it. 3. Extent of territory claimed by them and called New Netherland. 4. Chartering of the West India Company, and its early settlements. Fiske, D. and Q. Col's, i. 97-II3, I I6-I I 7, 277-279.

Research. - Swedish settlements on the Delaware. O. S. Leaf., 96; Fiske, D. and Q. Col's, i. 237-242.

\section{Ill Government of the Dutch Colonies.}

TOPICS AND REFERENCES.

r. New Amsterdam. 2. Character of the New Netherland government. 3. Peter Stuyvesant. O'Callaghan, ii. bk. 6, ch. viii.; Fiske, D. and Q. Col's, i. I31-133, I62-20I ; Lodge, Short Hist., 286-292 ; Thwaites. Colonies, I98-202 ; Drake, Making Va., r23I38; Hart, Contemp's, i. 529-537.

RESEARCH. - Constitution and character of the government of

Holland at this time.

\section{Civil War in England. - Its Effect on the Colo- nies.}

Topics ANd REFERENCES.

r. The royalist party, called Cavaliers, and the parliamentary party, called Roundheads. 2. Confusion and weakening of authority over the colonies. 3. Execution of the king. 4. The Commonwealth and Protectorate in England. Green, ch. viii. sects. 7-10; Gardiner, 537-576; Larned, England, ch. xvii. 


\section{Substantial Independence of New England.}

TOPICS AND REFERENCES.

1. Attitude of the New England colonies during and after the English civil war. 2. Theory of the relation of the colonies to the English crown. Fishe. Civil Goit, I 56-i 58 .

3. Failure of the attempt of Parliament to charter Massachusetts anew. Fiske, Beginnings, I60-162: Palfrey. ii. tor.

4. The Massachusetts mint and its significance. 5. Substitutes for coined money in the colonies. Weeden, i. 32-45, 190-I92, 325326; Palfrey, ii. 403-405.

6. Cromwell's attitude toward the colonies.

RESEARCH. - The origin of coined money. - The two purposes which money serves. and the reasons why they are served best by the so-called precious metals. - Why and under what conditions can a paper note be made to serve satisfactorily as a representative substitute for coined money? Jerons, chs. iii., r.-vi., xvi.-xviii.

\section{Persecution of Quakers in Massachusetts.}

TOPICS AND REFERENCES.

1. The Friends, or Quaters. 2. Their persecution in Massachusetts and elsewhere. Fiske. Beginnings, I79-I9I : Higginson, 203-206; Doyle, iii. I26-I46: Hart. Contemp's, i. 479-4\$6.

RESEARCH. - Characteristics of the Quakers (Hallowell, ch. i.).

\section{Virginia and Maryland during and after the Eng- lish Civil War.}

\section{TOPICS AND REFERENCES.}

r. Virginia in sympathy with the king. 2. Treatment of the colony by Parliament and Cromwell. Doyle, i. 2SI-302: Fishe, Old Va., ii. I6-2 I : Lodge, Short Hist., If-IS: Hart, Contemp's, $233-236$.

3. The Maryland Toleration Act of 1649 (text in MacDonald. i. 104-106; Hart. Contemp's. i. 291-294). 4. Influx of expelled Puritans from Virginia. 5. Their conduct in Maryland. W. H. Browne, 57-S9: Fiske, Old Va.. i. 30I-3IS; Doyle, i. 402-416; Hart, Contemp's, i. 262-267. 
CHAPTER II.

POLITICAL AND SOCIAL DEVELOPMENT OF THE EARLY COLONIES.

23. Virginia. In origin and in form and character of society and government there was much unlikeness between the seven English colonies that existed when the Protectorate in England was overthrown and monarchy was restored.

Virginia had been colonized first by a company, royally chartered, most of whose members remained in England, keeping the whole direction of the colony there and governing it wholly through officials of its own. In I6I9 the colony passed under the control of men who were wise and generous enough to give instructions that the Virginia planters "might have a hand in the government of themselves;" whereupon the colonial governor caused two representatives to be elected from each of eleven settlements or plantations, who were to meet with a council which the company appointed, forming a general assembly, - the first of American legislatures, and probably the first colonial legislature in the world since those of the ancient Greeks. Two years later the company, led by Sir Edwin Sir Edwin Sandys, a man of great influence and ability, sandys. established this system of partly representative government more formally and firmly by embodying it in an ordinance, adopted on the $24^{\text {th }}$ of July, I62I. ${ }^{1}$ The

' This was more nearly a written constitution of government than the agreement to be spoken of presently, which the Pilgrim 
broad-minded men who brought this about were leaders in the party which resisted the tyrannical attempts of King James to destroy the political rights of the English people. Hence the king was hostile to them, and he was able, with the help of a subservient bench of judges, to annul their charter and take the colony out of their hands. He then began to plan a new scheme of government for Virginia, and would, of course, have swept away its representative legislature; but he fell sick soon afterward and died (March, I625). His son and successor, Charles I., plunged instantly into quarrels with his subjects at home, which kept him busy, and Virginia was let alone. Except that its governor and council were appointed thenceforth by the crown, the government of the colony was unchanged, and its general assembly lived on through the whole of the colonial time. The popular representatives in the assembly, called burgesses, were elected by vote of all the free Assembly of Burgesses. male "inhabitants" of the colony until I670, when the suffrage was restricted to "freeholders and housekeepers."

Excepting Virginia, every one of the early colonies had its origin in a movement of escape from intolerant laws concerning religious practices and beliefs. Two of them (Connecticut and Rhode Island)

\section{Religious} Origins. represented secessions from the main body of the exiles ;

Fathers of the Mayflower adopted eight months before. This Virginia ordinance created the apparatus of a representative government, which the Mayflower Compact did not; but the latter was the agreement of the people themselves, while the former was a grant from men who exercised sovereignty over the people in the king's name. Both instruments are of memorable interest in American history ; but neither of them can be called " the first of written constitutions," as the "Fundamental Orders" of Connecticut (see sect. 26) can be, in the strict modern sense. 
in four instances the migration was self-directed by those who took part in it; in the remaining case (that of Maryland) it was not.

24. Plymouth. In the matter of government, the Mayflower Pilgrims, on arriving at Plymouth, were singularly placed. They came to America with no government provided for them by the authority in England which claimed sovereignty over their new home, and with no authorization to govern themselves. Self-government was forced on them, in a primitive way, by the necessities of their situation, impelling them to excrcise a natural right. To agree on some organization of authority amongst themselves was all that they could do. They framed such an agreement and signed it, on the I ith of November (Old Style, being the 2 Ist, New Style), beMaytlower fore landing from the ship. ${ }^{1}$ If we can call this compact. "Mayflower Compact," as it is known, a constitution of democratic government, it was the simplest ever written, and the first (see footnote, sect. 23). It gave sufficient authority to the governor, chosen yearly thereafter (John Carver in the first year, and William Bradford in most of the thirty-six following years), and sufficient force to the simple ordinances that were enacted in meetings of the whole small body of the Plym-

1 "We," it said, "having undertaken, for the glory of God and advancement of the Christian faith and honor of our king and country, a voyage to plant the first colony in the northern parts of Virginia, do, by these presents, solemnly and mutually, in the presence of God, and of one another, covenant and combine ourselves together into a civil body politic, for our better ordering and preservation and furtherance of the ends aforesaid; and, by virtue hereof, to enact, constitute, and frame such just and equal laws, ordinances, acts, constitutions and offices, from time to time, as shall be thought most meet for the general good of the colony. Unto which we promise all due submission and obedience." 
outh freemen, until 1639. After that time deputies were , chosen to form a representative legislature, in place of the original meeting of all. From the beginning to the end of its separate existence, the Plymouth colony was a self-constituted republic, existing as such by sufferance of the government that claimed dominion over it.

25. Massachusetts. Very different in political structure was the colony next planted on the New England coast. That came, as we have seen (sect. 10), to an appointed territory, and came fully constituted and organized in advance, - " the Governor and Company of Massachusetts Bay," - endowed with all the powers of selfgovernment that the sovereignty assumed by the king of England could confer. It came as a corporate body, created by royal charter, empowered to acld to its membership without limit, and, apparently, on its own terms. It exercised that power of admitting new members by adopting a rule, in the year after its arrival in America, that " no man shall be admitted to the freedom of this body politic but such as are members of some of the churches within the limits of the same." This shut out all but members of Puritan churches, since no other religious bodies were

Restriction of the franchise to church members. allowed, for some time, to hold services in the colony. It did not exclude other persons from residence in the colony, for many who were not Puritan church members came in ; but it denied them political rights. They were not "freemen" of the body politic; they had no vote. This peculiar qualification of the suffrage became a cause of deep discontent; but, with a slight relaxation (in I662, by what was called the "Halfway Covenant"), it was stoutly maintained for more than half a century, until the cherished charter of the "Governor and Company" had been annulled. 
At the outset, the general body of the "freemen" of the colony could exercise their political franchise only by being present at the meetings called the "general court." They elected the twelve "assistants provided for in the charter;" the assistants elected the governor; the governor and assistants made and executed laws. But in the second year of the colony the yearly election of the govEarly crnor was taken from the assistants and given Early
Represen- to the general body of freemen; and in the third
tation.

year a representative legislature was created, formed of deputies from each town. Its sessions were still called meetings of the "general court."

26. Connecticut and New Haven. Disapproval of the narrow restriction of political rights in Massachusetts was among the causes that led to the secession and migration which planted a separate colony in the Connecticut valley. The first three Connecticut settlements were made by emigrants from the three Massachusetts towns of Newtown (afterwards Cambridge), Watertown, and Dorchester, and each brought part of its town and church organization with it, setting the same in operation on the new ground at once. Their local government suffered no break, therefore, and a general or commonwealth govermment was created immediately, by an assembly of the magistrates of the three towns, to form a "general court." In 1639 the whole body of "the inhabitants and resiFundamen- dents" of the three towns adopted what they

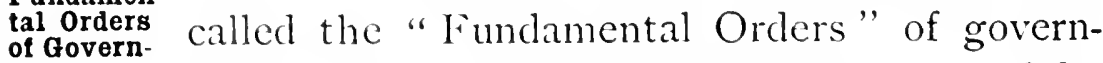
of Govern-
ment. crees which form, in the most complete sense of the term, a written political constitution; and, in that full sense, it is the first that is known to have been framed as a scheme of self-government by any community of people in the 
world." "We the inhabitants and residents of Windsor, Hartford, and Wethersfield," said they, in these "Orders," "well-knowing where a people are gathered together . . there should be an orderly and decent government established according to God, to order and dispose of the affairs of the people at all seasons as occasion shall require, do therefore associate and conjoin ourselves to be as one public state or commonwealth." Here, then, we have again, as at Plymouth, the creation of a self-constituted commonwealth, derived from no exterior sovereignty, and resting on none, until, after a quarter of a century, its constitution was uselessly confirmed by a charter from the king.

The same self-making of government was performed at New Haven, in the founding of a colony there that was joined a little later to Connecticut. Authority at New Haven was based on a "Fundamental Agreement," in six resolutions; but the community had nothing of the democratic spirit of its near neighbors, up the river, since none but church members were admitted to the franchises of the little state.

27. Rbode Island. In like manner, Roger Williams and his followers accomplished their self-organization of government on Narragansett Bay, by a compact as simple as that of the Plymouth Pilgrims. It united them,

1 Dr. Fiske calls attention to the fact that "this document contains none of the conventional references to a 'dread sovereign' or a 'gracious king,' nor the slightest allusion to the British or any other government outside of Connecticut itself, nor does it prescribe any condition of church membership for the right of suffrage. It was the first written constitution known to history that created a government, and it marked the beginnings of American democracy. of which Thomas Hooker deserves more than any other man to be called the father." - Beginnings of New England, p. 127. See, also, footnote on page 63 . 
"with such others as they shall almit." in a "town fellowship:" but stipulated that the fellowship should be "only in civil things." thus decharing a separation of the affairs of the "state "from the affairs of the "church." Their civil gorernment was the first in history to be barred from interference with the freedom of the soul.

28. Maryland. In the case of Marylund the political formation was wholly different from that of any of the colonies described above. The king of England, in that instance, transferred to one of his subjects. I.ord baltimore, almost the whole sorercignty that he clamed orer a portion of American territory parting with the exercise of that sorereignty so completely that his relation to Maryland became only that of a feudal suacrain or overlord. This created what was known in the Middle Ages

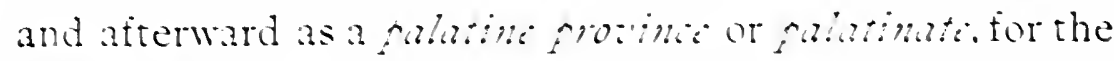
sorerelgats rasson that the powers conferred on its lord conferred
on Lord Were those exercised in the palace of the king. on Lord

He could grant titles of nobility coin money. create cours. appoint judges, hear appeals from them. approve or annul all colonial procedings and be practically. in fact. a sorereign within his Aomain. But he was not to be an absolute sorereign, any more than the king of England was constitutionally such. Hy the terms of his patent he was required to sive the freemen of his province a voice in the making of their laws. At first they were all called together tor that purpose in an assembly like the "folk-moots" of the carly English : but in 163 they besan to choose delesates to the assembly, to sit with the goremor. and repesentative government existed in Marylund from that time.

29. The Constitutional Differences and the Fundamental Likeness. To review, now, the variety of political constructions in the tirst English-American col- 
onies: Virginia had been planted originally by a company resident in England, to which the king had granted a large piece of territory, with a somewhat limited power to govern the settlements made in it; but the grant to that company had been annulled by linglish courts, and the colony became then what is called a "crown colony," governed directly by the king. Massachusetts had been planted by a company which held a similar grant from the king, by a charter that was also a constitution of government; but the company, instead of remaining in England to send out colonists and rule them, transferred itself to America, and was itself the colony which it had royal authority to found and rule. Maryland was a "proprictary province," so called, - the property or principality of a lord, who owned its soil and was the sovereign of its people. The remaining three colonies - Plymouth, Connecticut, and Rhode Island - had been planted without authority,

Differences in early colontal governments. and self-government had been organized in them by their inhabitants. Rhode Island had already received a charter from the English government, and Connecticut was to be chartered later; but all three were not only self-planted, like Massachusetts, but were self-constituted republican states.

Under the wide differences in their political construction there was a fundamental likeness between these colonies, in the fact that the people in all of them had what the Virginia company described as "a hand in the government of themselves." There was a representative legislature in every one; having more independence in some than in others, but exercising everywhere a large measure of democratic power, and striving incessantly against all outside restraints. This was because they were English colonies, of English creation, peopled mainly by Eng- 
lishmen, who brought from home the expectation of

Resem-

blances

in early

colonial

govern-

ments. being listened to by their government, and of being represented in the making of their laws and the levying of the taxes they paid. There was no such thing in French or Spanish colonies, nor even in those planted by the Dutch. The nearest approach to it in the Dutch-American colony of New Netherland was a self-perpetuating board of "Nine Men," whom the arbitrary governor consulted when it pleased him to do so; and even that unrepresentative board was not created until the colony had existed for nearly forty years.

Popular representation in government had an ancient origin among the Germanic peoples; but feudalism destroyed it almost everywhere on the European continent. In England it survived, through many vicissitudes, sometimes in vigorous exercise, sometimes preserved feebly, more in form than in spirit, but never given up. At the time when the six colonies we now speak of were planted, the English people were engaged in a decisive struggle Popular re- with their kings, to recover for their represenpresen-
tation in tatives in Parliament the full measure of their England. ancient constitutional powers, which had been slipping away. They had accomplished that, and more; and the spirit of their struggle, as well as the fruits of it, had reached their colonial plantations in the New World.

30. Local governments. - Town, Parish, County, and Hundred. Quite as important as the general legislatures in which the people were represented - in some views more important - were the local organizations in which they managed their neighborhood affairs. These, too, with the training to use them, were brought by the colonists from their mother-land. The early English people had been organized in democratic townships (tun- 
scipes), all the freemen of which assembled in meetings (called gemots or moots), at which the affairs of the tun or town were regulated, and from which four "best men " were chosen to represent the tun in moots of Tuns and larger districts, called hundreds and shires, the Tun-moots. latter corresponding to the counties of later times. Feudalism and the Norman conquest brought about a great change in the old English townships, converting or absorbing them into small lordships, called manors, in which, however, some semblance of the ancient tun-moot or townmeeting was still retained. Meantime the Christian church had been forming parishes that were bounded generally by the old township lines, and the priests called parish meetings, which gradually took up a parish good deal of the same kind of local business meetings. that the town meetings had transacted, thus keeping alive amongst the people the practice of local self-government, which might otherwise have been suppressed.

This most important practice was brought by the English to America, and introduced in the several colonies in somewhat different forms. The Puritan New Englanders put the old township system and the later parish system together, by grouping themselves in church societies and congregations when their first settlements were made, each church becoming the nucleus of a town. This naturally organized the inhabitants of the towns, brought them into intimate and democratic relations with one another, and trained them in the habit of meeting to discuss and act on all matters of common concern. Church meetings became town meetings, and the latter grew, probably, to more importance in New England than they possessed in the days of the old English tun-moot. The whole structure of government in New England was built up from the ground- 
work of these democratic towns. Their representatives composed the "general courts:" they were the units of all political organization - the primaries of all action in public affairs.

In Virginia and Maryland, with their separated plantation settlements, local government was organized necessarily in looser modes. Virginia colonists brought with them the established English church, and with it the parish, in its English form. To some extent, in some places, the parish vestry meetings acquired political functions, but their influence in that direction was slight. The comty was the smallest territorial division in which vestry and the people of Virginia were able really to organmeetings in ize their political action, or to associate themmirginla. selves politically in informal ways. It became the unit of representation in the House of Burgesses at an early day: the magistrates of the county courts, appointed by the governor, had most of the functions of local govermment put into their hands: the elections of burgesses were held in the county court-house, and it was there, on court days, that the planters came together and listened to speeches on public matters, or discussed them in private talk. A lively political spirit was cultivated by these gatherings, but it was much less democratic in character than that of the New England towns. In Maryland, where the English manorial system was instituted by Lord Baltimore, the most important organization of local govermment was in districts called by the old Fnglish name of the landirit. There were

Hundreds in Maryland. settlements in Virginia called hundrets, but they had no essential purpose to serve. The Maryland landrid was the district of elections, of militia trainings, and of nearly all popular meetings of every kind. 
31. Social Structure and Character of Virginia and Maryland. In social structure and character Virginia differed widely from the colonies at the north. Every element of English population was represented in the early emigration to James River, including a considerable number of Puritan settlers; but the majority of those going to that part of America

Early settlers in Virginia. were people who abhorred opposition to the throne and the established church. As the English Puritans were driven to range themselves more and more against king and church, Virginia grew hostile to them, and most of those who had come into the colony were finally (I648-49) driven away into Maryland, about a thousand in number. Their places in Virginia were more than filled by an extensive immigration from England of the defeated royalists, which began in $\mathbf{1 6 4 9}$. In that year the population of Virginia was about I 5,000; it seems to have been doubled in the next eleven years, while England had no king, and the newcomers were generally from the royalist side. Many of them came from the Royalist stock of the English gentry, and many more immigrants. from the class of land-owning farmers called "yeomen," generally bringing enough of means for the buying of estates in land, and for becoming tobacco-planters on a considerable scale. They gave a stamp of character to one side - an aristocratic side - of Virginia society, that was never lost.

Agriculture, the most democratic of occupations in most times and places, was made aristocratic in Virginia by the tobacco plant, which gave better profits to a lordly system of cultivation on big plantations, by the cheap labor of purchased servants (see page 75) or convicts or slaves, than to the tillage of the humbler farm. Virginia society was moulded, politically and economi- 
cally, by that fact. It tended toward the creation of large estates in land, and toward the rise of an all-controlling class of wealthy, strong-willed men, surrounded by helpless or humble dependents, and living a much separated country life. The abundance of large rivers in Virginia made it possible, in the early colonial time, to place every

Intluence of tobacco culture.

considerable plantation on a navigable stream. Each wealthy planter had his own wharves, from which he shipped his tobacco crop, and to which the ships came that brought back most of the proceeds in English goods. This mode of business left little for local merchants to do ; little chance, too, for manufacturing to arise; almost nothing that could build up towns. In Maryland the conditions were much the same.

32. Social Structure and Character of New England. Very different were the circumstances in colonial New England, and very different the social tone. There the dominant part of the population had been picked from England by a sifting out of extremely earnest reReligious ligious minds. They were people to whom the spirit of early matters of religion were the most important in coloolsts.

life, and whose views of religion were grave and stern. Many of them were from English families of the gentry class, and quite commonly they were people of education and of comfortable means. The Puritan ministers who came with them, and who exercised a commanding influence, were mostly men of a remarkably high order in character and mind. If there existed any class that could be called aristocratic in New England, these strong, dictatorial divines were its chiefs; but all the conditions of life, on the small country farms and in the many towns, were such as tend toward the democratic plane.

33. New Netherland. - The "Patroon" System. 
In the Dutch colony of New Netherland, under the Dutch West India Company, an unfortunate attempt had been made to establish a kind of feudal system, by offering lands, not directly to settlers, but to a class of landlords, called patrons or "patroons," each of whom, when he had bought from the Indian owners a tract of land, might settle it with colonists who became, not only his tenants, paying him rent, but his subjects, to a considerable extent. Locally he was their governor, their judge, their military captain, and he controlled their church. Under this Americanized feudal system several enormous tracts of land were secured. One of them, obtained by Killian van Rensselaer, extended along the Hudson for forty-eight miles, and was twenty-four miles in breadth. Naturally, the plan failed to bring many immigrants into the colony, and it was abandoned in 1638 ; but not until it had done great mischief, leaving troublesome monopolies in the ownership of land and lasting social marks.

34. Slavery and Indentured Servitude in all the Colonies. Both negro slavery and another system of bondage, which white people were subjected to, crept into Virginia in 1619, when that was the sole settlement of the English in America, and both of the evil systems made their way into the other colonies at a later time. Twenty negroes from Africa were brought to Jamestown that year and sold; and one hun- slavery. dred poor boys and girls were brought from London at about the same time to be "bound" or indentured to the colonists for a term of years. This latter was the beginning of a system of "indentured servitude" which spread from Virginia through all the colonies, and which, for a long period, exceeded negro slavery in extent. Multitudes of men and women, as well as boys and girls, were sent into 


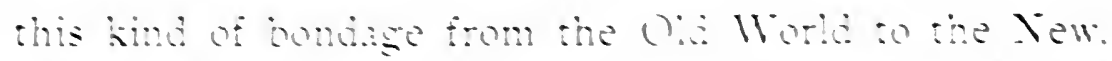

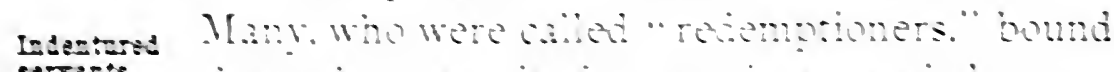

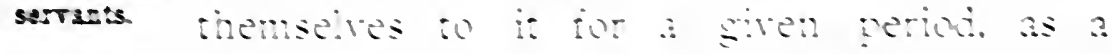

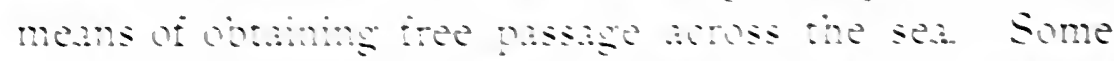

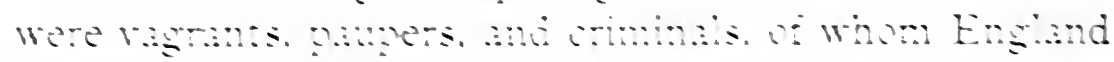

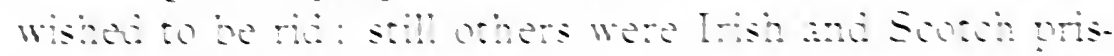

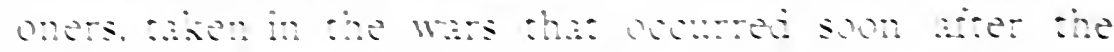

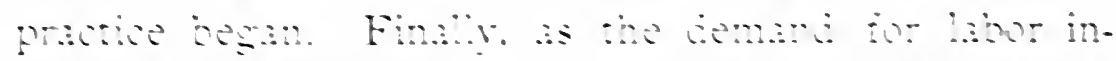

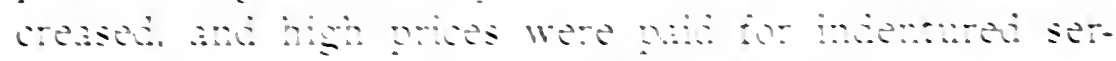

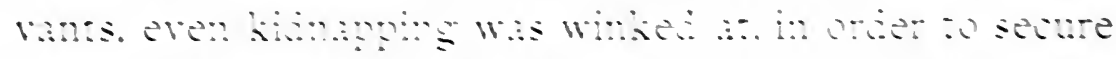

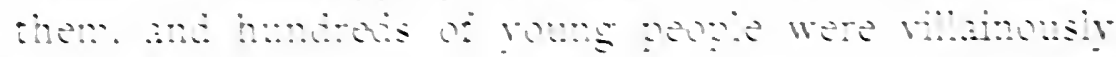
tas?

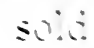

Mำ A

\section{Tirsinis.}

Tomes A

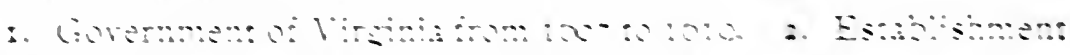
or

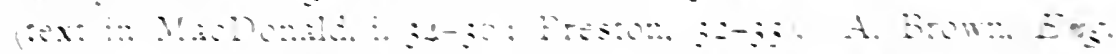

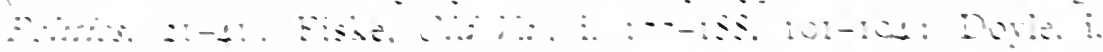

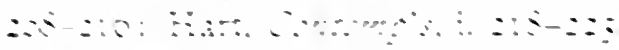

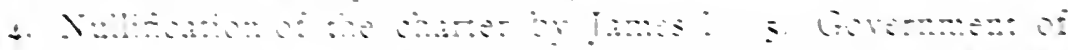
t.

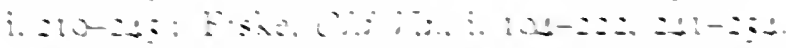

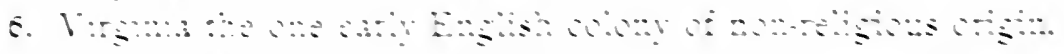
Кะ " w A

\section{Z. Pirmouts}

To:

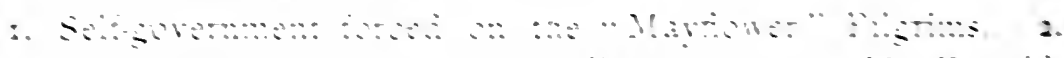

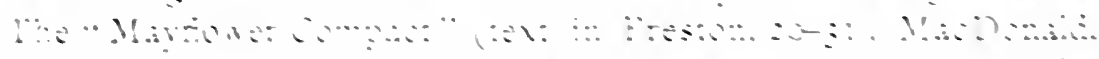

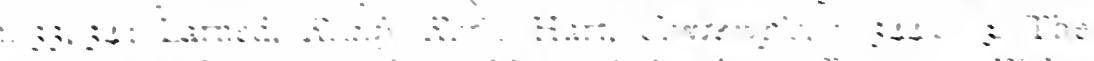

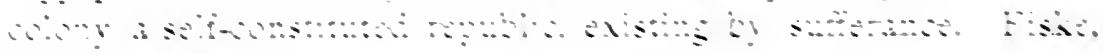
$\therefore \therefore \therefore \therefore \therefore: \therefore: 0$ 


\section{Massachusetts.}

TORICS AND REFERFAES.

1. Early political structure of the Massathustes colony. 2. Its endowment with self-gowement by royl charer. 3. Its power to control its own membership as a body politic. Winsor, fisto.

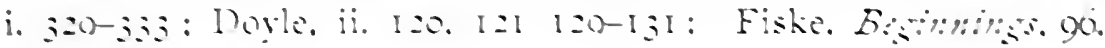
103-105.

4. Admitance of none bu church members o political rights.

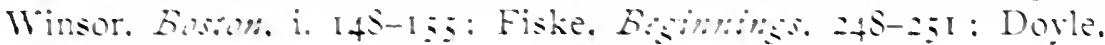
ii. $140-14$.

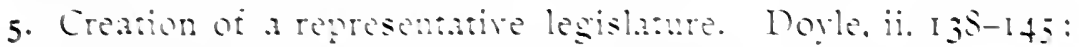

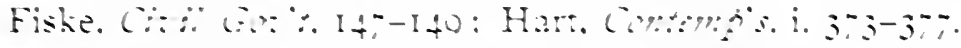

REsEARCH. - Some of the oualifoations for wotng now required

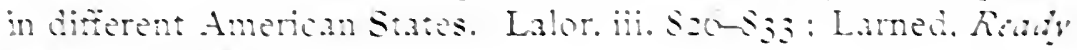
Ris., vi. $6-3-0,7$.

\section{Connecticut.}

TOPICS AND REEERFiCES.

r. Peculiar transfer of awn and church orsanizations from Massahusets. 2. Spontaneous creation of a commonwealth governmeni. 3. The "Fundmental Oriers" itext in Hart. C\%-

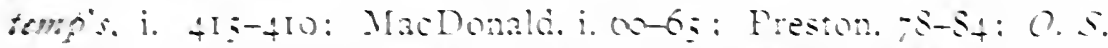

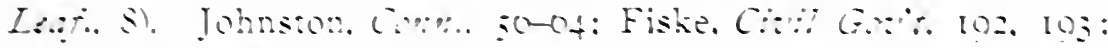

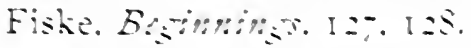

4. The "Fundamental Agreement "of New Haren. Fiske, B:-

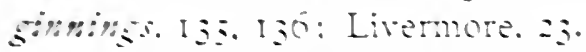

RESEARCH. - Written constitutions. Fiske. Cä Gar ch. wi.

\section{Rhode Island.}

TOFICS AND REFERENCES.

I. Self-orsanizaton of goverment hy Koger Williams and his followers. 2. Their seguration of church and state. I. K. Green.

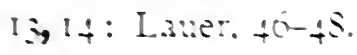

KEsEARCH. - Keasons for and against an exercise of political authority in matiers of religion.

\section{Marjland.}

TOPICS AND REFERENCES.

I. Feudal character of the sovereignty inanserred to Lord Balimore. 2. Nature of the "palatinate" created by his patent 
(text in Preston, 62-77; MacDonald, i. 53-59). 3. His powers and their limitation. Fiske, Old I a., i. 256-266, 269-272, 275-2S1; Fiske, Civil Gov't, Ijo-IjI; Browne, IS-20; Eggleston, Beginners, 23t-236.

4. Rise of the representative assembly in Maryland. Fiske, Old la., i. $28_{3}-2 S_{5}$; Browne, 35-36.

Research. - Palatinates in Europe. Larned, Ready Ref.

\section{Constitutional Differences and Fundamental Likeness.}

TOPiCs AND References.

I. Variety of political constitutions in the early colonies. 2. The colonies alike in having representative legislatures. 3. Distinction of English colonies in this respect. Hinsdale, Am. Gov't, 33-3j: Fiske, Civil Gov't, I 54-1 56: Schouler, Const. Studies, 9-17 ; Johnston, The U.S., 9.

4. Peculiar survival of representative government among the English people. 5. Their recent struggle for its preservation. Fiske, Civil Gov't, 39, 40; Larned, England, 23, 373-420; Green, ch. viii. sects. $3-9$.

RESEARCH. - The Germanic origin of representative government.

Fiske, Am. Pol. Ideas, 69-72.

\section{Local Governments. - Town, Parish, County, Hundred.}

Topics AND Referexces.

I. Early English origin of town meetings. 2. Later English origin of parish or vestry meetings. 3. Township and parish systems combined by the New Englanders. 4. Government in New England built up from the democratic towns. Fiske, Civil Gov't, 35-71, I6-2I ; Fiske, Am. Pol. Idkas, 3I-53: Doyle, iii. Io-17.

5. Parish and county systems in Virginia and the "hundred" in Maryland. Hosmer, A.S. Freedom. i IS-гzі : Fiske. Civil Govit, $57-66,75-77$.

RESEARCH. - The system of local gorernment organization in the student's own State. 
31. Social Structure and Character of Virginia and Maryland.

TOPICS AND REFERENCES.

I. Early Virginia colonists mainly royalists and churchmen. 2. Expulsion of Puritans and immigration of defeated Cavaliers. 3. Aristocratic influence of tobacco culture. 4. Conditions adverse to the rise of towns. Fiske, Old Va., ii. 9-18, 23-30, 3435, I74-I8I, 203-2I8; Hosmer, A.S. Freedom, I22-125; Thwaites, $96-98,100-104,106-109$.

32. Social Structure and Character of New England. TOPICS AND REFERENCES.

I. Religious selection of the New England colonists. 2. The English classes represented in them. 3. Conditions of life tending toward democracy. Winsor, Boston, i. I48-149; Fiske, Am. Pol. Ideas, I7-3I ; Fiske, Beginnings, I 40-15I ; Doyle, iii. 57-64; Weeden, i. 28I-282; Hosmer, Adams, 89 .

\section{New Netherland. - Patroon System.}

TOPICS AND REFERENCES.

I. The system of landholding undertaken in the Dutch colony. 2. Its failure and the evil results. O'Callaghan, i. II $2-I 28$; Schuyler, i. II-26; Fiske, D. and $Q$. Col's,'i. I33-I40; MacDonald, i. $43-50$.

\section{Slavery and Indentured Servitude.}

TOPICS AND REFERENCES.

r. Beginnings of slavery in the colonies. 2. The system of indentured servitude. Bruce, j. ch. ix ; Fiske, Old Va., ii. I 8 I-203; Cooke, Ir9-123; Thwaites, 98-Ioo; Doyle, i. 66-68; Ballagh. 


\section{CHAPTER III.}

THE COLONIES UNDER CHARLES II. AND JAMES II. 1660-1688.

35. Virginia under Charles II. With the new king, Charles II., the Royalist or Cavalier party, crushed a dozen years before in England, came back into power (I660) and had its revenge. Then the English Puritans were oppressed, and the Puritan colonies in America had nothing but hostility to expect. Nevertheless, the latter suffered less than the planters of the south. A hard blow to the prosperity of Virginia and Maryland was struck by one of the first enactments of the new governNarigation ment, called the Navigation Act of I660, which Act, 1660. will be described on a later page. It shut the tobacco planters from every market for their product except England, which could not take up the whole supply. This brought down the price to a ruinous point, and left unsalable crops on the planters' hands. For the consolation of the aggrieved Virginians, their old governor, Sir William Berkeley, whom they had reinstated without waiting for authority, and who went to England to make his bow to the restored king in I66I, came back with instructions that were full of piety and exceedingly wise. He was "to take especial care that Almighty God be devoutly and duly served," "the Book of Common Prayer as now established read," and laws "for the suppression of vice, debauchery, and idleness" passed. $\mathrm{He}$ was to encourage the planters " to build towns upon 
every river," - “one town at least to be built upon every river." 1

It is to be feared that Sir William did not keep these instructions in mind; for his government in Virginia thereafter was not one that would cultivate piety or encourage the building of towns. He had always been a despot by nature, and he now became more despotic than before. His royal master was beginning already to set as vile an example of bad government as England ever knew, and Berkeley seems to have copied the pattern in several respects. He surrounded himself, it was charged, with scandalous favorites, who allowed broken private fortunes to be repaired at public expense. Just as England, in the first excitement of the

Berkeley's despotism, country over its restored king, had elected a Parliament of Cavaliers who did everything that his majesty wished, so Berkeley, in $\mathrm{I} 66 \mathrm{I}$, secured a House of Burgesses that gave him a free rein. For fifteen years he kept the subservient House in existence, not allowing it to be dissolved. Practically, the political rights of the colonists were suppressed, while their economic condition grew steadily worse, and the result was an increasing state of discontent.

36. New England and the King. 1660-1661. The Puritan colonies of New England fared better than Cavalier Virginia, for some years. There was no lack of hostile feeling toward them, in and around the English court, and it was fomented by the sufferers from persecution in Massachusetts, who bore complaints to the king; but the solid strength which that colony had now attained, buttressed by the three lesser colonies in the New England confederation, was not encouraging to a hasty

1 Sainsbury, Calendar of State Papers: Colonial, I66I-68, p. Iro. 
attack. The colonists took care to proroke no attack, and sent loyal addresses. to give assurance of the affection with which they welcomed the king to his reërected throne. Massachusetts was the first of the four united colonies (December, I660) to make that dutiful offering;

Massachusotts asserts her "Lib. erties," 1661 . but, as if to prevent any possible misunderstanding of what it conceived to be its relations to the English crown, this was followed a few months later by an important statement "Concerning our Liberties." which set forth the powers that "the Governor and Company" beliered to be conferred on them by the patent or charter received from King Charles the First. That patent, they declared, made them "a body politic, in fact and in name," "rested with the power to make freemen," which "freemen have power to choose annually a governor," etc.. and "to set up all sorts of officers." having "full power and authority . . . for the gorernment of all people here. . . without appeal, excepting law or laws repugnant to the laws of England:" and such "gorermment is privileged . . . if need be by force of arms. to defend themselves, both by land and sea." Finally, they declared. "we conceive any imposition . . contrary to any just law of ours not repugnant to the laws of England, to be an infringement of our right."

37. Connecticut and Rhode Island Chartered. New Haven Absorbed. 1660-1663. Connecticut, Plymouth, and New Haren followed the example of Massachusetts in sending loval addresses to the king. Rhode Island had acknowledged and proclaimed hing Charles in advance of them all. The memorial of Con. necticut was followed by her governor, the younger John Winthrop, who went to England in the summer of $166 \mathrm{r}$ to solicit a charter from the king. He was a gentleman 
of such tact and address that he secured a charter which annexed the settlement at New Haren to the colony of Connecticut, granting to the latter a zone of territory as long as the continent is wide,

Connect1-

cut's charter. bounded on the north by the line of Massachusetts, on the south by the Atlantic, and rumning from Narragansett Bay on the east " to the South Sea on the west." New Haven resisted this arbitrary annexation without avail. Its people had given particular offence to the king by sheltering and shielding two of the judges (Colone] Whalley and Colonel Goffe) of the court which tried the late king and sentenced him to death. Those "regicides," as they were called, being

\section{Reglcides}

In New England, $1660-1661$. pursued by royal officers, were hidden in New Haven and its neighborhood and helped to escape. Hence the readiness with which Connecticut was permitted to annex the smaller colony. It was a proceeding so intolerable to some in New Haven that they migrated a few years later $\left(1666-\sigma_{j}\right)$ to what had then become New Jersey, and founded Newark, on the Pas-

Migration to the Passaic. saic; while Mr. Davenport, the father of the colony, withdrew to Boston and ended his days in that town.

The Rhode Island and Providence Plantations, as well as Connecticut, had success at this time in applying for a royal charter (issued in $166_{3}$ ), and the usual carelessness of the day in such matters described conflicting boundaries. The Rhode Island charter was made notable by a clause declaring: "Our royal will $\begin{gathered}\text { Rhode } \\ \text { Island's }\end{gathered}$ and pleasure is that no person within the said colony, at any time hereafter, shall be in any wise molested, punished, disquieted, or called in question, for any differences in opinion in matters of religion." This respectful concession to the principle of religious liberty is made extraordinary by the fact that, when the charter 
containing it was issued, the king and his party were suppressing in England every form of religious worship except that of the established church.

38. The Founding of the Carolinas. 1663-1693. Three months before the issuing of the charter to Rhode Island (March, I663), another was granted to a company of high personages, resulting in the founding of a new proprietary colony, out of which came our two Carolinas,

Palatinate of the Carolinas.

North and South. This charter created a "palatinate," like that of Lord Baltimore (see sects. 6 and 28). Furthermore, in the spirit of the Rhode Island charter, it added to those extensive sovereign powers a special permission to be inclulgent to people who "cannot, in their private opinions, conform to the public exercise of religion according to the liturgy, form, and ceremonies of the Church of England."

The territory of the newly chartered colony, called the Province of Carolina, Early settle-
ments from had been emments from braced in vaVirginia.

rious former grants, but never occupied in any effectual way. Two small settlements from Virginia, on Albemarle Sound, east of the Chowan, had been made in 1653 and 1662 . These became the nucleus of the colony in its northern part. Between 1665 and Slavery and 1670 , im mi-

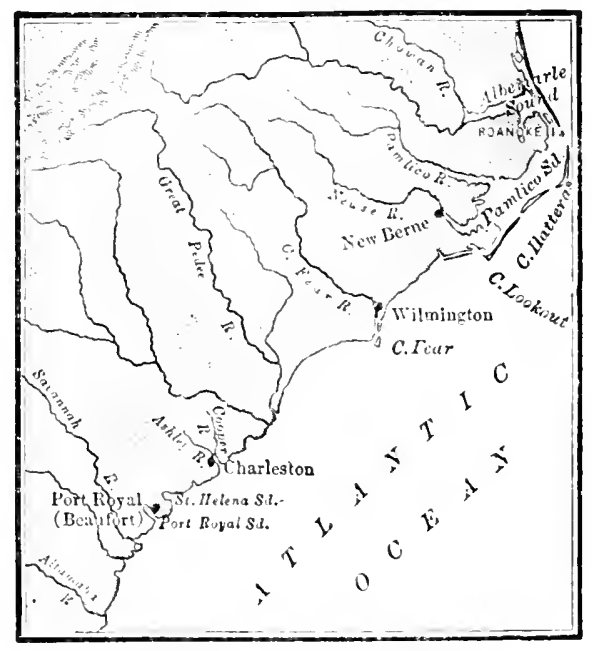

EARLY SETLLEMHNTS IN THE

CAROLINA GRANT.

servitude. grants from Barbados and from England planted settlements farther south, on the Cape Fear River and at 
the point where the city of Charleston now stands. In I672 the colony received a governor from Barbados, Sir John Yeamans, who brought with him a number of negro slaves.

A constitution for Carolina had been drafted by a hand no less distinguished than that of the great English philosopher, John Locke. He prepared it as the secretary of the Earl of Shaftesbury, one of the proprietors, and the instrument is supposed to have represented the views of that nobleman much more than his own. Its main purpose, as stated in the preamble, was "that the government of this province may be made most agreeable to the monarchy under which we live," "and that we may avoid erecting a numerous democracy." It provided for the creation, on one hand, of an hereditary nobility, of "landgraves" and "casiques," with a "grand feudalized land system and system of courts; on the other hand, of a body of serfs, called "leet-men" and "leet-women," whose serfdom should be perpetual; for, said the constitution, "all the children of leet-men shall be leet-men, and so to all generations." In addition to the serf system, it established negro slavery, and every "freeman" was given "absolute power and authority over his negro slaves." It is gratifying to know that this "grand model" of government, as it was called, could not be made to work, and was abrogated in 1693. Even after that time the settlements in Carolina (already treated as in two sections and described as "our colony north-east of Cape Fear" and "our colony south-west of Cape Fear") languished for some years in a disordered and unprosperous state.

39. Conquest of New Netherland, which becomes New York. 1664. The list of English colonies in America was now increasing fast. Two more were added 
in 1664, as a consequence of the capture of New Netherland from the Dutch. England had never given up her clain to that important territory between the two groups of her American colonies, and the time for enforcing it was thought to be reached in I664. Several reasons for that conclusion were found, and the king and his ministers resolved to make a sudden seizure of the Dutch settlements without any previous declaration of war. Before doing so, in March, I664, the king issued a patent Grant to the his brother James, Duke of York, grantDuke of ${ }^{\text {Grant }}$ ing to that prince all the territory that lies beYork, 1664

tween the Connecticut and Delaware rivers, together with Long Island and several other islands, and a certain district in Maine. This nullified the grant lately made to Connecticut and the older grant to Massachusetts, so far as concerned everything west of the Connecticut River; but tricks of that sort were nothing to a Stuart king. In April the Duke of York commissioned Colonel Richard Nicolls to be his deputy-governor in the great province thus given him, over which his powers of government were not to be those of a palatine prince, but had no other limit save that of conformity to English law. Within a few clays the same Colonel Nicolls was appointed by the king to head a commission, instructed

Commis-

sioners to

visit New

England. "to visit the several colonies of New England, and to examine and determine all complaints and appeals in all causes, as well military as criminal and civil, and to proceed in all things for settling the peace and security of that country." The projected seizure of New Netherland appeared, therefore, to be connected in the plans of the king with a design against the independence of New England.

In May Colonel Nicolls and his associates sailed from England with a small fleet and several hundred troops. 
After a short stay at Boston they went on to New Amsterdam and made an easy conquest of the place. The stout-hearted Dutch governor, Stuyvesant, would have defended his little town if he could; but his force was small, his fortifications were slight, and the inhabitants, many of them disaffected, would not take arms. He surrendered on the 6th of September, obtaining quite favorable terms. Colonel Nicolls assumed the New Amgovernorship, and his first act was to change sterdam the name of New Amsterdam to New York. New York. Soon afterward, the province in general was given the same name. Fort Orange was called Albany, and other names were changed.

40. Origin of New Jersey. 1664. Two months in advance of the capture of his province, the Duke of York had sold to Lord Berkeley and Sir George Carteret that portion of it which lies between the Hudson and Delaware rivers, from Cape May to a line drawn from $4 \mathrm{I}^{\circ} 4 \mathrm{O}^{\prime}$ of north latitude on the Delaware to $4 \mathrm{I}^{\circ}$ on the Hudson. This tract was to be called New Jersey, in commemoration of a gallant defence of the isle of Jersey made by Sir George Carteret, against the Parliamentarians, in the English civil war. It was conveyed to the new proprietors with all the powers of government given in the royal grant to the duke. In the following February (I665) the proprietors issued a very liberal frame of government, called "The Concession and Agreement of the Lords Proprietors," pledging freedom of conscience and providing for the representation of the "freemen of the province" in a legislative body.

41. Resistance to the King's Commissioners in Massachusetts. 1664-1666. Meantime, Colonel Nicolls was settling the government of New York, and his colleagues of the New England Commission were striv- 
ing in vain to carry out their instructions and exercise authority within the jurisdiction of the chartered Governor and Company of Massachusetts Bay. In Connecticut, Plymouth, and Rhode Island, the Commissioners were allowed to hear certain appeals to them, as their commission directed; but Massachusetts would permit nothing of the kind. "The Commissioners," wrote one of them (Sir Robert Carr), in a subsequent report, "visited all the other colonies before this, hoping that their submission would have abated the refractoriness of this, which the Commissioners much feared;" "but neither examples

Commis.

sioners'

nor reason could prevail with them to let the report.

Commissioners hear so much as those particular causes.. . which the king had commanded them to take care of." "They of this colony," continued Sir Robert, "say that Charles I. gave them power to make laws and execute them, and granted them a charter as a warrant against himself and his successors, and so long as they pay the fifth of all gold and silver ore [which, if any should be found, the Massachusetts charter reserved to the crown], they are not obliged to the king but by civility. They hope by writing to tire the king, the lord chancellor and the secretaries, and say they can easily spin out seven years by writing, and before that time a change may come." 1

They did, in fact, "spin out" the controversy for twenty years, defending what they had declared to be their "liberties" (see sect. 36) with a determination that seems amazing when we remember that, much as the colony had prospered, its total population was probably

Spinning Spinning
out the con- less than 30,000 , that opposition to the ruling troversy. church members and ministers was strong and growing, and that many substantial inhabitants con-

1 New York State, Documents, iii. Io. 
demned the attitude taken toward the king. The minority controlling the government went forward with no wavering or yielding in their independent course.

Territorial rights were defended as resolutely as political rights. One construction of the language of the Massachusetts charter would give the colony a boundary three miles to the north of the headzuaters of the Merrimac, and take in a large part of what is now New Hampshire and Maine; another construction would place it three miles beyond the mouth

Disputed northern boundary. of that stream. The king's commissioners adopted the latter interpretation, and removed the Massachusetts officials in Maine. On the first opportunity they were reinstated by the General Court at Boston; and this was done in the face of a royal command "that the government of the Province of Maine continue as the Commissioners have left it." The king's missive which bore this plain mandate (April, I666) commanded further that the governor of the colony, Richard Bellingham, and others, should be sent to England "to attend his Majesty," "when all allegations or pretences on behalf of said colony shall be heard." 1 Neither command was obeyed.

It is evident that the king and his counsellors knew not what to do with this audacious colony. If they had had no troubles at home, they might have brought force to bear ; but England was sickening already of its restored king and his scandalous court. So the rulers of Massachusetts could take advantage of royal embarrassments, as their predecessors had done thirty years before.

42. Berkeley's ill-government in Virginia. 16601676. While Puritan Massachusetts was thus hardened in the temper of independence, Cavalier Virginia was going through an experience which tended, at least, to 1 Sainsbury, Calendar of State Papers: Colonial, 1661-68, p. 372. 
produce the same state of mind. As stated before (sect. 35). Gorernor Berkeley, once popular, was making himself odious by a manner of govermment like that of the English king and court. He and the king between them were said to have let loose on the colony a devour-

\section{Loss of}

political

rights. ing swarm of official parasites: and, even in local matters, the people had been deprived of political rights. Formerly they had elected the parish restries, which managed certain local affairs; but the boards of restrymen had acquired power to fill racancies in their own number: and so the people were shut out from all action on matters of public concern.

A most flagrant illustration of the king's shameless contempt of public and prirate rights was siren to the Virginians in 1673 . when he signed a grant which turned them and their country. like an estate with serfs, orer to two farorites, the Earl of Arlington and Lord Culpeper, whom he wished to reward. That atrocious grant was Grant to Ar. in the nature of a lease of the colony for thirtylugton and one years. During that time Arlington and
Calpeper.
1673 .

Culpeper were to be its lords, controlling its gorernment, taking its rerenues, and wringing from it as much profit as they could. The outraged colonists sent a delegation to London which succeeded in buying the consent of the holders of the grant to a cancellation of its worst features, and in wimning the promise of a charter that would give the colony some rights of its own. The charter was actually drawn up: but sinister influ-. ences, always working in the courts of the Stuart kings, kept it from the king sand, and it was nerer signed.

43. Bacon's Rebellion in Virginia. 1676. The increasing disaffection in Virginia caused by all these wrongs. was brought at last to an outbreak in 1676 , by the failure of Govermor Berkeley to defend settlers in 
the northern parts of the colony against a savage Indian attack. A crowd of maddened planters came together in May, placed themselves under the command of a resolute young man, Nathaniel Bacon, and prepared to take the field. Bacon applied to the governor for a commission, and received what he took to be a promise, whereupon he and his followers began their march. They were soon overtaken by a proclamation commanding them to disperse. Some obeyed, but the larger part went on and drove the savages from their bloody work. Berkeley, in great wrath, gathered a mounted troop and set out to put Bacon under arrest; but he was stopped in his course by a rising at Jamestown, so threatening that he had to hasten back and make terms with the insurgents, by conceding the election of a new House of Burgesses, to be assembled at once. Bacon was one of the burgesses elected. He

A new

House of

Burgesses. acknowledged the illegality of his action, the governor pardoned all concerned, and peace seemed to be restored. The Assembly then proceeded to pass acts which reformed many of the abuses of recent years. No doubt Bacon was active in these measures, and no doubt the old governor entertained ugly feelings toward all who had a hand in' the work.

What he planned, or what he did, has never been learned; but Bacon is said to have had warning of treacheries that endangered his life. He disappeared from Jamestown one night, and soon returned with a following of 600 armed men, demanding to be commissioned for another campaign against the Indians. The commission was issued and used with prompt effect; but in the midst of his operations on the frontier Bacon was denounced by the governor as a rebel, and a proclamation was issued against him. Then followed a brief 
period of actual civil war, in which Governor Berkeley seemed to be vanquished completely; but Bacon, at the moment of his triumph, was prostrated by a sudden illness and died (October, 1676). What he would have done

Bacon's death and shown commanding qualities, and the movement character. had he lived, it is impossible to judge. He had he led seems more democratic in spirit than the Massachusetts resistance to King Charles's commissioners, a few years before. Virginia and Massachusetts, the two chief colonies, were anticipating strangely, by a hundred years, the lead they would take in establishing the independent political rights of the transplanted Englishmen in America.

Bacon's party fell to pieces when he died, and the Berkeley's governor recovered full power, which he used revenge. for a vengeance more savage than has been known in America since. Twenty-two of the leading insurgents were executed, and many more were punished heavily, in less brutal ways. In the following spring the old governor was recalled, and soon after reaching England he died. Colonel Chicheley and Lord Culpeper were successive governors during the next few years. The colony had made some recovery of popular rights, as the consequence of the late rising; but there seems to have been little of political life, and the general poverty, caused

\section{Tobacco} by low prices of tobacco, was great. After rerlot, 1682. peated attempts to reduce the supply of tobacco by a general stoppage of production for one year, there was finally a mob-rising, in 1682, to destroy the plants, and this was not suppressed until some of the ringleaders had been hanged.

44. King Philip's War in New England. 16751678. The Indian outbreak in Virginia, which Bacon crushed, was nearly simultaneous with one that gave to 
all New England its most terrible experience of savage war. This war in New England was begun by that tribe of the Wampanoags, or Pokanokets, whose friendship had been won by the Pilgrims at their first coming, and preserved in appearance for more than fifty years. There seem to have been no flagrant wrongs of which the Indians could complain ; but they were

Cause of the war. made to feel more and more that the white men were their masters; they were called to account for what they did by the white men's magistrates ; they had sold lands which they were sorry they had given up; they had lost independence, and their pride was sore. An outbreak was brought about in 1675 by the trial and execution of three Wampanoags for the murder of one of their own race. It was led by the son and successor of Massasoit, named Metacom by his own people, but called Philip by the whites. Philip began war in June, I675, by destroying two villages, killing men, women, and children with tortures too horrible to be described. Massachusetts sent speedy help to Plymouth, and the Wampanoags were driven from their own territory to that of the Nipmucks, who joined them in furious attacks on settlements in the Connecticut

Attacks on settlements. valley, and on those farther east, almost to Boston itself. In October the Narragansetts were found to be making ready to take the field, and were surprised in their camp by an attack so destructive that their strength was broken by the single blow. Wherever the savages could be reached and struck, they stood no chance against the white man's wrath; but most of the country was still covered with forest, in which they could watch for opportunities to surprise some settlement or ambush some troop on the march. Warfare of that horrible kind went on for nearly two years, spreading to the Indians of New 
Hampshire and Naine. It was ended in the summer of

Death of

King

Philip.

I678, when Philip - called King Philip - was hunted down and slain. A thousand white men and a great number of women and children perished in the war; many women and children were carried into barbarous captivity; over forty towns had suffered, and twelve were destroyed. The white population of New England at about the time of the outbreak of King Philip has been estimated at 60,000, fully half of it in Massachusetts ; the Indians are supposed to have numbered about 36,000 . Many of these, including the Mohegans as a whole, took no part in the war. Of the tribes that took part, few male members were left; most of those not slain were sent to the IVest Indies to be sold as slaves.

45. English Loss and Recovery of New York. Governor Andros. 1673-1674. These years of trouble in America had been years of war and of grave threatening to domestic peace in England, whose people suffered more and more from the total want of principle and of self-respect in their king. His shameful war with Holland after the seizure of New York was followed by

Second war with
Holland. a still more shameful war with the same country

in 1672 . In the course of this latter war the Dutch recaptured New York and held possession of it for six months (1673-74). Then, when public feeling in England compelled the king to make peace, Holland yielded the colony a second time, and it was granted once more to the Duke of York.

On recovering the province, in 1674 , the Duke of York sent out a new governor, Major Edmund Andros (afterward Sir Edmund). who played an important part in American history during the next fifteen years, and left a bad name in it, because of the hardness and harsh- 
ness with which he used his arbitrary powers. His vigor was useful in some important matters, especially in measures which established an alliance of the English with the Five Nations of the Iroquois,

Alliance with the Five Nations. and organized the management of Indian affairs. $\mathrm{He}$ was not so careful, however, to cultivate the good-will of his subjects and neighbors. The duke's province, by the terms of his grant, extended eastward to the Connecticut River; but Colonel Nicolls, the first English governor, saw that it was unwise to try to steal so much territory from the colony of Connecticut, and made a compromise, which placed his boundary only twenty miles beyond the Hudson. Andros, on the contrary, attempted to enforce the full claim; but the men of Hartford faced him so resolutely, even in the midst of their dreadful Indian war, that he drew back. He did, however, secure the whole of Long Island, which Long Island added to New York. had been in dispute between Connecticut Englishmen at one end and Manhattan Dutchmen at the other.

A more irritating conflict arose between Andros and Philip Carteret, governor of New Jersey. The grantees of the New Jersey province, Carteret and Berkeley, had divided it between them, and Berkeley had sold his part - West Jersey - to two Quakers. By the Dutch reconquest, in 1673 , the grant was

Sale of West Jersey to Quakers. supposed to be extinguished, and the Duke of York, on recovering his proprietorship, made a new grant of East Jersey to Carteret, which seemed to convey no political sovereignty, as the original grant had done, but mere ownership of the soil. Andros, accordingly, claimed to be governor of New Jersey, as well as New York, and seized the person of the Jersey governor; but his conduct was disapproved by the Duke of York, who then conveyed to Carteret full governing powers. The same 
was done to the Quaker purchasers of West Jersey, where the contentious Andros had been ruling with an equally high hand.

Andros was now called to England, and a better man, Colonel Thomas Dongan, was sent out in his place. Meantime, the deputy-governor of New York had trouble with the people, who would not endure any longer to be governed in a purely arbitrary way. Amongst all the New York's English colonies, theirs only had no represenfirst Assembly, 1683 . tative legislature, and their demand for an Assembly became now so resolute that it moved the duke. The new governor brought instructions for an election, which was held soon after he arrived, and the first representative Assembly in New York was convened in October, 1683 .

46. William Penn. In New Jersey, the two Quaker buyers of Lord Berkeley's grant had quarrelled soon after their purchase was made, and William Penn, the foremost member of their sect in England, was called in to arbitrate between them. This resulted in Penn's becoming engaged, as a trustee, in the management of West Quaker pur- Jersey affairs. A little later, East Jersey was chase of
East Jersey, 1682. and others, and so the whole New Jersey province passed under Quaker control. In its Quaker character it was soon overshadowed by another, which arose beside it, as Penn's personal domain.

This excellent man, William Penn, the son of a distinguished English admiral, Sir William Penn, had been reared in habits of wealth, in the midst of the influences of a corrupt and frivolous court, but had broken away from them all. At the age of eighteen or nineteen, while a student at Oxford, he joined the most despised and abused of religious sects, because the simple purity and 
Christian democracy of its teaching took hold of his reason and his heart. He bore persecution with his fellow believers; bore the anger of his father and the ridicule of his courtly friends, and won respect by the calm dignity with which he carried himself through it all. Admiral Penn enjoyed the friendship of the king and the Duke of York, and their favor was extended to his son. In 1670 the admiral died, leaving an ample fortune, besides a claim on the crown for $£ \mathrm{I} 6$,000. When the heir to the claim, William Penn, became interested in projects of Quaker colonization, he offered to take a The grant grant of the territory between Maryland, New York, and New Jersey, in payment of the royal of Pennsylvania, 1681. debt. His proposal was accepted, and in March, I68I, he received the patent which conveyed to him that magnificent domain. He wished to name it either Sylvania or New Wales; but the king prefixed "Penn" to the "Sylvania," in memory of the admiral, and so the name has stood.

47. The Founding of Pennsylvania. In this case the royal charter created " a province and seigniory," but not of the palatine order, the immediate sovereignty of the king being reserved. In emergencies, the proprietor and his representatives might make laws; but legislation in general for the province was to be with "the advice, assent, and approbation of the freemen " hereof, "or of their delegates or deputies."

\section{Terms of} Penn's charter. The king pledged himself and his successors not to impose any custom or taxation on the province unless "with the consent of the proprietary, or chief governor and assembly, or by act of Parliament in England." This royal affirmation of a jurisdiction in Parliament over colonial affairs was something new, and indicates the growing strength of that body under the restored English crown. 
Penn's territory, as conveyed by the royal grant, did not touch the sea. That was an imperfection which he sought to correct by obtaining a grant from the Duke of York of a strip of territory claimed by the latter on the western shore of Delaware Bay, and down to Cape Henlopen. It was territory covered by the older grant to Lord Baltimore; but the Swedes had settled it first; the Dutch had taken it from the Swedes; the King of England had got it back from the Dutch and had given it to the Duke of York; so that Baltimore's title to that part of his Maryland principality seemed to be extinct. This grant, and the uncertain definition of Penn's southern boundary in the king's grant, opened double disputes between him and the hęirs of Lord Baltimore, which went on for many years. They were not settled until "Mason I767, when the southern boundary of Pennsyland Dix-
on's Line," vania was fixed finally by two surveyors, named 1767. Charles Mason and Jeremiah Dixon, and became famous in later history as "Mason and Dixon's Line."

In the summer of 1682 Penn sailed from England with about 100 colonists, mostly Quakers, and was preceded and followed by so many that not less than 3000 are believed to have been brought to the Delaware within the first year. Some settlements had been planted already on the western bank of the river, and one of them, changed in name from Upland to Chester, became the seat of government for a time. An assembly of freemen, held there in December, adopted

\section{Penn's}

"Frame of a "Frame of Government," submitted by Penn, Government," 1682 . and a body of laws. The people of the district on Delaware Bay, called "the lower counties," which Penn held only by deed from the Duke of York, with no political power, were represented in this assembly, and were annexed to Pennsylvania by an Act of 
Union, passed with their own consent. Freedom of worship for all who acknowledged one God was established by the laws; but only those believing in the divinity of Jesus Christ could hold office or vote. If qualified by that belief, all inhabitants who bought or rented certain quan. tities of land, or paid certain taxes, were recognized "freemen," entitled to vote.

Before Penn's arrival in the province, his cousin, William Markham, sent out as his deputy in $\mathrm{I} 68 \mathrm{I}$, had taken steps toward buying lands from the Indians; and there seems to be little doubt that Penn himself had a meeting with the Delaware or Lenape tribe,

\section{Penn and} at Shackamaxon, and negotiated a treaty of purchase with them there. Though such a meeting has been often described and pictured, there is no positive proof that it occurred. It is an altogether probable incident, however, in William Penn's dealings with the red men, whose confidence and affection he won. ${ }^{1}$

48. Philadelphia. 1682-1685. A few days after his landing at Chester, the proprietor was rowed in a barge from that town to the site on which he began immediately to plan and build the city of Philadelphia. Within three years the town was reputed to have 2500 inhabitants, and the province 8000 . Pennsylvania had risen at a bound to the rank which she never lost, among the most flourishing of the colonies in the New World. A just and large-minded man had been made the architect of the young commonwealth, and when, in 1684 , other affairs called him to England, he had reason to feel satisfied with the foundations he had laid.

1 Copies of many of the Indian deeds of land to Penn, stating the things given in payment, are in the first volume of Pennsylvania Archives (1664-1747), with facsimiles of the curious pictorial marks with which they were signed. 
If he could have stayed with the people as their governor, it is probable that their rights and his authority would have found an easy adjustment; but as it was, the Frame of Government worked badly, and underwent many unsuccessful changes in the fifteen years of his absence abroad.

In that period, the so-called "lower counties,"

Separation

\section{of the}

Delaware counties, 1691 . over which Penn had no political control, broke away from their union with Pennsylvania (I691), and assumed practically the independence which gave being, at last, to the little State of Delaware.

49. Annulment of the Massachusetts Charter. 1684. Since the close of the last war with Holland ( 1674$)$ the political situation in England had been undergoing a remarkable change. Circumstances had broken down the party in opposition to the court, and left the king more absolute in power than he had been since the early years of his reign. ${ }^{1}$ The kingdom suffered heavily from this Tory reaction, and its colonies suffered quite as much. The old design against Massachusetts, to break the stubborn independence of her Puritan rulers, was renewed, with advantages not held before. The king was stronger, not only at home, but in the colony itself. A

Edmund party quite of the Tory character was rising,

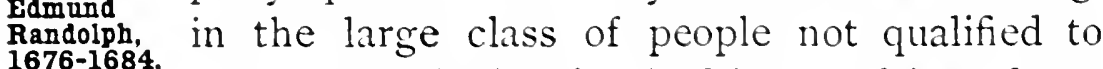
1676-1684. rote. The disaffection had been cultivated artfully by an agent, Edmund Randolph, sent to Boston in I 676 .

The measures that were taken cannot be traced in de-

1 It was at this time that the king's party began to be called "Tories" and their opponents "Whigs." "Tory" was an epithet from Ireland, where it signified an outlaw of the bogs; "Whig" was a Scotch word of obscure origin; both were meaningless in their political use. 
tail here. It is enough to say that the cherished charter of Charles I. to "the Governor and Company of Massachusetts Bay" was finally "cancelled, vacated, annihilated," by a decree of the English Court of Chancery, on the 2 Ist of June, I684. The ruin to the Massachusetts colonists which this decree involved was limited by nothing but the mercy of the king. It left them with no rights. Their charter was their $\begin{gathered}\text { At the } \\ \text { mercy of } \\ \text { the ing. }\end{gathered}$ title-deed for everything they owned; it was their warrant for everything they had done; it was the ground of everything in their colonial life. To declare it void was to declare that the king had never surrendered ownership of the soil on which they stood; that they were trespassers on his property and might be dealt with as he pleased; that they had never been empowered to organize a colonial government ; that all the acts of their colonial government were invalid and all their laws annulled. They had no reason to hope that the king would give the decree any less than this sweeping effect, and he showed very soon that no generous intention was in his mind. But before his plans for deal-

Death of ing with the colony had been perfected, he was stricken with apoplexy and died, in February, I685.

50. The Rule of "Captain-General " Andros. 16861689. James, Duke of York, who then came to the throne, as James II., differed from his late brother, in some respects, for the worse. Finding his colony of Massachusetts delivered up to him, by an English court, for whatever treatment he chose to bestow, he planned to crush the other colonies, or most of them, to the same state, and then tie them together under one royal governor, who should have the largest possible powers. He chose for that office his old hard-handed servant, Sir Edmund Andros, who always did what he was told, 
in the most offensive way. Andros, commissioned as "Captain-General and Governor of his Majesty's Andros in - Territory and Dominion in New England," was sotts.

sent to Massachusetts in 1686 to begin his work, and the high-spirited colonists of the Bay writhed under his absolute authority for the next three years. Their General Court was abolished; their town meetings were stripped of the control of local taxes; their press was gagged ; the writ of habeas corpus was suspended ; all public records were seized and brought to Boston; arbitrary taxes were levied, and property owners paid extortions called "quit-rent" to save the titles to their lands.

Going to New Haven in October, Andros demanded a surrender of the Connecticut charter; but the chercharter ished parchment was spirited away and hidden, 0ak. as tradition tells, in the hollow trunk of a tree, known afterwards as the "Charter Oak." He assumed the government of Connecticut, however, as well as that of Plymouth, Rhode Island, New Hampshire, and Maine. New York and New Jersey were subjected to his jurisdiction in the spring of I68S, and he then ruled

Extent of Andros's rule. from the Delaware to the St. Croix, with little limit to his power. No change in the government of the other colonies was made ; but a suit to break the charter of Lord Baltimore, in Maryland, was begun.

51. The "Glorious Revolution" in England. 1688. Happily the rule of Captain-General Andros, as well as that of his royal master, was brief. Before the end of the year I688 a "glorious revolution" (so considered and described at the time) drove James II. from England, and called his daughter Mary, with her husband, William, Prince of Orange, to the throne. 
TOPICS, REFERENCES, AND RESHARCH. IOZ

TOPICS AND SUG(IESTEH REAIHNG ANI) RISEARCH.

\section{Virginia under Charles II.}

\section{TOPICS AND REFLRENCIS.}

1. Navigation Act of 1660 and its effect on Virginia. Hiruce, i. 355-365; Doyle, i. 306-310.

2. The restored grovernment of Sir William lierkeley. Cooke, 216-236; Ilart, Contemfis, i. 237-241.

RESEARCH. - What is to be thomght of the instruction from lingland that Virginia planters should be encouraged " towns upon every river" ? llow are towns lorought into existence?

\section{New England and the King.}

TOHJS ANJ REJJRENCLS.

1. Attitude of New linglanders toward the restored monarchy. 2. The Massachusetts statement "Concerning our Liberties." Winsor, Boston, i. 349-356; Doyle, iii. 146-150, 173-175; Hart, Contemp's, i. 454-457.

RESEARCH. - The meaning of the term "a body politic."

\section{Connecticut and Rhode Island Chartered. - New Haven Absorbed.}

TOPICS ANI) REFERENCES.

I. Charter for Connecticut secured by the younger John Winthrop (text in MacDonald, i. 116-119; I'reston, (6)-109). 2. Territory granted in the charter. 3. Reasons for hostility to New Haven at the English court. Doyle, ii. I 50-102; Hart, Contemp's, 420-422.

4. Migration from New Haven to the l'assajc. Fiske, I). and Q. Col's, ii. $13,14$.

5. 'The Rhode Island charter (text in Macl)onald, i. 125-133; Preston, 110-120). Its provision for religious liberty. Arnold, i. ch. ix.

RESEARCH. - Vengeance of the restored Engrish monarchy on the "regicides." (ireen, $603-604$. Persecution of Nonconformists in lingland. Green, (106-610; Gardiner, 585-588, 590; Larned, England, 449, 451. 


\section{The Founding of the Carolinas.}

Topics AND REFERENCES.

I. The palatine proprietary province founded in the Carolinas. 2. Previous settlements in the territory of the new colony. 3. Early intrcduction of slavery and servitude. 4. John Locke's constitution (text in MacDonald, i. I20-I 25, I 49-I68). McCrady, i. ch. i.-v. : Doyle, i. $43 S-45 S$; Fiske, Old Va., ii. 270-27S ; Hart, Contemp's, i. 275-2So.

RESEARCH. - John Locke: for what was he distinguished? Larned, England, +69 .

\section{Conquest of New Netherland, which becomes New York.}

TOPICS AND REFERENCES.

I. English seizure of the Dutch colonies without a declaration of war. 2. The king's grant to his brother, the Duke of York (text in MacDonald, i. I33-I39). 3. The double commission to Colonel Nicolls. 4. The Dutch surrender. 5. Changes of names. O'Callaghan, ii. b'k 6. ch. vii ; Fiske, D. and Q. Col's, i. 283-292 ; Hart, Contempss, i. 537-5+1.

\section{Origin of New Jersey.}

TOPICS AND REFERENCES.

I. Sale of territory by the Duke of York. 2. Provision for the government of the province (text in MacDonald, i. I39, I4I). Fiske, D. and Q. Col's, ii. Io-15; Hart, Contemp's, i. 563-566.

\section{Resistance to the King's Commissioners in Massachusetts.}

TOPICS AND REFERENCES.

I. Submission to the commissioners in Connecticut, Plymouth, and Rhode Island. 2. Refusal in Massachusetts to let them hear appeals. 3. Grounds of the refusal. Hutchinson, i. 229-257; Winsor, Boston, i. 357-363; Palfrey, ii. 5S2-590, 597-61 8 ; Frothingham, Rise of the Rep., 53-63; Doyle, iii. I $82-192$.

4. Success of Massachusetts in prolonging the controversy. 5. Defence of territorial claims of the colony. 6. Disobedience to 
TOPICS, REFERENCES, AND RESEARCH. IO5

royal commands. Palfrey, ii. 6r8-634; Doyle, iii. I92-197; Hutchinson, i. 260-269.

7. Growing opposition to the king of England. Green, 618-62I ; Larned, England, 452-456.

RESEARCH. - The claims that conflicted with those of Massachusetts in New Hampshire and Maine. Palfrey, i. 204-206, 524525, ii. 6IS-62I ; Hutchinson, i. 3I3-3I9.

\section{Berkeley's Ill-government in Virginia.}

TOPICS AND REFERENCES.

r. The people deprived of political rights. 2. The king's grant to Arlington and Culpeper. 3. Unfulfilled promise of a charter. Burke, ii. appendix; Doyle, i. 3I3-3I9.

\section{Bacon's Rebellion.}

TOPICS AND REFERENCES.

I. Immediate occasion for the outbreak. 2. Election of a new House of Burgesses and its action. 3. Renewal of hostilities between the insurgents and the governor. 4. Bacon's death and its consequences. - His character. 5. Berkeley's savage revenge. 6. Berkeley's successors. - The Tobacco Riot. Burke, ii. I94; Cooke, 237-297 ; Doyle, i. 319-352 ; Fiske, Old Va., ii. ch. xi.; Hart, Contemp's, i. 242-246.

\section{King Philip's War in New England.}

TOPICS AND REFERENCES.

I. Causes of the Indian outbreak. 2. Spread of hostilities. 3. Consequences of the war to whites and Indians. Fiske, Beginnings, 2I I-24I ; Doyle, iii. ch. iii. ; Contemp's, i. 458-46I ; Hubbard, O. S. Leaf., 88 .

\section{English Loss and Recovery of New York. - Governor Andros.}

TOPICS AND REFERENCES.

I. Affairs in England. - Renewed war with Holland. - Loss and recovery of New York. 2. Governor Andros and his aggressions in Connecticut and New Jersey. 3. Quaker purchase of 
West Jersey. Fiske, D. and Q. Col's, ii. 25-6r ; Roberts, i. 103I 14, I 78-186.

4. New York under Governor Dongan. - Its first Assembly. Roosevelt, Nequ York, 5I-57; Fiske, D. and Q. Col's, ii. I68-I 7I.

\section{William Penn.}

TOPICS AND REFERENCES.

I. Penn's engagement in New Jersey affairs. 2. His life and character. 3. Circumstances of the royal grant to him of a vast American province (text in MacDonald, i. I83). Fiske, D. and Q. Col's, ii. I I4-I18, 140-150; Sharpless, 30-39.

Research. - The early life of Penn. Hodges, ch. i.-iv.

\section{The Founding of Pennsylvania.}

Topics AND ReFERENCES.

I. Character of the proprietary province created by Penn's charter. 2. Jurisdiction of Parliament over colonial affairs affirmed. Fiske, D. and Q. Col's, ii. I 5 I-1 53.

3. Additional grant to Penn by the Duke of York. 4. Disputes with Lord Baltimore and their settlement. - "Mason and Dixon's Line." Hinsdale, Old N.W., 98-103; Fiske, Civil Gov't, 152.

5. Penn's first settlements. 6. The first Pennsylvania Assembly and the "Frame of Government" (text in MacDonald, i. 192199). 7. Annexation of the "lower counties." Hart, Contemp's, i. $557-558$.

8. Penn's dealing with the Indians. Fiske, D. and Q. Col's, ii. $158-166$.

RESEARCI. - Were the Indians rightful owners of the soil of this continent when the whites came to settle upon it? If so, had their chiefs the right to sell tracts of it? When making such sales, were they likely to understand the nature of the transaction? Where one tribe had driven out another, which was the rightful owner?

\section{Philadelphia.}

TOPICS AND REFERENCES.

r. The founding of Philadelphia and the progress of the colony. 2. Penn's return to England. - The colony in his absence. 3. 
TOPICS, REFERENCES, AND RESEARCH. IO7

Political separation of the "lower counties," which became Delaware. Hodges, ch. v.-vi.; Fiske, D. and Q. Col's, ii. 153-158; Hart, Contemp's, i. 554-557.

\section{Annulment of the Massachusetts Charter.} Topics AND References.

x. Changed political situation in England. Green, 639-642.

2. A growing Tory party in Massachusetts. 3. Annulment of the Massachusetts charter. - The colony at the mercy of the king. Ellis, ch. xiii. ; Winsor, Boston, i. 364-375 ; Frothingham, Rise of the Rep., 77-79; Fiske, Beginnings, 255-267; Doyle, iii. 284-292, 298-299; Hart, Contemp's, i. 462-463.

4. The king's death. Green, 643.

\section{Rule of "Captain-General" Andros.}

TOPICS AND REFERENCES.

r. Accession of King James II. 2. Rule of Andros as CaptainGeneral and Governor of New England. 3. Extension of his authority to New York and New Jersey. Hutchinson, i. 353-372; Winsor, Boston, ii. I-I3; Fiske, Beginnings, 267-27I ; Doyle, iii. 303-323; Hart, Contemp's, i. 423-425.

\section{The "Glorious Revolution" in England.}

TOPICS AND REFERENCES.

I. Expulsion of James II. from the throne. - Accession of William and Mary. Macaulay, ch. ix. ; Green, 644-651, 657-660; Gar. diner, 643-648; Larned, Eng., 466-467. 


\section{STATE OF THE COLONIES IN THE LAST YEARS OF THE SEVENTEEN'TH CEN'TURY.}

The Enslish Rirolution of 1688 . The English Revolution of I6SS, which swept the intolerable Stuart dynasty from the throne, which riveted upon the monarchy a parliamentary constitution that could not any longer be misunderstood, and which drew England into a long conflict with France, was an event of great importance to the Englishmen of the colonies, A newera. as well as to those at home. It opened what was really a new era in history, on both sides of the sea. Before we try to sketch the working of changes produced by it on the American side, it will be well to survey briefly the state of the colonies when the seventeenth century was drawing to its close.

Pupulation of the Colonics. Of the thirteen colonies afterward federated in the Republic of the United States, all save Georgia had then been planted, but the Carolinas were not yet formally divided, and the separateness of Delaware was not Now Eng- quite a fixed fact. Among them, the New England land. group was the most populous; its people had gripped the resources of their country with the greatest energy, making the most of what it gave them, and their communities had acquired the firmest footing in the land. Of these Massachusetts was so much in the lead that its people far outnumbered all the rest. As estimated by Mr. Bancroft, the Bay Colony, together with Plymouth and Maine (both small), contained about 44,000 people in I6SS; while Connecticut held I7,000 to 20,000 , Rhode Island (with Providence) 6000, and New Hampshire 6000, making a total for New England of 73,000 to 76,000. The same estimate gives Virginia a population of 50,000, Maryland 25,000, New 
York 20,000, Pennsylvania and IJelaware 12,000, New Jersey 10,000 , and the Carolinas 8000, together. This reckons the total population of the English colonies in America at 200,000. ${ }^{1}$

Economic Condition. In all the colonies, the products of industry were limited in variety, but more so in the south than in New England, where every natural resource was turned to account as fast as it could be done. Except in forest trees, the New England soil gave little that the colonists could use for outside trade. They cultivated it for their own foods, and made early use of its pastures for cattle and sheep; but it yielded them only a small surplus of breadstuffs and meats for sale. Their one staple commodity in the early years, and their chief one for a long period, was fish. Says Mr. Weeden, the economic historian of New England, writing of the period between 1662

New England fisheries. and 1685 : "The business of the fisheries enters into all the doings of the time. Whenever we turn over the stray papers of a seventeenth century merchant, we find evidences great and small of his constant intercourse with fish and fishermen." The fisheries led to ship-building, for which the neighboring forests furnished the best of timber, and both together stimulated enterprise in navigation and the carrying trade. "Sawing lumber," says Mr. Weeden, "building and freighting vessels, constituted commerce;" "but the immediate motive to cut timber, or to lay a keel, was in the immediate return always ready and waiting for a projected cargo of fish." 2 The New Englanders built ships to sell, but they kept more and more of them in their own hands, and used them busily, in an increasing commerce with the neighboring colonies, with the West In-

Shipping and commerce. dies, with England, and with Spain. From their own ports they carried mostly fish, timber, lumber, masts and spars,

1 Bancroft, Hist. of the U.S. (author's last revision), ii. 6os.

2 Weeden, Economic and Social Hist. of New England, i. 247, 371 . 
staves, and sometimes "houses ready framed." From southern ports and the West Indies they took tobacco, sugar, tar, pitch, and other commodities, going chiefly abroad. With numerous excellent harbors on their coast, the New Englanders were impelled by every circumstance to be a maritime and commercial people, and the impulse was obeyed.

Virginia and Maryland were as well supplied as New England with good timber, and had no lack of fine harbors, on Chesapeake Bay and on their noble rivers; but they did almost nothing in ship-building, took almost no part in the

\section{Virginla} carrying trade, and put their forests to little comand Mary- mercial use. They lacked the stimulus and train-
land.

ing of a great fishing industry; and the tobacco culture in those colonies was stifling to everything else (see sect. 31). "The Virginia planter did not, like the New England farmer, have to seek the foreign purchaser; the buyer of the only staple of Virginia sought its plantations." 1

In the Carolinas, all industries were still in their small beginnings. The northern district was beginning to compete with New Hampshire and Massachusetts in the exportation of tar, pitch, timber, and other products of the kind The Caro- called "naval stores;" the southern district was belinas. ginning experiments with rice, cotton, and indigo; but only rice gave promise, so far, of success. Furs to England, and pork, beef, hicles, and tallow to the northern colonies and the West Indies, were the main exports from the Carolinas at this time.

Pennsylvania was very young as an English colony, and Pennsyl- its early products were altogether from the forests vania and
Now Jer-

sey.

known. In New Jersey the conditions were much the same.

New York was somewhat laggard in growth. Except on Manhattan and Long Islands, its settlements were a fringe along the banks of the Hudson, up to Albany, with Sche-

1 Bruce, Economic Hist. of Virginia, ii. 435. 
nectady for a solitary outpost toward the west. The fur trade, its chief interest, was greatly cut down by the fierce wars of the Five Nations with the French and with the tribes of the whole region of the Great Lakes, even to Illinois. The farms and forests of the province were furnishing something to colonial commerce, in timber and foodstuffs, but to no large extent. The city of New

Now York. York, however, was the convenient centre of a good deal of trade.

The English Natigation Acts. ${ }^{1}$ All development of the resources of the colonies, all attempts to multiply their industries and extend their trade, were grievously hampered by English laws which aimed to gather every kind of profit from them into English hands. The short-sighted selfishness of such laws was not peculiar to England, but governed the colonial policy of every nation in that age. It expressed itself first in what is known as the Navigation Act of Act of I65 I, passed by the Parliament of the Common- 1661 . wealth of England, after the execution of King Charles. That act forbade the importation of goods into England in any other than English ships or ships of the country producing the goods. Its main purpose was to stop the employment of Dutch ships in English trade; but the commerce of the colonies was badly injured by the effects of the act. English traders and shippers were not satisfied, however, with this law, and in 1660,1663 , and 1672 , after the monarchy had been restored, fresh enactments were devised for Acts of the purpose of monopolizing every gain to be got 1660 , and from colonial trade. The first of the new Naviga- 1672. tion Acts required the colonies to import and export everything in English ships. The next one allowed nothing from Europe to enter any colony unless it had been passed through (i.e., been laclen at and shipped from) an English port, and had been carried "directly thence." The declared object

1 Bruce, Economic Hist. of Virginia, i. 345-365; Weeden, Economic and Social Hist. of New England, i. 232-24I. 
of this measure was to keep the colonies in "a firmer dependence" on the mother country. Finally, the legislation of ${ }_{1} \epsilon_{72}$ forbade the shipping of certain enumerated commodities, including tobacco, sugar, cotton, ginger, and indigo, from any colony without a bond being given for their delivery in England, or else payment of a heavy duty in advance; the purpose being to stop evasions of the law. These oppressive enactments were accompanied and followed by many others that were much complained of, under the general name of the "acts of trade."

That the navigation laws and other "acts of trade" did not strangle the colonies in their infancy was because they could not be fully enforced. The New Englanders, with their chartered "home rule," and with their own shipping in Contrahand, could not be controlled by the acts; and that band was a principal reason for the steady hardening of a determination in the English government to break the charters, regardless of the bad faith involved. Virginia, as a royal colony, and dependent on other ships and shippers for the handling of her trade, was more at the mercy of the English laws. While the Dutch were at Manhattan, they managed much contraband trading with Virginia; after they lost their footing in America, the navigation acts were more strictly enforced in Chesapeake Bay.

In the earlier years of the colonies, there were none but English merchants and ship-owners who watched America to make sure, as far as possible, that nothing was bought and sold there, nor shipped thence, to the profit of anybody but themselves. But as the colonists became able, more and

Oppresslve "acts of trade."

more, to makc things for themselves, another class, composed of manufacturers and mechanics, began to demand laws for the suppression of all colonial industries that could come into competition with their own. This demand was just becoming energetic at the time now described. It was inspiring strenuous efforts to induce the colonists to devote themselves to the production of "naval 
stores," - spars, timber, pitch, tar, hemp, etc., - and to let lighter manufactures alone. We shall find it working much more vigorously in the period that follows.

Slavery and Indentured Servitude. There were slaves in all the colonies, and there were indentured or bound white servants (see sect. 34) in them all. Everywhere except in the Carolinas the indentured servants, up to this time, outnumbered the slaves. It was not until after the eighteenth century was begun that negro slavery became dominant in the labor system of both Virginia ${ }^{1}$ and Maryland. In all the colonies there were Indian slaves, - captives taken in the Indian wars, - and their number in the Carolinas was considerable; elsewhere it was small. In the northern colonies there were no industries in which large gangs of slaves could be employed with profit, and that kind of unintelligent, driven labor never came into extensive use. On moral grounds there was no objection to it felt very widely, except Little in Rhode Island and amongst the Quakers. Rhode moral Island passed an act in $16_{5} 2$ declaring that "no to slavery. black mankind or white" shall be "held to service longer than ten years." 2 Subject to this limitation, both slavery and bond service were tolerated. In the Massachusetts "Body of Liberties," adopted in $\mathrm{I} 64 \mathrm{I}$, it was declared: "There shall never be any bond slavery, villeinage, or captivity amongst us, unless it be lawful captives taken in just

1 "In 1671 there were 6000 servants to 2000 slaves in Virginia. By 1683 the number of servants had doubled, while that of the slaves had increased by only one third. From this time forth servitude gave way before slavery, which was forced on the colony in the large importation of negroes by the royal African Company under its exclusive charter. It was the policy of the king, and of the Duke of York, who stood at the head of the company, to hasten the adoption of slavery by enactments cutting off the supply of indented servants." Ballagh, Hist. of Slavery in Virginia (Johns Hopkins Studies), p. ro.

${ }^{2}$ Records of the Colony of R. I., i. 243. 
wars, and such strangers as willingly sell themselves or are sold to us." I In what manner the few negro slaves finally found in Massachusetts were obtained does not appear. There seem to have been less than 400 in the colony at the close of the seventeenth century.

The Quakers of Pennsyliania began to take ground against the importation and purchase of African slaves as early as 1696 ; but slavery existed in the province, to a limited extent, for more than a century after that time. The Indentured number of indentured servants in Pennsylvania was servants in Pennlarger than elsewhere. This resulted from Penn's sylvania. wide advertising of the attractions of his province, in Germany and other parts of the continent, as well as in England, which drew a multitude of poor people, who paid for their passage to America by selling their labor in advance for a term of years. A student of the subject has estimated that "at least one third of the early immigrants were servants." 2 In New Jersey they were numerous; they were fewer in New York, where more negro slaves were owned; but slavery got no more of an economic footing in New York than in other parts of the north.

Education and Litcrature. It is a fact undoubted, that the early colonists of New England were generally of a class better educated and more intellectual than those who came to other settlements in the New World. It was necessarily so, because, as a rule, they were people who had been moved by a belief - by a deep conviction of mind - to seek the new home. We cannot help seeing that the beliefs which moved Early New Englandthem were thoughtfully formed, even when there ers. seems to be narrowness in some of the grounds on which they rest. They represent a mental quality quite above that which appears in the common motives of

1 Mass. Hist. Soc. Collections, 3d series, vii. 23I.

2 Geiser, Redemptioners and Indentured Serwants in Pennsylrania, p. 27 ; Hart, ed., Am. Hist. told by Contemporaries, ii. ch. xvi. 
life. There are proofs of that quality in two facts which especially distinguish the New England colonies, when compared with their neighbors of the middle and southern zone. The first appears in the prompt and broad provision for public education that was started by the pioneers of Massachusetts Bay as soon as they had fairly housed themselves (see sect. 11), and followed in all the settlements as they spread. The second is found in the great body of valuable writings that has come down to us from those New England colonists of the first and second generations; the histories, narratives, and chronicles, the descriptions, the disquisitions, and controversies, which make us acquainted with them, and with what they thought and did, so much more than with the fathers of our country in other parts. The proportion among them of men and women who wielded a vigorous and sometimes eloquent pen was certainly large for that day. The names of William Bradford, Edward Winslow, John Winthrop, Nathaniel Morton, Edward Johnson, John Mason, Francis Higginson, William Wood, John

New Eng. land writors. Josselyn, Roger Williams, Nathaniel Ward, Daniel Gookin, Thomas Hooker, John Cotton, Anne Bradstreet, Increase Mather, to say nothing of less noted writers, make up a remarkable list, for communities so young and so small. ${ }^{1}$

In Virginia the widely separated plantation life, and the absence of towns, made any such school system as that of New England impossible; but the interest in education was not the same. The influence of the government was against it, after the overthrow of the London Company (see sect. 5), which had planned the founding of a colonial university and voted to endow it with ro,000 acres of land. That excellent project was killed by the killing of the company. In 660 a new movement for the founding Education pany. In r660 a new movement for the founding invirof "a college and free school" was started by the Virginia Assembly, but it languished until I69r, when the college of William and Mary was established, with the help of

1 Tyler, History of American Literature, 1607-1765. 
the king and queen, who gave it their name. This seems to have been the first educational institution in Virginia, though there were, of course, teachers, privately employed.

Of five Virginia colonists in the first century who wrote some account of the country and their experiences in it, only two, William Strachey and Alexander Whittaker, were permanent settlers; the remaining three - namely, Captain John Smith, George Percy, and John Pory - were transient in their stay. So, too, was George Sandys, who, while holding office in Virginia, completed a translation of Ovid that was famous in its day.

Both in schools and in literary production, the other colonies, in this period, had not much to show. Penn had large ideas of education, and was influential, no doubt, in

Pennsylbringing about the opening of the Public Grammar vania and School of Philadelphia, in 1689; but many political Now York. troubles in the early years of the colony frustrated his intention to make that the centre of a system of schools. In New York there was a sad neglect of education, and more, apparently, after the English took the province than before. In the middie of the next century it was said by the colonial historian, William Smith, "Our schools are of the lowest grade."

Massachusetts was the first of the colonies to obtain a printing-press. It was brought from London, with an equipThe press. ment of type, and with several printers, by a minbridge in $16{ }_{3} 8$. A second press was added to the Cambridge printing establishment in 1660 , long before any were working in other parts of the country. 'The next to arrive was set up near Philadelphia, by William Bradford, in $x 686$. Seven years later Bradford removed his business to New York. ${ }^{1}$

The French and their Claims in America. Throughout the seventeenth century colonization had been pushed by the

1 Eggleston, The Transit of Civilization from England to America in the Seventeenth Century, ch. v.; Fisher, ch. xxi. 
French in the valley of the St. Lawrence, and in the regions surrounding the gulf of that name, quite as vigorously as by the English on the coasts farther south, but with very different results. The English colonies were described with truth as "plantations;" they were really planted communities, well-rooted, and growing with a life and nourishment of their own. To a greater or less extent, their people were self-governed, self-sustained, self-dependent, - trained for the care of themselves, and for feelings that identified them more with the country to which they had come than with the country they had left. The settlements in New France had no such planting; they were formations, not growths. All the energy they possessed was put into them by the paternal government of France, or by the trading companies that had monopolies in them, or by mis-

Paternally governed colonies. sionary priests. Everything was done for them; they were not allowed to do anything for themselves. Except traders and some adventurers, few colonists went to the country under any impulse of their own. They were gathered up by the king's agents and sent out in ship-loads, mostly young men and women, many of whom married with no knowledge of each other and were settled on small farms. It is not surprising to find the government of New France complaining that idleness, drunkenness, and disorder prevailed.

With all the efforts made to send out colonists to New France, the white population, about 1683 , did not exceed ro,ooo, it is said, scattered along both banks of the St. Lawrence, as far up as Montreal, where settlement was begun in 1640. But French missionaries, coureurs de bois, and ambitious explorers had been penetrating the far interior of Fronchexthe continent, learning its geography, obtaining in- ploration. fluence among its Indian tribes, and establishing vast territorial claims for France, with an energy that the English did not imitate in the least. At some time not later than 1640 , Jean Nicollet had gone beyond Lake Huron to Lake Michigan. In I669 Jesuit missions were established at Sault Ste. 
Marie and Green Bay. In 1673 Father Marquette and Louis Joliet made their way from Green Bay to the Mississippi River, and down that great stream to the Illinois, on which a new mission was planted by Marquette. In 1679 the famous explorer, La Salle, built a vessel on the Niagara River and navigated the Great Lakes to the foot of Lake Michigan, whence he went on to the Illinois and built a fort. Three years later, traversing the same route for the third time, he descended the Illinois to the Mississippi and the Mississippi to the Gulf, completing the exploration of the great river, and formally declaring that he took possession of the whole wide country drained by its tributaries for the king of France.

Thus, before the closing of the seventeenth century, the French had laid hands on the whole country west of the Appalachian mountain ranges, with none practically disputThe ing their claim to it except the "Five Nations" French of the confederacy of the Iroquois. Between those Iroquols. and the French there was continual war, and the

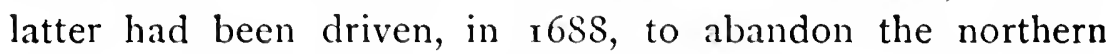
shore of Lake Ontario and the whole river St. Lawrence above Montreal to their savage foes. 'This was the situation at the opening of a long series of wars which was then at the point of outbreak between the English and the French. ${ }^{1}$

1 Parkman, La Salle, and the Discovery of the Great West; Sloane, The French Hor and the Revolution, ch. iii.; Hinsdale, The Old Northovest, ch. iii.-iv. 


\section{COLONIAL DEVELOPMENT.}

1688-1774.

\section{CHAPTER IV.}

THE PERIOD OF STRIFE WITH FRANCE. I690-I 760.

52. Overthrow of Andros. - A New Charter for Massachusetts. 1689-1691. When news of the flight of James II. from England, and of the elevation of King William and Queen Mary to the throne, reached Boston, in the spring of I689, Massachusetts rose against Andros, as England had risen against James, imprisoned him for a time, and then sent him to London, to be dealt with by the new king and queen. Strenuous efforts to secure a restoration of the old charter were begun at once, and persevered in for three years; but $\begin{gathered}\text { Efforts to } \\ \text { recover the } \\ \text { old charter. }\end{gathered}$ reasons of English policy prevailed in the end, against the hope that the colonists entertained. The best they could obtain was a new charter, issued in October, I69I, which took away much of the self-government they had enjoyed so long. Their governor and other chief officials were to be appointed thereafter by the king; their general court was restored, but its acts were subject to veto by

Provisions of now charter, 1691. the governor or by the crown; their right of suffrage was made to depend on a property qualification, and no longer on membership in a church. 
Massachusetts was thus reduced to the status of a royal province, but not quite to that of Virginia and New York, where the people had no charter to define their rights. Territorially the colony was enlarged, by Annexation the annexation to it of Plymouth Colony and of Plymouth
and Maine, 1691. a time, with New York, under the same governor, Lord Bellomont. Connecticut and Rhode Island, whose charters had never been judicially annulled, were untouched, and their governments were unchanged.

53. New York and Jacob Leisler. 1689-1691. In New York, after learning of the revolution in England and the downfall of Andros at Boston, the deputy-governor, Nicholson, undertook to maintain his authority, wicholson and did so till the following June, when he was deposed. deposed, practically, by the militia trainbands of the town, and sailed for England to complain. One of the captains of the militia, Jacob Leisler, a wealthy German citizen, then took direction of affairs, expecting to be justified in what he did. Unfortunately, misled Jacob by ignorance and by bitter democratic feelLeisler. ings against an aristocratic class of citizens, he pursued a course which placed him fatally in the wrong. When, after long delay, King William appointed a governor and a deputy-governor, and the latter arrived in advance of the former, Leisler was mad enough not only to refuse surrender of the fort he held, but to fire on the king's troops, of whom the deputy had brought a small force. Even after the governor, Colonel Sloughter, came (March, I69I), Leisler held out, insisting on a written order from the king ; but his men surrendered, and he was seized. A fortnight later, he and his son-in-law, Milborne, were tried and condemned for firing on the troops. In May they were hanged. The 
THE PERIOD OF STRIFE WITH FRANCE. I2I

fair opinion seems to be that Leisler meant to be a patriot, but lacked knowledge and judgment for the part he undertook, and that his execution was a shameful crime.

Governor Sloughter brought instructions for the election of an Assembly, and the people were represented regularly in the government of the province from that time. For a long period they were divided between two factions, "Leislerians"

Leislerians and Aristocrats. and "Aristocrats," whose bitter quarrels and struggles had little to do with the interests of the community at large.

54. New Jersey. 1689-1702. In New Jersey, the overthrow of Andros left both provinces with no settled government, and with an open question as to whether the authority of the proprietors had been restored or not. This unsettled state continued until I 702, when the proprietors resigned their pretensions to a right of government, and the two Jerseys were united in a single royal province, with a legislature of its own, but under the same governor as New York.

55. Pennsylvania. 1689-1701. To the proprietor of Pennsylvania the change of king in England brought trouble for some years. The Stuarts had been friendly to him, and he owed them for much favor. Naturally, he was regarded with distrust by the new court. There was no interference, however, with the gov- Ponn and ernment he had established in Pennsylvania K1ng until I693, when Penn's enemies prevailed with 1693-1694. King William, and the great Quaker proprietor was stripped of political authority in his province, though his property rights in it, as a mere estate, were undisturbed. For a single year it was made a royal province, under the jurisdiction of the governor of New York; then, in 
August, I694, the king's opinion of Penn seems to have changed, and all the powers conferred by his patent were restored.

In 1699 Pennsylvania was visited by its proprietor for the last time. He found Philadelphia grown to a city of four thousand people, and the whole colony increasing and thriving materially, but distracted by dissensions, even among the sober-minded Friends, and dissatisfied with the working of the Frame of Government. Throughout the two years of his stay he labored for an agreement upon amendments, and it was not until the eve of his departure, in I7or, that he signed with Ponn's last reluctance a "Charter of Privileges," as it was "Charter of named, in which he conceded more than he privileges." wished to do, for the sake of peace. This charter remained the constitution of the colony until the colony became a State.

56. Maryland. 1689-1715. Maryland had its own revolution, imitating the movement in England, as Massachusetts and New York had done. The Protestant inhabitants, who formed a majority of the population, rose in insurrection, in July, I689, deposed the governor, and brought about the election of a convention, which arranged the government provisionally, while waiting for a response to appeals that went to England, both for and against the abrogation of proprietary rule. AntiCatholic feeling in England bore too strongly against Lord Baltimore to be resisted, and the government of Maryland was taken out of his hands by the king in I69I. Then, once more, as in I654 (see sect. 22), the tolerance which the Lords Baltimore had upIntolerance
revrived,
iegl held was swept away. Catholic forms of wor1691.

ship were forbidden, and no further admittance of Catholics to the province was allowed. The Church 
of England was established by law, and taxes were levied for its support. Until the death, in I715, of the Lord Baltimore of that period (Charles Calvert), Maryland was governed as a royal province; but the proprietary government was restored to his son, Benedict, who had withdrawn from the Catholic church.

57. Virginia and the Carolinas. 1689. Virginia had shared very fully the feeling in England against King James, and the revolution, being accepted with satisfaction, caused no change in the course of affairs. Nothing occurred in the Carolinas to mark the revolutionary event. The two sections of the province, beginning to be distinguished commonly as North Carolina and South Carolina, were increasing in population very slowly, and still struggling through the long disorderly period of inefficient proprietary government.

58. Beginnings of the Conflict with France. 16901713. The revolution in England led to long wars with France. The Prince of Orange, who then became king of England, was the leading spirit in a great movement of combination among European powers to resist the aggressions of the French king, Louis XIV. England, drawn into that movement, was involved in a succession of tremendous conflicts, which became most important in the end as a struggle between the English and the French for supremacy in the New World.

The first of these wars, known in Europe as the War of the League of Augsburg, but called "King ring wilWilliam's War" by the colonists, and described $1690^{11 a}$ 's War, sometimes in American history as the First 1697. Intercolonial War, was opened on this side of the ocean by raids from Canada on the northern settlements of the English, in the winter and spring of 1690 . Count Frontenac, then governor of New France, did not scru- 
ple to employ his savage Indian allies in such ruthless attacks. One expedition of French and Indians from Montreal surprised the outlying settlement at Schenectady and barbarously massacred some sixty men, women, and children, carrying into captivity about thirty more. Other expeditions brought the horrors of the tomahawk and the scalping knife into New Hampshire and Maine.

Massachusetts retaliated promptly by a small naval expedition, under Sir William Phips, which captured Port Royal, in Acadia. While this was in progress, a congress of representatives from Massachusetts, Plymcongress at outh, Connecticut, and New York met at New Now York. York (May, I690) and planned a combined campaign. Two expeditions, against Montreal by land and against Quebec by sea, were undertaken accordingly, and failed lamentably, with great discouragement to the colonies, and with consequences of public debt and paper-money mischiefs that weighed on them for years. In America, the war, throughout, was one of savage raids from Canada, retaliated by expeditions that had little effect. It was ended by the treaty of Ryswick, in $\mathbf{I} 697$.

Peace lasted but five years; then a fresh alliance against Louis XIV. was formed. England was joined with Holland, Austria, and most of the German states, in what is known as the War of the Spanish Succession, which raged for twelve years (I702-I7I4), in the Netherlands, Irance, Spain, Germany, Italy, America, and on the sea. In American history it is called the Queen Second Intercolonial War, or "Queen Anne's Queen
Warne's 1702- War," - King William having died at the 1714. $^{1702-}$ beginning of it and being succeeded by the Princess Anne, sister to Queen Mary, who had died in I 694. 
THE PERIOD OF STRIFE WITH FRANCE. I25

Again the French of Canada led their savage allies into Maine and New Hampshire, and down the valley of the Connecticut, to do horrible work at Wells, Saco, Casco, Deerfield, Lancaster, and other frontier settlements, in I703 and I704. Again there were retaliating expeditions which ravaged French settlements on the Acadian coast, and which finally, after a failure in I706, captured Port Royal in I 709, and renamed it Annapolis, in honor of the queen. Again, too, there were undertakings, in I 709 and I7II, for the conquest of Canada, by expeditions in which colonial forces were to coöperate

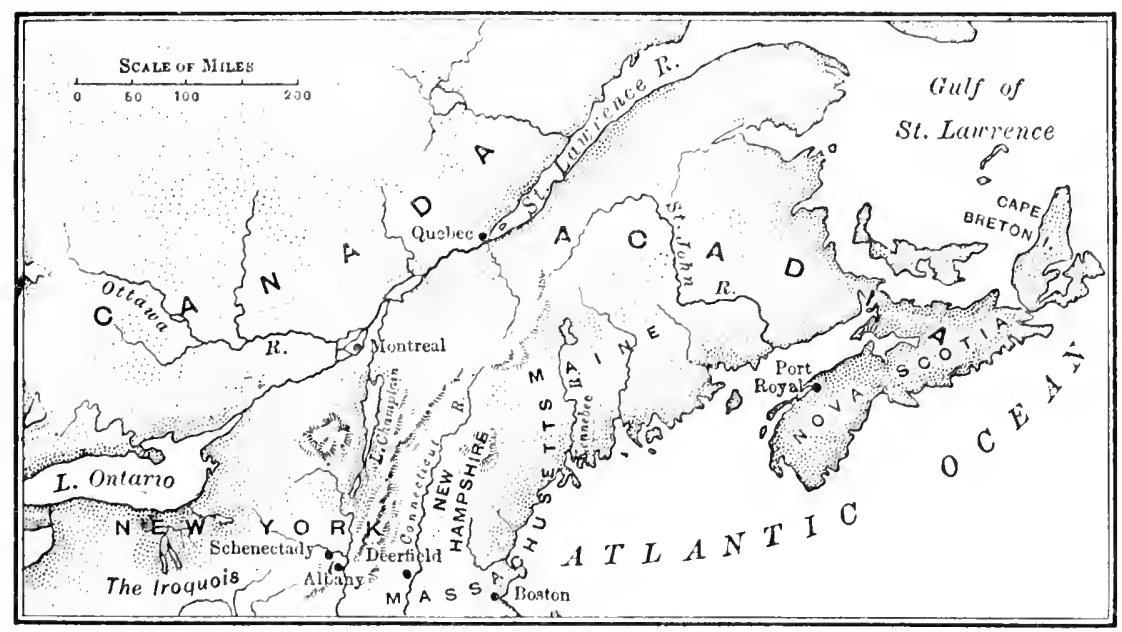

PRINCIPAL FIELD OF KING WILLIAM'S AND QUEEN ANNE'S WAR.

with English fleets and troops; but they were mismanaged and failed. The French had made peace with the Five Nations, binding the latter to neutrality, and they could not strike the English in the valley of the Hudson without intruding on the Iroquois domain. Hence New England had to bear most of the suffering of the war.

In America the conflict was not favorable to the English; but on the European field the English and 
Dutch armies, commanded by the Duke of Marlborough, won a series of astonishing victories, which broke the military prestige of France and humbled its arrogant king. He was forced to cede Acadia (named Nova Scotia by the English), Newfoundland, and Hudson Bay to England, by the treaty of Utrecht, in

Treaty of Utrecht, 1713.

I7I3; agreeing further that "France should never molest the Five Nations subject to the dominion of Great Britain." But, while they gave way to this extent on the seaboard, the French in America were steadily widening and strengthening their hold of the two great interior valleys; winning the friendship of the Indians of the west, fortifying themselves at Detroit, planting colonies and trading stations near the mouth of the Mississippi and in the lower valley of the Ohio and on the Illinois. In appearance, if not in fact, France was binding the better and greater parts of North America to the dominion of her king.

59. Growing Antagonism between the Colonies and the English Government. Experience in these conflicts with the French gave painful proof of the disadvantages to England that resulted from the political separateness of the American colonies, and the want of power to concentrate their military strength. The overcoming of those disadvantages was made difficult by the increasing disposition of the colonists to resent and resist interference with their domestic affairs. It was no longer Massachusetts or New England alone that showed a Local independence demanded. jealous sense of independent rights. The revolution in the mother country had given an object-lesson to the colonies that was instantly learned. By establishing the supremacy of Parliament in the government of Englishmen at home, it carried to English minds everywhere the conviction that no author- 
ity in government which did not represent the governed had any rightful claim to obedience or respect.

It was especially becoming a fixed idea in the minds of the colonists that taxes ought not to be levied on them by any authority save that of their own legislatures. By holding the purse strings of government they meant to control it, as the whole history of England had been teaching them how to do. To provide moneys only from year to year, by annual acts of assem-

Taxation reslsted. bly, even for governors' salaries, and thus to keep those officials dependent; to make all appropriations specific, for one designated use, and for no other; to have their own colonial treasurers, responsible to their own representatives, - these were now common aims in the colonies, and they were pursued nowhere more stubbornly than in New York.

On the other hand, the dominant Whigs in England were unwilling to apply to the colonies the doctrines of representative government which they had established in the English constitution. Thus the English on the two sides of the Atlantic were becoming op- opposing posed in this period, even while they stood together in fight with France. Both felt the Opposing
ideas of
colonial colonlal
union. need of some unity of government in the colonies, for their own defence, and the subject was discussed; but colonists and English officials were each determined that no kind of union should be formed that might strengthen the other. The former would place the bond of union in a representative federal assembly; the latter would tighten it in the hands of a vice-royal governor and an appointed council. At the same time the several colonies were held apart by many jealousies and differences, and the prospect of a union among them was not at all bright. 
60. The Board of Trade.-Oppressive "Acts of Trade." 1696-1706. In I696 a special commission was established for the joint superintendency of commerce and colonial affairs. This Board of Commissioners for Trade and Plantations (commonly referred to as the Board of Trade or the Lords of Trade) was looked to thereafter for information and advice on questions of colonial and commercial policy, the two subjects being dealt with as one. The Board recommended a number of sharp measures which the government did not venture to carry out. In 1697 it advised the appointment of "a captain-general of all the forces and all the militia of all the provinces;" but the appointment was not made. In I 7O it proposed an act of Parliament to extinguish all charters and reduce the colonies to equal "dependency," and a bill to that effect was introduced in the House of Lords; but it did not pass. Nor did another bill for the same purpose that was brought into the House of Commons in 1706 , on a report from the Board.

In matters of trade there was less hesitation to make the hard hand of parental control felt. New regulations for the enforcement of the navigation laws were passed in 1696, and in 1699 the determination of England that the colonies should do no important manufacturing for themselves was embodied in an act declaring ":Protecthat, "after the first day of December, I699, no English wool, or manufacture made or mixed with wool, industries. being the produce or manufacture of any of the English plantations in America, shall be loaden in any ship or vessel, upon any pretence whatsoever-nor Ioaden upon any horse, cart, or other carriage - to be carried out of the English plantations to any other of the said plantations, or to any other place whatsoever." 1

1 Bancroft, Hist. of the U.S. (author's last revision), ii. $8 \mathbf{I}$. 
61. The Witchcraft Madness in Salem. 1692. In 1692 an affliction worse than oppressive government came upon Massachusetts, in an epidemic of frenzy on the subject of witchcraft, which seized the people of an important town. The superstitious belief that men and women might obtain a supernatural power to do harm to others, by wickedly selling their souls to Satan, was common everywhere in that age of the world. In all countries there were cruel laws against the supposed crime of witchcraft, and many supposed witches had been put to death; but never elsewhere does there seem to have been such madness on the subject as that which made Salem the scene of horrible tragedies in 1692. Between July and September in that year nine innocent men and women were hanged; one old man was pressed to death; eight more who were condemned to die, and about a hundred and fifty who waited trial, were in prison when the season of madness passed.

62. Huguenot and German Immigration. Several colonies were now receiving an increased immigration, and from excellent classes of people, especially out of Germany and France. The German immigrants, mostly refugees from the country called the Palatinate, on the Rhine, which had been devastated barbarously by armies of Louis XIV., were settled in North Carolina, Virginia, Pennsylvania, and New York. Persecution of Protestants (Huguenots) in France had been driving great numbers from that country, and many found homes in America, South Carolina and New York receiving the larger share.

63. The Carolinas. 1690-1713. South Carolina was now entering on a more prosperous career, founded mainly on the cultivation of rice, and negro slavery was having a proportionate growth. Charleston was rising 
to importance as a seat of trade, and a centre of wealth and culture.

In North Carolina much disorder still prevailed. The colony was afficted with a serious Indian war, in I 7 I I-I 3, begun by a horrible massacre of frontier settlers in September of the former year. The Iroquois tribe of TusThe caroras, which led in this attack, was driven Tuscaroras. finally from the country, and migrated to New York, where it was received into the Iroquois confederacy, making that a league of "Six Nations," instead of Five.

64. Incidents of Progress. 1701-1710. A notable event in Connecticut, within this period, was

Yale

College, the founding at New Haven, in I zor, of the col1701. lege which received somewhat later the name of its principal early patron, Elihu Yale. No less notable was the appearance at Boston, on the 24th of April, The first I704, of the "News-letter," the first newsnewspaper. paper printed in the New World.

In I692 a postmaster for the northern colonies had been appointed by the king, but there seems to have been little that he found it possible to do. In I7 Io, Beginning however, an act of Parliament provided regulaof a postal tions for a postal system, which was gradually
system,

1692-1710. developed from that time; though some colonists were anxious lest a precedent for parliamentary taxation should hide itself in the postage rate.

65. The Hanoverian Kings. - Ministry of Sir Robert Walpole. 1714-1742. Queen Anne died in 17 I4, learing no direct heir. A son of James II., styled "the Pretender," because he claimed to be the rightful king of England, was exiled in France, and excluded from the succession by an act of Parliament, which gave the crown to a German prince, George, Elector of Hanover and 
Duke of Brunswick-Luneburg, whose grandmother was the daughter of James I. This brought to England the family of sovereigns sometimes called Hanoverian, sometimes referred to as "the House of Brunswick," which still holds the throne. The English had no liking for their foreign king, who could not even speak their language, and a strong Tory party favored the Pretender's claims. Hence King George I. and the Whigs who sustained him held the government by a tenure that was insecure for many years. They were in no position to have trouble with the colonies, nor war with foreign powers, and the wise minister, Sir Robert Walpole, who conducted the government, avoided both. For Sir Robert a quarter of a century he kept England at peace, and generally in a state of prosperous content.

66. British Officials in the Colonies. In his political treatment of the colonies, Walpole refused to be guided by the Board of Trade. The Board took its opinions for the most part from the royal governors in America, who were not often men of character or ability, and who, having many quarrels with the colonial assemblies, represented to their superiors that the people of the plantations had no aim but to break themselves free from all British ties. It is abundantly proved that this was not then, nor long afterward, the fact. With increasing resoluteness, the English in America were claiming all the rights which the English in Great Britain enjoyed; especially the right of self-taxation, the right to control the expenditure of their own public moneys, and the right to a free press; but they claimed those rights as members of the British Empire, - as subjects of the British crown, - and there is no sign of a wish on their part, in those days, to be anything else.

67. The Question of Taxation. In one particular, at 
least, the colonists weakened very seriously the ground on which they denied the right of the British Parliament to lay taxes upon them. They would not tax themselves for what seems to have been a reasonable share of the burdens of the war with France, nor, after the war, for a reasonable share of the cost of fortifying and garrisoning their own frontiers. It was this which gave to the royal governors and the Board of Trade their strongest argument when they appealed to Parliament to annul all charters, unite the colonies under a common government, and impose upon them a direct imperial tax. They might have persuaded Parliament to act Walpole on taxing the They might have persuch Parliament to act colonies. on their advice, but Sir Robert Valpole, who controlled it, was not to be moved. "I will leave the taxing of the British colonies," he is reported to have said, "to some of my successors, who may have more courage than I have, and be less a friend to commerce than I am." So those follies of arbitrary government were put off by Walpole's good sense until he lost control of Parliament, which happened in I739; and then they were postponed still further by war with Spain and new wars with France, into which England was pushed.

68. Industrial and Commercial Oppressions. But, while Walpole refused to adopt the colonial policy urged by the Board of Trade in political matters, he accepted its commercial ideas, and satisfied the increasing demand of English merchants and manufacturers for measures to suppress colonial industries that seemed hurtful to British trade. ${ }^{1}$ These intolerable measures were evaded to a large extent.

1 "Every form of competition by colonial industry was discouraged or forbidden. It was found that hats were well made in the land of furs; the London company of hatters remonstrated, and 
69. The Carolinas. 1719-1729. The wretched govermment in South Carolina which the proprietors maintained was overthrown in I7I9, when the colonial Assembly refused to recognize the proprietary officials any longer, and seated a governor of its own choice. The revolutionary proceeding was winked at in England, where the proprictors were thought to have forfeited their charter by neglect and misuse, and a royal governor was sent out. Ten years later (I 729) the proprietary rights were purchased by the crown, and both Carolinas then came under the direct rule of the king.

70. The Founding of Georgia. 1732-1752. In I732 the last of the thirteen colonies which originally formed the United States of America was founded, as an enterprise of noble benevolence, by General James Oglethorpe. General Oglethorpe was moved by a deep feeling of pity for those unfortunate people who, in that age, suffered imprisonment for trifling oglethorpe. debts. As a means of opening some hopeful future to them, and to others in need, he procured a charter from the king, creating a province named Georgia, to em-

their craft was protected by an act forbidding hats to be transported from one plantation to another. . . . English iron-mongers asked for a total prohibition of forges, and the English landlords of furnaces for preparing the rough material, because the fires in America diminished the value of British woodlands. In the conflict the subject was postponed. . . . In the seventh year of George I. the importation of East Indian goods into the colonies was prohibited, except from Great Britain. . . . Furs from the plantations were enumerated among the commodities which could be exported only to Great Britain; so, too, ore from the abundant copper mines of America. The reservation of the pine-trees of the north for the British navy was continued. . . . For colonists to manufacture like Englishmen was esteemed an audacity, to be rebuked and restrained by every device of law." Bancroft, Hist. of the U.S. (author's last revision), ii. 239-243. 
brace the country that adjoins the Carolinas, between the Savannah and the Altamaha rivers, and from the sources of those streams duc west to the Pacific. For twenty-one years it was to be placed under the guardianship of a corporation, "in trust for the poor." This was in territory claimed by Spain; but the English were resolved to make it their own. The first company of emigrants, led by Oglethorpe in person, sailed from England in November, 1732, and planted its settlement at Savannah early in the following year.

The province was to have no representative government until the twenty-one years of trusteeship were ended; meantime it was to have no slaves, and no intoxicating liquors were to be sold within its bounds; but slavery is said to have made its appearance within seven years, and rum, probably, was not behind. The government by trustees was abandoned, and Georgia became a royal or crown colony, with a representative Assembly, in I 752 .

71. English Neglect of the Western Country. 16091716. The long neglect of the English in America even to explore the great expanse of continent beyond their narrow fringe of colonies on the coast seems very strange. Some traders had made their way across the mountains into parts of the western wilderness; but no exploration like that of the French, and no attempt to lay hold of the country, by posts, missions, or stations of any kind, had been made. The great valley to the west of them, which stretched its wide arms to the foot of the Appalachian hills, was little better known to the English who claimed it, in the first quarter of the eighteenth century, than it had been to the first colonists, a hundred years before. It was not until i 7 I6 that an enterprising governor of Virginia, Alexander Spotswood, 
THE PERIOD OF STRIFE WITH FRANCE. I 35

led a gay party of cavaliers across the Blue Ridge into the beautiful valley of the Shenandoah, and learned what a garden of paradise was there. Of the vast region beyond the further Alle-

Spots-

wood's exploration, 1716. ghanies he had so little notion that he supposed, from something the Inclians told him, that Lake Erie might be seen from one of the latter peaks. But he did become impressed with a sense of the need of vigorous action to hold, at least, the mountain passes, against the French, and urged the British government to take steps to that end.

Others of the royal governors had begun to realize the seriousness of the situation. which French activity in the west was bringing about; but the English government and the colonial assemblies were strangely indifferent still. A single measure, considerably at his own expense, was taken by Governor Burnet, of New York, in I726, when he bought land at Oswego, from the Six Nations, and established there, first a

trading-post, and then a small stone-walled fort. $\begin{aligned} & \text { Fort at } \\ & \text { oswego, } \\ & 1726 .\end{aligned}$ But that English foothold on Lake Ontario was a trifling thing compared with the forts and garrisons at Niagara and at Crown Point which the French added soon afterward to their chain of strong posts.

72. The Scotch-Irish in the Appalachian Valleys. 1704-1750. Something vastly more important, how. ever, for the strengthening of the British colonies, than the mere building of forts, was being done at this time in Pennsylvania, with little consciousness of the effect. The large immigration to Penn's province had now pushed its settlements to the mountains, and a great stream which began to pour into the country from the north of Ireland flowed naturally into the valleys that lie between the parallel ridges of the Appalachian sys- 
tem, stretching away to the southwest. It was a migration of people whose home had been in the Irish

Home of province of Ulster for two or three generations, Home of
the Scotch- but whose ancestry was Scotch. Oppressed Irish.

on all sides, by the state, by the church, and by their landlords, these Scotch-Irish, as they are known, were drawn toward America by good reports of the freedom and prosperity enjoyed there, especially in the famous Quaker's lands. By many thousands every year, through all the half-century that preceded the

Immigra-

tion to

America. American Revolution, they were coming in a scarcely broken stream, until half a million of this strong, intelligent population is believed to have been transferred to America, and settled mostly on the colonial frontier. A few went into other colonies, but the great majority sought the mountain region of Pennsylvania, filling it and pressing along its valleys into western Virginia and the highlands of the Carolinas, whence it overflowed, a little later, into Kentucky and Tennessee. The Scotch-Irish were not alone in that southwestward movement through the Appalachian valleys, for German and other immigrants were taking the same course; but the strength and character then given to the frontier settlement of the colonies came from the first-mentioned stock.

73. Death of William Penn. Pennsylvania was having a remarkably prosperous growth; yet in some respects it had disappointed Penn's hopes. It had caused him many troubles, and had cost him more than it yielded in return. In 17 I 2 he proposed to relinquish his powers of government to the crown for $\mathcal{E}_{12}, 000$, but was stricken with paralysis in the midst of the negotiation, and never recovered from the stroke, though he lingered in life for six years. The proprietorship of 
THE PERIOD OF STRIFE WITH FRANCE. I37 the province passed at his death (I7I8) to three of his sons.

74. Benjamin Franklin in Philadelphia. It was socn after that time (in I723) that Benjamin Franklin ran away from an irksome apprenticeship to his brother in Boston, and came, a penniless lad of seventeen, to begin his great career in Philadelphia, and to plant in that city many fertile ideas that have borne important fruits. He was the first of the grand characters of the coming Revolution to appear on the stage of action. When Franklin began typesetting in Philadelphia, neither Washington nor Jefferson nor John Adams was born, and Samuel Adams was an infant in arms.

75. Rise of the Newspaper Press. - The Winning of its Freedom. Before Franklin left Boston he had experience in that city of the want of freedom for the press. His brother, who published one of the three newspapers in Boston, had lately been imprisoned for a month, by order of the Assembly, on account of some article that gave offence. There were no other newspapers in America at the time, except one in Philadelphia, which a son of the early printer, Bradford, had founcled in I7I9. In I725 one appeared in New York, and after that time they were multiplied, in Maryland, South Carolina, Rhode Island, and Virginia. A second newspaper started in New York by one Zenger, in I733, gave rise, in the next year, to a famous trial, which resulted in a decisive vindication of the right of publishers to print true statements of fact concerning public affairs.

76. Third Intercolonial War. 1739-1748. In I 739 Walpole was overcome by his political opponents in the English government, and the nation was carried, against his will, into a war 
with Spain. The colonies took little part in this war, except in Gcorgia, on the border of Spanish territory, where some fighting occurred.

In $17+3$ the hostilities between England and Spain became part of a great general war, in which most of the European powers were engaged, with England, Holland, and Austria on one side, against France, Spain, Prussia, and several minor states, on the other. To "king England, this War of the Austrian Succession, Goorge's as it is known (called "King George's WVar," 1743-1748. or the Third Intercolonial War, in American history), brought neither glory nor gain. The one not-

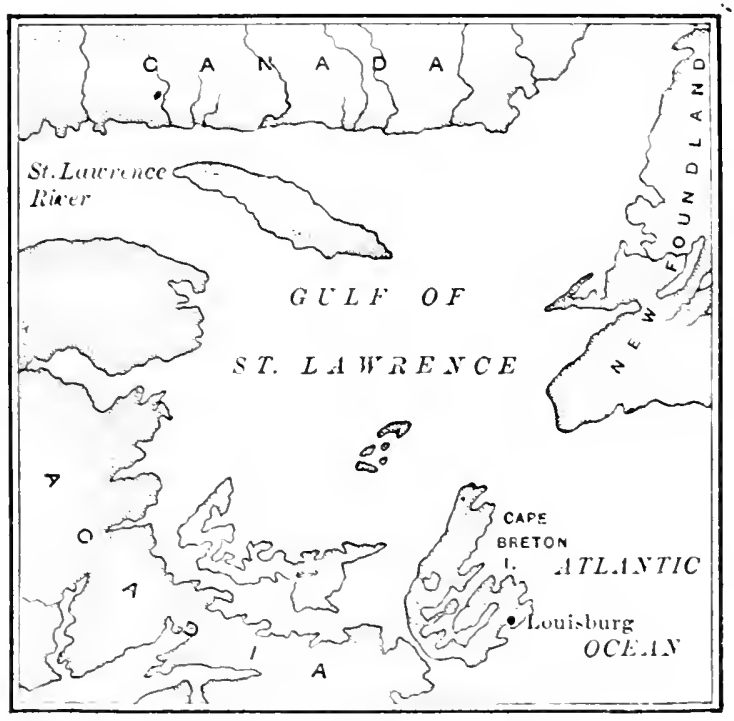

LOUISBOCRG THF KEY TO THE GULF OF ST. LAWRENCE. able exploit in it was performed by the New Englanders, as an undertaking of their own, with no help but that given by a British fleet, which blockaded the harbor of Louisbourg, in the island of Cape Breton, while they reduced the powerful defences of

the place. For a score of years, at enormous cost, the French had been fortifying that harbor for a naval sta-

\section{Capture of} tion, and it was their stronghold on the coast. Capture of Mansbourg, Massachusetts was the leader in the expedition 1745.

against it, and furnished about three fourths of the troops and equipments sent. The 4000 men of 
this small colonial army had no training, their officers had no military experience, their commander, William Pepperell, a wealthy merchant, was entirely new to the business of war, but they took Louisbourg (June, I745), after a siege of six weeks.

The Assembly of New York, having a quarrel with its governor, George Clinton, would provide no means for expelling the French from Crown Point, nor for fortifying against them, even to defend a settlement at Saratoga, which was left to be raided and destroyed, with a sacrifice of thirty lives. The border settlements in New England were protected with more vigor and success, against repeated attacks.

77. French and English in the Upper Ohio Valley. 1748-1753. The war settled nothing between England and France. Peace was made in 1748 (Treaty of Aixla-Chapelle) by each giving back what it had taken from the other; and every discerning person could see that the open question of boundaries between French and English territory in America, which the treaty left untouched, was sure to be the cause of another war in no long time. Hitherto that question had been a pressing one only on the northeastern border of the English settlements and claims; but now the two peoples were coming to close quarters on the west. The meyond the first English settlement beyond the mountains 1748-1750. in western Virginia was made on a branch of the Kanawha in I748; and a company in that year obtained a crown grant of half a million acres, to be located somewhere in the Ohio valley. Two years later this Ohio Company sent one Christopher Gist, with a party, to make the first known English exploration of the country bordering on the upper waters of the Ohio. Many traders with the Indians, from Pennsylvania and the southern colonies, 
were now in that country, and settlers were making ready to follow in their track.

At the same time the French, already well established along the line of the Great Lakes, and in the country between the western end of Lake Erie, Lake Michigan, and the lower Ohio, were entering the upper valley of the Ohio from points near the eastern end of Lake Erie, and were formally taking possession of that region

French in western Pennsylvania, 1749-1763. in the name of their king. This was done by an exploring expedition under Céloron de Bienville in I749. Early in 1753 more decisive action was taken, by a French force which came across Lake Erie to Presque Isle (now the city of Erie), and thence to French Creek, on which stream two forts, Le Bœuf and Venango, were built and garrisoned, for the purpose of holding an easy line of communication between the Alleghany River and the lake.

78. Opening of the Final Conflict with the French. 1753-1754. It was then, and because of that action of the French, that George Washington made his first appearance in history. Virginians, it will be remembered, claimed a northern boundary line, under the charter of I609, which ran northwestwardly, instead of due west (see sect. 3), taking in the territory on which the French were now laying hands. That claim had been strengthened in 1744 by a treaty, signed at Lancaster, which Virginia joined Maryland and Pennsylvania in making with the Iroquois, whereby the latter conveyed all rights belonging to them as conquerors of the tribes of the west. On these grounds, when news of the building of the forts on French Creek was received, Governor Dinwiddie of Virginia made haste to send a warning to the officer in command that he had intruded on English 
THE PERIOD OF STRIFE WITH FRANCE. I4I soil. The message was conveyed (1753) through the wilderness by George Washington, then lately appointed major and adjutant-general of the militia forces of Virginia, though but twenty-one years of age. Of course, the French officer at Fort

Washing-

ton's

entrance

into His-

tory, 1753. Le Bœuf declined to vacate his post; and a working party was then sent out from Virginia, in the

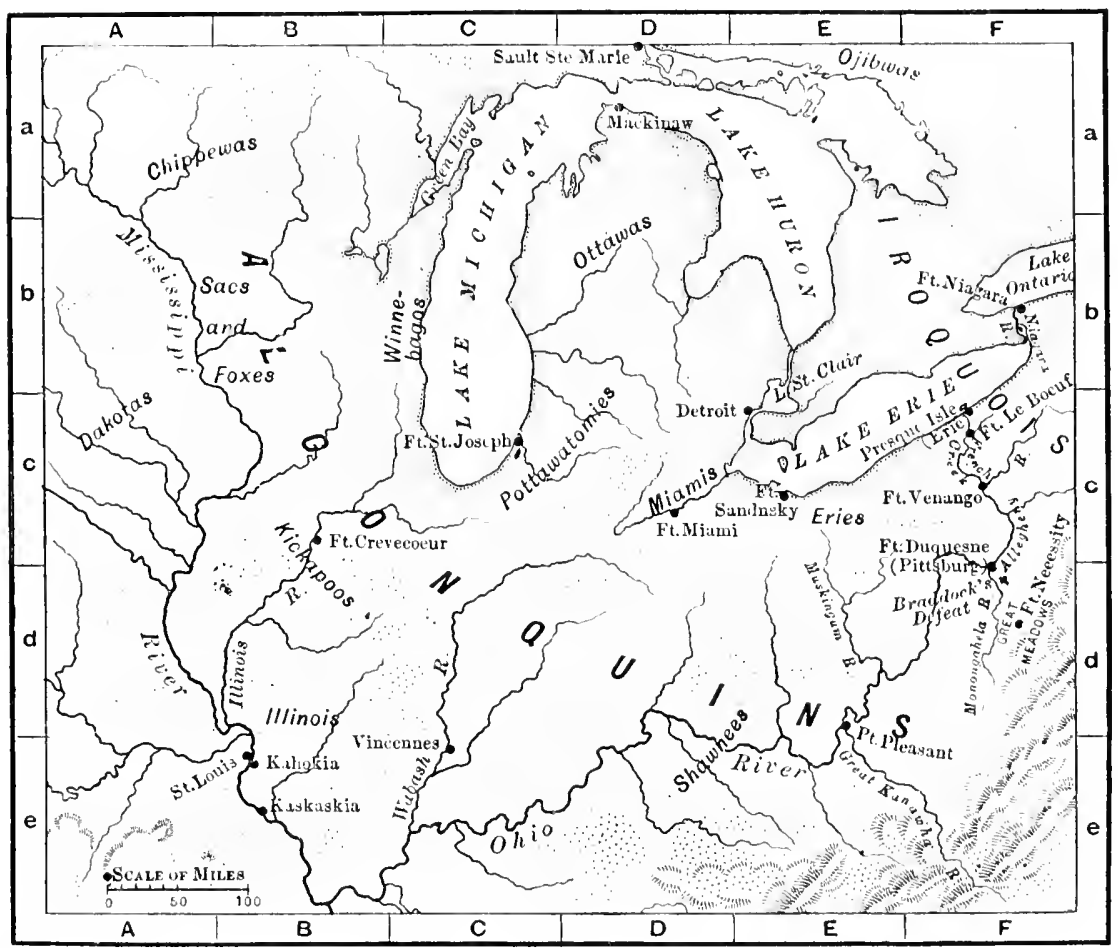

FRENCH POSTS IN THE UPPER MISSISSIPPI VALLEY AND AROUND THE GREAT LAKES.

spring of 1754 , to build an opposing fort, at the junction of the Alleghany and the Monongahela, where Pittsburg now stands, while Washington followed, soon after, with two hundred men. Before the latter could reach the ground the English fort-builders were driven off, and the French were continuing the work they had begun. 
Washington, moving forward, came by surprise on a French scouting party and attacked it hilling ten and taking twenty-one prisoners. This opened the final confict which decided that Englishmen and not Frenchmen should be masters of the destiny of the American world. Falling back to Great Meadows and being slightly reinforced, Vashington built a small fort, which

Great Meadows. he called Fort Necessity. and endeavored to 1754 .

hold his ground against a thousand French and Indians: but his small force was too poorly provisioned and equipped to stand a siege. and he had to accept terms which allowed him to lead his men back to their homes.

79. Indifference of Many Colonies to the French Adrance. Engiand was now aroused, and began, for the first time. to make serious preparations for fighting out her colonial quarrels with France. But except in New England. whose border settlements had been harassed sorely by the French, the colonists still looked with much indifference, it would seem, at the movements of the rival people who were hemming them in. In New lork the Assembly coolly answered the governor's appeal for means to repel the French invasion attitade of by saying that the building of a fort. " at a place New Yors. called French Creek, at a considerable distance from the river Ohio." "does not by any eridence or information appear to us to be an invasion of any of his majesty"s colonies: " and it was with great reluctance that this sceptical body finally roted Sio.000. In Pennsylunia, where the large Ouaker element of population had always refused to vote money for military use, and where the people in seneral were retusing to levy any tax which did not apply to the wild lands of the proprietors, the answer of the Assembly was much the same. They 
said plannly to the governor that "they had rather the French should conquer than give up their privileges." New Jersey did nothing. Maryland made a tardy appropriation of $\$ 6000$. Even in Virginia, which claimed the invaded territory, the Assembly appeared more anxious to defeat the governor in an old matter of quarrel than to drive out the French.

Looking back from our own time at the situation as it existed then, one can see that England could have afforded much better than the colonies could to let the French win the lakes and the great rivers and valleys of the west. If the English government could have foreseen that the overthrow

In the light of after events. of its own authority in the colonies would follow the expulsion of France from America, it might reasonably have stood back, to let events take their course. There were sagacious men, both in England and in the colonies, who suspected that nothing save the presence of the French on their borders could keep the colonists in subjection; but the contrary view prevailed. England became eager for the conquest of New France, and so cleared the way to independence for the colonies; while the colonies themselves were mostly cool toward the undertaking at first, and discouraged the very effort by which their speedy emancipation was guaranteed.

80. Plans of Colonial Union. 1754. In view of all the circumstances, it can hardly be wondered that the British government entered the war with an intention to tax the colonies by act of Parliament for their share of its cost. That intention appeared in action taken after the meeting of a congress of colonial commissioners, called by order of the Lords of Trade and held at Albany, in June, I754. New York, Pennsylvania, Maryland, and the four New England colonies were repre- 
sented by some of their ablest men; but the provinces farther south took no part. The special purpose of the congress was to strengthen the English alliance with the Six Nations, who were being seduced by the French ; but the congress took up the subject of a colonial union, and several plans of organization were discussed. One, Franklin's submitted by Benjamin Franklin, was adopted, plan of

unlon.

after some amendments, and recommended to the provincial assemblies and the Board of

Trade. It contemplated a general government, to be administered by a president-general, appointed by the crown, and a grand council, to be chosen by the several colonial assemblies. The result of the recommendation is thus related by Franklin, in his own account of his life: "The assemblies did not adopt it [the recommended plan], as they all thought there was too much prerogative in it, and in England it was judged to have too much of the democratic. The Board of Trade therefore did not approve it, nor recommend it for the approbation of his majesty; but another scheme was formed, supposed to answer the same purpose better, whereby the governors of the provinces, with some members of their respective councils, were to meet and order the raising of troops, building of forts, etc., and to draw on the treasury of Great Britain for the expense, which was afterward to be refunded by an act of Parliament, laying a tax on America." So England entered the final contest for empire in America with intentions that were destined to cost her the best part of the fruits of her success.

81. Braddock's Defeat. 1755. Neither England nor France had declared war; but both proceeded to hostilities, and were fighting battles at sea and on land for two years before they gave up the pretence of being at peace. Early in 1755 , both sent considerable forces to America, 
THE PERIOD OF STRIFE WITH FRANCE. I45

the English under General Braddock, the French under Baron Dieskau. General Braddock and his regiments were landed in Virginia, and there, at a conference with several of the provincial governors, four simultaneous attacks on the French were planned; one, to be led by Bracldock in person, against the new fort (on the site of Pittsburğ), which had been completed and Fort called Fort Duquesne; a second against Crown Duquesne. Point, under Colonel William Johnson, Superintendent of Indian Affairs in New York, and powerful in influence with the Six Nations; a third against Fort Niagara, which Governor Shirley, of Massachusetts, would command; the fourth in Acadia, to clear the French from the forts they held on the northern side of the Bay of Fundy and Chignecto Bay.

Some compa-

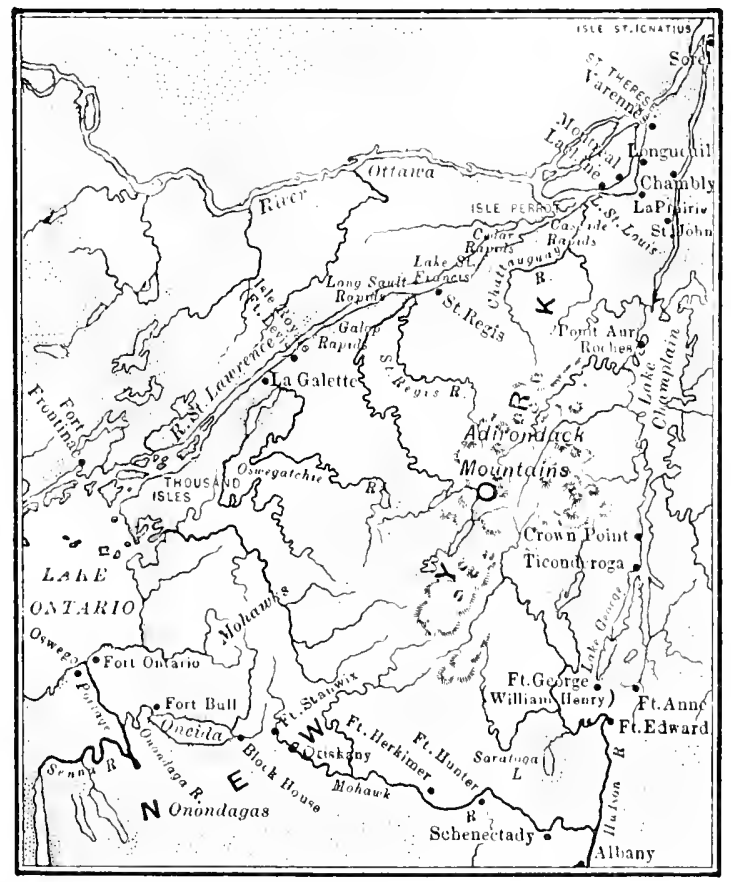

MILITARY POSTS IN THE FRONTIER REGIONS OF NORTHEASTERN NEW YORK AND NEIGHBORING CANADA. 1 nies of Virginians were added to Braddock's British regiments, and Washington was invited to join his staff. But the British

1 From Miles's History of Canada, reproduced in Winsor's America, v. 557. 
general, who knew nothing of war with savages in the wilderness, was scornful of information from those who The day of did know, and a terrible disaster was the redisaster, July 9 , sult. Attacked in the forest, when near Fort 1755.

Duquesne, by hidken foes, who fired from behind trees, he would not let his men fight in the same backwoods fashion, but compelled them to stand in line, exposed to the fire of the hidden enemy, until they broke and fled in wild disorder, leaving their wounded to be tomahawked and scalped. Out of a total of about 2200 in Braddock's command, nearly soo are believed to have been lost. Braddock himself was mortally wounded and died during the retreat. His second in command abandoned the whole frontier, leaving it at the mercy of the savages, who swarmed against it for months, at the instigation of the French.

Governor Shirley's expedition against Fort Niagara got no farther than Oswego, finding the forces of the enemy unexpectedly strong. The army led by Colonel other Johnson was attacked while in camp at the expeditions. head of Lake George, and won an important victory, shattering the French army, wounding Baron Dieskau, and taking him prisoner; but it did not advance to Crown Point. Johnson contented himself with building an opposing fort, named William Henry, at the head of Lake George, and another at the head of boat navigation on the Hudson, called Fort Elward; while the French built Fort Carillon, afterwarc called Fort Ticonderoga, at the outlet of Lake George into Lake Champlain.

82. Dispersion of the Acadian French. 1755. Of the four morements planned for 1755 , only one had complete success. That in Acadia drove the French entirely from the Bay of Fundy and the neighborhood 
THE PERIOD OF STRIFE WITH FRANCE. I 47 of Chignecto Bay, where they had been keeping up continual intrigues among the Acadian french of the Nova Scotian peninsula, inciting them to hostile acts. As the Acadians continued to give trouble, and refused to swear allegiance, a resolution to remove them and scatter them in other colonies was taken, and that harsh measure was carried out in the fall of I755. About 6000 were forcibly shipped to clifferent points in the English colonies, whence many of them made their way to the French settlements in Louisiana; some escaped to Canada; a few were left

\section{Long- \\ fellow's "Evange- line."} behind. The sad tale is told, but not with historical accuracy, in Longfellow's poem of "Lvangeline."

83. The European "Seven Years' War." In May, I756, war between England and France was formally declared. Both nations had then become engaged on opposite sides of another great European quarrel. France had joined Austria, Russia, Sweden, and other powers, in a combined attempt to crush the king of Prussia, Frederick the Great. England went into alliance with Frederick, in order to have his help in defencling the German dominion (Hanover) of King George. The far-reaching and tremendous conflict then opened is described in European history as the Seven Years' War; but the colonists called their part of it, as well as the American hostilities that preceded it, the French and Indian War.

84. The Turning of the Tide. 1756-1758. For the campaign of 1756 , in America, the Irench government sent out an excellent soldier, the Marquis de Montcalm, to take command, while a dilatory general, Lord Loudon, was opposed to him on the British side. Things went badly with the British for the next tivo years. Oswego and Fort William Henry were lost, and the 
whole border, from New York to Virginia, was harried

william Pitt, the elder,

1758. by French and Indian raids. So far, the arms of France were triumphant, and the outlook for the English in America was very dark. But suddenly, in the summer of 1758 , an amazing change occurred. A great British statesman, the elder William Pitt (afterward the Earl of Chatham), had risen to power, and his prodigious energy was imparted to the conduct of the war.

The successes of 1758 in America (from which Lord Loudon was recalled) were the reduction, again, of Louisbourg, after a siege of seven weeks, the expulsion of the French from Fort Duquesne, and the capture and destruction of Fort Frontenac, on the Canadian shore of Lake Ontario, where the city of Kingston stands now. One dreadful disaster marked the year. A force of 6000 British regulars and 9000 provincial troops was Repulse at sent against Ticonderoga and Crown Point. It Ticonderoga, July 8,1758 . was nominally commanded by Major-general Abercrombie, but really by Lord Howe, who was a man after Pitt's own kind. Unhappily, Lord Howe was killed in a chance encounter with the enemy, before reaching Ticonderoga, and an ill-judged assault on the fort, directed by Abercrombie, was repulsed with such terrible slaughter that he made no further attempt.

85. Conquest of New France. 1759-1760. The supreme and decisive achievement of the war came in the next year (1759), when Quebec, supposed to be the invincible citadel of Canada, was taken by General Wolfe. The British fleet and army reached Quebec at the end of June, and found the French, under Montcalm, prepared to defend it with nearly double the force that Wolfe had been able to bring. More than ten weeks were spent in attempts to find some way of reaching the 
THE PERIOD OF STRIFE WITH FRANCE. I49 enemy on the heights that they held. At last the way was found, between midnight and dawn of the $3^{\text {th }}$ of September, when 4800 of the besieging troops climbed to the summit without discovery, and defeated the raver levies of Montcalm in an open battle fought on a broad plateau, known as "the

Capture of Quebec, September Plains of Abraham." Both Wolfe and Montcalm re-

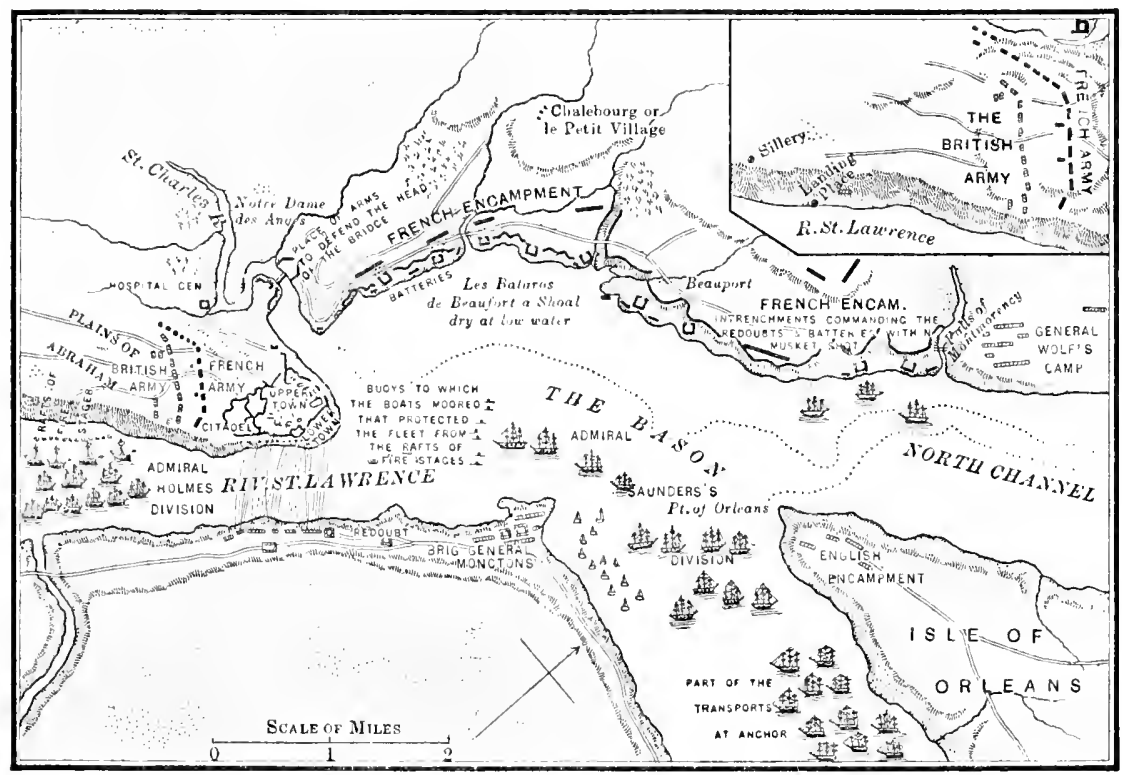

PLAN OF THE SIEGE OF QUEBEC. 1

ceived mortal wounds in the fight. The former died on the field, in the moment that he knew it to be won; the latter expired the next day.

Before this most fatal of all possible blows to the power of France in America had been struck, and while Wolfe was still sparring with his antagon ist for the chance to deliver it, General Amherst (who had been in command at the taking of Louisbourg, in the previous year) led I I,000

1 From Miles's History of Canada, reproduced in Winsor's America, v. 542. 
men against forts Ticonderoga and Crown Point, and other forced the French to abandon both. Fort French Niagara, at the point where the river Niagara reverses.

flows into Lake Ontario, had been surrendered to an expedition sent against it in July, and this compelled a quick retreat of garrisons from Venango, Le Bœuf, and Presque Isle. All the French posts farther west were cut off. A hopeless fight was kept up in other quarters until September of the following year ( I 760 ), when the surrender of Montreal carried with it the surrender throughout Canada of all the French forces in arms.

86. Cession of all French Territory in North America. 1763. In Europe, the great Seven Years' War went on for two more years, and terms of peace were not finally settled until February, I763, when the treaty of Paris was signed. By that treaty France ceded to Great Britain the whole vast territory that she had claimed in North America east of the Mississippi River, excepting the settlement at New Orleans, and two small islands near the coast of Newfoundland, which she kept for fishing stations, with certain fishery rights. New Orleans and the region claimed by France on the western side

France cedes

Louisiana

to Spain ;

Spain cedes

Florida

to England,

1763. of the Mississippi, which she called Louisiana, were given up to Spain. Spain at the same time ceded Florida to Great Britain, whose sovereignty in America became then complete from the Atlantic to the Mississippi, and from the Gulf of Mexico to the Polar Sea, excepting in the little district where the city of New Orlcans was growing up.

In the war which had that great result, the colonies, notwithstanding their backwardness at the beginning, appear to have borne their full share of the fighting and the cost. In testimony given three years after the peace, before the House of Commons, Dr. Franklin said : 
"The colonies raised, paid and clothed near 25,000 men during the last war, a number equal to those sent from Britain, and far beyond their proportion; they went deeply into debt in doing

Part of the colonies in the war. this, and all their taxes and estates are mortgaged, for many years to come, for discharging this debt.'

87. Pontiac's War. 1763-1764. In assuming that France could transfer to them a sufficient title to the great territory she had claimed, the English were forgetful of the native occupants, by whose friendly sufferance the French had been holding all that they called their rights. English garrisons took the place of the French throughout the west, with little effort to win the assent of the surrounding tribes. The natural consequence was a fierce and widespread resentment among the savages, leading to a great combination of hostilities. tribes, secretly worked up with rare ability by Pontiac, an Ottawa chief. Nearly the whole of the Algonquian stock, together with the Hurons or Wyandots, the Senecas, and some tribes of the lower Mississippi, were brought into the plan of a simultaneous attack on all the western English posts. The attacks were made in May and June, I763, with appalling success almost everywhere except at Detroit and at Fort Pitt. The garrison at Detroit was besieged by Pontiac in person for six months, and held out until relieved. Fort Siege of for six months, and held out until relieved. Fort Detroit, Pitt was relieved more promptly, by Colonel Henry Bouquet, whose energy and capability were conspicuously shown in this Indian war, which lasted until near the end of i 764. Pontiac's combination was finally broken up, and peace was made by Sir William Johnson with nearly all the tribes. But Pontiac himself retreated to the neighborhood of the Mississippi, where he was assassinated in 1769 . 
TOPICS AND SUGGESTED READING AND RESEARCH.

\section{Overthrow of Andros.- A New Charter for Massachusetts,}

TOPICS AND REFERENCES.

r. Andros deposed in Massachusetts. 2. The new charter (text in MacDonald, i. 205-2 I2). 3. Government as a royal province, and annexation of Plymouth and Maine. 4. Connecticut and Rhode Island. Hutchinson, i. $372-3 S_{7}$; Doyle, iii. 339-358, 372-383; Fiske, Beginnings, 27I-27S; Fisher, 21 $8-225$.

\section{New York and Jacob Leisler.}

TOPICS AND REFERENCES.

r. The Revolution in New York. 2. Authority assumed by Jacob Leisler. 3. Leisler deposed and executed. 4. "Leislerians" and "Aristocrats." Winsor, America, v. I 89-194; Roosevelt, New York, ch. vi.; Fiske, D. and Q. Col's, ii. ISI-208, 2122 I 5 ; Frothingham, Rise of the Rep., $83-85,88$, 93-95; Fisher, 24I247.

\section{New Jersey.}

Topics AND REFERENCES.

1. Union of the two Jerseys in a single royal province. Fiske, D. and Q. Col's, ii. 239-240; Fisher, 255-256; Hart, Contemp's, ii. $68-72$.

\section{Pennsylvania.}

TOPICS AND REFERENCES.

I. Penn's troubles in England. 2. Suspension and restoration of his political authority. 3. His last visit to the province. lts condition. 4. The "Charter of Privileges" (text in MacDonald, i. 224-229). Fiske, D. and Q. Col's, ii. 294-3I I ; Winsor. America, v. 207-2II ; Fisher, 260-263; Hart, Contemp's, ii. $65-68,7+-77$.

\section{Maryland.}

Topics AND REFERENCES.

I. The revolution in Maryland. - Lord Baltimore deprived of the government. 2. Religious intolerance renewed. 3. Proprietary government restored to the fourth Lord Baltimore. Browne, I 49-156, I $84-202$; Fiske, Old l'a., ii. 1 59-169; Fisher, 272-275. 


\section{Virginia and the Carolinas.}

TOPICS AND REFERENCES.

r. Unaffected by the revolution in England. Cooke, 300-30r ; Fisher, 277-278, 292; Hart, Contemp's, ii. 90-98.

\section{Beginnings of the Conflict with France.}

Topics AND REFERENCES.

I. How England was led into successive wars with France. Their importance to America. 2. Incidents of "King William's War." 3. Colonial Congress at New York in 1690. Bancroft, ii. I77-I85; Parkman, Half Century, i. ch. i., and Frontenac, ch. $\mathrm{x}-\mathrm{xxi}$.; Hildreth, ii. 126-127; Frothingham, Rise of the Rep., 8793; Drake, Border IVars, ch. i.-xiv.

4. "Queen Anne's War." - Its chief incidents. 5. Results of the war. - French cessions of American territory to England (text in MacDonald, i. 229-232). Parkman, Half Century, i. ch. iii.-ix.; Drake, Border IVars, ch. xv.-xxviii.; Seeley, Expansion, I 53-1 55 ; Bancroft, ii. I92-2I I ; Hart, ii. 337-339.

6. Progress of the French in laying hold of the interior. Parkman, Half Century, ii. ch. xvii.; Roosevelt, The Winning, i.33-35 ; Bancroft, ii. 186-I9I ; Hosmer, Miss. Valley, 30-50; Dunn, ch. ii. RESEARCH. - The significance in English and European history of the strife for America. Seeley, Expansion, 148-162.

\section{Growing Antagonism between the Colonies and the English Government.}

Topics And References.

I. Spread of independent feeling in the colonies. 2. Object lessons in representative government, in self-taxation, and in the "holding of the purse strings," that were learned from England. 3. English ideas as to colonial government. Frothingham, Rise of the Rep., 108-110, 123-128; Fisher, 208-211 ; Hart, Contemp's, ii. I33-I 4 I, I 54-I69, 352-353.

4. Effect of the presence of the French on the colonial situation. 5. Opposing views of the needed colonial union. Frothingham, Rise of the Rep., 109-122; Seeley, Expansion, 82-83.

REsearch. - Fruits in England of the Revolution of I 688 which gave an object-lesson to the colonies. Macaulay, England, close of ch. $x$. 
60. The Board of Trade. - Oppressive "Acts of Trade."

TOPICS AND REFERENCES.

1. Reëstablishment of a Board of Trade in England. 2. English colonial policy identified with commercial policy. 3. Sharp measures recommended by the Board, but not adopted. 4. Oppressive restrictions on colonial manufactures and tracle. Frothingham, Rise of the Rep., ro7-1oS; Hart, Contemp's, ii. 129-131 ; N. I. State Doc's, i. xxviii.; Bancroft, ii. 73-82 ; Hildreth, ii. I97I99.

RESEARCH. - Effects of the English commercial system on colonial feeling. Lecky, iii. 324-328.

\section{The Witchcraft Madness in Salem.}

Topics ANi ReFERENCES.

r. Prevalence of the superstitious belief in witchcraft. - The awful tragedy to which it gave rise in Salem. Lowell, $8 \mathrm{I}-\mathrm{I} 50 ; \mathrm{Pal}$ frey, iv. 96-132 ; Fiske, $N$. F. and $N$. E., ch. v. ; Hart, Contemp's, ii. $35-48$; Upham.

\section{Huguenot and German Immigration.}

TOPICS AND REFERENCES.

r. Immigration from the Palatinate of the Rhine and from France. Bancroft, ii. 265, 266 ; Cobb; Baird, ch. v. and ix.-xiv. ; Hart, Contemp's, ii. 77-79.

\section{The Carolinas. 1690-1713.}

TOPICS AND REFERENCES.

r. Advancing prosperity in South Carolina. 2. Indian war in North Carolina. 3. The "Five Nations" of New York made "Six Nations." McCrady, i. 53I-546; Fiske, Old Va., ii. 298304; Fisher, 292-294; Schoolcraft, I04-II3.

\section{Incidents of Progress.}

TOPICS AND REFERENCES.

r. Founding of Yale College. 2. The first newspaper. 3. Beginnings of a postal system. Hart, Contemp's, ii. 255-258; Bancroft, ii. 258 ; Fiske, Old Va., ii. 373-374. 
65. The Hanoverian Kings. - Ministry of Walpole.

TOPICS AND REFERENCES.

I. Succession to the English crown fixed by Parliament. 2. Weakness of the position of the first Hanoverian kings. 3. Peace policy of Sir Robert Walpole. Green, 666, 694-696, 699-700 ; Lecky, i. 376-377 ; Larned, England, 495, 509-51 5.

66. British Officials in the Colonies.

Topics AND REFERENCES.

I. The colonists misrepresented by their British governors. 2. Their claims and aims. Bancroft, ii. 246-25 I, 340-342; Fisher, 210-2II ; Lecky, iii. 296-297.

\section{The Question of Taxation.}

TOPICS AND REFERENCES.

I. Unwillingness of colonists to tax themselves for their own defence. 2. Walpole's refusal to tax the colonies. Lecky, i. 360 ; iii. 344-345; Morley, Walpole, 167-169; Annual Register, 1765, p. 25 .

68. Industrial and Commercial Oppressions.

TOPICS AND REFERENCES.

I. Measures to satisfy English merchants and manufacturers. Lecky, iii. 324-328; Winsor, America, v. I 49, 222-227.

\section{The Carolinas. 1719-1729.}

TOPICS AND REFERENCES.

I. Extinction of proprietary government. McCrady, i. ch. xxix.xxx. ; Winsor, America, v. 325-327.

\section{Founding of Georgia.}

Topics AND RefERENCES.

I. The grant to General Oglethorpe, and its benevolent object (text in MacDonald, i. 235-248). 2. Beginnings of settlement. 3. Futile prohibition of slavery and intoxicating liquors. 4. The trusteeship and its ending. Bancroft, ii. 28I-299; Winsor, America, v. ch. vi. ; Fisher, 303-312; Hart, Contemp's, ii. I 10-I 26.

REsEARCH. - The life and character of General Oglethorpe.

H. Bruce. 


\section{English Neglect of the Western Country.} TOPICS AND REFERENCES.

1. Neglect of exploration beyond the mountains. 2. First expedition into the Shenandoah valley. 3. Recommendations of Governor Spotswood and action of Governor Burnet. Hinsdale, Old V. WV., It-IS; Cooke, 3It-3I5; Hart, Contemp's, ii. 3i6-324; Parkman, Half Century, ii. 45-46.

\section{The Scotch-Irish in the Appalachian Valleys.}

Topics AND REFERENCES.

I. Causes of immigration from the north of Ireland intn Pennsylvania. 2. Spread of settlement into the Appalachian valleys. 3. Southwestward movement. 4. Other immigration taking the same direction. Fiske, Old Va., ii. 390-399, and N. F. and N.E., 259-262; Roosevelt, The Hinning, i. IOI-IIt; Bancroft, ii. 265266; Hanna, i. ch. xxxix.; MacLean, ch. ii.

RESEARCH. - Eminent Americans of Scotch-Irish descent. Hanna, i. ch. iii.

\section{Death of William Penn.}

Topics AND ReFERENCES.

I. Inheritance of the proprietorship of Pennsylvania by Penn's sons. Gordon, ch. ix. ; Sharpless, ch. vi.; Fiske, D. and Q. Col's, ii. $316-317$.

\section{Benjamin Franklin in Philadelphia.}

TOPICS AND REFERENCES.

I. Time and circumstances of the coming of Franklin to Philadelphia. Franklin, 3I-47.

REsearCH. - The early life of Franklin. Franklin, Autobiography.

\section{Rise of the Newspaper Press. - The Winning of its Freedom.}

TOPICS AND REFERENCES.

1. Want of freedom for the press in Boston. 2. Early colonial newspapers. 3. The Zenger trial and its results. Franklin, 3I35 ; Fiske, D. and Q. Col's, ii. 24S-257: Winsor, America, v. 198200 ; Frothingham, Rise of the Rep., 12S-130; Hart, Contemp's, ii. 192-199. 
THE PERIOD OF STRIFE WITH FRANCE. I57

REsEARCH. - The freeing of the press in England. Routledge, ch. xx. ; Larned, Ready Ref.

\section{Third Intercolonial War.}

TOPICS AND REFERENCES.

I. War with Spain in I739. 2. "King George's War." - Its name in European history. 3. Capture of Louisbourg by the colonists. 4. The New York border left undefended. Bancroft, ii. 293-3II ; Parkman, Half Century, i. ch. xviii.-xxiv.; Fiske, N. F. and N. E., 249-256; Drake, Louisbourg; Hart, Contemp's, ii. $346-349$.

\section{French and English in the Upper Ohio Valley.}

Topics ANd REFERENCES.

I. Treaty of Aix-la-Chapelle (text in MacDonald, i. 25 I-253). Unsettled boundary questions. 2. First English exploration and settlement west of the Alleghenies. 3. The French in the upper Ohio valley. Parkman, Half Century, i. ch. xvii.; Winsor, Mississippi, 171-1 83 , and America, v. 8-1 2, 490-492; Fernow, ch. v.vi. ; Bancroft, ii. 336-337, 343-344, 362-366 ; Hinsdale. Old $N$. $W$., 57-6r ; Fiske, N.F. and N.E., 264-270; Seeley, Expansion, 3I-32; Hart, Contemp's, ii. 354-356.

\section{Opening of the Final Conflict with France.}

\section{Topics and ReFERENCES.}

I. The claim of Virginia to the region entered by the French. Hinsdale, Old $N . W ., 73-75,103-109$.

2. Mission of George Washington to warn the intruders away. 3. His second mission, commanding a small force.-Opening hostilities. Washington, i. 9-124; Bancroft, ii. 377-385; Fiske, N. F. and N. E., 270-276; Lodge, Washington, i. 63-79.

RESEARCH. - The early life of Washington. Irving, i. ch. i.-iv.; Lodge, i. ch. ii.-iii.

\section{Indifference of many Colonies to the French Advance.}

TOPICS AND REFERENCES.

I. Attitude of New York, Pennsylvania, and other colonies. Parkman, Half Century, i. ch. xxiii., and Montcalm, i. ch. vi.; 
Franklin, 196-206; Winsor, America. v. 494; Fiske, N. F. and N. E., 277-278; Hildreth, ii. 433-4tI ; Hinsdale, Old N.W., 60 ; Sloane, 99.

2. Why England had more reason than the colonies for indifference. Lecky, iii. 290-295; Johnston, United States, 30-32.

\section{Plans of Colonial Union.}

Topics ANd Referexces.

x. Colonial Congress at Albany, 1754. 2. Plan of colonial union recommended by it (text in MacDonald, i. 253-257; O. S. Leaf., 9). 3. Opposing reasons for rejection of the plan. 4. Board of Trade's scheme of union and taxation. Franklin, 23I-233; Frothingham, Rise of the Rep., IIt-121, I32-I5I; Fiske, N.F. and N. E., 279-2So; Hart, Contemp's, ii. 357-360.

\section{Braddock's Defeat.}

TOPICS AND REFERENCES.

I. Hostilities without declared war. 2. The four English expeditions planned. 3. Braddock's disastrous failure. 4. Other movements and results. 5. Fort-building on lakes Champlain and George and the upper Hudson. Bancroft, ii. +19-424, 435-438; Parkman, Montcalm, ii. ch. vii.-x.; Fiske, N. F. and N.E., 28I301; Winsor, America, v. 495-505; Sloane, ch. iv.: Washington, i. IfI-ISo; Franklin, 240-258: Hart, Contemp's, ii. 365-367.

\section{Dispersion of the Acadian French.}

TOPICS AND REFERENCES.

I. Reasons for the removal of French inhabitants from Nova Scotia. 2. Their dispersion. Bancroft, ii. 425-434; Parkman, Montcalm, i. ch. viii.; Winsor, America, v. 415-4I7; Sloane, 48-49; Hart, Conte'mp's, ii. 360-365.

\section{The European "Seven Years' War."}

TOPICS AND REFERENCES.

r. The opposing combinations of European nations in the war. Fiske, N. F. and N. E., 30I-303; Sloane, 3S-39; Larned, England, ${ }_{4} 8 \mathrm{r}$.

RESEARCH. - The European circumstances of the war. Macaulay, Essays, Frederick the Great. 


\section{The Turning of the Tide.}

Topics And ReFERENCES.

r. Two years of French success and English disaster. 2. The amazing change brought about by the elder William Pitt. 3. English successes of 1758 . - Bloody repulse at Ticonderoga. Fiske, N. F. and N.E., 303-325 ; Bancroft, ii. 447-495; Parkman, Montcalm, ii. ch. xviii.-xxiii.; Winsor, America, v. 505-530; Sloane, ch. v.-vi.; Green, 716-724.

RESEARCH. - The character and career of the elder Pitt. Macaulay, Essays, Chatham.

\section{Conquest of New France.}

TOPICS AND REFERENCES.

r. The taking of Quebec by General Wolfe. 2. Capture of Crown Point, Fort Ticonderoga, and Fort Niagara. 3. General downfall of French power in America. Parkman, Montcalm, ii. ch. xxiv.-xxx.; Winsor, America, v. 53I-559; Bancroft, ii. 4985I2, 522-527; Fiske, N.F. and N.E., ch. x.; Sloane, ch. vii.-viii.; Hart, Contemp's, ii. 369-372.

\section{Cession of all French Territory in North America.}

TOPICS AND REFERENCES.

I. Cessions from France to Great Britain by the treaty of Paris. 2. Cession from France to Spain. 3. Cession from Spain to Great Britain (text in MacDonald, i. 26I-266). Parkman, Montcalm, ii. ch. xxxi.-xxxii.; Bancroft, ii. 537-542; Sloane, I I I-II4.

4. The part borne by the colonies in the war. Hildreth, ii. 5145I6; Lecky, iii. 295; Hart, Formation, 37-40.

REsearch. - Effects of the Seven Years' War on the later history of Great Britain. Mahan, Sea Power in Hist., 326-329.

\section{Pontiac's War.}

TOPICS AND REFERENCES.

r. Reasons for a rising of western Indians against the English. 2. Pontiac the leader. - Extent of his combination. 3. Result of the war. Parkman, Conspiracy of P.; Bancroft, iii. 4I-49; Hinsdale, Old $N . W$., I 48 ; Sloane, 101-103. 
CHAPTER V.

THE PROVOCATIONS TO REVOLT. I760-I775.

88. King George III. In the fall of I 760 , immediately after the overthrow of the French in America, a new king, George III., came to the British throne with very old-fashioned notions of kingship in his mind. His greatgrandfather and his grandfather, the first and second Georges, had been helpless royal figures in the hands of their ministers, and a system of ministerial government had grown up which the young king was taught to look upon as unconstitutional and needing to be put down. According to his lights, he was a conscientious young man, but narrow-minded and ill-informed. Parliament, as then constituted, represented few people except a small landlord class, and it was more or less corruptly controlled. For the last two generations the cabinet ministers had held that control; but now the king took it into his own hands. Those who helped him to do so, and who were known as "the king's friends,"

\section{"The}

king's
triends." soon became his chief ministers; Pitt had to resign; statesmanship was superseded by the wilful orders of an ignorant sovereign, carried out by pliant servants, who obeyed his commands.

This was England's last experience of dictatorial kingship, and it happened at a time when the government could easily be intoxicated with a new sense of power. India had been won, as well as America, and British supremacy on the broad ocean had been made an un- 
questionable fact. In such circumstances, at such a time, it was inevitable that a prince like George III. would plunge the expanded empire into serious trouble, until he and his "friends" could be restrained. It was inevitable that they would try experiments in highhanded government, both at home and in the colonies, and that they would try them in stupid ways. They began those experiments in England, with an attempt to break down the freedom of the press, and they abused the rights of Englishmen in their own island, for a time, even more than the rights of the colonists were abused.

89. Tightening the Reins of Colonial Government. 1760-1761. As to the latter, it was a matter of course that King George and his revived Tory party should take up the long-debated project of taxing the colonies and of tightening the reins of imperial government, to limit their "home rule." Neasures to invigorate the administration of the navigation laws, and of all the enactments called "acts of trade," were undertaken first. By an order in council the customs officers in the colonies were directed to apply to the courts for searchwarrants of a kind called "writs of assistance," which would authorize them to enter any private house and search for smuggled goods. An

\section{Writs of} assistance, 1760. application of that nature was made to the superior court at Boston and argued in February, i $76 \mathrm{I}$. James Otis was engaged by merchants of Boston and Salem to oppose it, and did so in a speech of marvellous power. "Otis was a flame of fire," wrote John Adams at a later day. "Then and there," he

\section{James} otis. added, "was the first scene of the first act of opposition to the arbitrary claims of Great Britain. Then and there the child Independence was born." Awed by the deep feeling stirred up, the court delayed its decision 
until it received instructions from England to issue the writs.

Close on the heels of this measure came another more odious still. Hitherto judges in the royal provinces had been appointed, as in England, "during good behaviour," which made their tenure of office independent of the crown. In 176I that constitutional practice was set Judges aside. On the death of the chief justice of "at the New York, his successor was appointed to pleasure." serve "at the king's pleasure," and instructions were sent to all colonial governors not to issue judicial commissions in any other terms.

90. Grenville's Measures. 1763. It was not, however, until the conclusion of the treaty of peace with France and Spain, in 1763 , that the government felt free to execute its new projects of colonial coercion in full. George Grenville, soon to be prime minister, and Charles Townshend, president of the Board of Trade, were chiefly accountable for what ensued. They began,

\section{Troops in} in March, with a proposal to Parliament that America. twenty regiments should be kept in America, at the cost of the colonies after the first year. Their next measure gave them authority to employ all the forces of the navy in the service of the custom-house, to enforce the "acts of trade."

At the same time, one of the most grievous of the acts of trade, called sometimes "the Sugar Act," sometimes "the Molasses Act," was amended and revived. It had been passed in 1733 , to stop the importation of sugar or molasses from the French West InThe Sugar - dies into the colonies, in order to "protect" 1763.

the sugar planters of the English islands. But the commerce of the New Englanders was half dependent on this sugar trade. They sold fish, lumber, staves, 
provisions, etc., to the French islands, took molasses and sugar in exchange, converted them mostly into rum, sold the rum elsewhere, and so, after a round of exchanges, got money in hand with which to buy English goods. To break the round, by cutting sugar out, was to break up half their trade, even with England herself. The impracticable stupidity of the measure had been discovered, and it had not been enforced until now, when it was suddenly resurrected; the sugar duties were reduced somewhat, and the exasperating new machinery of enforcement was brought into vigorous play.

The next undertaking was to stop the growth of the colonies, by prohibiting their expansion into the great interior valleys from which the French had been expelled. To that end a royal proclamation was issued in October, I763, establishing governments in eastern Canada (named Quebec) and in east and west Florida, but setting apart the whole territory between the Alleghanies and the Mississippi and

Western

settlement forbiddon, 1763. north and west of the Great Lakes for the use of the Indian tribes (see Map IV.). White settlers were forbidden to enter this region, and those who had already made homes "westward of the sources of the rivers which fall into the sea from the west and northwest" were commanded to withdraw. ${ }^{1}$

1 In a subsequent report of the Lords of Trade it was acknowledged that the primary object of this extraordinary measure was to confine "the western extent of settlements to such a distance from the sea-coasts as that those settlements should lie within reach of the trade and commerce of this kingdom, . . . and also of the exercise of that authority and jurisdiction which was conceived to be necessary for the preservation of the colonies in a due subordination to and dependence upon the mother country;" with the secondary object of promoting the fur trade. This fairly illustrates the wisdom of statesmanship in the government of George III. 
91. The Stamp Act. 1764-1765. But the crowning measure of Grenville's policy was announced in a series of "Declaratory Resolves" of Parliament, in March, I764, and carried out in the spring of the next year. The "Stamp Act" then passed imposed a direct tax on the colonies, by requiring certain stamps, sold officially at prices ranging from three pence to ten pounds, to be affixed to all legal and commercial documents, to every newspaper, pamphlet, and almanac, and to every pack of cards. There were less than fifty votes in the House of Commons against the enactment;

Colonel

Barró's speech.

but one fine speech in opposition was made by

Colonel Isaac Barré. Merely as a tax, the stamp tax was not intolerable; but as a challenge to the political doctrine which the colonists had inherited from their British ancestry, that "taxation without representation is tyranny," it roused a more wrathful resistance than anything done before. The defenders of the stamp tax argued that the colonies were "virtually represented" in Parliament, - as much so as many of the most important English cities, which elected no representatives in those days, but were assumed to be cared for and

Doctrine of "virtual representation." spoken for by every member of the House of Commons. This ridiculous doctrine of "virtual representation" held its ground in England for more than half a century, until Parliament was reformed in 1832 ; but it made no impression on the American mind in 1764 .

On the first announcement of the intended bill, Boston, in town meeting, had led off, and half the colonies had followed, in strong remonstrances, beyond which few seemed ready to go. But when news of the actual passage of the Stamp Act arrived, a young man in the Virginia Assembly, Patrick Henry, spoke words that 
were like a trumpet call. In a speech of matchless eloquence and boldness, he stirred the people from Georgia to Maine. A famous passage of his speech was one in which he cried: "Cæsar had his Brutus - Charles the First his Cromwell - and

Patrick Henry's speoch, 1765 . George the Third" - pausing when some in the Assembly cried "Treason!" and then continuing - "may profit by the example. If that be treason, make the most of it."

Early in June, the Massachusetts Assembly sent a circular letter to all the colonies, proposing a general meeting of delegates from each, "to consult together" on the subject of the Stamp Act. The proposal was approved, and on the 7 th of October delegates from nine colonies met in congress at New York. Able and dignified in its membership, Stamp Act Congress, October, this "Stamp Act Congress" discussed the situation with calmness, and agreed upon a temperate but firm declaration of "the most essential rights and liberties of the colonists, and of the grievances under which they labor by reason of several late acts of Parliament." In this congress the actual beginning of an American Union may be said to have been made.

Meantime, while these decorous expressions were being given to the public feeling, a less orderly part of the people were venting it in more or less riotous ways. Secret societies, pledged to resist the stamp tax, were spreading rapidly through most of the colonies, calling themselves "Sons of Liberty," having caught "sons of the name from a phrase in Colonel Barré's Liberty." speech. In some of their public demonstrations the Sons of Liberty set mobs in motion which did outrageous things. The worst proceeding was in Boston, where the house of the chief justice and lieutenant-governor, after- 
ward governor, Thomas Hutchinson, was sacked, and a Riots in precious library of books and historical manuBoston and Now York, 1765.

scripts was barbarously destroyed. Though a stout supporter of the authority of king and Parliament, Hutchinson had used his influence against the passage of the Stamp Act, and did not deserve the animosity with which he was assailed. In New York, defiant of a large body of troops, the Sons of Liberty made a bonfire of Lieutenant-Governor Colden's coach, with his effigy in it; threatened to hang him if the troops fired on them, and forced him to give up the stamps he had received. In other places the stamps were seized and destroyed. Generally, in all the colonies, the officers appointed to sell the stamps were compelled to resign.

92. Repeal of the Stamp Act. 1766. As another mode of making their displeasure felt in England, many people had been for some time past forming agreements not to use English goods, but to wear homespun, to promote wool-growing, and to carry on spinning and weaving in their homes.

Before the end of the year in which it was passed, the Stamp Act was seen to be impossible of enforcement, and indefensible on constitutional grounds. Pitt, who had been ill when it passed, now praised the colonists for resisting it, and demanded its repeal. Lord Camden, one of the ablest jurists of the day, supported Pitt's demand. The effects of the act had made it hateful to English merchants and manufacturers; and, altogether, it was assailed by influences which Parliament could not resist.

Tho Do- A new ministry, headed by the Marquis of claratory Rockingham, had lately displaced that of GrenAct.

ville, and it carried a repealing bill through both houses in March, I 766, but tried to save the dignity of 
the government by a Declaratory Act, asserting the right of the English Parliament to make laws binding the colonies "in all cases whatsoever."

93. The Townshend Acts. 1767. The British troops quartered in the colonies were a continuing cause of irritation and offence, especially at the head- The Billetquarters, in New York. By what was called the ing Act. "Billeting Act," the colonial assemblies were required to provide quarters and supplies for them, according to an exact prescription ; but the New York Assembly asserted a right of judgment in the matter, and ordered the same supplies for the troops that would be furnished to them in other parts of the king's dominions. This was seized upon as proof that something peremptory must be done.

Charles Townshend, the foremost advocate of colonial government by the whip, had now become the ruling spirit in the ministry of the day. Pitt had been persuaded to lend his name to that ministry as its nom- pittmade inal premier; but he was broken in health, and Earl of soon gave up all duties, accepting a peerage as $\mathbf{1 7 6 6 .}$ Earl of Chatham, and leaving Townshend in the management of affairs. The latter, in May, I767, brought several bills into Parliament, suspending the legislative functions of the New York Assembly; imposing duties on wine, oil, fruits, glass, paper, lead, painters' colors, and tea, for a revenue to support civil government in the provinces and provide for their defence ; formally legalizing writs of assistance; and, finally, empowering the crown to create a general civil list of crown officials in every colony, wholly dependent on the pleasure of the king. The revenue bill was claimed to be a concession to the theory of the colonies that $\begin{gathered}\text { The } \\ \text { revenue }\end{gathered}$ Parliament might tax them indirectly, by cusbill. toms duties, levied for the general regulation of British 
trade, but might not raise revenue from them by direct tax. But this measure was so plainly aimed at a political end, and so much else of grave menace to popular rights went with it, that the Townshend bills as a whole caused deeper alarm to thinking men in America than the Stamp Act had done.

84. Writings of John Dickinson and Samuel Adams. 1767-1768. The feeling produced when the Townshend bills became law was very grave. In December an able Pennsylvanian, John Dickinson, began publishing a series of what came to be known as the "Farmer's Letters,"

The which had a powerful effect. They pleaded with "Feterser's the English government for conciliation and with the colonies for moderation, but showed with remarkable plainness the "dangerous innovation" of the Townshend acts upon the liberties of the people. In the general approbation of these letters there was proof that the colonists still desired to be British subjects, but only on the terms of freedom that British subjects enjoyed in the British Isles. Unfortunately there was no statesmanship in the English government to be influenced by such proofs. 'The king was completely in control. Townshend had died in September, and Lord North, a man of good abilities, but with no will of his own, took his place in a cabinet of ministers who served practically as his majesty's chief clerks.

Early in I 768 the Massachusetts Assembly adopted a series of addresses, to English ministers and to the king,

The work of Samuel Adams. and sent a "Circular Letter" to " each house of representatives or burgesses on the continent," inviting correspondence, with a view to action on some uniform plan. These remarkably well-written papers, strong in argument and temperate but firm in tone, are believed to have been entirely the work of 
Samuel Adams, the popular leader in Massachusetts, who took, from this time, a leading part in the larger colonial field. More than any other man, he planned, inspired, directed, and organized the movements which prepared the colonies for their united revolt. Even he had been seeking only to secure for the English in America the same rights and same principles in their government that Englishmen enjoyed at home. According to his own testimony, it was not until later in this year I 768 that he came to be convinced that separation from the mother country was the only means of escape from wrongs that ought not to be endured.

Several late occurrences had helped, no doubt, to force this conviction on Mr. Adams's mind. Governor Bernard had been ordered from London to dissolve the Massachusetts Assembly, because it refused to rescind its "Circular Letter," and the other colonies had been threatened with like treatment if they responded to the letter. Revenue seizures made without legal warrant, and attempts to seize men for enforced naval service, had led to collisions between Boston citizens and the officers of a British frigate, and those collisions had led to an order for sending two regiments to Boston, to be quartered on the town. Finally, the British

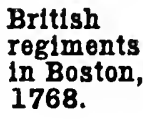

British in Boston, 1768. authorities had begun to seek testimony on which to arrest Adams and other leaders for treason, with a declared intention to send them to England to be tried. This last proceeding was denounced with special bitterness in England by Burke, Barré, and other rationalminded men.

95. Action in Virginia. - Non-importation. - Partial Repeal of the Townshend Acts. 1769-1770. Virginia had received a governor, Lord Botetourt, who tried to conciliate the people; but they were not to be recon- 
ciled to such measures as he had to carry out. Washington, Jefferson, and Patrick Henry were now members of the Assembly, and they took the lead (May, 1769) in

Virginla

declara-

tions. passing declarations as strong as those of Massachusetts, against the Townshend acts and against the threatened carrying of men beyond sea for trial. Copies of these declarations were sent to all the other assemblies, with invitations to concur. As required by his orders from London, the governor dissolved the Assembly, whereupon the members met in convention and passed resolutions, drawn up by Washington, which recommended an organized and systematic stopping of the importation of English goods until the obnoxious acts were repealed. All the colonies soon joined in carrying out this plan. ${ }^{1}$

Again, as in 1765-66, the abstention of the colonists from using British goods raised a clamor in the British business world which the government could not resist. It was driven once more to a repeal of its own acts; but tried again, as in 1766 , to undo its blunder without healing the sore effect. On the $5^{\text {th }}$ of March, I 770 ,

Tea tax retalned 1770.

Lord North moved the repeal of the revenue act, excepting its preamble and the duty on tea, which, he said, "must be retained as a mark of the supremacy of Parliament and the efficient declaration of its right to govern the colonies." This, as appeared afterward, was demanded by the obstinate king.

96. The "Boston Massacre." 1770. On the 5 th of

1 The exports from Great Britain to New England, New York, and Pennsylvania were cut down by this action from $£ 1,363,31 \mathrm{I}$, in 1768 , to $£ 504,603$ in 1769 . The falling off in exports to the southern colonies was much less, for the reason that they were much less able to manufacture for themselves. Bishop, History of American Manufactures, i. 374 . 
March, the day of Lord North's motion, a tragical and exciting event occurred in Boston. The soldiers of two regiments brought from Halifax had been in the city for nearly a year and a half, making themselves disagreeable in many ways, but carefully restrained from any use of their arms. They were jeered at frequently by boys and men of the ruder class, and on this day, unhappily, a squad of nine was provoked to fire into a crowd of unarmed people, killing four and wounding seven, of whom two afterward died. This "massacre," as it was styled, produced a fierce excitement in Boston, and a great town meeting, making Samuel Adams its spokesman, demanded that the regiments be sent away. Governor Hutchinson (who had succeeded Bernard) bowed to the storm, and removed the soldiers to a fort in the Bay.

97. The Carolina Regulators. 1771-1772. After this, for some time, a state of comparative quiet prevailed in all the colonies except the Carolinas, where a conflict occurred between the royal authorities of the province and the inhabitants of the western frontier. Those rude, hardy, "up country" settlers had received little attention from the colonial government, except in harassing ways. Having no proper courts in their own region, they had formed companies called "Regulators" which dealt with criminals by what afterward got the name of "lynch law," and they refused obedience to warrants issued by the far-away royal courts. The resulting by the far-away royal courts. The resulting Alamance, conflict came to a crisis of battle on the Alamance, North Carolina, in I 77 I, and the Regulators were defeated with heavy loss.

Many of the defeated Regulators now crossed the mountains and joined a body of settlers who had defied the king's proclamation of 1763 (see sect. 90), and planted themselves on the Watauga and Holston rivers, 
within what afterward became the State of Tennessee. There, under the lead of John Sevier and James Robertson, a community derived mostly from the Scotch-Irish "Watauga stock framed a government for itself, by what Assocla- were described as the "Articles of the Wation, "1772. tauga Association" ( I 772), constituting the first practically independent commonwealth on American soil.

98. "Lord Dunmore's War." 1774. From this time, bold encroachments on the Indian hunting grounds beyond the mountains went on, both southwestwardly and northwestwardly, until a savage outbreak of war was provoked, in the spring of 1774 . The clash came in consequence of the brutal murder of the whole family of Logan, a friendly and much esteemed chief, the story of whose wrongs, told with pathetic eloquence in a reputed speech of his own, is one of the most familiar pieces of early American literature. The governor of Virginia was held to be mainly responsible for what occurred, and the war is commonly referred to as "Lord Dummore's War." It Battle of was ended in October, by a terrific battle at Point Plea- Point Pleasant, on the Great Kanawha, where 10, 1774. the Indians, under the Shawnee chief Cornstalk, were so crushingly defeated by the backwoodsmen, commanded by General Andrew Lewis, that their country was practically free to white settlement from that time.

99. Fresh Exasperations. - Institution of "Committees of Correspondence." 1772-1773. After the partial repeal of the Townshend acts, the non-importation agreements in the colonies were not effectively carried out; but the use of tea, except as smuggled from the Burning of
the Gaspee, smuggling, and other breaches of the acts of Dutch, was generally stopped. Against that 1772 .

trade, British naval officers on the coast were kept active, and the commander of one ressel, the Gas- 
pee, in Narragansett Bay, was accused of wanton destructiveness in what he did. Complaints against him having no effect, the exasperated people at length, in June, I 772, attacked his ship, while aground, captured it, and burned it, setting the crew on shore.

Close on the heels of this exciting event came an order from the king that the Massachusetts judges, who held their seats at his pleasure, salaried by should also take their salary from the crown. If there had been any quieting of rebellious feeling in Massachusetts, this roused it afresh; and it was now that Samuel Adams set on foot a movement which organized the patriotic party of the colony in a remarkably effective way. His plan was the creation of "committees of correspondence," to act representatively for the patriots of every town, as agents of communication and common action between all parts. Every town soon had its committee, and all were keeping in close touch with one another, under the constant influence of the Boston leaders, of whom Samuel and John Adams, Dr. Joseph Warren, and John Hancock were in the front. A little later, in the spring of $\mathrm{I} 773$, the idea of the committees of correspondence was taken up in Virginia, and developed into an inter-colonial system of consultation and agreement. This proved to be a most important measure of preparation for what now came to pass.

100. The "Boston Tea-Party." 1773. Seeing that the colonists could in no way be forced to buy taxed tea, King George conceived the notion that they might be bribed. That they cared for anything more than the three pence per pound of duty was more than he could understand. His scheme was to pay such a drawback to the East India Company on tea taken to America that it might be sold there, even after paying Townshend's 
duty, at a price below that of the smuggled Dutch teas.

King His obedient ministers arranged things with King
Goorge's
scheme. were shipped to Boston, New York, Philadelphia, and Charleston, in the fall of 1773 . When the coming of the tea-ships was known, the patriot party in every one of the four ports determined that no sale of the cargoes should be allowed. At New York, Philadelphia, and Charleston, the appointed consignees of the cargoes were persuaded to decline receiving them; but the Boston consignees would agree to no such course. When the ships arrived at that port, urgent efforts were made to induce Governor Hutchinson to send them back, but he refused, and ordered the fort to fire on them if they attempted to leave port. In this extremity, a party of determined men, disguised as Indians, boarded the ships and poured the contents of the tea-chests into the sea (December I6, I763).

101. The Punishing of Boston and Massachusetts. 1774. Naturally, King George and his party were enraged by this act, and a sharp punishment of Boston and Massachusetts was planned. Burke, in one of his grandest speeches, argued for a just conciliation, by repealing the tea duty, and others made the same plea, but without avail. By large majorities in both houses, five acts for the regulation of American affairs were passed in the spring of I 774 . One of them, called the Port Bill, closed

Port Bill ard Regu- clear. A second, known as the Regulating Act,
lating Act. lating Act. annulled the charter of Massachusetts, made the authority of its royal governor and his council supreme, and forbade town meetings for any other business than the election of officers for the towns. A third act provided that any magistrate, revenue officer, or sol- 
dier indicted in Massachusetts for murder should be sent to England for trial, - which plainly gave encouragement to violent military acts. The fourth law removed all legal hindrances to the quartering of troops. The fifth, called the Quebec Act, aimed to extin- Quebec guish the western territorial claims of all the Act. colonies, by adding the whole region west of the mountains, and north of the Ohio River, to the province of Quebec (see Map IV.).

To enforce these acts of atrocious despotism, General Gage, with four regiments added to his command, was sent to supersede Governor Hutchinson, placing Massachusetts under military rule. He came with instructions to arrest Adams and other Boston leaders and send them to England for trial, but saw that it was not prudent to make the attempt. He found the patriots of Massachusetts undaunted, and supported in their attitude by all the colonies, south and north. Contributions to relieve the suffering which the Port Bill caused, and messages to encourage the oppressed city and province, came in from all sides.

102. The Continental Congress. 1774. Virginia declared that an attack on one colony was an attack on all, and endorsed the proposal of a Continental Congress, ${ }^{1}$ already made in various quarters, asking Massachusetts to name the time and place. The Massachusetts Assembly did so; and that immortal body, the Continental Congress of 1774, was invited to meet at Philadelphia, every province responding heartily to the invitation. When, on the $5^{\text {th }}$ of September, the Congress came to-

1 "From the constant use of the phrase 'the whole continent,' to express general action, came the fine adjective so long significant of union-continental." W. M. Sloane, The French War and the Revolution, p. I72. 
gether, in Carpenters' Hall, twelve colonies were represented, and its roll-call is full of great names. ${ }^{1}$ None came from Georgia, but the Georgians were in full accord. With the opening of this meeting the first act of revolution may be said to have begun.

103. Now England Temper displayed. - The Suffolk County Resolutions. 1774. The Continental Congress, meeting at Philadelphia on the 5th of September, soon had news from Massachusetts of exciting events. On the Ist of the month General Gage had sent troops from Boston to seize some powder that was stored for the provincial militia at Quarry Hill. As reports of this proceeding ran from town to town, colored with rumors of fighting, the whole country had risen up, and not less than 20,000 men were believed to be on the march for Boston, before messages sent out by the patriot leaders could bring the sudden movement to a stop. This formidable demonstration opened Gage's eyes ; and he was enlightened still more when he heard of the excitement in other provinces. He had not believed that the men of Massachusetts would really face a conflict with the king's troops, nor that the other colonies would come to

\section{General} Gage
awakened. their help if they did. Now he began to see the truth, and began to try to make it known to the ministry and the king. "The people," he wrote to London, " are numerous, waked up to a fury, and not a Boston rabble, but the freeholders of the county;" and he gave his opinion that the act for regulating the government of Massachusetts could not be car-

1 Among the members of the First Continental Congress were Samuel Adams, John Adams, Roger Sherman, John Jay, Philip and William Livingston, John Dickinson, George Washington, Patrick Henry, Peyton Randolph, Richard Henry Lee, Edmund Pendleton, John and Edward Rutledge, Christopher Gadsden. 
ried into effect with an army of less than 20,000 men. At the same time he made haste to build fortifications on Boston Neck.

On the $9^{\text {th }}$ of September a convention of the touns and districts of Suffolk County (embracing Boston) adopted a series of bold resolutions, reported by the intrepid Dr. Joseph Warren, declaring,

The Suffolk among other things, that all crown officers in the province should be seized as hostages if a single arrest for political reasons should be made. This left no cloubt as to the spirit with which the people most immediately concerned were facing the prospect of a conflict with British power.

104. Action of the Continental Congress. 1774. Nor could there be any reasonable doubt of the readiness of the other colonies to stand by Massachusetts, after the Continental Congress had declared itself. On receiving the resolutions of the Suffolk County Convention, the Congress approved them, and resolved that if any attempt should be made to enforce the Massachusetts Regulating Act, against the opposition of the inhabitants, "all America ought to support them." After four weeks of earnest debate and deliberation, it adopted a Declaration of Rights, especially Declarait adopted a Declaration of Rights, especially tion of setting forth the claim of the people of America to "a free and exclusive power of legislation in their provincial legislatures," "in all cases of taxation and internal polity." A respectful petition to the king, an address to the people of British America, including Quebec, and an earnest address to the people of Fingland were also adopted and sent forth. "Permit us," said the address to the English people, "to be as free as yourselves, and we shall ever esteem a union with you to be our greatest glory and our greatest happiness." 
Before adjourning, the Congress agreed on a systematic plan of commercial non-intercourse with Great Britain, and formed an association to give it effect. The covenant entered into for that purpose declared, among other things, this: "We will neither import nor purchase any Slave trade slave imported after the first day of December renounced. next, after which time we will wholly discontinue the slave trade, and will neither be concerned in it ourselves, nor will we hire our vessels nor sell our commodities or manufactures to those who are concerned in it." Finally, a second Congress was called to meet on the soth of May, I 775 .

105. The "Olive Branch" offered by Lord North. February, 1775. The appeals of the Continental Congress, which all just minds admired, were treated by King George and his party with contempt. Lord Chatham, Lord Camden, Burke, Fox, Barré, and others exerted their eloquence and their powers of argument to dissuade Parliament from driving the Americans to a despairing clefence of their rights, and Franklin, as agent Efforts for for several of the colonies in England, labored peace. to the same end. These efforts were supported, too, by petitions from London, Bristol, and other cities; but nothing availed. Parliament adopted an address to the king which declared rebellion to be existing in Massachusetts, and the king pledged himself in reply (February 9, I775) to enforce "obedience to the laws and the authority of the supreme legislature;" yet, a few days later, Lord North, with the king's consent, proposed and carried a resolution in the House of Commons which he looked upon as an "olive branch" of generous compromise. It offered to exempt the colonies from all taxation excepting duties for the regulation of commerce, provided they would tax themselves to the satisfaction of 
Parliament and the king; but it promised no restoration - of free government to Massachusetts, nor guarantees to any colony of future respect for the simplest constitutional rights. It was hoped that some of the provinces, New York especially, might be brought, on these terms, to break away from New England, and leave that troublesome section to be dealt with alone; but the scheme failed. Jefferson prepared and

"Olive branch" rejected.

Congress adopted a reply to the proposal which exposed the delusiveness of its terms.

106. Arming for the Conflict. - The "Minute Men." 1774-1775. Meantime, in every colony, the people had been ratifying the declarations and pledges of the Continental Congress, and armed organizations were springing up in all parts of the land. In Massachusetts the Regulating Act had been made of no effect by the mere force of public feeling, which would not permit councillors, judges, sheriffs, or jurymen to serve under the commission of the king. Practically, the province had placed itself under a provisional government of its own, composed of the members chosen for its Assembly, who were not permitted by General Gage to meet at their appointed time and place. They met elsewhere, in October, I774; appointed a "Committee of committeo Safety," with Warren for its chairman, and of Safety. gave to that famous committee large discretionary powers, to collect military stores, and to call out the militia, one fourth of whom, styled "Minute Men," were to be ready always for answering a summons to arms. 
TOPICS AND SUGGESTED READING AND RESEARCH.

\section{King George III.}

Topics AND References.

I. Character and training of George III. 2. Circumstances that gave power to the king and his "friends." Lecky, iii. 1 I-25; Green, 726-730; Fiske, Am. Rev., i. 38-45; Sloane, I05-107; Hart, Contemp's, ii. 373-374.

3. Experiments of the king and his "friends" in high-handed government. Lecky, iii. 76-89, I39-166; Green, 731-734; Hosmer, Hutchinson, $7 \mathrm{I}$; Sloane, I 29-130.

RESEARCH. - General character of the first twenty years of the government of George III. Seeley, Expansion, I76-I77; Macaulay, Essays, Chatham (second Essay).

\section{Tightening the Reins of Colonial Government.}

TOPICS AND REFERENCES.

r. "Writs of Assistance" (text in MacDonald, i. 258-261). Speech of Otis against them. 2. Appointment of Judges to serve "at the king's pleasure." Bancroft, ii. 546-552; Sloane, I 24-126; Hutchinson, iii. S9-95; Hosmer, Adams, 39-45, and Hutchinson, 49-62; Hart, Contemp's, ii. 374-378.

Research. - Otis's argument against Writs of Assistance. Tudor, Otis, ch. vi.; J. Adams, Works, x. 314-355.

\section{Grenville's Measures.}

\section{Topics AND REFERENCES.}

1. George Grenville and Charles Townshend: their offices in the British government. 2. Employment of army and navy to enforce "Acts of Trade." 3. The "Sugar" or "Molasses" Act (text in MacDonald, i. 272-28I ). - Its purpose and effect. I3ancroft, iii. 30-36; Lecky, iii. 332-337; Hutchinson, iii. ro2-1 I2; Hart, Contemp's, ii. $381-382,415-417$.

4. King George's proclamation forbidding settlement west of the mountains. Hinsdale, Old N.W., ז20-141 : King, ch. iv.; Roosevelt, The Hinning, i. I66.

RESEARCH. - The claim that King George's proclamation of I 763 was to protect and pacify the Indian tribes. Kingsford, v. 133I45; Fernow, I73-I 77. 


\section{The Stamp Act.}

Topics And ReFERENCES.

I. The Stamp Act and its provisions (text in MacDonald, i. 281-305; Preston, I 88-I91 ; Larned, Ready Ref.). 2. Why it roused so much resistance. 3. The doctrine of "virtual representation." 4. Patrick Henry's speech. 5. The Stamp Act Congress and its action. 6. The "Sons of Liberty" and their doings. - Riotous conduct of mobs. Frothingham, Rise of the Rep., I 64-196; Bancroft, iii. 55-58, 70-71, 95-1 16, 134-164; Hosmer, Hutchinson, ch. iv., and Adams, 50-53; Tyler, P. Henry, 58-79; Fiske, Essays, i. 27-3I ; Lecky, iii. 339-36I ; Hutchinson, iii. I 6-128; Hart, Contemp's, ii. 402-404, 397-400; Sloane, i I 8, I33-I39.

Research. - The question of the right of Parliament to tax the colonies. Lecky, iii. 34I-344, 353-356; Franklin, Works, vii. $501-502$.

\section{Repeal of the Stamp Act.}

TOPICS AND REFERENCES.

I. The repeal of the Stamp Act. 2. Authority of Parliament asserted in a Declaratory Act (text in MacDonald, i. 316-317). Lecky, iii. 36I-375 ; Bancroft, iii. I67-2I4 ; Hosmer, Adams, 7888 ; Morse, Franklin, 112-132; Hart, Contemp's, ii. 404-412; Sloane, 139-I4I.

\section{The Townshend Acts.}

TOPICS AND ReFERENCES.

1. The "Billeting Act." - Action of the New York Assembly (texts in MacDonald, i. 306-313, 317-320). 2. Pitt's nominal ministry, and his elevation to the peerage. 3. Townshend's bills and their alarming provisions (texts in MacDonald, i. 320-330). Hosmer, Adams, 98-100 ; Lecky, iii. 378-386; Bancroft, iii. 221-257; Sloane, I42-I47; Hart, Contemp's, ii. 413-4I5; Hutchinson, iii. I68-I 82.

\section{Writings of John Dickinson and Samuel Adams.}

Topics AND REFERENCES.

I. The "Farmer's Letters" of Dickinson. 2. General approval of them and what it showed. Stillé, ch.iv.; Dickinson, Writings, i.; Bancroft, iii. 264-265; Hart, Contemp's, ii. 423-426. 
3. Lord North's ministry. - Its subservience to the king. 4. Addresses and "Circular Letter" of the Massachusetts Assembly (text in MacDonald, i. 330-334). 5. Work and influence of Samuel Adams. 6. Dissolution of the Massachusetts Assembly. - Collisions between citizens and naval officers. - Troops ordered to Boston. 7. Threatened arrest and conveyance of Adams and others to England for trial. Sloane, I 47-I5I; Hosmer, Adams, I02-1 19; Bancroft, iii. 262-263, 272-276, 284-294; Frothingham, Rise of the Rep., 206-233; Lecky, iii. 387-395; Hart, Contemp's, ii. 420-423; Hutchinson, iii. I 83-224.

\section{Action in Virginia. - Non-importation Agree- ments. - Partial Repeal of the Townshend Acts.}

\section{TOPICS AND REFERENCES.}

I. Virginia declarations (text in MacDonald, i. 334-335) and proposals to stop importation of English goods. 2. Effect of the non-importation policy in England. 3. Repeal of the Revenue Act, excepting the duty on tea. 4. Object of the retention of the duty on tea. Sloane, I54-157; Lecky, iii. 396, 401-404; Frothingham, Rise of the Rep., 233-241 ; Bancroft, iii. 347-348, 380-385.

RESEARCH. - Extent of the abstinence in the colonies from the use of English goods. Franklin, Works, vii. 44I : Winsor, America, vi. 76-80: Hart, Contemp's, ii. 439-441.

\section{The "Boston Massacre."}

Topics ANd References.

I. Boston citizens fired upon by British troops. - Removal of the regiments from the city. J. Adams, lVorks, ii. 229-236; Hosmer, Adams, 160-182, and Hutchinson, ch. vii.; Bancroft, iii. 370-378; Lecky, iii.397-40I ; Hart, Contemp's, ii. 429-431; Hutchinson iii. $263-280$.

\section{The Carolina Regulators.}

TOPICS AND REFERENCES.

r. Origin of the "Regulators." 2. Their conflict with the government. - Battle of the Alamance. Roosevelt, The Winning, i. 105-I10; Sloane, I51, I59-160; Bancroft, iii. 232-233, 394-395, 398-403; Am. Hist. Ass'n, 1894.

3. Settlers in East Tennessee. - Articles of the Watauga Association. Roosevelt, The Winning, i. I72-193; Phelan, ch. i.-iii. 


\section{8. "Lord Dunmore's War."}

TOPICS ANi References.

1. Provocations to an Indian outbreak. - Murder of Logan's family. 2. Battle of Point Pleasant. Winsor, Westward, ch. v.; Roosevelt, The Winning, i. ch. viii.-ix.; Jefferson, iii. 156-165.

\section{Fresh Exasperations. - Institution of Commit- tees of Correspondence.}

\section{Topics AND ReFEREnCES.}

r. Tea smuggling. - Burning of the Gaspee. 2. Massachusetts judges to be paid by the king. 3. Committees of Correspondence organized in Massachusetts. 4. The idea taken up in Virginia and developed into an inter-colonial system (text in MacDonald, i. 336-337). Bancroft, iii. 4I 4-4I 5, 423, 426-428, 436-437; Hosmer, Adams, 190-206; Sloane, 160-162; Frothingham, Rise of the Rep., 265-286.

RESEARCH. - The objections to a payment of judges' salaries by the king. J. Adams, ii. 316-3I7; iii. 513-574.

\section{The "Boston Tea-Party."}

Topics AND References.

1. King George's scheme for selling taxed tea to the colonies. 2. Treatment of the tea-ships at New York, Philadelphia, and Charleston. 3. The "tea-party" at Boston. Hosmer, Adams, 235-236, 243-256; Frothingham, Rise of the Rep., 296-314; Fiske, Am. Rev., i. 82-92; Hart, Contemp's, ii. 431-433; Hutchinson, iii. 422-44I ; Bancroft, iii. 443-458; O.S. Leaf., 68; Sloane, r66-I68.

\section{The Punishing of Boston and Massachusetts.}

Topics and References.

I. The five revengeful acts of Parliament (texts in MacDonald, i. 337-356). 2. Governor Hutchinson superseded by General Gage. - Massachusetts under military rule. 3. Sympathy and support from other colonies. Lecky, iii. 421-439; Frothingham, Rise of the Rep., 317-330, 344-348; Hosmer, Adams, 264-274, 280-288; Bancroft, iii. 47I-482, iv. 5-I 8 ; Hutchinson, iii. 454-460; Washington, ii. 4 I 8-426, 429-436. 
RESEARCI. - The suffering produced in Boston. Frothingham, Rise of the Rep., 324. - Provisions of the Quebec Act. Kingsford, v. 22+-261; Hinsdale, Old $N . W$., I $+1-1+3$.

\section{The Continental Congress.}

TOPICS AND RIEFERENCES.

I. A Continental Congress proposed. 2. Meeting of the Congress. - Its illustrious members. Frothingham, Rise of the liep., 359-365: Hildreth, iii. $3^{S-42}$; Bancroft, iv. 23-24. 30-36; Sloane, I 70-176: Hart. Contempis, ii. $+3+-439$.

103. New England Temper displayed. - The Suffolk County Resolutions.

TOPICS AND REFERENCES.

I. Effect of an attempt to seize provincial powder. 2. Its revelation to General Gage. 3. Suffolk County resolutions (text in Am. Archizis, i. 776-7Sz). Fiske, Am. Rev., i. 106-109; Bancroft, iv. $5=-60$.

\section{Action of the Continental Congress.}

Tol'ics AND ReFErexces.

I. Promised support to Massachusetts. 2. Declaration of American Rights (text in MacDonald, i. 356-36r). 3. Petitions and addresses. 4. Association and covenant to stop trade with Great Britain (text in MacDonald, i. $362-367$ ). 5. Action concerning the slave trade. J. Adams, i. I 49-164; ii. 365-400: Morse, Adams, ch. ii.: Hosmer, Adams, 307-321 ; Frothingham, Rise of the lief., 364-391; Bancroft, iv. 6I-77; Lecky, iii. $+43-455$; Hildreth, iii. +2-46: Hart, Contempis, ii. $+39-4+1$.

REsearch. - Address of the Congress to the inhabitants of the P'rovince of Quebec, and its effect. Kingsford, v. 249-255, 26z267.

105. The "Olive Branch" offered by Lord North. TOPICS AND REFERENCES.

r. Reception in England of the appeals of Congress. 2. Concessions offered by Lord North (text in MacDonald, i. 367-368). 3. The reply of Congress (text in MacDonald, i. 385-389). Hil- 
TOPICS, REFERENCES, AND RESEARCH. I 85

dreth, iii. 57-65; Bancroft, iv. 96-105, I I 4-120, 127-130; Frothingham, Rise of the Rep., 406-413; Lecky, iii. 456-46r.

106. Arming for the Conflict. - The "Minute Men." TOPICS AND REFERENCES.

r. General approval of the action of Congress. 2. Armed organizations. 3. Practical nullification of the Regulating Act in Massachusetts. 4. "Committee of Safety." 5. Massachusetts "Minute Men." Frothingham, Rise of the Rep., 392-395, and Siege of Boston, 4I-43; Bancroft, iv. I 2I-I25, I30-I3I. 


\section{THE MAKING OF A NATION.}

1775-1800.

\section{THE STATE OF THE THIRTEEN COLONIES AT} THE BEGINNING OF THE WAR OF INDEPENDENCE. ${ }^{1}$

The Country and the People. - Conditions of Life. The population of the thirteen colonies at the beginning of the War of Independence was probably not far from 3,000,000 (some have estimated more, some less), of whom about 500,000 scattered were slaves. It was a population so scattered on a popula- narrow fringe of seaboard country 1200 miles long, ton. and so separated by obstacles to transportation and travel, that it could not exert its whole military strength. Its territory was crossed by many large rivers, not one of which was bridged, and all descriptions of the roads represent them as being very rudely made. In their command of the ocean an enormous advantage was held on the British side.

Generally speaking, these Americans of the later colonial period lived as comfortably, no doubt, with as much of personal independence in their lives, as any people in the world. Actual poverty was quite uncommon in most of the colonies, while considerable wealth was not. Trade, ship-building, ship-owning, cod-fisheries, whale-fishing, had enriched many in the northern and middle colonies; tobacco, rice, and indigo culture, by slave labor, had done the same in the south; and the minor industries of the farm and the shop were 
everywhere in a prosperous state. It was the prosperity of the colonies - the signs of wealth among them that most excited the determination in England to tax them and to monopolize their trade. Their and wealth. country was looked upon as a piece of British national property, - an imperial estate, - which the tenants ought to cultivate for the benefit of its landlords instead of making themselves rich.

Domestic Manufactures. The very efforts of the home government to compel the colonists to buy British goods drove them into manufacturing as far as possible for themselves. There seems to have been as much of public policy as of gain-seeking in what they did to that end. They formed societies and committees "for the promotion of arts and economy;" offered premiums for flax-growing, for spun yarns and woven fabrics, for leather-dressing and shoe-making, and the like; opened spinning

Promotion of industrial arts. schools; organized spinning-matches between the young women of towns and neighborhoods, and spinning and weav. ing exhibitions, to stimulate household manufacturing, which had to be depended on mostly for the results desired. The outcome of all this persevering effort was, that when they undertook retaliation for oppressive ineasures of the British government, by leagues and pledges not to buy certain classes of English goods, they were tolerably well prepared to supply themselves. This was truer of the northern and middle colonies, however, than of those at the south, where the different conditions of society and labor forbade the same results. "The household industry of the New England provinces, and of some parts of the middle colonies, was nearly or quite equal to the ordinary wants of the

Extent of household industries. inhabitants for clothing," at the opening of the War of Independence; "but the scarcity and dearness of clothing and camp furniture, particularly of woollens suitable for the use of the army, was early experienced." 1

${ }^{1}$ Bishop, History of American Manufactures, i. 390. 
Class Differences. Differences of wealth had produced in some colonies marked differences of class. That effect was most notable at the south. The exceptionai circumstances of the wealthy planters, especially in Virginia, made them proud, masterful, accustomed to the exercise of authority, and gave the superior men among them an advantageous training virginia for leadership in the public affairs of a revolutionleader. ary time. That they furnished somewhat more than their proportion of leaders to the Revolution, and to the politics of the Union for some decades after it was constitutionally formed, is an explainable fact. The circumstances of the planters of South Carolina differed essentially from those existing in Virginia. They lived less on their plantaoharles- tions, which were, to a great extent, in unhealthy ton. places. Their residence was in Charleston, more than on their estates, and that city, the one important seat of trade at the south, centralized every kind of influence in itself.

Hereditary wealth in lands and slaves caused a class distinction in the southern colonies; in New York that distinction was caused by hereditary wealth in lands alone. Some of the great patroon estates, of Dutch creation (see sect. 33), had survived on the Hudson, and some others of like magnitude had been acquired during the English rule. They were preserved from division by what is known as the law of Primo- primogeniture, which makes the eldest son in a geniture. family the sole heir to his father's lands, and so keeps the estate unbroken from generation to generation. Until after the Revolution that law prevailed in the southern colonies and in New York. The families holding these socalled "manors" gave the lead to what was looked upon as an aristocratic caste, the influence of which in public affairs

Class dif ferences in New York. was resented and opposed by a strong democratic party among the people. That antagonism of classes became violent in the Leisler episode (see sect. 53), and existed long afterward, entering more or less 
into the subsequent rally of parties for and against the oppressive measures of the British Parliament and crown. Many, however, of the wealthy families - Schuylers, Livingstons, Van Rensselaers, Jays, Clintons, for example took the patriotic side. The colonial Tory party was stronger in New York than elsewhere, mainly for the reason that New York city was the British military headquarters, and the army officers brought potent influences to bear on its people, in both a social and a business way. Despite such influences, the Whig or patriot party showed remarkable determination and strength.

Colonial Massachusetts was not without a very well-marked class to which some social deference was paid, but its claims to such deference were founded on superior culture quite as much, at least, as on superior wealth. Education in the elementary sense was almost universal; the Massachufiner cultivation of thought, language, and manner, setts. which never becomes universal, seems to have conferred more than usual distinction in the old Puritan community, and commanded especial respect. But all classes were as nearly of one mind as it is possible for a mixed public to be, on the subject of their political rights. There were not a few Tories in the province, many of them, like Governor Hutchinson, men of sincere conviction, to whom their country was very dear, and who believed they were doing it the best service by resistıng rebellion against the Parliament and the king; but they were largely outnumbered by the people who felt justified in going to any length of resistance when their liberties were assailed. While this was generally true of the colonies, the Tory party was more numerous in most of them, and more respectable in character, than used to be supposed.

Political Literature. A century of controversy with English kings, ministers, and parliaments, defending their colonial charters and their constitutional rights as British subjects, had stimulated and educated the people of the colonies remarkably in the direction of political knowledge and thought. 
Especially in its later years, the argumentation of that exciting dispute had been, both in England and in America, an intellectual influence of great force. In both countries it had trained men, not only in political thinking, but in the clear and strong expression of political thought. It produced, as a consequence, in the generation that brought the controversy to its crisis, such a body of political literature, Political English and American, as can hardly be matched and ing in any other time. in any tongue. The parlia. writing. mentary oratory of Great Britain has nothing to surpass, if anything to equal, the speeches on American questions of Burke, Chatham, Fox, and others; while the speeches, pamphlets, memorials, formal addresses, and declarations which poured from colonial lips and pens - from James Otis, Patrick Henry. Benjamin Franklin, Samuel Adams, John Adams. John Dickinson, Joseph Warren. Thomas Jefferson. Thomas Paine. George Mason, Richard Henry Lee, Peyton Randolph, Daniel Dulaney; Christopher Gadsden. John Jay, the youthful Alexander Hamilton. and many more-represent the high mark of American literature in the political field. ${ }^{1}$

Othir Litcraturi. In other fields, two American names had been written so high as to be counted among Edwards and the few of great distinction in the world at large.

Franklin. Jonathan Edwards in philosophy and Benjamin Franklin in science and all practical wisdom had won that

I Speaking in January, 1775 . in the House of Lords, Chatham said of the addresses and declarations that had emanated from the Continental Congress at Philadelphia, in the previous year: "For myself, I must arow that in all my reading - and I have read Thucydides and have studied and admired the master-states of the world - for solidity of reason, force of sagacity, and wisdom of conclusion under a complication of difficult circumstances, no body of men can stand in preference to the general congress at Philadelphia. The histories of Greece and Rome give us nothing equal to it." 
rank. Massachusetts had added to the chronicles of her earliest historians a fine work by her scholarly 'Tory governor, Thomas Hutchinson; an ambitious ecclesiastical history, the "Magnalia Christi Americana" of Cotton Mather; a painstaking "Chronological History" by Thomas HistoriPrince, and spirited Indian war narratives by Ben- ans. jamin Church, Samuel Penhallow, and Samuel Niles. Virginia and New York had found worthy historians, the former in Robert Beverley, William Byrd, and William Stith; the latter in Chief Justice William Smith, who wrote provincial history from the Tory standpoint, and Cadwallader Colden, a fellow loyalist, to whom we owe the first history of the Five Nations of the Iroquois. Of lighter literature nothing of much value had been produced.

Slazery and the Slave T'rade. Slaves were still held in all the colonies; but the employments for slave labor were really profitable in none of them except Maryland, Virginia, the Carolinas, and Georgia, and even there the system was rooted only in the tide-water and midland parts. It gained little footing in the mountainous western borders of the southern colonies, where large plantations were never formed. At the beginning of the Revolution there are supposed to have been about 165,000 slaves in Virginia, I 10,000 in South Carolina, So,000 in Maryland, 75,000 in

\section{Distribu-} tion of slaves. North Carolina, 16,000 in Georgia, being 446,000 in those five provinces, against about 55,000 in the remaining eight. Of the latter number, I 5,000 are estimated for New York, 10,000 for Pennsylvania, 9000 for Delaware, and 7600 for New Jersey, leaving for the four New England colonies (Maine included in Massachusetts) some I3,400. Slavery had had more growth in New York than in the other northern colonies; but even there it was rooted so slightly that gradual emancipation by law was adopted before the century came to its end. Quaker sentiment in Pennsylvania had always condemned human bondage, and, as soon as the Emancipaprovince became free to act for itself, it took measures ( 790 ) 
for ending slavery within its bounds. In the same year Massachusetts struck down the institution more summarily, by a declaration in its state constitution that all men are free, which, according to a judicial decision rendered soon afterward, gave freedom at once to every slave. In the other parts of New England slavery was extinguished by acts of gradual emancipation, or died out naturally within the next few years.

In several of the colonies, including Virginia, the importation of slaves from Africa would have been stopped some time before they assumed independence, if royal authority had

\section{English} not interfered to prevent. The Virginia Assembly English
responst- passed an act for that purpose in I 769 , and the
bilty.

governor vetoed it, in obedience to commands from the king. Several previous attempts to place a cluty on the importation of slaves had been similarly annulled. Legislation of the Massachusetts Assembly to stop the increase of slaves in the province was vetoed by Governor Hutchinson in $177 \mathrm{r}$, and again by General Gage in 1774 . In suggestions offered to the delegates sent from Virginia to the Continental Congress of $\mathrm{I} 774$, Jefferson gave prominence to this among the wrongs which the colonies had suffered at the hands of King George. ${ }^{1}$ In fact, the English government fostered slavery systematically in the colonies, for the increase of the slave trade, which was cherished as a principal source of national wealth. In making peace with Spain, by the

\section{The} treaty of Utrecht, in $\mathrm{I}_{7} \mathrm{r}$, it had exacted and obAssiento. tained a contract, called the Assiento, for the exclusive supplying of Spanish colonies with African slaves, and

1 "There was a great and general dislike to the excessive importation of negroes, and . . every attempt to prohibit or restrict that importation was rebuked and defeated by England. . . The state governors were forbidden to give the necessary assent to any measure restricting it, and the English pursued this policy steadily to the very eve of the Revolution." Lecky, Hist. of Eng. in the Eighteenth Century, ii. ch. v. 
BEGINNING OF WAR OF INDEPIENDENCE. 193

the traffic which that contract secured was enormous in extent. Traders in the English colonies had their share of it, which was not small. Rhode Island and Massachusetts, especially, were engaged heavily in the pitiless trade, Now Engand the greater part of the rum distilled from smug- land and gled West India molasses went to buy captive ne- trade. groes on the African coast, for sale to the English colonists of the south and to the West India colonies of France and Spain. Original responsibility for the great evil of slavery in America rests, therefore, not unevenly on England and the English colonies, north and south alike. 


\section{CHAPTER VI.}

THE AMERICAN REVOLUTION AND WAR OF INDEPENDENCE. $\quad 1775^{-1} 783$.

107. Lexington and Concord. - "The Shot heard round the World." April 19, 1775. Gage had orders to arrest both Samuel Adams and John Hancock, on the charge of high treason, and to send them to England for trial; but though they were daily within reach of the governor, he made no attempt to lay hands on them for weeks. At length the two specially offending patriots were reported to be visiting friends at Lexington, and Gage thought it possible to seize them in that quiet village without setting any dangerous tumult astir. At the same time the opportunity would be good for destroying certain military stores which the patriots had collected at Concord, not far beyond. Accordingly, on the night of the I8th of April, 800 British troops were sent out from Boston, with great secrecy and silence, to surprise Lexington in its sleep. Everybody knows the thrilling story of what happened then: of the alertness of the Boston patriots; of the effective plans of Warren for sending warnings into the country, whatever direction the troops might take; of the signal lights paul from the North Church belfry, which told Paul Revere. Revere, at Charlestown, what way to ride; of the effect with which he rode, rousing the farms and villages as he went; of the wakening of Adams and Hancock and their quiet departure through the fields 
to Woburn; of the first bloodshed of the War of Independence on Lexington Green, as the sun came up on the morning of Wednesday, the igth of April, on Lexingwhen a little company of minute men, who ton Green, would not disperse at Major Pitcairn's command, received the fire of the British advance; of the fight at Concord, where

"the embattled farmers stood,

And fired the shot heard round the world;"

of the dreadful retreat of the exhausted soldiers of King George, through miles of country that swarmed Fight at with maddened people, ambushed all along the concord. road. The tragic incidents of that memorable day are familiar to every American child. Before it ended, twenty-

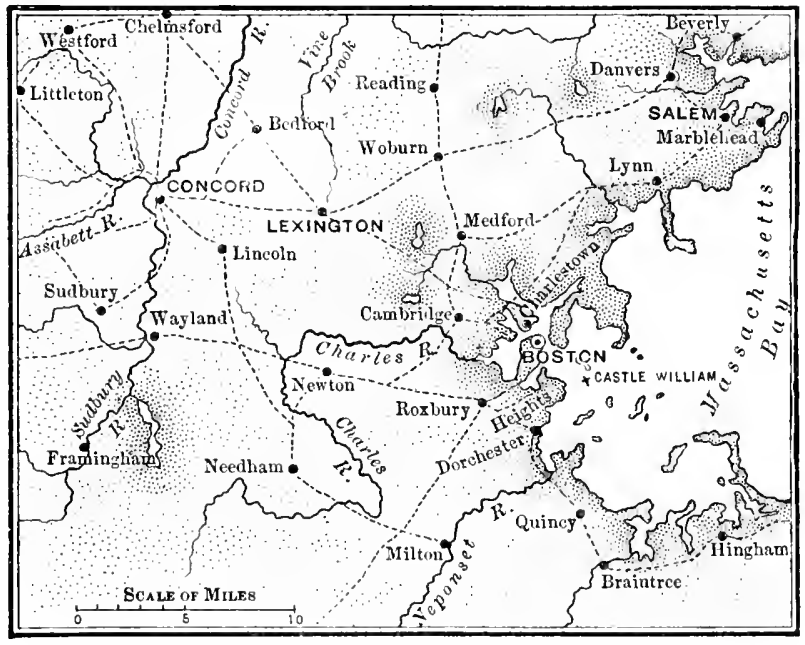

BOSTON, LEXINGTON, CONCORD, AND VICINITY.

three towns had joined the fighting, and 93 Americans had fallen, wounded or killed, while the British had lost 273.

As the exciting tale of battle was borne swiftly in all directions, it found the major part of the people ready 
everywhere to accept the gage of war that Great Britain had now thrown down. Minute men from all New England were hurrying toward Boston before the next day's sun went down, and the end of the week found Gage Boston
besloged beleaguered in the city by 13,000 resolute men. bosloged. They were poorly equipped in every way, and not provisioned at all; they were little trained, except in the use of their muskets; the only experience among their officers was that of men who had served in the "French and Indian War" of fifteen years before; but they were bent on driving the British regulars out of Boston, and the British fleet out of the Bay. Israel Putnam commanded the Connecticut men, John Stark led those of New Hampshire, Nathanael Greene was colonel of a Rhode Island regiment, and General Artemas Ward, a veteran of the last war, much disabled in health, commanded the whole.

108. Effect of the News. April-May, 1775. The spirit kindled in New lingland flamed up in every other colony as fast as news of the igth of April sped west and south. New York heard of it on Sunday, and that same day there was a rising of the Sons of

The news In Now York. Liberty which practically swept the royal government out of power. Arms, military stores, and provisions, destined for the British troops at Boston, were seized; possession was taken of the customhouse, and a committee of one hundred citizens was appointed to take direction of public affairs. New Jersey took instant steps to assemble a provincial congress. At Philadelphia a great town meeting, on Tuesday, the 25 th, agreed to defend their lives, their property, and their liberty "with arms," and even a Quaker company was formed. In Maryland the freemen demanded and the governor surrendered the arms and ammunition of the 
province. Virginia was alrearly ablaze with an excitement of its own; for Governor Dummore had carried off a quantity of gumpowder from the colony magazine, and the militia of Hanover, with l'atrick Henry at their head, were starting for Williamsburg to de- virginia mand that it be restored. Before they reached in arms. the capital Dunmore paid for what he had taken, and they turned back; but he provoked another rising soon after and fled, taking refuge on a man-of-war and acting as an enemy of the province from that time. South Carolina had not waited for a British act of violence before taking the attitude of war. On the 2 Ist of April, a full fortnight before Charleston knew of what had happened at Lexington, the men of that town had laid hands on the royal arsenal and the public magazines, having appointed a committee of five, with Henry Ialurens at their head, to place the colony in a state of defence. In North Carolina the popular demonstration at Newbern was such that the governor withdrew to Fort Johnson and sent his wife to New York; while the Scotch-Irish inhabitants of

\section{Mecklon-} burg Declaration. Mecklenburg County adopted resolutions which are claimed to have been the first demand for independence that was uttered by any assembly of people.

109. Capture of Ticonderoga and Crown Point. May 10, 1775. As quickly as the slow travel of the time could bring it to them, the New linglanders besieging Gatge at Boston had assurance of support from every British-American community except Quebec. Meantime they had been pushing operations of war outside of the siege. An expedition set on foot in Connecticut, but carried out mainly by hardy settlers of the Green Mountain region (then known as the "New Hampshire Grints," but soon afterward called Vermont), surprised 
the strong fort at Ticonderoga, on the morning of the Ioth of May. The "Green Mountain Boys" who performed this fine exploit were led by Ethan Allen; Benedict Arnold, of Connecticut, joining them as a volunteer. The surrender of Crown Point followed, and these two important captures gave the provincials more than two hundred cannon, with a quantity of ammunition and other stores.

110. Second Continental Congress. - Appointment of Washington to Chief Command. May-June, 1775. The second Continental Congress opened its sessions at Philadelphia on the Ioth of May. Franklin, who had arrived from England only five days before, was now, with Dickinson, in the Pennsylvania delegation; Samuel and John Adams had come again from Massachusetts, with the dignified John Hancock in their company; Patriots Virginia had sent Washington again, with Lee, present. Henry, and Randolph, but Randolph was recalled very soon by duties in the colonial Assembly and Thomas Jefferson was delegated in his place; Jay and Livingston from New York, Gadsden from South Car. olina, and other staunch patriots from the first Congress, were seated anew. Randolph was made president until called away; then Hancock was honored with the place.

The action of Congress still invited reconciliation. While adopting, on one hand, a calm declaration of "the causes and necessity for taking up arms," it addressed, on the other hand, another petition to King George. At the same time it made common cause with New England in the hostilities already begun, by adopting the forces in arms, or to be in arms, as a "Continental Army," assuming the direction of it and appointing its commander-inchief. On the request of the Massachusetts delegation, 
George Washington, of Virginia, was so commissioned; and by that inspired act the achievement of American independence and the successful founding of the federal republic of the United States were assured. What Washington would

Washington appointed, June 15, 1775. be to the great revolutionary undertaking no man could have foreseen. He had given more promise of high military capacity, perhaps, than any other in the colonies who wore a sword, and he had won the perfect trust of all who knew him best; but how little, after all, could any in that day have known of the unique greatness of the man! As we look back now at the events of the history in which Washington's figure is so grand, we cannot imagine a successful outcome of the revolt, or a successful binding up of the colonies in one nation, without him. He was not the greatest of soldiers, he was not the greatest of statesmen; but he combined with perfection the qualities, both moral and intellectual, that were needed for what he did.

The greatness of Washing ton. They produced in him a character so massive, so strong, so majestic, that it bore up the whole cause.

Under the commander-in-chief, four major-generals, Artemas Ward, Israel Putnam, Philip Schuyler, and Charles Lee, - with eight brigadier-generals, including Richard Montgomery, John Sullivan, and Nathanael Greene, were named. The appointment of Charles Lee, an English adventurer, unprincipled and worthless, was a grave mistake.

Thus, in answer to a general expectation and desire, the Continental Congress took upon itself the conduct of whatever there should need to be of war. But, while assuming the responsibilities of the impending struggle, it assumed no power to enforce an order it might give, or authority to levy a dollar of taxation for the expenses 
incurred. Its whole exercise of a nominal authority to direct the common action of the thirteen colonies was left dependent on the willingness of each provincial government to be submissive to its advice. Professor von Holst and other recent historians have maintained, with what seems to be sound reasoning, that, being a revolu-

The missed opportunity tionary body, in a revolutionary crisis, the Continental Congress might properly have claimed and exercised all the functions of a national legislature, from the beginning, and would probably have been sustained by popular opinion in doing so. Instead of taking that strong, consistent course, it went only halfway. Consequently, the respect and deference which the Congress commanded at the outset was lost, and state governments, when formed, became the only governments felt and known in reality by the people, who struggled through their war of independence with nothing that could be called a governing head.

111. Bunker Bill. Jure 17, 1775. While continental sanction was being given to the New England proceedings of war, those proceedings were acquiring more importance from fresh events. Reinforcements had raised the British force in Boston to about 10,000 men, whereupon General Gage prepared for a movement to extend his lines. The provincial leaders learned his intention, and undertook to frustrate it by sending Colonel Prescott, with about 1200 men, in the night of the I6th of June, to occupy and fortify a rise of ground near Charlestown called Bunker Hill. When Prescott reached the ground Breed's he thought it best to advance a little farther, to Hill. $\quad$ the next eminence, called Breed's Hill, and there his men were set silently to work. The British cliscovered nothing till the morning of the $I 7$ th; then their frigates in the harbor opened fire on the unfinished 
work, without much effect. At noon they had determined to storm the rising fortification, which endangered them if the besiegers should be able to bring heavy guns into place. About 3000 veteran soldiers were landed near Charlestown, under General Howe, and led in two columns, one against the entrenchment on Breed's Hill, the other against a supporting body of Americans, who

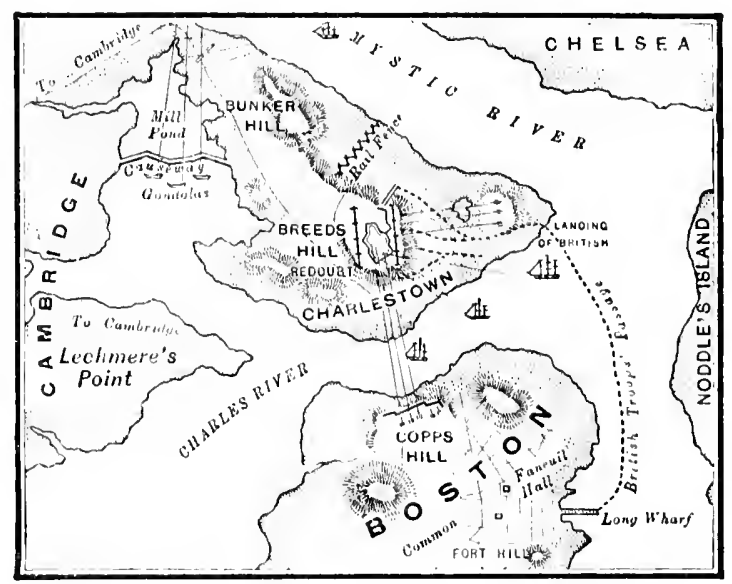

PLAN OF THE BATTLE OF BUNKER HILL. had taken position

on the flank of the latter, behind a rail fence. Both columns were repulsed, with terrific loss to the assailants, the Americans having reserved their fire until the British came within fifty yards. After some time, during which the village of Charlestown was set on fire by shells from the fleet, a second assault was made, with the same result. By this time the Americans had nearly exhausted their ammunition, and none came to them, though sent for again and again; nor did they receive reinforcements, except as many volunteers came over to join them during the day. Had the needed men and gunpowder come, the third assault, made late in the after-

The thitrd noon, would probably have failed. As it was, when the defenders of the hill had emptied their powder horns, their clubbed muskets were poor weapons against the bayonet, and they gave way.

For their victory, if it was a victory, the British had 
paid a fearful price, losing 1054 in killed and wounded, or more than a third of their force, and the proportion of officers struck down was unusually large. The Americans lost 449, about one fourth of the number engaged ; and among the killed was the noble Dr. Warren, who had joined the force on the hill as a volunteer. His death was a heavy loss to the American cause. But the battle gave more encouragement to the losers than to the winners of the ground on which it was fought.

112. Washington's Task. - Expeditions to Canada. July-December, 1775. On the 2d of July, two weeks after the battle of liunker Hill, General Washington arrived at Cambridge and took command. There were I6,000 men in the force around Boston, all New Englanders; but 3000 came soon from Pennsylvania, VirThe Amert ginia, and Maryland, including a famous company can army. of Virginian sharpshooters, with Danicl Morgan at their head. The 19,000 then assembled formed an army in numbers alone; of real organization it had none. The men had been enlisted by different committees, for different short terms, with great uncertainty as to the sources from which pay or even food would come. They were accoutred in all sorts of fashions, and sheltered in all sorts of makeshift ways. Such were the hard conditions of the task of war which Washington had undertaken to direct; and, though they slowly settled into something better, there was always such a chaos of diverse authorities behind him as would have broken down any courage and constancy less invincible than his.

Months of preparation were needed before Washing-

Expeditions into Canada.

ton could venture any serious attempt to drive the British out of Boston; but while he toiled at his task, two expeditions were sent into Canada, for the capture of Montreal and Quebec. One, led 
from Ticonderoga by General Montgomery, took the former town (November 12); the second, commanded by Benedict $\Lambda$ rnold, after great sufferings in a march through the Maine wilderness, was joined by Montgomery in a daring assatult on the walls of Quebee (1)ecember 31) which nearly had success; but Montgomery fell, his men wavered, and were driven back. Morgan and his company, who formed part of the expedition, had actually entered the town, and were captured; Arnold received a severe wound.

113. Ripening of the Public Mind for Independence. 1775-1776. In these months a great change in public feeling had been wrought by news from England. King George had launched a proclamation, in violent terms, against the "open and avowed rebellion" in $\Lambda$ merica, and had contracted with certain despotic German princes for the hiring of 20,000 soldiers, I [essians and Hosslans others, to be employed for the suppression of hired by the revolt. The effect of this last-named mea- Goorgo. sure, when known, was to swell the number of patriots who were ready to renounce allegiance to the king ; and the Congress at Philatelphia began to take steps which led plainly that way. To Virginia, South Carolina, and New IIampshire, whose royal governors had fled from their posts, it gave advice that they frame governments for themselves. It recommended that South Carolina should seime British ships in its ports; that Virginia should take arms against Dummore, who was gathering forces at Norfolk and offering freelom to slaves; that New York should place its troublesome governor, Tryon, under arrest. It appointed a committec to correspond with foreign powers. It was moving steadily toward a position in which independence would have to be declared. 
In October the New Iork governor, Tryon, took refuge on a British ship of war. Dummore and the Virginians fought a battle at Great Bridge, near Norfolk, in December, and the colonists took the town. It was bombarded soon afterward by a British ship and destroyed. Early in the year 1776 information came of an act of Parliament authorizing the capture and confiscation of all American ships and cargoes, and the forcible enlistment in the British navy of captured crews. At nearly the Palno's same time a remarkable pamphlet, entitled pamphlet, "Common Sense," which set forth the argu1776.

ments for independence in a striking way, was published by Thomas Paine, an Englishman, lately arrived in Philadelphia. The effect of Paine's pamphlet, helped by the new act of Parliament, was to ripen the sentiment in favor of independence very fast.

114. Boston given up by the British. March 17, 1776. Early in March, 1776 , the preparations of Washington for a decisive movement at Boston were complete. What he had to do is indicated by one passage in a letter which he wrote to the president of Congress a few

Washing. ton's preparation. months before: "To maintain a post within musket-shot of the enemy for six months together without powder," he wrote, "and at the same time to disband one army and recruit another, within that distance of twenty odd British regiments, is more, probably, than ever was attempted;" but he accomplished the feat. The enemy knew nothing of his desperate straits until too late. At last he had powder enough, guns enough (dragged from Ticonderoga),

Seizure of Dorchester
Heights.

tools enough, men enough, for a venture; and on the night of March 4 he seized and fortified Dorchester Heights, which so commanded Boston harbor that his Ticonderoga cannon would drive out 
the British fleet. Howe, who had superseded Gage, ordered an attack on the new works, but thought better of it, and finally gave notice that he would quit the town if permitted to go in peace, but would lay it in ashes if fired on; and so, by tacit agreement, the besieged army and fleet, with 900 of their Tory friends, made an undisturbed retreat to Halifax, leaving behind them a rich prize of military stores.

115. War in North Carolina. - Demands for a Declaration of Independence. February-June, 1776. An exciting clash of war had occurred meantime in North Carolina, where British agents had enlisted some I600 Scotch Highlanders and started them toward the coast, to meet expected expeditions from Boston and from Ireland, and to take part in a grand campaign. But the march of the Scotchmen was stopped at Moore's Creek (February 27) by North Carolina militia, who put them to rout. This battle so roused the province that the force sent from Boston, under Sir Henry Clinton, dared not land, when it arrived, but waited in Albemarle Sound for the fleet from

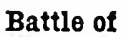
Moore's Croek, Fobruary 27 , 1776 . Ireland until May. Before that time, the energetic Carolinians had elected a provincial congress, which met and (April 12) empowered the delegates of the colony in the Continental Congress "to concur with the delegates in the other colonies in declaring independency and forming foreign alliances." In Georgia a provincial congress had already, in February, instructed its delegates substantially to the same effect; while South Carolina, on the 26th of March, established the constitution and organized the government of an independent state.

The lead which the southernmost colonies had thus taken in pronouncing for independence was now followed quickly. Rhode Island spoke next, on the $4^{\text {th }}$ of 
May. On the Ioth of the same month the General Court of Massachusetts (reëstablished, accordThe colo-
nies spear- ing to the old charter, in the previous summer) Ing out.

called on the towns to express themselves on the subject, and they did so by their town meetings that month. Virginia, in a convention specially chosen, voted unanimously for independence on the I $4^{\text {th }}$ of May; and the same convention, on the $\mathrm{I} 2$ th of June, issued a famous "Declaration of Rights," setting forth Dirginia Declaration that "all men are by nature equally free and of Rights. independent," and that " all power is vested in and consequently derived from the people." Before the end of June every one of the remaining colonies, except New York, had declared for independence, or empowered its delegates in Congress to act in unison with the rest.

The delay in New York was caused by the strength of the Tory party there, animated by an expectation that the whole force commanded by General Howe, now increased by Hessian arrivals, would soon be knocking at the gates of the Hudson River valley. In the military view, immense importance attached to the possession of that river and valley, which parted New England

Washington at New York, Aprll, 1776.

from the colonies farther south, and which would, if held by the British, unite them with Canada and with the Six Nations of Indians, whose savage alliance they were trying to engage. To secure New York, Washington had hastened thither with his army, as quickly as possible after Boston was relieved; but his command had dwindled to about 8000 men, and Howe was coming from Halifax with a vastly greater force.

116. Independence declared. July 4, 1776. On the $4^{\text {th }}$ of July, I776, - most memorable of all days in American history, - the step was taken which separated 
the English in America from the English in Britain politically, and a new great nation was born. Congress had prepared for it three weeks before, by appointing a committee to draft the contemplated Declaration of Independence, and that immortal manifesto was composed by Thomas Jefferson, whose broad understanding of political principles and fine

Author of the Declaration of Independence. gifts of expression had been shown in some notable examples before. As the Declaration came from Jefferson's pen, with a few verbal changes suggested by Franklin and John Adams, it was reported to Congress on the $2 \mathrm{~d}$ of July, and adopted, after slight amendments, on the

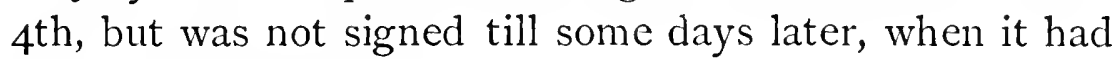
been duly engrossed.

The resistance to Great Britain was now no longer a rebellion, but the struggle of a new nation for its life.

Congress had already recommended that governments based on the "authority of the people" be established in every colony, and seven such independent governments, either provisional or permanent in constitution, had been organized before the general declaration of independence was put forth.

Formation of state governments, 1776-1777. These were in Massachusetts, New Hampshire, South Carolina, Rhode Island, Connecticut, Virginia, and New Jersey. Delaware and Pennsylvania adopted state constitutions in the next September; Maryland followed in November; North Carolina in December; Georgia in February, and New York in April of I 777. The "thirteen colonies" had then completed their transformation into American States.

117. British Repulse at Charleston. June 28, 1776. Almost simultaneously with news of the Declaration of Independence, a cheering message from Charleston was carried through the land. Sir Henry Clinton had been 
joined by the squadron from Ireland, which brought fresh forces, and had attacked the fortifications in Charleston harbor on the 28 th of June. The main defence of the harbor was a rude fort, built hastily of palmetto

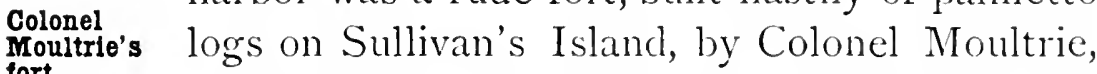
fort.

who held it, with I 200 men. General Charles Lee, sent to take command in the south, had scorned this work and given orders for its abandonment; but Moultrie, sustained by President Rutledge, of the provincial congress, refused to withdraw. The result was that the valiant Moultrie and his force repulsed the attack, losing but 37 in killed and wounded, while the loss of the assailants was 205 .

118. Battle of Long Island. - Retreat of Washington from New York and through New Jersey. AugustDecember, 1776. The months that followed these good tidings were filled with disheartening events. By the end of July not less than 30,000 British troops and a powerful fleet were assembled on Staten Island and in New York Bay, General William Howe and Admiral Lord Howe in command. They were busily preparing New York to attack the city, which Washington must try to defend against them, with a militia force captured. now increased to some 20,000 men. On Long Island he had fortified Brooklyn Heights, which commanded New York, and half of his little army, stationed there, was overwhelmed by 20,000 of Howe's reterans on the 27 th of August, losing 1000 prisoners, besides 400 in wounded and killed. The remainder of the American force, hemmed in by the enemy, was rescued with skilfulness by Washington and brought across the river, on the night of the 29th. The loss of the Heights made New York no longer tenable, and Howe entered the city on the $15^{\text {th }}$ of September, the Americans retreating north- 
ward, fighting stubbornly as they drew back to a strong position, up the river, among the hills. At the same time they were threatened from the north, the British commander in Canada, Sir Guy Carleton, having attempted an invasion by way of

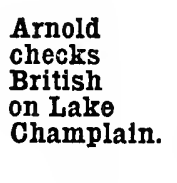

Lake Champlain ; but Benedict Arnold, in command at Ticonderoga, got a fleet of small vessels afloat and checked his advance, though defeated, in a stubborn fight (October I I).

Hostile criticism began now to assail the sorely tried commander-in-chief; envious rivals intrigued against him ; ignorant men in Congress in- Intrigues terfered with $\begin{gathered}\text { against } \\ \text { washing- }\end{gathered}$ his plans. Fort ton.

Washington, on the Hudson, was lost in consequence (November I6), with a garrison of nearly 3000 men, and the wretched impostor, General Charles Lee, now back from the south, had en-

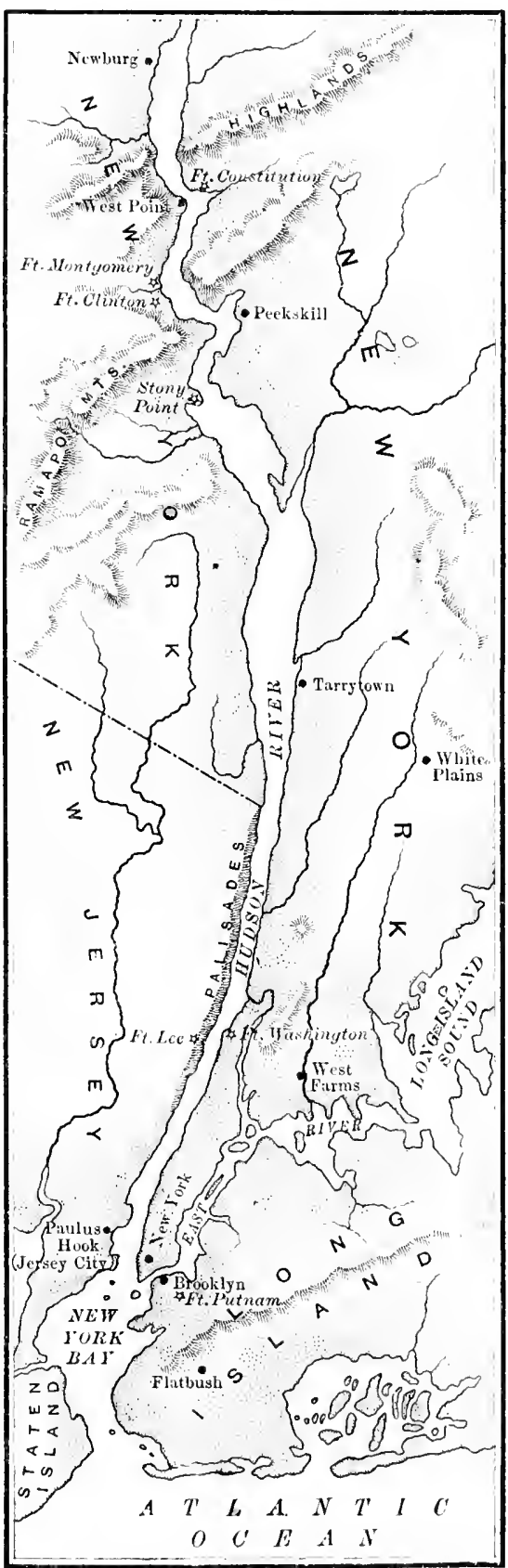

THE FIELD OF WAR ON THE HUDSON. 
couragement to disobey orders, keeping 7000 of the meagre American force away from the commander's control at a most critical time. But, happily for the American cause. Lee put himself, presently, in the way of being caught by the british, and one serious cause of mischief was removed for a time. Washington had then crossed the Hudson and retreated through New Jersey, to a point beyond the Delaware, pursued by I,ord Comwallis, with British and Hessian troops. The short terms of so many of his militia-men had expired that hardly 3000 remained, and most of those would be entitled to discharge at the end of the year. There was no money for their pay, and no public credit on which to raise funds. Vrashington and some of his officers borrowed what they could on the pledge of their own estates. "These are "Thotimes the times," wrote Thomas Paine, "that try that try men's souls." None but the stoutest-hearted
mon's souls." could feel hopeful of the cause. Some thousands in New York and New Jersey accepted Howe's offer of British protection, swearing allegiance to the king. Philadelphia expected nothing but a speedy invasion, even Congress giving way to panic and adjourning to Baltimore, December i 2.

119. The situation changed. - Washington turns upon his pursuers. December 25, 1776-January 3, 1777. In this dark hour of the war there came a sudden revelation to his despairing countrymen of the extraordinary powers of the man who upheld their cause. Lee's force, greatly dwindled, had reached him at last, and Schuyler, commanding in northern New York, had sent him a few men, so that, by Christmas eve, he had about $6000 \mathrm{in}$ hand. With these he resolved to strike at the enemy, who were feeling secure, in lines scattered along the castern side of the Delaware, where they waited for 
the river to freeze. Ilaving seized every boat within reach, Washington planned to send his little army across the river in three divisions; but only one of the three overcame the great difficulties caused by ice, and that was the one which he personally led. With 2400 men he reached the eastern bank of the Delaware on Christmas morning, marched nine miles to Trenton, drenched with the sleet of a northeast storm, and surprised and captured rooo Hessians, besides a large quantity of arms and stores. This was only the beginning of his new campaign. By the 2d of January he had established his army near Tren-

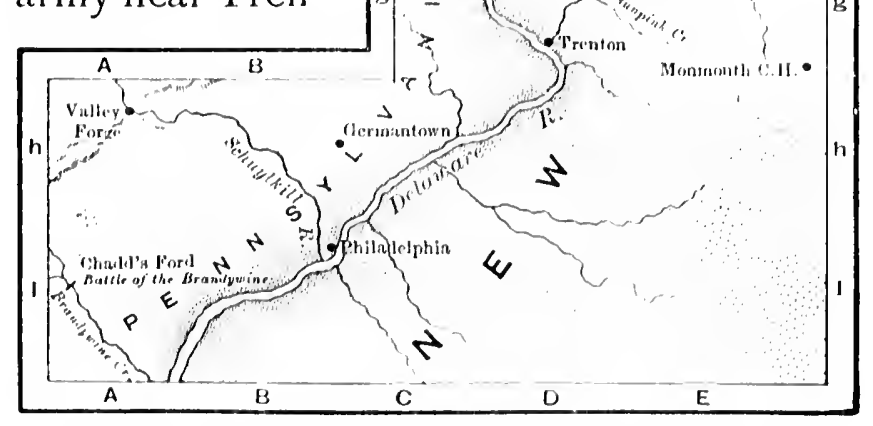

THE SEAT OH WAR BETWELN THE IIUUSON AND DII.AWAR 1:.

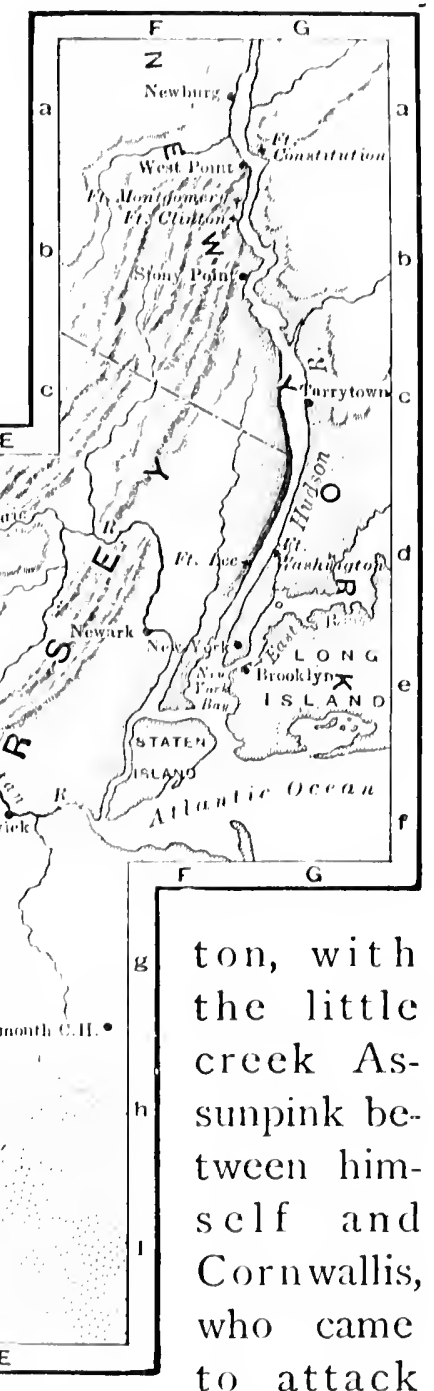

him there in

force. The

latter was now sure, as he cxpressed it, that he had "run down the old fox;" but Washington, leaving his campfires burning and a few men working at entrenchments in 
front, slipped away during the night and marched rapidly toward Princeton, where the British had collected stores. Near Princeton he routed a body of 2000 troops, taking Battle of more prisoners, and then, entering the town, Princeton,
January 3, gathered up more of the enemy's ammunition 1777. and arms. From Princeton he moved on to the heights around Morristown, while Cornwallis fell back to New Brunswick. Substantially all that the British had gained since Washington began his retreat through New Jersey was recovered by this brilliant campaign of ten days.

These successes were immensely helpful to the American cause, both at home and abroad. It was now recognized in foreign circles that the crude American army had a great soldier and a man of great character at its head. France was more than willing to give secret aid against England, if her aid was not likely to be thrown away. She had contributed a million dollars, even before independence was declared. Three commissioners from Congress - Franklin, Arthur Lee, and Silas Deanewere now in Paris, negotiating for more open support. The fame of Franklin gave him an extraordinary influHelp trom ence, and the negotiation was helped greatly France. by Washington's late campaign. Two millions of livres (about $\$ 400,000$ ) was promised yearly by the French government; several cargoes of stores were sent over; the authorities winked at the fitting out of privateers in French ports; and not a few French gentlemen prepared to offer their services, among them the young Marquis de Lafayette. Some secret assistance was also obtained from Spain.

120. Burgoyne's Invasion. -- Capture of his Army. - Undeserved Credit to General Gates. July-October, 1777. During the remainder of the winter of 1777 
no military movements of note were undertaken on either side. But the next season brought important events. The British government had ordered a formidable invasion of northern New York from Canada, to secure the valleys of the Hudson and the Mohawk throughout their length. It was made on two lines, one by way of Lake Champlain, the other from Lake Ontario to the Mohawk, thence to a junction with the first. The main movement, under General Burgoyne, began with success. The Americans were easily forced out of Ticonderoga, and beaten in a battle at Hubbardton, early in July. They drew back to Fort Edward, and then to Stillwater, near Saratoga, obstructing the way to delay Burgoyne. Before he could reach Stillwater, large numbers of the militia and untrained farmers of western New England and eastern New York

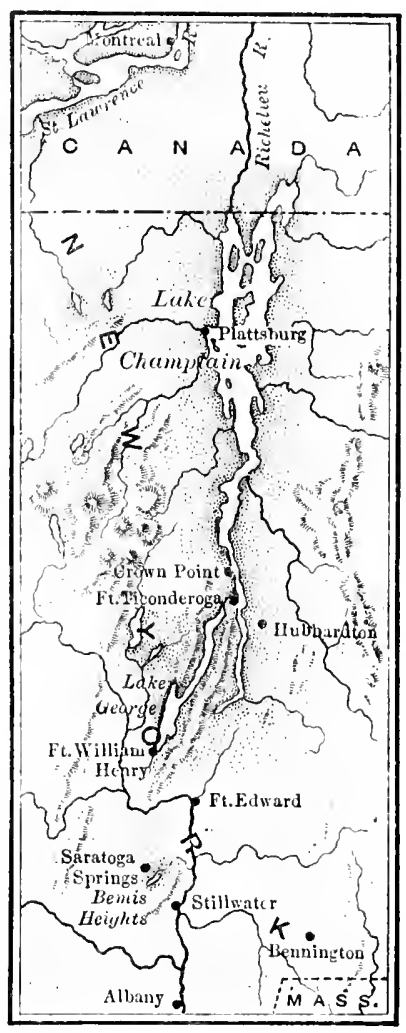

ROUTE OF BURGOYNE'S INVASION. were joining the American forces there, or gathering on the flanks of his march.

The invasion caused unusual excitement, for the reason that the British had taken savages into their service, professing to be able to keep them under control. This employment of Indians was disapproved by many British officers, and denounced in England, but was insisted upon by the ministers of the king.

Indian allies of the British. Feeling on the subject was heightened by a pathetic tragedy, occurring in July, when a beautiful young woman, 
Jenny McCrea, betrothed to an officer in the invading army, and on her way to join him for marriage, was killed and scalped by some of Burgoyne's savage scouts. A fiery rage was kindled everywhere by this dreadful story as it ran through the land.

The serious trouble of Burgoyne began on the 16 th of August, when 1000 of his German troops, sent with 100

Battle of

Benning-

Indians to seize militia stores at Bennington,

ton, $\mathrm{Au}$ -

gust 16,

Vermont, were surrounded and most of them 1777 . captured, after a fierce fight. This was mainly the exploit of a crowd of farmers in their shirtsleeves, commanded by General Stark. Soon afterward, Burgoyne had news of the disastrous failure of the expedition from Lake Ontario, which Colonel St. Leger was leading to join his own. St. Leger had been resisted with obstinacy at Fort Stanwix (now the city of Rome), near the headwaters of the Mohawk, and had fought a hard battle at Oriskany (August 6) with 800 of the local militia, whose commander, Colonel Herkimer, received St. Leger's a mortal wound in the fight. Then, a fortnight fallure. later, reports came to him of the approach of a body of troops from the main American army, and exag. gerated stories were told him of disaster to Burgoyne. Already discouraged, he now became panic-stricken, and fled from his camp before Fort Stanwix ${ }^{1}$ (August 22), abandoning everything, pursued by even his own faithless Indians, and losing all but a small remnant of his force.

i On the $14^{\text {th }}$ of June, 1777 , Congress had adopted a design for the flag of the "United States of America," consisting of thirteen alternate red and white stripes, with a blue field containing white stars in the corner. The first military use of the flag is said to have been made during this siege of Fort Stanwix, where one was improvised out of a red petticoat, a white shirt, and an officer's blue cloak. 
Burgoyne was then in a desperate situation. The militia on his flanks, in Vermont, under General Lincoln, were breaking his communications and cutting off his supplies. He heard nothing from General Howe, who had been expected to move up the Hudson, from New York. By the middle of September he had no alternative but to fight his way through, without help, if he could. Having crossed to the western side of the Hudson, he attacked the Americans in their strong position near Stillwater, on Bemis Heights, September I9, and Battlos on again October 7 , both battles being fought $\begin{gathered}\text { Bemis } \\ \text { Heights. }\end{gathered}$ on nearly the same ground, known as Free- $\begin{gathered}\text { September } \\ 19, \text { october }\end{gathered}$ man's Farm. Both attacks were repulsed, and,

7,1777 . being entirely hemmed in at Saratoga, his army reduced from 10,000 to less than $6000 \mathrm{men}$, with no source of supplies, Burgoyne surrendered, October i7. He surrendered on terms which promised permission to his army to return home, but Congress would not allow the promise to be fulfilled.

The credit for this most telling blow to British hopes was won without being deserved by General Horatio Gates, who had persuaded Congress to appoint him to supersede General Schuyler in command of the northern forces, and who reached the field on the igth of August, after Burgoyne's fate had really been sealed. The honors of the fighting in both bat-

Unmerited credit to Gates. tles belonged to Benedict Arnold and Daniel Morgan; but the whole apparent glory of the defeat and capture of Burgoyne settled at once on Gates, and he began to aspire to Washington's place. He was an accomplished intriguer, and Congress, which meddled constantly with the military commands, offered a good field for that kind of work.

121. Why and how General Howe was kept from 
meeting Burgoyne. August-October, 1777. Why Howe made no more northward to meet Burgoyne must now be told. He was supposed to have had orders to do so, but the orders were pigeon-holed in London by a careless minister and never sent. Free, therefore, to act on his own judgment, he planned a new movement against Philaclelphia, expecting to finish it before Burgoyne would need his help. He had a splendid army, of more than I 7,000 men, while Washington, in New Jersey, had but half that number. The latter could not save Philadelphia, but he could make the road to it long and the travel slow. He so manœuvred his little force that the British general, after trying for nearly three weeks to make his movement by land, gave up the attempt, and took the route by sea. August was nearly ended when he landed Battle of his army at the head of Chesapeake Bay. Wash-
Brandywine, Sep- ington had moved down to confront him, taking
tember li. 1777. 11, a strong position on Brandywine Creek, with his force increased to about I I,Ooo. The Americans were outflanked and forced back, in the battle that ensued (September I I) ; but they had hindered the British advance, and they continued to hinder it for a fortnight more until the 26th, when Howe's troops entered Philadelphia, and the sittings of Congress were transferred to York.

Within a week after the British occupation of PhiladelBattle of phia, Washington had planned an audacious atGerman- town, tack on the headquarters of their force, in the ber 4,1777. suburb of Germantown, which he executed in the early morning of October 4, very nearly with success. But a heavy fog caused confusion and collisions between different columns of the attacking party and spoiled a promising attempt. The Americans retreated with heavy loss. 
122. Intriguing for Gates, to supplant Washington. - The "Conway Cabal." November, 1777. On the surface of things, Washington had scored nothing but a record of defeats in this year's campaign, and Gates had performed the grand exploit of the war. Hence shallow lookers-on, in and out of Criticism
of Wash-
ington. Congress, became contemptuous again of the great solclier, and began to call for the intriguing wearer of stolen plumes to be put in chief command. Congress had lost many of its ablest and noblest men : Franklin had been sent to the mission in France, Patrick Henry was called home to be governor, Jefferson to sit in the legislature of Virginia, Rutledge to be chief magistrate of South Carolina, and Jay to assist in framing a constitution for New York. An increasing pettiness of character appeared in the remaining body, and provincial jealousies cropped out in it more and more.

The most serious danger to the American cause arose from the encouragement that Congress gave to intriguing officers like Lee and Gates. In the fall of 1777 the scheming for the latter was carried on actively by a faction in which one General Conway was conspicuous, and which got the name of the "Conway Cabal." It succeeded so far as to bring about, The
"Conway
Cabal." in November, the appointment of Gates to the presidency of a "Board of War," which had power to interfere seriously with the plans of the commander-in-chief. But the mean character of the conspirators was betrayed by their own conduct, while the dignity and noble spirit of Washington were impressively revealed. The heart of the people went out to him with increased admiration and trust; his detractors were scorned.

123. The Winter at Valley Forge. - Suffering of the Army. - State of the Country. December, 1777-May, 
1778. To watch the British forces in Philadelphia and make his own as safe as possible, Washington chose a position at Valley Forge, on the Schuylkill, about twentyvalley one miles from the city, where he established Forge. winter quarters from December until May. The sufferings of the troops in that dreadful winter, and the heroic patience with which they were borne, have been clescribed many times. The soldiers were sheltered well, in $\log$ huts that they built, but every need of clothing and food was ill-supplied. In one report to Congress, when remonstrated with for going into winter quarters, Washington wrote: "We have this day no less than 2898 men in camp unfit for duty because they are barefoot and otherwise naked. . . . Numbers still are obliged to sit all night by fires." This dreadful state of want in the army was due in part to faults of organization and management, which Congress would not reform, and in part to the lack of a central government having credit or power to tax. Congress had borrowed to the extent of "contl- its ability, and it had issued paper money (called nenta1 , cur- "Continental currency") based on no substanrency." tial security, and not, of course, redeemable in coin, until its bills were losing all their nominal worth. In different degrees, the States had done the same. The financial situation of the country, burdened with the war, and with most of its commerce cut off, was very grave.

In this trying winter two friends who had come from abroad to give help to the young republic were a source of great cheer and support to the commander-in-chief. One was the youthful Lafayette, who won Washington's affections almost as a son; the other was the Lafayette and SteuBaron Steuben, a highly trained officer from the Prussian army of Frederick the Great, to whom Congress gave the office of inspector-general, and 
who imparted a new quality to the army by the discipline he taught and inspired. At this time, too, a long intimacy of friendship was being knitted between Washington and young Alexander Hamilton, Alexander who had come to the general's staff in the previous March.

124. Treaty of Alliance with France. - Peace Overtures from England. February-June, 1778. Before the winter ended, an event of great importance and long hoped for was realized by the signing (February 6, I 778) of a treaty of alliance with France. France recognized the independence of the American States and pledged open support to them, the States agreeing on their part to make no peace with England till their independence was achieved. A year later (April, I779) Spain joined the alliance, under a treaty with France, but not with the States.

The first effect of this alliance was the passage (February) of two acts by the British Parliament, making conciliatory overtures to the States. One repealed the Tea Act and the act which nullified the Massachusetts charter, declaring, further, that Parliament would not exercise its right to levy taxes

\section{Effect} of the allance.

in the American colonies; the other provided for the sending of commissioners to America to treat for peace. The second effect was a declaration of war (March 13) between Great Britain and France.

The offered concessions were insufficient and came too late. Most people in England could see that this was so, and a demand arose for Lord Chatham at the head of the government, with power to make some honorable peace. Even King George might not Death of have ventured to resist this demand; but Chat- Chatham, ham was stricken (April 7) with a mortal ill1778. ness, while speaking in the House of Lords against any 
consent to American independence, and died on the I I th of the following month. Lord North's commissioners came to America in June, but were told plainly that nothing less than an acknowledgment of the independence of the States would receive consideration.

125. British Evacuation of Philadelphia. - Battle of Monmouth. - Treachery of Charles Lee. June, 1778. The British gained nothing from the possession of Philadelphia, and Sir Henry Clinton, who displaced Howe in May, was ordered to evacuate that city and concentrate his forces at New York. His rear-guard marched out on the i8th of June, and Washington, breaking camp, moved instantly in pursuit. On the night of the $27^{\text {th }}$ the American army, about equal in numbers to Clinton's, had arrived within reach of the latter, in an advantageous position near Monmouth Court House, New Jersey, and prepared to attack. Unfortunately, the treacherous General Charles Lee, lately freed from captivity by exchange, was in command of the advance. It is now known that Lee, while a prisoner at New York, gave information and advice to Howe; but that treason was not discovered till long afterward, and Washington seems to have been obliged to restore the scoundrel to his command when he came back. The result was a new piece of treachery, which nearly caused a calamitous overthrow of Washington's plans. Instead of attacking the enemy on the morning of the 2.8 th, as he was directed to do, Lee gave bewildering orders, throwing his divisions into confusion, and finally comBattlo of manded a retreat. Lafayette, serving under Monmouth, Lee, sent a hurried report to Washington of
June 28, 1778 . what was being done, and the commander arrived on the scene in time to stop the retreat, restore order, re-form a line of battle, under fire, and repel what 
had now become a British instead of an American attack. This was so splendidly done, showing such discipline and such generalship, that the battle of Monmouth had the effect of a victory, though the object aimed at was not attained.

The wrath poured by Washington on Lee, in a few blasting words, was a revelation of fierce temper kept usually in subjugation by a strong self-command. The culprit, ordered to the rear, was court-martialed and leniently deprived of command for a year, but afterward dismissed from the army, and did mischief no more.

126. Washington again guarding the Hudson. 1778-1779. Clinton and his army made their way to New York, and Washington stood on guard again by the Hudson River, to keep the British from breaking communications between New England and the other States. From the beginning to the end of the war, that was his vitally important task, on which all other campaigning must depend. He now hoped to trap the enemy in New York, with the help of a French fleet and French troops; but when the fleet came, in July, its largest vessels could not cross the bar, and the project was given up Count d'Estaing, the lles, JulyFrench com November, French commander, then joined in an attack $\mathbf{1 7 7 8 .}$ on the British at Newport, which, outside of New York, was their sole foothold in the thirteen States; but the undertaking failed.

127. Tory and Indian Raids on the Frontier. - Sullivan's Expedition to Western New York. 17781781. Extensive operations of war in the Northern States were now given up by the British military authorities, who turned their attention to the south; but a purely revengeful and vindictive warfare against frontier settlements in New York and Pennsylvania was 
carried on by Tories and savages in British pay. Tory inhabitants of the New York border, driven from their homes, had gathered in the neighborhood of Fort $\mathrm{Ni}$ agara, both in Canada and in western New York. The Mohawk Indians went with them, and the Senecas and The Butlers Cayugas were their allies. Numerous raids by and Brant. Tory rangers and Indians were made from the Niagara region, on the border settlements within reach, the active leaders being Colonel John Butler, his son Walter, and the Mohawk chieftain, Thayendanegea, or Joseph Brant. There were fearful atrocities committed in some of these raids, most horribly in the valley of

Wyoming and Cherry Valley massacres,

July-November, 1778. Wyoming, northeastern Pennsylvania, where Butler's rangers and a band of Senecas destroyed a Connecticut settlement in July, I 778. Hardly less infamous was the destruction of a settlement in Cherry Valley, New York, in November of the same year, by Tories and Indians under Walter Butler and Brant. Formerly Brant was held chiefly accountable for the savagery of this border warfare, but historical investigation has cleared him of the charge. He appears to have been more civilized than most of the white men with whom he served. $\mathrm{He}$ was not present at Wyoming, and his warriors at Cherry Valley are said to have had little or no hand in the butchery that was done. In excuse for the Butlers it is said that they could not restrain their Indian allies; but they gave opportunities to the savages which they knew would be improved.

To check this barbaric warfare, General Sullivan, with 5000 men, was sent by Washington, in the summer of $\mathrm{I} 779$, to ravage the country of the hostile tribes, and to drive the Tories from their stronghold on the Niagara. After one engagement near Elmira (formerly called 
Newtown), where I 500 British troops, Tory rangers, and Indians were defeated with heavy slaughter, Sullivan's forces swept over the lands of the Cayugas and Senecas, in the lake region of central New York and in the fertile valley of the Genesee, destroying General villages and corn-fields, with such effect that those tribes never recovered their strength. But Fort Niagara was not reached, and a dreadful harrying of the Mohawk valley and other border regions went on through 1780 and I $78 \mathrm{I}$.

\section{Conquest of the Northwest by George Rogers}

Clark. 1778-1779. A more important expedition into the wilderness of the west had been undertaken in the previous summer (I778) by a bold young surveyor, George Rogers Clark, commissioned by Governor Patrick Henry, of Virginia. In the last few years many settlers had gone into the Ohio valley, James Harrod, Daniel Boone, and other pioneers having begun the actual occupation of Kentucky in I774 and I775. Colonel Hamilton, commanding at Detroit, was known to be inciting the Indian tribes of the region to a combined attack on these frontier settlements, and Clark offered to undertake the expulsion of the British from their whole western domain. Authorized by Governor Henry, he enlisted about I 80 hardy riflemen, with whom he descended the Ohio to the Mississippi and passed up the great river, surprising and occupying the posts at Kaskaskia and Kahokia - the latter near the site of St. Louis. In the following winter, hearing that Hamilton was at Vincennes, on the Wabash, gathering a force of Indians and whites, he made a wonderful march capture of across country and captured him there. Clark Vincennes, expected reinforcements to join him for an $\mathbf{2 4 , 1 7 7 9}$. expedition against Detroit; but they were diverted to 
attack a body of Indians "on the war path," at Chickamauga. Even without the capture of Detroit, the conquests of Clark gave the States a claim to the northwest which had great importance when boundaries were settled at the close of the war.

129. Stony Point. - British Subjugation of Georgia and South Carolina. 1779-1780. After their retreat from Philadelphia in 1778 , the British attempted nothing with their regular forces at the north, except some destructive raids along the coast, until the end of May, I779, when Clinton captured a small fort which the Americans were building on the Hudson, at Stony Point.

\section{Storming} of Stony Point, July 15,1779 .

It was retaken three weeks afterward by General Wayne (called "Mad Anthony"), whose storming of Stony Point, by the use of the bayonet and without firing a shot, was one of the famous exploits of the war.

The military energies of the British were now being directed almost solely to the subjugation of the Southern States. At the end of December, 1778, Savannah was taken by a force from New York, and Georgia was practically subdued before spring. General Lincoln, who had won distinction in the campaign against Burgoyne, now commanded the Continental forces in the south; but they were too weak for effective use.

In September the French fleet, under Count d'Estaing, which had been in the West Indies since the fall of I 778 , came back to the American coast, and a joint attack on Savannah was arranged between Lincoln and Slege of d'Estaing. For three weeks regular siege opSeptember-
October, commander, fearing autumnal storms, insisted 1779 .

upon an assault (October 9, I779), which failed disastrously, entailing a loss of 1000 men. Among the 
killed was Count Pulaski, a distinguished Pole, who entered the American service in I777. The sicge was abandoned and the French fleet withdrew.

Sir Henry Clinton was now prepared to enter the southern field in person for a vigorous campaign. In December he sailed from New York for Savannah, with 8000 men, followed by 3000 more. General Lincoln, who had but 7000

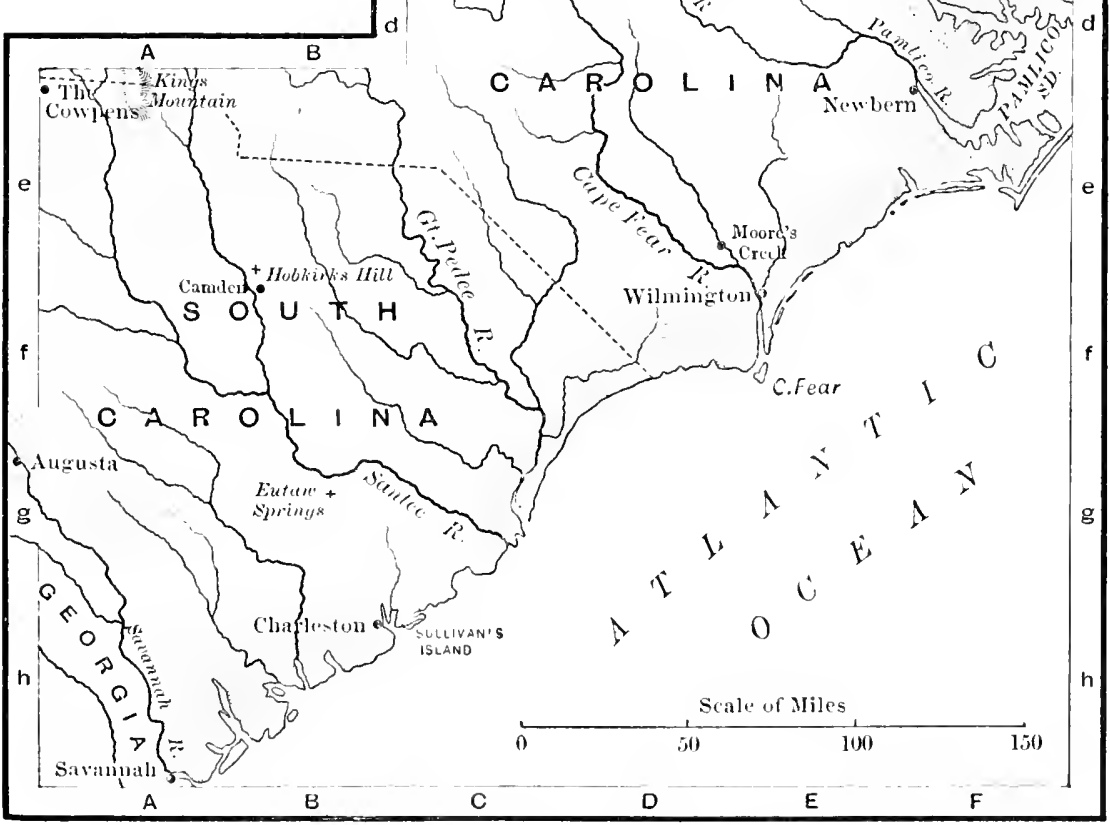

THE SFAT OF WAR IN THE SOUTH.

troops, mistakenly allowed them to be shut up in Charleston, which Clinton invested early in the spring of I $7 \mathrm{SO}$. By the I2th of May Lincoln's situation had become 
hopeless, and the city, with the whole American army,

Surrender
of Charles ton, May

was surrendered that day. Within a few weeks the British were in possession of the entire State, and Clinton, with most of his army, returned to New York, leaving Lord Cornwallis in command in the south.

130. Naval Warfare. - Exploits of Paul Jones. 1779. Naturally, in the early years of the war, the Americans could do little at sea. A feeble navy of cruisers was set afloat and a number of privateers received letters of marque; but the British were able to strike harder blows at American commerce than the Americans could strike in return. The latter gained something in naval strength from the French alliance, by obtaining ships and equipments and by having the free use of French ports. It was then that the Scottish sailor, Captain Paul Jones, commissioned by the Continental Congress, began to distinguish himself by the daring and success of his operations on the British coasts. In I 779 he was put in command of a small squadron which Franklin had fitted out in France. His flagship was an old ressel built for the India trade, slightly altered and re-named the Bon Homme Richard. On the $23 \mathrm{~d}$ of September Jones encountered two British frigates, convoying a large fleet of merchant ships. With the Bon Homme Richard he attacked the larger of the two, the Serapis, while one of his consorts fought the other. The battle which then took place between the two principal ships was one of the most

The Bon

Homme

Richard

and Se-

rapis,

September,

23, 1779 . desperate ever fought. Before it ended the two ressels were lashed together, with the muzzles of their guns almost touching each other's sides; both were on fire, and more than half the crew of each were helplessly wounded or dead. Sheer 
exhaustion forced the Serapis to surrender at last. The Bon Homme Richard was in a sinking state, and went down the next morning, soon after the survivors of her crew had been transferred to the captured ship. By his daring operations Paul Jones gave a serious check to British trade.

131. Deplorable State of South Carolina. - Disastrous Campaign of Gates. May-August, 1780. After the surrender of Charleston, it fell to the lot of South Carolina to suffer the bitterest experience that was undergone by any State. Clinton and his successor, Cornwallis, pursued a policy which outlawed a large part of the people, who would not swear allegiance and give active support to King George. Such patriots were hunted by British troops and Tory partisans, their property destroyed or confiscated, their families and friends cruelly abused. No general combination among them could be formed, and they were gathered in small bands, under leaders of remarkable ability and skill, carrying on a harassing warfare, of the partisan or guerrilla kind. The exploits and adventures of some of

Partisan warfare. those bands, under Francis Marion, Thomas Sumter, James Williams, Andrew Pickens, and other famous captains, furnish many romantic tales to the history of the time. Colonel Tarleton, who was notorious for brutality, and Major Ferguson were the commanders most active against them on the British side.

It was Washington's wish that General Greene, his most capable lieutenant, should succeed Lincoln in the southern command; but Congress, with unpardonable perversity, took the selection from him and appointed its unworthy favorite, Gates. From his own dwindled forces in the north the commander-in-chief had sent some 2000 well-tried troops to the Carolinas, under Baron De Kalb. 
Gates reached them, at Hillsborough, North Carolina, in July, and was joined there by a few militia, forming altogether a little army of about 3000 men. With this he

Battle of

Camden

August 16, rushed forward into South Carolina, and wrecked his army utterly in a blundering battle at Camden (August i6, I780), from the field of which he was one of a small number who escaped. The brave De Kalb fought hopelessly until he had received mortal wounds.

132. Discouraging circumstances of the Country. 1780. This ended the accidental reputation of Gates. Even Congress gave him up, and Washington was permitted, a few weeks later, to put Greene in his place. But the dreadful defeat at Camden had been a dangerous blow to the American cause. It came when the circumstances of the country were in their most discouraging continental state. The paper money poured out by Concurrency. gress, based on nothing but a promise, and even the promise made by no substantial authority, had lost all worth. Washington had to levy forced contributions on the surrounding country to feed his men. Practically they had no pay, and little prospect of any to come. Desertions were increasing and new recruits were hard to obtain.

In July there was a momentary gleam of cheer, caused by the arrival of 6000 French troops, under Count de Rochambeau, sent as the result of a visit made by Lafayette to France. More were to follow, but a British fleet

Rocham-

beau's army.

blockaded them in Brest, and they never sailed. Thus far the French alliance had been sorely dis-

appointing: some increased aid in loans and helpful supplies, and some diversion of English forces to other fields of war, had been its only fruit ; but now there was hope that Washington would be enabled to strike 
important blows. It was a hope that soon sank. The French fleet that brought Rochambeau's army to Newport was immediately blockaded by a British squadron in Narragansett Bay, and the French troops were kept near at hand to support it against expected attack. A whole year was yet to pass before Washington would be able to make use of this reinforcement from France.

133. Attempted Treason of Benedict Arnold. September, 1780. And now came the appalling disclosure of a plot of treason in the army, from which the country had made but a hairbreadth escape. The traitor was Benedict Arnold, whose record as a soldier had been unsurpassed in brilliancy by any made since the war began. In the expedition to Canada, in defending Lake Champlain against Sir Guy Carle-

Cause of Arnold's treason. ton, and in the battles which accomplished the defeat and capture of Burgoyne, his services had entitled him to a promotion which politicians in Congress gave to less deserving men. He resented this treatment, and later circumstances, arising while he held command at Philadelphia (June, I 778-March, I 779), increased his feeling. At length, in his bitterness, he projected a great act of treason, to avenge what he deemed to be his wrongs. His first step was to ask for and obtain the command at West Point, on the Hudson River, which had been fortified strongly and was much the most

West Point. important American post. To lose it was to lose the river, and probably to ruin the American cause. In secret correspondence with Sir Henry Clinton, Arnold planned to betray this citadel of the Hudson to the enemy. On the 22d of September he arranged the last details of the plan with Major André, a young major officer of Clinton's staff, who ventured to meet André him inside of the American lines. As the unfortunate 
André returned from that meeting, he was caught, and papers found on his person disclosed the plot. Arnold got news of André's capture in time to escape and make his way to New York, where he received a British commission, and did service against his own countrymen in barbarous raids during the remainder of the war. It was André, the young British officer, who had to pay the penalty for the traitor's crime, since stern military law required his execution as a spy.

134. The Southwestern Mountaineers to the Rescue. October, 1780. The shock of the discovery of Arnold's treason was the last painful experience of a gloomy year. It was followed soon by a great uplifting change in the situation at the south, coming from an unlooked-for source. After his overwhelming victory at Camden, Cornwallis expected to subjugate North Carolina with ease, and moved his main army into that State. Before doing so he sent his partisan commander, Ferguson, into the hill region on the border of the two Carolinas, to enlist Tory recruits and to hunt down the armed Whigs. In carrying out his mission Ferguson pushed so far into the western wilderness that he stirred up those people of the mountains, - the Scotch-Irish and Huguenot frontiersmen of western North Carolina, western Virginia, and eastern Tennessee, - who had been busy fighting and watching their Indian neighbors, and had taken no part hitherto in the war on its eastern side. These formiclable riflemen now swarmed out of their

Battle of

King's

Mountain, 0ctober 7, 1780. mountain settlements, put Ferguson to flight, and pursued and surrounded him on a rocky ridge called King's Mountain, which he thought he could hold, with his I Ioo men, against any possible attack. But the irresistible mountaineers stormed the height; Ferguson and 400 or more of his followers 
were killed and woumded; the remainder surrendered; the Tories of the "up-country" were crushed.

135. Greene's Campaign in the Carolinas. 17801781. The southern situation was greatly changed by this unexpected event. Cornwallis's plans were frustrated and he fell back. Both British and American troops were sent southward from the northern commands, and early in December Greene superseded Gates. He had several finc officers to assist him, including Danicl Morgan and Ilenry Lee, the latter a splendid cavalry officer, father of the more famous Robert E. Lee. Morgan, sent westward with 900 men, opened the new campaign by nearly destroying a more than equal force under: 'Tarleton, in a remarkably managed battle, fought at a place called the Cowpens, on the I 7 th of January, i $78 \mathrm{I}$. Cornwallis then moved in pursuit of Morgan, and was led nearly to the

\section{Battle of} the Cowpens, January 17,1781 . Virginia line, in a baffled effort to keep Morgan's forces from being reunited with Greene's. Greene gave him battle at Guilford Court House (March 15), and Battle of failed to drive him from his ground, but so Gullford crippled him that he retreated to Wilmington House, three days afterward, to be within reach of the British fleet. Greene then marched straight into South Carolina, while Cornwallis went off to Virginia with the main body of his troops, but left forces in South Carolina as strong as Greene's. Two considerable battles were fought during the next six months, at Hobkirk's Hill, April 25, and at Eutaw Springs, September 8 . The Americans were defeated in the first, and could not claim a victory in the second ; but they gained all the fruits of success. At the end of their campaign the British held no ground in South Carolina save the city of Charleston, and the state government was restored. Military critics 
hare greatly praised the greneralship by which Greene accomplished these results.

136. The Beginning of the End. - Yorktown. May-October, 1781. Meanwhile, in Virginia, the grand crisis of the war was clrawing near, - the master-stroke was being prepared. When Cornwallis, quitting the Carolinas, brought his main command to Petersburgr, Virginia, joining a considerable body of troops there, he was only opposed by a little army of about 3000, mostly militia, under Lafayette. But Steuben was in the State, rapidly raising and organizing an increased force. Lafayette retreated, and Cornwallis pursued him nearly to the Rapidan, but, after some overrumning of the country, turned back to the seaboard, finally placing his army at Yorktown (August, i $78 \mathrm{I}$ ), on the peninsula between the York River and the James. This brought him into easy communication with Sir Henry Clinton, at New York, and the position was one of safety so long as British flects controlled the sea. It happened, however, that a French

The coming of the French fleet. flect, stronger than the British naval force in American waters, was coming from the West Indies to Chesapeake Bay at just this time. Its coming had been arranged for with the French admiral, Count de Grasse, by Washington and Rochambeau, some time before. P'rimarily, they had planned to have its help in a combined attack on New York; but when Washington learned of Cornwallis's movements, he saw his opportunity for taking the army of that general in a trap. Keeping Sir Henry Clinton deceived by movements which seemed to threaten New York, he suddenly transferred 2000 of his own troops and 4000 of Rochambeau's, with great secrecy and celerity, from the Hudson to the James. They were marched to the head of Chesapeake Bay and conveyed thence by shipping to 
the peninsula above Yorktown, where Lafayette, who had followed Cornwallis, with an increased forec, was already entrenched. Already, too, the French fleet was in possession of the bay, a British squadron had been driven off, and 3000 French soldiers from the West Indies had been landed to strengthen Lafayette. The trap was effectually sprung, and the whole scheme had been carried out so skilfully that the British commanders suspected nothing of what was on foot until too late to interfere.

Washington reached Lafayette's headquarters on the I $4^{\text {th }}$ of September ; his forces from the north arrived between the I 8 th and the 26th, and siege operations were begun. Cornwallis held out until the 17 th of October, when the hopelessness of his situation was confessed by raising the white flag. On the Igth he gave up his sword, and his men,

\section{Cornwal.}

lis's sur-

render,

October 19,

1781. 7247 soldiers and 840 seamen, laid down their arms, as prisoners of war.

137. Peace. In reality that surrender was the ending of the War of Independence, though partisan hostilities were kept up, especially in the south, and though British and American armies confronted each other for many months more, while Charleston and New York were still in the enemy's hands. King George's obstinacy postponed for a few months, but it could not prevent, the beginning of steps toward an arrangement of peace. Parliament forced it on. Lord North and his ministry were driven to resign on the 20 th of March, I782, and King George was compelled to accept Lord Rockingham for prime minister, with a Whig cabinet, made up mostly of statesmen

Resigna-

tion of Lord North, March 20, 1782. who had steadily opposed the American war and the measures that brought it about. An agent, Mr. Oswald, 
sent to Paris by one of the new ministers, Lord Shelburne, conferred at first with Franklin alone. This led

Peace negotlations at Paris.

to more formal negotiations, in which John Jay, John Adams, and Henry Laurens were associated with Dr. Franklin as commissioners empowered by Congress to represent the United States. At the same time Lord Shelburne, who became prime minister in July, opened peace negotiations with France and Spain. In the course of the subsequent parleyings the American commissioners found reason to believe that Vergennes, the French minister, was more than willing to weaken the future growth of the United States by making the Alleghanies their western boundary, and that Spain had the same end in view. That led them to cease counselling with Vergennes, and their further negotiations with the British ministers were carried on in a private way, until agreements were reached and the articles Treaty, No of a treaty signed provisionally on the 3oth of vember 30, November, I 782. It was not to have effect until 1782 , and September 3,1783 .

the settlement of peace between Great Britain and France. When that came to pass, the same treaty, unchanged, was signed on the 3 d of September, $I_{7} S_{3}$, and was ratified on both sides.

138. Terms of the Treaty of Peace. The United States secured western territory to the Mississippi, and from the Floridas to the Great Lakes; but the eastern and western extremities of the northern boundary line were so imperfectly described in the treaty that dis-

Boundaries and fisherles.

putes about them lasted for many years. In the important matter of fisheries, the Americans were given equal rights with British fishermen to take fish on all the British-American coasts. Concerning the American loyalists or Tories, who had sided with the mother country in the conflict, a question of great 
embarrassment arose. Feeling against them was so bitterly unforgiving in many States that they had been and were being driven into exile, with confiscation of their property, wherever they lost the protection of the British arms. It was not only cruel treat- Treatment ment, but unwise, as we look at it now. It is of American
loyalists. certain that the loyalists mistook what was right and best, in opposing separation from the British Empire; but it is equally certain that a large number of them did so conscientiously, and would have accepted the result of the war in good faith, becoming citizens as loyal to the new republic as they had been loyal to the king. Many of them were persons of character, of culture, of capability, of importance in their occupations and their means, and the country suffered a serious loss when it drove them out. But many others of the Tory faction, especially in New York and the Carolinas, had been malignantly and barbarously active in the war, and had excited a hatred that extended to the whole loyalist class. Great Britain felt bound to provide in the treaty for the protection of these people, its partisans; but the feeble government of the United States, as then constituted, could only promise to recommend to the several States that they restore confiscated property and allow exiled loyalists to return to their homes. It did so, and fulfilled the promise, but with no effect. It was equally powerless in another matter which the treaty touched, relating to the payment of debts that were due to British creditors when the war broke out. The obligations of the treaty were totally disregarded in most of the States, and their action provoked the British

Debts to British creditors. government to keep possession of several forts in the west for many years.

It has been estimated that the loyalists who left the 
United States during or immediately after the War of Independence numbered no less than Ioo,ooo. From The exiled New York alone i2,000 went a short time loyalists. before the British evacuation of the city, in I783. For the most part they found hones in Nova Scotia and Canada, where they received grants of land, and in the Bahamas, which attracted many from the south.

139. Dissolving the Continental Army.- Retirement of Washington. 1781-1783. Until the terms of peace between Great Britain and France were agreed upon, in January, $\mathrm{I}_{7} S_{3}$, and until news of that agreement reached America, late in March, the American and British forces were both kept under arms. A cessation of hostilities was then proclaimed on both sides. Washington communicated the proclamation of Congress to the army on the Igth of April, exactly eight years from that day at Lexington when the war began. Most of the soldiers were then permitted to return to their homes.

In the last year of its service there had been increasing disaffection in the army, and nothing but the potent influence of Washington had prevented some riolent Discontent outbreak. The pay of the soldiers was far in of the army. arrears, and they feared that, if disbanded, no attempt would be made to meet their claims. To keep his experienced officers, Washington had persuaded Congress to promise half-pay for life to those who served until the end of the war; but there seemed to be less and less prospect that Congress would be able to make its promise good. Mean spirits were ready to work upon every doubt and every fear. Gates was again a leader among these, and one of his staff, Major Armstrong, wrote an inflammatory address which was circulated in 
the camp at Newburgh (March I I, I 783), calling for a general meeting of the army to discuss its wrongs. Washington foiled the dangerous design by making the meeting an official one and address- $\begin{gathered}\text { The New- } \\ \text { burgh ad- }\end{gathered}$ ing it himself, in terms which shamed the mal- $\begin{aligned} & \text { dress, } \\ & \text { March, } \\ & 1783 .\end{aligned}$ contents. He then induced Congress to commute the promised half-pay for life into a sum equal to full pay for five years, and to offer it immediately in certificates bearing interest at six per cent. The commutation, though much denounced in the country, proved generally acceptable to the officers, and mutinous disaffection was checked. Enough remained, however, to be dangerous still, as appeared three months later, when an outbreak of eighty soldiers in Pennsylvania drove Congress from Philadelphia to Princeton in fright.

These and some prior demonstrations among the soldiers gave rise to much distrust of the army, as the time for its dissolution drew near. The feeling was increased when, in the spring of 1783 , a secret society, or brotherhood, called the Order of the Cincinnati, ${ }^{1}$ was formed among the officers of the army and navy, to be perpetuated by their sons, for the innocent pur- cinclnnati. pose of keeping alive the friendships and associations of their service in a common cause. Some sinister design in the organization was suspected, especially that of seeking to establish an hereditary aristocracy; and the order was so fiercely denounced that the hereditary feature of its constitution was given up by many state societies, but not by all. It has an existence still in several States.

New York remained in the possession of the British

1 So named to suggest the likeness of its members to Cincinnatus, the Roman, who left his plough to command the army of his country, and returned to it when the campaign was closed. 
until the 25th of Norember, when the last of their troops

British

evacuation

of New

York, No-

vember 25,

1783. sailed away. On the $4^{\text {th }}$ of December Washington took leave of his officers and departed for his home at Mount Vernon, receiving proofs at every stage of his journey that the immeasurable greatness of his service to the country was well understood. At Annapolis, where Congress was then sitting, he resigned his commission and asked leave to retire to private life. He submitted a statewashing- ment of moneys that he had expended from his ton returns to private

life.

private fortune during the war, amounting to $\$ 64,3$ I 5 , for which he desired reimbursement; but of pay for his personal services he would take none. On Christmas ere he reached the home which he had seen but once in eight years.

TOPICS AND SUGGESTED READING AND RESEARCH.

\section{Lexington and Concord. - "The Shot heard} round the World."

TOpICS AND REFERENCES.

r. Gage's attempt to seize Adams and Hancock at Lexington and destroy stores at Concord. 2. Paul Revere's ride. 3. The first bloodshed of the war on Lexington Green. 4. Fighting at Concord and British retreat. 5. The New England rising. - Gage beleaguered in Boston. 6. Character of the besieging army. Frothingham, Siege of hoston, ch. ii.: Fiske, $A$ m. Rer', i. I20-126; Bancroft, iv. I 52-166: Hosmer, Adams, 329-331; Sloane, i $83-187$.

\section{Effect of the News.}

TOPICS ANI REFERENCES.

r. Effect of the news in the middle colonies. 2. Uprising in Virgrinia and the Carolinas. Bancroft, iv. $176-1 s ı$; Hildreth, iii. 69-74; Frothingham, kise of the Rep., 415-4Is; Tyler, Hensy, ch. x.; McCrady, ii. ch. xli. 


\section{Capture of Ticonderoga and Crown Point.}

Tol'ics AND REFERENCES.

r. Connecticut origination and Vermont undertaking of the expedition. 2. What it gave to the patriots. Robinson, ch. vii.; Hall, ch. vi.-vii.; Fiske, $A$ m. Rev., i. 129-I32; Hildreth, iii. 74$76 ;$ Bancroft, iv. ${ }_{1} \$_{2}-1 \$_{3}$.

\section{Second Continental Congress. - Appointment of Washington to Chief Military Command.}

TOPICS AND REFERENCIES.

I. Leading members of the Congress. 2. Declaration of the causes of armed resistance. and petition to the king (text in MacDonald, i. 374-3\$5). Bancroft, iv. 190-192, 199-200; Morse, Adans, 87-93.

3. Adoption of the forces in arms as a "Continental Army." 4. Appoincment of Washington to chicf command. 5. His unique greatness. 6. Other military appointments. Washington, ii. 476493; Adams, ii. 4I5-4I8; Lecky, iii. 465-472; Bancroft, iv. 204213; Fiske, Am. Rov', 133-136; Morse, Adams, 93-100; Lodge, Washington, i. 131-133; Sloane, 195-199.

7. Failure of Congress to assume needed powers. Holst, Const. Laze, 6-12; Johnston, United States, 56-57; Frothingham, Rise of the Rep., 42I-428.

ResearCh. - Foreign estimates of Washington. Guizot, Essay;

F. Harrison, Washington, 3-27; E. A. Freeman, 62-103.

\section{Bunker Hill.}

Tolics And ReFEREnCEs.

I. Fortification of lireed's Hill. 2. Unsuccessful assaults by the British troops. 3. Reasons for their final success. 4. Why the American cause suffered no effect of defeat. Frothingham, sicge of Boston, ch. iv.-vii.; Carrington, Battles, ch. xv.-xvii.; Fiske, Am. Kc\%., i. 136-146; Bancroft, iv. 213-231; Sloane, 199-202.

\section{Washington's Task. - Expeditions to Canada.} TOPICS AND REFERENCES.

r. State of the American army besieging Boston. 2. Washington's difficulties, and the primary cause of them. Washington, iii. 8-70, 245-249; Carrington, Washington, ch. v.; Fiske, Am. 
Re'., i. I47-157; Bancroft, iv. 239-243. 247-250: Lecky, iii. 482488 ; Frothingham, Sicse of Boston, eh. viii.-xi.; O. S. Leaf., 47 ; Lodge, Hishington, i. 133-1 4h.

3. The expeditions to Canada. Carrington, Battles, xx., xxi.; Robinson, ch. viii.; Hall, ch. x.-xiii. ; Fiske, Am. Rev., i. 165-169; Bancroft, iv. 29I-308: Washington, iii. 121-127.

\section{Ripening of the Public Mind for Independence.}

TOPICS ANI REFERENCES.

1. King (ieorge's proclamation of rebellion. 2. His hiring of Hessians and the effect in America. E. J. Lowell, ch. i.-v. ; Bancroft, iv. 269-272, 276-279, 347-358; Fiske, $1 \mathrm{~m}$. Rev., i. I 72, I 73.

3. Movements in Congress toward declared independence: Advice to colonies. - Correspondence with foreign powers. 4. Act of Parliament against American commerce. 5. Paine's pamphlet entitled "Common Sense." Frothingham, Rise of the Rep., 4+5489; Lecky, iii. 494-49S; Winsor, America, vi. ch. iii.: Bancroft, iv. 3ro-3I6, 359-37I ; Sloane, 2II-2I4; Hart, Contemp's, ii. 500504 .

RESEARCH. - Life and character of Thomas Paine. Sedgwick, Paine; Fiske, Am. Rev., i.

\section{Boston given up by the British.}

\section{TOPICS AND REFERENCES.}

r. Washington's difficulties in the siege. 2. How he forced the British out. Washington, iii.3 I3.444-470, 475-48 I : Frothingham, Siege of Boston, ch. xii.; Carrington, Hashington, ch. viii. : Fiske, Am. Rev., i. 169-172; Bancroft, iv. 322-331; Lodge, Hishington, i. I $4 S-15$ I;O. S. Leaf., 86 .

\section{War in North Carolina. - Demands for a Decla- ration of Independence.}

TOPICS ANI REFERENCES.

r. Battle of Moore's Creek with 'Tory Scotch Highlanders. 2. Frustrated British plans. 3. Action in the Carolinas and Georgia favoring independence. 4. Action in other colonies. Virginia Declaration of Rights (text in Larned, Ready Ref., lir-

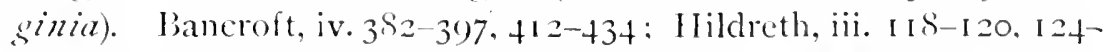
127, I3I-I32; Frothingham, lise of the Kep., +99-530; Fiske, 4m. Rew., i. I 75-190; NacLean, ch. v. 
5. The situation in New York. - Its military importance. Strength of the Tories. Sabine, i. ch. iii.; Flick, ch. i.-v.

RESEARCH. - Military importance of the line of the Hucison River.

Washington, vi.231-232; Mahan, Sea Power in Hist., 342-343.

\section{Independence Declared.}

TOPICS AND REFERENCES.

r. The composition, adoption, and signing of the Declaration of Independence (text in MacDonald, ii. I-6;O. S. Leaf., 3; Am. Hist. Leaf., I ; Larned, Ready Ref.). 2. Formation of state governments. Higginson, ch. xi.; Frothingham, Rise of the Rcp., 532-558; Morse, Jefferson, 32-40, and Adams, i24-129; Hildreth, iii. I32-1 $3 S$; Bancroft, iv. I I2-125, 435-452.

\section{British Repulse at Charleston.}

TOpics AND REFERENCES.

I. Colonel Moultrie's fort. 2. His repulse of the British attack. Carrington, Battles, ch. xxviii.; McCradly, iii. ch. vii.; Bancroft, iv. 397-4I ; Fiske, Am. Rez., i. I98-200.

118. Battle of Long Island. - Retreat of Washington from New York and through New Jersey.

Topics ANI References.

r. British capture of New York and Washington's retreat. 2. Invasion from the north checked by Arnold. 3. Criticism of Washington and intrigues against him. 4. Washington's retreat through New Jersey. 5. The "times that try men's souls." Washington, iv. 362-376, v. I-I 26 ; Carrington, II'ashington, ch. ix.-xiii., and Battles, ch. xxix.-xxxvii.; Winsor, Ameria, vi. 275293 ; G. W. Greene, Greene, ii. I 52-295 ; Fiske, Am. Rez., i. I98229, and Essays, 78-83; Bancroft, v. 24-87; Hildreth, iii. ch. xxxiv.; Lecky, iv. i-25; Lodge, Washington, i. I 54-174; Hart, Contemp's, ii. 559-562; Sloane, 238-250.

119. The Situation changed. - Washington turning upon his Pursuers.

TOPICS ANI REFERENCTS.

r. Position of the two armies near the Delaware. 2. Washington crosses the Delaware. 3. Battles of Trenton and Princeton. 
- Recovery of lost ground. 4. Effect of the brief campaign. Help secured from France. Washington, r. I27-170; Carrington, Washington, ch. xiv.-xv., and Battle's, ch. xxxriii.-xli.; Winsor, Amerian, vi.367-379; Hildreth, iii. ch. xxxv.; Fiske, Am. Rev., i. 229-24I ; Bancroft. $\therefore$. 8S-1 10; Lecky, iv. 27-56: Lodge, It ashington. i. 174-179; Morse, Franklin, 219-239; Sloane, 251-264.

\section{Burgoyne's Invasion. - Capture of his Army. - Undeserved Credit to General Gates.}

TOPICS AND REFERENCES.

I. Object of the British invasion from the north. - The two lines of the morement. 2. Burgoyne's success in the beginning. 3. British emplorment of Indians. 4. Country people in arms. Their victory at Bennington. 5. Failure of St. Leger. - Siege of Fort Stanwix and battle of Oriskany. 6. Failure of Howe to move up from New York and meet Burgoyne. 7. Desperate situation of Burgoyne. 8. The two battles on Bemis Heights. - Burgoyne's surrender. Carrington, Battles, ch. xliii.-xlviii.; Fiske. Am. Rev.. i. 260-298. 325-343: Bancroft, v. 157-173. 1S2-191; Hildreth, iii. 196-21 5: Lecky, iv. 63-69; Sloane, 265-271. 275-279: Stone, i. ch. ix.-xiii.: Robinson, ch. xi.-xii.: Hart, Contemp's, ii. $56,5-568$.

9. Unmerited credit to General Gates and its mischicrous effects. Fiske, $A$ m. l'er', i. 296-297; Jildreth, iii. 215.

\section{Why and how General Howe was kept from meeting Burgoyne.}

TOPICS ANI REFERENCES.

r. What carelessness and want of judgment brought about. 2. Washington's mancuvring to keep Howe engaged. 3. American defeat at Brandywine. 4. The British win Philadelphia. 5. Washington's frustrated attack at Ciemantown. Washington, r. $435-438,+44-412.502-504$. 507-50S, vi. I-29. 45-8S, 93-103; Carrington, Il ashington. ch. xviii.-xix., and liattles. ch. xlix.-lii.; Mahan, Sea l'ower in Hist., 3+3-34t: Winsor, America, vi. 379389); Fiske, $A$ m. Le'í.. i. 299-324; Bancroft, v. I74-ISI, I92-199; Lodge, thashington, i. 18S-196. 
122. Intrigues for Gates against Washington. - The Conway Cabal.

TOPICS AND REFERENCES.

x. Shallowness of the criticism of Washington. 2. Declining character of the Continental Congress. 3. The "Conway Cabal." Washington, vii. 39; Fiske, Am. Rev., ii. ch. ix.; G. W. Greene, Greene, ii. I-40 ; Bancroft, v. 210-2I 2, 2I 4-2I 7 ; Hildreth, iii. 232237 ; Lodge, Washington, i. 206-22 I.

\section{The Winter at Valley Forge. - State of the Country.}

TOPICS AND REFERENCES.

r. Position of Valley Forge. 2. Washington's report of the condition of the army. 3. Causes of the ill state of things. Washington, vi. 252-268, 300-351, 357-360, 379-383 ; Fiske, Am. Rev., ii. 25-3I ; Lecky, iv. 60-63; Bancroft, v. 2I 2-22I ; Tower, i.ch. x. ; Carrington, Washington, ch. xx.-xxi.; Hart, Contemp's, ii. 568573.

4. The "Continental currency." - Financial state of the country. Bolles, i. ch. iii., and ix.-xiii.; Sumner, The Financicr, ch. iv., and Am. Currency, 43-50.

5. Lafayette, Steuben, Hamilton. Tuckerman, ch. i. I4-26; Kapp, ch. v.; Lodge, Hamilton, I4-26; Fiske, Am. Rev., ii. 5055 ; Hart, Contemp's, ii. 485-488; O. S. Leaf., 97-98.

\section{Treaty of Alliance with France. - Peace Over- tures from England.}

TOPICS AND REFERENCES.

I. Alliance with France and pledges given. 2. Peace overtures from England. 3. Demands in England for peace. Morse, Franklin, 266-285; Winsor, Westward, ch. ix. ; Fiske, Am.Rev., ii. ch. viii.; Tower, i. ch. ix.; Hildreth, ii. 239-249; Bancroft, v. $244^{--253}$

125. British Evacuation of Philadelphia. - Battle of Monmouth. - Treachery of Charles Le日.

TOPICS AND REFERENCES.

r. Circumstances leading to the battle at Monmouth. 2. Treachery of Lee while Howe's prisoner. - His conduct at Monmouth. 
3. Generalship and discipline shown in the battle. 4. Lee courtmartialed. Washington, vii. 66-97; Carrington, Washington, ch. xxii., and Battles, ch. liv.-lvii.: Fiske, $A m$. Rev., ii. 56-71, and Essay's, i. 83-95; Lodge, Washington, ii. 226-233; Bancroft, v. $271-278$; Sloane, 295-298.

126. Washington again guarding the Hudson. Topics ANd References.

r. Washington's main task in the war. 2. Unsuccessful coöperation with French fleet and troops. Fiske, Am. Rer', ii. 72-80; Lodge, Washington, i. 234-249; Bancroft. v. 284-285.

\section{Tory and Indian Raids on the Frontier. - Sulli- van's Expedition to Western New York.}

Topics AND References.

I. Character of the warfare waged by Tories and Indians on the frontier. 2. Joseph Brant and the Butlers. 3. Wyoming and Cherry Valley. 4. Sullivan's expedition. Winsor, America, vi. ch. viii.; Stone, ii. ch. i. ; Roberts, ii. 426-432; Fiske, Am. Rer', ii. $82-94$.

\section{Clark's Conquest of the Northwest.}

TOPICS AND REFERENCES.

I. P'rogress of settlement in the Ohio valley. - Pioneers of Kentucky. Roosevelt, The Winning, i. ch. x.; Winsor, Westridrd, I3-2I, and ch. iv., viii.; Drake, Ohio Valley States, 93-I 30.

2. Hostile plans of the British commander at Detroit. 3. George Rogers Clark's campaign. 4. Importance of Clark's conquests. Roosevelt, The Winning, ii. ch. i.-iii. and viii.: I) unn, ch. iv.; Hinsdale, Old $N$. It ., I 52-159; Fiske, $4 \mathrm{~m}$. Rer., ii. Iог-гоo; O.S. Leaf., 43; Bancroft, v. 309-3ı6; Hart, Contemp's, ii. 5795 s.

129. Stony Point. - British Subjugation of Georgia and South Carolina.

TOPICS AND REFERENCES.

I. Loss and recovery of Stony Point. 2. British efforts concentrated on the south. 3. Failure of a second coöperative undertaking of American and French forces. 4. Surrender of Ameri- 
TOPICS, REFERENCES, AND RESEARCH. 245

can army at Charleston. Carrington, Battles, ch. xli.-lxiii.; McCrady, iii. ch. xix.-xxiii.; Winsor, America, vi. 460-474; Lecky, iv. 127-130; Hildreth, iii. 274-282, 292-295, 304-305; Bancroft, v. 366-379; Sloane, 312-3I6.

\section{Naval Warfare. - Exploits of Paul Jones.}

TOIICS AND REFERENCES.

I. Weakness of the Americans at sea. 2. Naval gains from the French alliance. 3. Paul Jones and his exploits. Winsor, America, vi.ch. vii.; Cooper, i. I79-209; Brady, ch. ix.-xi.; Hart, Contemp's, ii. 587-590.

\section{Deplorable State of South Carolina. - Disas- trous Campaign of Gates.}

Topics ANd References.

I. Partisan or guerrilla warfare. - Famous Carolina leaders. 2. Congress and General Gates. 3. The defeat at Camden. McCrady, iii. ch. xxv.-xxx.; Fiske, Am. Rev. ii. I 79-194; Hildreth, iii. 307-309, 313-317; Bancroft, v. 380-390; Sloane, 316-319; Lecky, iv. 13I-13t; Winsor, America, vi. $475-478$; Simms.

\section{Discouraging Circumstances of the Country.}

TOPICS AND REFERENCES.

I. Seriousness of the Camden disaster. 2. Worthlessness of "Continental currency." 3. State of the army. 4. Arrival of Rochambeau and a French army. - Disappointed hopes from them. Fiske, Am. Rev., ii. I96-205; Hart, Formation, 89-92, and Contemp's, ii. 60I-603; Bancroft, v. 439-450; Lecky, iv. 135-I 43 ; Lodge, Washington, i. 264-272 ; Sloane, 322-324, 327-328; Washington, viii. 507 .

\section{Attempted Treason of Benedict Arnold.}

TOPICS AND REFERENCES.

I. Arnold's military career and his treatment by Congress. 2. His attempted revenge. 3. Importance of West Point. 4. Capture and execution of Major André. 5. Arnold in the British service. Washington, viii. 449-45 $8,472-475,493-494,498-502$; Fiske, Am. Rev., ii. ch. xiv.; Bancroft, v. 423-438; Winsor, 
America, vi. 447-468; Lecky, iv. 145-159; Lodge, W Washington, ; $273-28 \mathrm{I}$.

\section{The Southern Mountaineers to the Rescue.}

TOPICS AND REFERENCES.

I. Cornwallis's invasion of North Carolina. 2. Major Ferguson and the mountaineers. 3. Battle of King's Mountain. Draper; Roosevelt, The Winnin, r, ii. ch. ix. : Carrington, Battles, ch. Ixv.; Bancroft, v. 394-40I ; McCrady, iii. ch. xxxiv.-xxxv.; Fiske, $A \mathrm{~m}$. Rer', ii. 244-249: Winsor, America, vi. 478-48o; Phelan, ch. vii.; Sloane, 319-322.

\section{Greene's Campaign in the Carolinas.}

Topics ANd REFERENCES.

r. Changed situation in the south. 2. Greene and his chief officers. - Battle of the Cowpens. 3. Battles of Guilford Court House, Hobkirk's Hill, and Eutaw Springs. 4. British situation at the end of Greene's campaign. G. W. Greene, Grecne, iii. b'k iv.; F. V. Greene, Greene, ch. x.-xiii.; Carrington, Battles, ch. Ixvii.-lxxi.; Winsor, America, vi. 480-495; Fiske, Am. Rev., ii. 249-268; Bancroft, v. 476-504; Hildreth, iii. 327-329, 34I-35I; Sloane, 330-336.

\section{Beginning of the End. - Yorktown.}

\section{TOPICS AND REFERENCES.}

I. Cornwallis in Virginia. - Lafayette's movements. 3. Position of Cornwallis at Yorktown. - His safety dependent on British control of the sea. 3. The coming of the French fleet. 4. The trap which caught Cornwallis. 5. The Yorktown siege and surrender. Washington, ix. 336-400, xi. 293-295; Carrington, Hashington, ch. xxxii.-xxxvi., and Battles, ch. lxxii.-lxxvi.; Lecky, iv. 2II-2I7; Fiske, Am. Rev., ii. 269-2S6; Bancroft, v. 505-522; Lodge, Hashington, i. 296-3I2; Sloane, 337-347; Hildreth, iii. 354-358 ; Tuckerman, i. ch. vi. ; Tower, ii. ch. xxv.-xxviii.; Hart, Contemp's, ii. 6i 5-6rs.

\section{Peace.}

TOPICS AND REFERENCES.

I. Consequences of Cornwallis's surrender. - What remained of the war. 2. Effect in England. - The king's obstinacy.- 
Resignation of Lord North. - The new cabinet. 3. Opening of peace negotiations. - American commissioners. Lecky, iv. 2I S232, 243-255; Morse, Franklin, 357-365; Bancroft, v. 529-580; Hildreth, iii. $4 \mathrm{II}-424$.

4. Suspected designs of France and Spain, and private agreement with Great Britain as to terms. 5. Preliminary and final treaty (text in MacDonald, ii. 15-2I). Winsor, Westruard, ch. xii.; Pellew, ch. vii.-viii. ; Lecky, iv. 275-284; Wharton, i. ch. ix. sect. I I I, and ch. xiii. sect. I 58 ; John Adams, i. ch. vii., iii. 300$35^{8}$, and viii. $5^{-1} 43$.

\section{Terms of the Treaty of Peace.}

Topics And References.

I. Boundaries. 2. Fisheries. 3. Treatment of American Loyalists. 4. Debts to British creditors. 5. Conduct of the States in disregard of the treaty. - Powerlessness of Congress. 6. New homes of exiled loyalists. Flick, ch. vii.-ix.; Lecky, iv. 273-275, 284-289; Curtis, i. 249-259; Hart, Formation, 96-98; Winsor, America, vii. I85-214; Sabine, i. ch. ix.-xiii.

\section{Dissolution of the Continental Army. - Re- tirement of Washington.}

TOPICS AND REFERENCES.

r. Cessation of hostilities. - Furloughing and discharging of soldiers. 2. Disaffection in the army during its last year. 3. The Newburgh Address. - Mischievous design foiled by Washington. 4. Commutation of half-pay. 5. The "Order of the Cincinnati." 6. British evacuation of New York. 7. Washington's resignation and return to Mount Vernon. Washington, x. I68I 84, 225-230, 270-274, 334-339; Irving, iv. ch. xxxi.-xxxiii ; McMaster, i. 103-I06; Bancroft, vi. 70-109; Curtis, i. 155-I7I ; Hildreth, iii. 428-443; Lodge, Washington, i. 323-34I. 


\section{CHAP'TER VII.}

THE UNITED STATES UNDER THE ARTICLES OF CONFEDERATION. I ISI-I 789 .

140. The "Critical Period." 1781-1788. Neither prosperity nor any hopeful prospect came to the country with the advent of peace. On the contrary, the years following were a time which Dr. Fiske has clescribed correctly as being "the critical period of American history." It was made critical by the want of a general government having power to do in and for the States as a whole what they could not do by separate action each for itself. They had gone through the war, very nearly to its ending, with no more organization of a general government than that with which they began it in 1775 . Until 178I the Continental Congress had continued to act on its own discretion alone, as to what it might do or might not, and the States had paid less and less respect to its orders, its advice, or its appeals. It had sought from the beginning a more definite organization of federal government ; but five years were consumed in the movement to that end. On the i I th of June, I776, the same day on which a committee was appointed to draft the Declaration of Independence, another committee was directed " to prepare and digest the form of a confederation to be entered into between these colonies;" but it was not till the middle of November, 1777, that Articles of Confederation were agreed upon in Congress and recommended to the States. Eleven States gave 
assent to them within the next year. Delaware delayed ratification until February, I779, and Maryland was not persuaded to accept the Articles until February, 178I. Not till then was there a constitutional confederation of the United States.

Adoption of Articles of Confederation, March, 1781 .

141. Cession of Western Territory by the States claiming it. 1780-1781.1 The obstructive attitude of Maryland was justified by sound reasons, and it forced a result of great importance to the future of the American nation. That result was the cession to the United States of the wide expanse of unoccupied western territory, to which seven of the thirteen States laid more or less conflicting claims. It will be remembered that Virginia, by virtue of her charter of 1609 (see sect. 3), strengthened by Clark's conquests in I 778-79 (see sect. 128), claimed not only the Kentucky district, lying due west of her old inhabited area, but also the whole northwestern region now cov-

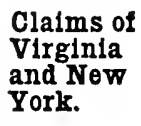
ered by the States of Ohio, Indiana, Michigan, Wisconsin, and Illinois. New York disputed that claim, so far as concerned the whole region subjugated by the Six Nations of the Iroquois. Their sovereignty, it was maintained, had passed to the British crown, and from the crown to the State of New York. Both those claims were disputed in part by Massachusetts and Connecticut, whose ancient charters gave them zones of territory from sea to sea. They could not deny that the zones were broken into by the Dutch occupation of New Netherland, by the English

Claims of Massachusetts and Connecticut. conquest from the Dutch, and by the grant to the Duke of York, nor deny that territory beyond the Mississippi had been given up to Spain; but they claimed all that was not thus taken out. As against the grant to 1 See Map VIII. 
IVilliam Penn, the Connecticut claim was maintained with obstinacy for many years, and asserted in practice by clatms of a settlement of emigrants from Connecticut in the Carolinas and

Georgia. the Wyoming region of northern Pennsylvania, where they suffered the dreadful massacre of I 778 (see sect. 127). In the south, similar claims were put forth by the Carolinas and Gecrgia, founded on similar royal grants.

Seven States were thus claiming the whole unoccupied territory in the west. The six States which had no such claims contended reasonably that the wilderness in question should be ceded to the proposed Confederation and become a national domain, until peopled for new States. Demands of Except Maryland, however, all yielded to the Maryland. need of a more definite general government and ratified the Articles of Confederation without waiting for any of the demanded cessions to be made. Maryland resisted until New York had authorized its delegates in Congress to "restrict its boundaries in the western parts by such line or lines . . . as they shall deem expedient ; " until Connecticut had offered a partial cession of lands, though not of jurisdiction; and until Virginia had signified her willingness, on certain conditions, to convey her title to all lands northwest of the cessions, Ohio River. The New York deed of cession 1781-1802. was executed in February, I78I; the Virginia cession was made complete in 1784 ; Massachusetts ceded her claims in 1785 ; Connecticut compromised hers in 1786 , securing a tract in northern Ohio, long known as the Connecticut or IVestern Reserve, and giving up the rest. The cession of South Carolina was executed in 1787 , that of North Carolina in 1790 , and that of Georgia not until ISO2.

142. Weakness of the Confederation. 1781-1789. 
Hard and long as it had been striven for, the adoption of the Articles of Confederation made little change in the structure or the working of government. By their own declaration, the Articles established no more than "a firm league of friendship" between the States. They were framed to give merely a legal form to the loose alliance of the past six years, few people being yet prepared to venture more. Their long difficulties with the British government had left the Americans with an almost unreasoning fear of any authority in government superior to that which they watched and controlled near at hand, in their several States. The whole tendency of their political situation had been to give their State governments the first place in all their political habits of thought. Their Confed-

All power in the States. eration of "the United States of America" was shaped accordingly, with all the energy of government distributed among its parts, and almost nothing left at the centre, for its action as a whole. It was the States that must levy and collect all taxes and imposts; the States that must raise all military forces, and clothe, arm, equip, and organize them in regiments, with officers, up to colonel, of their own appointment; the States that must (if they saw fit) provide the means and the mandates for almost everything that the Congress of the Confederation might undertake to do. Congress had no revenue at its own command. It stretched no arm of authority to any citizen, through any judge or courtofficer of its own, to make itself felt and respected as the real government of a real nation. It had the sole right to declare war, but was de- nossof of pendent on State legislatures for money, men, Congress. and arms. It had the sole right to make treaties with foreign powers, but was dependent on State legislatures 
for an enforcement of the obligations of such treaties when made. It was authorized to contract public debts, but was dependent on State legislatures for means to pay even the interest on what it owed. It was made the tribunal of "last resort" in all disputes between the States, but had no power whatever to enforce its decrees.

Besides this utter want of efficient powers in the Congress of the Confederation, there were fatal weaknesses in its make-up and its modes of action. Each State might send to it not less than two nor more than seven delegates, who cast, however, but one vote for their State. These delegates were paid by the Legislation States, and niggardliness reduced the number incongress. sent quite generally to two; sometimes none were sent. When a majority of the delegates of a State agreed on a question in Congress, they could cast its vote; when they disagreed evenly and were tied, its vote was lost. Yet no'measure of importance could be adopted without the vote of nine States. How small an opposition might defeat any measure can readily be seen. And this feeble and fettered body was not merely the legislature of a general government, but was in itself the whole government, - a government with no executive hand or head, and no judicial arm. We cannot wonder that it lost prestige and respect; that service in it lost attraction for able and ambitious men; that its meetings were neglected, even when grave matters were in hand. We cannot wonder that the United Loss of States were less like one nation when the war prestige. ended than when it began, and grew less in that likeness so long as the Articles of Confederation were in force.

143. Commercial Depression. Thus paralyzed in its 
general government, it was impossible for the country to recover prosperity when it recovered peace. The main causes of depression in it were causes which nothing but an efficient national government could remove. It had not suffered a ruinous destruction of wealth or population in the war; but the foreign commerce of the country had been broken up, eign trade. and nothing could restore it but a responsible government, capable of making commercial treaties with foreign nations, capable of fulfilling the terms of such treaties when made, and capable of regulating the conduct of trade between the States. While they remained under British law the Americans had had free and large dealing with Great Britain and her other colonies, but were restricted in commerce with the remainder of the world. Now they had lost the advantages of the British connection, and found no willingness in other nations, except France, Sweden, and the Netherlands, to arrange commercial treaties with them, because the observance of such treaties by the States could not be guaranteed.

The internal commerce of the country was injured even more by the existing condition of things. Each State possessed the right to a protective tariff and a navigation act of its own, and could tax the passing of ships and products from other States across its boundary lines. Some fierce out-

Commercial warfare between the States. breaks of petty commercial warfare were the early result, especially between New York and its neighbors on both sides.

144. Ruinous effects of irredeemable paper money. But the ruin of trade by these conditions was hardly so great a cause of suffering as the general economic breakdown which the flood of irredeemable paper money, 
issued by Congress and the States, had brought about. When the measurement of values is lost, as it is by the use of such fictitious money, a few shrewdly speculative people are sure to make themselves rich at the expense of the community at large. The inevitable outcome, soon or late, is debt and poverty for the mass; and the

Harsh debt and poverty in the United States, after Harsh
of debtont the "Continental currency" of the war time

had run its course to worthlessness, were very great. Debt in those days was treated worse than we now treat crime. Debtors, no matter how innocent of dishonesty, were often imprisoned hopelessly for years; and most of the prisons of the time were in a horrible state. The heartlessness of creditors was one of the provoking causes of a dangerous outbreak of rebellion

\section{Shays's Re-} bellion, that occurred in Massachusetts in I 786. Shays's 1786.

Rebellion - so named from its principal leader - was an attempt to stop proceedings against delinquent debtors, by breaking up the sittings of the courts. Another object of the insurgents was to force a new issue of fictitious money in the form of irredeemable notes. They would not believe that such so-called money had been the source of their troubles. They paper thought it had been made worthless by conmoney. spiracies against it, and that sharp laws compelling everybody to take it were all that could be needed to keep it good. This delusion was so common that it carried the elections of 1786 in seven States, and started them again upon fatuous experiments in making money with the printing-press.

Of real money, in valuable coin, or bank promises payable in coin, the country had almost none. It had no coinage of its own, though Congress, in 1785 , approved and adopted a plan of coinage devised mainly by 
Gouverneur Morris, assistant to Robert Morris in the superintendency of finance. From that plan, to which Jefferson contributed some features, came the Decimal admirable system of clecimal coins, based on coinage. the Spanish dollar, which this country has enjoyed, with little change, ever since it established a mint. But the mint was not created and coining undertaken until after the Congress of the Confederation passed away and a new national government took its place.

145. Dread of a Strong General Government. - Impending Dissolution of the Union. 1786. Of the instructed and thoughtful people of the States there was doubtless a large majority at all times who could see clearly that present happiness and a hopeful future for the country could never be secured without a more national union of its parts. There were some pure patriots of shrewd brain who could not see it so, and Samuel Adams was one. Their dread of a strong government was greater than their

Attitude of Samuel Adams and others. dread of anything else, and they would not accept it as a remedy for any public ill. The popular majority was with them for years, against Washington, Franklin, Jefferson, Madison, Hamilton, Jay, and most of the great leaders of the time. Three attempts to amend the worst features of the Articles of Confederation were made and failed, no amendment being possible without the concurrence of every State.

By i786 an actual dissolution of the "league of friendship" appeared to have begun. Rhode Island recalled her delegates from Congress, and would send no more. New Jersey refused flatly to pay any part of her quota of revenue needed for the general Dissolution government, and all the States together paid bogun. in that year but one fifth of the $\$ 2,000$, 000 required. 
Several States were raising troops in violation of the Articles of Confederation: in New England there was talk of secession if an offer from Spain, of a treaty of commerce in exchange for a surrender of all claims to the navigation of the Mississippi River below the Yazoo, should be refused; while the settlers in Kentucky were threatening to put themselves under British protection if any such bargain were made. The ultimate crisis of the "critical period " had been reached; and yet there was no visible chance of success for any" open and direct proposition to strengthen the constitution of government for the dissolving Union of the States. But happy circumstances arising in that most anxious year brought about the needed action in an indirect way.

146. The Circumstances which led to a Constitutional Convention. 1785-1787. The circumstances which led to the framing of a constitution of really national government for the United States had their beginning in a conference at Mount Vernon, between Conference commissioners from Virginia and Naryland, Conference
at Mount for the purpose of jointly regulating and exVernon.

tending the navigation of the Potomac River. The influence of Washington, Madison, and Jefferson brought that conference about, and it was probably the same influence which pushed further in the same direction, first to bring Delaware and Pennsylvania into the discussion of a common commercial system, and, finally, to invite a convention of commissioners from all the States to consider the needs of their trade. A resolution to that end, drawn by Madison, was adopted by the legislature of Virginia in January, I786, and attempts were made to assemble the proposed convention at Annapolis on the itth of the following September. 
At the appointed time only five States had commissioners in attendance, and these thought it useless to take up the work for which they were convened. They annapolis adopted, however, an address to the country, Convention, prepared by Hamiiton, urging the appoint1786. inent of a new body of commissioners from all the States, to meet at Philadelphia in the coming May, not merely to consider the commercial situation, but to "devise such further provisions as shall appear to them necessary to render the constitution of the federal govemment adequate to the exigencies of the Union." For some time there seemed to be no probability that more would come from this endeavor than came from the Annapolis meeting; but as signs of anarchy thickened, people were driven to regard it with a desperate hope. Virginia gave a great lift to that hope in December, when Washington consented to be one of seven commissioners to the proposed convention from that State, and Patrick Henry, ${ }^{1}$ Madison, Randolph, and Mason were named with him in the notable list. New Jersey acted next, and then Pennsylvania appointed a famous delegation,

The Virginia and Pennsylvania delegations. including Franklin (home from France in 1785 , when Jefferson went out to take his place), Robert Morris, the great financier of the Revolution, Gouverneur Morris, who devised our decimal coinage, and James Wilson, a profoundly able jurist, who took a notable part in the subsequent work. A convention bringing such men together could hardly occur without some important result; and Congress was moved by public opinion to make it an authorized body, which was clone on the Ist

1 Patrick Henry opposed the movement, however, and refused the appointment. 
of February, i787. By that time six States had named delegates, and their example was followed presently by six more. Rhode Island, alone, would send none.

147. The Work of the Convention. May-September, 1787. The great Convention began its sessions at Philadelphia on the $25^{\text {th }}$ of May, I 787 . Besides those named already, the men of most distinction in its membership were Hamilton (commissioned from New York, but tied up with two opposing associates), John Rutledge, from South Carolina, and John Dickinson, who had organiza- changed his residence to Delaware. The gention. eral standard of ability and character was very high. Washington was chosen president of the Convention, and his wonderful influence ranks first among all the causes of success in its rork. To prevent public wrangling over troublesome questions while its own discussions were going on, the Convention sat with closed doors, and allowed no report of its proceedings to be published; nor was anything known of its debates or votes for many years.

The differences of opinion, disposition, and interest among the members were very great. Some came for the sole purpose of opposing any change that might possibly reduce the political independence of the States; but these were few. A large majority was found to be determined that some structure of positive nationality should be framed. The strong delegation from Virginia led proceedings firmly to that end. They gave The vir- direction to the debate from the beginning, ginia plan. by bringing forward a plan of government, drafted mainly by Madison, which swept the Articles of Confederation out of view, and turned the thought of the Convention to a work, not of mending and patching, but of new construction throughout. It was a bold 
project, since nothing in the credentials of the delegates gave them authority to do more than revise and amend the existing Articles of Confederation; but the majority of the Convention were not men who would enter on so momentous an undertaking with tied hands. The day after their discussions in committee of the whole began, they adopted the following: "Resolved, That it is the opinion of this committee that a national government ought to be established, consisting of a supreme legislative, judiciary, and executive." This determined and established at the outset the foundations of the scheme of government to be framed. It was to be a national govern-

A national government projected. ment; it was to be a supreme government; it was to be a government that should exercise all governing powers, making, adjudicating, and executing the laws within its sphere.

This speedy settlement of the main question in dispute - between a national government and a mere "league of friendship" - did not bring the Convention to easier problems in its task. The most troublesome conflicts of opinion and feeling were still to be faced. First and worst among them came one from the distrust and anxiety which the smaller States felt in contemplating a national union with States larger both in population and wealth. How could they be protected from oppressive uses of national power by a few large States? At first they could see no safety for themselves unless the existing equal vote of the States in legislation should be maintained. But that was a concession which the larger States could not make. The latter insisted, and rightly,

Proportionate representation. that there must be representation in the national legislature proportioned to population, and that it must 
be a representation, not of States, but of the people, as citizens of the United States, choosing their representatives by their own direct votes. At last a happy compromise was found. The Convention had agreed already that "the national legislature ought to consist of two branches," and it was decided (by an extremely close vote) that the members of the first branch should be elected by the people of the several States, "according to some equitable ratio of representation," while those of the second branch should be chosen by the State legislature, and that in the second branch the States should have equal votes. ${ }^{1}$ Thus our compro- two Houses of Congress, the House of Remise on
state representation. and the Senate, coming from the States, were made up. After that agreement had been reached the smaller States felt assured of safety in the Union, and most of their delegates joined heartily with those who labored to make the new general government a substantial one in sovereignty and strength.

The next problem of great seriousness arose from the fact that some States contained large numbers of slaves and others had few or none. Were the slaves to be counted as part of the population entitled to represencompro- tation in Congress, or not? South Carolina mise on
slave repre- insisted that they must be reckoned so, and sentation. would be hostile to the new Constitution if that were refused. North Carolina and Georgia were almost as imperative in the same demand. The proposition seemed intolerable to the northern delegates; but to save their whole work from being wrecked on it,

1 Constitution, Art I. sect. 2, clause 3, and sect. 3, clause I; Amendment 14 , clause 2. 
they consented at last to a representation in Congress for three fifths of the slaves. ${ }^{1}$

Another question concerning slavery was settled by another compromise. Thirteen years before this time, the First Continental Congress had declared with solemnity, and with undoubted sincerity: "We will neither import nor purchase any slave imported after the first day of December next, after which time we will wholly discontinue the slave trade" (see sect. 104). But slave labor had been growing more profitable to the rice and indigo planters of South Carolina and Georgia since that time, and now they were fierce in opposition to any restriction of the traffic in slaves. They were likewise opposed to placing the regulation of commerce among the functions of the general government, which New England most ardently desired; but were willing to yield that point if satisfied on the other. So a really shameful bargain was struck between the New Englanders and the planters of the far South, which left the African slave trade open for twenty years - until r $808 .{ }^{2}$ This mercenary bargain

Compro-

mise on slave trade. in dealing with a great moral question was bitterly condemned, and by no people more severely than by the illustrious Virginians of that day.

A third concession to the slave-holding interest, destined in future times to be a dangerous cause Fugittro of irritation in the country, was embodied in a slaves. provision for the recovery of persons " held to service or labor in one State" and "escaping into another." 3

The greater difficulties encountered in framing the new constitution were overcome by the three important

1 Constitution, Art. I. sect. 2, clause 3.

2 Constitution, Art. I. sect. 9, clause I.

${ }^{3}$ Constitution, Art. IV. sect. 2, clause 3. 
compromises: (I) representing the States, small and

The throe large, equally in the Senate of the United great com- States; (2) counting three fifths of the slaves in promises.

apportioning seats in the national House of Representatives; (3) prohibiting importation of slaves, but not until isos. Stubborn differences of opinion appeared on many other points, but none that were seriously threatening to the success of the Convention in its task. In this brief history we cannot trace its roork in detail, nor dwell upon the features of the incomparable structure of federative national government which it designed and perfected for this republic of many united states. That is a political study that will need to be pursued elsewhere.

148. The Struggle and the Victory for the New Constitution. September, 1787-July, 1788. The work of the Convention was finished on the $\mathrm{I} 7$ th of September, i 787. It was made a provision of the Constitution that it should be submitted to conventions specially elected in each State, and that when ratified by nine States it should become the Constitution of a general submission government for those States, even if rejected to the by the remaining four. Then, for ten months, the adrocates of the Constitution, who took the name of Federalists, fought desperately with its opponents to win acceptance for it in the States. Reasonable argument was overwhelmingly on their side; but prejudices, local jealousies, petty views of local interest, trivial fears, were enlisted easily on the other side and hard to overcome. Nothing less than unsparing and prodigious exertion on the part of the strongest men in the country could have achieved the victory that was won. The highest honors of that victory belong to Alexander Hamilton and James Madison, who 
explained the provisions of the pending Constitution, and showed what their working would be, in a series of remarkable essays, published first in Hamilton a newspaper between October, 1787 , and Jume, and Madison.

I788, and collected afterward in a famous book entitled "The Federalist," which is, to this day, the best exposition of the American Constitution, and one of the ablest treatises on the principles of gov-

"The Federnment that has ever been produced. Of 85 essays that make up "The Federalist," Hamilton wrote 5 I, Madison 29, and John Jay 5. The influence of these writings in bringing about the adoption of the Federal Constitution was very great.

Little Delaware was the first State to ratify, on the 7 th of December, I787. Pennsylvania followed on the I 2 th of the same month, and New Jersey on the I 8 th. Georgia opened the new year by a unanimous Ratificaratification, January 2 , and Connecticut came tions. next, on the $9^{t h}$. A sharper contest ensued in Massachusetts, where the Federalists carricd a ratifying vote, on the 6th of February. Samuel Adams, who opposed the Constitution at first, yielded assent to it in the end. Maryland was carried more easily on the 28 th of April, and South Carolina with some difficulty on the $23 \mathrm{~d}$ of May. One State more would create a federal union of nine and give the Constitution effect; but the Federalists were battling with little hope in all the remaining five. They did win two of the five in June, - New Hampshire on the 2Ist, Virginia on the 25 th, - and they added New York on the 26th of July. The hardest fight of all was in New York, where Hamilton, by sheer force of argument, during weeks of debate, turned a hostile majority of two thirds into a finally favoring majority of three. 
So the Lonion under a mational constitution was formed by ederen sates. North Carown hed aloot from it until Norember. I - So, and Rhude Ishand until Inne. I, -

149. The Ordinance of 1787. The old Contimental congress. now about to cisapener irom history hat

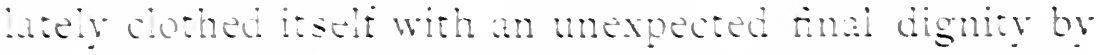
onc reaty sovereign and greaty important at. That act was an orimance, passed in Juh, I, - - for the

\section{The noth-}

Testern or ganization and govermment of the northesttert:tory. ern ierritory which the contecteration had acquired from the states (see sect. 141). The measure was pressed by a company organized in the interest of a large number of the oftecrs and soldiers of the late war. who wished to make new homes for themselves in the west. General Rutus futmam, General Samuel larsons. and Rer. Manasseh Cuter. of Massachusets. Were the leading promoters of this Ohio Company as it was named, and negotintions with Congress were conducici by the sentleman last mamed. He and his associates are credited with some of the wisest provisions of the ondinance, affecting the future

\section{Schools.} of five great States. It was provided that ever be encouraged : " that "no person demeaning himself in a peacable and orderly manner shall ever be Guarantees molested on acount of his mode of worship of freadom. or religious sentiments:" that "there shail be neither slavery nor involuntary sorvitude in the said cemitory, othewise than in the pumishment of crimes: "1

1 The exclusion of shery hat been proposed by fefferson, in I - St. When he drated an orimunce of government for the whole westem territory, both north and soutli of the Ohio, which con. gress did not adopt. 
IXIER ARTICLES OF CONFEDERATION. 265 and that "the said tertitory and the States which may" be formed therein shall forever remain a pat of this conferlerang of the United States." "These and other provisions were declared to be "articles of compact between the original States and the people and States in the said territory, and forever remain unalterable, unless by common consent." lt was stipulated in the ordiname that not less than three nor more than fire states should be formed in the ter-

Five States tormed. ritory described. The result has becn the formation of five, namcly, ()hio, Indiana, Michigan, Misconsin, and lllinois.

In the beginning this Vestern Territory, as it was nimed, was placed under a single government, and its first governor Wis Gencral Arthur St. Clair. In ()etober and Normber, I $-5 /$, a million and a half acres of land on the Muskingum and Ohio rivers were sold to the ()hio Company, three and a halt millions to an associated organization of speculators, and two first sales millions to a private buyer, at two thirds of a of land. dollar an acre. A great movement of cmigration to these lands bewan at once, and settlements arose rapidly along the northern banks of the (Ohio. Marietta and Cincinnati (named Losantiville at first) were the towns of quickest growth.

150. Election of George Washington for the First President of the Reconstituted United States. Beforc its dissolution, the oll Congress made provision for bringing the new Federal Constitution into operation, by directing that presidential electors should be chosen in Jannary, $1-89$; that the electors should meet and cast their rotes in Fibruary; that the votes should be comnted by the two Housis of the new Congress (to be elected meantime in the screral States) on the first 
Wednesday in March (which fell that year on the 4th), and that the meeting place of the Congress for that purpose should be the city of New York. It was the 6th of April, however, before a quorum of the House and the Senate reached New York. On that day the electoral votes were counted, and Washington was found to be the unanimous choice for President, while John Adams had received a majority of the second votes cast and was chosen Vice-President thereby. ${ }^{1}$

TOPICS AND SUGGESTED READING AND RESEARCH.

\section{The "Critical Period."}

Topics AND References.

I. How the period following the war was made critical. Fiske, Critical Period. 55-63.

2. Preparation and adoption of the Articles of Confederation (text in MacDonald, ii. 6-15). Curtis, i. I $24-1+1$; Am. Hist. Ass'n, I894. 227-236: Fiske, Critical Period, 90-94; Am. Hist. Leaf., 7, 20, 28: O. S. Le'af., 2.

REsEARCH. - The Confederation compared with other federal unions, before and since. Hart, Introduction, I-86.

\section{Cession of Western Territory by the States Claim-} ing it.

TOPICS ANi REFERENCES.

I. Claims of seven States to western territory. 2. Demand of other States for its cession to the Confederation. 3. Maryland's persistence in that demand. 4. Dates of the several cessions.

1 As the Constitution provided then, two candidates were to be voted for by each presidential elector, without designating President and Vice-President. The largest number of votes (if a majority of the whole) elected the l'resident: the next largest elected the VicePresident. This was changed by a constitutional amendment in I SO.f. 
Hinsdale, Old $N . I^{\prime}$., ch. xi.-xiii.; Donaldson, ch. iii.; Roosevelt, The I'inning, iii. 243-251; Fiske, Critical P'eriod, 187-196; King, 161-173; Hart, Contempis, iii. 138-142; Am. Hist. Leaf., 22.

Research. - Views of the time as to the future of the valley of the Mississippi. Madison, Letters, i. 136-1 fo.

\section{Weakness of the Confederation.}

TOPICS Ani RefEREnCES.

I. Cause of defectiveness in the Articles of Confederation. 2. Dependence of the general government on the States. 3. The weakness of Congress. 4. The slight opposition that might defeat any measure. 5. Resulting loss of character in Congress and the Confederation. Madison, Letters, i. 320-328; The Federalist, No. I 5, 21-22; Fiske, Critical Period, 94-105; McMaster, i. 130-139; Lodge, Hamilton, 36-46; Hart, Contemp's, iii. 120-122. 125-137, I 77-1 82 , I 95-197.

\section{Commercial Depression.}

Topics And ReFErences.

I. The causes of commercial depression. 2. Loss of British trade, and lack of power in the general government to establish commercial arrangements with other nations. 3. Commercial warfare between different States. Curtis, i. 276-290; Fiske, Critical Period, 134-1 +7; Bancroft, vi. 47-49, I36-1 53; Sumner, The Financier, ii. ch. xxiv.; Weeden, ii. 8 I6-819, $8_{3} 6-8_{39}$, 843 ; McMaster, i. 205-208; Morse, Jefferson, 77- 44 ; (iay, $48-55$.

RESEARCH. - The slight general distress in the country during the war. Sumner, The Financier, ii. ch. xxix.

\section{Ruinous Effects of Irredeemable Paper Money.}

TOPICS AND REFERENCES.

I. Effects of losing a measure of values. 2. Treatment of debt and debtors in those days. 3. Shays's Rebellion in Massachusetts. - Its main objects. 4. Extent of the paper-money delusion. Madison, Letters, i. 243-245, 255-256; Fiske, Critical l'eriod, 162IS6; Bancroft, vi. 167-176; McMaster, i. $281-355$, foo-404; Sum-

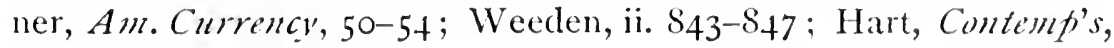
iii. ${ }^{8} S_{3}-18_{4}, 191-194$. 
5. Scarcity of coined money. 6. Origin of our decimal system of coins. Roosevelt, Horris, 103-10S; McMaster, i. I87-200.

REsEARCH. - Services of Robert Morris as Superintendent of

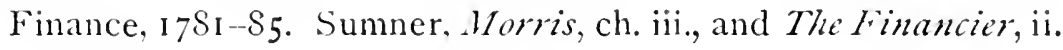
ch. xxiii.

145. Dread of a Strong General Government. - Impending Dissolution of the Confederation.

Topics ANd References.

I. Dread of a central government felt by Samuel Adams and his followers. Hosmer, Adams, $38 \mathrm{I}-392$; Holst, United States, i. 3039; Roosevelt, Morris, I2S-132.

2. Leading men who strove for a government of national authority and power. 3. Unsuccessful efforts to amend the Articles of Confederation. 4. Signs of an impending dissolution of the Confederation. McMaster, i.356-389; Lodge, Hamilton, 50-53; Washington, x. 345-3+6, xi. I-3, I2, So-S2 ; Holst, Const. Law, I3-I+; Madison, Litters, i. 169-173, 195-198, 20I-202, 205-208, 229-230. RESEARCI. - I. Advances in religious freedom during this period.

- Action in Virginia. Bancroft, vi. 154-159; Hunt, ch. ix. 2. Conflicting views of New England and the western settlements on the question of the navigation of the Mississippi. Roosevelt, The Irinning, iii. ch. iii.

\section{The Circumstances which led to a Constitu- tional Convention.}

Tot'ics AND References.

I. The conference at Mount Vernon. 2. The convention at Annapolis and its appeal for a constitutional convention. 3. Response of Virginia and other States. - Action of Congress. Hunt, ch. x.; Bancroft, vi. I\$z-203; Fiske. Critical P'eriod, 212-222; McMaster, i. 389-399; Elliot, i. 92-120; Gay, 55-63; Curtis, i. 340-365; Schouler, i. 32-39.

\section{The Framing of the Constitution.}

TOPICS AND REFERENCES.

I. Distinguished members of the Constitutional Convention. 2. Influence of Washington, its president. 3. Privacy of the proceedings. 4. Determination of the majority, Virginia in the lead. 
5. The first and fundamental resolution. 6. The question of representation, between large and small States: how compromised. 7. The same question between slave States and free States: how compromised. 8. Questions relative to the slave trade and the general regulation of commerce: how dealt with. 9. Concession relative to fugitive slaves. Madison, Papers, ii.-iii. 685-I624 (or the same in Elliot, v. 5), and Letters, i. 343-355; Washington, xi. I 28156; Bancroft, vi. 207-276, 292-367; Curtis, i. $374-488$, ii. 3-487; Federalist. Holst, Const. Law', 16-24; Fiske, Critical P'riod, 222-305; McMaster, i. 43S-453: Hunt. ch. xiii.-xiv.; Gay, ch. vii.viii.: Roosevelt, Morris, I33-I65; Stillé, ch. vii.; Lodge, Hamilton, 57-65; Schouler, i. 39-5I ; Hart, Contcmp's, iii. ch. x.; O. S. Leaf., 70.

REsearch. - r. The method devised for the election of President and Vice-President: its failure in working to realize the expectations with which it was planned. Holst, Const. Law, 86-90; Bryce, i. 35-4I; Madison, Papers, I I I9-I I24, I I4I-I I50, I I 52, I $88-$ I2 I I Federalist, 68. 2. The fundamental difference between the English system of government and that framed in the American Constitution. Bryce, i. 32-34, 237-238, and ch. xxv. 3. Hamilton's plan of a constitution. Madison, Papers, iii. appendix, xvi.-xxviii.

\section{Struggle and Victory for the New Constitution.}

\section{TOPICS AND REFERENCES.}

r. Opposition to the Constitution. 2. The great and victorious struggle for it in the States. 3. Exertions of Hamilton, Madison, Jay, and others. - The essays of "The Federalist." 4. The States which ratified and when. 5. The States which held aloof. Elliot, i. 3I $8-338$; Bancroft, vi. 37I-438, 452-462; Curtis, ii. 49I-604; Fiske, Critical Period, ch. vii.; McMaster, i. 454-50r ; Hunt, ch. xv.-xvii.; Gay, ch. ix.; Tyler, Henry, ch. xviii.; Hosmer, Adams, 392-401 ; Lodge, Hamilton, 65-80; Schouler, i. 60-78; Hart, Contcmp's, iii. ch. xi.; Johnston, Am. Orations, i. $24-43$.

Researcir.- r. Frounds and motives of the opposition to the

Federal Constitution. Ford, ed., Pamphlets, 1-23, 91-115, 272-

275, 277-322; Madison, I'apers, ii. 662-663; Washington, xi. I $83-186$. 2. Importance of the fact that the Constitution was ratified by special conventions, and not by state legislatures. Holst, Const. Law, 28. 


\section{The Ordinance of 1787.}

TOPICS AND REFERENCES.

I. Character and purpose of the ordinance, passed by the old Congress (text in O.S. Leaf., 13; Larned, Ready Ref.; MacDonald, ii. $2 \mathrm{I}-29)$. 2. The Ohio Company and its influence. 3. Important provisions of the ordinance. 4. The five States developed under it. 5. First land sales and beginnings of settlement. Hinsclale, Old $N . H^{\circ}$., ch. xv.; Cutler, i. ch. iv.-xii.; Winsor, Westa'drd, ch. xiv.; $N$. A. Rez. (Poole), April, i876; Drake, Ohio Vtalley States, I 53-I72; Dunn, ch.v.; King, ch. viii.; Hart, Contemp's, iii. I 54-1 58; Donaldson, I 49-1 59 .

150. Election of George Washington, First President of the Reconstituted United States.

TOPICS AND REFERENCES.

I. Action of the old Congress, providing for the presidential election. 2. Election of Washington and John Adams. Irving, iv. ch. xxxvii.; Bancroft, vi. 466-472 ; McMaster, i. 502-503, 525535 ; Hildreth, iv. $38-56$; Schouler, i. 79-82. 


\section{CHAPTER VIII.}

THE FOUNDING OF A NATIONAL GOVERNMENT. I $789-$ I 80 I $^{1}$

151. Inauguration of President Washington. - Organization of Government under the Federal Constitution. 1789. On the $23 \mathrm{~d}$ of April President Washington arrived at New York from Mount Vernon, and the ceremony of his inauguration was performed on the last day of the month. The ability and industry of Congress were taxed at once by the need of many important laws for organizing the new government and giving authority and direction to its acts. The Con- Madison's authority and direction to its acts. The Con- leadership, gress proved to be a highly capable body, con1789. taining many experienced and strong men, foremost among them James Madison, of Virginia, who sat in the House of Representatives and exercised the leading influence in its work. Before its first session ended, in September, this hard-working Congress passed tariff and tonnage acts, to provide revenue for the national treasury; instituted three departments of administration for the executive branch of government, defining their duties and powers ; planned and organ-

Work of the first session of Congress, ized the judicial branch of government, establishing a system of federal courts ; confirmed the territorial legislation of the Continental Congress, by reënacting the great Ordinance of 1787 (see sect. 149), and agreed upon twelve constitutional amendments for submission to the States. 
On most of these measures there were spirited debates, and nearly every issue that has risen since in American politics, between opposing interests in different parts of the country or opposing ideas, came to the surface then. The scheme of duties discussed in framing the first

First national national tariff was so moderate as to seem insigrtariff.

nificant now ; but it raised at once the question between duties levied solely for revenue and duties applied with a view to giving some substantial adrantage, or "protection," to commodities produced at home against competing articles brought in from abroad. The theory of "protection" carried the day, but the practical application of it was exceedingly mild.

A motion to tax the importation of slaves by a duty of ten dollars on each kindled instantly the feeling First slavery question. that grew more passionate in American politics until, after more than seventy years, the cause of it perished in the flames of civil war.

The three executive departments instituted were that of foreign affairs, called the State Department, the TreaFirst executive departments. ington appointed Alexander Hamilton to the

sury Department, and the Department of IVar. Treasury, Thomas Jefferson to the Department of State, and General Henrey Knox to that of Viar. As the country was then situated, nothing else in its grovernment was so important as a wise and strong handling of financial affairs. In choosing Hamilton for that trust Washington picked, without doubt, the one man in America who had, not only the grasp of needed knowledge, but Hamilton. the boldness, the energy, the convincing power to carry others with himself and accomplish what should lay, from the beginning, a sure foundation of credit and prosperity for the young republic of the 
United States. Congress left the gravest financial problems of the hour to be studied by the Secretary of the Treasury, and when it reassembled in January, I790, he submitted a report on the public debt and public credit which is monumental as a work of statesmanship in public finance. Jefferson, coming from France near the end of 1789 , did not enter on the duties of his office until the following March; meantime

Jefferson and Jay. . John Jay, already named for Chief Justice of the Supreme Court, conducted the Department of State.

Of the twelve constitutional amendments proposed by this first Congress, ten were ratified within the next two years. Nine of them were in the nature of First cona guarantee of certain fundamental rights, - stitutional free speech, religious freedom, jury trial, and ments. the like, - which the framers of the Constitution had omitted intentionally, believing it to be unnecessary. The tenth amendment was a concession to the widespread feeling that stood guard over "state rights." It declared that "the powers not delegated to the United States by the Constitution, nor prohibited by it to the States, are reserved to the States respectively or to the people."

152. Hamilton's Report on the Public Debt and on Public Credit. 1790. Simply stated, the whole argument of Hamilton's famous report on the public debt was to demonstrate the sound policy of a plain, unflinching, unquibbling honesty in the payment of every dollar of the public debt, however incurred and by whomsoever claimed. The debt of the late Confederation was found to be something more than $\$ 54,000,000$, of which nearly $\$$ I 2,000,000 was for loans made in Holland, France, and Spain. Nobody opposed Debt of the Confederaa full payment of the foreign debt; but concerning the 
payment of large parts of the $\$ 42,000,000$ claimed by creditors at home, there were specious objections raised. Much of it was represented by certificates which had sunk in market value, as the prospect of their final payment seemed to fade, and which speculators had been and were still buying up for small sums. Another considerable part was in Continental currency, the latest holders of which obtained it, probably, for some petty fraction of its nominal worth. Considering these facts, many people saw no reason for paying the Continental notes and certificates in full, according to the promise. that they bore on their face. At the same time nobody could propose a practicable plan for determining how much of the promise should be repudiated and how much fulfilled. Hamilton's powerful reasoning prevailed. His plans for "funding" the whole debt, by an issue of Funding United States bonds bearing interest, payable the debt. at definite times, with a "sinking fund" of moneys set apart for the payment of the bonds, and with a due provision of additional revenues to guarantee the whole, was approved and the necessary measures were passed.

But, besides the debts of the Confederation, there were $\$ 25,000,000$ or more of debts which the several States had contracted in the prosecution of the War $\underset{\text { of state }}{\text { Assumption }}$ of Independence; and Hamilton contended debts.

that those should be assumed by the general government, because they represented expenditures for the common national cause. This part of his recommenclation was violently opposed. The bitterest hostility came from those who saw that the assumption of these state debts would tend to strengthen and nationalize the general gorernment, and who regarded such a consequence as one to be feared. On the other hand, 
in Hamilton's mind, and in the minds of those who shared his political views, that undoubted effect of the Assumption Bill gave the weightiest of reasons for carrying it through. On the merits of the argument, however, it could not be passed, and its final success was gained by a bargain which secured the needed votes. Opportunity for the bargain was given by a lively struggle then in progress over the question of locating the national government in a capital subject to its own control. Certain southern Congress-

Jocating

the nationa! capital. men, opposed to the assumption of state debts, were so eager to plant the projected capital city on the Potomac that they arranged with the assumption party for an exchange of votes which accomplished the desires of both. The whole war indebtedness of the country, both general and local, was taken in hand, for unhesitating payment, and American credit rose instantly high; while the federal union was powerfully cemented and nationalized by that sovereign act. From the other side of the transaction there came a board of commissioners who acquired the soil of the District of Columbia and planned the beautiful city that bears Washington's name. Both results were eminently good; but the method of attaining them was bad. It was denounced, and justly, at the time; for great dangers in legislation are opened and corruptions encouraged by such trafficking of votes.

153. The Slavery Question. - First Abolition Memorials. 1790. The grim "slavery question," breeding an "irrepressible conflict" in the nation already, had its hearing in Congress again. Memorials received "from the people called Quakers," and from a "I'ennsylvania Society for Promoting the Abolition of Slavery," of which Franklin was president, stirred up a passionate debate, and called out a committee report, which the House of. 
Representatives adopted, affirming the powerlessness of

Death of Congress to interfere with slavery in the States. Franklin. Franklin's signature to the Pennsylvania memorial was one of his last acts. He died on the 17 th of April, I790.

154. First Census. - First Patent Law, etc. 1790. At the second session of the First Congress, the first act to provide for a national census of population, the first naturalization act, the first patent act, and the first copyright act, were passed. The policy embodied so early in the patent act, of giving a wise stimulation to the inventive genius of the people, and thus cultivating a keen attentiveness to economies of labor and time, has been of immeasurable influence in advancing the welfare of the country along material lines. The union of thirteen States became complete while this session was in progress, by the tardy action of Rhode Island, which ratified the Constitution in June. North Carolina had done the same in the previous November.

The census taken in 1790 showed a total population of 3,929,000, of whom 3,172,000 were white, 698,000 were negro slaves, and 59,000 were free blacks. Of the white population, I,900,000 were resident north and I,27 I,O0O south of "Mason and Dixon's line." All but 40,000 of the slaves were held in the States south of Pennsylvania.

155. The National Bank Question. 1790-1791. A third session of the First Congress was opened in December, in Philadelphia, which became the seat of government for ten years, while the federal capital on the Potomac was being prepared. Again the leading subjects of debate and legislation were introduced by the fertile Secretary of the Treasury, who brought forward plans, (I) for a necessary enlargement of revenue by 
increased customs-duties and by an internal tax; called excise, and (2) for strengthening the organization of capital and credit in the country, besides Excise tax. aiding the financial operations of government, through the creation of a national bank. Legislation for the proposed excise tax, which touched nothing but distilled spirits, was adopted without much debate; but the project of a national bank, to be connected in interest with the government, to be employed by it, and to be a moneyed power, more or less under its control, was violently opposed. In this, as in his former $\begin{aligned} & \text { objects of } \\ & \text { a nattlonal } \\ & \text { banl. }\end{aligned}$ proposals, Hamilton aimed at the solidifying of the Union as a fabric of real nationality, and he roused again the hostility of those who thought it better to invigorate the local governments of the States than to raise over them a more sovereign government and unify them by its strong embrace.

156. The Doctrine of "Implied Powers" in the Constitution. That antagonism between two political views, in which state sovereignty and national sovereignty were the opposing aims, took on a new phase from Hamilton's argument in support of his project of a national bank. Madison, Jefferson, and others contended that the Constitution gave Congress no authority to charter banks, and cited the tenth article of the recent amendments, which declares that "the powers not delegated to the United States by the Constitution, nor prohibited by it to the States, are reserved to the States respectively or to the people." In reply Hamilton pointed to the eighth section of the first article of the Constitution, which sets forth, in seventeen clauses, the powers expressly given to Congress, and adds an eighteenth clause (known since as the "elastic

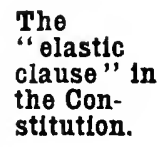
clause"), giving it the broad, undefined power "to make 
all laws which shall be necessary and proper for carrying into execution the foregoing powers." The proposed bank, he argued, is a necessary and proper instrument for government use in borrowing money, paying debts, handling revenue, and providing for the general welfare. Hence the power to create it is implied.

This doctrine of "implied powers" in the Constituticn - a doctrine that gives elasticity to that fundamental code, making it capable of indefinite stretching, by free interpretation - opened a new breach between the men who wanted a strong nation and the men who cared most for strong States. The division then begun has run through American politics ever since, ranging "Strict" " a "stict construction of the Federal Constituand "free" a "strict construction of the Federal Constitution. tion," to limit the powers it confers, against those on the other side who construe it with partiality for strong claims. The latter were successful with the bank bill in Congress and successful in satisfying the scruples of the President, who signed the bill after carefully weighing the constitutional arguments on both sides. Chartered for twenty years, the bank

The first National Bank. was founded with a capital of $\$ 20,000,000$, the government holding $\$ 2,000,000$ of its stock. Its principal seat was in Philadelphia, but eight branches were placed in other cities, and the helpfulness expected from the bank by the business interests of the country was given in full.

The country, in fact, was realizing already immense effects of good from the great political change

Intluence of the new political system, it had undergone. The steadying influence 1789-1792. of the new system of government on all general conditions was not to be clenied. Internal trade, no longer troubled at state boundary lines, was 
beginning to flow in beneficent streams. Foreign commerce was reviving in the atmosphere of public and private credit which Hamilton's wise measures had diffused; shipping enterprise was active again ; production of every kind was finding fresh encouragements, and prosperity was reaching all districts and every class. But a speculative spirit was wakened, also, that would do mischief in the end.

157. Vermont and Kentucky admitted to the Union. 1791. At this time the Union received its first accession of new States. Vermont and Kentucky were admitted as its fourteenth and fifteenth members in February, I79г. Since I777 Vermont had maintained an independent existence as a politically foreign State. Its territory had been in dispute between the royal provinces of New Hampshire and New York, but mostly settled under what were known as "the New Hampshire grants." A royal decision in Rival
claimants
to Vermont. I764 gave the disputed district to New York, and the government of that province unclertook to set aside the New Hampshire grants. This provoked the "Green Mountain boys" to resist. In 1777 they organized the government of an independent State and named it Vermont. The new State applied repeatedly to the Continental Congress for admission to the Confederation, and was kept out by the influence of New York. Notwithstanding these rebuffs, and though tempted by the British authorities in Canada, the Vermonters coöperated with the States of the Confederation throughout the Revolutionary War. Terms were arranged finally with New York, in October, I 790, and Vermont was received into the union of States.

Kentucky had been governed hitherto as a district of Virginia, but its settlers, now multiplying rapidly, had 
obtained the consent of that State to their political separation, and were to organize their distinct government in June, I792. Congress, in advance, decreed their admission, to take place at that time.

158. Hamilton and the policy of "Protection to Home Industries." 1791. The Second Congress, assembled in October, I79I, took no measures of great moment in hand. Hamilton wished to round out his economic policy by a systematic measure of "protection," for the upbuilding of home manufactures, and urged his project in an elaborate report. It contemplated not only a thoroughgoing " protective tariff," but likewise a system of bounties to encourage productive enterprise ; of premiums for useful inventions ; of liberal appropriations for the building and improvement of roads and canals; and, generally, of governmental stimulation to productive industries wherever it could be applied with effect. For the needed authority Hamilton appealed again to what he held to be "implied" in the Constitution, though not expressed. In this use of it, the doctrine of implied powers became more obnoxious than ever to "strict constructionists," especially as leadInternal im. ing toward a policy of "internal improvements" provements. that might be of illimitable scope. Congress took no action on this report; but a complete set of policies for future political parties, and of arguments for future politicians, was stored up in the document and came finally into use.

159. Indian War. - Harmar's and St. Clair's defeats. 1790-1791. Some increase of the small federal army was made necessary at this time by a war with the northwestern Indians, conducted so badly that two appalling disasters had occurred. In the first instance an expedition commanded by General Harmar suffered 
defeat with terrible slaughter in a fight on the Maumee (October, 1790); in the second, a larger force, of some I 400 militia and regulars, led by the governor of the Territory, General St. Clair, into the depths of the wilderness, was surprised and overwhelmed by the savages (November 4, I79I), as Braddock's had been, and was more than half destroyed. Fresh forces were now raised, and the command was given to General Anthony Wayne, who subdued the hostile tribes in the course of the next three years.

160. Reëlection of President Washington. 1792. The term of President Washington would expire in the spring of I793, and he longed to be released from the cares of his office, but yielded to appeals from all sides and allowed himself to be named for a second term. Again he was chosen unanimously, and again the next highest number of votes was given to John Adams, reelecting him Vice-President, over George Clinton, of New York.

161. The Arraying of Political Parties, Federalist and Anti-Federalist (afterwards called Republican). 1793. There were two political parties in the country now, still called Federalist and Anti-Federalist, but arrayed with more distinctness than hitherto, and mainly on lines which clivided Americans in their politics for half a century to come. Washington had tried to conduct a non-partisan administration; but even he could only hold himself above partisan feelings, while his two chief ministers and advisers, Hamilton and Jefferson, led the rallying of political opinion in the country on opposing sides. Hamilton's measures, aims, and doctrines brought the cleavage about, as we have seen. The Constitution was no longer in question; its acceptance by everybody was complete. Disputes in politics now were over the 
meanings of its language. - the constructions to be put

The new disputes in politics.

on it. - the powers that it gave to the general Federalists became Anti-Federalists. Madison. the very "Father of the Constitution." as he has been called. being one. Jefferson. who was in France during the framing of the Constitution. Was foremost of all in opposing the course given to the gorermment by Hamilton's strong hand.

The opposition was not only to Hamilton's measures and to his constitutional doctrines. but to a monarchical

Hamiliton's inclination that was beliered to be lurking in distrust of Federalist minds. Hamilton never concealed democracy.

his admiration for the English Constitution: but he knew that the gorermment of the L'nited States could never take on a monarchical form. and there is no reason to suppose that he aimed at that result. He was distrustful of democracy, however. - afraid to have the government of the comtry fall under the control of the people at large, - and wished to strengthen as much as possible the influence of certain classes, whose wealth. or business interests, or education would make them careful in political affairs. Those classes formed the bulk of the party that rallied round him, and its spirit was essen-

Jefferson's faith in the people. tially aristocratic, without doubt. It was naturally antagonistic to those who believed, as Iefferson believed, in the rightful sovereignty of the whole people. and who had faith in the training of the whole people to prudent and wise action in public affairs.

The antagonism between the two parties heated more animosity than erer appears in politics now. The coun. try was trying a momentous experiment in gorermment, 
never tried on so large a scale before. The statesmen who formed and led opposing political parties were groping nearly in the dark, guided mostly by theories, and they were constantly alert with suspicions and fears. Their judgment of motives was warped by their nèrous alarms. It was believed seriously by Jefferson and his followers that Hamilton and John Adams and the Federalists generally were a band of conspiring monarchists, who worked insidiously to break the republic down and make lords of themselves. In turn, the Hamiltonians were convinced that Jefferson and his leading associates were mere demagogues, striving recklessly for power as the leaders of a mob. We know now, from the private correspondence of these men, and from other revelations of them, that such notions were utterly unjust. Hamilton, Jefferson, Adams, Madison, and their colleagues in the lead of the contend - Patriotism ing parties were all patriotic statesmen, of the sides. high class in ability and character ; but they represented two orders of mind, and they looked at public questions from two points of view.

Even those who reject the main political doctrines of Hamilton may think it was best for the country that his view, and not Jefferson's, prevailed in the beginnings of the government. The effect of his measures, which tended powerfully to consolidate and nationalize our federal union at the outset, and to make the supremacy of its general government felt, would seen to have been a need at the time. The state jealousies and the theories of "State rights" and "State sovereignty," which opposed those measures, did mischief in later times, but they never again had power to do such harm to the nation as they might have done if carried into practice and precedent then. 
At the same time, it can be seen that there were and are serious dangers in Hamilton's doctrines, pressed, as Dangers on he was disposed to press them, to the extreme. both sides. They can easily be carried so far as to make too much of government, - assign too many duties and powers to it, - make it what is called a "paternal government," undertaking things that ought to be done by the people for themselves. Hamilton would probably have carried them too far in those paternal directions, if he had had his way fully ; and he would have centralized the government too much, taking local matters out of local control much more than is good for the political training of the people. Jefferson and the Jeffersonians were right in discerning those tendencies, and right in their distrust of the anti-democratic spirit of the Federalist party. Hamilton and the Hamiltonians were equally right in fearing that the policy adrocated by their opponents would cause a dangerous slip backward toward the feebleness of the old Confederation, from which they had just escaped. There was reason and right in the opinThe partles ions and feeling of both parties ; there was dana needed check to each other. ger in both when they ran their inclinations to the extreme. They were a needed check upon each other, and the same checking and counter-checking of the same opposing tendencies has been a natural necessity in American politics ever since.

162. The French Revolution in American Politics. 1789-1793. Antagonism between the two parties was intensified, soon after the beginning of Washington's second term, by excitements rising out of the terrible revolution then maddening france. A warm sympathy with the revolutionary movement had been universal in the United States at first. There was a certain American exultation in it, because it came as a sequel to the 
American Revolution, and that feeling was increased by the prominence of the part taken by Lafayette. But, as the Revolution ran its awful course and Lafayette was driven to flight, and as the ruthlessness of the rising Jacobin party was more and

American feeling toward France. more displayed, a strong reaction was produced in conservative minds. To Federalists, generally, the revolutionists seemed to be dragging France into hopeless anarchy, while Anti-Federalists were still able to look upon them as heroic champions of the rights of man.

163. France and England at War. - "Citizen Genet." 1793. News came in the spring of I 793 that the French revolutionists had declared war with England, and this was followed by the arrival of a new minister from France, sent to demand aid from the United States. Our government then had troublesome questions to face, because the treaty of 1778 with the king of France pledged help to him in defending his possessions on this side of the sea. Was that treaty binding now, since the royal government that made it had been overthrown, and since France was not de-

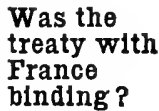
treaty with France binding? fensively but aggressively at war? Washington and his advisers decided, after considering these questions with care, that they were justified in taking a neutral stand. Jefferson, as Secretary of State, seems to have acquiesced in that decision; but the mass of his party was so enthusiastic in friendship for France, and so hostile to England, that the neutrality proclaimed by the President was hard to preserve. "Citizen Genet," as the new French minister was styled, received such extravagant demonstrations of welcome that he was badly misled, imagining that the people would overrule their government, and allow him to push them into war. He took a defiant attitude toward the government; commis- 
sioned privateers: established prize courts in French Conduct of consulates : enlisted seamen and troops ; bought "Clitizen Genet," munitions of war: and, finally, was said to have 1793.

threatened to appeal to the people against the action of the President. This latter insolence he denied; but there seems to be good evidence that the charge was true. His conduct angered all Americans of proper feeling, and the gorernment was supported by public opinion in demanding his recall. He never returned to France, however, but married and was settled quietly in New York for the remainder of his life, after being superseded early in I794.

164. Enmity between Jefferson and Hamilton. 1793. Jefferson was then no longer Washington's Secretary of State, having resigned at the end of 1793 . The opposition between him and Hamilton had grown to emmity, and, as the latter prevailed oftenest in the cabinet counsels, Jefferson found himself uncomfortably Retirement placed. He retired to private life, but still exRetirement
of Jeffer- ercised the leading influence in his party - the son, 1793. "Democratic-Republican" party, as the AntiFederalists were now named. For many years their organization was spoken of commonly as the Republican party, and its distinctness from the later political party of that name must be kept carefully in mind. In after years it preferred to be called, as it is now, the Democratic party.

Hamilton remained in the govermment for more than Retirement a year after Jefferson's retirement; then he, of Hamil- too, withdrew; but continued to exercise a
ton, 1795. powerful influence in public affairs.

165. Impending War with England.-Peace Mission of Chief Justice Jay. 1793-1794. The situation of the country, between the powers at war, was made 
difficult by the conduct of both. England seemed determined to regard the United States as practically the ally of France, while the french were angry because that alliance was refused. The rights of neutrals in trade with countries at war was not defined then by gen-. eral agreement as it has been since, and many questions were in dispute. The English, being masterful at sea, endeavored always to put narDisputed
rights of
neutrals. row limits on neutral rights, and the french followed their practices as far as they could. But the naval weakness of the latter compelled them to invite neutral ships to undertake the commeree of their West India colonies, which they had jealously kept to themselves in times of peace. This opened to the Americans an immensely profitable and extensive trade; but lingland mantained that war could not create a commercial privilege not existing before, and numerous American ressels engaged in the French WVest Indian trade were caught by her cruisers and condemmed by linglish courts.

This, however, provoled less feeling than another English practice of the time. The activity of American shipping was causing a great clemand for sailors in American ports, at higher wages than the English paid, with better treatment, and numerous desertions from English ships were induced.

British

search and impressment. Complaining that American courts and American law gave them no proper help to recover such deserters, the English govermment directed its naval officers to search American ships for them and take them wherever found. Many who claimed to be American citizens were "impressed" in this exasperating manner; for nativity was hard to prove, as between Fuglishmen and Americans, and England had never conceded the right of a born subject to cast off his allegiance to her crown. 
It had been hard enough before for Americans to endure the continued holding of their western forts by British garrisons, and to bear what they believed to be malicious tampering with western Indians by some of - the officers at those forts. Now that a new cause of bitter feeling was adcled to the old, there seemed

Washington's effort for peace. to be little possibility of avoiding war. Washington, however, made one last, earnest effort for peace. With authority from Congress, he commissioned the Chief Justice, John Jay, as a special envoy, to negotiate with the British government for more friendly relations; and Jay departed on his mission in May, I794.

166. "Whiskey Rebellion" in Pennsylvania. 1794. At that time peace at home was threatened by rebellious opposition in western Pennsylvania to the excise. There, and in western North Carolina and Virginia, the conversion of grain into whiskey afforded to the farmers, in and beyond the mountains, the best means of marketing their crops. Hence the tax on distilled spirits was especially resented in those parts of the country. In the summer of 1794 the riotous demonstrations in Pennsylvania became so rebellious that Washington, by proclamation, called out about I 3,00o militia, placed them under General Henry Lee, then governor of Virginia, and sent them to the scene of trouble, along with commissioners appointed to deal with the insurgents and investigate their grounds of discontent. This strong measure was effective; the whiskey rebellion collapsed; the authority of the govermment was vindicated, and respect for it was notably raised.

167. The Jay Treaty with England. 1794-1796. Mr. Jay's negotiations resulted in a treaty, signed at I sondon November 19, 1794, which did not reach the United States till the following March. Its provisions (except- 
ing one article, relative to West India trade) were not known to the public till after it had been ratified by the Senate, at a special session held in June. Then a tempest of rage, in every part of the country, but especially at the south, burst on all who had to do with the making of the treaty or accepting its terms. It was not such an arrangement with England as any American statesman of the time would have made if the circumstances of the country had not been what they were. Washington signed it after long hesitation; for, though it did not go near to the bottom of the causes of quarrel between England and the United States, it was a first step toward that end. It secured the surrender of the western forts in June, 1796. It provided for a payment, on one hand, of the disputed debts to British creditors, and of indemnity, on the other hand, for recent illegal captures of American ships. ${ }^{1}$ It established a solemn agreement between the two nations that private

Provisions of the treaty. debts should never thereafter be sequestered in war. It provided for joint commissions to determine the disputed boundaries in America. But it did not bind England to stop impressments from American ships. It opened the ports of the United States to British ships, in return for privileges in the British West

Objections to the treaty. Indies that were thought to have no worth. It secured no compensation for slaves set free by the British in the War of Independence and taken with them when they left. For these and other shortcomings the treaty was raged against, as a piece of cowardly truckling to Great Britain, worse in effect than any consequence of war.

1 Under these provisions the United States ultimately received about $\$ 6,000,000$ in indemnity for illegal captures, and paid less than $\$ 3,000,000$ on British debts owed at the outbreak of the Revolution. Schouler, ii. 27. 
Gradually a reaction of opinion took piace, and many of those who had denounced the treaty came to see that its acceptance was wise.

168. Important Events in the West. 1795-1796. The Jay treaty gave deep offence to France; and Spain, too, complained. After long efforts, a treaty with the latter country had just been concluded (October,

Narigation of the Mississippl.
I 795), which would free the narigation of the Mississippi and give important privileges to American merchants at New Orleans. Spain now threatened to repudiate it, because of what she claimed to be inconsistent agreements with England; but in the end the important Spanish treaty came into effect.

On the Ist of Jume, I 796. Temnessee, the sixteenth State - the second formed in the great interior valley -

Admission of Tennessee, 1796. was admitted to the American Lnion, and Andrew Jackson, its first federal representative, came to Congress in the fall of that year. (On that same ist of June, British garrisons marched out and American garrisons marched in to the western forts of the Dellvery of western torts, 1796.

United States. Soon aftermard the Mississippi was opened to free navigation by the flatboats of traders from the Ohio and its tributaries, and they could market their products from the Spanish town of New Orleans. The west was coming into American history with quick strides.

169. Retirement of Washington.-Election of John Adams. 1796-1797. Nashington was now making glad preparations to quit the presidential seat. He could not yield asain to the appeals that were made to him for another term of public service, and his positive decision was announced on the I 7 th of September. I796. by the publication of his "Farewell Address," - a noble 
utterance of wise counsel to his countrymen, which can never lose its impressive weight and force in the minds of the American people so long as they do not lose their sense of truth and

\section{Washing -}

ton's

"Farowoll Address.' right. It is especially a most solemn admonition to the country to beware of factiousness and violence in party spirit; to discourage sectional jealousies and antagonisms; to avoid entanglement in the policies and politics of the Old World; - every one of which warnings bears all the wislom now that it bore when Washington wrote.

In the presidential election that followed, John Adams and Thomas linckney were the understood candidates of the Federalists (no. formal nominations being made in those days), while the Republicans, or Democrats, were united in desiring to elect Thomas Jefferson, but divided somewhat in their second choice. When the electoral votes were counted, Adams was found to have received $7 \mathrm{I}$, and Jefferson 68, which made Adams I'resident and Jefferson Vice-P'resident.

170. Quarrel and Hostilities with France. 17971798. President Adams, inaugurated March 4, I797, kept the cabinet of his predecessor, which proved to be a mistake. Its members could not throw off the powerful influence of Hamilton, even after the retirement of that masterful statesman from public life, and troublesome frictions in the govern-

Continuation of Hamfliton's Influence. ment and in the Federalist party were produced. At the outset, the new administration had serious ill-feelings in France to face. Our minister there, from I 794 until late in 1796 , had been James Monroe, a Republican, warm in friendship with the French republicans and strongly opposed to the treaty with England negotiated by Mr. Jay. His course had not been satisfactory to 
President Washington, and he had been recalled, General C. C. Pinckney being sent in his place. The French government, already bitter in feeling toward this country,

\section{Minister} Pinckney ordered out of France, 1797.

resented the change, and refused to receive the new minister, ordering him out of France. President Adams had news of this affront before the middle of the month (March, I797) in which his presidency began, and called a special session of Congress to take such measures as it seemed to demand. Hostile acts on the part of the French authorities, in lawless seizures of ships and goods, were increasing from day to day, and war appeared inevitable ; but the President and the more sober-minded of his party friends sought anxiously for means to avoid a resort to arms. Congress sanctioned the appointment of three envoys extraordinary, who should convey to France the wish of the American government to deal fairly with its complaints. John Marshall and Elbridge Gerry were associated with Pinckney, the rejected minister, in this important mission, and the three reached Paris in the fall of the year.

Unofficially, the envoys were treated courteously, but no official hearing was given to them for months. Meanwhile they were beset by three emissaries from

Talloy -

rand's omTalleyrand, the French minister for foreign afIssaries, X. Y. Z., fairs, who gave them to understand that they could hope for nothing unless they placed a large gift of money in Talleyrand's hands for the men who were then at the head of the French government (styled the Directory), besides making a loan of some millions to the public treasury of France. As they spurned such overtures, their mission was futile, and their reports of the rascally proposals, and of the treatment they had undergone, roused intense feeling in the 
United States when published, in April, 1798. In the publication of their despatches the three emissaries of Talleyrand were not named, but designated as X. Y. Z.

That a serious var did not follow was only because the French government soon manifested a different state of mind. It had been intoxicated for two years past by the prodigious achievements of its young general, Napoleon Bonaparte; but Bonaparte had led his army on a wild expedition to Egypt and Syria, and appeared more than likely to lose it there. A formidable coalition of European powers was armed against the dreaded republic, and it had enough fighting in prospect on the other side of the Atlantic without pushing its quarrel in America. But the war spirit kindled by the "X. Y. Z. Correspondence" raged fiercely in the United States for some time. The tide of public feeling was with the Federalists; the Republicans were borne down. Military preparations were hurried on, and Washington was appointed commander-in-chief, with Hamilton next in command. For its navy the country had three lately finished frigates, the Constitution, the

Military prepara-
tions and naval fights, ingts, Constellation, and the United States; but vessels were bought and adapted to naval use, and four small squadrons were formed, while a swarm of privateers was let loose on French merchant ships. The Constellation fought sharp battles with two French frigates, one of which, L'Insurgente, she captured, while the other escaped. These were the only important engagements of the war.

171. The Alien and Sedition Acts. 1798. The Federalists, now strong in popular favor, were puffed up, as we may say, with too much of a sense of power, and adopted high-handed measures against their opponents, as parties in such circumstances are apt to do. On both 
sides. the political press of those days was indecent in abuse and slander of public men, and some foreigners employed on Republican newspapers were especially venomous in the use of their pens. In exasperation, the Federalists, controlling Congress, passed acts which struch with blind rage at the freedom of the press and other sacred rights. One hnown as the Alien Act (Iune z: I 798), empowered the President. for two years. to expel from the country any alien whom he judged to be " dangerous to its peace and satety" and to imprison any who refused to obey his order to depart. The power was never used, but the creation of it was justly alarming to the public mind. Anuther starting and dangerous measure was the Sedition tet (July I 4. I79S), which made it a crime to combine and conspire in opposition to any measure of the government " directed by proper authority: " and which also made it criminal to "write, print, utter, or publish" "any talse, scandalous, and malicious writing or writings against the govermment of the L nited States, or either House of the Congress of the Lnited States, or the President." Luder these acts there were sereral prosecutions, which harmed the authors of the law more than its victims.

\section{The Kentucky and Virginia Resolutions.}

1798. If the Federalists were carried in one wrong direction by an evil party spirit. to a serious threatening of civil liberty, the Republicans, in their opposition. went at least equally far on another vicious line. Jefferson and Madison prompted some of their party to adrance the constitutional theory that each state has a right to judge for itself whether acts of the seneral govermment are or are not within the limit of the powers delegated to that government, and the conseguent right, when such acts. in its judgment, are wanting in authority. to declare them 
"void and of no force." Resolutions applying this doctrine to the Alien and Sedition laws, and pronouncing them roid, were adopted by the legis Dootrine of lature of Kentucky in Norember, i 798 . Their nullificaauthorship was not known at the time, but Jefferson, some years afterward, acknowledged them to be his. At nearly the same time the Virginia legislature adopted a series of resolutions, drawn by Madison, which set forth a somewhat similar but more guarded view of state rights. Madison lived long enough to see the Union brought into great peril by the "nullification" doctrine of the Kentucky resolutions, and he then disclaimed, for Jefferson as well as for himself, any purpose to do more than force attention to the dangerous character of the Federalist laws.

173. Overthrow of the Federalist Party. 1800. The Federalists suffered most from their errors, and went down in the presidential election of I Soo, never to have power in the national government again. Their legislation had been wanting in respect for the most cherished of rights. Their disposition was not democratic; they felt and expressed distrust of the common mass of people, whom Jefferson and the statesmen of his school trusted most for the guarding of the welfare of the nation as a whole. By the death of Washington, which came suddenly and shocked the country on the I 4 th of December, I 799, the Federalist party suffered an irreparable loss. Though he tried to be of no party, the "Father of his Country" was plainly drawn in opinion toward Federalist views, and his great influence over the party gare it strength. It was torn by factious quarrels among its leaders after that restraining influence had been withdrawn. Further weakening came from the cooling of war excitements, 
after peace negotiations, invited by France, were reTreaty with opened in the spring of 1800 . From those France. negotiations came a treaty which cancelled the treaty of 1778 , with all its obligations of alliance, but left the United States to indemnify its own citizens for

French spoliation claims, 1800 . the French spoliations of the late war. The claims then arising were shamefully neglected for almost a century, no provision for their settlcment being made until i 885 .

174. John Marshall, Chief Justice. 1801-1835. In two branches of the government the Federalists lost power in the elections of $\mathrm{I} S 00$. In the third branchthe Judicial - they left a great jurist, John Marshall, of Virginia, appointed Chief Justice of the Supreme Court of the United States by President Adams, in January, I SoI. Mr. Marshall held that high office until I835, during which long term his profound decisions on questions of constitutional law had a measureless effect. They went far toward establishing the Federal Union on that bed-rock of sovereign nationality which the Federalists sought. Marshall succeeded Hamilton in the true Federalist work.

175. Election of Jefferson and Burr. 1800. For reëlection, Adlams received but 65 electoral votes, against 73 cast for Jefferson and the same number for Aaron Burr. The tie between Jefferson and Burr carried the election into the House of Representatives, which chose the former for President and the latter for Vice-President, as the voters of their party had intended; though some of the Federalists attempted to give the higher office to Burr. 
TOPICS AND SUGGESTEI) READING AND RESEARCH.

151. Inauguration of President Washington. - Organization of Government under the Federal Constitution.

Torics AND REFERENCES.

I. Inauguration of President Washington. 2. Character of the First Congress. 3. Leading measures of the First Session. Hunt, I68-I69; Schouler, i. SI-I05; McMaster, i. 533-534, 540-544; Hart, Formation, I4[-I43.

4. The first tariff law. McMaster, i. 544-552; Hunt, I69-I74; Hildreth, iv. 65-9I, 96-99; Schouler, i. 87-92. Johnston, $A m$. Politics, $2 \mathrm{I}-22$.

5. Debate on the slave trade. Hildreth, iv. 9I-96; McMaster, i. 552-555; Schouler, i. I 42-I 45 ; Hart, Formation, I46-I 47.

6. The three executive departments first instituted. 7. The Constitutional Amendments. Schouler, i. 93-96; Hildreth, iv. IOI-IOS ; McMaster, i. 555 ; Lodge, Hashington, ii. 6I-72; Hart, Formation, I43-I 45 ; Johnston, Am. Politics, 20-2 I.

Research. - I. The President's Cabinet. Holst, Const. Laze, 9095; Bryce, i.ch.ix. 2. The executive departments of the Federal Government as now organized. Congressional Directory for the current year. 3. Reasons for the omission originally of a declaration of rights in the Constitution. Madison, Letters, i. 423-427; Hamilton, The Federalist, No. 84. 4. The Federal judicial system. Bryce, i. ch. xxii.-xxiii.

\section{Hamilton's Report on the Public Debt and on Public Credit.}

TOPICS AND REFERENCES.

r. The argument of the report (text in MacDonald, ii. 46-58; Hamilton, iii. I-45). 2. The debt of the late Confederation. Where owed and in what forms and amounts. 3. Grounds of objection to full payment of claims at home. 4. Hamilton's plans and their success. Hunt, I 79-I 82 ; Lodge, Hamilton, 85-96, I I 7I20; Gordy, i. I I8-I 2 I ; McMaster, i. 567-579; Schouler, i. I 30-I36; Hildreth, iv. I 52-I 7 I, 206, 214-2 I6; Holst, United States, i. 83-85. 
5. The state debts. - Reasons for and against the assumption of them. 6. The bargain by which the assumption bill was carried through. 7. The just denunciation of it. Hunt, IS2-200; Morse, Jefferson, 97-106; Lodge, Hamilton, 121-129; Hildreth, iv. 171I 74, 206-2I6: Schouler, i. I36-I +2: Gordy, i. I I I-I 2S; Holst, United

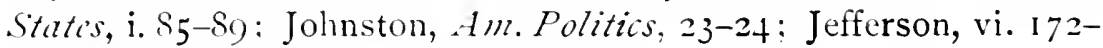
I74; Madison, Letters, i. 507-522.

\section{The Slavery Question. - First Abolition Memorials.}

TOPICS AND REFERENCES.

I. Memorials against slavery and the slave trade. - Report adopted by the House of Representatives (text in MacDonald, ii. 58-60). 2. Death of Franklin. Holst. United States, i. S9-94; Hildreth, iv. I74-205: Schouler, i. I $45-150$ : Hart, Formation, I 5I-I 52.

\section{First Census. - First Patent Law, etc.}

TOIICS AND REFERENCES.

I. Acts mentioned. - Policy of the Patent Act. - Its importance. Hildreth, iv. 220-22I; McMaster, i. $5 S_{2-5} S_{3}$; Schouler, i. I 29-I 30.

2. Ratification of the Federal Constitution by North Carolina and Rhode Island. Hildreth, iv. I 77-150, 209; Schouler, i. I 27-12S.

3. Population shown by the census of 1790 . Hildreth, iv. 301 . REsearch. - How have the patent laws stimulated invention?

Important results of American invention. Celebration of the Beginning of the ad Century of the American Patent System, I89I: Addresses.

\section{The National Bank Question.}

Torics AND ReFERENCES.

I. I'hiladelphia the temporary seat of government. 2. Hamilton's proposal of excise (text in MacDonald, ii. 6I-66: Hamilton, iii. 95-105). 3. His project of a national bank, and his objects, financial and political (text in MacDonald, ii. 67-76; Hamilton, iii. Io6-I 46: Hart. Contemp's, abr'g'd, iii. 276-28I). 4. Its opponents and their objections. Madison, Littirs, i. $52 S$ : Lodge, Hamilton, o6-104, I3I-I32; McMaster, ii. 25-32; Holst, United States, 
i. 104-106: Schouler, i. I 58-160; Gordy, i. 129-131: Hildreth. iv. $251-262$ : Hart. Formation. 150-151.

REsEARCII. - How woukd the national bank strengthen the organization of eapital and credit in the country? White, Ioncy and banking, bk. ii. ch. i. and ir.

\section{The Doctrine of "Implied Powers" in the Constitution.}

TOPICS AND ReFerexces.

r. The constitutional argument against the national bank project. 2. Hamilton's reply to it. 3. His doctrine of "implied powers" and the division produced by it. 4. The "elastic clause" of the Constitution. 5. Results from the establishment of the bank. 6. Prosperity of the country. Jefferson, v. 284-289: Hamilton, iii. 249-251. iv. 104-13S; Madison, Litters, i. 52S. 546 ; Hunt, 20I-204: MacDonald, ii. 76-9s: Lalor, i. 199-200: Hildreth, iv. 262-267: Lodge, Hamilton, 104-106. 133-I35; Gordy. i. 135-137; Schouler, i. I60-162.

Resetrch. - Chief Justice Marshall on the rule by which the

Constitution is to be construed. Marshall, IVritings (case of (iibbons 2 . Ogden), 2\$\$-291: Magruder, 172-179.

\section{Vermont and Kentucky admitted to the Union.}

TOPICS AND REFERENCES.

I. Previous history of Vermont. 2. Separation of Kentucky from Virginia. Hildreth, iv. 267-272: Schouler. i. I $49-150$.

\section{Hamilton and the Policy of "Protection" to Home Industries.}

Topics ANd Referexces.

r. Hamilton's report on manufactures: its recommendations (text in Hamilton, iii. I92-2S+: MacDonald, abr'a'd, ii. 9S-r Iz). 2. His renewed appeal to "implied powers " in the Constitution. 3. The policy of "internal improvements" toward which it led. 4. Outcome of the report. Elliott. 93-II2; Lodge. Hamilton, IOS-IIt; Schouler. i. IS6-IS7; Hildreth. iv. 307-30).

REsEARCH. - Summarize the recommendations and argument of Hamilton's report. 


\section{Indian War. - Harmar's and St. Clair's De- feats.}

TOPICS AND REFrRENES.

I. The two disasters - General Wayne's ultimate success. Mc.Master. i. 503-103: ii. 45-47. 69-72: Schouler, i.15I-158, I01197: Hildreth, is. $28-28$;.

\section{Reëlection of President Washington.}

TOPICS AND REFERENCES.

I. Lnanimity of the realection of Washington. - The opponent of Adams. Mcdaster, ii. \$5-SS: Schouler, i. 21z-213: Lodge, Hashington, ii. $230-23$ I.

\section{The Arraying of Political Parties.}

TOPICS ANI REFERENCES.

I. Washington's non-partisan endearor. 2. The measures which first divided parties, mllying them round Hamilton and Jefferson. 3. Changes from the former "Federalist " and "Anti-Federalist" parties. 4. The new subjects of contention. 5. Character of the Hamiltonian party. - Suspicions of its monarchical inclinations. 6. Democratic beliefs of Jefferson and his party. 7. Causes of the animosity between the two parties. Holst. Cnitid stater. i. So-Sz, 10S-112: Gordy, i. 103-117. 132-15S: Johnston, 20-2S: Hunt, 204-214: Schouler. i. 105-177. 241-242: Hildreth. iv. 291-

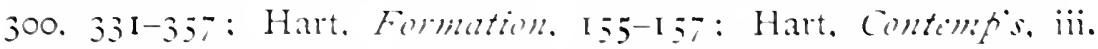
$296-205$; Lodge. Hamiltm. 130-1 +2: Lodge, II asinington, ii. 216-

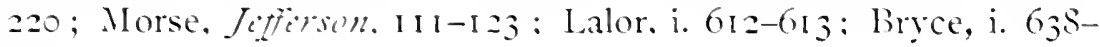
$6+3$.

8. Injustice of the two parties to each other. 9. Tendencies and dangers in the extreme riews of both. xo. Their needed checking and counter-checking of each other.

RESEARCH. - I. The continued tendency in party politics to division on similar lines. brown. Inituic of Politial Partics (.4tlantic, November. 1000). 2. Estimates of Hamilton and Jetferson

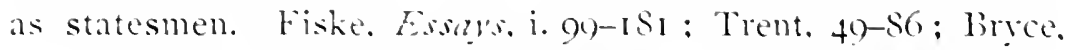
i. 64l: Ames. ii. $256-204$. 3. Differences hetween the two parties as defined by lefferson in 1798 and 1813 . Alm. Hist. Rer.. iii. 
TOPICS, REFERENCES, AND RESEARCH. 3OI fis-4So, and Jefferson, Ir ritings (Ford ed.). ix.373-376. 4. Difference between a centralized govermment and a centralized administration. Tocqueville, i. I07-1 เ2.

\section{The French Revolution in American Politics.}

TOPICS ANI) REFERENCES.

I. Early and later feeling in the United States concerning the French Revolution. McMaster, ii. So-07.30S-310: Lodge, II ashinston, ii. I $36-1+4$ : Morse, Jiffirson, 1 f6-1 47 : Gordy, i. 176-179; Hildreth, iv. fI I-tiz: Hart, Formation, I 57 ; Holst, inited States, i. 107 .

\section{France and England at War. - "Citizen Genet."}

TOPICS AND REFERENCES.

r. Obligations of the United States under the alliance treaty of I 778 with France. 2. The difficult preservation of neutrality. 3. Attitude of the Anti-Federalists or Republicans, and conduct of "Citizen Genet." Hamilton. iv. 357-390.393-406: Jefferson, II ritings (Ford ed.), vi. 2IS-23I, 371-393, 396-39S: McMaster, ii. 971 f1 Gordy. i. 179-200; Schouler, i. 242-256: Hildreth. iv. flz-

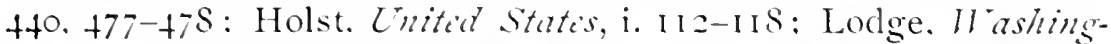
ton, ii. I +4-I6I ; Lodge, Hamiltan, I6I-175; Morse, Jiffirson. 147-165; Johnston, Am. Politics, 30-33; Hart, Formation. I 5160: Hart, Contempis, iii. 305-312: MacDonald. ii. I $12-114$.

RESEARCH. - Did the United States, in this case, fairly fulfil its treaty obligations to France? Madison, Litiors, i. $651-654$.

\section{Enmity between Jefferson and Hamilton.}

TOPICS AND REFEREXCES.

r. Resignation of Jefferson from the cabinet. 2. His party. newly named. 3. Ketirement of Hamilton. Schouler. i. 20z-2iz, 2S6-2S7; Hildreth, iv. 357-373, 453-457, 53S: Morse, liffirson. 162-165: Hamilton, iv. 293-305: Jefferson, Writings (Ford ed.). vi. IoI-109. See, also, references under sect. I6r. 
165. Impending War with England. - Peace Mission of Chief Justice Jay.

TOPICS AND REFERENCES.

I. Exasperating concluct of England and France in their war with one another. 2. Rights of neutrals in dispute. 3. The right of search and impressment claimed by England. 4. Other causes of bitter feeling in the United States. 5. Washington's last effort for peace. McMaster, ii. I65-I88; Schouler, i. 260-272; Gordy, i. ch. xiv.; Hildreth, iv. $48 \mathrm{I}-489$; Lodge, Washington, ii. I65-I 76; Johnston, Am. Politics, 33-36; Hamilton, iv. 519-532, 536-539, 5+9-557; Hart, Contemp's, iii. 3I 2-3I 4.

\section{6. "Whiskey Rebellion" in Pennsylvania.}

TOPICS AND REFERENCES.

I. Causes of special hostility to the excise in the mountain regions. 2. Vigorous suppression of the rebellion and the effect. Hamilton, iv. 575-604; v. I-I 2, I6-26, 3I-33, 38-54; McMaster, ii. 4I-43, Is9-203; MacDonald, ii. I30-I35; Hildreth, iv. 498-5I6; Holst, Unitud States, i. 94-104; Gordy, i. ch. xiii. ; Lodge, Hamilton, I $S_{0-1} S_{5}$; Schouler, i. 275-280; Hart, Formation, 163-164; MacDonald, ii. I30-I 35 .

\section{The Jay Treaty with England.}

Tolics ANd References.

I. Main provisions of the treaty (text in MacDonald, ii. I I I30). - Its inadequacy. 2. The rage against it in the United States. 3. Later reaction in its faror. Pellew, 30I-317; McMaster, ii. 21 2-235, 245-256, 263-284; Hunt, ch. xxiii.; Lodge, It ashington, ii. I 76-207; Holst, United States, ii. I22-I28; Hildreth, iv. 539-564, 594-616; Johnston, Am. Politics, 37-39; Gordy, i. ch. xv. ; Schouler, i. 280-305, 307-3I4; Hart, Formation, I62-I63; Hart, Contimpis, iii. 315-319; Hamilton, v. Io6-137.

REsEARCH. - The speech of Fisher Ames in advocacy of the Jay Treaty. Ames, ii. 37-7I. 
TOPICS, REFERENCES, AND RESEARCH. 303

168. Important Events in the West.

TOPICS AND REFERENCES.

r. Treaty with Spain. 2. Admission of Tennessee. 3. English delivery of western forts and opening of the Mississippi. Schouler, i. 307, 3I4-3I7; McMaster, ii. 284-287; Hildreth, iv. 569-570.

RESEARCH. - Importance to the western settlements of the free navigation of the Mississippi. Roosevelt, The Winning, iii. ch. iii.; F. A. Walker, The Making of the Nation, I ro-r 12.

\section{Retirement of Washington. - Election of John Adams.}

TOPICS AND REFERENCES.

I. Washington's Farewell Address (text in Larned, Ready Ref.). 2. Circumstances of the election of Adams from one party, for President, and Jefferson from the other, for Vice-President. McMaster, ii. 289-307 ; Hildreth, iv. 685-691 ; v. 25-30, 42-45; Schouler, i. 327-335; Lodge, Washington, ii. 243-254, 270-274; Holst, United States, i. I 32-137; Morse, Adams, 257-268; Johnston, Am. Politics, 40-43; Hart, Formation, I64-165.

ResearCH. - Summarize the topics of Washington's Farewell Address.

\section{Quarrel and Hostilities with France.}

TOPICS AND REFERENCES.

r. Mistake of President Adams in keeping Washington's cabinet. Hart, Formation, I65; Schouler, i. 34I-344.

2. Ill-feeling in France toward the United States. - Affront given. - Hostile acts. 3. Treatment of American envoys extraordinary. - The "X. Y. Z. Correspondence." 4. War feeling in the United States, but checked in France. - Naval engagements. Morse, Adams, 273-287, 291-305; Morse, Jefferson, I79-193; Schouler, i. 344-35\$, 373-392, 42\$-435, 439-44t: McMaster, ii. 31I-323, 344, 367; Holst, United States, i. I28-132, I38-I +2 ; Hildreth, iv. 645-684, 702-704, v. 45-63, 94-95, 125-159, 191-213, 220-223, 250-267, 304; Johnston, Am. Politics, 44-46; Cordy, i. 265-312; Hart, Formation, r66-I68; Hart, Contemp's, iii. 322326. 


\section{The Alien and Sedition Acts.}

TOPICS ANU REFERENCES.

r. Violence of party newspapers and pamphletecrs. 2. Highhanded measures of the Federalists (texts in Macl)onald, ii. 1371 f8; Larned, Leady liefo). 3. Cherished rights and liberties assailed. (iordy, i. ch. xix. McMaster, ii. 3So-403, +17-419, 424427; Schouler, i. 392-403, 420-421: llildreth, v. 213-217, 225232 ; Lalor, i. 56-5S; Hart, Firmation, I6S-170; Johnston, $A m$. P'olitics, $47-4^{8}$; Holst, Lnited States, i. $1+2-1+3$.

\section{The Kentucky and Virginia Resolutions.}

TOPICS AND REFERENCES.

r. Dangerous doctrine of "nullitication" advanced by the Republicans. 2. Its expression in Kentucky, and more molerately in Virginia (texts in MacDonald, ii. 1 $49-157$ : Larned, Ready Refo). Holst, Lnitid states, i. 143-167: Lalor, ii. 672-677: Gordy, i. ch. xx.; Hunt, ch. xxvi.-xxvii.; Hildreth, v. 232-235, 272-277, 296301 ; Johnston, Am. Politics, 4\$-50; Hart, Finmation, 170-171; Hart, Contemp's, iii. 329-331 ; Morse, Jiffirson, 193-195; Schouler, i. +22-425; Benton, liew, i. ch. Ixxxvii., Ixxix.

\section{Overthrow of the Federalist Party.}

TOPICS AND REFERENCES.

I. Causes of defeat to the Federalist party in s Soo. 2. Effect of the death of Washington. 3. New treaty with France. 4. "French Spoliation Claims." Morse, Adams. 305-321 : Schouler, i. 500-501 ; Holst, Unitid Stater, i. 179-1\$2; Gordy, i. ch. xxi.; Hildreth, v. 337-340, 321-331, 353-357, 3\$6-3\$o, 39s-39). flf-fis; Hart, Formation, 171-175; Hart, Contempis, iii. 333343 ; McMaster, ii. 452-45+, 42S-430, 527-529.

RESEARCH. - The "French Spoliation Claims." Whaton, Digest,

ii. 714-72S; Webster, iv. 152-17S; Benton, I icai. i. 4\$7-521.

\section{John Marshall, Chief Justice.}

TOPICS AND REFERENCES.

I. Appointment of John Marshall, Clief Justice of the Supreme Court, and the influence of his constitutional decisions. Ma- 
TOPICS, REFERENCES, ANI) RESEARCH. 305 gruder, ch. x.; Cooley, et al., ch. ii.; Morse, Adtums, 321-322; Schouler, i. tio.

Research. - The constitutional decisions of Chief Justice Marshall. Magruder, $182-201$.

\section{Election of Jefferson and Burr.}

Topl's An1) ReFEREnCES.

I. Circumstances of the election. Morse, Jeffirson, 195-208; McMaster, ii. 497-527 ; Holst, United States, i. 168-177; Schouler, i. 4 So-48s; Hildreth, v. 389-392, 402-408; Johnston, Am. P'olitics, $52-54$. 


\section{EXPANSION IN THE GREAT VALLEYS. 1800-1840.}

\section{CHAPTER IX.}

THE IOUNG NATION HARASSEI BY OLDER POWERS. I So I - I Sog.

176. The United States at the Beginning of the Nineteenth Century. The census of I 800 showed the population of the United States to be 35 per cent. greater than in 1790 , numbering 5,306,000, almost equally divided by the southern boundary line of Pennsyliania - the "Mason and Dixon's Line," so called, which came to be the line of dirision between free and slave States. But the white people of the north numbered 2,600,000, Free and against $1,700,000$ in the south. The south had slave popu- added 200,000 to its slaves in ten years, while
lation, 1800 .

the north held 4000 fewer blacks in slavery than when the decade began. Of 36,000 slaves in northern States, 20,000 were in New York.

Pennsylvania was the most populous, and, on the whole, the most prosperous State. Philadelphia was the largest and finest city; but New York was making a rapid adiance. In Washington, the new seat of federal government, just buildings enough had been erected to give Congress an unfinished place of meeting, and to shelter the officials and servants of the government in a rather comfortless way. 
Something less than half a million people were now making homes in the wilderness west of the Alleghany Mountains, mostly spread along the banks of the Ohio and its southern branches, the greater number in Kentucky and Tennessee. The vast Northwestern Territory had received no more than 50,000 inhabitants at this time, and none of their settlements touched the lakes, except at the old French

Northwestern Territory. post of Detroit. It had been divided (May, I80o) between two territorial governments, one extending over what became, two years later, the State of Ohio, the other organized for the Territory of Incliana, which embraced what remained. Census-takers in the latter found less than 5000 white people to count. In the southwest a third Territory, named Mississippi, had been formed in I798, in the region west of Georgia, claimed by that State.

Between the communities growing up in the valley of the Ohio and the older ones east of the mountains the intercourse, in trade or otherwise, was very slight; the interests common to them were few; there was little to bind them together, and much, apparently, to force them apart. Nature, by her channelling

Interests of of their waterways (see Map I.), drew the valley people away from the east and the Atlantic, to seek their outlets of trade, their means of development, the satisfying of their ambitions, in the southwest and on the Gulf, where the Spaniards ruled. The roads, canals, and railways that would in time check this natural detachment of the valley from the coast were yet to come.

Those natural forces by the help of which man is now overcoming natural obstacles were scarcely known when the nineteenth century began. Steam was a servant just mastered and little tricd. Watts had been building 
steam engines of his final pattern for a dozen years; but, even in I 803 , only five engines were known

Steam enSteam an-
steamboats. to be working in the whole United States. ${ }^{1}$ steamboats. William Henry, John Fitch, James Rumsey, Oliver Evans, and other inventive mechanics in America and Europe had been experimenting for a quarter of a century or more with boats propelled by steam; but six years were yet to pass before Fulton would realize their dream, by establishing a steamboat on the Hudson River (ISO7), making regular trips between Albany and New York.

A much simpler invention, but one of momentous consequence to the United States, had been perfected in whitney's I793, when Eli Vhitney constructed his macotton gin. chine, called a "gin," for separating the fibre of cotton from the seed. Cotton culture had been discouraged by the expensiveness of that necessary separation when done by hand. At the same time an almost unlimited demand for the fibre had been created in England, by inventions of machinery for spinning and weaving, by the organizing of the factory system, and by the use of steam power. Instantly, Whitney's "cotton gin" made it possible for southern planters in the United States to respond to the English demand. In I 790 there

\section{Cotton cul-} ture and slavery.

had been no exportation of cotton; in I Soo the value of the export was $\$ 5,700,000$. From that time the production rose as fast as slave labor could spread it over the extreme southern States, and the value of slave labor was correspondingly raised.

This not only rooted the institution of slavery with new

1 Mr. Henry Adams cites this statement from a report made in 1903 by Benjamin H. Latrobe. an eminent engineer. Hist. of thi United States during the First Administration of Thomas fifferson, i. 7 o. 
fixity in those "Cotton States," as they came to be called, but gave it a new hold upon their neighbors, which profited by the rise in the price of slaves. As agreed in the framing of the Constitution, the importation of slaves from outside of the Union was to cease in I 808 . Thereafter the plantations would depend for their labor on the home supply. Virginia, Maryland, and Kentucky would then become sources of such supply, and a fresh interest in the perpetuation of slavery was given thereby to those States. The sentiment favorable to emancipation, which had been growing in them, was overcome, and the deplorable division of the States on the slavery question into two disputing and angry sections, marked off from each other by "Mason and Dixon's Line" and by the Ohio River, was soon a menacing fact.

The sectional division had another cause; for industrial differences, between the agricultural south and the manufacturing, mercantile, maritime north, had been leading toward political differences

Industrial

causes of sectional division. since early colonial times. The northern States, especially those of New England, were drawn by their leading interests toward the doctrines of government which Hamilton and the Fecleralists worked out; while the very different interests of the southern States bent opinion in politics the contrary way.

177. The Political Change brought about by Jefferson's Election. 1800-1801. In Mr. Jefferson's view, the political change brought about by the defeat of the Federalist party and his own election, in I800, "was as real a revolution in the principles of our government as that of 1776 was in its form." In taking direction of the government he wished to make it, as he set forth in his inaugural address, "a wise and frugal government, which shall restrain men from injuring one another, which shall 
leare them otherwise free to regulate their own pursuts of industry and improvement. and shall not take from the mouth of labor the bread it has eamed." "This," he Jetferson's said, "is the sum of good goremment." In a theors of national letter written the summer before his election he government. had derined his theory, as concerned the constitution. thus: "That the states are mdependent as to ererything within themselves and mited as to ererything respecting foreign mations. Let the general goremment be reduced to foreign concerns only, and let our affairs be disentangled from those of ali other nations. exept as to commeree, which the merchants will manage the better the more they are left free to manage for themselres. and our general gorernment may be reduced to a rery simple organization, and a rery unexpensive one." To conform the general goremment to this theory would assuredly have been a revolutionary change: but it was not brought about, as we shall learn, because of circumstances and dispositions in men that were too strong to be overcome.

In the management of those foreign concems to which he woukd restrict the general soremment. Iefferson ex-

Theory of peaceablo coercion. pected to dispense with war, exeept in a commercial form. He believed that we could compel other countries to rectify wrongs done to us by withholding trade from them till they did so. "Our commerce," he said, "is so valuable to them that they will be glad to purchase it, when the only price we ask is to do us justice. I beliere we have in our hands the means of peacable coercion." This theory of the practicability of "peaccable coercion" was brought to trial presently by President Jefferson, and disappointed his hopes.

178. The Tripolitan War. 1801-1805. Disbelier- 
ing in the necessity for war, the leresident touk measures to cut down military and naval expenditure, and his cabinet officers, among whom were Madison in the State Department and Albert Gallatin in the Treasury, gave him hearty assistance to that end. But he and they were soon taught that they could not rid themselves of war and naval expenditure so readily as they had planned. The comtry was struck by an cnemy who had no trade to be embargoed, and who could feel nothing but hard

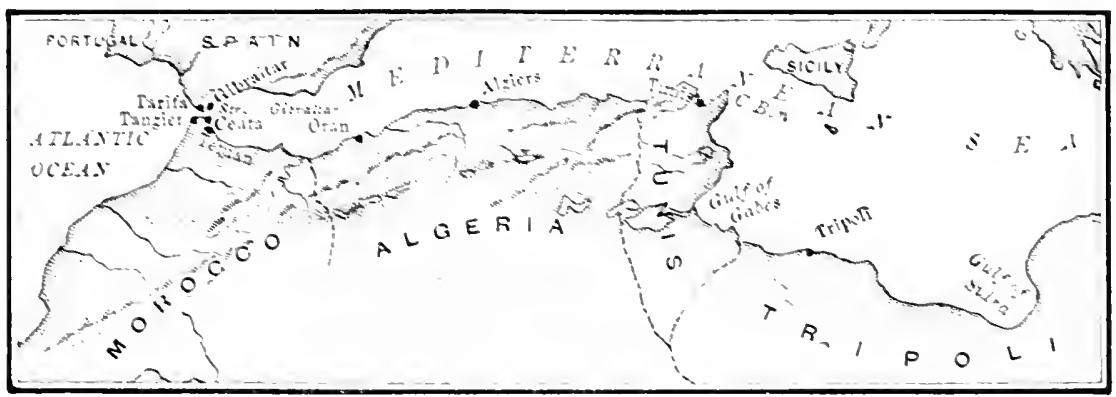

THE BARRARY STATES.

blows. This was the Pacha of Tripoli, one of the socalled Barbary States of north Africa. all of which states had been practising piracy and leving blackmail on the rest of the world for four hundred years. Europe had been willing to pay the

\section{The}

Barbary pirates. pirates for letting its commerce alone, rather than unite in an undertaking to break up their nests. So far. the Lnited States had followed the European example: but the demands of Tripoli became insolent beyond endurance in the spring of ISor, and Commodore Dale was sent out to the Mediterranean with a squadron of three frigates and a schooner, to fight the corsairs and blockade their ports. He did both with good cffect: but the war he operied went on for four years keeping the small American may in active and expensire use. 
179. The Louisiana Purchase. 1801-1803. In the summer of ISOI it was discorered that Napoleon. ruling France with the title of First Consul, had obtained from Spain, in the previous October, a secret treaty ceding back to France that great territory west of the Mis. sissippi called Lousiana (including also Xew

Spanish

cession of

Louisiana

to France,

1800 .

Orleans on the eastern side of the river). which the Spanish crown acquired in the peace arrangements of 1763 (see sect. 86). Napoleon was then projecting a restoration of the colonial empire of France, and his scheme was most alarming to the Lnited States. If Spanish control of the mouth of the Mississippi and Spanish occupation of the western bank of the river had seemed intolerable to the American inhabitants of the valley dependent on it, how much more so must the transfer of that control from decaying Spain to an aggressive power like France appear?

Jefferson realized the seriousness of the situation, and when the time came to make plain declarations, he did not hesitate to say that the United States would never Jefferson's submit to the presence of French authority in $\underset{\text { whainds. }}{\text { wew Orleans. "The day that France takes }}$ possession of New Orleans." he wrote in April, I SO2. "seals the union of two nations who in conjunction can maintain exclusive possession of the ocean. From that moment we must mary ourselves to the British fleet and nation." "This he wote to I ivingston, our minister to France, and Napoleon was to be told what he had said. For Jefferson to meditate an alliance with Eigland against Fance was no trifling thing.

It happened at the moment that France and England were at peace, and the warning had no effect: but peace lasted for only a year. Within that year Napoleon failed disastrously in an undertaking to subjugate and reënslave 
the revolted negroes in Hayti, and his colonial schemes wore no promising look. Now that he had determined to reopen war with England, he threw those schemes suddenly aside. President Jefferson had been pressing proposals for the purchase of New Orleans, and of the Floridas, which were supposed to have been included in the cession from Spain to France, and Mr. Monroe had been sent to assist Mr. Livingston in negotia- The bartions on that line. When Monroe reached Paris, gain with in April, ISo3, he found the First Consul alNapoleon, ready treating with Livingston for the sale of all Louisiana, including New Orleans. As for the Floridas, they were still held by Spain. The bargain was closed quickly; at a price about equiralent to $\$$ i $5,000,000$, and a treaty signed on the $2 \mathrm{~d}$ of May (but dated April 30), which conveyed to the United States all that France had ceded to Spain in $I_{7} \sigma_{3}$ and that Spain had ceded back to France in I SoI (see Map XT.).

By nothing else ever done in the name of the United States, from the presidency of Washington to the election of Abrabam Lincoln, was the Federal Union so impressed with the stamp of sovereign nationality as it was by this act, which expanded the bounds of its govermment from the Mississippi to the Rocky Mountains: and yet it was the act of a party which questioned nationality in the Union and sorereignty

Party inconsistencies. in its government, and it was opposed by a party which had never lost an opportunity before to magnify both. Jefferson did not shut his eyes to the inconsistency of the transaction with his theories of the Federal Constitution, nor hesitate on that account to do what every practical consideration of public interests required. He confessed frankly that he could not find authority in the Constitution for a purchase of territory, and his wish was to have it 


\section{It EXPANSION IN THE GREAT VALLEYS.}

sanctioned by a constitutional amendment: but his political friends dissuaded him from raising the The const. question, lest the fichle and faithiess master question.

of France should change his mind beiore the transfer of temitory had been made. Genemlly on their part. they found authority for what they wished to do as readiy as the Federalists had done. They argued as eagerly for "implied powers" in the Constitution and against " strict constructions" as they had argued to the contrary a dozen years before. All exept the President: he was unconvinced: but he yelded to his party.

With like contradiction of their own doctrines, the Federalists in general opposed the ratification of the treaty and the legislation needed to carry it out. Hamilton apAttitude of prored the acquisition: but most of the FederFederalists. alists of New England - the remaining stronghold of the party - were alamed by the prospective loss of weight and infuence for their own small section in an expanded Union, and fought the treaty with all their power. They maintained that new territory could not be incorporated in the Lnion, not eren by an ordinary constitutional amendment, if a single State withheld assent. Some of them emphasized their opposition with threats of secession, and attempted afterward to make the threat good.

The treaty was ratified and the needed legislation for organizing government in the new domain passed. The latter created a "Territory of Orleans," embracing what is now the State of Louisiana, and a "District of Loui-

\section{Organiza-} siana." corering the whole remainder of the purOrganiza- chase. The District was first attached in gor-
tion of gor- chasent.

ermment to the Territory of Indiana, then organized as the Territory of Louisiana, and finally had its name changed to the Territory of Missouri, in ISI2. The 
boundaries of the Louisiana Purchase were ill-defined, and the American government, for many years, pressed claims to IVest Florida, as forming a rightful part of it. Lately the French archives have shown that that claim was not good, but that, according to the boundaries. understanding between France and Spain, which they concealed, the southwestern boundary of the Purchase should have gone beyond the watershed of the Mississippi and taken in the Texas region, to the Rio Grande.

180. Secession plotting. - Aaron Burr's Intrigues. - Burr and Hamilton Duel. 1803-1804. The extreme Federalists of New England, who had threatened secession, were not slow in starting a plot to that end. Apparently there were few who took part in the plot; but it had one most deplorable result. The project of the conspirators aimed at a separate union of northern States, of which it was necessary that New York should be one. To secure New York, they conspired with VicePresident Aaron Burr, an adroit and unscrupulous politician, who had won his way to impor-

Separate union of northern States. tance by disreputable schemes. In the presidential election of I SoO Burr had been guilty of base intrigues to cheat Jefferson out of the presidency, and the leading Republicans were now treating him in consequence as he deserved. To revenge himself, he entered into a secret arrangement with the New England secessionists to help them carry New York into a league of northern States. He was to be brought forward for governor of New York by the Republicans of his own faction, and the conspirators were to give him what they could of the Federalist vote. All went well as planned, except the election; Burr failed to receive the needed rotes. Hamilton had opposed him strenuously, and was reported to have expressed opinions which gare Burr a pretext for demand- 


\section{I6 EXPANSION IN THE GREAT VALLEYS.}

ing the barbarous satisfaction of the duel. As duelling was then sanctioned by much influential opinDeath of
Hamilton, ion, Hamilton felt called upon to meet him, 1804.

though determined to fire his own pistol in the air. The meeting took place at Weehawken, July IJ, I So4, and Hamilton received a wound from which he died the next day. One of the greatest of men in American history had been slain by one of the meanest and worst.

181. Presidential Election. 1804. The discomfiture of Burr and its dreadful sequel stopped the plotting of the secessionists for some years, and the Federalist party was weakened further by what came to light. In the presidential election of $\mathrm{I} 8 \mathrm{O} 4 \mathrm{Jefferson}$ was reëlected by I62 electoral votes against I4, and George Clinton, of New York, for Vice-President, received the same vote. The mode of election had been changed by a constitutional amendment which came into force in September of that year, and the votes of the electors for President and Vice-President were then, for the first time, distinctively cast.

182. Burr's Conspiracy in the Southwest. 18051807. Though indicted in New Jersey for murder and shumned almost universally, Burr served out his vicepresidential term, which ended March 4, I 805. In those last months of his official stay in Washington it has been found that he opened treasonable conferences with the British minister there, and with certain delegates from New Orleans, who had been sent to complain of the form of government under which they were placed. To both, it seems, he proposed a scheme for separating the western States and Territories from the American Union, and making a conquest of Mexico, to form an empire, of which he intended, no doubt, to be the head. In a cautious way his project was discussed that winter 
with others, and there appears to be little doubt that he won some important adherents, among them General James Wilkinson, general-in-chief of Wilkinson. the army and lately made governor of Louisiana. Wilkinson was a life-long intriguer, - a man of Burr's own kind. He had been of the Gates coterie in the Revolution, and was prominent in the Conway Cabal (see sect. 122).

In a long journey made during the summer and fall of I 805, through Kentucky and Tennessee and down the Mississippi to New Orleans, Burr appears to have found many who were ready to promise help to his scheme. The inhabitants of New Orleans and its district, mostly French, were dissatisfied with their arbitrary transfer to the United States, and more so because refused immediate citizenship and self-government, which they claimed to be their right. In

Discontent in New Orleans. Kentucky and Tennessee there was much jealousy of eastern influence in the government, and the spirit of lawless adventure was easily roused. Altogether, there was enough to encourage an adventurer as desperate as Burr. In the summer of I $\$ 06$ he went west again, and soon afterward there was a mustering of men and boats, provisions and munitions, at points on the Ohio and Cumberland rivers, supposedly in preparation for a filibustering attack on the Spanish colonies of Florida or Mexico, or both. Something at this juncture alarmed Wilkinson, and he became suddenly active against Burr, sending information to Washington and taking measures at New Orleans to frustrate his plans. Thereupon (November 27, I 806 ) the President issued a proclamation commanding the arrest of all concerned, and Burr fled into the wilds of the Mississippi

Territory, attempting to reach the Gulf coast. He was

Burr's arrest and trial, 18061807. 


\section{IS EXFANSION IN THE GREAT TALLEYS}

cantwed in February and brought o triat for treason.

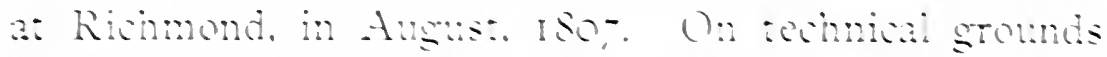
he esaned punishmen by law out he suttered as Cam sulfered curng the remander of a how ibe Some of

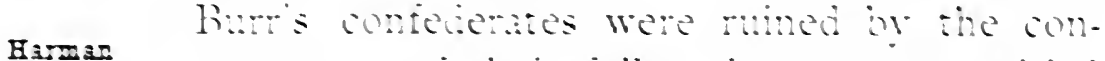
Blenser- secuences ot their föy : the one most pitied rasset was Hamm Hemerhasse an Irish actileman

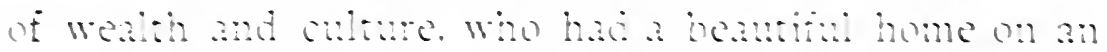

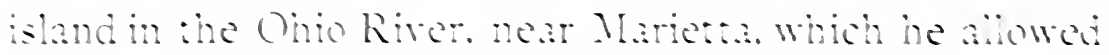
to become the renderous and entre of hum s phot.

183. End of the Tripolitan War. 1805. The war

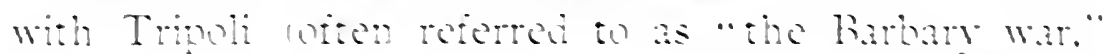
and sometimes as "the Alsertas wa" was ended in

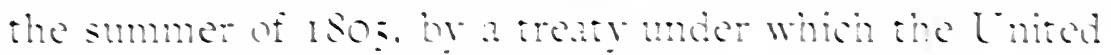

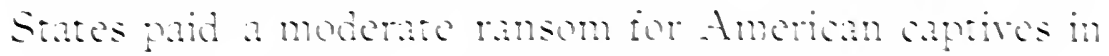
the lathas hands. la was not a tommphat comolusion: but a creditabie example of resstano to the insolent

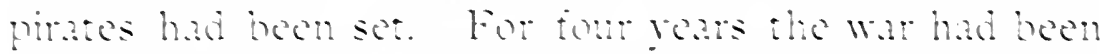
siving a traming o offices and semen bin the small American may which proved ramable at a litio lator

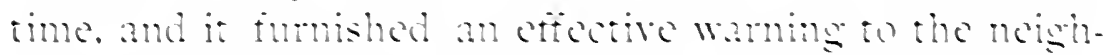

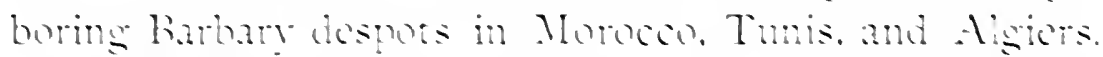

184. Renewed Offensiveness of British Conduct. 1803-1805. Koncwal of war bowown liwat hritain and France hat renewed the werberma conduct of the British soromment, in its troatmont of nourals and neutraltrade and in its impressment of scamentrom American ships. Fommerly its admiralty comms had conceded

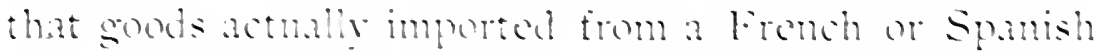

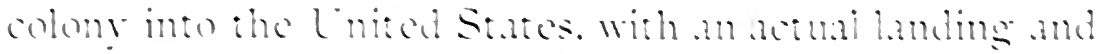

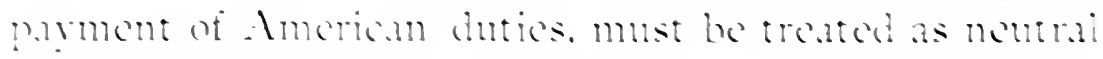

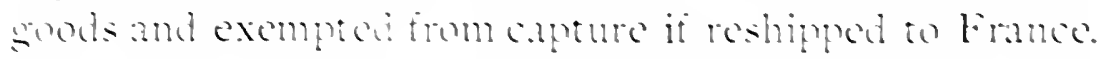

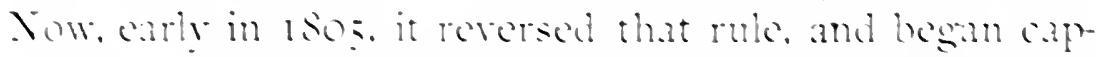
tures which execeded a hundred in mumber before the par closed. 
185. Prosperity of the Country. - Expansion of National Sentiment. 1803-1806. Notwithstanding the enormous losses thus inflicted, the ocean trade, almost wholly in American hands, was richly profitable; the shipping interests of New England and New York were having a prodigious development: foreign capital was Howing into the country, to share the advantages offered by its position, its productive resources, and its neutral flag: and general prosperity prevailed. The recent expansion of national territory was awakening a livelier sentiment of mationality than had existed before. The founding of claims for a further expansion, to the Pacific. was already under way; for the Rocky Mountains were being crossed, in I SO5. by an expedition which President Jofferson had sent, two years before, to explore the Missouri to its source. The ex-

Exploration of Lewis and Clark, 1804-1805. plorers, Captains Lewis and Clark, pushed on and planted their flag in that (Oregon region which no other nation could claim on ralid grounds.

The revenue of govermment in this flush time of trade rose far above its frugal expenditure, and promised an extinguishment of public debt much sooner than had been planned. In his annual message of I $\$ 06$ the President set forth the happy condition of the treasury, managed with rare ability by Secretary Gallatin, and recommended measures of Congress to apply the expected surplus "to the great purposes of the public education, roads, rivers, canals, and such other objects of public improvement as it may be thought proper to add to the constitutional enumeration of federal powers." He ended his recommendation by saying: "I suppose an amendment of the Constitution, by consent of the States, necessary, because the Jefferson's enlarged views of government, 1806. objects recommended are not among those enumerated 
in the Constitution, and to which it permits the public moneys to be applied." This was a conception rery different from that expressed five years before, when he wrote: "Let the general wormment be relued to foreign concerns only." That he should have been brought to contemplate so great an enlargement of the functions of the general government. eren by constitutional amendment. gires us interesting eridence of the rapid nationalizing of political ideas that was groing on in the American mind.

186. Abolition of the African Slave Trade. 1807. In the same message to Congress President lefferson called attention to the approach of the time ( 1808$)$ when the Constitution required the importation of slares from foreign souress to be stopped, and recommended legisliztion to that end. It was acoordingly made unlawful to bring any slare into the country from abroad after the last day of the year sog and heary penaltics were laid upon violations of the act.

187. Destruction of Neutral Trade. - British Orders in Council and Napoleonic Decrees. 1806-1807. The pleasant prospect. contemplated in 1 SO6, of surplus revenues to become applicable to purposes of education and improved means of communication in the combry was not enjoyed long. It depended on the kecping of some

power:

England's

struggle

with him.

1805-1807.

\section{Napoleon's}

part of the protitable adrantages of neutrality. in the deadly struggle between lingland and the ruler of France: and that strugerele was be suffered to exist. Xipnoleon (now a self-crowned cmperor) hat become absolutely the master of france and of half Europe besides, and he used them as he pleased for his merciless purposes of war. The end of 1 Sog foumd Spain, Italy, Austria, all (icmany, and the Netherlands 
obeying his commands, and Russia being humbled to alliance with him by dreadtul defeats. England alone of the great powers had been able to withstand the terrible warrior, and she only because his amies could not reach her island while her maties lept possession of the seil. His last hope of crossing the narrow Strait of borer perished in s So5. when the combined fleets of France and Spain were destroyed by Lord Nelson at Tratalgar. Then the conflict became a strange one, between land power and sca power, each beyond the other's reach. How could they pursue their war? (Only by striking at the commeree on which both depended for all that gave them their power. So they began, with naval

Commercial blockading on one side and military coast-guarding on the other, to do, if possible, by ruin and staration, what they could not do with bullets and shells. A double motive impelled bingland to this system of commercial warfare. While weakening Napoleon, it would likewise check the startling growth of the American carrying trade, in rivalry with her own. She opened her undertaking in May. I So6, by an "order in council " which declared that all the coasts, ports, and rivers of western Europe, from lirest to the Elbe, should be considered as in a state of blockade, with the consequence that any ressel bound for any part of that coast and intercepted at sea by british cruisers would be subject to capture as prize of war. This was what came to be known as a "paper

\section{Paper} blockading. blockade," there being little or no attempt to block the entrance to ports and rivers by naval fores actually on the watch. The sole object was to multiply the prizes which british cruisers might catch at sea. Napoleon, then lording it at the Prussian capital, retaliated in Norember by an edict, styled the Berlin Decree, which not only declared the British islands to be similarly blockaded, 
- on paper, - but forbade all commerce in British merBritish chandise, and commanded the seizure of such orders and

Napoleonic decrees,

1805-1807. to the Baltic Sea. His power was so great that he planned a "continental system" of commercial war, for the ruin of British manufactures and trade. The British government retorted in January and November, I SO7, by new orders, aimed at the suppression of all maritime commerce of France and her allies, except as it might be licensed and taxed at British ports. Napoleon met this by a decree from Milan, in December, commanding the seizure of any vessel that had submitted to the orders of his foe.

So far, then, as the warring powers could enforce their orders and decrees, neutral commerce - which had come to be mainly American commerce - was destroyed; but the evasion was extensive, and American shipping was not driven from the sea.

188. British Search and Impressment. 1807. The country was angered less by the English orders and French decrees than it was by the persistent impressment of seamen from American ships. With increasing insolence, British officers were pursuing that high-handed practice, even in American waters, at the very entrances of the most important ports. The climax of insult in

The

Leopard and the

Chesa-

peake, 1807. the matter was reached in June of that year, when the Chesapeake, an American frigate, just outfitted at Norfolk and wholly unready for battle, was overhauled as she sailed out of Chesapeake Bay by a British frigate, the Leopard, whose captain demanded permission to search for three deserters, claimed to have been received into the Chesapeake's crew. On refusal, three broadsides were poured into 
her, killing three and wounding eighteen men. Having nothing in readiness, she returned only a single shot, which one of her officers fired with a coal from the cook's galley; and her flag was struck. The three men claimed as deserters were taken, and proved to be Americans, wrongfully impressed before, and now styled deserters because they had escaped from their captivity. A fourth man was found hidden on board, who turned out to be a British deserter in fact.

189. An Experiment in "Peaceable Coercion." The Embargo Act. 1807-1809. Since Lexington there had been no excitement in the country so great as this unexampled outrage produced. A few Federalists still justified British conduct in everything; but they were very few. Almost universally there arose a cry for war; yet war did not follow. It did not follow for two reasons: (I) the indifference of the southern States to maritime and commercial interests, which centred almost wholly in the north; and (2) the extraordinary influence of President Jefferson, whose unbelief

Influence of President Jefferson. in war as a remedy for national wrongs overcame all contrary feelings in the public mind.

President Jefferson believed, as we have seen, in the practicability of extorting justice from other nations by simply refusing to have dealings with them when their conduct was wrong. He was able to persuade his country to act on that belief. He persuaded Congress to reduce the American navy to a fleet of little gunboats, for harbor defence only, and to stop the construction of larger warvessels, for ocean service, even while British cruisers were driving the merchant shipping of the country from the sea. In April, iso6, he obtained authority from Congress to prohibit the im-

Non-importation act, 1806. portation of British goods, as a measure of peaceable coer- 


\section{EXPANSION IN THE GREAT VALLEYS.}

cion; but the operation of the act was deferred for twenty months, while abortive attempts to negotiate with the English government were made once more. On the $4^{\text {th }}$ of December, $\mathrm{I} 807$, the non-importation act was carried into effect, and nine days later it was followed by a more heroic measure. This latter was an embargo act, which Embargo forbade the exportation of anything from the Act, 1807. United States to any foreign port, ordering every foreign ship in American waters to depart and every American ship to be held fast. In a word, it ended what British orders and Napoleonic decrees had left of American trade; and that suppression of the external commerce of the country was persevered in till the end of Jefferson's term, while New England went frantic over the idleness of its ships, and the cotton and tobacco of the south had no sale.

The rage of the shipping interest against the embargo was fierce. The old Federalist belief that Jefferson and his party were under French influence in whatever they did came to life and did mischief again. Apparently there were whispers of secession in some quarters once more, and the governor of Canada sent an agent, named

John

Henry John Henry, into New England, on a mission of papers. intrigue. Three years afterward Henry sold the information he had gathered to the government of the United States; but his papers named nobody and disclosed no really treasonable act.

Everywhere, as the months of stagnation in the country dragged on, disgust and disaffection grew bitter; for no

Fallure

of the

ombargo. signs of any effect on the conduct of France or England appeared. Napoleon welcomed the embargo as a blow to England, and he helped to enforce it by orders of his own; while his minister at Washington confessedly used influence to have it pro- 
longed. The British West Indies were half starved by it, and England suffered from the pinching of her supplies of cotton and food; but high prices in the food market were agreeable to the landlords who ruled England, and they were not in haste to remove the cause.

The experiment of "peaceable coercion" had failed. The President himself was compelled at the end to admit that "it costs more than war" $;^{1}$ though he still believed that it would have wrung justice from England in a bloodless way if an absolute em-

Peaceable coercion more costly than war. bargo could have been enforced. But the influence of his opinions was no longer what it had been. His party suffered in popularity with him, and most likely it would have been beaten in the presidential election of ISOS, if the opponents of the embarco policy Election of ISo8, if the opponents of the embargo policy Madison, could have acted together. As it was, their division gave the presidency to Mr. Madison, the candidate of his choice; but the Federalists swept New England, and cast 47 electoral votes, against 14 in I804.

190. Substitution of Non-intercourse for the Embargo. 1809. Nevertheless, the administration was strong enough in Congress to carry, in January, I809, an act enlarging its powers for the enforcement of the embargo; and this proved to be more than the country would endure. The town meetings of New England were soon speaking as they spoke in 1774 , so threateningly, and with so much concurrence of feeling in the middle States, that Congress was seized with a panic which the supporters of the embargo could not resist. The latter were beaten in an attempt to prolong the measure till June, and a bill was passed which ended it on the day of Jefferson's retirement, March 4, i 809. The alternative

1 Writings, ed. by Washington, v. 433 (not contained in Ford's edition). 


\section{EXPANSION IN THE GREAT VALLEYS}

of war was not accended. hwever nor was the dies of

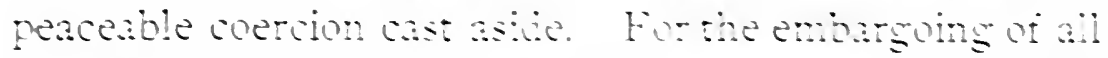

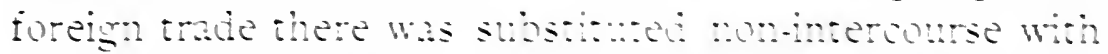
England and France This wa done by an as whin excluded the shos of those comones fom Amering

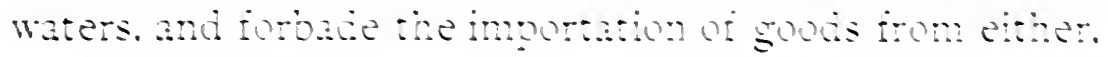
until one or both gare ericence of resper for nensa! rignts.

191. Political Effects. The poiticil eftects ot the

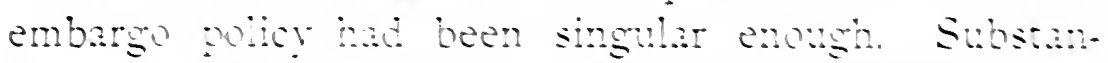

The partes exchange

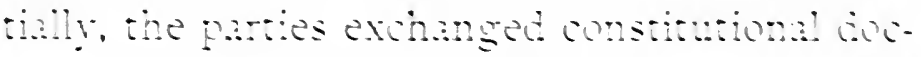
doctises.

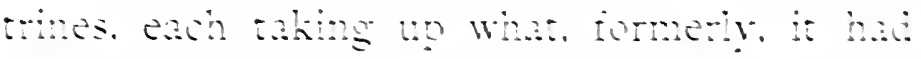

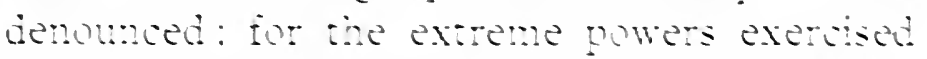
in the Embargo tot and in subray messures to entome it, were drawn from the Constandion by Fetemastio

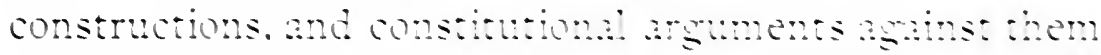

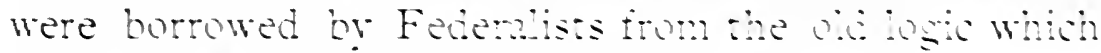
the Repubitans hat thrown astie.

192. Territorial Reorganization. 1805-1809. In February, Ison, an act was pised which betsched the

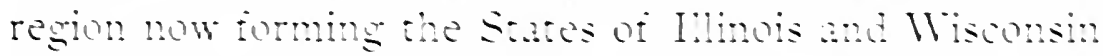

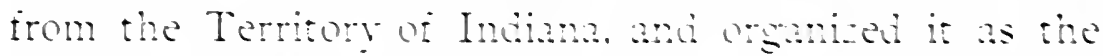
Territory of Illinots. The resion between lakes Erie. St.

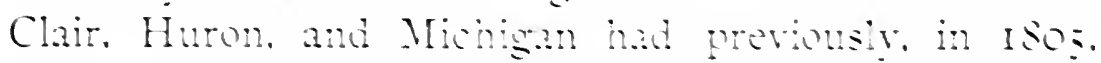
been separated from Indiana to form the Territory of Michigan.

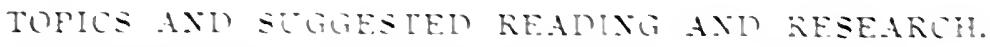

176. The United States at the Beginning of the Nineteenth Century.

TOPIC ANR REERETCRS.

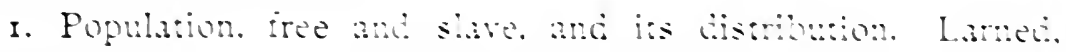
Kerativerit

2. The southwestem and nothwestern sctilements. 3. Early 
difierences of interest hetween communities of the (hio valley

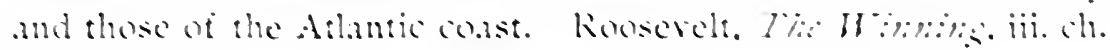
iii. : ir. ch. .

4. Resimnings of the steam ensine and of steam nuxigntion.

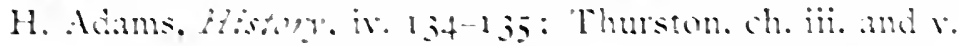

5. Whimey " comon win "and its aftects on slavery. Holst.

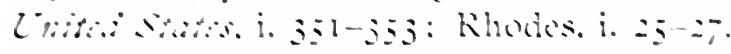

6. Other cusces of a scotional division of the stutes.

\section{The Political Change wrought by Jefferson's Election.}

TOPLS AND REFRENTES

I. Jefiersons view of the revolution in principles of goremment. - His general aims. 2. His theory of the functions of the sen-

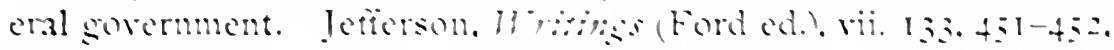

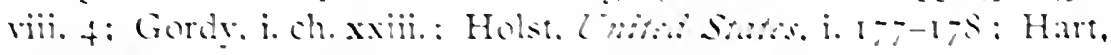

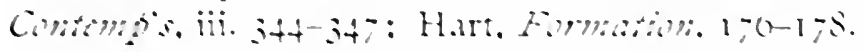

3. His plans of "peacable coercion" as a remedy for national

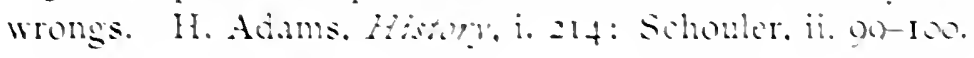

\section{The Tripolitan War.}

TOPICS ANR REFERACES.

I. Causes of the war. 2. Commodore Dale sent to the Mediter-

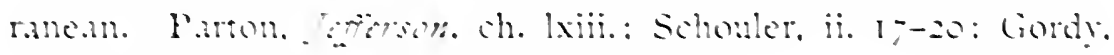
i. $+15-4=0$ : Hart Conson

\section{The Louisiana Purchase.}

TOMICS ANU KEFERFNCES

I. Cession of Lousian from Span to France. 2. American feeling on the subject - Simd aken by the Fresident. 3. Sale

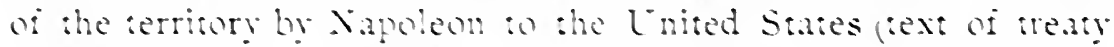

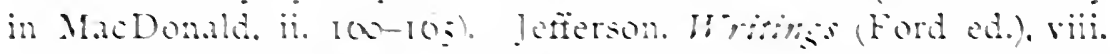

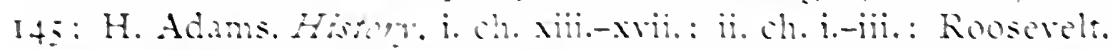

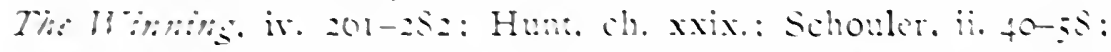

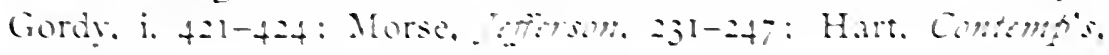

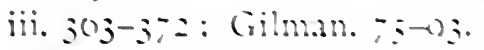

4. The constitutional question imolved. 5. Partisan inconsis-

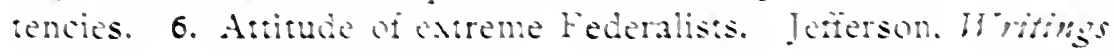


(Ford ed.), viii. 247 ; H. Adams, History, ii. ch. iv.-r.; Holst, i. Is3-I94: Gordy, i. 425-432: Roosevelt, The Winning, iv. 2S22St; Hart, Contemp's. iii. 373-3So; Morse, Jifferson, 247-25s.

7. Organizations of government in the new territory. H. Adams, History, ii. ch. vi.; McMaster, iii. 13-32: Gordy, i. 432-438.

RESEARCH. - The more important effects and results that have come from the Louisiana Purchase. Am. Hist. Ass'n Reports (Davis), I 897 , I49-160: Papers (Robertson), i. 253-290.

\section{Secession Plotting. - Burr's Intrigues. - Burr and Hamilton Duel.}

TOPICS AND REFERENCES.

I. Disunion plotting with Burr. 2. Discomfiture of the plotters. - Duel and death of Hamilton. H. Adams, History, ii. ch. viii.: McMaster, iii. 47-54; Schouler, ii. 68-74; Gordy, i. ch. xxvi.; Holst, United States, i. 194-199; Hart, Formation, I88-189; Lodge, Hamilton, 245-250; Johnston, Am. Orations (Nott), i. I 1 7-I $2 S$.

\section{Presidential Election.}

TOPICS AND REFERENCES.

I. Weakening of the Federalist party. - Reëlection of Jefferson. 2. Constitutional change in the mode of election. Morse, Jefferson, 263-27I ; H. Adams, History, ii. 200-206: Schouler, ii. 74-75.

\section{Burr's Conspiracy in the Southwest.}

TOPICS AND REFERENCES.

r. Burr's schemes. 2. Discontent and frontier lawlessness that encouraged them. 3. Easy frustration of the conspiracy. Parton, Bur, ch. lxv.; Roosevelt, The Hinning, iv. 284-307; H. Adams, History', ii. 394-fo9, iii. ch. x.-xiv.; McMaster, iii. 54Ss; Schouler, ii. I33-138; Hart, Contemps, iii. 356-359; MacDenald, ii. 165-171.

\section{End of the Tripolitan War.}

Topics and ReFerences.

I. Treaty concluded. 2. Important trạining of the American nayy in the war. McMlaster, iii. 200-208; Schouler, ii. 75-77, 104-106, I2t; H. Adams, History, ii. 425-436. 


\section{Renewed Offensiveness of British Conduct.}

Torics AND References.

I. Reversed ruling of British courts. 2. Increased captures of American merchantmen. H. Adams, History, ii. ch. xiv.-xv.; iii. 43-53, So-102, 197-203; Schouler, ii. IO8-II 2, II4-II 8, I32-I 33 ; McMlaster, iii. 225 .

185. Prosperity of the Country. - Expansion of National Sentiment.

TOPICS AND ReFERENCES.

I. Profit and loss in the ocean carrying trade. McMaster, iii. $225-226$.

2. Exploration of the Rocky Mountain region and beyond. Roosevelt, The Winning, iv. ch. vii.; Hart, Contemp's, iii. 381384 .

3. Increased public revenue. - Extinguishment of debt. 4. President Jefferson's recommendation of public improvements at national expense. 5. Significance of his changed views. Jefferson, viii. 494 ; H. Adams, History, iii. I-2 1, 345, 348; Morse, Jefferson, 292-294.

Research. - Albert Gallatin and his administration of the Treasury Department. Stevens, Gallatin, ch. vi.

\section{Abolition of the African Slave Trade.}

TOPICS AND REFERENCES.

I. The act fulfilling the intention of the Constitution (text in MacDonald, ii. I71-176). Holst, United States, i. 317-328; H. Adams, History, iii. 356-367; Schouler, ii. I 42-147.

187. Destruction of Neutral Trade. - British " Orders in Council" and Napoleonic Decrees.

TOPICS AND REFERENCES.

I. Circumstances of the conflict between England and Napoleon. 2. Its reduction to a system of commercial warfare, destructive of neutral trade. 3. Successive orders and decrees of the combatants. - Their aim and effect. H. Adams, History, iii. 38s-391, +16-421, iv. 79-127; Gordy, i. 5II-540; McMaster, iii. 248-275; Schouler, ii. 156-161, 170-176; Holst, United States, 
i. 200-20I ; Morse, Jefferson, 286-296 ; Hart, Contemp's, iii. 400403 .

RESEARCH. - Importance to the world at large of the resistance made by England to Napoleon. - Grounds on which her Orders in Council may be defended. Mahan, Influence of Sea Power, ii. ch. xviii.-xix.

\section{British Search and Impressment.}

Topics AND ReFERENCES.

I. Increasing insolence of British naval officers. 2. The Chesapeake outrage. H. Adams, History, iv. ch. i. and vi.; McMaster, iii.240-246, 253-270; Hart, Formation, 192-194; Hart, Contemp's, iii. 385-400; Schouler, ii. I63-I 70; Gordy, i. 507-5Io; Morse, Jefferson, 296 .

\section{An Experiment in "Peaceable Coercion." -} The Embargo Act.

Topics AND References.

I. The cry for war, and why war did not follow. 2. President Jefferson's gunboat policy. 3. The non-importation act and the embargo act (text in MacDonald, ii. 176-1 77). 4. Effect of the embargo in the United States. 5. The John Henry intrigue. 6. Failure of the embargo to affect the conduct of England or France. 7. Injury to Jefferson's influence. H. Adams, History, iv. ch. vii.xii., xiv.-xv., xx.; Schouler, ii. I76-1S6, 194-207; Gordy, i. ch. xxxii.-xxxiii.; McMaster, iii. 276-309; Holst, United States, i. 20I-2I 5 ; Hildreth, vi. 36-44, 48-58, 69-79, 84-93, 96-I I 3 ; Parton, Jefferson, ch. lxvi. ; Morse, Jefferson, 296-312, 316-317; Hart, Contemp's, iii. 403-406.

REsEARCH. - The character of John Randolph, of Roanoke, and his political course. Trent, S9-150; H. Adams, Randolph.

\section{Substitution of Non-intercourse for Embargo.}

TOPICS AND REFERENCES.

I. Rebellious threatenings in New England. 2. Repeal of embargo act. - Suspension of commercial intercourse (text in MacDonald, ii. I77-I 83 ). H. Adams, History, iv. ch. xvi.-xix.; Hildreth, vi. II3-I3S; Gordy, i. ch. xxxiv.-xxxv.; Schouler, ii. 
TOPICS, REFERENCES, AND RESEARCH. 33I 207-220; Holst, United States, i. 215-225; McMaster, iii. 3I8336.

\section{Political Effects.}

TOPICS AND REFERENCES.

I. Reversing of former political doctrines by both parties. Hildreth, vi. I40-I43; McMaster, iii. I97-198.

\section{Territorial Reorganization.}

TOPICS AND REFERENCES.

r. Formation of the Territories of Michigan and Illinois. Hildreth, vi. I3s. 


\section{CHAPTER $\mathrm{X}$.}

SECOND WAR WITH ENGLAND. 1809-I8I7.

193. Mr. Erskine's Blunder. - President Madison misled. 1809-1810. When Madison took the reins of government from Jefferson, on the 4 th of March, i 809, the outlook in foreign affairs was dark; but an unexpected brightening appeared soon on the British side. The British minister then at Washington, Mr. Erskine, received instructions which led him to agree with President Madison that the orders in council should be withdrawn, and that the President, by proclamation, should end the interdictions of commerce with Great Britain, but should continue them against France. This arrangement was announced and the President's proclamation issued on the 2ist of April, to the unspeakable joy of the country, and three months of a busy revival of trade ensued. It took that length of time for the report of what Mr. Erskine had done to reach England and for the action of his government on it to be reported back. The message when it came was a blow. Erskine had

Erskine's

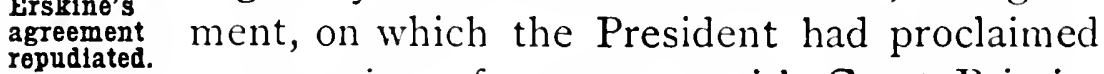
a reopening of commerce with Great Britain, was repudiated, and the orders in council, instead of being annulled, were only replaced by a new order, declaring a paper blockade of the whole of Italy, Holland, and France.

The situation was now worse than before. Angry 
feeling on all sides was increased. Erskine was recalled, and a new British minister, Mr. Jackson, notorious amongst the English diplomats for offensive ways of doing business, was sent in his place. Non-intercourse was proclaimed again; but nobody could feel satisfied with its effect. The futile measure was maintained, however, until the Ist of May, I8ro, when Act of May Congress, not knowing what else to do, restored $\mathbf{1}, \mathbf{1 8 1 0}$. freedom to commerce, but authorized the President, if England withdrew her orders or France her decrees before the $3 \mathrm{~d}$ of the next March, then in that case to prohibit intercourse with the nation that kept them in force.

Mr. Jackson, the new British minister, arrived in September, I809, and was not slow in making himself as disagreeable as he was expected to be. Before many communications had passed between Jackson. him and the government, he had offered such insults that the latter would receive nothing further from his hands. This produced no special consequences; but some foolish Federalists in northern cities made great social efforts to show Mr. Jackson that his conduct was approved.

194. The Trickery of Napoleon. 1809-1811. In the behavior of Great Britain at this time there was really less of practical hostility to the United States than in the doings of the despotic master of France. The embargo act had suited the aims of Napoleon's "continental system ;" but he was angered by the non-intercourse act, which interdicted trade Napoleon's anger at non-intercourse act. with France, and not with her subject-allies, Holland, Naples, and Spain. That offence to him was increased by the mistake which reopened commerce with Great Britain during three busy months. He had begun, 
therefore, a new series of spoliations, more outrageous than his earlier ones, not only ordering seizures and confiscations of American vessels and cargoes in Spanish and Neapolitan ports, but treating their crews as prisoners of war. In March, ISIO, he issued secretly a The Decree general decree, known as the Decree of Ramof Ramboulllot, 1810 .

bouillet, which swept into his net all American ships within his reach, and when his brother Louis, whom he had made king of Holland, failed to carry out the decree in Dutch ports, he drove him from the throne and annexed Holland to France. The plunder secured was so great that it appears in Napoleon's own estimate of his revenue for the year as amounting to $\$ 6,000,000$, and other estimates have made it more nearly ten millions than six.

The act passed by Congress on the ist of May, i 810 , repealing the non-intercourse act, but providing for the

Promised revocation of French decrees, 1810 . revival of it against one or the other of the powers at war, according to their behavior, suggested a characteristic piece of trickery to Napoleon's mind. He gare notice (August 5, I 8 IO) to the American minister at Paris "that the decrees of Berlin and Milan are revoked, and that after November I, they will cease to have effect, - it being understood that in consequence of this declaration the English are to revoke their orders in council, and renounce the new principles which they have wished to establish; or that the United States, conformably to the act you have just communicated, cause their rights to be respected by the English." 1 To one of his own ministers he said at the same time, "We commit ourselves to nothing," - which was true. His scheme was to push the United States into hostilities with England,

${ }^{1}$ H. Adams, History of the United States, v. 255. 
while he should do as he pleased in the matter of the decrees. The American government was not critical of the notice received from France; it assumed that the Berlin and Milan decrees would be revoked as promised, on the ist of November, and that revocation meant restitution of the property seized. Accordingly, on the $2 \mathrm{~d}$ of November President Madison proclaimed the revocation, and interdicted commercial intercourse with Great Britain, to take effect on

\section{President}

Madison's proclamaton, 1810. and after February 2, I8ri. But weeks and months passed without bringing anything from France to show that the decrees were not in force, and no questioning could draw a distinct answer as to what had been or would be done. Publication of Napoleon's correspondence has made it known since that, as late as April, ISII, he was ordering his ministers "to gain time, leaving the principles of the matter a little obscure until we see the United States take sicles."

195. Occupation of West Florida. - Louisiana admitted as a State. 1810-1812. In another quarter the foreign relations of the country were complicated at this time. Since I SoS the people of Spain had been struggling to break the yoke which their imbecile court allowed Napoleon to lay upon their necks. The whole Spanish colonial empire was in consequent disorder, and revolutionary movements in most of the American provinces were taking place. In the district of Revolution West Florida (see Map IV.) that adjoined New $\begin{gathered}\text { in West } \\ \text { Florlda, }\end{gathered}$ Orleans many Americans had settled, and they 1810 . found the opportunity good for a revolution of their own. Accordingly, in the summer and fall of ISIO, they seized the Spanish fort at Baton Rouge, held a convention, declared independence, and applied for annexation to the United States. President Madison would not 
recognize their revolution, but deemed it proper, in such circumstances, to take possession of the region, which the United States had been claiming since I $\mathrm{SO}_{3}$ (see sect. 179). It was occupied, accordingly, by Governor Claiborne, of the Orleans Territory, in December, I 8 Io. Congress approved the President's action, and passed, at the same time, an act authorizing the inhabitants of the Territory of Orleans to adopt a constitution preparatory to admission as a State. The new State The State of thus formed received the name Louisiana, and The State of was admitted to the Union in April, I8I2. 1812. West Florida as far eastward as Pearl River was annexed to it; the remainder, to the Perdido, was declared to be a part of Mississippi Territory, though possession was not taken until I 813 .

196. Federalist Opposition to the Admission of Louisiana. 1811. The proposed admission of Louisiana revived a threatening spirit in the New England Federalists, who denied the constitutional right of the existing Union to add new States to itself (see sect. 179).

Speoch of Their then leader, Josiah Quincy, of Boston, Josiah, declared in debate (January I 4, I 8 I I): "If 1811. this bill passes, it is my deliberate opinion that it is virtually a dissolution of the Union; that it will free the States from their moral obligation; and, as it will be the right of all, so it will be the duty of some, definitely to prepare for a separation, - amicably if they can, violently if they must."

197. Dissolution of the United States Bank. 1811. In home affairs an agitating question was raised by the approaching expiration of the charter of the United States Bank. The bank had proved useful to the business of the country and to the government, and Mr. Gallatin, the able Secretary of the Treasury, was most 
anxious for its preservation; but jealousy and distrust of it in the Republican party were rooted too deeply to be overcome. Congress refused to extend the charter, and the bank in due time was dissolved.

198. Feeling for and against War with England. 1811. Meantime, relations with England had not been changed seriously by the fresh interdiction of trade. Still obstinate on the subject of the orders in council, and contending with truth that Napoleon's decrees had not been revoked, the British government was showing, nevertheless, a more conciliatory disposition, by sending an agreeable minister to Washington, and offering a partial reparation of the outrage on the Chesapeake. Of actual provocations to war, so far as concerned the old grievances, there were less from England in I8II, and more from France, than there had been at any time within the past five years ; but an outbreak of Indian hostility, occurring that summer in the Indiana Territory, was supposed to have been instigated by emissaries from Canada, and became a new charge against England in the long account of wrongs. Tethreatening league, cumseh, or Tecumthe, a Shawnee chief of ability, assisted by his brother, styled the Prophet, had renewed the undertaking of Pontiac, to form a league of tribes for resistance to the advance of the white race. The territorial governor, William Henry Harrison, with a force of regulars and volunteers, broke up the movement in a sharp battle fought on the Pattle of Tippecanoe (November 7, I8II). Tecumseh, 1811 . who was absent at the time, found his project frustrated, and took refuge in Canada, giving color to the belief that he had acted under an influence from the authorities there. This caused some fresh excitement of antiEnglish feeling; and so did an encounter that happened 
in May, between the American frigate President and a Aftair of British sloop of war, the Little Belt. Exactly the little how or why they came to exchange shots, and Belt,

which fired first, was never made clear. The Little Belt, a smaller vessel than the President, suffered badly in the short fight.

The temper of the country does not seem to have been touched very sharply by these events, and the influences opposed to war were strong. Despite all losses and restrictions, the merchant shipping of the United States was enjoying a more profitable activity than it was likely to have in a state of declared war with England, the powerful mistress of the seas. It was principally a New England interest, and it confirmed New England Federalism in leanings toward Great Britain, in detestation of Napoleon and France, and in dread

War feelof the party in power. On the other hand, ing, north the south and the new western States had no and south.

maritime interest, and adhered to the old feelings of the Revolution, against England and in favor of France. Pennsylvania was with the south in those feelings, and New York leaned the same way.

199. The "War Hawks" in Congress. - Henry Clay. 1811-1812. The situation was one in which slight influences could turn the scale for or against war. The decisive influence came from a group of young men who appeared in the House of Representatives that year. We may almost say that it came from a single member of the group, its cloquent leader, Henry Clay. Clay was a Virginian by birth, but had settled in Kentucky after finishing his studies in law, and had risen quickly to distinction in that State. Twice, already, he had filled vacancies for a few months in the Senate of the United States; now, in I8I I, he 
came to a seat in the House of Representatives, and took command, as it were ; was made Speaker, "speaker" and ruled the House as no one in the Speaker's clay, 1811. chair had ruled it before. Along with brilliancy and power as an orator of the popular type, he had the personal force, the enthusiasm, and the self-confident, high spirit of a natural leader of men. $\mathrm{He}$ was hot with the anger of Kentucky over the humiliations of the country, especially those coming from British hands ; and he found a number of young members more than ready to join him in a demand for war. John C. Calhoun, of South Carolina, was a prominent member of the group.

The vehemence of these "war hawks," as they were styled, soon produced a great effect. Congress passed bills for increasing the army, for raising volunteers, and for calling out the state militia, and some very inadequate provision for strengthening the navy was made; but the controlling idea of the war party was to prepare for a conquest of Canada, and they deprecated the thought of much resistance to the great power of England at sea. Events proved them to be utterly mistaken in their forecast of the projected war.

200. War declared. June 18, 1812. The peace party included many Republicans, conspicuously John Randolph, a Virginian of erratic genius; but the war party, helped by the disclosure at this time of the John Henry correspondence (see sect. 189), had its way. President Madison, with reluctance, began the action it desired, on the ist of April, is 8 2, by recommending an embargo for sixty days, which was understood to be preliminary to a declaration of $\begin{gathered}\text { Embargo } \\ \text { for ninety }\end{gathered}$ war. Congress enacted the embargo for ninety days. days; but, on the Ist of June, at the end of sixty days, a 
message from the President recommended that war be declared. A bill embodying the portentous declaration passed the House on the 4 th, the Senate on the i 7 th, and was signed by the President on the 18 th. It was carried by southern and western votes, against the opposition of New England and New York, and at a moment when the principal reason for war was removed;

Orders in

withdrawn,

June 17,

1812 .

for news came in July that the British government had withdrawn the offending orders in council, and had announced the fact in Parliament one day before the American declaration of war. Furthermore, it had sent proposals for an armistice and a renewal of negotiations, in case hostilities should have been begun; but it gave no sign of willingness to abandon impressments from American ships, and the authorities at Washington refused the truce. Defence of "sailors' rights" became then the single object of the war.

201. Opening Disasters. - Hull's Surrender at Detroit. - Battle of Queenstown Heights. 1812. The nation was undertaking a war which large masses of its people resented or disapproved; for which its economic condition and its military organization were wretchedly prepared; and to conduct which its officers of experience were few and old. That the sanguine expectations of the "war hawks" would be disappointed was an almost inevitable result. The disappointment began with the first invasion of Canada, undertaken from Detroit, Kull at in July, by a Revolutionary veteran of good Detrolt. record, General William Hull. The British authorities in Canada had acted more vigorously than the Americans, and Hull found them readier to strike at him than he at them. He fell back to his fort at Detroit, was followed and beleaguered by British troops 
and the savage warriors of Tecumseh, and surrendered to them, August 16 . The unfortunate general was afterward disgraced from the army by court-martial, and only saved from a death sentence by the President's compassion; but later opinion lays blame for the disaster quite as much on his military superiors as on Hull.

The next attempt to enter Canada had no better success. It was made on the I $3^{\text {th }}$ of October from Lewiston, on the Niagara River, below the Falls, by forces under General Van Rensselaer about 6000 strong. A footing on the opposite heights of Queenstown was gained by about 900 of Van Rensselaer's

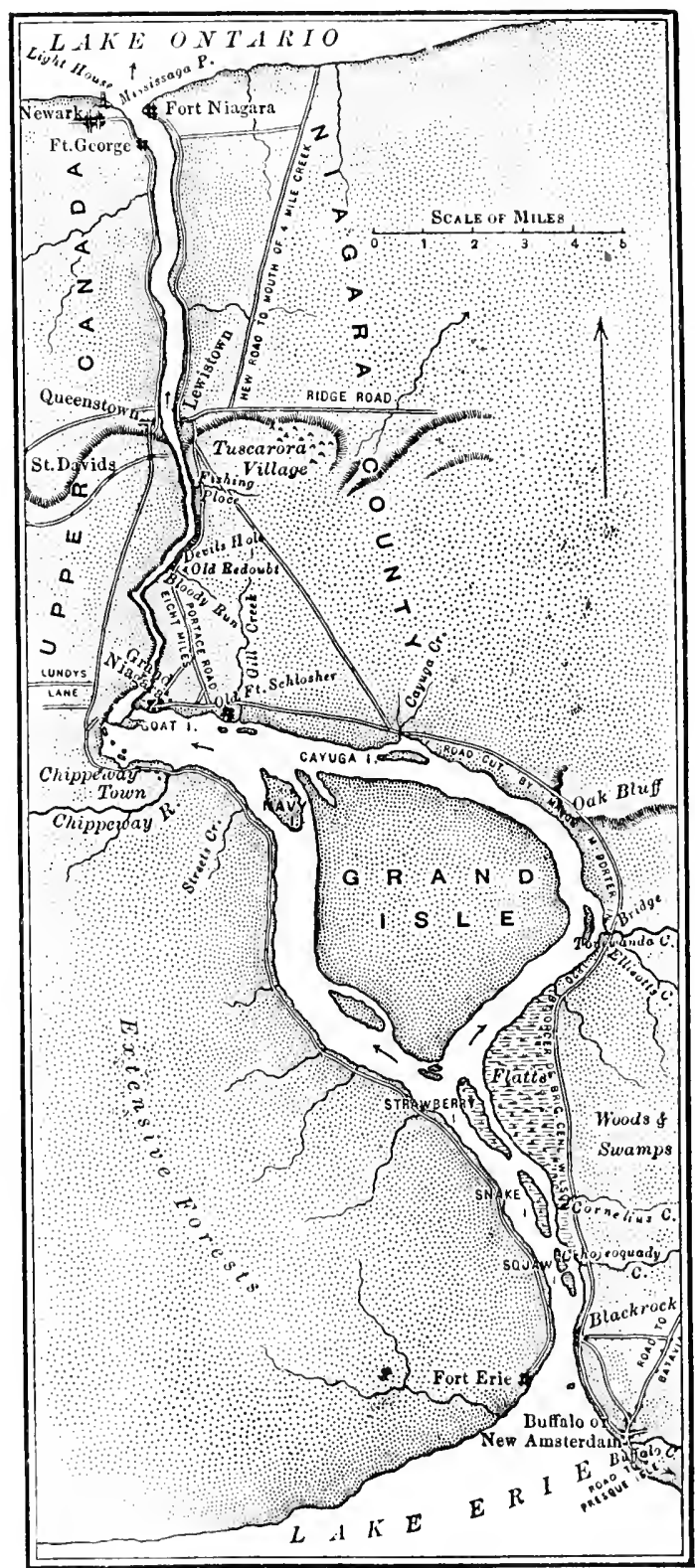

MAP OF NIAGARA FRONTIER IN I\$I2-I4.

Reproduced, with a few adaptations, from a "Gazetteer of the Province of Upper Canada," published in 1813 . 
men; but reinforcements camc to the British, while none reached the Americans, and the latter, in a helpless position, had to lay down their arms. The British commander, General Brock, received a mortal wound in the fight. The officer who won most distinction in this battle was Lieutenant-Colonel Winfield Scott.

202. Naval Triumphs. 1812. While disaster attended the American operations of war on land, the little navy of the United States was winning laurels at sea. Its total count of war-ships was but I 8 , large and small, only three of which were ready for service when hostilities began; and against it was a navy of not less than a thousand ships. But, ship for ship, in single encounters, the American vessels proved to be generally better in build, stronger in armament, more accurate

The Constitution and the

Guerri ore, 1812 . in gunnery, more skilful in seamanship, and the English were astonished and dismayed by the results of the sea-fighting that occurred. On the Igth of August the frigate Constitution, Captain Isaac Hull, captured the British frigate Guerrière, after a battle of two hours. On the I 8 th of October the British sloop-of-war Frolic was taken by the American sloop Wasp; but both were caught soon

\section{The}

United

States and the Macedonia, the Constitution and the Java, 1812. after by a bigger British man-of-ivar. Seven days later the frigate Macedonia surrendered to Captain Decatur, commanding the United States; and the year's record of naval victories was closed on the 29th of December, when the Constitution destroyed the Java in a battle off the coast of Brazil. Meanwhile, a swarm of commissioned privateers was pillaging British commerce almost as heavily as British cruisers pillaged that of the United States.

203. Second Disaster in the West. 1813. Before 
the year closed Commodore Chauncey had put a small naval squadron afloat on Lake Ontario, and Lieutenant Elliot had gone to Lake Erie to do the same; for little could be done toward recovering the ground lost in the west until full control of the lakes was secured. The western command had been given to General Harrison, and late in the fall he began a movement from Indiana for the recovery of Detroit; but 900 of the best of his troops, under General Winchester, proceeding winohestoo carelessly in advance, were overpowered in January by British and Indian forces, on the ter's defeat, January, river Raisin, not far from what is now the city of Monroe. Four hundred perished, including sick and wounded, who were given up to the tomahawks of the savages; the survivors were made prisoners of war. This fresh disaster checked the movement till the following year.

204. Reëlection of President Madison. 1812. Excepting the repulse of a British attack on Ogdensburg, there had been nothing but disaster in the military operations of the first year. In naval warfare there had been nothing but success; and, probably, it was the naval victories that saved the war party from overthrow in the presidential election that fall. Mr. Madison was reëlected, defeating a combination of dissatisfied Republicans and Federalists, who voted for DeWitt Clinton of New York. Daniel Webster was one of the Federalist congressmen elected in New Hampshire that year.

205. Naval Occurrences on Salt and Fresh Water. 1813. On salt water the naval triumphs of 1812 were not equalled in the following year. Only two small armed vessels were taken from the enemy, while a sore reverse was suffered, the unfortunate frigate Chesapeake succumbing to the Shannon (June I), in a fight that was no chance encounter, but a duel, deliberately 
planned. Captain Bloke of the Shannon had challenged Captain Lawrence of the Chesapeake, and

The Chesapeake and the Shannon, June, 1813.

waited for him outside of Boston Bay. The two ships were about equal in men and guns, but the Shannon had the better trained crew, and reduced her antagonist in fifteen minutes to a helpless state. Captain Lawrence, wounded mortally, cried, "Don't give up the ship," but it was a vain appeal.

By this time enough of the enormous navy of England was concentrated on the American coast to blockade British the principal harbors and shut in most of the blockade. American fleet ; but privateers, built and rigged to outsail every enemy afloat, were numerous at sea and actively at work.

It was on the inland fresh waters that the navy now distinguished itself, and the hero of the year was Captain Oliver H. Perry, detailed to command on Lake Erie and the upper lakes. At Presque Isle, now Erie, Perry constructed two brigs and three schooners in great haste, and brought fire more small ressels from the Niagara, at Buffalo, to make up his fleet. With these, on the roth

\section{Perry's} victory on Lake Erie, September $10,1813$. of September, off the islands near the mouth of Sandusky River, he encountered a squadron of six vessels which Captain Barclay, of the British navy, had fitted out with equal difficulty at the western end of the lake. The battle was obstinate on both sides. Perry's flagship, the Lawrence. became so injured and unmanageable, and the carnage on her was so fearful, that the surviving officers could do nothing but strike their flag; but the indomitable commander had left the ship before that occurred, - luad transferred himself to another vessel, the Niagara, on whose deck he won the fight.

206. Recovery of Detroit and the West. - Futile 
Campaigning on the New York Frontier and the St. Lawrence. 1813. "We have met the enemy and they areours" was Perry's famous despatch to General Harrison, for whose movement on Detroit this conquest of the lakes cleared the way. Both Harrison and Perry made haste to Detroit River, from which the British forces and Tecumseh's Indians retreated together, through Canada, making their way to

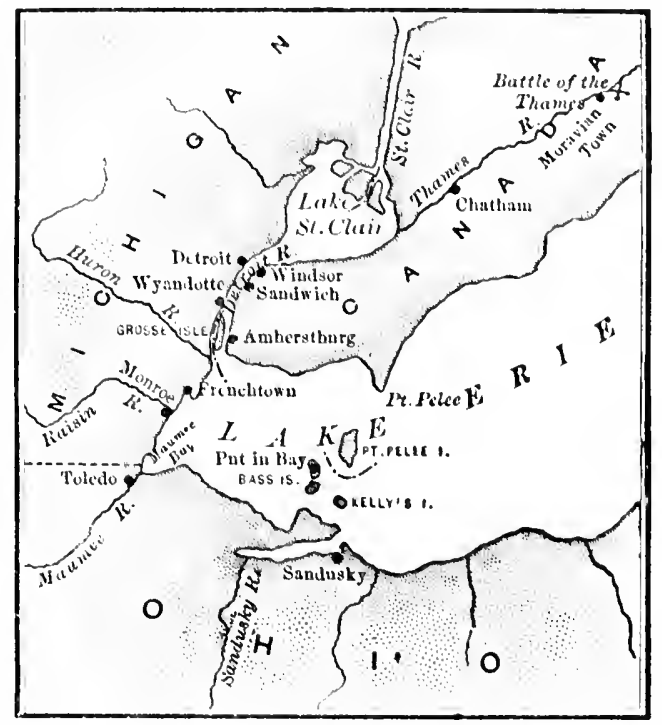

WESTERN LAKE ERIE IN THE WAR OF ISI2. the Thames River and up that stream. Harrison pursued and overtook them near Moravian Town, a few miles above Chatham. In the battle fought there (October 5), Tecumseh was killed, his followers were scattered, three quarters of the Battle of the Thames, October 5 , British troops were captured, and the conquest of western Canada, for the time being, was complete.

On the New York frontier there was much activity, with nothing but momentary results. The little town of York, capital of Canala West, now grown into the city of Toronto, was captured, and its pub-

Burning of lic buildings were burned, - an act of vandalism which General Dearborn, the American commander, disclaimed and denounced. Fort George, near the mouth of the Niagara, was taken, but the garrison escaped, and drove back a pursuing force (at Stony Creek) with heavy loss. 
Meantime, the important naval station at Sackett's Harbor was exposed to attack and nearly lost. It was saved by the capable energy of Jacob Brown, a New York General Ja- militia officer, who won a general's commission cob Brown. in the regular army by that service, and was advanced not long afterward to the chief command on the northern frontier. Nothing was done to make use of the positions gained at the western end of Lake Ontario, but all possible forces, even Harrison's, were drawn eastward for an expedition down the St. Lawrence, to capture Montreal. The expedition commanded by General Wilkinson (of former notoriety in connection with Burr, see sect. 182) failed miserably, and was abandoned at an early stage, after an ignominious engagement known as the battle of Chrystler's Farm. Then the British, more promptly than the Americans, returned their forces to the neglected Niagara frontier. In December they recovered Fort George, crossed the river, surprised the important Fort Niagara, and proceeded, with their Indian allies, to ravage the whole American shore of the river. They burned the village of Buffalo, in retaliation for some equally barbarous destruction by the American garrison which retreated from Fort George.

207. The Creek War. 1813. Late in the summer of 1813 the Creek Indians, in Mississippi Territory, formerly half won to the projects of Tecumseh, and freshly stirred up by both English and Spanish emissaries, rose against the white settlers and committed a horrible massacre at Fort Mims (August 30). General Andrew Jackson, of the Tennessee militia, was put in command of forces sent against them from that State, and carried on an energetic campaign for seven months, completely breaking the power of the tribe.

208. Fall of Napoleon. - Its Effect on the War in 
America. 1814. At the opening of the year I 8 I 4 there was not much promise in the prospects of the war, nor did the prospects brighten as the year advanced. The military despotism of Napoleon was tottering to its fall. Half a million of Germans, Russians, and Austrians were in northern France, moving irresistibly upon Paris, while the British army of Wellington $\begin{gathered}\text { The allies } \\ \text { in France, }\end{gathered}$ fought its way across the Pyrenees from Spain.

1814.

On the last day of March the victorious allies entered Paris; on the 4th of April the abdication of Napoleon was signed. The forces of Great Britain were then free to be turned upon the United States.

209. Last Attempt against Canada. - British Advance to Lake Champlain. - Macdonough's Naval Victory. 1814. Before the effects of this great change in circumstances were felt, one last attempt to carry the war into Canada was made. General Jacob Brown was in command, with General Winfield Scott among his brigadiers. Early in July Brown crossed the Niagara from Buffalo and took Fort Erie, which commanded the entrance to the river from the lake (see Map on page 34I). Thence he advanced down the river to Chippewa, near Niagara Falls, where a sharp engagement occurred (July 5). The enemy retreated to Fort George, and Brown followed; but they were reinforced, and he was not, and he found it necessary to draw back. At Lundy's Lane, so called, near the Falls, he made a stand, and there, on the $25^{\text {th }}$ of July,

Battle of

Lundy's Lane, July 25, 1814. a desperate battle was fought, in which both Brown and Scott received serious wounds. The slaughter, nearly equal in the two armies, was very great. Both claimed a victory, but the gain belonged to the English, since the Americans retired to Fort Erie and were besieged there within a few days. The siege and defence of the 
fort, for nearly two months, were notable incidents of the war. In the end the besiegers were baftled, but the heroic defence had been fruitless; the works were destroyed and abandoned, and the American forces came back to their own soil.

There was no longer any thought of a conquest of Canada: the war had become one of defence against powerful attacks. An invading army from Canada had adranced to the head of Lake Champlain, and a squadron of small ressels and gunboats was in preparation to coopperate with it, in a movement toward the Hudson, on the old route of Burgoyne. Commodore Thomas Macdonough prepared a similar but weaker squadron to oppose the adrance, and waited for it in Plattsburg Bay; Battles of while General Macomb held a fortified position Plattsburg, near Plattsburg with scarcely 2000 American 11, 1814. troops. On the IIth of September the invading forces made their simultancous attacks by lake and land, and were defeated in both. Their invasion was brought to a sudden end. Mr. Roosevelt, in his "Naral History of the Mar of I $S$ I, " ranks Macdonough's exploit above every other in the war, and says of him that "down to the time of the Civil War he is the greatest figure in our naral history."

210. Raids on the Atlantic Coast.-- Capture and barbarous treatment of Washington. 1814. The Atlantic coast was now suffering, not only from a close blockade, but from ravaging attacks, especially in Chesapeake bay and farther south. In August a strong force of veteran British troops landed in Patuxent River, Mary.. Capture of land, and marched to Vashington, meeting only Washing-
ton, Angust a feeble resistance at Bladensburg (August 24), 24, 1814. from voluntecrs and militia, who were easily put to flight. The national capital was taken; the un- 
finished capitol building, the President's house, all but one of the other govermment buildings, and many private dwellings were burned, in retaliation, it was said, for the destruction of public buildings at York. The occurrence was shameful to both nations: to the English as an act of deliberate barbarity on the part of a commanding officer; to our own as an exhibition of feebleness in the govermment which guarded its own seat in so negligent a way. The Secretary of War, General Armstrong, was removed in consequence, and

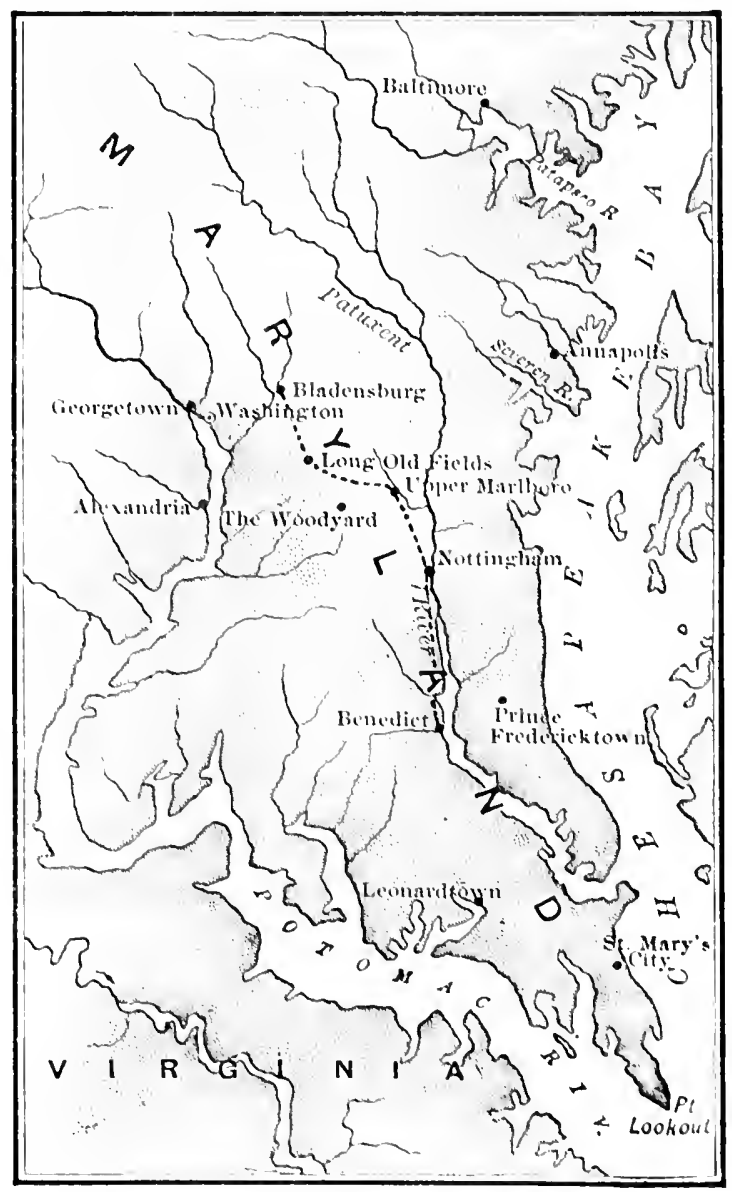

MARYLANI IN THE WAR OF ISI2. his department was conducted for a time by the Secretary of State, Mr. Monroe.

The capture of Washington was followed a fortnight later by an attack on Baltimore; but that city was saved by the stout defence of Fort McHenry, at the entrance to its port. Through the night of September it the 
fort was bombarded heavily by the British fleet, and Attack on

Baltlmore,

September the sight of its flag, still floating at sunrise on 14, 1814. the ramparts, inspired a young Baltimorean, Francis Scott Key, to write the song of "The Star Spangled Banner."

211. Disheartening State of the Country. - New England Disaffection. - The Hartford Convention. 1814. The affairs of the country were now in a most disheartening state. Its military forces were on the defensive everywhere; the few vessels of its navy were mostly shut up in blockaded ports; the resources of its treasury seemed exhausted almost hopelessly ; its commerce was nearly extinct; outside of New England the banks had stopped payments in specie, and coin

\section{New Eng -}

land dissat- had disappeared ; distress and discontent were isfaction with the war. increasing, and the New England disaffection was taking a serious tone. Individually, a large part of the New Englanders had done their part patriotically in the war; Massachusetts had furnished even more than her share of recruits to the army; but officially the attitude of the dominant Federalists had been obstructive throughout. Several of the States had refused to obey calls for their militia; banks and capitalists were deterred by strong influences from subscribing to national loans; the Massachusetts legislature adopted resolutions, in February, I 814, that were wholly in the spirit of the Virginia Resolutions of I798 (see sect. 172). A suspicion, which lacked proof, that the blockading fleet off New London had been signalled to from shore with blue lights, gave rise to the name "Blue-Light Federalists" for the anti-war party as a whole.

In the fall of I 8 I 4 Massachusetts voted money to support a state army of Io,ooo men, and invited her New 
England neighbors to send delegates to a convention which met at Hartford, December i 5. Only Massachusetts, Connecticut, and Rhode Island were officially represented, and the extremists among the delegates appear to have been checked by moderate men. The only known action of the convention, in a secret session of three weeks, was a published report which demanded certain amendments of the Federal Constitution, and recommended the holding of

\section{Hartford}

Convention, December, 1814. another convention, "to decide on the course which a crisis so momentous might seem to demand." What ultimate action was contemplated has been always a question in dispute; but the men of the Hartford Convention were looked upon as conspiring secessionists, and that stigma was on them to the end of their lives. So far as disloyalty to the Union had arisen in New England, it expired then. Peace came unexpectedly, so soon after the Hartford Convention adjourned that all the feelings represented in it were swept away.

212. Negotiations at Ghent. - The Treaty of Peace. 1814. Since the $7^{\text {th }}$ of August, I8 I4, commissioners from the United States and Great Britain had been negotiating at Ghent. Their meeting was the remote consequence of an offer of mediation made by the Russian government in September, I8I2. President Madison had accepted the offer, and sent Messrs. Gallatin and Bayard to act with John Quincy Adams, our minister to Russia; but when those gentlemen reached Russia, they found that Great Britain had declined the offer. Soon afterward, however, the British government made known its willingness to discuss terms of peace directly with representatives of the United States; whereupon Henry Clay and Jonathan Russell were commissioned to join Adams, Gallatin, and Bayard at Ghent, where the con 
ference was to be held. Three English commissioners met them, and parleyings went on for more than Britush four months, with small hope of success till demands. near the end. At first the British commissioners demanded part of Maine, and the setting apart of nearly the whole of the old Northwestern Territory, along the lakes and to the Mississippi, to be a wide belt of neutral land, given up to Indian tribes. These demands were so emphatically refused, and the American commissioners showed such readiness to break up the conference and go home, that more reasonable instructions came from London to the gentlemen on the other side. With all her advantages in the war, England was most anxious for peace. She was weary of war; the situation in Europe was still precarious, and her commerce was badly broken by the American privateers. Hence the American commissioners, by stout insistence, secured better terms in the end than the condition of their country gave them reason to expect. But the treaty signed on the $24^{\text {th }}$ of December, I8I4, contained no

Terms of the treaty of Ghent, December 24, 1814 . mention of the naval searches and impressments that had been the chief provocation to war. The question about them was settled by being dropped; for the English stopped practising what they still held to be their right. Other important questions, relating to the Newfoundland fisheries and the navigation of the Mississippi, were postponed for future settlement; and so the treaty was scarcely more than an agreement that matters between the two nations should be as they were before the war. There was little to show for the 30,000 lives it was estinated to have cost the country, and the hundred millions, or nearly, that it had added to the national debt.

213. Battle of New Orleans. 1815. Unfortunately, 
the news of peace did not reach America in time to prevent the bloodiest battle of the war, fought a full fortnight after the treaty was signed. A formidable expedition against New Orleans, from Jamaica, had reached Louisiana in the latter part of December, and had been making slow approaches to the city, where General Jackson, the ener-

Expedition

from Jamalca. getic Tennesseean, held command. After much cannonading of the breastworks behind which Jackson had placed his men, the British commander, General Pakenham, ordered an assault. It was repulsed by so murderous a fire from the rifles of the backwoodsmen of the west that more than 2000 of the assailants fell. General Pakenham was among the killed, and his successor in command made a cautious retreat.

Protected by their works, the total loss of the Americans, in killed and wounded, was only 7 I. News of this remarkable victory went through the country almost simultaneously with the despatches from Ghent. It made General Jackson the principal hero of the war.

214. War with Algiers. 1815. Before the year closed, the country had new cause to regard its little navy with pride. The Dey of Algiers had become insolent and piratical again, and needed to be chastised. As promptly as possible after the settling of peace with England, Commodore Decatur was sent with a strong squadron to perform that task. It was done so effectually that the Dey signed a treaty in June, on Decatur's deck, surrendering his captives, paying indemnities, and renouncing all claim in future to a tribute of gifts. It was the last of our troubles with the pirates of the Barbary coast.

215. Final Decay and Dissolution of the Federalist Party. One of the consequences of all that had occurred 
was the disappearance of the Federalist party within the next few years. Its unpopular temper (see sect. 161) and the disloyal attitude of some among its leaders toward the Union and the national government were among the causes of its dissolution; but these were not all. In reality, it had been superseded by its opponents, who had taken into their own hands and were carrying out the nationalizing aims for which the party of Hamilton was formed. Broad constructions of the

Cause of

Federallst

Constitution and strong claims for the genweakness.

eral government were not being clisputed any longer. A little later those disputes would be revived, as we shall see, but meantime the Federalists had lost their footing as an opposition party, and had no ground to stand upon, after the grievances of the war were cleared away. Their organization fell to pieces, and they strayed into other political camps. In the presidential election of I 8 I 6 they cast but 34 electoral votes, from Massachusetts, Connecticut, and Delaware, for Rufus King, of New York. James Monroe, who had been Secretary of State under Madison since I $8 I I$, and acting Secretary of War during some months in I 8 I4-I 5 , was chosen president by I 83 votes.

216. Protective Tariff. - United States Bank. Internal Improvements. 1816. The extent to which Hamiltonian doctrines and measures were now accepted in the Jeffersonian party was shown in the last year of Madison's administration, by the adoption of an avowedly protective tariff, by the creation of a new national

Demands for protec-
tive tariff. bank, and by the passage through Congress of

a large appropriation for improving the navigation of rivers and building roads and canals. For eight ycars past, non-intercourse, embargo, and war had been shutting out foreign goods and giving home 
manufactures the most effective "protection" they could possibly have. When that was taken away by the return of peace, the manufacturers cried aloud for the protection of a higher tariff, and Congress acted upon their appeal. Between the interests of the makers and the interests of the consumers of things the former carried the day, as they have done ever since. Singularly enough, the champions of the protective policy arose in the non-manufacturing south, Calhoun and Clay in the lead, while Webster and others from New England opposed it with

Now Eng-

land's attitude. voice and vote. New England cared less at the time for her manufactures than for her shipping interests, which languished after the war.

The appropriation for internal improvements was proposed by Calhoun, and passed by a small majority, but vetoed by Madison, who held with Jefferson that an amendment of the Constitution was needed first. This question raised one of the issues on which new party lines were to be drawn.

TOPICS AND SUGGESTED READING AND RESEARCH.

193. Mr. Erskine's Blunder. -- President Madison misled. 1809-1810.

TOPICS AND ReFERENCES.

I. Agreement with the British minister repudiated in England. 2. Non-intercourse proclaimed again. - The repealing act of May I, I810. 3. Conduct of the new British minister, Mr. Jackson. McMaster, iii. 339-362 ; H. Adams, v. ch. iii.-vi.; Schouler, ii. 3I3-3 17, 320-323; Hildreth, vi. I65-I 79, I 83-194, I96-207; Quincy, 195-204; Gay, 283-289. 


\section{The Trickery of Napoleon.}

TOPICS AND REFERENCES.

r. Hostility of Napoleon. - His increased spoliations. 2. His promised revocation of decrees. 3. P'resident Madison's consequent proclamation. 4. Subsequent conduct of Napoleon. $\mathrm{H}$. Adams, v. ch. vii.-xiv., xvi., xviii. ; NcMaster, iii. 362-369, 391399, 408-4II ; Madison, Letters, ii. 508-5II, 5I8-520, 523-525; Quincy, 226-235; Hunt, 310-313; Schouler, ii. 334-344, 362-364; Hildreth, vi. 2I 4-223, 232-234; Gay, 289-300, 31 5-3I 9.

\section{Occupation of West Florida. - Louisiana made a State. 1810-1812.}

Topics ANd References.

r. Revolutionary movement in part of West Florida. - Possession taken by the United States. 2. State organization of Louisiana. - Division of West Florida. McMaster, iii. 369-375, 378379 ; H. Adams, v. 305-31 5, 319-325; Schouler, ii. 345-348; Hildreth, vi. $223-226$.

196. Federalist Opposition to the Admission of Louisiana.

Topics AND RefERENCES.

I. Speech of Josiah Quincy. Quincy, 205-218; Schouler, ii. 348-349; H. Adams, v. 325-327 ; McMaster, iii. 375-378; Hildreth, vi. 226-228; Hart, Contemp's, iii. 4IO-4I4.

\section{Dissolution of the United States Bank.}

TOPICS ANI REFERENCES.

r. Refusal to renew the charter of the bank. H. Adams, v. 327-337; McMaster, iii. 379-390; Schouler, ii. 350-353; Hildreth, vi. $211-212$.

198. Feeling for and against War with England. 1811.

Topics Ani References.

r. Relations with England in I8Ir. 2. Schemes of the Shawnee chief Tecumseh. - Supposed complicity of the English. - Battle of Tippecanoe. 3. Affair of the "Little Belt." 4. Feeling at the 
TOPICS, REFERENCES, AND RESEARCH. 357

north, and at the south and west. H. Adams, vi.ch. i.-v.; Schouler, ii. 357-360, 365-370; Hildreth, vi. 242-248, 251-259; McMaster, iii. $528-536,402-406,+12-423$.

\section{The "War Hawks" in Congress. - Henry Clay. 1811-1812.}

TOPICS AND REFERENCES.

I. The group of "war hawks." - Clay, Calhoun, and their associates. 2. The plans of the war party. Schouler, ii. 345, 371-374; Schurz, Clay, i. 67-83: McMaster, iii. 427-44I; H. Adams, vi. I 22-1 53; Holst, United States, i. 225-230; Hildreth, vi. $259-260,262-287$.

\section{War declared. June 18, 1812.}

TOPICS AND REFERENCES.

I. Action of President and Congress (text in MacDonald, ii. 183I92). - Embargo, followed by war. 2. Sectional character of the vote for war. Schurz, Clay, i. 83-85; McMaster, iii. 444-452, 456458 ; H. Adams, vi. ch. viii.-xi.; Holst, United States, i. 230-240 ; Hunt, ch. xxxi.; Clay, i. I \$2-194; Schouler, ii. 374-394; Hildreth, vi. 290-306, 313-325; Madison, Letters, ii. 535.

3. British orders in council withdrawn one day before the American declaration of war. 4. American refusal to reopen negotiations. 5. The one object for which the war, finally, was fought. Schurz, Clay, i. S7-SS; Gay, 319-320; Hildreth, vi. 343-35I ; H. Adams, vi. ch. xiii.; Schouler, ii. 406-409; McMaster, iv. I-8. RESEARCH. - British views of the occasion of the war. James, vi. I I 2-I I 5 .

\section{Opening Disaster. - Hull's Surrender at De- troit. - Battle of Queenstown Heights. 1812.}

\section{TOPICS AND REFERENCES.}

I. Disadvantages of the United States in the war. 2. General Hull's expedition and his surrender. 3. Attempt to enter Canada at Queenstown. H. Adams, vi. ch. xiv.-xvi.; McMaster, iii. 54I-549, 556-560; iv. S-I3; Schouler, ii. 394-40I ; Hildreth, vi. 335-343, 357-359; Clarke (on Hull), ch. ii.-iv.

RESEARCH. - Views of the opponents of the war. Hildreth, vi.

319-325. 


\section{Naval Triumphs. 1812.}

TOPICS AND REFERENCES.

1. Comparison of British and American navies. 2. The principal sea fights of iSIL. 3. Privateers. Roosevelt, Aiazal it iar. ch. ii.-iii.: H. Adams, vi. ch. xvii.: vii. ch. xiii, Mc.Master, iv. 70-91: James, vi. 203-21S, II 5-202: Hildreth, vi. 364-372. 397399: Schouler, ii. 402-406: Hart. Contempss. iii. $+1+-+17$.

\section{Second Disaster in the West. 1812.}

TOPICS AND REFERENCES.

I. Naval preparations on the lakes. - Their importance. 2. Harrison's movement to recover Detroit, and its disastrous beginning. McMaster, ir. 19-30: H. Adans, vii.ch. iv.: Schouler, ii. to9-4 12.

204. Reëlection of President Madison. 1812.

TOPICS AND REFERENCES.

1. The combination against Madison. - His reëlection. $\mathrm{H}$. Adams, vi. +I2-4It; McMaster, ir. I9I-203; Hildreth, vi. 375377 ; Schouler, ii. fo9-412.

205. Naval Occurrences on Salt and Fresh Water. 1813.

Topics AND Referexces.

I. Capture of the Chesapeake by the British frigate Shannon. - Death of Lawrence. 2. Blockade of Atlantic ports, with most of the American fleet shut in. 3. Perry's victory on Lake Erie. Roosevelt, Naial $t^{\circ}$ ar. ch. r-vi.: H. Adams, vii. ch. xi.xii., and II 5-127: Mc.laster, iv. 91-0), 30-35: Schouler, ii. $+34^{-}$ $437,+25-426$ : James, vi. $275-32+$ : Hildreth, vi. $+20-426,+30-43 \mathrm{I}$. $+3+-437$.

206. Recovery of Detroit and the West. - Futile Campaigning on the New York Frontier and the St. Lawrence. 1813.

TOPICS AND REFEREXCES.

I. Effect of Perry's victory on western military operations. 2. Retreat of British from Detroit River. - Pursuit by Harrison. - 
TOPICS, REFERENCES, AND RESEARCH. 359

Battle of the Thames. - Death of Tecumseh. H. Adams, vii. ch. vi.: Hildreth, vi. $437-43$ : Mc.laster, iv. $3 \$-4$.

3. Campaign on the New lork frontier. - Partial burning of York. 4. Defence of Sackett's Harbor. - Cieneral Jacob Brown. 5. Abortive expedition against Montreal. 6. British successes and ravages on the Niagara frontier. H. Adams, vii.ch. vii.-viii. :

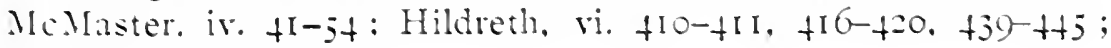
Schouler, ii. $t=6-+30$.

\section{The Creek War. 1813.}

Torics AND REFEREXCES.

1. Kising of the Creeks. 2. General Jackson's campaign against them. H. Adams. vii. ch. ix.-x. : Mclaster, iv. 156-173: Hildreth, vi. $+46-450 .+7 i-4$ iso: Schouler, ii. $+30-434$.

208. Fall of Napoleon and its Effect on the War in America. 1814.

TOPICS AND REFERENCES.

I. The alliance which overthrew Napoleon. 2. British forces set free for use in America. Seeley, Mizfolion, I+3-2 Io: Hildreth, vi. $+90-+92$.

209. Last Attempt against Canada. - British Advance to Lake Champlain. - Macdonough's Naval Victory. 1814.

TOPICS AND REFERENCES.

I. Chippewa. - Lundr's Lane - Fort Erie. 2. Naral and military rictories at Plattsburg.-Commodore Macdonough. $H$. Adams, viii. ch. ii.-ir. Mclaster, iv, 56-09; Hildreth. vi. fig. $+92-40$. $31+517$ : Schouler, ii. $+4 j-+49$; Cullum, ch. vi.: Roose-

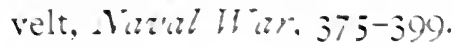

210. Raids on the Coast. - Capture and Barbarous Treatment of Washington. 1814.

TOPICS AND REFERENCES.

I. Battle of Bladensburg and capture of Washington. 2. Attack on Baltimore. - The song of "The Star Spangled Ranner."

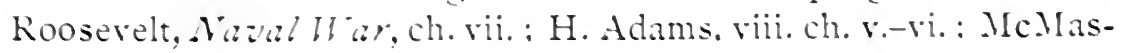


ter, iv. 121-155: Cullum, ch. vii.; Hildreth, vi. $4 \delta_{3}-48 s, 499-513$, 519-520: Schouler, ii. $+49-456$.

\section{Disheartening State of the Country. - New England Disaffection. - The Hartford Convention. 1814 .}

\section{TOPICS AND REFEREACES.}

I. The military situation and the financial condition. H. Adams. viii. ch. viii.-x.: Hildreth, vi. 524-529, 556-557.

2. Conduct of Federalists in New England. 3. The Hartford Convention and its report (text in MacDonald, ii. 19\$-207). H. Adams, viii. ch. i. and xi.: Holst, Linited States, i. 240-272: McMaster. iv. ch. xxviii. Johnston. Am. Politics. $7 \$-\$ 5$ : Hildreth, vi. $+65-473.531-535.545-554$ : Hunt, ch. xxxiii. : Schouler, ii. $458-$ 476: Quincy. 356-355: Lodge. Cabot. ch. xi.-xiii.

\section{Negotiations at Ghent. - Treaty of Peace. 1814.}

TOPICS AND REFERENCES.

I. Circumstances which brought about the negotiation. 2. First demands of the British commissioners. 3. The terms of peace agreed upon (text in MacDonald, ii. 192-19\$: Larned, Reid!y Ref.). J. Q. Adams, ii. ch. viii.: iii. ch. ix.: Schurz, Clay, 99-125: Morse, J. Q. Adams, 75-98: H. Adams, vii. ch. ii. and xiv. : ix. ch. i.-ii.: McMaster, iv. $256-277$ : Schouler, ii. $+17-+19)+42-+45$. 477-4st: Hildreth. vi. fol, 491-492. 520-530. 54. 566-570: Hart, contemps.s. iii. $+26-429$.

\section{Battle of New Orleans. 1815.}

Torics AND Referexces.

I. Expedition from Iamaica against New Orleans. 2. The unnecessary battle and its fearful slaughter. 3. l'restige of Jackson. Pạton. Jackson, ch. i.-xxiii. : Cullum, ch. viii.: Roosevelt, laral II $a$. ch. x. ; H. Adams, viii. ch. xii.-xiv. McMaster, iv. 1/3I90: Schouler, ii. $+55-49$ I Hildreth, vi. 557-565; Hart, Contemp's, iii. $+22-425$. 
TOPICS, REFERENCES, AND RESEARCH. 36I 214. War with Algiers. 1815.

Topics Anil References.

I. Renewed trouble with Barbary pirates. 2. Decatur's expedition and its results. McMaster, iv. 351-356; Hildreth, vi. 577578 .

\section{Final Decay and Dissolution of the Federalist Party.}

Torics And References.

r. Causes of the disappearance of the party. 2. Its doctrines not now disputed. 3. Presidential election of $18 \mathrm{~s} 6$. H. Adams, ix. 92-103, I22-124; Johnston, Am. Politics, $S_{5}-S_{7}$; Hildreth, vi. 594-60I ; Schouler, ii. 512-513 ; Johnston, Am. Orations, i. 99IOI.

\section{Protective Tariff. - United States Bank. -} Internal Improvements. 1816.

TOPICS AND REFERENCES.

I. Hamiltonian doctrines and measures approved by Jeffersonians. 2. The protective tariff of I $S \mathrm{I} 6$ adrocated in the south and opposed in New England. 3. New United States Bank (text in Macloonald, ii. 207-212). 4. Appropriations for internal improvements vetoed by Madison. Schurz, Clay, i. 126-1 38 ; Burgess, Midile Period, 2-I 2, I 4-IS ; Schouler, ii. 495-499 ; Gordy, ii. 349354, 356-357 : McMaster, iv. 309-3I +, 319-340, +10-415; H. Adams, ix. 105-IIS. I3I-13t: Hildreth, vi. 582-592, 6I7-6is; O. L. Elliott, I63-I94; Hart, Contemp's, iii. 434-440. 


\section{CHAPTER XI.}

AMERICAN DEMOCRACY FINDING INDEPENDENCE. ISI $5-1 S 2 S$.

217. The New Spirit in the Country. - The Democratic Development. 1815-1828. Though the causes of the War of ISI 2 with England were not formally removed, they disappeared at the close of the war. The fall of Napoleon, putting England and France at peace, had encled the state of things from which those causes came. The same erent ended the mischievous influence

Effects of peace in in American politics which, for almost a quarter of a century, had ranged one party on the side of England and the other on the side of France. It ended, too, the humiliations which the young, undeveloped republic had been suffering so long at the hands of the contending powers in Europe, with serious harm to its public spirit and national pride.

The effects which came to the United States from the return of general peace, after Napoleon fell, were immediate and very great. A more independent spirit - a more unitedly American spirit - arose; the attention of the people was given more closely to their home affairs; and because those effects became marked after the peace with England, some have ascribed them to the war, calling it "our second war of independence." In reality, there was a second and completer acquisition of American indepentence at this time, won partly, perhaps, by the second war, but it came to us more as a 
consequence of the general peace restored to Europe and to the world at large.

The effects of that event were increased by influences now acting on the whole country from the young communities of the west. Only four new States had been formed in the Mississippi valley; but the Territories beyond them were filling with population so fast that two more were knocking already for admission to the Union, and five came in within the next five years. The circumstances of pioneer life, simple and wholesome, if rude, in all that primitive domain, were developing a spirit more purely democratic and more entirely American than had appeared anywhere before. A really unclassed society had never existed in the old States in their most primitive days, but it was formed by the conditions of western settlement (wherever slavery did not enter), because land-ownership, in some degree, was almost universal, wagre-working

Democracy in the West. rare, and the social footing of all men substantially the same. Until new commonwealths began to be formed in the interior of the country, quite removed from old influences, the political system of the American Union had been republican, but not democratic; for the suffrage in the older States had been given to property owners or tax-payers only, and limited in many cases by disfranchisement on religious or other grounds. The new States, excepting Temnessee, made every adult male citizen a voter, and their democratic example was pushing the older States,

Western influence on one by one, to do the same. Hence the spirit of the nation was now beginning to take much of its tone from a young, vigorous, untrained, often rough democracy, in pioneer communities that were making themselves felt more and more. Their influence on the character and 
history of the republic during the next generation or two is plainly seen.

218. Steam Navigation. - Road and Canal Building. 1807-1825. A new era in the settlement and development of the vast interior of the country was opening, through the introduction of steam navigation on rivers and lakes, the improvement of roads on the principal lines of emigration, and the undertaking of the most important of all early canals. Fulton's first steam-

Lake and river steamboating, 18071818 . boat, as stated before, began her trips on the Hudson in I SO7. The first steamer on western rivers was launched at Pittsburg in ISI I, and taken to New Orleans. The first on the Great Lakes was built at Sackett's Harbor in I $S \mathrm{I} \sigma$; the first on Lake Erie began trips from Buffalo to Detroit in ISIS. From that time the new carrier of people and merchandise came into use very fast, and the movement of both, over widening stretches of the country, was quickened and increased at an extraordinary rate.

In IS2O the Cumberland Road, the first and for a long time the only work of "internal improvement" taken in hand by the general government, was

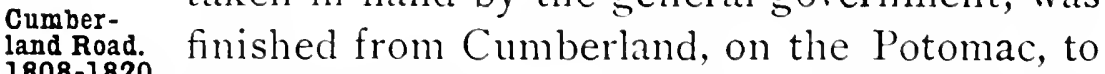
1808-1820. Wheeling, on the Ohio River. Between isI7 and I 825 another more important undertaking was carried through, with remarkable energy, by the State of New York, stimulated by its able governor, DeWitt

The Erle

Canal, 1817-1825.

Clinton. This was the building of the Erie Canal, 364 miles in length, from the Hudson River to Lake Erie, opening travel and transportation by water from the seaboard to the far western extremity of the chain of Great Lakes. The great canal became at once the chosen thoroughfare of westward emigration, traversed by millions, in an endless proces- 
sion to homes in the heart of the continent, and became, too, the main channel of traffic between the east and the west. The State of New York was populated and enriched by the stream of trade and travel, and its seaport, at the mouth of the Hudson, was made the chief commercial emporium of the New World.

219. Literature and Liberal Thought. 1816-1825. There are many signs to show that the country was moved by fresh impulses, on many lines of its advance, in the years that followed the war. They were impulses, not generated at the time, but simply set free from the distractions and constraints of the troubled period which the whole preceding generation had been living through. They showed themselves as plainly in a new liberation of thought, and of the expression of thought, as in the liberated spirit that is mentioned above. The first notable writings in this country that belong to pure literature - being, that is, something more than strong reasoning on religious and political topics, or more than clear narrative in good English - appeared then, or were germinated in young minds, under the influences of that time. It was in I $8 \mathrm{I} 7$ that Bryant's "Thanatopsis" was published in the "North American Review," then passing through its second year. It was in $\mathrm{r} S \mathrm{Ig}$ that the classic "Sketch Book" of Irving was put in print. It was in I 820 that Cooper gave

Bryant, Irving, Cooper, 1817-1821. his first novel to the world, and he followed it the next year with "The Spy." Before these there had been nothing of their kind that holds a living place in American literature; but what a harvesting there was in the next score or two of years, from minds that were ripened in the schools and colleges of that time! From Emerson, born in $\mathrm{ISO}_{3}$,

Emerson, Hawthorne, Longfellow, Whittier, Holmes. Hawthorne, born in ISO4, Longfellow and Whittier in 
I So7, Dr. Holmes in I Sog! It was the dawn of what, thus far in the history of American literature, has been its golden age.

Quite as striking is the movement of change in religious thought and feeling that became manifest in those "Liberal quiet years, beginning in the circle which has ity." Boston for its centre and thence widening out. The harsh and bitter beliefs of early Puritanism had been losing their hold upon the Congregational churches of New England for many years; but the decisive break from them came within the period now spoken of, when the powerful influence of William Ellery Channing began to have a wide range.

220. The Political "Era of Good Feelings." 18171824. The state of political quietude at this time was the most remarkable that the country has ever known; for the intense passions of the past score of years, excited by circumstances growing out of the conflict in Europe, subsided quickly after the removal of their cause, and a profound reaction ensued. As the old Federalist party fell to pieces, it left, for the time being, only one coherent party in existence, which was the party in power. All the original political issues that divided people into parties at the outset were in full force still, and were working out the same divisions of opinion and the same conflicts of interest as before; but it took time to reorganize them in party forms. Meanwhile a singular appearance of political peace was produced, which caused the years of the administration of President Monroe to be called "The Era of Good Feelings." 1

1 Mr. Schouler, in his History of the United States, states that the earliest use he has found of this phrase is in the heading of a

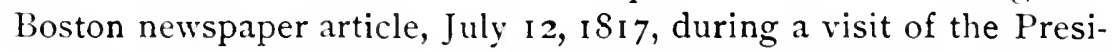
dent to New England. He refers, also, to a statement in Niles's 
221. Bank Inflation and the "Crisis" of 1819. 18111821. At first, the political "good feeling" of this era coincided with a quite general state of satisfaction, produced by apparently "good times." Manufactures were suffering, notwithstanding the raised tariff, and shipping interests were depressed, but the great inflow of commodities from abroad was yielding a rich revenue to the government and giving activity to trade, while Europe was buying largely of American breadstuffs for a time. The appearance of prosperity was heightened by an inflation of banking and bank paper-currency, which had its beginning when the first bank of the United States was dissolved, in ISI I (see sect. 197). A mischievous multitude of banks, of the species called "wild-cat" at a later time, sprang into existence then, under state laws loosely framed,

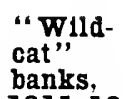

banks,

1811-1819. which subjected them to little regulation or restraint. These banks issued notes in reckless quantities, based on no sound security, and made equally reckless loans of them, spreading a credit system that had nothing substantial to rest upon, on either the lender's or the borrower's side. The second Bank of the United States was chartered in I 8 I 6 with the hope that it would check the mischief, and be, as the first Bank had been, a strong regulator of banking and monetary operations; but its early management made matters worse. In I8I 8 a new management in the Bank of the United States found its affairs in such a state that sharp measures, reducing loans and collecting

The second United States Bank. debts, were needed to save it from failure; and that action broke the bubble of fictitious credit and speculative trade. The break came in I 8 I9, and there was much Register of July I2, I 823, that Boston gave that name to the "æra" when the President was there. 
depression and distress for the next two years, except in Massachusetts, where the banks and currency had been kept in a generally sound state.

222. Supreme Court Decisions. 1819-1824. At this time, and within the next few years, the Supreme Court of the United States, under the lead of Chief Justice Marshall, found opportunity, in a number of cases that came before it, to pronounce a series of vitally important decisions, establishing its own authority as the final tribunal on questions of constitutional law : broadly construing and enforcing the clause of the Constitution which forbids the States to impair the obligations of contracts, and sustaining Hamilton's doctrine of "implied powers." Excepting Marshall and one other, the justices of the Supreme Court when these decisions were rendered (ISI9-24) had been appointed by Presidents Jefferson and Madison; but the effect of their decisions was to establish the sovereign nationality of the federal government which Jefferson and Madison had feared.

223. The First Seminole War. - General Jackson's Proceedings. 1817-1818. The most disturbing political event in the early part of the Momroe administration was the first of two wars with the Seminole Indians of Florida. In ISI 7 General Jackson was put in command of forces sent against those Indians, who lived in Spanish territory, but who had been in collision with the Georgians on frequent occasions, for many years.

\section{Jackson's} Jackson proposed to make the war one of conconquest of quest, for the overthrow of the weak Spanish Florlda.

authority in Florida, and he always claimed that the govermment had given him reason to suppose that it approved his plans. There was fierce disputing on the subject for years.

At all events, Jackson, in a campaign of five months, 
not only subdued the Seminoles, but took substantial possession of Florida, capturing St. Mark's and Pensacola, turning out the Spanish garrisons, and putting American forces in their place. More than that, in violation of all principles of international law, to say nothing of justice, he hanged two British subjects - a Scotch trader, Arbuthnot, and an Englishman named Ambrister - whom he believed to have aided the Seminoles, though evidence that

Arbuthnot and Ambrister, 1818. they did so was slight. His lawless conduct was both shameful and embarrassing to the country; and yet his popularity, consequent on the victory at New Orleans, was so great that the government did not dare to rebuke him, or disclaim responsibility for what he had done. It had to deal with the offended govermments of England and Spain as best it could.

224. Purchase of East Florida. - Spanish Boundaries defined. 1819.' The outcome was fortmate, particularly on the Spanish side of the matter; for Spain became convineed that her Florida territory would be always insecure. She consented, therefore, to give it up to the United States, as an offset to American claims for spoliations in the past wars, amounting to about $\$ 5,000,000$ as a whole. The treaty of cession signed in February, I 8 I9, was made doubly important by defining boundaries in the west between the possessions of the United States and Spain. The line defined ran by the Sabine, the Red, and the Arkansas rivers (with meridian lines between them), up to the 42 d degree of north latitude, which parallel it followed to the Pacific coast. All claim to territory north of the $42 \mathrm{~d}$ degree was renounced by Spain.

225. Convention with Great Britain. - The Oregon 1 See Map XV. 
Country. - Fisheries. 1818. This last provision of the Florida treaty gave important support to contentions of the United States with Great Britain over the region on the Pacific called Oregon, in the basin of the Columbia River. American claims to that region were founded on the fact that, while Spanish and English royagrers had skirted the coast in earlier times, an American ship was the first (in I792) to enter the

Columbia; that the first exploration of the Oregon. country from the mountains to the sea was made by Lewis and Clarke in I8O4-O5 (see sect. 185); and that the trading settlement of Astoria was founded by John Jacob Astor's fur company in I $S$ I. Since I $S$ I3, however, the British had been in actual possession of the country, and were not easily to be driven out. Four months prior to the Florida treaty with Spain (in October, I $\$$ I 8 ), a convention with Great Britain established the 49th degree of north latitude as the northern boundary of the United States from the Lake of the Woods to the Rocky Mountains, and proJoint occu- vided that the country west of the mountains pation of should be held jointly by the two nations for
Oregon, 1818.

ten years. As a matter of fact, the Oregon boundary question remained unsettled for twenty-eight years, instead of ten.

The fisheries question, postponed in the negotiations at Ghent, was settled by this convention of I 8 I 8 .

\section{Fisheries} Within certain limits, it restored to American question. fishermen the privileges they had formerly enjoyed on the eastern coasts of British America, which were held to be annulled by the IVar of I 8 I2. On the remaining coasts they were to do no fishing within three miles of the shore.

226. The Question of Slavery Extension. 1816- 
1821. In settling our western boundary with Spain, there would have been, probably, an effort to push it beyond the Sabine and take in the Texas country to the Rio Grande, if a startling excitement of sectional feeling on the slavery question had not been rising at the time, in connection with the admission of new States. At the end of the first year of the Monroe administration there were twenty States in the Union, Indiana and Mississippi having been admitted in I8I6 and I8I7. In exactly one half of them - all north of Mason and Dixon's line Mismsssslpp1 and the Ohio River - slavery had been or 1816-1817. was being extinguished by measures of gradual emancipation; while in the other half the prospects of its extinction were growing less. This gave the slave labor and the free labor interests an even representation in the United States Senate; but in the other House of Congress the slaveholding States were losing ground at a rapid rate, despite the representation they had sccured for three fifths of Slaveholding States their slaves. The greater streams of populalosing power in House. tion flowing into the empty spaces of the continent were moving, and would move, toward the regions in which labor was free. These facts had become alarming to the slaveholding interest, and it saw no mode of holding power in the Union except that of offsetting numbers in States against numbers in people, to keep itself strong in the Senate, against the House.

By a tacit agrecment, the balance established in I8I7 was maintained in the next formation of States, - Illinois in I8I8 and Alabama in the succeeding year. But then arose the question of dealing with the vast territory of the Louisiana Pur- 1818-18ig. chase, which came to us with slavery sanctioned by its 
Spanish and French laws, and which, thus far, had stood open to the slaveholder and his slaves. One slaveholding State, Louisiana, had been carved already from that territory, and a slaveholding population was spreading up its streams and over its inviting lands.

227. The Missouri Compromise. 1820-1821. ${ }^{1}$ The question came seriously into Congress in February, I 8 I9, when a bill to authorize the people of Missouri to form a state government was taken up for discussion in the House of Representatives, and Mr. Tallmadge, a New York member, moved to amend it by a provi-

Tallmadge's amenamont, 1819. sion that "the further introduction of slavery or involuntary servitude be prohibited," and "that all children of slaves born within the said State after the admission thereof into the Union shall be free." This opened a passionate debate, and the whole country was shaken by the excitement produced. Threats from the south of a dissolution of the Union and civil war were answered by declarations from the north that the spreading of slavery was more dreadful than disunion or war. The discussion resulted in the adoption of Mr. Tallmadge's amendment in the House, while the Senate threw it out. The session being then near its close, the bill was dropped; but a vehement agitation of the subject, in all parts of the country, went on.

When Congress met again, in December, i8 19, it received an application from the people of Maine to be Application separated from Massachusetts and allowed to

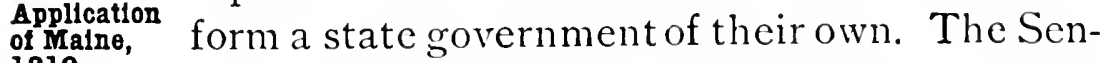
1819.

ate coupled this with the application from Missouri, and efforts were made to bring about the admission of the two States together, onc with slavery and 
one without. The House refused, and the two branches of Congress were at a dead-lock for some weeks. Finally a compromise, famous in American history as "The Missouri Compromise," was arranged. Mis- The Missouri was to be admitted with no restriction; sourl combut in all the remainder of the territory bought 1820 . from France "which lies north of $36^{\circ} 30^{\prime}$ north latitude" (that being the southern boundary line of Missouri), slavery was to be prohibited forever. Fourteen northern members of the House were persuaded to join those of the south in passing Malne
admittted,
1820 . this compromise act, Maine being admitted to statehood at the same time (March 3, I820).

But the Missouri question was not ended; for when, at the next session of Congress, the people of the applicant Territory submitted the constitution they had framed, it was found to contain a provision that free colored people should not come within its bounds. This violated the provision of the Federal Constitution that "the citizens of each State shall be entitled to all the privileges and immunities of citizens in the several States," inasmuch as colored people had been admitted to citizenship in some of the northern States. A new excitement in Congress and in the country was produced. Both south and north there was a growing dislike of the compromise, and a strong The
question
reopenened. disposition to throw it aside. It was objectionable to one party because it conceded to Congress the power to interfere with slavery in the Territories; and to the other party because it permitted even a limited extension of slavery to new States. After weeks of debate there appeared to be no hope of a peaceful agreement, and the slaveholding States seemed prepared to break from the Union and fight for the territory in dispute. 
But that conflict of feeling was overcome at last by the exertions and the extraordinary influence of Henry Clay. Mr. Clay succeeded, on the 28th of February, $\mathrm{I} 82 \mathrm{I}$, in carrying a joint resolution through the House

Clay, and the final agreement. by the narrow majority of 86 against 82 , which admitted Missouri to the Union on the "fundamental condition" that the objectionable clause in its constitution should never be construed to authorize the passage of any law excluding any citizen of another State from the privileges and immunities to which he is entitled under the Constitution of the United States. The Senate concurred; Missouri agreed to the condition, and the President, in due time, proclaimed the admission of the new State.

Again, as in the framing of the Federal Constitution, the irreconcilable antagonisms between a society based on slave labor and one founded on the institu-

Postponement of the cllablo conflict." tions of freedom had been stifled temporarily by compromise. Whether or not it was best for the country that this should be done, and done again, to defer an inevitable conflict, is a question that has had much debate. The longer the postponement, the more terrible the conflict at last; but if it had come too early to be decisive, there would have been, perhaps, only a beginning of long-lasting and ruinous hostilities between disunited States.

228. Unanimous Reëlection of President Monroe. 1820. In I 820 the Federalist party had disappeared as a national organization, and no other had taken its place. Factions in state politics were numerous, and the sectional issue upon slavery had become deeply marked; but there was nothing that could be rallied as an opposition to the reëlection of President Monroe. No candidate was brought forward against him, and he enjoys 
the distinction of being the only President save Washington to whom the office was given with unanimity. A single elector, in New Hampshire, cast his vote for John Quincy Adams, merely, as he said, to preserve Wash. ington's distinction; but the unanimity of Monroe's election was broken only in appearance by that vote.

229. International Improvements and Protective Tariffs. 1822-1824. The existing political situation, with but one party having a national footing in the country, could not last long. The old fundamental questions, inherent in the Federal system and its Constitution, were sure to be raised as party issues again. Such a question was that relating to internal improvements, now beginning to be made urgent by the spread of interior settlement, increasing the need of improved means of travel and Monroe's internal improvements. traffic. President Monroe was in agreement with Jefferson and Madison on this question, arguing against the power of Congress to undertake roads and canals without an amendment of the Constitution; but the issue was not yet distinctly formed.

Another rising question, on which parties were certain to come to a more definite division soon, was that touching the "protection" of home industries by high tariff rates. The protective tariff of $18 \mathrm{I} 6$ had not satisfied the manufacturers for whom it was framed, and attempts to raise the scale of duties were made in every Congress from I820 till I 824, when they ob- Tariff of tained success. The bill then passed not only 1824. raised the barrier against foreign products of the spindle and loom, the furnace and the forge, by increased duties, but it protected wool-raising in Ohio, hemp-growing in Kentucky, lead-mining in Illinois and Missouri, and other industries in other States, and so made up the 
small majorities in the two Houses by which it was passed. The "navigating and fishing States," Massachusetts, New Hampshire, and Maine, together with the cotton, tobacco, and sugar-planting States, cast their votes almost solidly against the bill. Clay was the foremost champion of what he named "The American System" of national policy, as he had been the chief adrocate of a mational policy of internal improvements, and it was not difficult to foresee that he would be in the lead of a distinct party formed on those lines.

\section{Attitude \\ of Clay}

and Web-

ster. Webster, contending for the shipping interests, which his State still valued more highly than its factories, appeared again, as in $1 S 16$, the weightiest opponent of the protective scheme.

230. The "Monroe Doctrine." 1823. It was President Monroe's fortune to associate his name with a principle of American policy which the people of all parties have accepted, and which has commanded so much attention and discission in other countries that it is famously known. In IS23 the Spanish-American provinces (except those of the West Indies) had all acquired substantial independence, and the Lnited States had recognized their independence in the previous year. In Spain itself a revolution had occurred in Iszo, which the Bourbon government of France (restored after the fall of Napoleon) had sent an army to suppress. In doing this, the king of France acted “The Holy for a league of European sorereigns, calling Alliance." itself "the Holy Alliance," the real object of whose members was to lend assistance to one another against popular revolts. It was understood that this so-called Holy Alliance, after making misgoverned people in Europe submissive to their yokes, intended to take Spanish America in hand, and its proceed- 
ings were watched with anxiety and indignation by England as well as the United States. Mr. Canning, then British Secretary for Foreign Affairs, suggested in August, I 823, that Great

Canning's suggestion, 1823 . Britain and the United States act together in opposing the trans-Atlantic projects of the dangerous league. No arrangement for that purpose was made; but when, in December, the President prepared his message, it was decided in his cabinet that he should state plainly the determination of the United States to oppose European meddling with American affairs. It has been claimed, with probable truth, that John Quincy Adams, Mr. Monroe's Secretary of State, was the author in substance of the declaration as it appeared in the President's message; but virtually the

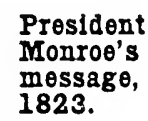
same cloctrine of American policy had been set forth by others more than once. The official statement of it by President Monroe gave the principle an importance which it has kept, for the reason that it expressed the mind of the nation, then and since. The language that embodied the so-called "Monroe Doctrine" appears in two parts of the message. First, in allusion to Russian claims and movements on the Pacific coast, it was said: "The occasion has been judged proper for asserting, as a principle in which the rights and interests of the United States are involved, that the American continents, by the free and independent condition which they have assumed and maintained, are henceforth not to be considered as subjects for future colonization by any European powers." With reference to the supposed intentions of the powers of the Holy Alliance, the language used was, in part, as follows: "In the wars of European powers, in matters relating to themselves, we have never taken any part, nor does it comport with our 
policy so to do. It is only when our rights are invaded Statement or seriously menaced that we resent injuries or of the Doctrine. make preparations for our defence. . . W owe it, therefore, to candor and to the amicable relations existing between the United States and those powers, to cleclare that we should consider any attempt on their part to extend their [political] system to any portion of this hemisphere as dangerous to our peace and safety. With the existing colonies of any European power we have not interfered, and shall not interfere, but with the governments who have declared their independence and maintained it, and whose independence we have on great consideration and just principles acknowledged, we could not view any interposition for the purpose of oppressing them, or controlling in any other manner their destiny, by any European power, in any other light than as a manifestation of an unfriendly disposition toward the United States."

Frequent attempts are made to give a broader meaning to this statement of policy than it can reasonably bear; as though the United States undertook to stand between other American states and the powers of the Old World in all matters. It means no such thing. Meaning The purpose expressed and the objects aimed of the Monroe Doctrine. at are plain, namely: (I) that ambitious powers in Europe shall neither make conquests in this hemisphere, nor overturn existing governments, nor extend their own political system to it, if the United States can prevent; and (2) that the American continents are no longer to be looked upon as open fields for new colonies uncler European control.

231. Visit of Lafayette. 1824-1825. In the last year of Mr. Monroe's administration as President the country was delighted by a visit from Lafayette. Wel- 
comed and entertained as a guest of the nation, the noble Frenchman received everywhere, during a stay of thirteen months, every attention that could be devised for showing the affection of a grateful people. The nation gave itself up to a more joyous excitement of patriotic emotions than it had ever experienced before, and the "Era of Good Feelings" was brought to a happy close.

232. Presidential Election of 1824-1825. - Its Determination in the House of Representatives. - "Bargain and Corruption" charged by the Jackson men. Attention was so centred upon Lafayette in the fall of I 824 that the presidential election passed with little stir. Nothing was at issue except questions of personal choice between several candidates, all of whom professed the same political principles and were stamped with the same party name. The Democratic-Republican organization was still alone in the field, but able no longer to concentrate its votes. Party conventions for that purpose were not yet in use. Hitherto it had sufficed for the congressmen of a party to meet in caucus and name a candidate ; but submissiveness to that kind of nomination had now come to an end. General Jackson had been proposed for President by the legislature of Tennessee, and certain shrewd politicians, who foresaw that masses of people would vote blindly for the "hero of New Orleans," were working in his interest with consummate skill. Other States had offered other favorite public men; but finally the list of candidates was reduced to four, namely, Mr. Crawford, the Secretary of the Treasury, General Jackson, John Quincy Grawtord, Adams, and Henry Clay. If the old feeling Jackson, in the country, which held its highest office clay, 1824. in reserve for the most eminently fitted men, had still 
prevailed, either Adams or Clay would have received the major rote. No other statesman of his day was the peer of John Ouincy Adams in solid attributes of character and mind; but his virtues and talents were adorned with no graces, and he took no care to make himself pleasing to the public which he faithfully served. Clay, on the other hand, surpassed most men in captirating gifts; but he was too impulsive, too ardent in his opinions, too honestly outspoken, to avoid making enemies who influenced great numbers of votes.

Jackson received 99 electoral rotes, Adams $S_{4}$, Crawford 4 , Clay 37, - which gave a majority to none. For Vice-President a large majority of votes was cast for Calhoun. The choice of President was now to be made by the House of Representatives, from the three candidates The elec- standing highest in the list of electoral rotes. toral vote. Had Clay been one of the three, it is nearly certain that he would have had the suffrages of the House. As it was, his influence determined the election, and Adams may be said to have received the presidency at his hands. Broken health had put Crawford really out of the question, and Jackson had given no eridence of being qualified for the great trust of the govermment of the United States. Of the three to be chosen from, Adams was the eminently fit man, and there is no reason to suppose that Clay had ever a moment's doubt as to what he should do; but the instant his preference was announced, the supporters of Jackson declared that he had bargained with Adams to be made Secretary of State. They had guessed shrewdly that Adams would invite Clay to take the State Department and that Clay would accept. It was the natural selection for the President to make.

Adams and Clay did what the plotters expected them 
to do, and it is one of the shameful facts in American history that they suffered seriously from the ceaseless cry of "bargain and corruption" then raised. In large parts of the country the public mind was poisoned by it; multitudes of people were persuaded by The " barthe mere persistence of the unsupported charge $\begin{gathered}\text { gain and } \\ \text { corruption" }\end{gathered}$ that a great fraud had been committed, which ory, $\mathbf{1 8 2 5}$. the next election must set right. The whole point of the invented story was in that next election, for which the conspirators were preparing a long campaign. Probably no one was more deluded by them than Jackson himself. He sincerely believed the story of frand, and considered the people of the United States, as well as himself, to have been intolerably wronged. It was in his nature to arrive at such a conviction without proof. At the bottom of that singular nature there was a very sturdy honesty; but it went with a bigoted mind.

233. Jackson Combination against the Adams Administration. - "State Rights " Reaction in the South. 1825-1829. The cries of "bargain and corruption," "the presidency sold," "the people cheated of their choice," were only preludes to the scheme of the Jackson campaign. Its managers planned to obstruct, cripple, and discredit the administration of President Adams in all possible ways. They were helped by the very uprightness and high-minded dignity of the President, who would stoop to no contest with them on their lower ground. They were helped in another way still more; for a radical "state rights" movement, then being revived in southern politics, went into alliance with them and gave them a large part of their strength. The Missouri struggle had awakened the slaveholding interest to a perception of the fact that there could be no safety for slavery except in narrow constructions of 


\section{SE EXFANSION IN THE GREAT YALIEYS}

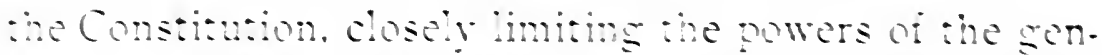

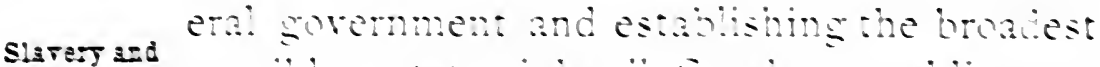

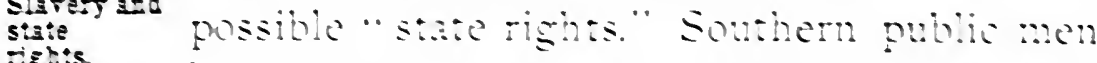
bessa to restet the enowasement that some ot them had siren to poutes ot intemal improvement and incostrial provection. and profoud reactons

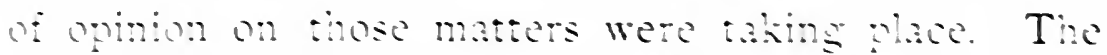

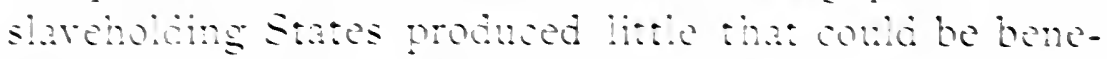

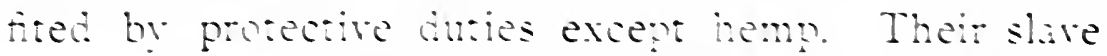

Changed

sosthern

Fiews of

isport

deties. labor could never be aprited ol an kind of

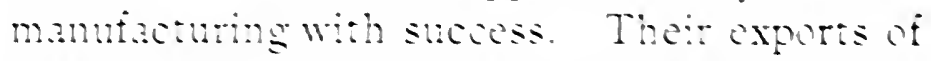
cotion and tobaco paid tor the jarges pat of the national importation of foreign soods. and southern economists were claming that wos ot the dutios collected on impors came theretore out of the pockets of suthern exporiers in the end. It was a wild theory but beame a seneral beilet. Southom public men like Canoun, who had asvosted protective Gutes, intemal mpowements and the broader chims of national soreroignty at the outset of their careers. now changed their rews.

234. The Ner Construction of Political Parties. 1825-1829. All this southem reaction iowart the cxtremest magnifyng of "state rights" was drawn into the Iackson moroment, and was usod by its shiltul managers with great sucess in working up a combimation against the sorernment. which really broke the latier down. The ineritable constumetion of new parties was thus hrousht about. ()n one side the protedionists. the adrones of roud and canal builing as national sational works, and those. Eonerally, who aihered to Republtcan Foderalistic vicws of the Constitution, and of
part. part.

the powers it swe to the soneral soremment: remained in support of the administration, and took the 
name of National Republicans. The opposition preferred to be known as the Democratic party, though it kept the old Jeffersonian title of Democratic-Republican, for formal use.

235. Deaths of Jefferson and Adams. July 4, 1826. Jefferson lived just long enough to witness this reconstruction of his party in a more democratic character than it had at first; and John Adams lived to see his son in the presidency, aathering, under a changed name, and partly from changed sources, a new party, which was, in reality, the Federalist party revived, though it denied that descent. By a remarkable and most impressive coincidence, both Adams and Jefferson died on the $4^{\text {th }}$ of July, I S26, being the fiftieth amiversary of the day on which they set their names to the great Declaration.

236. The Panama Congress. - Georgia and its Indian Tribes. 1825-1827. Of details in the history of the four years of the administration of President Adams there is little that needs to be told here. It is the history of a govermment that was hampered and baffled by malicious opposition from beginning to end. The notable incident of its first year was an invitation to join the Spanish-American republics in a congress to be held at Panama, for consideration of common interests among the nations of the New World. The government desired to be represented in the Congress, for the purpose of cultivating friendly relations with neighbors who had modelled their independent governments on our own, being careful at the same time to aroid entanglement in their politics, or responsibility for their acts. But opposition in Congress delayed action so long that the Panama meeting took place with no delegate in attendance from the United States.

In a much graver matter the government was crip- 
pled by congressional opposition, being deprived of power to fulfil its treaty obligations to the Creek and Cherokee Indians of Georgia, in protecting them from aggressive and oppressive acts by that State. The President was permitted to do nothing to uphold the national authority against a defiant State.

237. "The Tariff of Abominations," 1828. In the last year of this ill-treated administration, a new tariff bill was passed, with grave future effects. The tariff of IS24 had not satisfied the manufacturers, and, to maintain themselves at the north, the Jackson men were forced to take part with the National Republicans

\section{Tariff} scheming by Jackson's supporters.

in amending the law. They are said to have schemed to construct a bill so disadvantageous to New England, by reason of high duties on wool and other raw materials, that the New England representatives would join those of the south in defeating it, and so take the odium of the defeat on themselves. But the New Englanders chose to rote for the objectionable bill, and it became a law, to the great indignation of the south. By this time Massachusetts had become a protectionist State, her manufactures having grown to more importance than Webster
and Cal- her shipping interests, and, just as Calhoun houn change grounds. changed his ground on the question in one direction, so did Vebster in the other. The latter contended that his constituents had been forced to accept the protective system as a national policy, and, having conformed their industries to it, they must now demand to have it fully carried out. The "tariff of abominations," as it was called, assumed a startling importance in the politics of the next few years.

238. Presidential Election of 1828. - The Jackson Triumph. The election canvass of IS2S surpassed all 
DEMOCRACY FINDING INDEPENDENCE. 385

that had gone before in the recklessness of slander and abuse with which it was carried on. President Adams was named for reëlection by the National Republicans, with Richard Rush, of Pennsylvania, for Vice-President, and Jackson and Calhoun were the Democratic nominees. There appears to have been small doubt of the result from the first. Adams carried New England, except one electoral vote in Maine, and he had the electoral vote of New Jersey and Delaware, with part of the rotes of Maryland and New York, $-8_{3}$ in all. Jackson had the rest ( $\mathrm{r} \mathcal{S}$ ), including the whole country west of the mountains and south of

Jackson's the Potomac and Ohio, along with the greater part of the middle Atlantic States.

In all but two States, South Carolina and Delaware, the presidential electors were now chosen by direct vote of the people, instead of being appointed by state legislatures, as was the commoner early mode. In some States the election was by districts, which caused a division of electoral votes, as in New York. Party politics in that State have always been complicated, and the situation in i $82 S$ was more than usually strange. Two years previously, at Batavia, in western New York, a man named Morgan, who had written a pamphlet purporting to be a disclosure of the secrets of the order of Free Masons, was mysteriously abducted by masked men, and never seen again in life. A body found soon afterward in the Niagara River was declared by many persons to be his, and the charge that he had been murdered by Masons caused fierce excitement in the State. The feeling ran into politics, and a new party, of Anti-Masons, hostile to all secret societies, and especially bitter against public men belong-

AntiMasonry, ing to the Masonic order, was formed. The previous 
political factions in Now lork. known as "Clintonians" and "Bucktails," were disorsanized by this new movement. Which divided both. The Clintonians were followers of Dellitt Clinton: his uponents, the Bucktails, took their name from an omament worn upon occasions by members of the Tammany Society of the city of Jew lork. which had beome an organization of areat political power. Apparenty. upposition to Jackson woukd hare been waak in Sow Jork State if anti-Masomy had not disturbed the Democratic rote: but the fact that General Tackson was a Mason and that Adams was not gave io electoral votes to the latter out of 30 .

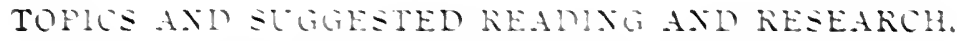

\section{The New Spirit in the Country.}

TOPIES AND KEFEREXIES.

1. Eliect of the pacitication of Europe on the Lnited States. 2. Why a more independent and move tmerican spirit arose after

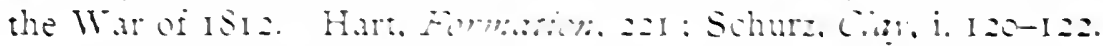
3. The new intuenes that came from the wes. Kooserelt. To:

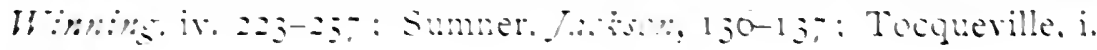
$6+6 ;$

\section{Steam Narigation. - Road and Canal Building.}

TOPICS AND KEFERENCES

I. beginnings of steamboating on rivers and lakes. 2 . The Cumberlant road. 3. Construction of the Erie Camal. MaMaster.

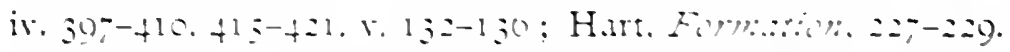

KESEAKCH. - The scthement of the west as controlled or intuenced

1 The "Tamm Society or Columbian Order." orsanized in IFo. was purely patrotic and non-partisan in the begiming: but came under the control of political managers who made it rinally. the central organization of the Democratic party in the city of New lork. 
TOPICS, REFEREXCES, ANI RESEARCH. 3S

by the course of navigable streams and by improvements in the means of transportation and travel. E. Howgh, in Cintury Magrasine, xli. 91, 201.

\section{Literature and Liberal Thought.}

TOPICS AND REFERENCES.

I. Beginnings of pure literature. 2. Change in religious thought. Hart. Formation, 224; Hart. (ontemps. iii. j1 2-51t; Richardson. i. $25 \$-260,257-292:$ Schouler, iii. $222-224$.

\section{The Political "Era of Good Feelings."}

TOPICS AND REFERENCES.

I. Causes of a singular state of political quictude. 2. "The Era of Good Feelings." schouler, iii. 3-1 2 : Sargent. i. zo-zl.

\section{Bank Intlation and the "Crisis" of 1819.}

TOPICS AND REFERENCES.

I. Business conditions at the beginning of the period. Taussig. 19-22; Schouler. iii. 3i-to.

2. Inflation of banking and bank currency- - How caused. "Wild-cat" banks. 3. Infuence of second bank of the Lnited States. Sumner. Jaths 75-70. I 20-135; Mcllaster. iv. 2So-31S, fit-510; Gordy. ii. ch. xxr.-xxri.; Schouler. iii. 109-121; Hildreth. vi. 679-6S:; Hart, Consems s, iii. +tI-t+5.

\section{Supreme Court Decisions.}

TOPICS AND REFERENCES.

I. Bearing and effect of important decisions rendered in this period. Hart. Fomation. 234-230: Hart. Contents, iii. +46-450: Sumner, Jadison, 12S-1 30; Lodge. Il costi\%. ch. iii.

\section{First Seminole War. - General Jackson's Proceedings.}

lopics AND REFERENCES.

I. General Jackson's practical conquest of Florida. 2. Execution of Arbuthnot and Ambrister. 3. Embarrassing position of the sovernment. Sumner, Jakisn, $52-6 ;$; Schurz, Clay, i.

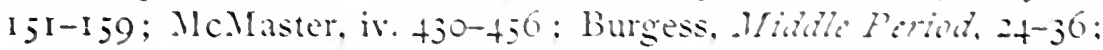
Gordy, ii. 372-35;; Schouler. iii. 5;-95; Hildreth, vi. 605-606. $6 z 7-6 z 5.640-646.654-65 s$; Clay. 1. 179-204. 


\section{DEMOCRACY FINDING INDEPENDENCE.}

\section{Purchase of East Florida. - Spanish Bound- aries defined.}

TOPICS AND REFERENCES.

r. Treaty with Spain (text in MacDonald, ii. 213-219). 2. Price paid for Florida. 3. Lines of western boundary. Benton, i. ch. xv.; Burgess, Middle Period, 20-24, 33, 36-3S ; McMaster, iv. 474483 ; Gordy, ii. 359-360, 363-364, 382-383, 38s-389; Schouler, iii. 95-96, 130-133, І 75-1 76, г 89 ; Hildreth, vi. 646-647, 658-659, 7 I 2 ; Schurz, Clay', i. I62-165; Hart, Formation, 233-234.

\section{Convention with Great Britain. - The Oregon Country. - The Fisheries.}

TOPICS AND REFERENCES.

x. American claims to the Oregon country contested by Great Britain. - Agreement for a joint occupation. 2. Settlement of the fisheries question. McMaster, vi. 457-474; Benton, i. ch. v.; Hildreth, vi.659-66o; Hart, Formation, 233.

\section{Question of Slavery Extension.}

Tolics ANd References.

x. Why Texas was not claimed from Spain. 2. Sectional feeling over the extension of slavery. 3. Equality in number of slave States and free States. - Its importance to the slaveholding interest. - Increasing inequality in population. 4. Admission of Indiana, Mississippi, Illinois, and Alabama. 5. Question concerning the Louisiana Purchase. Schouler, iii. 96-I о , I 36-I 47, I 76-1 78 : Schurz, Clay, i. I63-164, I72-175; Hart, Formation, 236-238; Gordy, ii. 390-400; Burgess, Middle Period, 5 I-58, 61-66; Holst, United States, i. 350-357; Nicolay and Hay, i. 322-324.

\section{The Missouri Compromise.}

Topics and Refinences.

r. Exciting proposal to exclude slavery from Missouri. 2. Proposal to pair Maine with Missouri. - Deadlock in Congress. 3. Agreement upon the "Aissouri Compromise" (text in MacDonald, ii. 219-224). Admission of Maine. Schurz, Clay, i. I72, I 75-I 82 ; Burgess, lidalle Period, 66-95; McMaster, iv. 570-594; Gordy, ii. 408-416; Holst, United States, i. 357-378; Schouler, 
TOPICS, REFERENCES, AND RESEARCH. 389 iii. IoI-I03, I 47-1 71 ; Hart, Formation, 238-240; Hildreth, vi. 66I$676,682-685,687-696$.

4. Reopening of the question by the Missouri constitution. Threatening situation. 5. Fundamental condition of the final admission of Missouri (text in MacDonald, ii. 225-226). - Influence of Henry Clay. Schurz, Clay, i. I83-193; Benton, i. 8-1o; Burgess, Middle Period, 95-103; McMaster, iv. 594-60I ; Gordy, ii. 4I6-439; Holst, United States, i. 379-38I; Schouler, iii. I 78-I86; Hart, Formation, 240-24I ; Hart, Contemp's, iii. 452-458; Hildreth, vi. 702-703, 705-712.

6. Wisdom of the Compromise. Schurz, Clay, i. r94-I99; Gordy, ii. 440-444; Burgess, Middle Period, I03-107; Schouler, iii. I 7II 73 ; Am. Hist. Ass'n, Annual Rep't, I893, 289-294.

\section{Unanimous Reëlection of President Monroe.}

Topics And References.

I. Circumstances of the election of I 820. Schouler, iii. 197-199.

\section{Internal Improvements and Protective Tariffs.}

Topics And References.

I. The questions on which new parties would be formed. 2. The protective tariff of I 824. 3. Clay's "American System." - Webster's opposition. Gordy, ii. 484-488, and ch. xxviii.; Holst, United States, i. 388-403; McMaster, iv. 4I0-4I 5, 422-426, 510-52 I ; Schouler, iii. 247-254, 295-298; Hart, Formation, 247-248, 253255 ; Schurz, Clay, i. 2I2-22 I; Benton, i. I-4, and ch. xiii.; Clay, v. 254-294; Webster, iii. 94-149; Taussig, 23-24; Elliott, I94-236. RESEARCH. - The policy of " internal improvements " as advocated by Mr. Clay. Clay, i. ch. xix., v. I I 5-135.

\section{The Monroe Doctrine.}

Topics AND RefERENCES.

r. Circumstances which called out the declaration known as the "Monroe Doctrine." - The "Holy Alliance" (text in Hart, Contemp's, iii. 479-480) and Spanish-American independence. 2. Canning's suggestion. 3. The two passages of President Monroe's message that embody the "doctrine" (text in MacDonald, ii. 228-23 I ; Hart, Contemp's, iii. 494-498). Gilman, I 56-1 74 ; Wharton, Digest, i. sect. 57; McMaster, v. 28-48; Hart, Formation, 


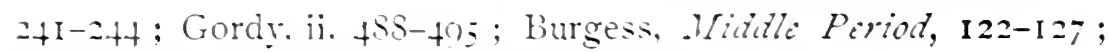
schouler, iii. 27/-290. 292-293: Tucker.

4. What it does and does not mean. Gordy, ii. 495-796; Burgess, .riddle Peried, rz-rzs: Schouler. iii. 290-291; Hart, Contemp's, iii. $499-501$.

\section{The Visit of Lafayette.}

TOPICS AND REFERFACES.

r. Entertainment of Lafayette as the nation's guest. Tuckerman. ii. ch. vii.; Sargent, i. S9-95; Benton, i. 29-3I; Schouler, iii. $316-324$.

\section{Presidential Election of 1824-1825. - The "Bargain and Corruption" Cry.}

TOPICS AND REFEREXCES.

I. The single party with four candidates. 2. Failure to elect by the popular rote. - Election in the House of Representatives. 3. Clay farors Adams and is made Secretary of State. - Cry of "bargain and comuption." 4. L'se of the charge in the next election. Schurz, Clay, i. 221-232, 236-25\%, 276-2\$6; Sumner. Jackson, -6-9): Quincy. J. Q. Allams. ch. vii.: McMlaster, v. 5;-Sr. 4 SS-513; Burgess, Widtle Pirind, 13I-Itt; Hart, Formation, 24-251: Gordy. ii. 5II-535: Schouler, iii. $304-316,324-329.33 S-$ 3+z; Benton, i. $+7-79$; J. Q. Adams, vi. $269,289-29+302-303 \cdot 3 \mathrm{Iz}-$ $317,+50-453 .+70-473,505-509.525$; Clay, i. ch. xiv.-xviii, $v 341-$ 355.

5. Jackson's belief in the matter. Schurz, Clay. i. 320-324.

233. Combination against the Adams Administration. - "State rights" Reaction in the South.

Torics AND ReFERENCES.

I. Organized opposition to the Administration. Hart, Formatioll, 259-260; Gordy. ii. 536-5t2, 54\$-550.550-560. 56s ; Schurz, Clark, i. 25\$-265: Sumner, fackson, roo-106: Schouler, iii. 33633\% 3tt-346. 400-413. +16-420: Sargent, i. 106-114.

2. The southern "state rights " movement. - Pro-slavery reaction against "protection " and "internal improvements." Burgess, Widille Period, roS-1 22. 1 29-130; Holst. Calhoun. 66-76; Sumner, Jaikson, roS-IIt; Schouler, iii. $3 S_{I-3} S_{5}$. 
TOPICS, REFERENCES, AND RESEARCH. 39I

234. New Construction of Political Parties. National Republicans and Democrats.

TOpics AND Referexces.

I. The two parties formed, for and against the Administration. Schurz, Clay, i. $31 \mathrm{I}-320$; Gordy, ii. $5+3-5+8$, $56 \mathrm{I}-568$; Burgess, Middle Period. $\mathrm{I}_{4-1}+6$.

\section{Deaths of Jefferson and Adams.}

TOPICS AND REFERENCES.

r. The extraordinary coincidence of their deaths on the 5 oth anniversary of the Declatation of Independence. Webster, i. 1o9I50; Benton, i. ch. xxxi.; Schouler. iii. $3 S 6-j S S$; Morse, Jefferson, $3+4$.

\section{The Panama Congress. - Georgia and the Indian Tribes.}

TOPICS AND ReFERExCES.

r. The Congress of the Spanish-American republics. - Opposition to a representation from the Lnited States. McMaster, $v+433^{-}$ 459; Holst. Cnited States. i. +09-432; Schurz. Clay, i. 267-275; Sumner, Jackson, ro6-1oS; Burgess, . Sidale Period. I $46-155$; Gordy. ii. 550-558; Hart. Formation, 25I-253 ; Hart. Contemp's. iii. 506-j0S; Schouler, iii. 35S-366; Webster, iii. 1 $7 S-217$; Benton, i. ch. xxy.

2. Powerlessness of the President to fultil treaty obligations with the Indians. Holst. United States, i. $+33-45$; Sumner, Jack-

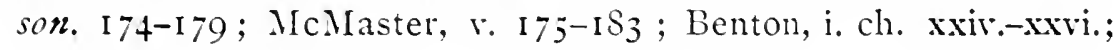
Hart, Formation, 255-256; Schouler, iii. 370-3So.

\section{The "Tariff of Abominations."}

Topics AND RefERENCES.

I. The tariff bill of ISzS. - Alleged scheme in framing it. 2. Massachusetts joins the "protectionist " States. - Changed attitudes of Webster and Calhoun. Taussig, 6S-Ior: Elliott, 236246; Sumner, Jackson, 197-206; McMaster, v. 227-255; Gordy, ii. 569-574; Lodge, IV ibster. 156-171; Burgess, Middle Period. 157-163; Hart, Formation, 257-25s ; Webster, iii. 22S-247 : Benton, i. ch. xxxiv. 
392 DEMOCRACY FINDING INDEPENDENCE.

238. Presidential Election of 1828. - The Jackson Triumph.

TOPICS AND REFERENCES.

I. Jackson's victory in the west, in the south, and in most of the middle States. 2. The Anti-Masonic party. 3. New York "Clintonians " and "Bucktails." Gordy, ii. $575-5 S_{1}$; Hart, Formation, 260-26z; Schurz, Clay, i. $287-292,340-3+1$; Sumner, Jackson, I I-I IS, 250-254; Schouler, iii. +34-+39; Burgess. Middle Period, I63-16; ; Mc.Master, $1517-519 ;$ Benton, i. ch. xxxviii. 
CHAPTER XII.

THE JACKSON PERIOD. I S29-IS4O

239. President Jackson and his Advisers. 1829. The election of Andrew Jackson to be President of the United States has been described as a political revolution, and there seems to be not much exaggeration in the phrase. Indeed, the contrast in character between him and his predecessors was little less than a revolution in itself. They had been picked, as statesmen, from the highest ciass of trained public ment from the highest ciass of trained public men, - Jackson men of trusted knowledge and judgment, and of $\begin{gathered}\text { and hreds } \\ \text { sors. }\end{gathered}$ trusted temper and self-command. The choice of General Jackson was made on no such ground. Bred under rude frontier conditions, he not only lacked political knowledge and general cultivation of mind, but his wilful and passionate nature knew nothing of discipline or self-restraint. His judgment was ruled by prejudices, and his first impressions gare him unalterable beliefs. Fortunately the American Union was among the objects of his most passionate belief, and that gave an important leading to his course.

All the influences surrounding the executive were revolutionized under the Jackson régime. Hitherto the President's counsellors had been the heads of the important departments of his administration, standing in responsible relations to the public and himself; but President Jackson took most of his advice from men who held subordinate places in the administration, or none at all. 
They were men whose only mark in American history was made by the doubtful methods they brought into our national politics, and the covert influence they had with a President whose military popularity and personal force gave him extraordinary power. They formed what was called at the time a "kitchen cabinet," The
cabitchen meaning that it was a private council, which superseded the functions of the proper cabinet of official chiefs. John H. Eaton, Secretary of War, was the only head of a department who seemed to belong to the "kitchen cabinet;" but Martin Van Buren, the Secretary of State, had the President's confidence, and exerted an influence that was generally good. The characters of the politician and the statesman were mixed remarkably in Van Buren, and he was unequalled as a politician in adroitness and skill. He was the acknowledged chief of a knot of able leaders in New York, known as the "Albany Regency," who ruled the Jackson Democracy of that State for many years.

240. The "Spoils System." 1829. The worst of the changes brought on the government by the altered influences surrounding the executive was a change of principle and of practice in dealing with employments in the national public service. During the forty years that had passed, from the organization of the federal govern-

Previous removals from office, 1789-1829. and nearly all of them for reasons with which party politics had nothing to do. Jefferson, who removed 39 of the number, displaced a few for political reasons, claiming that it was just to do so because Federalists held most of the places; but Madison, Monroe, and John Quincy Adams appear to have made no changes on political grounds. Mr. Crawford, Monroe's Secretary of 
the Treasury, procured the passage of an act in I820, which fixed a four years' term for many offices, and so opened an opportunity, without arbitrary re- Four years' moval, for frequent changes to be made; but $\begin{gathered}\text { term of } \\ \text { office. }\end{gathered}$ neither Monroe nor Adams took any advantage of the law. They are said to have reappointed every official whose record of service was satisfactory; though half the public servants whom Adams treated in that high-minded way were openly enlisted against him, in the Jackson campaign.

Already in some of the States - in New York most of all - the political factions had made "spoils" or prizes of everything in the public service to which a

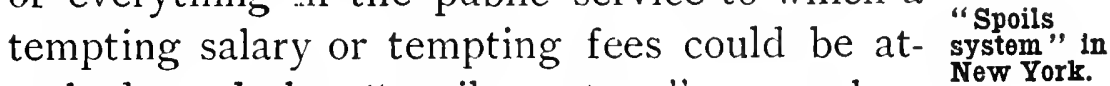
tached ; and that "spoils system," as we characterize it, which debases politics and drives men of high character out of public life, was carried into the national administration upon the instant that Jackson took it in hand. To punish his enemies and reward his friends was a maxim of policy that his mind approved. In the first year of his presidency he removed 734 officials, to make places for his own partisans,

Jackson's removals, 1829-1830. and by their similar treatment of subordinates it is estimated that more than 2000 changes were made. "Rotation in office" was announced to be the Democratic policy, in order to give as many citizens as possible their turn at what was sometimes described coarsely as "feeding at the public crib." For more than fifty years thereafter the pestilence of the "spoils system " raged in American politics with no check.

241. Forecast of Presidential Policy. 1829. The first annual message of President Jackson was a significant forecasting of some of the lines on which his mind was being moved. One passage gave warning of hostil- 
ity to the United States Bank. Another indicated the Hostllity to general purpose of the Administration to enter the Bank. upon a new championship of independent rights and powers in the States. That purpose was revealed more distinctly in remarks on the subject of internal improvements, and on the Indian question that had risen in Georgia during President Adams's term. The whole policy of internal improvements was condemned. It was recommended that the general government leave all unHostility to dertakings of public works to the States, and internal
improve- distribute its surplus revenue among them for improve-
ments. the President repeated his arguments and recommendations on the subject more strenuously, in vetoing a bill which required the government to take stock in a Kentucky turnpike road. He found the policy hard to kill, even in his own party; but opposition to internal improvements by the federal government did become a Democratic doctrine before the end of the Jackson rule.

242. Treatment of Indian Tribes. 1829-1843. On the Indian issue between Georgia and the general government the President upheld the State in its violation of national treaties with the Cherokees and Creeks, and its defiance of the national government to protect those tribes in their treaty rights. Later, the Cherokees carried their case to the Supreme Court of the United States, and obtained mandates which the governor and legislature of Georgia refused to obey, and which President Jackson refused to enforce. Within the next few years the southern Indian tribes east of the Mississippi Formation were forced to migrate westward into the Inof Indaan dian Territory, which was set apart for them
Territory, dian 1834. in I 834 . A second war with the Seminoles of Florida, most cruel and destructive on both sides, and 
lasting for eight years, from I835 till I 843 , was consequent on this measure. A shorter conflict in the northwest, with Indians of the tribes of Sacs and Foxes, which were removed to the farther west, occurred in 1832 . It was known as the "Black Hawk War," from the name of the leading chief.

243. President Jackson and the Protective Tariff. Calhoun and "Nullification." 1829-1830. On one subject of importance to the champions of state rights, the President gave less satisfaction in his message of 1829 . He spoke of the tariff in terms which showed that the doctrine of "protection" to home industries against foreign competition was attractive to his mind. His attitude was a disappointment to the south. Intense feeling on the subject had been worked up, especially in South Carolina, since the passage of the "tariff of abominations" in the previous year. Vice-President Calhoun and others were leading a movement to bring the theory of " nullification," propounded in the Kentucky Resolutions of 1798 (see sect. 172) into practical operation, by causing the State of South Carolina to declare the protective tariff laws null and void of effect within the limits of the State, and to take measures for resisting the enforcement of those laws. This proceeding of "nullification" was claimed to be not rebellious in its nature, but the exercise of a strictly constitutional right. The argument relied upon to prove it so was furnished mainly by Calhoun, in a series of elaborate papers, beginning with one sent by him to the South Carolina legislature, and adopted by that body

South Carolina "Exposition." as its own "Exposition," immediately after the passage of the tariff of 1828 .

Nor was it only as a remedy for the immediate grievance of the tariff that the minds of the South Carolinians were 
dweting on the dortune of mathotion. For when in

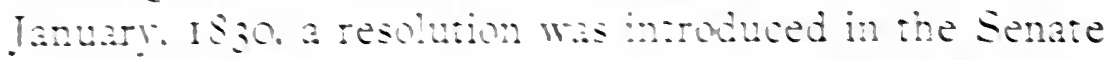
which seemed to have the pumper of restricting the sale

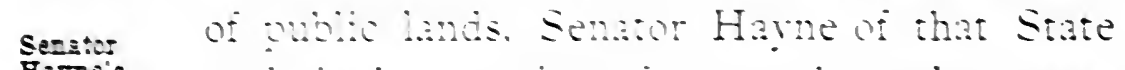

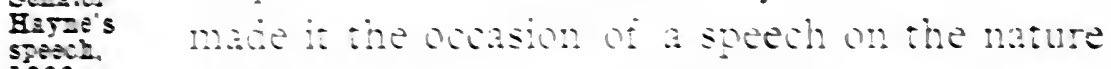

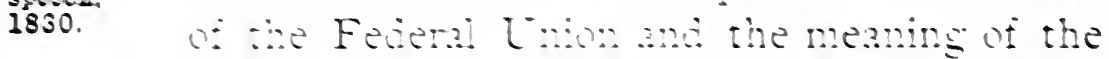
Constantina bathy un to an emphatic statement of the

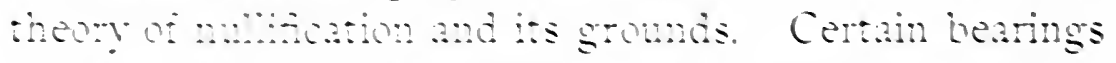

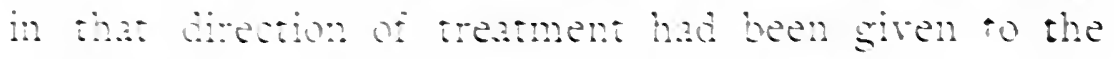
pub"io and gueston by some expessons from the manufactumg States ot the ens. Those Szates wereshowing a seltish jelons of westem expansion, becanse their

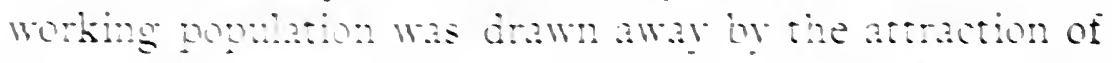
chen fams and wases were mised. The land question was thus comacted whin the antit cuestion, in southern vews : and hence it was ant the most importand debate

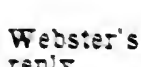

jest.

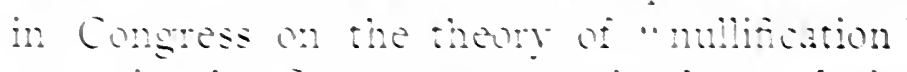
arose in the senate uno a simple resolution of momiry concming the sales of public lands. Danie. Ilebste" then deavered his grentest oonstitutional specin - perinas the mot powertul, in both argument and eloguence of a.t his speeches - on the zoth of Iamary Is

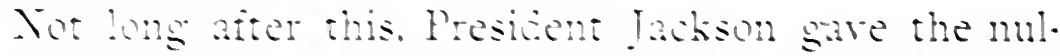
lifers a check. Despite the inclination he had shown toward proverionist beliets they felt confdent that his notions of "state rights" womid tend him to deal as tendewly with a mathation of tartit law by South Carolina as he has deat with the mulination of Indian treaties in the Georgia case. They did not reckon on the difterent vews which a mind like Jacksons would take of his official dut toward a ha that be believed in, and his duty tomard one which he disapproved. He believed to a certain extent in protective taritis, and he believed 
rery ardently in the necessity for presering the Lnion of States. The latter was one of the strongest convictions he had, and it is not likely that Calhoun could have persuaded him that mullification did not mean disunion, eren if he had been on good terms with Calhom. But President Jackson was just discorering. in the winter of ISjo, that when his conduct in the Seminole war (see sect. 223) was discussed by the cabinet of Mesident Monroe, Calhoun had not been as he supposed his sole champion, but had striven to have him called to sharp account. His consequent wrath against Calhom may have added some heat to his feeling against the morement of which Calhoun was the notable head. On Tefferson's birthday (April I3) in Isjo, at a banquet where the nullifiers expected to talk principally about the Kentucky resolutions of I 798 , he discomfited them by offering as a toast, "Our Federal Lnion: It must be preserved." After that there was little doubt as to what his attitude toward their projects would be.

244. Cabinet Reconstruction. 1831. The President s rupture with Calhoun led, in the spring of ISBI, to a reconstruction of his cabinet, three of the members of which were political friends of the Tice-President and were dismissed. Tan Buren and Eaton resigned, the former to become openly, with Tachson's approval, a candidate, first for the rice-presidency, during a second term to be claimed for Iackson in the presidency, and then for the hater's seat. to which Calhoun had aspired. The reconstructed cabinet included Edward Livingston, of Louisiana, in the State Department, Louis MiLane, of Delaware, in the Treasury. Lewis Cass, of Michigan, and Levi Moodbury, of Xew Hampshire, Secretaries of War and the Nary, and Roger B. Taney, of Maryland, as Attorney-General. 
At the same time the "kitchen cabinet" underwent an important change, Duff Green, who edited a Washington newspaper, dropping out, to follow the fortumes of Calhoun, and Francis P. Blair coming from Kentucky to take his place, and to found a famous administration journal named "The Globe."

245. The Bank Question in the Presidential Canvass. 1832. By this time it was well settled that Jackson would be put forward by the Democratic party for reelection in I $_{32}$, and that the National Republicans would oppose him with Henry Clay. It was equally certain that the Anti-Masons, now grown to be quite a formidable party in several northern States besides New York, would be, in some manner, in the field. So far, the substantial issues between the President and his opponents related only to internal improrements and the character of the Order of Free Masons. Clay wanted a more positive and stirring question in the canvass, and beliered it was to be found in the President's hostility to the United States Bank. That hostility had been exotfered pressed a second time in the message of $i S_{j O}$; bank char-
ter rejected, but there are said to have been proposals to the 1838: bank, in $S_{3} \mathrm{I}$, of a modified charter, which the administration would approve and which the officers of the bank were willing to accept. Clay, Webster, and other political champions of the bank objected, however, to the offered compromise, and insisted on staking the fate of the institution on the presidential fight. This was a double blunder, in statesmanship and in political management, as they learned to their cost ; but their will prevailed, and the gauntlet on the bank question was thrown down by the National Republican convention which nominated Clay, in December, $I_{3} I^{1}$ Its main appeal to 1 This presidential election of $18_{32}$ was the first in which the 
the country against Jackson was on the ground that he would veto a re-charter of the United States Bank. Then, to force the issue, the bank was persuaded to apply for the new charter at once, and the question was fought over in both branches of Congress through most of the session, with final success to the bank. The chartering act was sent to the President on the $4^{\text {th }}$ of July, I 832 , and he returned it on the Ioth with a veto message, in which all possible arguments against the bank, both sound and unsound, were arrayed with extraordinary skill. The effect of that message in the country was more fatal to the opponents of Jackson than they suspected till the returns of the election, four months later, came in.

246. The Tariff Act of 1832. Almost simultaneously with the bank bill and the veto message, another gage of battle was thrown into the arena of combat by the passage and signing of a new tariff act, which amended the "abominations" of the act of 1828 so far as concerned the manufacturer's complaints, but which virtually challenged the nullifiers to do their worst. Clay had appeared in the Senate this session, and the act was substantially his, embodying the principles of his "American system," keeping high duties on articles in competition with home products, and lowering or abolishing them on commodities not produced at home. His imperious influence carried the measure, which reduced revenue very little, and that little in no way that suited the south. It was to go into effect on the $3 \mathrm{~d}$ of March, 1833. The President was sufficiently satisfied with it to sign the act.

247. Reëlection of President Jackson. 1832. The candidates were formally nominated by national conventions of the several parties. There had been some previous use of nominating conventions in certain States, but not much. 
excitement of the presidential canvass was now at its height. The Democrats had formally nominated Jackson and Van Buren in the previous May, and the Anti-Masonic party, long before, had named William Wirt. That the opposition to Jackson was divided mattered little, for the country gave him an enormous majority over both Clay and Wirt. He carried every State except Massachusetts, Rhode Island, Maryland, Delaware, and Kentucky, which went for Clay, Vermont, which gave Wirt a majority, and South Carolina, which had a nullifying candidate (John Floyd) of its own. The Bank of the United States was doomed to death by the popular verdict which its friends had inroked, and an impatient magistrate waited for the earliest opportunity to execute the decree.

248. The Nullifying Ordinance of South Carolina. The "Compromise Tariff." 1832. But the President had nullification to deal with first. On the $24^{\text {th }}$ of November a State Conrention, called by the legislature of South Carolina, passed an ordinance which declared the tariff acts of 1828 and $S_{32}$ to be null and of no effect in that State; which forbade appeals from State to Federal courts, in any case arising under the ordinance; and which declared that South Carolina would secede from the Union if resistance to her proceedings should be attempted by the United States; but the ordinance was not to take effect until the ist of February, I 833 .

And now it was that the best of the strong stuff in the character of President Jackson was called out. With a quiet and eren gentle firmmess that was most admirable he laid his iron hand on the rebellious State and bade it beware. Two vessels of the navy were ordered to Charleston, and General Scott was sent to the city with troops, not behind him, but within easy call; and then, on 
the Ioth of December, a proclamation, addressed to the people of South Carolina, first reasoned with them, to show the shallowness of the arguments by which they had been misled, and

Prestdent

Jackson's

proclama-

tion, 1832. finally said to them with solemn emphasis: "The laws of the United States must be executed. I have no discretionary power on the subject; my duty is emphatically pronounced in the Constitution. Those who told you that you might peaceably prevent their execution deceived you. . . . Their object is disunion. But be not deceived by names. Disunion by armed force is treason." 1

It was a scant majority of the people of the State who had put the nullifiers in control of its government; but they answered the President with defiance. Their legislature proceeded to pass laws for carrying the ordinance of nullification into effect,

\section{South}

Carolina's

defiance. and to put the State under arms; whereupon the President applied to Congress for further powers, to remove custom-houses, suspend or abolish customs districts, and use other means for meeting the demands of the situation, besides those of arms. The necessary legislation was undertaken at once; but conciliatory influences were working actively at the same time. Mr. Clay was now willing to lower the barriers of his "American system," and led the way in revising the tariff once more. The two measures, "Force Bill" and "Compromise Tariff," were under debate when the Ist of " " February came, and South Carolina postponed the operation of her ordinance to await the re"Force
Bill" and
"Compro-
mise mise 1833. sult. Both bills reached the President and were signed by him on the $2 \mathrm{~d}$ of March. The "Compromise Tariff" act

1 This proclamation, one of the most admirable and important of American state papers, is known to have been written by Edward Livingston, the Secretary of State. 
provided for successive deductions from the rates of duty until, in I 842 , there should be none to exceed 20 per cent. The nullifiers professed satisfaction, reassembled their convention, repealed their ordinance, and peace was restored. On both sides there were boasts of victory, with some ground for both; but the puerile doctrine of nullification had been destroyed practically, and that should suffice for our satisfaction with the event.

249. Removal of Government Deposits from the United States Bank. 1833. And now the President was free to turn his attention to the Bank of the United States. He considered that the people, in reëlecting him by a great majority, had endowed him with the sovereignty of their will, and his arbitrary disposition was increased. Especially concerning the bank, he believed that he had received a command straight from the people, against which nothing should have weight. He doubted the soundness of the institution and the safety of the public

Congress and Secretary of Treasury favor the bank. funds that were trusted to it. At his request, Congress investigated and decided that the deposits in the bank were safe. It was the same Congress, however, which had voted to re-charter the bank, and, having no confidence in its judgment on the subject, the President determined to act on his own. By law, it was the Secretary of the Treasury, not the President, who had authority to remove the deposits, and Secretary McLane was a believer in the bank. McLane, accordingly, was transferred to the State Department, from which $\mathrm{Mr}$. Livingston was sent as minister to lirance. Then the President invited to the Treasury a Mr. Duane, a known opponent of the bank, who might be expected to take the action desired. But Mr. Duane proved intractable in the matter, refusing to disturb the business of the country by a sudden with- 
drawal of government deposits from the bank, and contending that it should not be done without congressional assent. His views were shared by a majority of the official cabinet; but the headstrong President, Dismissal urged on by some of his advisers in the of Duane. "kitchen cabinet," and by the Attorney-Gen- ment of eral, Roger B. Taney, would not be turned from 1833 . the course he had determined to take. Duane was dismissed, and Taney was put in his place. In September the latter ordered the public money in the bank, about $\$ 10,000,000$ in amount, to be drawn as needed, and no more deposits to be made. The effect, as predicted, was serious for a time; but the bank went through the disturbing operation, and, obtaining a charter from the State of Pennsylvania was carried on for

F'ate of the a few years more, till a day of general ruin arrived and it went down in the crash.

There are many good reasons for believing that the Bank of the United States, as a centralized monetary power, peculiarly exposed to political influences, was a dangerous institution to have growth, and that it was best for the country that it should be brought to an end; but sound principles of constitutional government were violated in the methods by which it was attacked and destroyed. A resolution by the Senate of censure on the President's conduct drew from him an elaborate protest, asserting the independence of the executive with great force. His party

Censure of the President expunged, 1833-1837. friends never ceased to demand the expunging of the censure from the Senate journal until they carried their point, in 1837 .

250. Aggressive Anti-slavery Agitation. - The Abolitionists. 1831-1836. Other agitations were now in preparation for the country, among them a new excite- 


\section{EXPANSION IN THE GREAT VALLEYS.}

ment of feeling on the subject of slavery. Hitherto the antagonism to slavery had been little more than a resisting disposition, manifested on occasional questions, like that which brought about the Missouri Compromise. Now it was becoming aggressive, and was being organized for persistent attack, not merely to oppose and restrict, william but to destroy. Its crusade was opened in a Gloyd Garrison, startling way by IVilliam Lloyd Garrison, a 1831. young man, then unknown and poor; who began the publication of "The Liberator," a small "abolition" journal, at Boston, in I83I. Garrison attacked slavery as an intolerable crime against humanity, for which the whole nation was accountable no less than the slaveholding States, and he denounced every compromise with the latter, including the compromises of the Federal Constitution and the Constitution itself. At first there were not many to approve the violence and the indifference to all consequences of disunion and civil conflict which this proposed; and the abolition agitation might have had little influence for many years, if the slaveholding interest, in fierce endeavors to put it down, had not attempted to crush free opinion and free speech in all the States.

The founding of "The Liberator" in I83 I was followed by the organization of a New England AntiAnt1- slavery Society in I 832, and of an American slavery
societies, society in the following year. If the early 1831-1832. membership of those societies was small, the zeal in them was burning and their activity intense. Through public meetings and printed tracts and periodicals, they labored with incessant energy to "rouse the national conscience;" but the first important effect of their work was an excitement of rage and alarm in the slaveholding States. The people in those States were 
stirred, not only by resentment at the attack on their labor system, which they looked upon as the most righteous and divinely sanctioned in the world, but by fear of the effect of the agitation on their slaves. They lived in dread of insurrections, and a recent murder- wat ous rising in Virginia (1831), led by one Nat $\begin{gathered}\text { Turner } \\ \text { insurrec }\end{gathered}$ Turner, had filled them with fresh alarm. Gar- tion, 1831. rison and his fellow abolitionists were denounced as malignant "incendiaries," whose purpose was to madden the enslaved blacks, incite them to revolt, and bring death and ruin on the south. Especially on that ground it was demanded that they should be silenced by force, - that their orators should be imprisoned, their presses stopped, their publications denied the use of the mails.

This fierce clamor from the south for the suppression of abolitionist speech and print had three effects, on three classes of people, in the north. It roused people of one class to defend the threatened freedom of tongue and pen; awakened them to new and serious thinking on the subject of slavery, and prepared them for any contention with it that did not repudiate the Constitution or recklessly imperil the national life. It moved people of another class to sympathy with the wrath of the slaveholders; made them unflinching political allies of the slaveholding

Three effects of the agita tion. interest, ready to go to any lengths with it, in Congress, or state legislatures, or courts of law ; and no less ready to serve it by mobbing the abolitionists, destroying their presses, and threatening their lives. People in the third class were merely fretted by the disturbance of the country. The class which grew most in numbers was the first. It was the anti-slavery sentiment of that increasing body of citizens which gradually dominated the free States and controlled political events. 
251. Suppression in Congress of the Right of Petition. 1835-1840. The first practical political question to be raised by the anti-slavery agitation concerned the right of petition, and it was forced on Congress by attempts to deny a hearing to appeals for the abolition of slavery in the District of Columbia. That the national government had supreme jurisdiction over its own seat could not be denied; nor could anybody dispute the guarantee, in the First Amendment to the Constitution, of "the right of the people . . . to petition the governEmancipa- ment." Nevertheless, in the session of I835tion peti-
tions 36 , when petitions for emancipation in the Dis. tions

trict began to reach Congress in great num. bers, a resolute effort to forbid their reception was begun. It was a fatuous undertaking, because it stirred infinitely more feeling in the north than anti-slavery agitators could possibly produce. More fatuous still was

Exclusion from the malls.

the attempt to exclude anti-slavery literature from the mails. This had the support of President Jackson, who recommended, in his message of I 835 , the passage of a law to prohibit "the circulation in the southern States, through the mail, of incendiary publications intended to instigate the slaves to insurrection." The anti-slavery societies denied that anything more "incendiary" than the doctrine of human rights in the Declaration of Independence was ever sent by them into the south, or that they circulated anything among the slaves to excite revolt ; nor does any fact contradictory of their denial appear to have been shown; but Mr. Calhoun and his followers seemed determined to make slavery a forbidden subject to all tongues and pens but their own. Even the law proposed by Jackson was not acceptable to Calhoun. He demanded that the States themselves should determine what printed matter 
should and should not be delivered in them through the United States mails, and he introduced a bill to that end ; but it suffered defeat in the Senate, and never reached the House.

The most effectual agitators of feeling on the subject of slavery, in all those years of impassioned agitation, were not the orators of abolition, but Calhoun and the public men whom he led. They could let pass no opportunity for disputing the rights of opposed opinion and speech; thus compelling men to strike at slavery in defence of free institutions at large. From December, I 835, until January, 1840 , the struggle to uphold the right of petition in Congress was maintained. It was then that John Quincy Adams performed

John Quincy Adams, 1835-1845. the highest service of his life. After leaving the presidency he had accepted an election to the House of Representatives, taking his seat in $\mathrm{I} 83 \mathrm{I}$. His own opinion was against an agitation at that time for the abolition of slavery in the District of Columbia ; but he held the right of petition to be a sacred right, and he made himself its most resolute and powerful champion in the House.

The slaveholding interest drew allies enough from the north to carry a resolution (known afterward as "The "the Atherton Gag") through the House, in Atherton Dec. I 838, which made it the rule that all peti- 1838 . tions and memorials relating to slavery "shall, without being printed or referred, be laid upon the table, and that no further action whatever shall be had thereon." From session to session thereafter, while Mr. Adams and other members continued to present petitions in always increasing numbers, this rule, which laid them unnoticed on the table, was made more stringent, until finally, in January, I840, the House was suppressed, 1840. prevailed upon to defy the Constitution entirely, by re- 
solving that "no petition, memorial, resolution, or other paper praying the abolition of slavery in the District of Columbia, or any State or Territory, or the slave trade between the States or Territories of the United States in which it now exists, shall be received by this House, or entertained in any way whatever."

252. Texas. 1835-1837. The “Slave Power," as it began to be called, had now succeeded in arraying all the Alliances of Slave Power.

feelings and judgments that are defensive of free institutions against itself. Nevertheless, for the time being, it was an almost irresistible power in the nation, made so by alliances with ambitious politicians in the north, who were clrawn to it by the attraction of its solidarity in the south. It was preparing, moreover, to increase its power, by further expansions of territory in which to create new slave States. The intention to acquire Texas for that purpose had been always in the southern mind, and the time for fulfilling the intention seemed now to be at hand. So many American and British settlers had gone into that province of the Mexican republic, since the Spanish rule in Mexico was overthrown, that their number was said to be 20,000 in I 835 . Generally they were looking forward to becoming part of the United States, and southern statesmen were planning to that end. These American and other English-speaking Texans were using slave labor, in defiance of the Mexican government, which had prohibited the importation of slaves in I 824 and decreed emancipa-

Texan

Inde-

pendence declared, 1836. tion in I829. In other matters they paid little respect to Mexican authority, then weakened by civil conflicts, and, after some collisions with President Santa Anna, they declared their independence, on the $2 \mathrm{~d}$ of March, 1836 . Before they were well organized, Santa Anna entered the country with 
a Mexican army and committed some dreadful atrocities at a fortified mission church, called the Alamo, and at Goliad; but that was the end of his suc- The Alamo, cess. On the 2 Ist of April his army was crush- $\begin{gathered}\text { San } \\ \mathbf{1 8 3 3 6} \text {. }\end{gathered}$ ingly beaten at San Jacinto, and he was taken prisoner by a small force of Texans under General Sam Houston, of Tennessee. The independence of Texas, though unacknowledged by Mexico, was won by the single battle. In October a constitution was adopted and a republican government organized, with Houston as president, to which government the United States gave recognition in the following spring. The Texas question stood at this point when Jackson's administration closed.

253. Extraordinary Growth of the Country.-Beginnings of a Mania of Speculation. 1825-1833. While the country went through the moral agitations and political excitements of these last years of the Jackson régime, its whole economic system was in a more than equally fevered state. Since recovery from the "crisis" of 1819 (see sect. 221), the increase in population, the spread of western settlement, the rise of new towns and growth of older cities, the eager activity of public and private enterprise in every field, had had no precedent in the modern history of the world. Between the census of 1820 and that of I 840 the total population rose from $9,638,000$ to $17,053,000$, of which of which latter number 9,728,000 were in the northern States, and 7,334,000 (including 2,486,000 slaves) were in the south. Ohio grew in that brief period from 576,000 to 1,502,000; Indiana from 145,000 to 678,000 ; Illinois from 53,000 to 472,000 ; Michigan (admitted as a State in 1837) from 8000 to 211,000 ; Arkansas (admitted in 1836 ) from 12,000 to 77,000 ; 
Missouri from 56,000 to 323,000; and almost the whole of this prodigious advance was prior to 1837 . It had been stimulated immensely by the completion of the

Steamboat and rallway.

Erie Canal in I 825, and quite as much, perhaps, by the rapid multiplication of steamboats on rivers and lakes. No other country in the world had utilized the steamboat so rapidly, or gained so much from it ; for no other had such waterways opening into such expanses of undereloped land. Railways, with steam locomotion, had their beginning in 1830 , and 1273 miles had been built in the United States within the next six years.

In the rush of this unparalleled progress it is not at all strange that even sober-minded people lost their heads, Specula- and saw no limit to the continued working of tion. the new agencies of travel and transportation that were driving it on. It seemed possible to mark a thousand spots where new towns would spring up in the next few years; and no less possible to forecast the growth of existing cities and towns. So speculation, especially in land, leaped from the reckoning of present facts to future possibilities, and went wild.

254. Second Era of "Wild-cat" Banking and Inflation. 1833-1837. It was just at the time when this fever of speculation was prepared for by the circumstances of the day that a mischievous stimulant was given to it by President Jackson's removal of government deposits from the Bank of the United States to a large number of state banks. For a short time, while Distribu- the change was going on, it gave business a
tion of
United
Sheck; but that soon passed and was followed
Bank tunds. by quite opposite effects. Naturally there was
a scramble for the deposits, and a fresh output of state charters for new banks, soon running into a new 
era of "wild-cat" banking, worse than that which followed the War of I8I2 (see sect. 221). Again there was an inflated and depreciated paper currency, an inflated credit system, and the speculative spirit was intoxicated still more.

Then came another measure of government which helped the mischief on. The last of the public debt having becn extinguished in 1836 , and a surplus exceeding $\$ 42,000,000$ having accumulated in the national treasury, an act was passed which ordered the distribution of all but $\$ 5,000,000$ of this surplus, as a loan without interest, in four quarterly instalments, among the States. The prospect of $\begin{gathered}\text { surplus } \\ \text { revenue, }\end{gathered}$ that large addition to funds in the States, for

\section{Distribu- \\ tion of 1837.} all sorts of public improvements and other purposes, gave still another impulse to speculation; but when it came, in 1837 , to the transferring of $\$ 9,000,000$ every three months from banks all over the country into state treasuries, the unsound monetary system began to give way under the strain.

Before that effect arrived, however, the President, in his headstrong way, against the advice of his official cabinet, had struck a blow that would, very likely, have sufficed to bring about the inevitable crash. Of the excessive revenue flowing into the treasury, a large part came from the speculative buying of public lands. Until the summer of 1836 the government received most of this land revenue in bank-notes of very uncertain worth. Then the President, becoming suspicious of the soundness of the banks and the value of their paper, issued an order that is famous in history as the "specie The circular". of July, I 836 , directing that coin only "specte," should be taken in payment for public lands. $1 \mathbf{1 8 3 6 .}$ This, acting together with the draft on the banks for the 
surplus funds, and the distribution of money in the country with no reference to current needs of business, gave a finishing touch to the unsound condition of affairs; but the general downfall and consequent misery did not come upon the country until after General Jackson had finished his presidential career.

255. Election of Martin Van Buren. - Rise of the Whig Party. 1836. Had the experience of 1837 come a few months earlier than it did, the election of the fall of 1836 might not have ratified Jackson's choice of Van Buren to take his place. As it was, the able politicianstatesman of New York was elected President by a clear popular majority over three opposing candidates. The National Republicans, the Anti-Masons, and some other The whig elements opposed to the Jacksonian Democracy party. had now united, and had taken the name of Whigs. Their candidate was General William H. Harrison. Judge Hugh L. White, of Tennessee, was a rival Democratic candidate, and Daniel Vebster received the votes of the Massachusetts Whigs. Of the electoral votes, Van Buren received I70, Harrison 73, White 26, Webster I 4 .

256. Influences and Effects of the Presidency of Jackson. It is more than possible that the natural movement of events, under any presidency in the government, would have swept the country on to a catastrophe in business, as ruinous, perhaps, as that which came in I 837 ; but President Jackson is responsible none the less for the effects of his arbitrary dealing with matters which he did not comprehend. In some degree, the panic of I 837 must be counted among his legacies to the country, when the eight years of his rule (called by more than one historian his "reign") at Washington was closed. The legacies of effect from that extraordinary adminis- 
tration of a personal will in the government were numerous and lasting and large. The national character was affected profoundly, through one whole generation, at least ; for the ruder and less eduGrowth of national cated people were fascinated and strangely influenced by this roughly powerful man. In one way it was an influence immensely good, helping to popularize national feelings, which still needed that culture, even in the north and west. Though he tried, as a southerner, to champion "state rights," Jackson's political instincts were wholly national, his patriotism wholly American, and his admirers throughout the country were made to feel as he felt. He gave them new reasons, too, for national pride. His peremptory way of doing things had some fortunate results in foreign affairs. It brought the country very close to war with France in 1835 , but it accomplished a settlement of long-pending claims for French depredations on American commerce in the Napoleonic wars. The persistent refusal of

Successful toreign policy. England to open her West India trade to American shipping was overcome in $\mathbf{I} 830$, and, though that was done by the suave diplomacy of Van Buren, Jackson got the credit of "bringing the English to terms."

On the other hand, the disposition of General Jackson to be "a law unto himself" was not calculated to disseminate law-abiding habits and respect for legal processes among the people who looked up to him with admiring eyes; and the country appears to Tendency to lawlessness. have shown a quite marked deterioration in that respect - a marked tendency to lawlessness and disorder during the period in which his example of character was the most conspicuous one and his influence very great.

257. The Business Collapse of 1837. In the early days of April, I837, when President Van Buren had been 
barely a month in the White House, the breaking of bubbles in the business world was begun, by commercial failures starting at New York. Each downfall caused others, and before the month ended the spreading process of panic and ruin had strewn the whole country with wrecks. On the Ioth of May the New York

Specie payment banks suspended the redemption of their notes suspended. in coin, and their example was followed everywhere within the next week. The prostration of business was the most nearly universal that the country had known.

To most people the catastrophe was a terrifying surprise, and its causes were utterly misunderstood. It was quite commonly supposed to be altogether a consequence of bad measures by the government, having the "specie circular" for its immediate cause and the overthrow of the Bank of the United States for a cause more remote.

\section{Collapse} not under stood.

than to quicken the disease, was a fact which not many could see. Those who believed that the trouble came wholly from ill-doings of the government were equally persuaded that the government might undo what it had done. Immediately there was clamor for a withdrawal of the "specie circular," and for a re-nationalizing of the Bank of the United States. Van Buren had Vanen's the wisdom and the courage to resist those dewisdom.

mands; and, among economists of the present day, enlightened by the added experience of sixty and more years, there is hardly a question of the sound statesmanship of his course, in which he braved adverse public opinion to the end of his term.

258. Action of President Van Buren. - His "In- 
dependent Treasury " System. 1837-1840. Having called a special session of Congress, to meet in September, the President set the circumstances of the country and of the government before it in a message of rare clearness and force. The aim of his exposition was to show that, instead of being called upon to palliate the effects of past excesses in business, by remedies that would only delay a true recovery, the government should take a lesson from what had happened, and should separate itself from the whole system of commercial finance, with the natural working of which it ought never to interfere. Since the suspension of the banks, the Treasury had been holding its own funds, and the President urged that that be made the established practice for the future. $\mathrm{He}$ asked Congress to provide for the system of an "independent treasury," with branches in the chief cities (called commonly the "sub-

An independent treasury. treasury" system), and so make it impossible for politics to enter into what ought to be a purely business management of banking affairs. Time has proved the wisdom of this proposal, and the independence of the Treasury has long been a fixed fact in the United States; but President Van Buren argued for it vainly at the time. The House rejected a bill in accord with his recommendations, which the Senate had passed; but he pressed the measure persistently until, in I 840 , it became law.

It is the distinction of Van Buren's administration that it contended bravely for sound principles of political economy, touching money and banking, and that it did so with important educating effects. The leaders of the President's party in New York, Silas 吕ew York Wright and others, shared his intelligent views law. on these subjects, and their influence brought about the adoption, in 1838 , of a general banking law in that State, 
which stopped the loose chartering of banks by special acts, and set a potent example of reform.

Apparent recovery from the great financial depression of 1837 was more rapid than the real cure. In exactly Recovery a year from their suspension the New York and relapse. banks felt able to resume specie payments, and resumption was quite general in the summer and fall of $18_{3} S$. Trade sprang up again in too lively a spirit ; there was too much buying of foreign goods, and land speculation began to revive. The result was a relapse in I 839 , brought on by a state of stress in England; and from this second collapse of business the recovery of the country was slow and hard.

259. The Texas Question. 1837. It was during these years, as related already, that the exciting and momentous struggle in Congress over the right of petition went on. As one effect of that new conflict, the Texas question began now to loom large in the politics Annexation of the time. A strong resistance to the proresisted. jected annexation of the Texan republic, as slave territory, was prepared. Proposals for annexation came to President Van Buren from a Texas agent at Washington, in August, ${ }_{1} 8_{37}$ and were declined. To accept them meant probable war with Mexico, as well as offence to a large body of the American people, and the question was not allowed to reach Congress, through any action of the executive, during Van Buren's term.

260. Rebellion in Canada. 1837-1838. An outbreak of rebellion in Canada, in $18_{37}-38$, growing out of a bad system of colonial government, awakened much sympathy in the United States, and a popular desire to help it on. Our government had difficulty in keeping the nation from becoming involved in another war with Great Britain, especially when a militia force from 
Canada invaded the American shore of the Niagara and burned a small steamer, the Caroline, which the rebels had used. In faithfully carrying out the obligations of international law and working for the preservation of peace, the President offended much heated public feeling, especially in his own State.

261. Presidential Election of 1840. In this, as in his dealing with the business troubles of the day, President Van Buren did his duty at the cost of public favor, and did it with a firmness that claims high respect. He coveted a reëlection; but that approval of his administration was denied. He was renominated by his party in I 840 , with little chance of success. The Whigs put General Harrison in nomination, again clisappointing the ambition of their leader, Henry Clay. For VicePresident they nominated John Tyler, of Virginia, a Calhoun Democrat, who had opposed Jackson's bank and tariff measures, but whose present party position was not well defined. No "plat-

Character of campaign. form," or declaration of principles and policy, was put forth by the Whig convention, its plan being to win votes on the mere demand for a "change." The plan was carried out with success, in an extraordinary campaign of songs and hurrahs. There was not much discussion of political questions, but more singing, cheering, marching, and meeting in great gatherings for every kind of political merrymaking than was ever known before or since; and "Tippecanoe and Tyler too" 1 were borne

${ }^{1}$ General Harrison figured in the campaign principally as the hero of the battle of Tippecanoe (see sect. 198). A foolish attempt by one of the Iemocratic papers to belittle him, by saying that a pension of a few hundred dollars and a barrel of hard cider would content him in his log cabin for life, gave a cue to the Whigs which they turned to good account. Log cabins and hard cider became effective features of the Harrison demonstrations. 
into office on a ware of cuthusiasm which nothing could resist. Van Buren carrice only one northern State, Illinois, and but five States in the south. Ilis electoral vote wats 6o: llarrison's, 2.3.

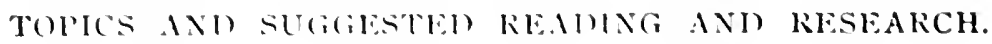

\section{President Jackson and his Advisers.}

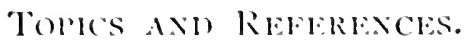

1. Contrasts between lresident lackson and his predecessors. 2. Ilis belief in the Union. 3. Changed influences surrounding the executive. - The "kitchen calinct." 4. Martin Van Buren and the "Albauy kewency" in New Vork. Wilson, Diarsion, 0-12, 23-26, 25-30: Roosevelt, Rimtm, 72-75; Parton, Jakson, iii. ch. xvi. ; Summer, /akson, 1 fo-145; Schouler, iii. 494-496; Shepard, 95-96: Holst, L mited statis, ii. 27-31.

\section{The "Spoils System."}

TOMUS ANI REFEREACES.

r. Removals from office hefore Jackson. Ialor, iii. 565-569; Morse, fiffirsm, 215-225; benton, i. 150-162.

2. Introduction of the four years" term of office. 3. "Spoils system" in Now lork and other States. 4. Its invasion of the

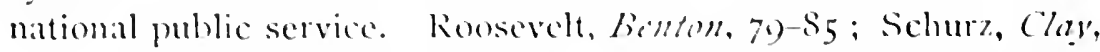
i. 332-336; Summer, Jakivon, 145-1f); Wilson, I)irivin, 26-27, 30-3t: Schouler, iii. 175, 453. 455-462; Fiske, Ciall Gorit, $261-$ 263 ; Slepard, $38-45,177-183$. 100: Sargent, i. $2 \$ 2-287$; Benton, i. 160, 162; Hart, (intemfsis, iii. 531-535.

\section{Forecast of Presidential Policy.}

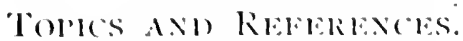

r. Waming of hostility to the United States Bank. Sumner,

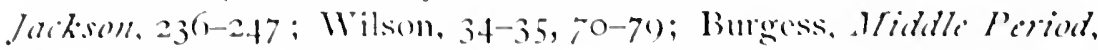
I1)0-200; Schurz, (\%ur, i. 351-35t; Schoulcr, iii. f6o-t7t; Ben. ton, i. 123-124, and ch. xlix.

2. "State rights" opposition of the lresident to internal improvements by the general government. liurgess, Middle Period, 
166-170; Sumner, Jackson, 193-194; Wilson, 38-39; Schouler, iii. fio-4is.

\section{Treatment of Indian Tribes.}

'POPICS ANI) RELEREN(ES.

r. Violation of national treaties ly (ieorgia upheld. 2. Refusal to enforce mandates of the Supreme Court. 3. Kemoval of tribes to Indian Territory. 4. Second Seminole War and Black llawk War. Sumner, Jarkion, 1So-183; Wilson, 35-3s; Schouler, iii. 477-4io; Benton, ch. li. ; Sargent, i. 177-179, 209-213; 110lst, Uniter States, ii. $292-311$.

243. President Jackson and the Protective Tariff. - Calhoun and Nullification.

TOPICS AND REFERENCES.

I. Attitude of l'resident Jackson towards the protective policy. 2. Feeling in the south. - Revival of the "nullification" theory. - Calhoun's writings (text in Macd)onald, ii. 231-237). Schouler,

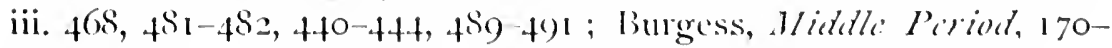
IS4; Wilson, Dirision, f1-52; 110lst, Calholln, 76-\$4, 96-103; Holst, Lrited Statis, i. 459-470; Summer, Jackson, 207-220; Roosevelt, b'nton, SS-96; Claty, v. 400-406; Hart, Contemp's, iii. $5+4-5+8$.

3. The Hayne and Webster debate, and how it arose (text in Webster, iii. 248-355; Maclonald, ii. 240-259; Johnston, Ile. Orations, i. 213-28z). Schonler, iii. 4is-4iss; Benton, i. ch. xliv.; Sargent, i. $160-174$.

4. The President's fecling. - His rupture with Calloun. Sumner, fackson, 151-159); Holst, (alhum, \$7-06); IVilson, 1)izrision, 52-54; hoosevelt, hinton, 97-0,8; Schouler, iii. 488-489, 498-50r; Benton, i. ch. xlvi., liii.

\section{Cabinet Reconstruction.}

TOPICS AND REFLRENCES.

I. Cause of cabinet changes in $183 \mathbf{3}$. 2. The new cabinet. 3. Change in the "kitchen cabinet." Sumner, faiks), 159-163; Wilson, Dizision, 54-55; Schouler, iii. 501-502 ; Benton, i. ch. liv.; Sargent, i. $18.4-1 \$ 6$. 


\section{The Bank Question in the Presidential} Canvass.

TOPICS AND REFEREACES.

I. Parties cundidates and issues. 2. Chay's wish to make the "bank question" a political issue. 3. P'roposed compromise refused. 4. Ke-chartering act of Congress retoed by the President (text in MacDonald, ii. zon-20\$). Schurz. Chan i. 35t-357.372-

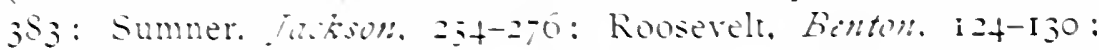

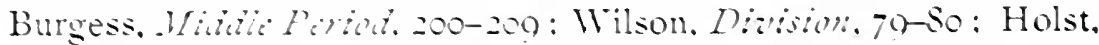
Lritic States. ii. 30-50: Peck, 1-5-192: Webster. iii. 391-t+7; Clay, r. 523-535: Benton. i. ch. lxiil.-lxriii.

\section{The Tariff Act of 1832 .}

TOPICS AND KEFEREACES.

I. Principles embodied in the tariff of 1 S32. 2. Its offensiveness to the south. Taussig. 102-10: : Elliott. 240-260: Schurz.

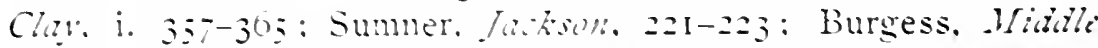

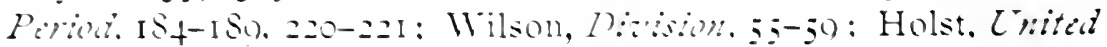
Statcs. i. fi-ti5: 1'eck, 153.15-101: Clay, v+37-486: Benton, i. ch. lxix.

Research. - De Tocqueville's view of American political parties in $I_{32}$ compared with what he distinguished as the "great parties" of an earlier time. Tocqueville. i. 222-227.

\section{Reëlection of President Jackson.}

TOPICS ANT REFERENCES.

I. Parties and their candidates in the presidential canvass. 2. Result of the election. Shepart, 202-212: Wilson, Dirtision,

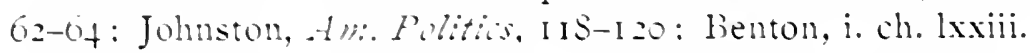

\section{Nullifying Ordinance of South Carolina. - The "Compromise Tariff."}

TOPICS AND ReFlerexces.

I. Ordinance of nullification (text in MacDonald, ii. 26S-27I : Larned, Kciril R.f.). 2. Action taken by the President. - His proclamation (text in MacDonald, ii. $273-283$ ). Holst, Cmitid

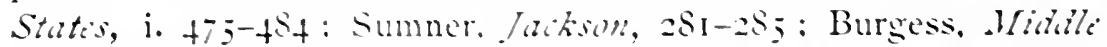

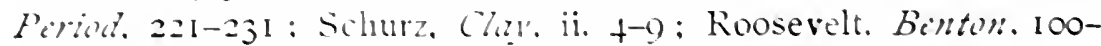
103: Peck, 193-19; ; Benton, i. ch. Ixxviii.-lxxx. 
3. Action in Congress. - The "Force Bill" (text in MacDonald, ii. $\left.2 S_{4}-2 S_{9}\right)$ and the "Compromise Tariff." 4. The settlement of the difficulty. Schurz, Clay, ii. 9-22; Burgess, Middle P'eriod, 23I-24I ; Sumner, Jaikson, 2S5-291; Holst, Calhoun, rot-I09; Holst, United States, i. 50I-505; Roosevelt, Benton, 103-II3; Taussig, I09-I 2 ; Peck, 203-2I4; IVilson, Division, 59-68 ; Clay, v. 536-569; Benton, i. ch. Ixxxi.-lxxxvi.

Research. - De Tocqueville's reasoning, in $\mathrm{I}_{3} \mathrm{I}-\mathrm{I} S_{35}$, as to "the chances of duration of the American Union." Tocqueville, i. 49 I-535.

\section{Removal of Government Deposits from the United States Bank.}

Topics AND References.

r. Question of the safety of government deposits in the bank. 2. The President's removal of them, and how it was accomplished (texts in MacDonald, ii. 289-303). Sumner, Jackson, 291-310; Johnston, Aml. Politics, 123-124; Schurz, Clay, ii. 25-31 ; Holst, United States, ii. 5I-68; Burgess, Midllle Period, 279-2SI ; Shepard, 213-215; Peck, 217-222; Wilson, Dizision, So-S2; Kendall, 374-392 ; Benton, i. ch. lxxv., lxxvii., and 371-400; Clay, v. 575620 ; Webster, iii. 506-55 I, iv. $3-8 \mathrm{I}$.

3. After history of the bank. Sumner, Jackson, 337-342 ; Benton, i. ch. cxi.

4. View to be taken of the overthrow of the bank. 5. The Senate's censure of the President. - The President's protest (text in MacDonald, ii. 306-3r7). The expunging of the resolution. Holst, United State's, ii. 68-76; Schurz, Chay, ii. 31-43, 99-106; Roosevelt, Benton, I32-I36, I39-1 +2 ; Peck, 224-241, 317-327; Benton, i.ch. xcix.-ci., ciii., cxxii.-cxxiv., cxli., clix.-clxi. ; Kendall, 392-422: Sargent, 25\$-273, 332-34t; Webster, iv. 103-I+7, 292297; Clay, vi. $+5-60$.

\section{Aggressive Anti-slavery Agitation. - The Abolitionists.}

Topics and References.

r. Beginning of a crusade against slavery. 2. Uncompromising ground of the Abolitionists. 3. Influence of their agitation pro- 
moted by the slaveholding interest. 4. Formation of anti-slavery societies. 5. Causes of feeling in the south. - Fears of insurrection. - Demands for silencing the abolitionists. 6. Differing effects in the north. 7. The anti-slavery sentiment that grew in the free States. Garrison, i. ch. vii.-xiv.: Goldwin Smith, 30-96: Schurz, Clay, ii. 70-7S; Burgess, Widdle P'riod. 2+4-25I; Holst, Unitid States, ii. So-11s: Peck, 269-273; Hart, Chase, 36-39, 55-66; Hart, Contemp's, iii. 595-597, 602-6I 4 .

RESEARCH. - President Jackson and other leading men in Washington, as seen by a sagacious foreign observer in $I_{35}$. Martineau, i. $1+7-1 S_{4}$.

\section{Suppression in Congress of the Right of Petition.}

TOPICS AND REFERENCES.

I. Attempt to reject petitions for emancipation in the District of Columbia. 2. Attempt to exclude anti-slarery writings from the mails. Holst, Calhoun. I2+-139, I +3-1 50: Holst, Unitid Statis, ii. I20-139, 235-245; Schurz, Clay. ii. 7S-S6: Shepard, 233-23S: Roosevelt, Binton, I63-170: Burgess, Middli Piriod, 25I-26I; Benton, i. ch. cxxx-cxxxi.; Peck, 273-2S1; Hart, Contemp's, iii. 619-622.

3. Persistent agitation of the slavery question by Calhoun and his followers. - The rights they disputed. 4. Defence of the right of petition by John Quincy Adams. 5. The "Atherton Gag," and final suppression of anti-slavery petitions. Holst, Unitid" States, ii. 245-289, $469-479$; Holst, Calhoun, I65-I $S_{1}$ : Schouler, iv. 296-302, 307-308, $+23-425$; Schurz, Clav', ii. I 52-163; Benton. i. ch. cxxxy, ii. ch. xxxiii.

REseARCH. - The attempt in $18+2$ to censure John Quincy Adams for presenting a petition which asked for the dissolution of the Union.

\section{Texas.}

TOPICS AND REFERENCES.

I. Feelings which the "slave power" had arrayed against itself. 2. Sources of its power. 3. Desire for Texas. - Situation in that Mexican province. 4. American and British settlers in Texas. 5. The successful Texan revolt. Roosevelt, Binton, 173- 
ISI ; Burgess, Middle Period, 290-294; Holst, United States, ii. 55I-57t; Schurz, Clav, ii. S7-9I ; Wilson, Division, I4I-I+3; Benton, i. ch. cxliv.-cxlv.; Hart, Contemp's, iii. 637-64I.

\section{Extraordinary National Growth. - Beginnings} of a Speculative Mania.

TOPICS AND REFERENCES.

I. Increase of population and spread of settlement since ISzo. 2. The principal stimulations. 3. Fevered spirit of speculation. Shepard, 247-252; Wilson, Division, 89-90, I02-ro4; Holst, United States, ii. I73-174, I78-IS6; Schurz, Clay, ii. 113-II4; Sumner, Jackson, I 36, 322-325.

\section{Second Era of "Wild-cat" Banking and Inflation.}

TOPICS AND REFERENCES.

I. Effect of President Jackson's removal of deposits. 2. Distribution of surplus revenue and its effect. The President's "specie circular" (text in MacDonald, ii. 327-329) and its effect. Shepard, 253-26I ; Roosevelt, Benton, I $4+-156$, I $89-192$; Schurz, Clay, ii. II 5-127; Wilson, Division, S6-SS, 91-92; Holst, United States, ii. 174-17S, IS6-194; Peck, 299-306; Benton, i. cl. cxlvi., clv.

\section{Election of Martin Van Buren.}

Topics AND ReFerences.

r. Circumstances and result of the presidential election of i $\$ 36$. 2. Formation of the Whig party. Johnston, Am. Politics, IzS, 132; Shepard, 219-24I ; Schurz, Clay, ii. 95-97; Sumner, Jackson, $374-382$; Benton, i. ch. clii.

256. Influence and Effects of Jackson's Presidency. TOPICS ANi REFERENCES.

I. President Jackson and the "Crisis" of I 837. 2. His influence on the character of his generation. 3. His national spirit. 4. The grood and evil of his influence. Schurz, Clay', ii. Io6-I I2; 


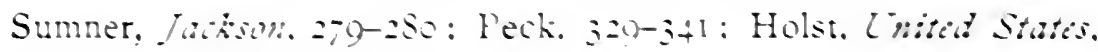
ii. $76-79$ : Peck. $329-3+1$.

5. Foreign affairs in President Jackson's administration. Sum.

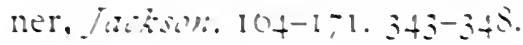

REsEARCH. - General Tackson in private life, as described by his intimate friends. Benton. i. ch. Alw: Kendall, asc: Parton.

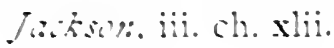

\section{Business Collapse of 1837.}

\section{TOPICS AND REFERENCES.}

I. Commercial failures and bank suspensions. 2. Common misunderstanding of the causes. 3. Demands on the government resisted by the President. Shepard. zti-z:s: Sumner, f\%. Cor

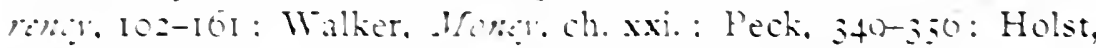

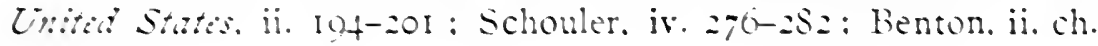
ii.-rii.

\section{Action of President Van Buren. - His "Independent Treasury" System.}

TOPICS AND REFEREACE:

I. Argument of the fresident's message. 2. Plan and purpose of the "independent treasury " system. 3. I)istinction of President Van buren's administration. Shepard, ch. ix.; Kinley;

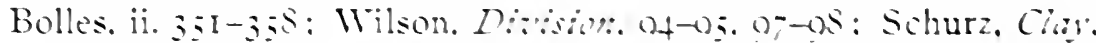

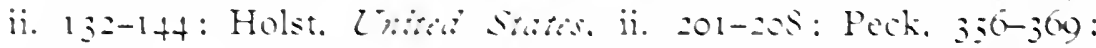

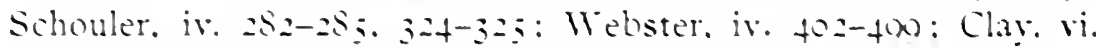
63. S0. $04-133.1,0-104$ : Benton, ii. ch, riii.. xi.

4. The general banking law of New lork. Wilson, Dision. $03-1) \div$.

5. Apparent recovery of business in 1 S. and relapse in 1 S39.

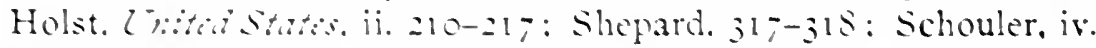
20)-204. 34i-34s: Benton, ii. ch. xx-xxiii.

\section{The Texas Question.}

TOPICS AND REFRENCE.

I. Annexation declined by President Van Buren. - Growth of opposition. Burgess. Mabile F'rod, 205-301: Schouler, iv 30330;: Shepard, 306-30;: Benton, ii. ch. xxiv. 
TOPICS, REFERENCES, AND RESEARCH. 427 260. Rebellion in Canada.

Topics And References.

I. Difficulty in aroiding war with England. Lodge, $H^{\prime}$ ister, 246-249, 252 ; Shepard, 300-306; Lothrop, 2S-37; Benton, ii. ch. lxxv.-lxxvi.

\section{Presidential Election of 1840.}

Topics AND References.

r. Re-nomination of Van Buren. 2. Whig nomination of General Harrison and John Tyler. 3. Peculiar character of the canvass and election. - The result. Holst, United States, ii. 360405; Schurz, Clay, ii. I7I-IS9; Shepard, 323-339; Schouler, iv. 327-34I; Sargent, ii. S9-96, I05-I I ; Benton, ii. ch. lviii. 


\section{SECTIONAL CONTENTION. $1840-1860$.}

\section{CHAPTER IIII.}

EXPANSION TO THE PACIFIC : FOR FREE LABOR OR SLATE LABOR: WHICH ? ISHISAS.

262. Death of President Harrison. - Vice-President Tyler as President. - His Rupture with the Whigs. 1841-1842. General Harrison enjoyed the honors of the presidency a single month. He died, after a brief illness, on the fth of April. Is +1 , and the Vice-President was called to his place. This put Mr. Tyler in a false position and produced an unfortunate state of things. He was a Democrat in his political opinions. elected to office by Whigrotes. In the rice-presidency there might have been no serions friction between him and the party with which he was expected to act: but in the presidency it was sure to come. More than friction came, in fact. soon after Congress met for a special Independent session in June. Both houses were controlled treasury aboulshed, by the IWhigs, and both acted under the im-

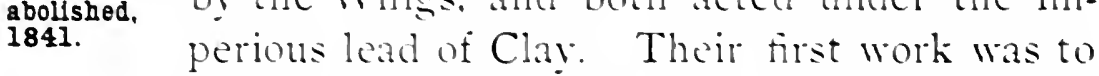
sweep away the independent treasury which Van Buren had labored so hard to create, and President Tyler signed their bill. Likewise he approved another measure in the Whig programme, which was to divide annually among the States the net proceds from the sales 
of public lands. In most parts of the country this distribution was demanded eagerly as a measure of relief, many of the States having overburdened themselves with debt in the wild period before $1 \$ 3 \%$. Some were failing to pay interest on their bonds: a few were bringing disgrace and discredit on the country by talk of repudiating their debts. The distributing act passed ; but with the proviso that, whencrer tariff $\begin{gathered}\text { Detaulting } \\ \text { States, }\end{gathered}$ duties should be raised above twenty per cent., 1841 . the distribution of land revenues should cease: and that proviso, as we shall sec, made the act of no effect.

But these were not the measures that Clay and the Whigs had most at heart. Above all things they wanted to incorporate a new Bank of the United States, and it was on a bill for that purpose that their clash with the President came. He vetoed it. on $\begin{gathered}\text { Bank } \\ \text { vatoes, } \\ \mathbf{8 4 1 1} \text {. }\end{gathered}$ grounds which might, apparently, be overcome.

After consultation with him, another measure was framed, supposed to be adapted to his riews : but either he had been strangely misunderstood, or else his views had changed, for when the new bill reached him he vetoed that, too. This ended the last attempt ever made to set up a great national bank, related in a semiofficial way to the government of the United States. Most students of the subject now give approval to Tyler's reto, as well as to Jackson's; but President Tyler's conduct in connection with the second bill does not appear in a favorable light.

The Whigs broke relations with the President and opened hostilities at once. Every member of the cabinet (he had retained Harrison's) resigned, excepting Daniel Webster, who was Secretary of State, and who had opened an important Resignation of Whig cablnet. negotiation with England which he wished to carry 
through. The acministration became practically a Democratic one, though not acknowledged as such by the Democratic party, and the fruts of their victory in Isto were snatched from the Whigs. Their next contict with ine President occurred upon a revision (ISta) of the "Compromise Tariff" of IS: Tarit of so great a falling off in the revenue from cus-
1842. toms that the gorernment was in distress. Many of the rates of duty were raised above twenty per cent. and this. by the effect of the proviso abore mentioned. rescinded the act for distributing land revenues. The Whigs suught to avert that efiect. but the President Wouid not consent.

263. "Dorr Rebellion" in Rhode Island. - AntiRent Disturbances in New York. 1841-1844. Two parts of the country, Rhode Island and New Fork, were disturbed seriousiy at this time by morements of popular discontent. The old roval charter of Rhode Island was stiil the basis of the govermment of that State. and

\section{Suttage in Rhodo} Island. its restriction of the sutfrage to frecholders of land had never been changed. In Ist the disfranchised citizens attempted to take by force what the privileged class refused to give, and set up a govermment at Providence which disputed authority with that of the old regime. The latter, having law on its side, could claim support from the federal government, which was given with effect. The revolutionary morement (called "the Dorr rebellion" from the name of its leader and governor-elect) collapsed in I $S_{f}=$ : but its end was attained. Rhode Island adopted a constitution which broadened the suffrage and silenced discontent.

The New York troubles had an equally ancient origin, in the old creation of Dutch patroon and English 
manorial estates (see sect. 33). The lands in those huge estates were let to tenants on perpetual lease's. Ant1-rent subject to annual rent payments and other disturbclaims, which grew more irksome as time went 1841-1844. on and as democratic ideas gained force. The manorial titles were disputed, and combinations were formed to resist payment of rents, by both lawful and unlawful means. At this period the doings of the "anti-renters" were very disturbing for some years. They failed to break the obnoxious land titles; but the troubles were ended gradually by concessions which enabled most of the tenants to buy their lands.

264. The Ashburton Treaty. 1842. Webster remained in the Tyler cabinet until May, is 43 , when he withdrew, having finished an important task. Ever since the peace of $1 / S_{3}$, our northeastern boundary, between Maine, New Hampshire, and the British provinces, had been in dispute. Webster had now brought it to a settlement, in a treaty concluded with Lord Ashburton, who came to Washington with special powers. The so-called Ashburton Treaty, signed August 9, I $S_{42}$, included an important arrangement for coöperation with England in a naval policing of the African coast, to stop the piratical slave trade. Furthermore, it disposed of questions arising out of the Canadian rebellion, or "Patriot War," and provided for the extradition of criminals escaping from one country to the other; but it left open the Oregon boundary question, which was destined to make trouble very soon.

265. Texas Annexation Treaty rejected by the Senate. 1844. Webster in the State Department had blocked action looking to the annexation of Texas, and his retirement gave the President a free hand to do in that matter according to his desire. President Tyler 
gave the portfolio of the State Department to a strong annexationist, Mr. Upshur, and opened secret negotiations with the Texas government, in the midst of which Mr. Upshur was accidentaily killed. Mr. Calhoun was then induced (March, I 844) to take the State

Calhoun negotiates, Department, for the purpose of carrying the
1844.

Texas business through. The result was a treaty of annexation, signed and sent to the Senate in April, but unexpectedly rejected there, after six weeks of debate, by 35 votes against 16 . The secret manner in which the President had acted, and the probable consequence of war with Mexico, weighed heavily against the treaty, even among southern public men. Jackson used his influence in its favor; but Senator Benton, of Missouri, and other staunch Jackson Democrats, were against it, and it was opposed in public letters by Clay and Van Buren, as meaning war, and as being a new cause of discord in the land.

The vital issue in the matter was that which arose between the "slave power," seeking an enlargement of its own absolute dominion, and the increasing opposition in the northern States to the aggressions of that power. The undisguised object of the acquisition was to secure True object four or more new slave States. Ingenious

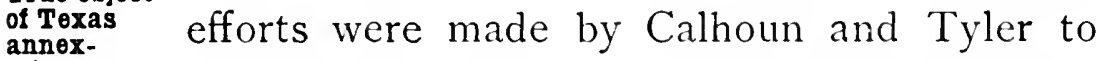
annexconvince the south that English and Mexican influences in Texas would abolish slavery there, unless the country was taken out of their reach; and those arguments, which consolidated the south for annexation, turned more feeling against it in the north. Whether the opposing forces would suffice or not to defeat the project was now to be seen; for the question went immediately to the great jury of the nation, in the presidential and congressional election of 1844 . 
266. The Texas Question and the Presidential Election. - Annexation accomplished. 1844-1845. Both parties had made their presidential nominations while the Texas treaty was pending in the Senate. The Whigs nominated Clay by acclamation, four days after his public announcement of opposition to annexation, and thus the party accepted his plattorm. ground. Van Buren, on the other hand, lost the Democratic nomination by reason of his similar declaration. James K. Polk, of Tennessee, lately Speaker of the House of Representatives, whose principal recommendation to the convention was the ardor of his desire for Texas, became the nominee. As a cunning bid for northern consent to the taking in of Texas, the American claim to Oregon was coupled with it, in a resolution which demanded "the re-occupation of Oregon and the re-annexation of Texas at the earliest

Texas

and

Oregon, 1844. practicable period." Both proposals were thus put in the light of being merely for the taking of what had formerly belonged to us; and the phrase "re-annexation of Texas" imposed, without doubt, on many ignorant minds. It was founded on the theory that Texas belonged by right to the Louisiana territory which we bought from France (see sect. 179); but it ignored the fact that we had abandoned that claim in our treaty of I 8 I 9 with Spain (see sect. 224).

News of the doings of this Democratic convention, held at Baltimore, May 27-29, I 844, were Birth of transmitted to Washington by the Morse sys- the electric tem of electric telegraphy, over a line that had 1844. been opened only four days before, and which was the first ever built.

Distinctly, the presidential election of I 844 turned upon the question of annexing Texas, and it seems to 
be certain that Clay would have won on that issue clay's if he had kept himself firmly on the ground mistake. which he took at first. But he grew anxious about southern rotes as the canvass went on, and wrote explanatory letters that showed a wavering state of mind. The effect was to turn against him an antislavery vote sufficient to cause his defeat. Garrison and the extreme abolitionists never voted, taking no part in political action; but other radicals in anti-slavery The Liberty opinion had formed a "Liberty party," which
party, had cast about 7000 votes in 1840 for James
1844. G. Birney, and which now named Birney for President again. The votes given to Birney, more than 60,000 in all, were fatal to Clay. They decided the election in New York, and the 36 electoral votes of that State turned the scale in favor of Polk.

Apparently, the jury of the people had decided that Texas, with her slaves and slave laws, should be taken into the Union, and that the weak and distracted republic of Mexico should be defied. Both President and Congress took that meaning from the election, and were eager to accomplish the annexation before a new President and a new Congress could come in. They conclucled that it could be done without treaty, by a

Texas annexed joint resolution of Congress, and acted on that 1845 . plan. The annexing resolution reached the President and was signed on the Ist of March, I 845 (see Map XV.). By its terms, four States, besides Texas proper, might thereafter be formed in the territory claimed by the annexed republic, and such States should be admitted to the Union with or without slavery, as they willed, if formed south of the Missouri Compromise line. What seemed to be a crowning triumph for the "slave power" had been won. 
At nearly the same time, in an act passed March 3, I845, the admission of Floricla to the Union, with a constitution that excluded free negroes and for- Florida and bade the legislature to legalize the emancipa- Iowa adtion of slaves, was extorted as an equivalent 1845.1846. for the admission of Iowa into the list of free States. ${ }^{1}$

On the other hand, in the same session, John Quincy Adams won his long, heroic battle for the right of petition, the House rescinding its unconstitutional rule.

267. The Programme of President Polk. 1845. The cabinet of President Polk included three men of subsequent note: George Bancroft, the histo- Poll's rian, who took the Navy Department; Robert cabinet. J. Walker, in the Treasury; and James Buchanan, Secretary of State. Mr. Schouler quotes a letter to himself from Mr. Bancroft, in which it is related that the new President, soon after entering office, said to the writer : "There are four great measures which are to be the measures of my administration: one, a reduction of the tariff; another, the independent treasury; a third, the settlement of the Oregon boundary question; and, lastly, the acquisition of California." 2 That programme was exactly carried out, and the history of its execution is the history of the administration of President Polk.

268. Settlement of the Oregon Boundary Dispute. 1845-1846. The Oregon business was the first to be taken in hand. Calhoun, under Tyler, had opened it already, and Buchanan resumed the discussion, proposing the 49th parallel for a boundary line. This proposal was rejected, the British government regarding

1 A boundary dispute with Missouri delayed the actual admission of Iowa until December, I 846.

2 Schouler, History of the United States, iv. 498. 
the Columbia River as the natural bound. The question went then to Congress, in December, I845, with a recommendation that twelve months' notice of the abrogation of the convention for joint occupancy of Oregon be given, and with uncompromising assertions of our right to the whole region of dispute. The undefined "Oregon" of that day was the country west of the Rocky Mountains, lying between the northern boundary of Mexico (which we had settled by our treaty The oregon of I 8 I 9 with Spain as being the $42 \mathrm{~d}$ degree of claim. north latitude - see sect. 224) and the southern boundary of Russian-American possessions, which both England and the United States had settled with Russia at the line of $54^{\circ} 40^{\prime}$. We had a well-grounded claim to the whole drainage area of the Columbia River (see sect. 225) ; north of that there seems to have been no reason for disputing the British claims. Nevertheless, the tone of the President's message and of the speeches that followed it in Congress revived a sense"Fift-four less cry of "Fifty-four forty or fight," which "Fifty-four
forty or
ilght."

dential campaign. Common sense prevailed in the end ; the $49^{\text {th }}$ parallel was seen to be a reasonable line, and the British government found a cogent reason for accepting it, in the fact that American settlers were filling the valley of the Columbia, and were likely, soon or late, to make the country their own. ${ }^{1}$ On that basis

1 The story told in many histories, that the measures of government and the movement of emigration which secured Oregon to the United States were consequent on the heroic undertakings of a missionary, the Rev. Marcus Whitman, who made a perilous journey across the continent, from the Columbia, in the winter of $18+3$, to rouse the country on the subject, has been discredited by some recent investigations. That the journey was heroically 
the Oregon boundary question was settled peacefully and honorably, in June, I 846 (see Maps X. and XV.).

269. War with Mexico.- Its Cause and Beginning. 1845-1846. To take the revolted Texans into the American Union while Mexico claimed them as the subjects of her government was a challenge of war. In the legal sense, a state of war followed at once, the Mexican minister quitting Washington, and the Mexican government refusing to receive an envoy from the United States; while American troops were despatched to Texas and a naval squadron to the Gulf. Actual hostilities did not occur immediately because the challenged nation was in a disordered state; and there would unjust have been no actual war if the annexation of $\underset{\text { claims of }}{\text { United }}$ Texas had involved nothing more than the States. taking of the territory which the Texans occupied and from which Mexican authority had been expelled. That was the province of Texas, as organized and named under the Mexican administration; the province within which the revolt had occurred, and outside of which it had made no change. That province extended southwestward along the Gulf from the Sabine River to the Nueces, beyond which stream the annexed "Republic of Texas" had no ground, either in past history or existing fact. But it claimed to the Rio Grande, and northward to the old Spanish bounds (see Map XV.); and it had assumed in the annexation treaty to convey that claim to the

undertaken and performed, and that $\mathrm{Mr}$. Whitman rendered important services to a party of emigrants with whom he returned in I 843, is unquestioned; but it is shown that his visit east was for purposes connected with his mission, and had no real connection with the stir of interest on the Oregon question. See Professor E. G. Bourne on "The Legend of Marcus Whitman," in The American Historical Review, January, I90I. 
United States. What this meant was described in plain terms by Senator Benton. of Missouri, an honest Benton's statesman, who opposed Tyler's treaty when views. it went to the Scmate in I $S_{+}$. "The treaty," he said, "in all that relates to the boundary of the Rio Grande, is an act of unparalleled outrage on Mexico. It is the scizure of 2000 miles of her territory without a word of explanation to her, and by virtue of a treaty with Texas, to which she is no party. This slice of the republic of Mexico, 2000 miles long and some hundred broad, - all this our President has cut off from its mother empirc and presents to us, and declares it is ours till the Senate rejects it. He calls it Texas! and the cutting off he calls re-annexation. Humboldt calls it New Mexico, Chihuahua, Coahuila, and Nuevo San Tander (now Tamaulipas), and the civilized world may qualify this r-annexation by the application of some odious and terrible epithet." 1 The "unparalleled outrage." as proposed in Is 4 . was condemned and rejected by the Senate: but now, in IS 45 , that same "slice of the republic of Mexico, 2000 miles long," was again called "Texas" by President Polk, and assumed to be acquired by the joint resolution which made Texas an American State.

Gencral Zachary Taylor, commanding the forces sent to Texas, was ordered by the President at the outset to cross the Nueces and take position on its southwestern side. Mexico, torn by fresh revolutions, submitted to the invasion for six months: but when, in January, is ${ }_{4} 6$, Taylor was ordered to move on to the Rio Grande, and to plant his army where it threatened Matamoras, Mexican forces came orer to oppose him: an American reconnoitring party was attacked, and President Polk

1 Benton, Thirty' Iears' licia', ii. 601-602. 
was given the opportunity to say, in an inflammatory message to Congress : "Mexico has passed the boundary of the United States, has invaded our territory, and shed American blood upon the flammatory American soil." Thoughtless people crerywhere accepted the statement, and were fired with what passes for "patriotism" in shallow minds. War, once begun, found support in that kind of feeling, north as well as south: though the iniquity of it was felt deeply by all that was best in the land. By the congressional elections of $\mathrm{I} S \mathrm{f} \sigma$ the party responsible for the war was reduced from a majority of 60 in the House of Representatives to a minority of $\$$.

270. War with Mexico.-Campaigns and Conquests. - Treaty of Guadalupe Hidalgo. 1846-1848. On the Sth of May, is f6, a few days after the first collision on the Rio Grande, General Taylor, at Palo Alto, repelled an attack in strong forec by the Mexicans, and retaliated the next day, striking the enemy at Resaca de la Palma and driving them back to the southern side of the rirer. The following week he crossed with his own army, took Matamoras, and waited to be reinforeed. There was a pause then for some months, in this quarter, while rolunteers were being raised and other military preparations made.

In the interval, General Kearney was ordered to move from Fort Leavenworth into New Mexico, and thence to California, while Commodore Sloat, commanding our squadron in the Pacific, was to scize desirable points on the California coast. At the same $\begin{gathered}\text { Salzure of } \\ \mathbf{1 8 4 6} \text {. }\end{gathered}$ time orders went to Colonel John C. Frémont, who had been exploring the Rocky Mountain and Pacific coast regions for some years, directing him to assist in securing that northern California country which Polk 
had marked for acquisition two years before. Frémont, Sloat, and Commodore Stockton, Sloat's successor, together with a few hundred American settlers, practically took possession of the country before Kearney arrived.

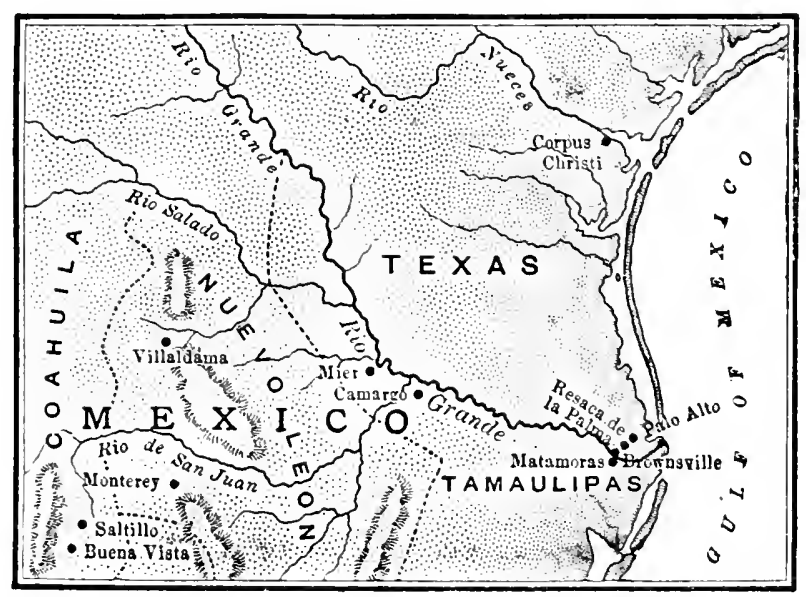

FIELD OF GENERAL TAYLOR'S CAMPAIGN.

The latter, meeting with no serious resistance, had occupied New Mexico, had established an American governor at Santa Fé, and had declared the province annexed to the United States. From Santa Fé General Kearney had sent part of his command, under Colonel

Monterey, Doniphan, southward, through Chihuahua, to a Soptember junction with General Taylor, who advanced
1846. in September from Matamoras to Monterey, capturing that fortified city after obstinate fighting for four day's (September 2I-24).

A new plan of campaign was now adopted, with General Winfield Scott in chief command, and part of Taylor's army was called to assist Scott's movement on the city of Mexico from Vera Cruz. At this juncture Santa Anna, who had regained power in Mexico, took advantage of the weakening of Taylor and attempted to 
overwhelm his small force of 5200 men by an attack with I 5,000. His attack (February 23, I 847), made at Buena Vista, not far to the southwest from Monterey, failed disastrously, costing him

Buena

Vista,

February

23,1847 . a loss of 2000 men. With this victory at Buena Vista the operations of General Taylor were closed.

On the 7 th of March, I847, Scott's army of about 1 2,000 reached Vera Cruz; on the 27 th the city was surrendered to it; a fortnight later its march to the Mexican capital, 200 miles distant, was begun. The mountain pass of Cerro Gordo was forced on the I8th of April, and there

Vera Cruz, March 27;

Cerro

Gordo,

April 18,

1847. was no more serious fighting till the capital was nearly reached. At Puebla the invading army rested during June and July, while unavailing peace

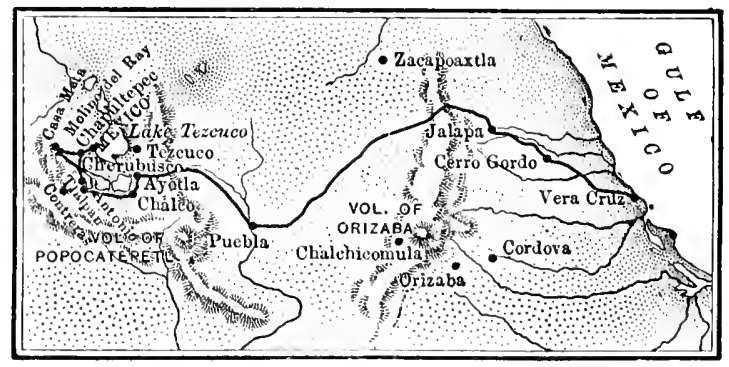

SCOTT'S ROUTE FROM VERA CRUZ TO MEXICO. negotiations were carried on. Early in August the march was resumed, and the defences of the city, held by about 30,000 men, were reached on the I8th. On the Igth the assault began, and three battles, Contreras, San Antonio, and Cherubusco, were Controras, San An tonio, Cherubusco, August 19fought that day and the next. Then another fruitless parley suspended the war for a few days. It was resumed on the 8 th of September, in successful assaults on Mexican positions at Casa Mata and Molino del Rey. On the $13^{\text {th }}$ the strong fortress of Chapultepec was stormed, Casa Mata, Molino del Rey, Chapultepec, Mexico, September its defenders were clriven into the city, and the city 
itself was then taken after three days of desperate fighting in the streets. The Mexicans had made an heroic defence; they were vanquished by qualities in the smaller American army which we can justly be proud of, even though we cannot feel satisfied with the occasion that called such qualities forth.

Notwithstanding the loss of their capital city, the Mexicans were not submissive until January, I 848 , when they opened negotiations with Mr. Trist, a commissioner from President Polk who had power to treat for peace.

Treaty of Guadalupe Hidalgo, February 2,1848 .

On the $2 \mathrm{~d}$ of February a treaty was signed at Guadalupe Hidalgo, by which Mexico relinquished all claim to Texas, established the Rio Grande as the southwestern boundary of that State, and ceded to the United States the great territory then called New Mexico and California, which included Nevada and Utah, parts of Colorado, Wyoming, and Arizona, as well as the California and New Mexico that are so named at the present time (see Map $X V$.). For this cession the sum of $\$ 15,000,000$ was paid to Mexico, and claims of Americans against that republic to the amount of $\$ 3,250,000$ were assumed, making the transaction a compulsory sale. Five years later, by what is known as the Gadsden Purchase, the remainder of Arizona, south of the Gila River, was bought for $\$ 10,000,000$ (see Map XV.).

271. Mormon Migration to Utah. - Gold Discovery in California. - Rising tide of Foreign Immigration. 1846-1849. Before the treaty with Mexico was signed, and, therefore, before either Utah or California had become part of the United States, events had prepared for the speedy settlement of both. The religious community calling itself the "Church of the Latter Day Saints," but known commonly as that of the Mormons, 
first formed by Joseph Smith at Palmyra, New York, in I 830, but removed to successive settlements, in Ohio (1831), in Missouri (1838), and in Illinois (I840), was driven by mob violence from its Early settlements of town of Nauvoo, Illinois, in the spring of r 846 . It migrated westward, across the desert plains and beyond the mountains, to the number of 17,000 souls. Smith, the apostle of these people, had been killed by the Illinois mob, and the new head of their church was Brigham Young. Young led them to the Utah valley of the Great Salt Lake, which was reached by the vanguard of their movement in the sum-

At Great Salt Lake, 1847. mer of I 847. They prospered in their distant settlement, and large bodies of converts were drawn into union with them there.

The event that drew a still larger population and with more rapidity into northern California was the discovery of gold, which occurred, near the site of the present city of Sacramento, in the winter of I 848. The discovery was followed by a pro-

Discovery of gold, digious rush of gold-seekers from every part of the world.

These special movements of population were coincident, too, with the beginning of an enormous increase of general immigration from Europe to the Increased United States, caused, first, by a failure of the lmmigrapotato crop and a consequent fearful famine in tion, $1845-1848$. Ireland, during the years $1845-46-47$, and afterward by political disturbances in Germany and elsewhere, in I848. That movement of immigration did not end with the ending of its immediate causes, but has continued ever since, transferring somewhat more, on an average, than a quarter of a million of people yearly from other countries to ours. 
272. Independent Treasury restored. - The Walker Tariff. 1846. Of the four measures planned by President Polk when he entered office we have traced the success of two: the settlement of the Oregon boundary and the acquisition of California. The remaining two were accomplished in ${ }{ }_{4} f$. when Van Buren's independent treasury was reestablished, and a new tariff law, described in purpose as being "a tariff for revenue with incidental protection," and known as "the Walker Tariff," was passed.

273. The Question of Slavery in the Territories. Intensified Feeling. - The Wilmot Proviso. 18461848. The rast addition now made to the national domain. by the Oregon treaty and by the results of the

\section{Increased}

ant1-

slavery

feeling in

the north. ilexican Mar, raised the question concerning slavery in the Territories to an importance so momentous - so manifestly vital - that it went to depths of feeling in the country which nothing had touched before. Churches were divided upon it. sectionally, and the old political parties were breaking up. Great numbers of northern people, who had acted more or less in alliance with the slareholding interest hitherto, went into the anti-slavery ranks.

In August, is 6 , the question arose in Congress on two measures, almost simultaneously, and was raised in each instance by Democratic representatives from the north. In the first instance, on a bill to organize the Territory of Oregon. Mr. Thompson, of Pennsyluania, mored an amendment excluding slavery, and the amendment was adopted by a large majority of the House; but the Senate stifled the bill. In the second instance, on a bill to appropriate money for the negotiations with Mexico, then in progress. Mr. Wilmot, of Pennsylrania, moved and carried a similar proviso, that slavery should 
exist in no territory acquired by treaty from Mexico; and that, too, caused the bill to fail in the Senate, after it had passed the House. At the next session of Congress, the "Vilmot Proviso" 1846-1847. was again attached by the House to a bill relating to the conquests from Mexico, and again rejected by the Senate; and again the latter body refused a territorial organization to Oregon if slavery was to be shut out. In IS 4 , however, after weeks of raging debate, the demand for a civil government in Oregon became so urgent that the Senate gave way, and passed a bill that contained the excluding clause (see Map XIV.). But nothing could be done to protect the great region called New Mexico and California from invasion by the slaveholder with his slaves.

274. The New Theory of Slaveholding Rights in the Territories. 1847. The "slave power " and its partisans had advanced now to a new constitutional theory on the subject, contending that the gencral government had no power to exclude from the Territories anything that was recognized as "property" by the laws of any State. Hence, they claimed, the owners of slaves, which were "property" under the laws of half the States, could not be barred from taking them into any part of that domain which belongs in common to all the States. When the settlers of a Territory acquired the "sovereignty " of a state organization, then they might exclude slavery by their laws, if they willed; but no legislative body had power to do so in advance of that time. This theory, put forward in I $S_{4} 7$ by Mr. Rhett, of South Carolina, in the Housc, and by Calhoun and Jefferson Davis in the Senate, was entirely new. The right of Congress to deal with slavery in the Territories had been established in practice for half a century, - particularly 
established by the Missouri Compromise, as well as by the confirmation of the Ordinance of 1 gs (see sects. 151 and 227). To ammul that long admitted right, and to open every Territory to slavery, now grew to be a fixed determination in the south. while the opposing determination grew as steadily at the north.

TOPIC AND SUGGESTED READING AND RESEARCH.

262. Death of President Harrison. - Vice-President

Tyler as President. - His Rupture with the Whigs. TOPIC AND REFERENCES.

I. Wr. Tytr's fulse position when mace President. 2. Whig

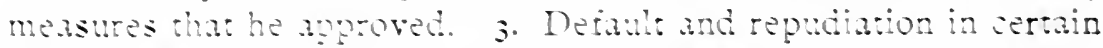
States. 4. The Frestents bank-bill veroes. 5. Whis hostibty. - Resignation of the cabinet. except Webster. Schurz, Clay, ii. 10s-210: Schouler, ir. 367-306; Witson, Distion. 153-139:

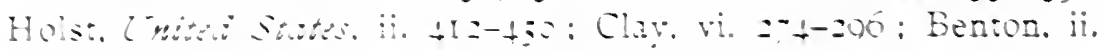

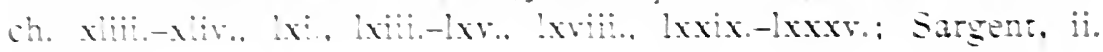
I: $:-1: 3$.

263. "Dorr Rebellion" in Rhode Island. - Anti-Rent Disturbances in New Fork.

TOBIC ANR REFERENCES.

1. Couse and resule of the "Dor Retelion." G. W'. Greene,

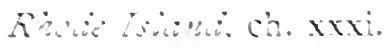

2. Origh ot the matrent disturbances in Tew lork. Schuyler. i. $: \div$ - -2.

\section{The Ashburton Treaț.}

TOBIC ANL REEEREXOES.

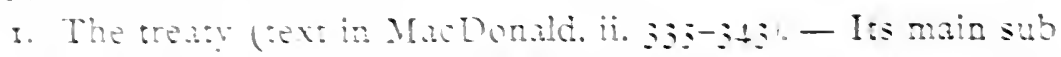

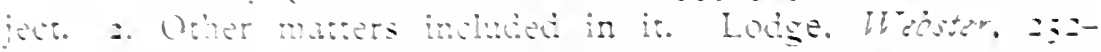

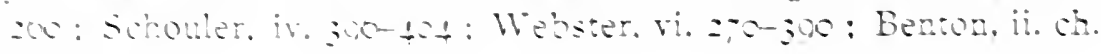
$\therefore-c$ ar.

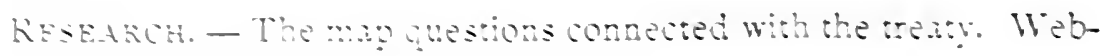
s.t. in. $14 ;-1 ; 3$ 
TOPICS, REFERENCES, AND RESEARCH. 447

\section{Texas Annexation Treaty rejected by the Senate.}

Topics AND References.

1. Action of President Tyler in securing the treaty. 2. Crounds of objection to it. 3. Objects of the annexation, in the interest of slavery. Holst, Calhoun, 2z2-245; Holst. C'nitid States, ii. 60z$657,673-677$; Schouler, iv, +40-451, +57-459, +70; Burgess, Mict alle Period, $302-30$ s; Wilson. Dirision. I $H^{-1}+5$; Schurz, Clay, ii. $235-241$; Benton, ii. ch. cxxxr., cxxxriii.-cxlii.

\section{The Texas Question and the Presidential} Election. - Annexation accomplished.

TOPICS AND REFERExCES.

I. Clay nominated in opposition to the annexation, against Polk, its adrocate. 2. Oregon claims coupled with the Texas question. - The false coloring of both. Wilson, Division, $1+5-1+6$; Schouler. ir. $+60-461,+65-469$. +71-t7t; Holst, United States, ii. 657-673: Shepard, 3+t-35t; Johnston, -tm. Politive, $1+5^{-1}+6$; Hart, Contimp's, iii. 649-652.

3. First practical use at this time of the electric telegraph. Sargent. ii. 231-232; Benton, ii. ch. cxxxiii.; Schouler, iv. +69.

4. Why and how Clay lost the election. - The Liberty party. Schurz, Clay, ii. 2+1-265; Schouler. iv. $+7+-4$ So; Hart. Contemp's, iii. 646-649; Johnston, Am. Politics, $1+6-1+7$.

5. Hurried action of President and Congress to accomplish the annexation (text in MacDonald, ii. 3+3-3+6). Holst, United States, ii. 677-712 ; Holst, Calhoun, 251-256; Burgess, Midille Period, 30S-310, 31S-323 ; Schouler, ir. 4Sz-4SS ; Benton, ii. ch. cxlvii.cxlviii.

6. Admission of Florida and lowa. Schouler, iv. $48 S-489$.

7. The triumph of John Quincy Adams. Sargent, ii. $25+-257$; Holst, United States, ii. $5+1-5+3$; Schouler, iv. + So- + SI.

RESEARCH. - The grief of the Whigs over the defeat of Henry

Clay. Schurz, Clay, ii. 265-267; Sargent, ii. 232-25t.

\section{The Programme of President Polk.}

Topics aNd ReFERENCES.

I. The cabinet of President Polk. 2. The four measures planned by President Polk. Schouler, iv. 49j-500. 


\section{Settlement of the Oregon Boundary Dispute.}

TOPICS AND REFEREXCES.

1. The undefined region of the dispute. 2. Senselessness of the cry. "Fiftr-four forty or fight." 3. The reasonable settlement made (text in McDonald. ii. 355-35s). Burgess. Mialle Feriod. $31 \mathrm{I}-31 \% 324-320$ : Holst. Calheun. 261-272: Schouler. ir. 504-

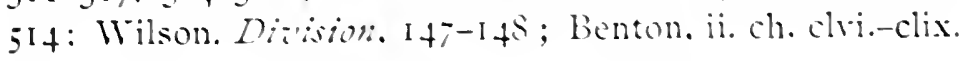

\section{War with Mexico. - Its Cause and Beginning.}

TOPICS AND KEFERFices.

1. Annexation of Texas proper would not have caused war. 2. War the consequence of our claming what had never belonged to Texas. 3. Senator Renton s characterization of the transaction. Benton. ii. ch. cxlix.: Hart, Cortents sii. 0 $5=-655:$ Schouler, ir. 5IS-525; Holst. Crittit states, iii. ch, ir.e vii.: Holst. Carborn. 274-279; Grant. i. 33-34: Webster. $1.23-261.271-301$; Rugess. Wridlic Piride $327-331$.

4. Collision provoked on the Rio Grande. - Intlammatory message of President lolk (text in MacDonald. ii. 3f6-333: Hart. Contellifis, ir. 20-2j). Schouler, ir. $525-528$ : Nicolay and Hay. i. 270-273: Lincoln. i. 100-10\%.

Resfarch. - I. The character of Thomas H. Benton. Roosevelt. Fintes. 2. Lowell on the Mexican War, in the "Biglow Papers."

270. War with Mexico. - Campaigns and Conquests. - Treaty of Guadalupe Hidalgo.

TORICS AND REFEREACES.

r. Opening of General Taylor's campaign. 2. General hearney's easy conquest of New Mexico - Seizure of Califormia. 3 . Taylor at Monterer. Grant, i. ch. vii.-viii.: Schouler. iv. $52 \$-335$ :

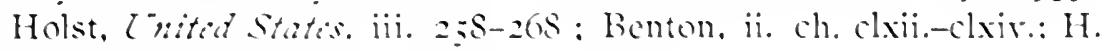
H. Bancroft xwii. ch. i.-xvi.

4. Taylor"s victory at Buena lista. 5. Cieneral Scott's campaign. - Capture of the city of Mexico. Paris i. ch. ir.: Grant, i. ch. ix-xii.: Hart. Contens ir. 2s-31: Holst. C nited States. iii. 331-335: Wilson, I)

6. Cessions to the United States by the treaty of Guadalupe 
TOPICS, REFERENCES, AND RESEARCH. 449

Hidalgo (text in MacDonald, ii. 365-372). Holst, United States, iii. 34t-347; Wilson, Division, I 52-1 53 .

7. The "Gadsden Purchase" (text in MacDonald, ii. 390-395).

271. Mormon Migration to Utah. - Gold Discovery in California. - Rising Tide of Foreign Immigration.

Topics AND ReFERENCES.

r. Origin of the Mormon Church. - Its successive migrations, and settlement in Utạh. Schonler, iv. $5+6-5+9$.

2. Gold discovery in California. Sherman, i. 6S-Sz; H. H. Bancroft, sriii. ch. ii.-iv.

3. Causes of increased immigration from Europe. IVilson, Diz'ision, I62-I64.

272. The Independent Treasury restored. - The Walker Tariff.

TOPICS AND REFERENCES.

r. The four measures of President Polk accomplished (text of treasury act in MacDonald, ii. 35S-365). Schouler, iv. 5I4-5IS; Wilson, Diaision, I5t-1 55 .

273. The Question of Slavery in the Territories. The "Wilmot Proviso."

TOPICS AND REFERENCES.

I. Shall the new domain be for slave labor or free labor?Intensified feeling in the country. 2. The question in Congress concerning Oregon. 3. The question concerning New Mexico and Ca'ifornia. - The "Wilmot Proviso." Shepard, 354-357; Holst, United States, iii. 2S4-30S, 322-327, 348-35s, 3S5-397, 400-40I; Holst, Calhoun, 279-285; Burgess, Middle: Pcriod, 334337, 340-34t; Wilson, Division, I 53-1 57 ; Schouler, iv. 543-546; Hart, Contempis, iv. 35-40.

\section{New Theory of Slaveholding Rights in the} Territories.

Topics and References.

I. The new constitutional theory of the "slave power." 2. The ground of conflict changed. Holst, United States, iii. 30S-320 ; Holst, Calhoun, 292-307, 310-313; Burgess, Middle Poriod, 342344 ; Benton, ii. ch. clxvii.-clxviii., clxxiv. 


\section{CHAPTER XIV.}

THE MADDENING SLAVERY QUESTION. IS48-I860.

275. Presidential Canvass of 1848. - Election of Taylor and Fillmore. The question between the "Wilmot Proviso" and the new claim of slaveholding rights in the Territories - the question, that is, between limiting and spreading slavery - was the one subject of absorbing interest in the country when the presidential election of 1848 approached; yet the politicians of the old parties made blind attempts to keep it out of the canvass, by taking no ground on either side. Large numbers, in consequence, broke away from them in the north, and combined, Whigs and Democrats, under the name of "Free Soilers," in a new anti-slavery

"Fre日 "Free
1848s," Buren, in New York. The New York Democrats in this movement had undertaken to array their own party against further extensions of slavery, and had failed. Among their leaders were such men as Silas Wright, Samuel J. Tilden, Dean Richmond, William Cul"Barm- len Bryant, and John A. Dix. They accepted burnors" and."Hunk- the queer name of " Barnburners," because their ors.'

opponents (whom they styled "Hunkers," or "old fogies") accused them of acting like a farmer who burned his barn to rid it of rats.

The Democratic national convention nominated Lewis Cass, of Michigan, for President; the Whig convention named General Zachary Taylor, one of the heroes of 
the Mexican War. The former convention issued some meaningless phrases on political questions, while the latter said nothing at all. The Barnburner Democrats, refusing to support Cass, put Van Buren in nomination, and their action was endorsed by a great convention at Buffalo, where Whigs, Democrats, and Abolitionists united in declaring for "free soil, free speech, free labor, and free men."

The nomination of Van Buren was not satisfactory to the general body of anti-slavery Whigs in New York, and most of them were persuaded to vote for General Taylor, the Whig nominee. Van Buren, in consequence, by drawing heavily from the Democratic vote in New York and little from the Whig vote, turned the election in Taylor's favor. The Vice-President elected was Millard Fillmore, of New York.

276. Pro-slavery and Anti-slavery Demands. 1849. When President Taylor entered office, in the spring of I 449 , the rush of gold-seekers to California was deciding the slavery question there, by filling the country with a population that had no use or desire for slaves. Prompted by the President,

California gold-hunters reject slavery, 1849. who had no sectional views on the subject of slavery, though a slaveholder himself, the Californians framed and adopted a free-state constitution, established a government, and applied for admission to the Union. The Mormons of Utah were organized politically already, in what they named the "State of Deseret," and the few inhabitants of New Mexico were taking steps to the same end. In the President's view the whole problem would solve itself, if Congress would let events take their natural course; but his proceedings and proposals in the matter were resented by the extremists of the south, whose prominent leaders were Jefferson Davis and Robert Barnwall Rhett. 
Nobody could think it possible to force slavery on the people who were gathering in California, nor to keep the increasing thousands of those people with no organized govermment for an indefinite period of time; but the California question furnished an opportunity for pressPro-slavery ing other pro-slavery demands, and to press demands. them in a threatening way. There were (I) the demand for opening the whole remainder of the territory lately Mexican to slavery; (2) for the surrender of a large part of New Mexico to Texas, on her boundary claims; (3) for fresh legislation to carry out that provision of the Constitution which declares that persons "held to service or labor in one State, under the laws thereof, escaping into another.... shall be delivered up on claim of the party to whom such service or labor may be due." 1 For the execution of this mandate of the Constitution a "fugitive slave law" had been

Fugitive slave law among the Federal statutes since I793; but that law entrusted the execution to state officials, who might be (according to a decision of the Supreme Court), and who were, forbidden by the laws of some States to perform the duties required. Therefore it was demanded, on indisputable grounds of constitutional obligation, that Congress should enact a more effective law, appointing Federal officials to carry it out.

Against these radical pro-slavery demands from one section came the radical anti-slavery demands from the

Ant1-

slavery demands. other, (1) for the WVilmot Proviso, applied to all present and future Territories : (2) for the abolition of slavery in the District of Columbia; (3) for the prohibition of all slave trade between the States. The feeling on each side took heat from the other, and conditions were well prepared for an outburst of flame.

1 Art. IV. sect. ii. clause 3 . 
277. Compromise of 1850. - Death of President Taylor. - Accession of President Fillmore. President Taylor, stout-hearted old soldier and patriot, regarded the threatening situation without dismay. Like Jackson, his feelings were wholly national; he scorned the sectional spirit, and was sternly unwilling to give way to it in the least. If he had had his way, the crisis reached a dozen years later might have come upon the country in I 850 or I $85 \mathrm{I}$, and possibly with a different result. But the temper of Congress was not so inflexible. Clay, "the great compromiser," brought his peculiar influence to bear on the strained feeling of the time, and postponed the inevitable rupture by a last

"The great compromiser." transient truce. Under his lead a conservative majority from both parties in Congress enacted a series of measures which were judged to be an acceptable "compromise" between the pro-slavery and anti-slavery demands. Webster, Cass, and Stephen A. Douglas were the prominent northern supporters of Clay in his undertaking; his scheme as a whole was opposed on one side by Jefferson Davis, and on the other side by Seward and most of the anti-slavery Whigs. The influence of the administration was against it until President Taylor's death, which occurred, after a brief illness, on the $9^{\text {th }}$ of July, I850. Mr. Fillmore, who be-

Death of President Taylor, July 9,' 1850. came President then, approved all the pending compromise bills, and signed them when they passed.

Nothing else in the compromise proceeding gave rise to so much feeling as Webster's participation in it. His speech in the Senate debate, which brought the weightiest argument and the most powerful influence to Clay's support, grieved and angered

Webster's "Seventh of March speech." a vast number of his old admirers in the north. It was looked upon, most unreasonably, as a bid for the presi- 
dency: as though the south could make him President without the good-will that he alienated in the north. Opinion at the present day does more justice to Vebster's sincerity. whatever may be its judgment on the wisdom of his course. He feared for the Union, and he convinced himself that nature had forbidden slavery in New Mexico and Ltah, which time proved to be the fact. In his grand way he said: "I would not take pains uselessly to reaffirm an ordinance of nature, nor to reënact the will of God." As for the Fugitive Slave Law, he adrocated jury trial for the fugitive. but he did not insist upon it, and he left the Senate, to become Secretary of State in Fillmore's cabinet, before the bill came to a rote.

The five measures of the "Compromise of IS;O" (I) established territorial goremments in Ltah and New MexThe five ico, with no reference to slarery: (2) admitted measures. California as a free State: (3) gave $\$ 10,000,000$ to Texas for her New Mexico claim: (4) substituted a new Fugitive Slave Law for that of 1793 : and (5) abolished the slave trade, but not slavery, in the District of Columbia. The several acts were passed by differing rotes, the radicals on the two sides roting together against the Texas proposition, and opposedly on everything else. In reality, the so-called "compromise" satistied only a middle feeling of cool conservatism in the country, that was peaceable enough without it: while the dangerous antagonisms were not pacified at all.

278. The Fugitive Slave Law. 1850. The antagonisms were not only not pacified, but they were intensified by one of the measures of the "compromise" - the Fugitive Slave Law. Had that law done no more than fulfil in a strict way the hard requirement of the Constitution, nobody who upholds the Constitution could deny 
that it was a rightful act. But it destroyed all the safeguards of frecdom for erery black man in every State. If a white man claimed him as a slare, it was not the white man who must prove of freedom his claim by more than a bare affidarit, but the negro who must prove his right to be free. He was denied eren the safeguards of a thief. whom the law assumes to be innocent till his suilt is proved. He could not testify in his own behalt. He was denied trial by jury. He was denied a judge of the bench: for the claim against his liberty was to be heard and determined, "in a summary manner." by a fee-paid commissioner, whom the law bribed against him, by making the official fee ten dollars if the black man was sent to slavery and five dollars if he was set free.

Such a law could not be enforced in northern communities without excitements of passionate feeling. Every case that occurred under it - every surrender of a claimed fugitive - did more than the abolitionists had erer done to convert northern people to some part, at least, of abolitionist beliefs. Senator Seward, in a Senate debate on the compromise measures, had made casual allusion to "a higher

The appeal to " a 18 \%." law than the Constitution," and the phrase was caught up. To obstruct, resist. frustrate, the execution of the statute came to be looked upon by many people as a duty dictated by the "higher law" of moral right. Legislatures were mored to enact obstructive "personal liberty" laws:" and quiet citizens were mored to riotous acts. Active undertakings to encourage and assist the escape of slaves from southern States were set on foot, and a remarkable organization of helping hands was formed. in what took the name of the

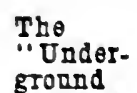
ground Rallway." "Underground Railway," to secrete them and pass them 
on to the safe shelter of Canadian law. The slaveholders lost thousands of their servants for every one that the law restored to their hands.

The story of “Uncle Tom's Cabin," by Mrs. Harriet Beecher Stowe, may fairly be counted among the pro-

\section{"Unclo}

Tom's ducts of the Fugitive Slave Law, and no other Cabln." book ever produced an extraordinary effect so quickly on the public mind. In book form it was published in March, I 52 , and it was read everywhere in civilized countries within the next two or three years. Its picture of slavery was stamped ineffaceably on the thought of the whole world, and the institution was arraigned upon it, for a more impressive judgment than Christendom had ever pronounced before. That the picture was not a true one of the general and common circumstances of southern slavery, but that the incidents put together in the story were all possible, has been proved beyond doubt.

279. Incidents of the Period. 1849-1852. In political affairs the domestic history of the United States, during the four years of Taylor and Fillmore, was filled almost entirely with the agitations to which slavery gave

\section{Material} rise. It was a time of great material prosperity prosperity. and advance. Railroad and telegraph building went on with rapidity; movements of travel and trade were enormously increased; steamers were supplanting sailing ressels on the ocean, as well as on rivers and lakes; large organizations of every kind of undertaking, in reform work, lecture-touring, news-collecting, and the like, were becoming practicable; life on all sides was broadened and quickened, and the nation was acquiring a new knowledge of itself.

Several occurrences of interest or excitement had their origin in foreign affairs. In I $850 \mathrm{Mr}$. Clayton, then 
Secretary of State, negotiated what seemed to be a treaty of importance with the British minister, Sir Henry Lytton Bulwer, to guarantee the neutrality of any ship canal that might be cut

\section{Clayton-}

Bulwer

Treaty,

1860 . through the Isthmus of Panama, or through Central America at any other point. But many years were to pass, and the Clayton-Bulwer treaty was to give way to another, before the long-projected inter-oceanic canal could be built.

Results of more importance came from a naval expedition sent to Japan in 1852 , under Commodore Perry, who succeeded in negotiating the first treaty by which the Japanese government conExpedition to Japan, 1862 . ceded rights and privileges of intercourse and commerce with any foreign people.

The rising of $1848-49$ in Hungary, against Austrian misrule, gave rise to two incidents of note. The first was a spirited correspondence between Chevalier Hulsemann, the Austrian representative at Washing- Tho ton, and Mr. Webster, after the latter became Secretary of State. Austria was offended by action taken in sending an agent to Hungary to watch the course of events, and Webster delighted his countrymen by the vigor of his reply to her complaints. The second incident was a visit to America, in $185 \mathrm{I}$, by Kossuth, the wonderfully eloquent Hunga- $\begin{gathered}\text { Kosssuth, } \\ \mathbf{1 8 5 1 .}\end{gathered}$ rian leader, who hoped to renew the struggle of his country with American help. He excited an enthusiasm which might have swept the United States into reckless meddling with European affairs, if those who were responsible for the government had allowed themselves to be moved by the momentary feeling of the people.

Since the annexation of Texas and the conquests from 
Mexico, a restless craving for more territorial expansion had been showing itself in parts of the south. Cuba was a special object of desire. P'resident Polk had tried without success to buy the island from Spain, and less scrupulous undertakings were then set on foot. President

Lopez

Taylor suppressed one filibustering scheme in Expedittion, I 849 . Another, concocted in I 85 I by a Cuban
1851.

named Lopez, launched an expedition of about 500 men from New Orleans and landed it in Cuba, where it suffered quick defeat. The leader and some others were executed, and a large part of the force perished in fight or from disease.

280. Presidential Canvass of 1852. Election of Franklin Pierce. If the Compromise of i 550 gave satisfaction, as was said above, to nothing but a middle feeling of cool conservatism in the country, that feeling must have been predominant, even after two years of a rigorous enforcement of the Fugitive Slave Law; for the anti-slavery sentiment of the north showed less vigor

Apathy

of anti-

slavery

forces. in the presidential election of $\mathbf{I} 852$ than four years before. The attempt in $18_{4} S$ to unite anti-slavery Whigs and Democrats in a common defence of "free soil" had had a discouraging result. Most of the Whigs had drawn away from it at the beginning, and now Van Buren and the majority of his followers were back within their old party lines.

Both parties, in the national conventions of 1852 , pledged themselves to maintain the compromise measures and to resist agitations on the subject of slavery ; but the Democratic party gave evidence of more heartiness in the pledge than the Whigs could show. Anti-slavery influences in the latter were strong enough to defeat Fillmore, the candidate of the southern Whigs, as well as Webster, who had a faithful following, and to make 
another military nomination, in the person of General Scott. For the Democratic nomination, Cass, scott Buchanan, and Douglas were rivals who de- $\begin{gathered}\text { aganst } \\ \text { Pierce, }\end{gathered}$ feated one another, and the prize went to Frank- 1852 .

lin Pierce, of New Hampshire, a pleasing gentleman, much liked by those who knew him, and one whose political views were highly satisfactory to the south. That was his strength, and the strength of his party. The time had come in American politics when the fighting for or against slavery was the only hearty fighting that could be done. The Democratic party gained strength from the firmness of its footing on the southern side ; while the Whig party, going positively to neither side, was weakened on both, and came to the end of its career. A surviving remnant of the Free Soil party nominated John P. Hale. Pierce was elected by an overwhelming majority of votes.

Both Webster and Clay died while the strife for the presidency went on, the former in October, the latter in June.

281. Minor Incidents of the Administration of President Pierce. 1853-1854. One event of the period of President Pierce looms so large that all others seem insignificant; but some incidents of importance occurred, which may be mentioned first. Once more Austria raised a question with the American government, by attempting, in Turkey, to lay hands on a Hungarian refugee, Martin Koszta, who had resided in America since The his escape from Hungary, and had declared his $\begin{gathered}\text { Kossta } \\ \text { affalr, }\end{gathered}$ intention to become a citizen of the United 1853. States. Captain Ingraham, of the United States sloop-ofwar St. Louis, forced an Austrian brig-of-war to give him up, and the captain's action was upheld. Mr. Marcy, Pierce's Secretary of State, justified the proceeding on principles from which this country is not likely to recede. 
Another important performane in the State Department was the negotiation of a treaty of reciprocity with Canada, opening the markets of each country to most of

Caradian

rociproct
treaty.

t854. the natural products of the other. free of duty, and increasing the privileses of American fishermen on the british-American coast. The traty Was ratifed in Is $\$$. and was in force until IS60. when it was abrogated by ation of the Lnited States.

Mith less eredit to itself, the administration of President Pierce was tolerant. at least, of unscrupulous designs Faver in upon Cuba, and winked at the doings of one

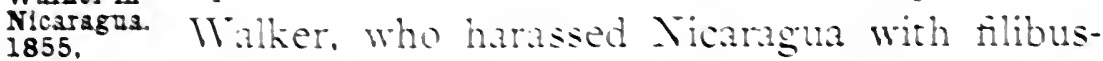
1855 .

tering undertakings for a number of years. It prompted also a strange proceding on the part of three American plenipotentiaries in Emope. Mr. Soule. Mr. Buchanan, and Mr. Mlason, who met at Ostend, in Oc. tober. Is 4 , and joined in preparing an extraordmary

The Ostend Manifesta. 1854 .

force if need 1, on the sround that the peace and safety of the Lnited states required the island to be ours. If. as people belierod at the time. the govermment was making ready to at on such adrice its plans were interfered with by another measure, which raised so much excitement in the county that nothing else could be taken in hand.

282. Repeal of the Missouri Compromise by the Kansas-Nebraska Act. 1854. 'That measure was one repealing the Mrssomi Compromise, thereby admiting slavery to the whole domain irom which the compact of IS2O (see sect. 227) had shut it out. In Iamuary ISミ+. its author, semator Douglas, of Illinois, reported from I Sce Irap III. 
the Senate Committee on Territories a bill to organize what was then called the Territory of Nebraska, embracing what is now comprised in the States of Kansas, Nebraska, the Dakotas, and so much of Montana, Myoming, and Colorado as lies on the eastern side of the Rocky Mountains (see Map Xi.). The report assumed, what seems to have entered no mind before, that the effect of the Compromise of $\mathrm{I} \$ \mathrm{~s}, \mathrm{o}$ in its provision relating to $\mathrm{New}$ Mexico and Utah, was to establish the principle of "popular sorereignty" or " squatter sorereignty," as Calhoun had styled it, with con-

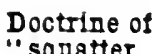
"squatter sovereignty." tempt; the principle, that is, "that all questions pertaining to slavery in the Territories, and the new States to be formed therefrom, are to be left to the decision of the people residing therein." Pursuant to this discovery, the Nebraska Bill reported by Senator Douglas prorided that States organized in the Territory should be "received into the Union with or without slavery, as their constitutions may prescribe." Subsequently a clause was added that repealed the enactment of I $820 \mathrm{in}$ positive terms, and two Territories, named Kansas and Nebraska, were created in the region, instead of one.

After three months of an excitement which exceeded all previous agitations, the Kansas-Nebraska Bill became law. It was opposed by every northern Whig in both branches of Congress, and by nearly half the northern Democrats in the lower House. In the Senate, Douglas carried with him all but four of his Democratic colleagues from the north. The political effect of the bill was to drive great numbers from the Democratic party in the northern States. who did not return to it, as in $\mathrm{I}_{4} \mathrm{~S}$; but a strong wing of that party still held the pro-slavery ground in nearly every free State. On the other hand, northern and southern Whigs 
parted company on the new slavery question so completely that their national organization came to an end.

283. Rise of the Republican Party. 1854-1855. The northern Whig leaders now hoped and strove to reconstruct their party on anti-slavery grounds, and to gather all the forces of opposition into its ranks; but that could not be done. To bring anti-slavery Whigs and Democrats into harmonious union an entirely new organ-

Union of antislavery the north. growth. In this case the growth was begun by a popular movement in several States, mostly western, during the summer of I 854 . In Michigan, Visconsin, and Vermont the people going into the new movement took the name of "Republicans," and that name was accepted as the morement spread. It adranced somewhat slowly in the east, not only because the old Whig organization gave way to it less readily there, but also because of hindrance from another political movement which was rumning at this time a short-lived career.

284. The "Know Nothing," or American, Party. 1852-1855. The movement in question had been started, about 1852 , in some eastern cities, by native Americans, who objected to the speedy way in which foreign immigrants were made citizens and endowed with political rights. At first it took the form of a secret society, whose members were bound by oath to divulge nothing of its plans. In jeering allusion to the ignorance they professed when questioned, they were called "Know Nothings," and accepted the name. As one consequence of the Kansas-Nebraska legislation, breaking former party ties, many roters went into the Know Nothing order, in $185+$ and 1855 . Many state elections were controlled by them, and a strong representation in Congress was 
secured. The secret methods of the order were then mostly abandoned, and assuming the name of the American Party, it entered the political field in an open way, absorbing the more conservative among the Whigs of the north, and the whole of the IVhig party in the south.

285. The Strife for Kansas. 1855-1856. In I $S_{55}$ the anti-slavery Whigs gave up the attempt to maintain their own party organization, and, with Senator Seward of New York as their acknowledged chief, went into the "Republican" movement, which then took form in every northern State. Events in Kansas were stimulating its growth.

When the Kansas-Nebraska Bill became law, Senator Sumner said: "It annuls all past compromises with slavery, and makes all future compromises impossible. Thus it puts freedom and slavery face to face and bids them grapple." 1 No description of the consequences of the bill could be more exact. The "grapple" came instantly in Kansas, where The
"grapple"
in Kansas. the first decision, for or against slavery, by choice of the settlers in the Territory, would have to be made. Which interest would bestir itself most effectually to populate that ground of strife became the grand question of the day. Bordered as Kansas was by the slaveholding State of Missouri, the advantages of position were on the slaveholding side; but the adrantages of

Emigration resource and spirit were on the other. Stimulated and assisted in all possible ways, a stream of emigration to Kansas was soon in motion from the free States. Strenuous efforts to move a counter-stream from the slave States were made, with less success; but in substitution for actual settlers, armed bodies

Invasions

from Missouri. of Missourians (styled "border ruffians" in the contro- 
rersies of the time) were marched in. to hold elections and overpower the actual occupants of the land. For nearly two years, from the spring of Is 5 , Kansas was the scene of a desperate strugsle between its real inhabitants and those invaders from the neighboring State. In that period three appointed sovemors of the Territory (Reeder, Geary: and Walker), who went out to it with pro-slavery sympathies, changed their riews when the facts of the situation became known to them. and each. in turn. was driven to resign because he would not be a party to the flagrant wrong. In the warfare of the fierce struggle there were lawless violence and barbarity on both sides. Lawrence, the principal hansas town. was half destroyed in $\mathrm{s} s, 6$ by a mob. collected and acting as the posse of a marshal of the Luited States. In retaliation. "old John Brown of (Dsswotomie" (of whom more old John will soon be told). leading a little band of his own Brown. sons and others, slew fire pro-slavery settlers on Pottarotomie Creek in cold blood. Nothing else in the life or death or character of that fierce hater of slavery can cleanse him of the foulness of this murderous deed.

286. Election of Speaker Banks. - Assault on Senator Sumner. How rapidly the new Republican party was consolidating the anti-slarery sentiment of the north became apparent when the Thirty-fourth Congress assembled in December. Is: 5 , and the House of Representatives attempted to elect a Speaker. At the end of a struggle which lasted two months. Aathaniel P. Banks, a Massachusetts Republican, was raised to the chair by the rotes of representatives most of whom had been chosen to Congress in Is $; 4$ as " Americans" or as Mhigs. The Republican party was now so broady organized that it could enter the presidential contest of 1856 with good hopes of success. 
Before that contest opened, the passionate feelings that went into it were heated yet more by a violent speech from Senator Sumner, on "The crime against Kansas," followed by a cowardly assault on the Senator, made by one of the Congressmen from South Carolina, Preston Brooks. The senator

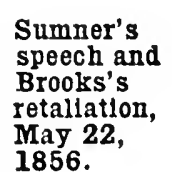

Sumner's speech and Brooks's May 22, 1856 . was struck repeated blows upon the head with a heavy cane, as he sat writing at his desk in the Senate Chamber, unable to rise until he had wrenched the desk from its fastenings, and then only to fall unconscious on the floor. For three years he was disabled by spinal injuries, and he never recovered full health. Brooks, applauded in his own State and other parts of the south, was not expelled from Congress, but resigned, and his district reëlected him, with only six opposing votes.

287. Presidential Canvass of 1856. - Election of President Buchanan. In June, I 856 , the presidential camvass was opened fully, by the Democratic nomination of James Buchanan and the Republican nomination of John C. Frémont. Previously, in February, the American party had named Millard Fillmore as its candidate, and the nomination was endorsed afterward by a remnant of the Whigs. The Democratic convention pledged adherence to the principles of the Kansas-Nebraska act; the Republicans declared it to be "the right and duty of Congress to prohibit in the Territories those twin relics of barbarism, polygamy and slavery; " the American party aroided the question. The latter figured little in the northern canvass, but importantly in the south, where the contest was entirely between Buchanan and Fillmore. The free-state rote for Frémont was heavier than Buchanan's by more than a humBuchanan, Flllmore, Frómont. dred thousand; but rotes were cast for the former in only four slave States, and there were only a few more than 
one thousand Republican rotes in those four. He was truly a sectional candidate, and that weighty argument against him was pressed rehemently; backed by continual declarations from southern newspapers and public men that the slave States would not submit to his election by a sectional vote. The argument and the menace had more influence in I $\$ 56$ than four years later, and no doubt it is fortunate they did.

Buchanan was elected, but not by a majority of the popular rote. He carried five northern States, and all of the south save Maryland, which gave Fillmore his only electoral votes. It could hardly be said that the country, by Buchanan's election, had accepted the Calhoun doctrine, that Congress had no power to exclude slavery from any Territory ; but the rote appeared to go close to that meaning; especially when coupled with the fact that the same election gave Buchanan a majority in Congress to support his administration.

288. The Dred Scott Decision. 1857. ${ }^{1}$ The "slave power" was triumphant; but a greater triumph was to come. Two days after Buchanan's inauguration, the Supreme Court of the United States made public its decision of a case in which it found opportunity to affirm the Dred doctrine of Calhoun. The case was of a slave Drodt's citt- named Dred Scott, who sued for the freedom
zenship. zenship. of himself and his family, and two questions were involved: (I) Could Dred Scott be recognized as a "citizen," with a right as such to sue in a United States court? The court decided that no slave or descendant of a slave could be a citizen of the United States. That sufficed to end the case, by putting Dred Scott out of court, and the justices were agreed at first that they should go no further; but pressure is said to have been put upon them 1 See Map XIV. 
to declare themselves, for political effect, on the second question brought into the argument of the case, namely: (2) Was Dred Scott made free by the act of his master, who took him for two years into the northern part of the Louisiana Territory, where slavery was forbidden by the enactment known as the Missouri Compromise? Chief Justice Taney, ${ }^{1}$ sustained by four associate justices from slave States and one from a free State, pronounced thereupon the opinion Unconstitutionality of the Missouri Compromise. that "no word can be found in the Constitution which gives Congress greater power over slave property than property of any other description ; " hence the enactment of 1820 "is not warranted by the Constitution and is therefore void."

And so the holding of slaves in any Territory of the United States, present or future, could be hindered by no power, residing anywhere, until its inhabitants acquired the sovereignty of the constitution of a State. The Douglas doctrine of "squatter sovereignty" or "popular sovereignty" went down under this absolute decision as completely as the authority of Congress went down, though Douglas tried hard to persuade himself and others that it did not.

289. Collapse in Business. - Mormon Rebellion. 1857. The Dred Scott decision, delighting the south and astounding the north, came on the country at a time when political feeling was much cleadened by troubles in the business world. For nearly a decade, successive occurrences in Europe - revolution and war on the continent, following famine in Ireland - had been disturbing production in that part of the world and stimulating it in the United States, until everything in the latter was overdone. The return of peace to Europe in I 856 was 1 Appointed in 1836 by President Jackson. 
followed in 1 s:- by a commorchl collapse nearly equal to that of $1 \mathrm{~S}:$.

Among the elents of the ban was a rebellious attempt of the Mormons in L ah of resist the appointment of a territotal soremor. Asphang the president of their churh. bushom louns. Posiden Fillmore had ap pointed lomen on the soremorsh when the Territory

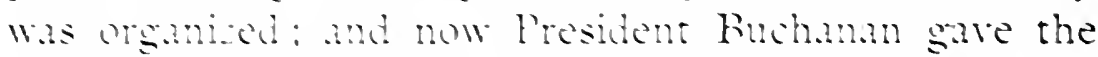
office a ? Gentile. The Mlomon opposition became so throuming that a onsidende amy esorted the new

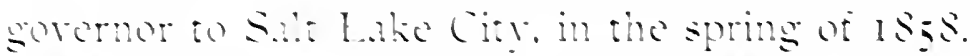

290. Kansas, and the Lecompton Constitution.

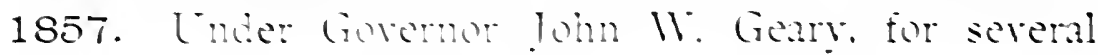
monhs. and tho? unde Goremor Robert I. Walker-

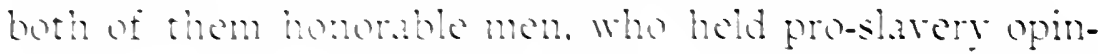

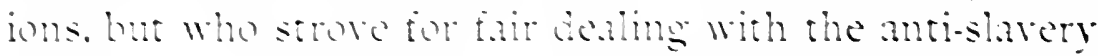
majority in the Temboy - a mud quicter state ot things

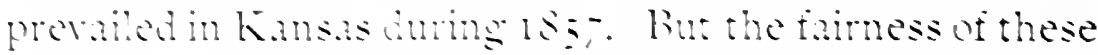
sovenors was not piensing to those at Mishington who

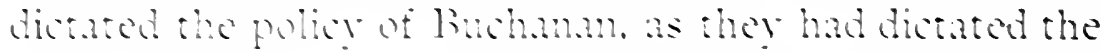

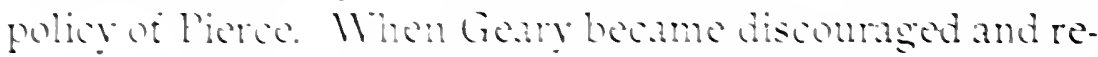

Assurances to Gorernor Walkes. signed. IV ather was persunded to take the place. l'esident buhamm nssuring him that he should

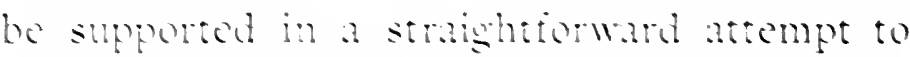
wsertain the will of the real inhabiants of hansas con-

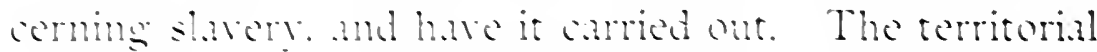
legishture, which the tree-state settlers would not recogni.c. hat ortered an chertion of delesates to a constitu-

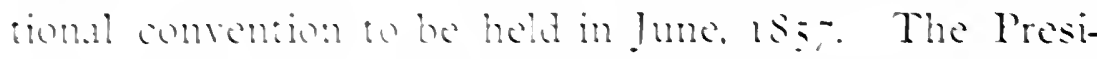
dent asted with 11 alker that am onstitution framed

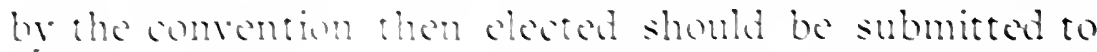

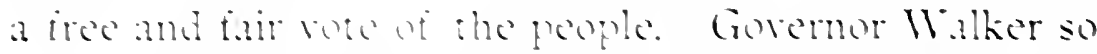
ammomod, and tried o persude the fredestate men to take put in the cherion: but the' teared framd. More- 
over, they had adopted a constitution, framed by a convention held at Topeka in October. I 55 . which they claimed to be the expression of the will of a majority of the Kansas people. Therefore they held aloof from the convention election, but they came out to rote in the election of a new legislature, and won seats enough to give them full control.

The pro-slavery convention, meating at the town of Lecompton, constructed a constitution which not only placed slare property on the same footing as other property, but forbade any alteration of that fundamental law. It then appointed an election, to be held in December, at which the people might rote, not for or against the constitution, but "for the constitution with slarery" or "for the constitution without slavery:" and, whatever their rote might be, the right of property in slares already brought into the Territory should not The "vile be impaired. This was "a vile fraud," said Gor- traud." ernor Walker, who denounced it without reserve, and he resigned when he learned that the administration would give it approval and support. In his letter of resignation he declared that he knew the Lecompton constitution to be the work of a small minority, and opposed by "an orerwhelming majority" of the Kansas people.

291. Revolt of Senator Douglas. - Defeat of the Lecompton Fraud. 1857-1858. At once Senator Douglas took a manly stand with Goremor IValker against the Lecompton fraud, breaking with the administration, and bringing about a rupture in the Democratic party that never was healed. The Lecompton constitution "with slavery" was carried easily constitution at the December election, for the free-state men would not rote. In February. I $S_{5} S_{\text {. it was sent to }}$ Congress by the President, who recommended the admis- 
sion of Kansas, with this for its organic law, and who asserted in his message that "Kansas is, at this moment, Submitted as much of a slave State as Georgia or South to Congress. Carolina." Then a battle opened in Congress which stirred the old excitement afresh. Douglas was the hero of the fight; the Republicans were content to be his allies, and gave him the lead. He could not overcome the strong Democratic majority in the Senate, but he did break that in the House. The result of a disagreement between the two branches of Congress was a shabby compromise, according to which the Lecompton constitution was offered to the people of Kansas with a bribe. If they voted to accept it, they should have statehood at once, and receive a large grant of governThe re- ment land. If they voted against it, Kansas fected bribe. would remain a Territory till its population rose to 93,000, and the land grant would be lost. ${ }^{1}$ The vote was taken on these conditions in August, and the proslavery constitution was rejected by I I, 300 against i 788 .

292. Rally of Northern Democrats to Douglas. The Douglas and Lincoln Debate. 1858. The question was settled; the attempt to fasten slavery upon Kansas had failed, and the cost of the attempt to the "slave power" had been greater than it knew. If the men who acted for it at Washington, and who controlled the President, planned deliberately, as some believe they did, to shatter the northern wing of their party and insure the election of an anti-slavery President, in order to excite the slave States to secession and rebellion, they planned well. Douglas was treated as a traitor to his party, and pursued with unmeasured abuse. The effect

1 Four days after the passage of the Kansas bill Minnesota was admitted to the Union with a free-state constitution. At the next session of Congress Oregon came in. 
was to rally the greater part of the northern Democracy to his support. His senatorial term was about to expire, and the election of the next legislature in Illinois became an exciting event. Against Douglas, Abraham Lincoln was put in nomination by the Republicans; and then followed a personal canvass of the State by these two men which had conse-

Douglas and Abraham Lincoln, 1868 . quences of immeasurable importance, for the reason that it drew the attention of the country to Mr. Lincoln and made something of his character and ability known.

In his own State Mr. Lincoln was famous and beloved already, as a man of singular wisdom and uprightness; but he had acquired no prominence before the nation at large. By good fortune it was arranged that Mr. Lincoln and Senator Douglas should hold seven joint meetings, for public debating of the questions at issue between them. Those debates, in the summer of 1858 , reported in many newspapers, were a revelation of Abraham Lincoln to multitudes of people in all the States. Such simple and clear, yet profound and powerful reasoning had never been Rerelation
of Lincoln to the peoplo. applied to the dreadful slavery question before. Douglas was a debater of extraordinary adroitness and force; but the stand he had taken, on his theory of "popular sovereignty," not caring, as he declared, "whether slavery be voted up or down," put his argument on grounds that showed to a disadvantage in most minds, under the search-light of moral sense and common sense which Lincoln turned upon them.

His bold fight against the Lecompton fraud gave the senator a strong claim to reëlection, and the result of the canvass was in his favor, so far as concerned that event; but he marred his future chance for the presidency by a new offence to the south. By shrewd ques- 
tioning, in debate at Freeport, Mr. Lincoln forced him to say that, in his judgment, the people of a Douglas's "Freeport, Territory, by "unfriendly legislation," might make it impossible to hold slaves, and thus practically nullify the Dred Scott decision. This "Freeport doctrine," as it was styled, raised a new clamor against Douglas in the south, and provoked a new constitutional claim, namely, that Congress must frotect slarery in the Territories by Federal law.

293. The Purpose of the Republican Party. Before his debates with Douglas began, speaking to the convention which named him for senator, Mr. Lincoln set forth the inexorable issue that the country had to face in these plain words: "IVe are now far into the fifth year since a policy [that of Douglas] was initiated with the avowed object and confident promise of putting an end to slavery agitation. Under the operation of that policy, that agitation has not only not ceased, but has conTheslavery stantly augmented. In my opinion it will not questlon
stated by stated by passed. 'A house divided against itself cannot stand.' I beliere this gorernment cannot endure permanently half slave and half free. I do not expect the Union to be dissolved - I do not expect the house to fall - but I do expect it will cease to be divided. It will become all one thing or all the other. Either the opponents of slarery will arrest the further spread of it, and place it where the public mind shall rest in the belief that it is in the course of ultimate extinction; or its adrocates will push it forward till it shall become alike lawful in all the States."

Four months later Senator Seward expressed the same belief in less penetrating words. "It is," he said, "an irrepressible conflict between opposing and enduring forces, 
and it means that the United States must and will, sooner or later, become either entirely a slaveholding nation or entirely a free-labor nation."

\section{Stated by}

The conviction expressed in these two utterances was now becoming ripened very rapidly in the minds of a majority of the people at the north: That the conflict between slavery and freedom was "irrepressible;" that no compromise could end it; and that the plain duty of the opponents of slavery was, not to undertake any violent uprooting of the system where it existed already, but, as proposed in Mr. Lincoln's perfect statement, to "arrest the further spread of it, and place it where the public mind shall rest in the belief that it is in the conrse of ultimate extinction." That was the undertaking for which the Republican party was formed, and the approval of which was drawing to that party a majority of the northern people.

294. John Brown's Attempt at Harper's Ferry. 1859. This undertaking gave no countenance to attacks on slavery in the slave States; least of all to such an attack as was attempted by John Brown (he of the Kansas war, see sect. 285), who, with eighteen followers, surprised and seized the

\section{Selzure} of the armory. United States armory at Harper's Ferry, on the night of October I6, I859. Brown's plan was to push on to some place in the Virginia mountains that he could fortify and hold, and from which he could make incursions to liberate and arm the slaves; but the people at Harper's Ferry and the neighborhood armed against him so quickly that he got no farther. By noon of the 17 th he was besieged in the engine house of the armory, and that night the besiegers were joined by a force of United States marines, under Colo-

Colonel

Robert E.

Lee, 1859 . nel Robert E. Lee (afterward General Lee, of the Con- 
federate army). The next morning they stormed the building and captured Brown, with six of his companions who were then alive. Ten of Brown's party and five of the townspeople had been killed in the fighting; Brown himself was badly wounded in the final assault. Two weeks after the capture he was tried for treason, conTraal and spiracy, and murder, and was condemned to oxecution. death; on the $2 \mathrm{~d}$ of December he was hanged. His bearing in the interval impressed even his captors; for he was calmly contented with his fate, and appeared to have no doubt that he had been an instrument in God's hands.

295. Threatening Declarations in the South. 18591860. If Brown had confederates, outside of his little armed company, they were few, and included no one in political life. This is the only conclusion to be drawn from evidence obtained on his trial and from the results Deepening of a Senate investigation. The political effect of feeling. his startling attempt was to deepen the feeling, pro-slavery and anti-slavery, that was already intense. This fact appeared when the Thirty-sixth Congress came together, three days after the execution of John Brown, and the House became engaged in a contest for Speaker that lasted two months. The Republicans lacked four of a majority; but they drew votes from the Democrats and elected their candidate in the end. Throughout the following session the tone of southern speeches and the southern press was more threatening than ever before. Again and again it was cleclared that the south would never submit to the election of a "Black Republican" President; yet those who cleclared so were preparing for action at the Democratic national convention that would almost insure that result. ${ }^{1}$

${ }^{1}$ See letter of Henry A. Wise in Nicolay and Hay, ii. 302. 
296. Presidential Canvass of 1860. - Election of Abraham Lincoln. When the delegates to the Democratic convention came together, at Charleston, in April, 1860, a majority of the whole convention, representing an overwhelming majority of the party in the free States, demanded the nomination of Douglas, as the only candidate whom the party could expect to elect. The southern minority declared that no candidate should have their support who would not repudiate the doctrines of Douglas and accept the latest slaveholding dogma, that Congress must protect slavery in the Territories from "unfriendly" territorial laws. On this the party was hopelessly split. Most of the delegates from the cottongrowing States withdrew, and the remaining convention adjourned, to meet again at Baltimore in June. At Baltimore a further secession of delegates from the slave States occurred, and Douglas was nominated by those who remained. The seceding Democrats named John C. Breckenridge of

Nominations of Douglas and Brecken ridge. Kentucky as their candidate, on the platform which the Douglas Democrats had refused.

Meantime, in May, the Republicans, in convention at Chicago, had made Abraham Lincoln their standardbearer, disappointing the expectation of many, Nomination that Senator Seward would be named. But of Lincoln. Lincoln had been growing in the esteem of discerning people, though few had yet discovered him to be, politically, the wisest and strongest man of his day.

A fourth nomination was made in May, by lingering adherents to the Whig and American parties, who united in what they named the Constitutional Nomination Union party, and brought John Bell, of Tenof Bell. nessee, with Edward Everett, of Massachusetts, into the field. 
Of the result of the election there could be but one doubt: would it be settled by the popular vote? Neither Douglas nor Breckenridge could hope to win a majority in the electoral college; but Lincoln might do so, and the Republican canvass for him was conducted with a vigor that his opponents could not rouse. It was in this presidential campaign, and by the champions of Lincoln, that

Lincoln

"Wide marching companies for torchlight processions (called "Wide Awake Clubs" at the time) were first organized and drilled. On the 6th of November the momentous election occurred, and the Republicans were victorious in every free State. The slave States were carried for Breckenridge, excepting Missouri, which gave Douglas a majority, and Virginia, Lincoln's Kentucky, and Tennessee, which were carried election. for Bell. New Jersey divided its electoral votes, giving Lincoln 4 and Douglas 3. In all, Iincoln had i 80 electoral votes, Breckenridge 72, Bell 39, Douglas I2. But this does not indicate the popular vote, of which Lincoln received I, 866,452 , Douglas I, 375, I 57, Breckenridge 847,953 , Bell 590,631.

TOPICS AND SUGGESTED READING AND RESEARCH.

275. Presidential Canvass of 1848. - Election of Taylor and Fillmore.

Topics ANd References.

r. The absorbing political question. - Blind attempts to keep it out of the presidential canvass. 2. New anti-slavery movement of the "Free Soilers." 3. "Barnburners" and "Hunkers" in New York. 4. Nominations for the presidency. - Result of the election. Holst, United States, iii. 358-385, 397-400, 402-403; Schurz, Clay, ii. 291-3I4; Hart, Chase, 95-ro2; Johnston, Am. Politics, I 56-1 57. 


\section{Pro-slavery and Anti-slavery Demands.}

Topics and References.

1. How the slavery question was decided in California. 2. President Taylor's policy. - Resentment of southern extremists. 3. Pro-slavery demands. - Grounds for claiming a new fugitive slave law. 4. Anti-slavery demands. - Heated feeling of the time. Schurz, Clay, ii. 319-33I ; Lothrop, 63-75, 77; Holst, United States, iii. 404-407, 4I3, 46I-484; Rhodes, i. I04-I I9; Hart, Chase, :20-123.

\section{The Compromise of 1850. - Death of Presi-} dent Taylor. - Accession of President Fillmore.

\section{TOPICS AND REFERENCES.}

I. Jacksonian spirit of President Taylor. - Different temper of Congress. 2. Compromise brought about by Henry Clay. - Its leading supporters and opponents. 3. Death of President Taylor. - Approval of compromise measures by President Fillmore. Lothrop, 79-103; Rhodes, i. I19-137, I7I-IS0; Holst, United States, iii. 484-496, 5I5-543; Schurz, Clay, ii. 33I-355; Clay, iii. ch. vi.-vii., appendix, and vi. 426-591 ; Seward, i. 94-13I ; Johnston, Am. Orations, ii. 46-83, I I $8-134$.

4. Webster's "Seventh of March speech." - Feeling excited by it (text in Webster, v. 324-367, and, abridged, in Johnston, Am. Orations, ii. 84-I17). Rhodes, i. I37-161 ; Holst, United States, iii. 497-507; Hart, Contemp's, iv. 52-56.

5. The five measures of the compromise (text in MacDonald, ii. 378-390). Holst, United States, iii. 543-548, 555-56I ; Rhodes, i. I8I-I 85 ; Schurz, Clay, ii. 355-364.

6. The feeling that was satisfied by the compromise. Holst, United States, iii. 56I-562, iv. I4-2I ; Schurz, Clay, ii. 366-375.

\section{The Fugitive Slave Law.}

TOPICS AND REFERENCES.

I. Provisions of the law (text in Larned, Ready Ref.; Hart, Contemp's, iv. 56-58), and how they destroyed the safeguards of freedom for black men. 2. Passionate feelings excited by the law. 3. Appeals to a "higher law." - Personal liberty laws (text in Hart, Contemp's, iv. 93-96). - Riotous acts. Rhodes, i. I85-189, 
207-213. 222-226, I62-I68. ii. 73-7t: Holst, Cnited States, iii. 548-555. ir. 21-70. v. 61-70: Schurz. Clay, ii. 369-372, 375-376; Nicolay and Hay. iii. ch. ii. : Lothrop. $104-105$ : Seward, i. 5I-93; Hart, Contimp"s. ir. St-9I.

4. The "L"nderground Railway." Hart, Contemp's, iv. So-83, 91-93; Rhodes, ii. 74-77: Siebert.

5. "Incle Tom $\$$ Cabin." Rhodes, i. $27 S-2 S_{5}, 362-365 ;$ Holst, Cilited Statis, ir. $237-242$.

\section{Incidents of the Period. 1849-1852.}

TOPICS AND REFEREXCES.

I. Material prosperity and advance. 2. Clayton-Bulwer Treaty (text in MacDonald, ii. 373-377). Rhodes. i. I99-202: Wharton, ii. ch. vi. sect. I 50.

3. Perry's expedition to Japan. Griftis, ch. xxrii--xxxiii.

4. The Hulsemann letter (text in Webster, vi. 4\$S-506). Rhodes, i. 205-206: Holst. L'nited Statis, iv. 65-75.

5. Kossuth's visit. Holst, Linitid Statis, ir. 75-100; Lothrop, II -I IS: Rhodes. i. 23I-243.

6. The Lopez expedition. Rhodes, i. 216-222; Holst. Crnited States. ir. $+5-63$.

\section{Presidential Canvass of 1852. - Election of Franklin Pierce.}

TOPICS AND REFERENCES.

I. Weakened anti-slarery sentiment. 2. Nomination of General Scott by the Whigs and of Franklin Pierce by the Democrats. 3. Cause of Democratic strength. - Election of Pierce. Holst. Unitid States. ir. I33-134. I 40-231: Rhodes, i. 243-26r, 269-27s; Nicolay and Har. i. 330-333.

4. Deaths of Webster and Clay. Rhodes. i. 26I, 2\$5-2SS.

281. Minor Incidents of the Pierce Administration. TOPICS AND REFEREXCES.

I. The Martin Koszta affair. Rhodes, i. +16-419.

2. Reciprocity treaty with Canada. Rhodes, ii. S-9: Traties and Consintions, $+48-+52$. 
3. "Ostend Manifesto" (text in MacDonald, ii. to;-t12).

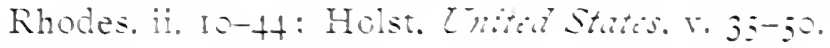

KesEARCH. - Walker's filibustering operations in Nicaragua and

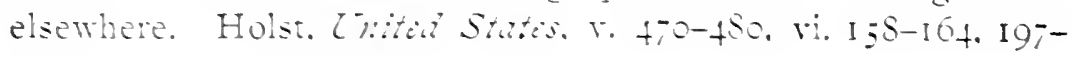
202 .

\section{Repeal of the Missouri Compromise by the Kansas-Nebraska Act.}

TORIC AND Refereices.

I. Senator Donglas's report and bill text in MacDonald. ii. 305-702. 2. Assumed effect of the Compromise of I\$50. 3. The primciple of "popular sorereignty" or "squatter sorereignty." 4. Division of Cebraska - Prorisions of the Kansas-Aebraska bill (texi in MacDonald. ii. 403-403). 5. Passage of the bill. Its opponents and supporters. 6. The political effect. Hart. Chasi: 133-135. I43-14-: Lothrop. 123-141: Holst. Crited States. ir. $28 z-461$ : Nicolay and Hay. i. 33-350: Rhodes. i. $424-400$. 494-506: Storey. II,-IIS: Lincoln. i. IS0-200: Davis, i. 27-2S:

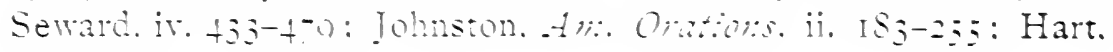
Com, s.

\section{Rise of the Republican Party.}

TOPICS AND RefEREXCES.

I. Faibre to gather andi-slavery forces into the Whig party, 2. Rise of the Republican party. 3. Lead of the west in forming the new pary. Rhodes. il. H-3: Nicolay and Hay i. ch. xa: Lothrop. ch. riil. Siorey i $7-130$ : Hart Chace I $50-152$ : Hart.

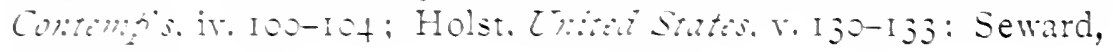
ir. $22:-240$.

\section{The American or "Know Nothing" Party.}

TOPICS ANI ReFERENCES.

I. Tative American organization against foreign-born citizens. 2. The secret society and its name. 3. Formation of the American party. Khodes. ii. 50-5: Holst. Cnitid Statcs. r. 79-129;

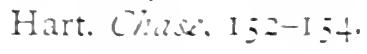




\section{The Strife for Kansas.}

\section{TOPICS AND REFERENCES.}

r. Why and how there was strife for Kansas. 2. Emigration from free States. - Armed invasion from Missouri. 3. The three governors who would not uphold the invasion. Rhodes, ii. 78-87, 98-107, 236-240: Nicolay and Hay, i. 393-418; Lothrop, I62-166; Holst, United States, v. 70-76, I3S-172; MacDenald, ii. +13-415; Seward, iv. 479-5I2; Hart, Contemp's, iv. rot-I 4 .

4. Lawless violence on both sides. - Mob destruction of Lawrence, and massacre by John Brown. Holst, United States, v. I72I 85, 286-313; Hart, Contemp's, iv. I It-1 I8; Rhodes, ii. I 5c-168, 215-220; Nicolay and Hay, i. ch. xxv.; ii. I9I.

\section{Election of Speaker Banks. - Assault on Senator Sumner.}

\section{TOPICS AND REFERENCES.}

I. Rapid anti-slavery consolidation in the Republican party, shown in the election of Speaker Banks. Rhodes, ii. ro7-II7; Holst, United States, v. I 86-223.

2. Senator Sumner's speech (text in Johnston, Am. Orations, ii. 256-28S) and Brooks's assault upon him. 3. Resignation and reëlection of Brooks. Storey, I3S-I64; Rhodes, ii. I3I-I 50 ; Holst, United States, v. 313-333; Johnston, Am. Orations, ii. 289-306.

\section{Presidential Canvass of 1856. - Election of President Buchanan.}

TOPICS AND REFERENCES.

I. Nominations of Buchanan, Frémont, and Fillmore. 2. Democratic and Republican declarations. Nicolay and Hay, ii. ch. ii.; Rhodes, ii. I69-186; Holst, United States, v. 256-270, 334-376.

3. Sectional vote for Frémont. - Menaces from the south. 4. Significance of Buchanan's election. Rhodes, ii. 202-21 5 , 220236; Holst, United States, v. 436-467.

\section{Dred Scott Decision.}

Topics AND ReFERENCES.

1. The case of Dred Scott in the Supreme Court. 2. The two questions involved. 3. Decision of the court that no descendant of a slave could be a citizen of the United States. 4. Further de- 
TOPICS, REFERENCES, AND RESEARCH. 48 I

cision that the Missouri Compromise enactment was unconstitutional (text in MacDonald, ii. 416-435). 5. Effect of the decision. Nicolay and Hay, ii. ch. iv.; Rhodes, ii. 249-27I ; Holst, United States, vi. ch. i.; Lincoln, i. 228-235 ; Hart, Contemp's, iv. I22I35; Lothrop, I81-I86.

\section{Collapse in Business. - Mormon Rebellion.}

Topics and References.

r. Causes of business collapse in 1857 . Blaine, i. ch. ix.; Holst, United States, vi. 99-I25; Rhodes, ii. 45-56.

2. Rebellious attitude of Mormons. Holst, United States, vi. I 29-1 50, 255-26r.

\section{Kansas, and the Lecompton Constitution.}

TOPICS AND REFERENCES.

I. Effort of governors Geary and Walker to deal honestly with the Kansas people. 2. Buchanan's assurance to Walker. 3. Freestate men hold aloof from the convention election. 4. The fraud of the Lecompton constitution (text in MacDonald, ii. 435-437). 5. Walker's denunciation of it. Rhodes, ii. 27I-28I ; Lothrop, I86I9I ; Holst, United States, vi. 47-96; Nicolay and Hay, ii. ch. vi.; Seward, iv. 574-6I 8 ; Hart, Contemp's, iv. II9-I 2 I.

\section{Revolt of Senator Douglas. - Defeat of the Lecompton Fraud.}

Topics And ReFerences.

r. Stand taken by Senator Douglas. 2. The fraudulent constitution sustained by President Buchanan. 3. Battle in Congress. - Division of the Democratic party. 4. Bribe offered to Kansas and rejected. 5. Defeat of the constitution. Rhodes, ii. 282-30I; Holst, United States, vi. ch. iv.-v.; Nicolay and Hay, ii. ch. vii.; Lothrop, I9I-I99.

292. Rally of Northern Democrats to Douglas. The Douglas and Lincoln Debate.

TOPICS AND REFERENCES.

r. Douglas's reëlection contested by Abraham Lincoln. 2. Reputation of Lincoln in Illinois. 3. The Lincoln and Douglas debates (text in Lincoln, i. 273-518). - Their revelation of Lincoln's abil- 
ity. 4. Election of Douglas. 5. His "Freeport Doctrine," and the new demand which it raised in the south. Nicolay and Hay, ii. ch. viii.-ix.; Morse, Lincoln, i. ch. v.; Rhodes, ii. 313-343; Holst, United States, vi. 267-29S; Tarbell, i. ch. xriii.; Burgess, Ciarl War, i. $46-j o$.

\section{The Purpose of the Republican Party.}

TOPICS AND REFERENCES.

I. Lincoln's statement of the issue. 2. Seward's statement. 3. The conviction to which a majority in the north was brought. Lincoln, i. 240-245: Seward, iv. 2S9-302; Hart, Contemp's, iv. I36I I I Holst, vi. $265-269.28_{3}-286$.

RESEARCH. - Compare this with Calhoun's view of the possibilities of the preservation of the Union. Holst, Calhoun. 339$3+9$.

\section{John Brown's Attempt at Harper's Ferry.}

Topics AND REFERENCES.

I. Brown's seizure of the armory at Harper's Ferry, and his plan. 2. Its quick discomfiture. 3. Death or capture of most of Brown's party. 4. His trial, condemnation, and execution. 5. His contentment with his fate. Holst, United States, vii. IS-59; Rhodes, ii. $3^{\delta_{3}-416}$; Nicolay and Hay, ii. ch. xi. ; Long, $8_{5}-86$; Hart, Contemp's. iv. I $44-150$.

RESEARCH. - Different views of John Brown and his undertaking.

Holst, Brow'n, 156-1 75, 204-232; Burgess, Civil War. i. 36-44; Thoreau.

\section{Threatening Declarations in the South.}

\section{TOPICS AND RefERExCES.}

I. No confederates of Brown in public life. - Political effect of his attempt. 2. Election of a Republican Speaker of the House. 3. Threatenings from the south. Rhodes, ii. 402.+17-4to; Holst, United States, vii. ch. ii.; Blaine, i. 155-156.

RESEARCH. - Helper"s book, "The Impending Crisis of the South," and its indication of a rising opposition to slavery in the south. Burgess, Cizil War, i. ch. ii. 
TOPICS，REFERENCES，AND RESEARCH. 483

296. Presidential Canvass of 1860. - Election of

\section{Abraham Lincoln.}

Topics AND REFERENCËS.

I. Southern secession from the Democratic national convention at Charleston. 2. Adjournment to Baltimore and second secession. 3. Nomination of Douglas by northern Democrats and of Breckenridge by southern. Rhodes, ii. 440-454, 473-475; Nicolay and Hay, ii. ch. xiii.-xiv.; Holst, United States, i. ch. iii., v.; Burgess, Civil War, i. 50-58, 69-70.

4. Nomination of Lincoln by the Republicans, and of Bell and Everett by Americans and Whigs. 5. Vigor of the Republican canvass. - The "Wide Awake" organization. 6. Election of Lincoln. Morse, Lincoln, i. ch. vi.; Nicolay and Hay, ii. ch. xv.xvi. ; Rhodes, ii. 454, 456-473, 477-502 ; Burgess, Civil War, i. 58-73; Holst, United States, vii. ch. iv., vi. ; Hart, Chase, I83196; Hart, Contemp's, iv. I 55-I 59; Lothrop, ch. xi.; Seward, iv. 679-680; Tarbell, i. ch. xix.-xx. 


\section{SECESSION, CIVIL WAR, AND REUNION. 1860-1880.}

\section{CHAPTER XV.}

THE WAR FOR THE UNION.

Its First Period: Sparing Slavery. I860-1862.

297. Secession begun. - President Buchanan's Message. - Efforts at Compromise. December, 1860-February, 1861. The Republicans had won the presidency, but they controlled neither branch of Congress; and a Republican President, opposed by majorities in the national legislature, could do no harm to slavery if he would. So argued the ablest statesman of the south, A. H. Ste- Alexander H. Stephens, of Georgia, in a speech phems, No- to the legislature of his State after the elec1860. tion of Lincoln was known. Nevertheless, the long-threatened movement of secession was set instantly on foot. South Carolina led the way, calling a convention to meet on the I 7 th of December for the action desired; and the Gulf States made ready to follow her lead. What would the national government do?

President Buchanan gave his answer when Congress met, on the $3 \mathrm{~d}$ of December, and his message was sent in. It was a message which Jefferson Davis (according to his own account) ${ }^{1}$ and other disunion leaders had

1 Davis, Rise and Fall of the Confoderate Government, i. 57-59. 
approved, in the main, before it was sent. They regretted that the President should feel called upon to question, as he did, the right of the slave States to secede; but that mattered little, since he went Buchanan's on to argue that no right or power to interfere message. with their secession could be found. Most of his feclings and opinions were in agreement with theirs, and if one of their own number had been President, they could hardly have controlled the executive arm of the government more completely than they did.

In Congress, the first impulse was to labor for some new contrivance of compromise. Many were ready to urge the repealing of all "personal liberty laws" in the northern States which hindered the execution of the Fugitive Slave Law; but that would not suffice. The slaveholding interest would listen to nothing less than the legalizing and protecting of slave labor in every Territory, as a constitutional right. Senator Crittenden, of Kentucky, proposed a constitutional amendment, restoring the Missouri Compromise line of $36^{\circ} 3 \mathrm{O}^{\prime}$, extending it to the Pacific, prohibiting slavery north of it, and protecting slavery south of it, according to the recent demand. Democrats

Proposed Crittendon Compromise. generally, at the north, and many Republicans were disposed to accede to this, if it would preserve peace. Mr. Seward appears to have had a hesitating inclination that way; but Mr. Lincoln stood firm in private remonstrance against the yielding of consent to any extension of slavery beyond its existing bounds. On other matters he would go far in concession for present peace, but not on that, which might postpone the threatened conflict, but only to bring

Mr. Lincoln's r $\theta-$ monstrance. it on at a later time. There was, he said, "but one compromise that would really settle the slavery ques- 
486 SECESSION, CIVIL WAR, AND REUNION.

tion, and that would be a prohibition against acquiring any more territory." I The Senate roted down the "Crittenden Compromise."

South Carolina had waited for no discussion of compromises, but held her convention and, on the 2oth of December, passed her "Ordinance to dissolve the Union between the State of South Carolina and other States united with her under the compact entitled the Constitution of the United States of America." Her example was followed in January by Mississippi, Alabama, Florida, Georgia, and Louisiana, and by Texas on the first of the next month. There the

Secossion of seven States. movement paused. In all these States there had been more or less of opposition to be overborne, and in Georgia, where Stephens led it, the opposition had been strong; but Stephens yielded readily to the action of his State, and most other Unionists appear to have done the same.

298. Surrender of Forts and National Property. Loyalty at Fort Sumter and Fort Pickens. December-January, 1860-1861. Meantime, the authorities of the seceding States were seizing forts, arsenals, arms, and other property of the United States, which the government at Vashington made no attempt to protect. It was believed that the Secretary of War, John B. Floyd, of Virginia, had prepared for these seizures by stripping arsenals in the northern States and filling those of the south; but that alleged treachery is disputed, and there seems to be some doubt about the facts. At least, it is certain that the heads of the national government, for some weeks after secession began, resisted nothing that the secessionists saw fit to

1 Lincoln, i. 657-659, 664, 668-669; Nicolay and Hay, iii. $2 S S$. 
do. In a few instances, however, there were officers of the army who defended their posts. The most notable example of such loyalty was given at Charleston, where Major Robert Anderson held command of three forts in the harbor, with a garrison of about sixty men. He had asked for more Major
Robert
Anderson. men, and they had been refused. On the 26 th of December, after the South Carolina ordinance of secession was passed, and while the President was listening to demands for the surrender of the forts, Major Anderson, on his own responsibility, spiked the guns of two of them, and concentrated his little force in Fort Sumter, the most defensible of the three (see Map in sect. 329). With difficulty, it appears, the President was dissuaded from ordering him back. Major Anderson's example was more than imitated at Pensacola, a little later, by Lieutenant Slemmer, who defied a command from his immediate superior to give up Forts Pickens and McRae. Abandoning the latter work, Lieutenant Slemmer held Fort Pickens until reinforced.

299. A Loyal Cabinet secured. December-January, 1860-1861. In the last days of December and early in January several changes in the cabinet of President Buchanan, caused by resignations, gave the administration a new character and altered the face of affairs. Joseph Holt, a loyal Kentuckian, took the place of Floyd, Secretary of War; General John A. Dix succeeded Howell Cobb, of Georgia, in the Treasury Department; Edwin M. Stanton became AttorneyGeneral in place of Jeremiah S. Black, who replaced General Cass in the Department of State. These were staunch Unionists and strong men, and their influence in the government was felt at once. General Dix thrilled the country (January 29) by telegraphing to treasury 
officials at New Orleans, where revenue cutters and cus-

General

Dix's telegram, January 29 , 1861. tom-house property were being turned over to the State: "If any one attempts to haul down the American flag, shoot him on the spot." But the message went too late; everything had been given up.

Early in January the President consented to an attempt to send 200 men to Major Anderson, at SumThe Star of the ter, with supplies; but the unarmed steamer West.

Star of the West which conveyed them was fired upon from hostile batteries already erected, and driven back.

300. Secessionists withdrawn from Congress. January-February, 1861. As fast as the revolting States accomplished their secession in due form, their senators and representatives withdrew from Congress, and before the end of January the Republicans were a majority in the House; while they lacked but one of a tie in the Senate vote. They were able in the latter Kansas body to pass two pending bills, received from admitted. the House in the previous session, one of which admitted Kansas to the Union, under a new constitution, adopted in 1859. The other bill, known as the Morrill "Morrill Tariff," made important changes in Tariff.

the duties levied on foreign imports, raising them from an average of about 19 per cent. to about 36. In both houses bills to organize the territories of Colorado, Nevada, and Dakota were passed. Both houses recommended to the legislatures of the States a constitutional amendment forbidding any future amendment that would give Congress the power to interfere with slavery in any State. The proposal met with no favor in the south.

301. Fruitless Peace Convention. - Organization of 
the "Confederate States of America." February, 1861. On the $4^{\text {th }}$ of February a Peace Convention of delegates from 2 I States met at Washington, on the invitation of Virginia, to seek anxiously for some ground of harmony; but it had no result. On the same day delegates from six of the seceding States met at Montgomery, Ala., and proceeded, first, to organize provisionally a Confederate government, and then to prepare the permanent constitution of the "Confederate States of America," for submission to the States. By unanimous vote, Jefferson Davis was chosen President and Alexander H. Stephens ViceJefferson
Davis,
President. President of the government thus formed.

302. Inaugural Address of President Lincoln.His Cabinet. March 4, 1861. On the 4th of March, I 86I, A braham Lincoln became President of the United States, and delivered an inaugural address which has taken its place among the masterpieces of political literature, - a model, in spirit, in thought, in expression, in accord with its occasion, that has never been surpassed. Of the duties he assumed and his intentions in performing them he said: "The power confided to me will be used to hold, occupy, and possess the property and places belonging to the government, and to collect the duties and imposts; but beyond what may be necessary for these objects, there will be no invasion, no using of force against or among the people anywhere." At the close he addressed himself with deep feeling to the discontented part of the nation in these words: "In your hands, my dissatisfied fellow countrymen, and not in mine, is the momentous issue of civil war. The government will not assail you. You can have no conflict without being yourselves the aggressors. You have no oath registered in heaven to 
490 SECESSION, CIVIL WAR, AND REUNION.

destroy the government, while I shall have the most solemn one to 'preserve, protect, and defend it.'

Abraham

Lincoln's I am loath to close. IVe are not enemies, but appeal.

friends. We must not be enemies. Though passion may have strained, it must not break our bonds of affection. The mystic chords of memory, stretching from every battlefield and patriot grave to every living heart and hearthstone all over this broad land, will yet swell the chorus of the Union when again touched, as surely they will be, by the better angels of our nature."

President Lincoln's cabinet, announced the following day, was composed of IVilliam H. Seward, Secretary The of State; Salmon P. Chase, Secretary of the cabinet. Treasury; Simon Cameron, Secretary of War; Gideon Welles, Secretary of the Navy; Caleb B. Smith, Secretary of the Interior; Edward Bates, AttorneyGeneral; Montgomery Blair, Postmaster-General. Mr. Bates was from Missouri, Mr. Blair from Maryland, the remainder were from free States. Mr. Cameron left the War Department in the following January, and was succeeded by Edrin M. Stanton, who had been Attorney-General in the last months of Buchanan's term.

303. Fort Sumter attacked and taken. ${ }^{1}$ April 1214, 1861. From the first hour of his responsibility the new President had appalling problems to face. Major anderson's Anderson reported that his provisions in Fort condition. Sumter were nearly exhausted, and that the hostile forces and batteries surrounding the fort were so formidable that 20,000 troops would be needed to defend it if attacked. What was to be done? Above all things, it was important that no blame for a beginning of warlike action should rest on the government, and no feel-

1 See map of Charleston harbor in sect. 329. 
ing on that score be provoked, north or south. On the other hand, it was equally important that the government should show no sign of weakness by giving up the fort. From either measure, evacuation or reinforcement, there were dangerous effects to be feared. The President listened to conflicting counsels on the subject, weighed them with the careful thought that made him the great man he was, and waited till the time drew near when Major Anderson must have supplies of food. Then he formally notified the governor of South Carolina that "an attempt will be made to supply Fort Sumter with provisions only; and that if such attempt be not resisted, no Notification to Governor Pickens, April 8, effort to throw in men, arms, or ammunition will be made without further notice, or in case of an attack upon the fort." The response to this notice was an immediate order to General Beauregard, commander of the Confederate forces at Charleston, which that officer obeyed by summoning Major Anderson to surrender, and by opening his batteries on the fort (April I2) when the surrender was refused. For thirty-four hours the bombardment was kept up, the few men in the fort returning the fire as effectually as they could, until their quarters were destroyed and their of Fort Sumter. magazine was surrounded by flames. On the afternoon of April r3, Major Anderson accepted terms offered by Beauregard, and on the following day, Sunday, April r4, he and his little company, with colors flying, marched out.

304. Loyal Uprising in the Country. - The President's Call for Troops. - Attack on the Sixth Massachusetts in Baltimore. April, 1861. The dreadful challenge which the government would not even seem to offer had been given by the revolting States, and the 
492 SECESSION, CIVIL WAR, AND REUNION.

aggressiveness of the act doomed their revolt to failure, by rousing and uniting such a feeling against it as nothing else could have stirred. No one knew the depth and strength of national sentiment in the country until news of the attack on Fort Sumter was flashed through the land and woke it with a shock. Party differences were nearly swept from men's minds for a time, in two thirds of the States. Prompt assurances went to the government that the power at its command, for maintaining its constitutional authority and resisting the destruction of the Union, was substantially the power of the whole population of the free States, and of the larger part of the people in the border slave States. President Lincoln had a rival and an opponent no Loyal stand longer, but a firm ally and a powerful supof Senator porter, in Stephen A. Douglas, the strong
Douglas. Douglas.
June 3 ,

enough, and only long enough, to make his stand known. In a speech at Chicago, on the ist of May, Douglas said: "There can be no neutrals in this war; only patriots - or traitors." On the $3 \mathrm{~d}$ of June he died, and the Union cause suffered its first great loss.

By proclamation, April I5, the President called for 75,000 of the militia of the States, to suppress combinations against the laws of the United States. The same proclamation summoned Congress to a special session

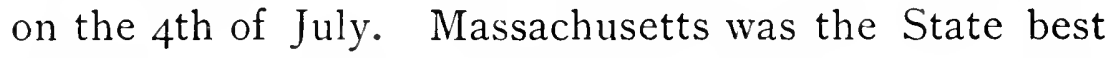
prepared to answer the call for militia, and the Sixth Massachusetts Regiment left Boston for Washington secession- on the I 7 th. Passing through Baltimore on Ist mob in
Baltimore, the I9th, the regiment was attacked by a mob, April 19. and had to fight its way from one railway station to another, losing four killed and one wounded 
in the fight. By burning bridges and tearing up tracks the Baltimore secessionists blocked the direct route to Washington for three weeks. They were suppressed by the strong loyal sentiment in Maryland, which soon gained the upper hand and kept it firmly throughout the war; but Washington was cut off from the north for some days, and in an almost defenceless state. After the Sixth Massachusetts, no regiments reached the city till the 25 th, when the Seventh New York and the Eighth Massachusetts arrived, by way of Annapolis, repairing bridges, tracks, and locomotives on the way. From that

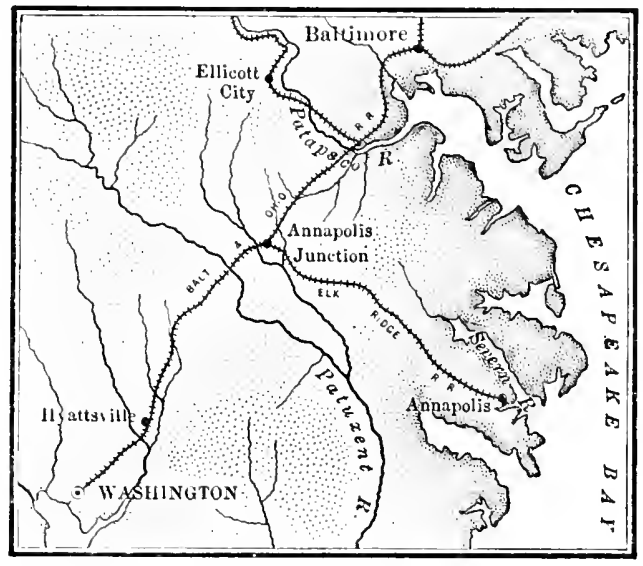

APPROACHES TO WASHINGTON FROM THE NORTH.

time the gathering of troops proceeded rapidly. On the $3 \mathrm{~d}$ of May the President called for 42,000 volunteers and for $\mathbf{I} 8$, 000 seamen, besides ordering an increased enlistment of regular troops.

305. Confederate Privateers. - Federal Blockade. British Proclamation of Neutrality. April-May, 1861. The Confederate Congress, sitting at Richmond, ordered the raising of 100,000 volunteers. On the 17 th of April the Confederate President, Davis, issued an offer of commissions to privateers, for preying on the ocean commerce of the country; to which President Lincoln replied on the igth, proclaiming a blockade of southern ports, and declaring that the proposed privateers would be dealt with as pirates when taken at sea. These 
494 SECESSION, CIVIL WAR, AND REUNION.

measures led the British government to issue a proclamation of neutrality, on the I 3 th of May, thus recognizing the Confederates as belligerents, putting their cruisers on a legal footing, and giving them the rights of war. This excited bitter feeling at the time; but, inasmuch as our own grovernment was forced before long to concede belligerent rights to the Confederates, there was nothing to be complained of with good reason in the queen's proclamation except the haste with which it was put forth.

306. Second Secession Movement by Four More States. April-May, 1861. In most of the slave States the effect of President Lincoln's call for troops was to reinforce the secession movement by large numbers of people who had resisted it before. The right to secede was one of the "state rights" they believed in, and, while opposed to the present exercise of the right, they were opposed to the cienial of it still more. They would opposition not take part in " coercing a sovereign State." to "coer- That was the attitude of many persons in the State." eight slave States that stood aloof from the first movement of secession. After the I $5^{\text {th }}$ of April such persons went over to the secessionists in a body, and joined in carrying Virginia, North Carolina, Arkansas, and Tennessee into the rebellious league. ${ }^{1}$ Another class of people in those States opposed secession to the end, and grieved bitterly over the breaking of the

1 Ordinances of secession were passed in Virginia, April 17 ; in Arkansas, May 6; in North Carolina, May 2I. The Tennessee legislature voted a military league with the Southern Confederacy on the Sth of May and ratified the Confederate Constitution, subject to a vote of the people, which was given affirmatively on the 8th of June. 
Union, but felt bound to accept the action and share the fortunes of their States. This was the feeling of General Robert E. Lee. It was not Robert E. the Southern Confederacy, but Virginia, that drew him away.

307. The Border Slave States. - Kentucky and Missouri held in the Union. April-September, 1861. None of the different feelings that carried Virginia and Tennessee into the Confederacy were effective in the mountain regions of those States. There, in West Virginia and East Tennessee, whose moloyal people, to a large extent, were of the strong eers. and stubborn Scotch-Irish stock, holding few slaves, caring little for the "peculiar institution" and less for "state rights," there was a faithfulness to the Union which nothing overcame.

A long, hard struggle between Unionists and secessionists in Kentucky was made successful to the former by President Lincoln's wise course. Had he yielded to the hot demand of northern radicals for hasty uincoln's and violent measures against slavery, every wisdom. border slave State would have become hostile; and no one else saw so clearly as he did how enormously the difficulties of the government would be increased if that occurred. In Missouri the contest for control of the State was severe, and the first serious operations of war were there. The Unionists had a bold and able leader in Francis P. Blair, Jr., of St. Louis, whose influence had brought about the formation and training of four regiments in that city Blair and Lyon at St. before the opening of the war. Blair's exertions were seconded energetically by Captain Nathaniel Lyon, U. S. A., who commanded the national arsenal at St. Louis, and he had the support of a large German popu- 
496 SECESSION, CIVIL WAR, AND REUNION.

lation in the city, which was loyal to a man. Blair and Lyon were able to baffle the designs of a secessionist governor and legislature, to save the arsenal from seizure, to make St. Louis safe, and, ultimately, to hold the State.

308. The Opposing States and People in the War. According to the census of I860, the population of the United States and Territories that year, in round numbers, was $31,440,000$. A few more than 9,000,000, or less than one third of this population, was found in the I I States now at war with the remaining 23 States; and over 3,500,000, or more than one third of the popu-

ComparaCompara- white inhabitants, the States of the revolting
tive num-
bers.

Confederacy numbered less than 5,500,000, against more than $21,500,000$ in the States and Territories adhering to the Union and upholding it in the pending civil war. From three of the latter States, some considerable number of men went south to join the armies of the Confederacy; but what they added to its military strength was offset, or nearly so, by the Unionists of West Virginia and eastern Tennessee who entered the armies of the United States.

In wealth, and in all the resources that make up military power, the superiority was even greater on the side of the loyal States. The active capital of the country, its mechanical industries, its commercial enterprises, Northern were almost entirely in their hands. Their resources. railroads and other means of transportation were more extensive and much better in equipment than those of the south. They were prepared for the self-supplying of most of their needs, in peace or war, while the instruments and agencies of trade with the outside world were under their control. In their mate- 
rial circumstances they had really no injury or deprivation to fear from the state of war.

On the other hand, the States of the Confederacy had little to draw upon for supporting a war except their plantations and the unskilled labor of their slaves. Their undertakings in manufacture were few and small, and not many of their

\section{Southern} deficlencles. people were mechanically skilled. They depended on the sale of their cotton and tobacco crops for means with which to purchase most things that they needed, aside from food. When the exportation and sale of those crops vere interrupted by the blockade of their ports, they were distressed by want of many of the commonest comforts of life; their armies were sorely crippled by lack of proper military supplies, and their railroads could hardly be kept in any serviceable state.

But, while they fought under great disadvantages, with a foe far more powerful in numbers and resources than themselves, the people of the Confederacy had important advantages of their own in the war. (I) They fought defensively, for the most part, in positions where their. forces were often matched fairly against larger numbers on the attacking side.

(2) Fighting on their own ground, their better knowledge of it, and their better means of learning all the move-

Confederato advantages. ments of their opponents, were often worth more to their commanders than many regiments of men. Their military movements, in shifting forces from one point of defence to another, were on lines much shorter than the attacking forces could be moved upon, which is an advantage of great importance in war. (4) The very stopping of their cotton production, and the overthrow of all prosperity among them, compelled them to devote themselves wholly to the war, making it the 
498 SECESSION, CIVIL WAR, AND REUNION.

sole business of everybody; while a large majority of the people on the other side were continuing their usual pursuits, and only detailing, as it were, a certain minority to conduct the war. (5) Their slaves, attempting no insurrection, but giving faithful service in labors of the camp as well as in those of the plantation, were no source of weakness to them, but one of positive military strength.

Considering all things, the 22,000,000 (almost) of people who upheld the Union were none too many, and their wealth and their resources were none too great, for the task they had taken in hand. To wear out the resisting power of $5,500,000$ of an indomitable race was an almost impossible thing to undertake and a dreadful thing to do.

309. The First Notable Victims of the War. Slaves declared "Contraband." May-June, 1861. The first advance from Washington was made on the $23 \mathrm{~d}$ of May, when troops crossed the Potomac to occupy Alexandria, and the neighboring Virginia shore. The advance was led by a much admired regiment from

Colonel New York, and its young commander, Colonel Ellsworth. Ellsworth, became the first notable victim of the war. While removing a Confederate flag from a hotel in Alexandria, he was shot by the owner of the house. Theodore The next death of note was that of Theodore winthrop. Winthrop, a brilliant young writer, who fell in an encounter at Big Bethel, near Fortress Monroe, on the Ioth of June.

The commander at Fortress Monroe, General Benja-

General

Butler's

min F. Butler, had given great satisfaction to dictum.

the country a few days before (May 24) by declaring that slaves who escaped from Virginia owners to his lines were "contraband of war," and 
should be surrendered to no claimants except those who took the oath of allegiance to the United States. This dictum was approved by the government, and settled its first line of policy in dealing with refugee slaves.

310. McClellan in Loyal West Virginia. - Its Secession from the old Dominion. 1861-1862. Late in May, an important campaign was opened in West

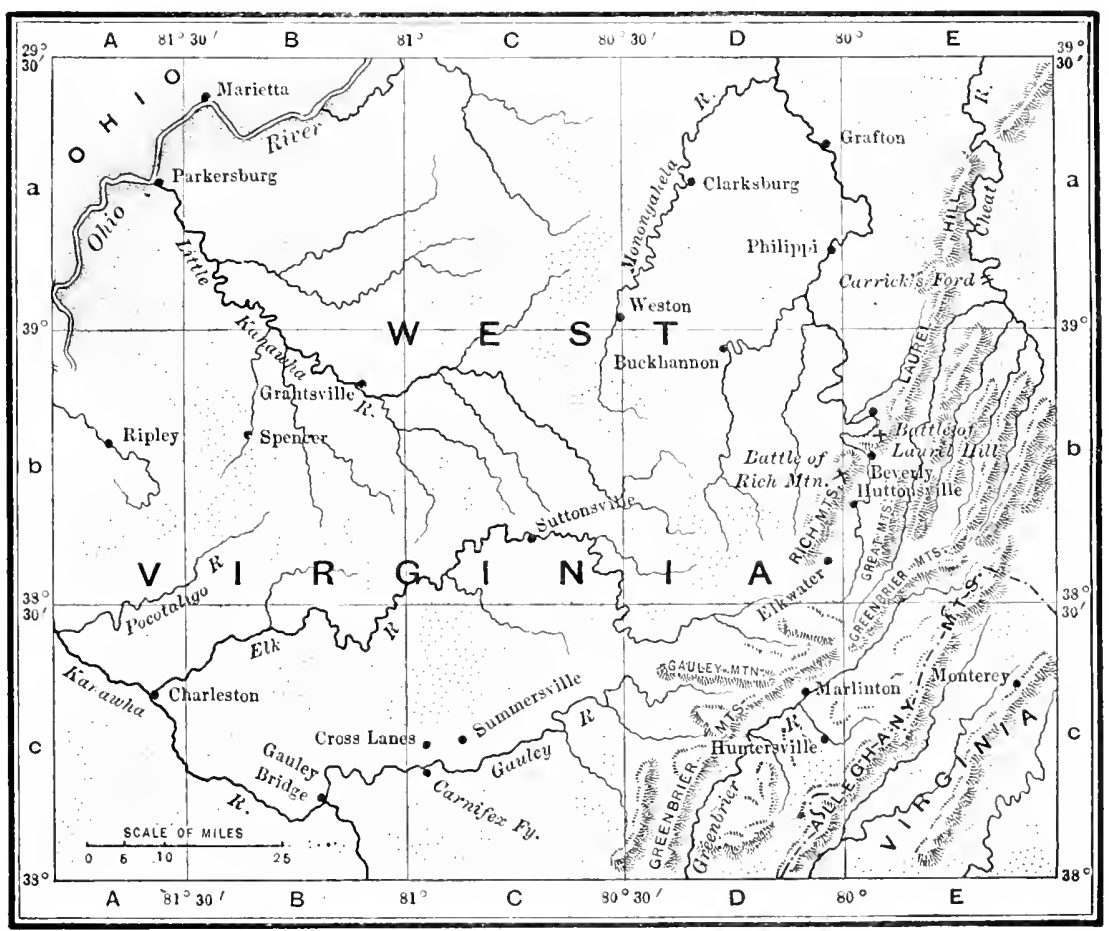

FIELD OF WAR IN WEST VIRGINIA.

Virginia by General George B. McClellan, a West Point officer of distinction, who had resigned from the army a few years before to accept employment in civil life. Like most officers from the north who had left the army, he had been prompt in answering the national call to arms. During June and the first half of July, McClellan's forces won a series of engagements at 
500 SECESSION, CIVIL WAR, AND REUNION.

Philippi, Rich Mountain, Laurel Hill, and Carrick's Ford, which freed West Virginia for a time. This protected the Unionists in action taken to organize what assumed to be the lawful government of the State of Virginia, and it was recognized at Washington as such. Some months later (May, I 862) this somewhat fictitious government of the old State of Virgimia authorized the organization of IVest Virginia as a separate State, which Congress admitted to the Union in December, I 862.

311. President Lincoln's First Message. - Action of Congress. July-August, 1861. The special session of Congress opened on the $4^{\text {th }}$ of July. The President's message to it was a remarkable paper, and it influenced the country with the singular power that always attended Mr. Lincoln's words. The unity of feeling in Congress was so great that a resolution pledging "any amount of money and any number of men" that might be needed was adopted in the House of Representatives with only five opposing votes, though 70 Democrats and Constitutional Unionists were in the membership of the House. What the President had done in advance of law was approved; authority was volunters, a loan of $\$ 250,000,000 ;$ an increase of revegiven to raise 500,000 volunteers and to make July, 1861. nue was provided for by higher duties and by an income tax, and an act "to confiscate property used for insurrectionary purposes," including slaves, was passed.

312. First Battle of Bull Run. ${ }^{1}$ - McClellan called to the Army of the Potomac. July-August, 1861 . By the middle of July the Union army on the Potomac, at and near Washington, numbered about 30,000 men, ${ }^{1}$ See Map XII. 
and $\mathrm{I} 8,000$ or 20,000 more were in the Shenandoah valley. General Irwin McDowell, an excellent officer of the regular army, commanded the former, and the latter force was under General Patterson, a veteran of the Mexican War. McDowell was confronted by General Beauregard, with nearly 22,000 Confederate troops, at Manassas Junction, and Patterson by General Joseph E. Johnston, who had but 9000 men. There was impatience in the country for some action by the main armies of the Union, and McDowell moved forward on the i6th of July. Patterson was directed to keep Johnston's force engaged and allow none to be sent to join Beauregard. He failed to do so, and the Confederates slipped from him, with fatal consequences to the movement of McDow-

Cause of Union defeat. ell. When the latter attacked his opponent, at the little stream called Bull Run, on Sunday, July 2 I, 6000 of Johnston's troops had reached the ground already, and the remainder arrived that afternoon, in time to change the fortunes of the day. The Union army had substantially won the battle, when the fresh troops broke their line, and a wild rout ensued. It was a mob rather than an army that fled back to the fortifications on the Potomac, and it seemed almost, for the moment, that the national cause

was lost. But after the first shock of humiliation and alarm, the spirit of the country and of the army rose again to more resoluteness than before.

General McClellan was now appointed to the command of the Army of the Potomac, and became the idol of its officers and men. For the work of military organization his ability was unsurpassed, and an army of imposing magnitude and power grew under his hands.

313. Important Commands and Commanders. - 
502 SECESSION, CIVIL WAR, AND REUNION.

McClellan at the Head. July-October, 1861. The command next in importance to McClellan's was that of the Department of the West, to which General Frémont was appointed on the $9^{\text {th }}$ of July. The Confederates in Missouri had then been driven by Lyon into the southwestern corner of the State; but they were rallying superior numbers against him, and he received

Battle of

Wilson's

Creek. no help, except from a small force under Sigel, a German officer, whose name began to be on men's tongues. On the Ioth of August Lyon was killed in a desperate battle fought at Wilson's Creek.

While one most promising career came thus to an untimely end in the west, another was opening not far ulysses S. away. Frémont had appointed General Ulysses Grant.

S. Grant to the command of a district on the Mississippi River, embracing southeastern Missouri and southern Illinois. Grant was a graduate of West Point who had left the army six years before, but returned to service as a volunteer. Soon after assuming his dis. trict command he seized Paducah, at the mouth of the Tennessee, - a position the importance of which he was to demonstrate at a later day.

The administration of the Department of the West by General Frémont proved unsatisfactory in many respects. Without authority, and in defiance of the well-considered policy of the government, he issued a Frémont's proclamation, on the 3 Ist of August, assuming emancipa-
tion prociamation, August, 1861 . of all persons in arms within his department, and threatening a summary execution of every one taken in arms within a certain region that he described. By the excitement that this caused, among thoughtless anti-slavery people who applauded it, on one 
hand, and in the border slave States on the other, serious mischief was done. The proclamation was modified by President Lincoln, to accord with the confiscation act of Congress; and finally, in October, it became necessary, for many reasons, to remove Frémont from his command.

The Department of the West was then divided, General Halleck commanding in Missouri, General Hunter

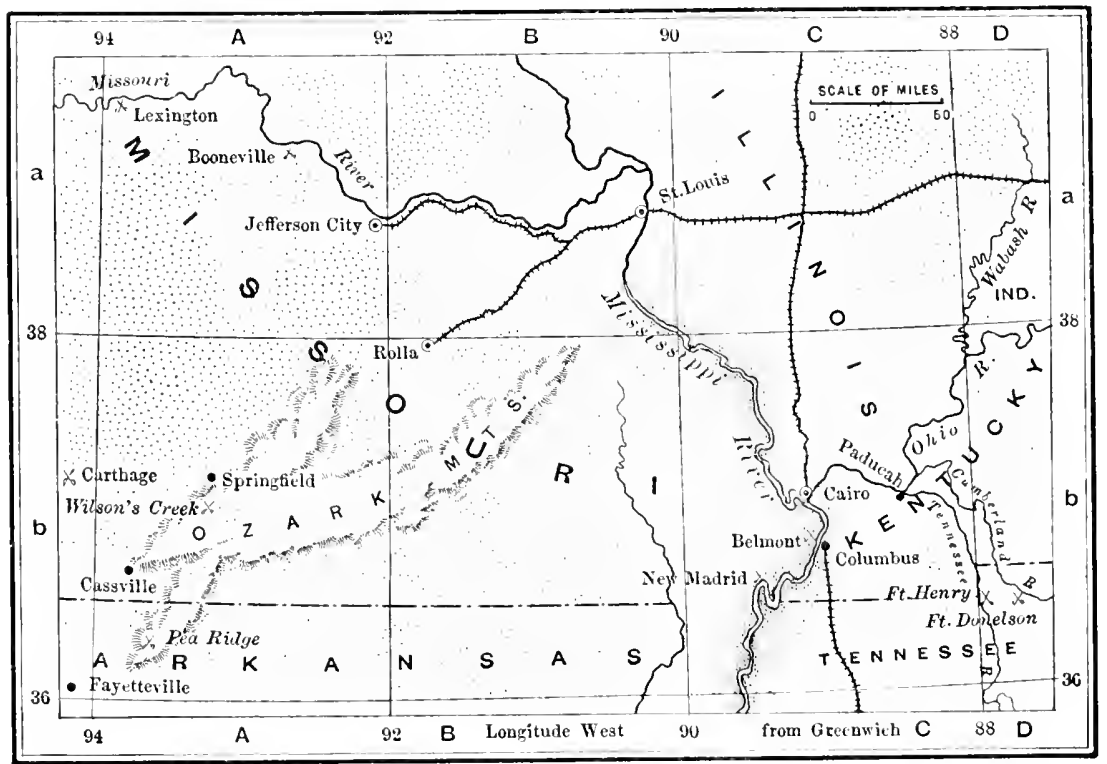

FIELD OF WAR IN AND AROUND MISSOURI AND WESTERN KENTUCKY.

in Kansas, and General Canby in New Mexico. At the same time General Don Carlos Buell was assigned to command the Department of the Ohio, and General Rosecrans to that of West Virginia.

At the end of October General Scott retired from the general command of all the armies (under the President, whom the Constitution makes Commander-in-chief), and General McClellan McClellan succeeds Scott. was raised to his place. At that time the Army of the 
504 SECESSION, CIVIL WAR, AND REUNION.

Potomac was i68,000 strong, in excellent condition, and splendidly equipped. It is now known from the Corfederate records that the army confronting it, under General Johnston, numbered but 4r,000 effective troops; but McClellan estimated them at 150,000 , and reported that he could not attack them in their intrench-

Strength

of Army of ments with less than 240,000 men. ConsePotomac. quently, throughout the fall and winter, the great army in his hands was unused.

314. The Blockade. - Joint Naval and Military Operations. 1861-1862. The most effective work of that period was in the blockading service of the navy, and in joint naval and military expeditions on the Atlantic coast. By purchasing and adapting steam ressels of every available kind, a sufficient navy had been made up for what became an effective blockade of southern ports. Nothing in the operations of the war could cripple the Confederate States more than a blockade that would keep their raw cotton and other sources of wealth from going out to be sold, and manufactures (of war materials especially) from coming in. This could not be done perfectly, for blockade-running by swift Blockade- British steamers was carried on with great running. energy and boldness, especially from ports in the Bahamas and Bermudas; but it was accomplished so far as to cause extreme porerty and clistress in the blockaded States, and to add enormously to the difficulties with which their armies were equipped and their railroads kept up.

Stoppage of the American cotton supply was ruinous to British manufacturers, and a hostile feeling toward the United States prevailed generally in the business circles of Great Britain, as well as among the people of the aristocratic class; but the working people of the 
English factories were steadfast in friendly sympathy with the American Republic through all the time of bitter suffering that the "cotton famine" brought upon them; and their fecling "Cotton
famine" in
England. was due largely to the influence of a few men like John Bright.

One naval exploit, in November, I86I, might have caused war with England, if public feeling had controlled the action of government. The Trent, a British steamer from Havana, was intercepted by an American war steamer, the San Jacinto, and two envoys, Mason and Sliclell, commissioned to represent the Confed-

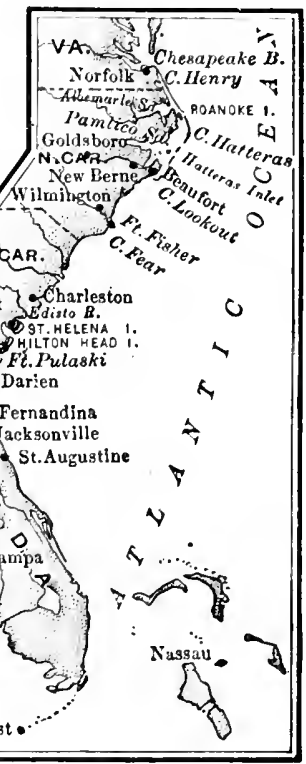

THE BLOCKADED COAST.

eracy in England and France, were taken from her and brought as prisoners to Boston. The act was in violation of international law, and when the British government demanded the release of the captives, they were given up; but the country was angered by the threatening manner of the demand.

The effectiveness of the blockade was improved steadily, after the first few months of war, by the capture of advantageous footings on the southern coast. 
506 SECESSION, CIVIL WAR, AND REUNION.

Forts commanding Hatteras Inlet were taken in August, IS6I ; Port Royal, South Carolina, in NoremBlockado
strength- ber; Roanoke Island and New Berne in Janened.

uary, IS62, and the entrance to Sarannah was sealed up in April by the reduction of Fort Pulaski, after a long siege.

315. First Breaks in the Confederate Line of Defence. ${ }^{1}$ February-April, 1862. Army and nary worked together with great success in these undertakings; and so they were beginning to do on the rivers of the west, where fleets of small gunboats had been put afloat. The first real break in the Confederate line of defence was accomplished in February, IS62, when General Grant and Commodore Foote, moring up the Tennessee,

Forts captured Fort Henry, on that river, and then Forts and Fort Donelson on the Cumberland, with gar-
Doneison. risons numbering $\mathrm{I} 2,000$ to 15,000 men. This opened the whole of western Tennessee to an advance. Grant moved up the Tennessee to Pittsburg Landing, near Shiloh, while General Buell came forward from Kentucky to Nashville, and thence, with a part of his army, to a junction with Grant. The Confederates had concentrated large forces at Corinth, Mississippi, under Battle of Albert S. Johnston and Beauregard, and Grant Shlloh, was nearly overwhelmed by an attack from ${ }_{\text {Apri1 6. }}$-7, them, April 6; but Buell reached him that night, and the Confederates were driven back the next day. The battle of Shiloh, fought fiercely for two days, was the deadliest engagement that had occurred, the losses in killed and wounded rising nearly to 10,000 on each side.

One division of Buell's army, under General O. M. Mitchell, was marching southward from Nashville, at 1 See IIap Xili. 
the same time, and reached Tuscumbia, in Alabama; but the position it gained was not held.

Opportunity for another break into the heart of the Confederacy had been opened in January by General George H. Thomas, who commanded, under Buell, in eastern Kentucky. Defeating the Confederates in a battle at Mill Spring, he cleared the way for an advance through Cumberland Gap into east Tennessee, where thousands of Unionists were watching eagerly for the old flag to reappear. President Lincoln had been urging such a movement from the

\section{Battle of} Mill Spring, January 19,1862 . first, but the opportunity gained by Thomas was allowed, for some reason, to go by.

After helping Grant to open the Tennessee and the Cumberland, Commodore Foote, with his gunboats, joined General John Pope in operations of great difficulty on the Mississippi, which resulted in the capture of strong fortifications at New Madrid (March I3) and Island No. Io (April 7). Many

New Madrid and Island No. 10. prisoners were taken, and the navigation of the Mississippi was cleared for a long distance to the south. Meantime the Confederates had been forced from southwestern Missouri into Arkansas, by General Curtis, and defeated (March 5) in an important battle at Pea Ridge.

316. Inaction in Virginia. January-March, 1862. While progress was made by the Union arms in the west and on the coast, the Army of the Potomac, bigger and better appointed than any other, was still in camp. Its prolonged inaction was hurting the national cause, and, on the $27^{\text {th }}$ of January, the President felt impelled to issue an order for "a general movement of the land and naval forces of the United

The President's order. States against the insurgent forces "to be made on the 
22d of February, with a special order that the Army of the Potomac be moved. In the west the appointed date was anticipated by General Grant. In Virginia, when the 22d of February arrived, the Confederate general, Johnston, was in motion, but the Union general, McClellan, was not. The former was evacuating Manassas, preparing to fall back behind the Rappahannock, lest the huge Potomac army should be launched against him. Two weeks later McClellan's columns were pushed Advance out to Manassas and Centreville, where they begun. found abandoned earthworks, partly furnished with painted wooden cannon - "Quaker guns," the soldiers called them - to make a show of armament where real artillery had been wanting.

317. The Merrimac and the Monitor. March 9, 1862. An event of greater importance than the evacuation of Manassas had happened just then in Hampton Roads. Both parties in the war were building ironclad ships. Such vessels had never, at that time, been tried in actual battle; though France and England had been experimenting with them for two years. The ConThe Mor- federates had raised a sunken steam frigate, rimac. the Merrimac, at Norfolk, and covered her with railroad iron; while the government of the United States had ordered an iron-clad vessel to be built on plans devised by John Ericsson, a Swedish-American engineer. Early in March, I 862, it was known that the Merrimac was about ready to come out of Norfolk, and great efforts were made to have her met by Ericsson's vessel, named the Monitor, when she appeared in Hampton Roads. On Saturday, March 8 , the Merrimac steamed slowly out of Norfolk, and attacked the blockading squadron, of five wooden ships. Their broadsides were harmless to her, and she destroyed with ease 
two sailing vessels, the Congress and the Cumberland. As the tide then was ebbing, the monster withdrew, to return next morning and complete her work. But that evening the Monitor came on the scene, - a queer,

Sinking of the Congress and Cumberland. low-lying, flat float, carrying a revolving turret, in which were two heavy guns, - looking, as described at the time, "like a cheese-box on a raft." When the Merrimac reappeared, on the morning of the 9 th, a battle occurred which revolutionized the naval

The battle. warfare of the world. The Monitor was easily handled, and could plant her shots as she pleased; the Merrimac was unwieldy, . and much at the mercy of her nimbler foe. Neither did much harm to the other; but the Confederate iron-clad retreated to Norfolk, and two months afterward, when the Confederates abandoned Norfolk, she

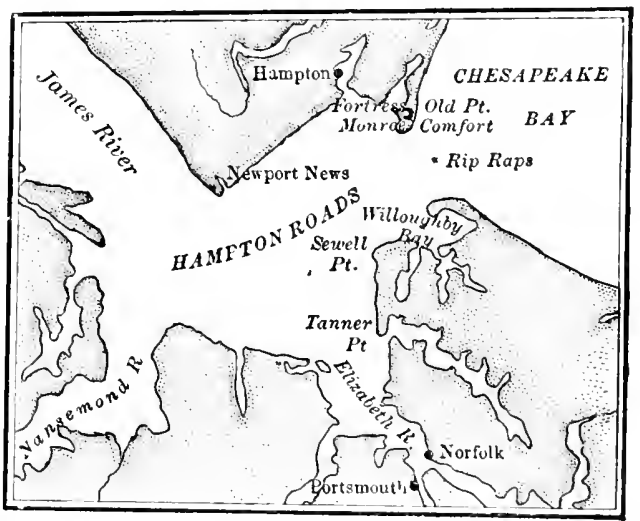

HAMPTON ROADS. was destroyed. There had been a panic in all the northern coast cities when they had the news of Saturday; the relief given them by Sunday's report was very great.

318. Work of Congress. 1861-1862. In Congress, during the session of $\mathrm{I} 86 \mathrm{I}-62$, important work was done. The financial situation, already desperate in the Financial Confederacy, had become grave in the north. distress. The banks, drained by heavy loans to the government, suspended specie payments in December, IS6I, and for 
seventeen years from that time there was no monetary circulation of gold and silver coin. Expenditures of government had risen to $\$ 2,000,000$ per day, and how to meet them was a question on which financial authorities were not agreed. The decision reached in Congress included one measure that had pernicious effects, and whether it was or was not necessary is disputed to The "Le- this day. That measure is known as the "Legal The "Le-
Act." Act." authorized an issue of $\$ 100,000,000$ of treasury notes, bearing no interest, not redeemable in coin, but "legal tender" in payment of all debts. In other words, the law compelled creditors to accept them, and so gave them a circulation that was forced. ${ }^{1}$ This was the beginning of a series of similar issues, which plunged the country into a long, costly experience of irredeemable, depreciated paper money, inflated prices, speculative business, and extraragant habits in public and private life.

Later in the session the tariff was revised again and Tariff. duties raised, - a process repeated at every session of Congress till the end of the war, - while a searching system of internal taxation was derised.

In March, on the urgent recommendation of the President, Congress adopted a joint resolution to the effect offer of that "the United States ought to coöperate compen-
sated eman. with any State which may adopt gradual abolclpation, March, 1862. ishment of slavery, giving to such State pecuniary aid," and Mr. Lincoln made persevering efforts to persuade the border slave States to accept

1 By a decision of the Supreme Court in I $\$ 69$ the legal tender acts were declared to be unconstitutional; but that decision was reversed in the following year. 
such aid. At about the same time Congress arlded an article to the military code, forbidding officers to restore fugitive slaves to their masters. In April Congress took another step on the slavery question, by abolishing slavery in the District of Columbia, with compensation, and with provision for

Emancipation in the District of Columbla, April. 1862 . colonizing any of the freedmen who wished to be settled in Hayti or Liberia.

At this time the Confederate Congress was passing a conscription act, requiring military service from every able-bodied citizen between the ages of eighteen and thirty-five.

319. Opening of the "Peninsular Campaign" against Richmond. ${ }^{1}$ April-June, 1862. When, at last, the Army of the Potomac took the field, the line of movement chosen by McClellan was by water to the foot of the peninsula between York and James rivers, thence to advance on Richmond, which had been the capital of the southern Confederacy since May, I86I. General McClellan was now relieved of the command of all forces except those in this " peninsular campaign." At the beginning of April, I862, a large part of his army had been landed near Fortress Monroe, and the

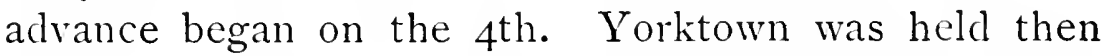
by only i 2,000 Confederates, but the fortifications were strong, and siege operations to reduce them Siege of consumed a month. When the siege guns Yorktown. were ready to open fire, the besieged withdrew (May 4), falling back to Williamsburg, where the van of the Union army suffered heavily in a battle fought next day. As the Confederates continued their retreat, the Army of the Potomac was pushed forward slowly to a line on the Chickahominy, seven to twelve miles from 1 See Map XII. 
5 I 2 SECESSION, CIVIL WAR, AND REUNION.

Richmond, which it reached on the 2 Ist of May. Mean-

\section{Norfolk} time the Confederates had evacuated Norfolk evacuated. and destroyed the Merrimac, opening James River to a forward movement of Union gunboats and the Monitor, and they, too, went up to a point only eight miles from the threatened city.

McClellan, whose army exceeded I00,000, with 73,000 opposed to him, thought nothing could be ventured without a larger force, and arrangements were made for sending McDowell to him, with a corps of 40,000, which had been held for the protection of Washington. But that plan was frustrated by an alarming raid into the "stonewall" Shenandoah valley, led by the Confederate Jackson's general, Thomas J. Jackson (better known as
radd.

"Stonewall " Jackson ${ }^{1}$ ), who made the beginning of his fame at this time. Jackson's brilliant exploit kcpt McDowell from joining McClellan.

320. Farragut's Capture of New Orleans and Opening of the Lower Mississippi. April-June, 1862. From the southwest, in these days, there was better news. A fleet of old wooden ships and gunboats, under Admiral Farragut, had run a gauntlet of forts on the lower Mississippi, destroyed or captured fifteen opposing vessels, including two clumsy iron-clads, and had taken the city of New Orleans (April 24). An army of 14,000

Butler

in New

Orleans,

May 1,

1862 . men, commanded by General Butler, had then been landed, the forts had been surrendered, and the city was entered by the Union troops on the Ist of May. A more brilliant naval achievement is hardly on record, and it gave the Confederacy a staggering blow.

1 A remark made by one of his fellow officers at Bull Run, that Jackson's command stood like a stone wall in the fight, gave him that name. 
From New Orleans Farragut pressed on up the Mississippi (see Map XIII.), and every town on the river as far north as Vicksburg was surrendered to him in the course of the next two months. Vicksburg, on high bluffs, powerfully fortified, was not to be taken so easily; its capture became the grand problem of the war in the west.

A bove Vicksburg the Confederates held no formidable position on the river. Movements of the Union army after the battle of Shiloh had expelled them from a stronghold named Fort Pillow. Then the Union gunboat flotilla (which Commodore Foote, disabled by a wound, had passed over to Commodore Davis), ran down to Memphis, destroyed nine Confederate gunboats in a sharp fight, and received the surrender of the town (June 6).

321. Failure of the "Peninsular Campaign." MayJuly, 1862. In McClellan's campaign a bloody battle, forced by the Confederates, was fought for two days, May $3 \mathrm{I}$ and June I, with losses of 5000 or 6000 on each side. Two corps of the Union army, which had passed the Chickahominy, were nearly overwhelmed. In this battle of

\section{Battle of} Fair Oaks, May 31June 1, 1862 . Seven Pines or Fair Oaks, General Johnston, who had hitherto commanded the Confederate forces in Virginia, was disabled by a wound, and General Robert E. Lee took his place.

Nearly a month went by after the battle of Fair Oaks before the armies in front of Richmond came to serious blows again, and then, as before, it was the Confederate general who attacked. Calling Stonewall Jackson from the Shenandoah, and leaving Richmond almost unde-

Opening of the "Days' Battles," June 2627,1862 . fended, Lee boldly launched the main body of his army 
5 I4 SECESSION, CIVIL WAR, AND REUNION.

against a single corps (Fitz John Porter's) that guarded the road over which McClellan received his supplies. For two days (June 26-27), in battles at Mechanicsville and Gaines's Mill, Porter held his ground, and received no reinforcements till too late. Two brigades came to him on the evening of the 27 th, in time to cover his retreat.

McClellan had now lost communication with his source of supplies, and must retreat, either down the peninsula or across to James River. He chose the latter, and all critics credit him with able management End of of the retreat. Lee followed him closely, and the "Seven there were five more day's of battle, principally Battles," July 1, at Savage Station, Glendale, and Malvern Hill, while the movement went on. At Malvern Hill Lee's army was repulsed with terrific loss, and the "Seven Days' Battles" ended with both armies in a shattered state.

The peninsular campaign against Richmond had failed, and the country was profoundly depressed. On the $2 \mathrm{~d}$ of July the President called for 300,000 more men. Faith in McClellan as a fighting soldier had long been waning, and now there was clamor for his removal; but his army was still devoted to him, and the President feared. the effect of a change. It was determined, however, against McClellan's protest, that his army should return to the Potomac. General Halleck was called to Washington to serve as general-in-chief, and General Pope, who had shown energy on the Mississippi, was put in command of an "Army of Virginia," formed of all the Virginia forces except McClellan's men. 
TOPICS AND SUGGESTED READING AND RESEARCH.

297. Secession begun. - President Buchanan's Message. - Efforts at Compromise.

TOPICS AND ReFERENCES.

I. Argument of Alexander H. Stephens against secession. McPherson, 20-26; Hart, Contemp's, iv. 164-169; Nicolay and Hay, iii. 266-275; Rhodes, iii. 207-2I2.

2. Action of South Carolina. 3. Position taken by President Buchanan. - His message approved by secessionists. Rhodes, iii. I1 $4-125,132-138$, 196-206; Nicolay and Hay, ii. 303-31+ 326335. 358-37I; iii. I-I6; Burgess, Ciril II ar, i. 74-89; Holst, United States, vii. ch. ix.; Nicolay, I6-20; Hart, Contemp's, iv. 182-187, 196-199.

4. Projects of compromise. - Crittenden's proposals. - Mr. Lincoln's position. Morse, Lincoln, i. I90-197, 20I-203: Nicolay and Hay, ii. ch. xxvi.-xxvii.; iii. ch. xiv., xvi., xviii.; Rhodes, iii. 146-179, 252-27 I Holst, United States, vii. 353-37S, 3SS-392, 407424: Burgess, Civil War. i. 96-100. IoS-II2; Blaine. i. 259-268; Storey, I84-194; Hart, Contemp's, iv. 193-195, 199-210; Lincoln, i. $657-660,664,668-669$.

5. The first secession morement, by seven States. - Loyal opposition. Nicolay and Hay, iii. ch. xii.; Rhodes, iii. 206-2I4, 272-280; Burgess, Civil War, i. 100-104: Hart, Contemp's, iv. r80-I82, I $88-189 ;$ J. Davis, i. 57-S6, I99-226.

\section{Surrender of Forts and National Property. -} Loyalty at Fort Sumter and Fort Pickens.

Topics AND REFERENCES.

r. Seizure of national forts, arms, and arsenals in the seceding States. - Supineness of the government. Rhodes, iii. I26132, 238-24I; J. Davis, i. 209-220; Nicolay and Hay, ii. 315326; Nicolay, I4-I6; Mclherson, 27-37; Burgess, Civil W'ar, i. $89-95$.

2. Loyalty of Major Anderson, at Charleston. - His preparation to defend Fort Sumter. 3. Similar fidelity of Lieutenant Slemmer, at Pensacola. Nicolay and Hay, ii. ch. xx.-xxi., xxiii.-xxr., xxix. ; 
iii. ch. iii.-v., viii.-ix.. xi.: Nicolay, 20-33. 38 ; Ropes, Story, i. 37+3; Rhodes, iii. I8I-I92, 216-236, 242-250, 280-285; Holst, United States, vii. 378-387; Battles and Leaders, i. 26-32, 40-46, 50-60.

\section{A Loyal Cabinet secured.}

TOPICS AND REFERENCES.

r. Changes in President Buchanan's cabinet. 2. Order telesraphed to New Orleans by Secretary Dix. Rhodes, iii. I86-i 87 , 25I-252, 286-287; Morse, Lincoln, i. I98-20I ; Nicolay and Hay, ii. 39I-399, iii. ch. vi., x.; Hart, Contemp's, iv. 204.

3. Steamer Star of the West fired upon at Charleston. Ropes, Story, i. 45-48; Holst, United States, vii. 396-405; Burgess, Civil War, i. I05-I08; Nicolay and Hay, iii. ch. vii.; Hart, Contemp's, iv. I72-I 75 ; Battles and Leaders, i. 60-62.

\section{Secessionists withdrawn from Congress.}

Topics AND ReFEREnCES.

I. Vacated seats. - Power given to the Republicans. 2. Kansas made a State. 3. The Morrill Tariff. 4. Organization of new Territories. 5. Constitutional Amendment recommended. Rhodes, iii. 27I-272, 312-3I3, 3I 5-3I6; Nicolay and Hay, iii. 234237, 2+2-2+3; Burgess, Civil War, i. I I2-I 6 .

\section{Fruitless Peace Convention. - Organization of the Confederate States.}

Topics AND References.

I. The Peace Convention invited by Virginia. Burgess, Civil IVor, i. I24-I29; Rhodes, iii. 290-29I, 305-30S; Nicolay and Hay, iii. ch. xiii.

2. Formation of the Confederate government. 3. Jefferson Davis and Alexander H. Stephens elected President and VicePresident. J. Davis, i. 229-2+3; Rhodes, iii. 29I-296; Nicolay, 39-44; Burgess, Civil IVar, i. II6-123; Battles and Leaders, i. 99-I ro; Hart, Contemp's, iv. Is9-192.

RESEARCH. - The Confederate constitution compared with the Constitution of the United States. Rhodes, iii. 322-325; J. Davis, i. 64S-672; McPherson, i. 9I-IO4. 
302. Inaugural Address of President Lincoln.His Cabinet.

Tolics AND REFERENCES.

r. Duties and intentions stated by the President. 2. His appeal to his "dissatisfied countrymen." Lincoln, ii. I-7; Nicolay and Hay, iii. ch. xxi.; Schurz, Lincoln, 65-66; Morse, Lincoln, i. 227-228; Burgess, Civil War, i. I4I-I45; Rhodes, iii. 316-3I8; Blaine, i. $282-283$.

3. President Lincoln's cabinet. Nicolay and Hay, iii. ch. xxii.; vi. 223-224; Schurz, Lincoln, 67-77; Morse, Lincoln, i. 234238, 275-28I ; Lothrop, 23I-233, 246-25I ; Hart, Chase, 202-208; Hart, Contemp's, iv. 293-295; Rhodes, iii. 3I9-320; Blaine, i. 283-286.

\section{Fort Sumter attacked and taken.}

Topics and References.

x. The problem of Fort Sumter. 2. The serious considerations involved. Lincoln, ii. I I-22, 26-28; Nicolay and Hay, iii. ch. xxiii.xxvi.; Morse, Lincoln, i. 24I-245; Rhodes, iii. 325-345; Nicolay, 50-53; Hart, Contemp's, iv. 2II-2I2; Hart, Chase, 208-2II ; Lothrop, 251-257; Ropes, Story, i. 76-83; Burgess, Civil War, i. $155-163$.

3. President Lincoln's action. 4. Confederate bombardment of the fort and its surrender. Nicolay, 53-68; Nicolay and Hay, iv. ch. ii.-iii.; Battles and Leaders, i. 62-83; J. Davis, i. 296-300; Rhodes, iii. 345-356; Ropes, Story, i. $84-87$; Burgess, Civil War, i. I63-I72; Morse, Lincoln, i. 245-250; Hart, Contemp's, iv. 213220.

304. Loyal Uprising in the Country. - The President's Call for Troops. - Attack on a Massachusetts Regiment in Baltimore.

TOPICS AND REFERENCES.

I. The north roused and united by the attack. - Stand taken by Senator Douglas. 2. The President's proclamation (text in Lincoln, ii. 34). Paris, i. ch. x. ; Rhodes, iii. 357-359, 368, 372 ; Nicolay and Hay, iv. 76-87; Nicolay, 69-77; Battles and Leaders, i. 84-98; Hart, Contemp's, iv. 22I-224, 230-239, 256-263, 307-309; 
Morse, Lincoln. i. 25I-254; Ropes, Story, i. 90-92; Blaine, i. 297300.

3. The Massachusetts Sixth Regiment at Baltimore. - Triumph of Unionists in Maryland. 4. The situation at Washington, April 19-25. Nicolay, ch. vii.-viii.; Nicolay and Hay, iv. 93-97, 105-132, 163-178; Rhodes, iii. 359-36+. 366-368, 372-380; Morse, Lincoln, i. 255-262; Burgess, Civil WVar, i. 178-179, 196-205; Lincoln, ii. $36-38$.

5. Call for volunteers and seamen (text in Lincoln, ii. 4I-42). Rlodes, iii. 394-395: Morse, Lincoln, i. 291.

\section{Confederate Privateers. - Federal Blockade. - British Proclamation of Neutrality.}

Topics AND REFERENCES.

I. Confederate military action. 2. Commissions offered to privateers. Rhodes, iii. 395-396; Nicolay and Hay, iv. 87-88; Soley, ch. vii.

3. Blockade proclaimed by President Lincoln (text in Lincoln, ii. 35, 38-39). Nicolay and Hay, iv. 89; Lothrop, 288-29r.

4. British proclamation of neutrality. - The only reasonable complaint of it. Nicolay and Hay, iv. ch. xv.; Lothrop, ch. xvi.; Rhodes, iii. 4I 7-433; Morse. Lincoln, i. 368-379; J. Davis, ii. 277282; Soley, 26-35, I 53-167.

\section{Second Secession Movement, by Four more States.}

TOPics AND REFERENCES.

I. Effect in the slave States of the call for troops. 2. Opposition to the "coercion of sovereign States." 3. Secession of four more States. 4. Feeling of Robert E. Lee and others. Rhodes, iii. 364-365. 381-387, 40I-403. 408-409, 41 I-41 4: Nicolay and Hay, iv. 89-92, 97-102, 245-253; Morse, Lincoln, i. 262-265, 268-269; Burgess, Civil IV ar. i. I79-186; J. Davis, i.301-302; Long, 87-96.

\section{The Border Slave States. - Kentucky and Missouri held in the Union.}

TOPICS AND REFERENCES.

r. Fidelity to the Union in West Virginia and East Tennessee. 2. The wise course of President Lincoln which held Kentucky. 
Nicolay, I37, I 43, and ch.xi.; Nicolay and Hay, iv. ch. xii.; Rhodes, iii. 391-392; Morse, Lincoln, i. 265-268; Burgess, Civil WVar, i. 19I-I95: Battles and Leaders, i. 373-377.

3. The struggle in Missouri. - Union services of Blair and Lyon. Nicolay and Hay, iv. ch. xi.; Burgess, Civil War, i. I86I9I ; Nicolay, ch. x. ; Rhodes, iii. 393-394; Sherman, i. ch. viii.; Battles and Leaders, i. 262-269; Morse, Lincoln, i. 269-270.

308. The Opposing States and People in the War. TOPICS AND REFEREXCES.

I. Population of the in States of the Confederacy compared with the 23 of the Union. 2. Comparison of wealth, resources, and circumstances. 3. Military advantages of the Confederate States. Hart, Practical Essays, 258-298.

\section{First Notable Victims of the War. - Slaves declared "Contraband."}

TOPICS AND REFERENCES.

r. Death of Colonel Eilsworth and Theodore Winthrop. Nicolay and Hay, iv. 3II-3I4, 3I9-320; Nicolay, Io9-II4; Battles and Leaders, ii. I48-I $5 \mathrm{I}$.

2. General Butler's dictum that slaves were "contraband of war." Hart, Contemp's, iv. 390-39I ; Nicolay and Hay, iv. 387-396; Rhodes, iii. 466-468.

\section{McClellan in loyal West Virginia. - Its Seces- sion from the Old Dominion.}

TOPICS AND REFERENCES.

I. General George B. McClellan. - His West Virginia campaign. 2. Unionist proceedings, organizing a loyal state government. 3. Subsequent separation from Old Virginia. Battles and Leaders, i. I26-I 48 ; Nicolay, I 43-I 54; Nicolay and Hay, iv. 200205, 28I-286, 327-340, vi. 297-313; Burgess, Civil War, i. 2062I2, ii. 230-233; McClellan, 49-65; Paris, i. 22I-225; Rhodes, iii. $435-437,442$; Blaine, i. ch. xxi. 


\section{President Lincoln's First Message. - Action of Congress.}

TOPICS AND ReFERENCEs.

I. Influence of the President's message (text in Lincoln, ii. 5566). 2. Unity of feeling and action in Congress. 3. Measures adopted. Morse, Lincoln. i. 29I-29S; Rhodes, iii. 437-442 ; Nicolay and Hay, iv. ch. xxi.; Burgess, Civil War, i. 226-233; Blaine, i. $332-347$.

\section{First Battle of Bull Run. - McClellan called to the Army of the Potomac.}

Topics ANd References.

I. Union and Confederate armies near Washington. 2. Forward movement of the Union forces. 3. Failure of plans. - Rout of the Union army. 4. Recovery from the disaster. - General McClellan appointed commander-in-chief. Paris, i. 225-256; Ropes, Story, i. ch. ix.; Sherman, i. 205-2I9; Cooke, Jackson, 56-76; Coppée, Thomas, 3I-35; Rhodes, iii. 437, 442-455; Nicolay, ch. xiii.-xvii.; Nicolay and Hay, iv. 3I4-3I9, 32 I-326, 34I-369; Battles and Leaders, i. I67-26I ; Hart, Contemp's, iv. 309-jิ14.

\section{Important Commands and Commanders. - Mc- Clellan at the Head.}

Topics AND ReFERENCES.

1. Appointment of Frémont in the West. 2. The situation in Missouri. - Death of Lyon. Nicolay and Hay, iv. ch. xxiii.; Battles and Leaders, i. 289-306; Paris, i. 326-338; Force, 4-7; Rhodes, iii. $468-469$.

3. Grant's first important command. - His seizure of the mouth of the Tennessee. Grant, i. 2II-2I7; Force, I8-I9; Nicolay and Hay, v. $48-49$.

4. Frémont's military administration. 5. His proclamation of emancipation, modified by the President. 6. Removal of Frémont. - Division of the western department. Lincoln, ii. 77-82, 85-87; Battles and Leaders, i. 278-2SS; Nicolay and Hay, iv. ch. xxiv.; Paris, i. 338-355; Rhodes, iii. 469-484; Burgess, Civil War, ii. $76-78$.

7. McClellan in general command. Lincoln, ii. 87-88. 
8. McClellan's army and his opponents. - Inaction in Virginia. Rhodes, iii. 490-496; Paris, i. 419-42I; McClellan, ch. vi.-viii.; Battles and Leaders, ii. I I2-I22, I 53-I 59; Ropes, Story, i. I69I83; Morse, Lincoln, i. 303-3I 7 .

\section{The Blockade. - Joint Military and Naval Operations.}

TOPICS AND REFERENCES.

I. Effectiveness of the blockade. 2. Its effects in the Confederate States. Soley, 35-46; Paris, i. 423-425, 43I-443; Rhodes, iii. 544-552; Nicolay and Hay, v. I-I I J J Davis, i. 47I-483; Hart, Contemp's, iv. 244-25I, 319-323.

3. The resulting "cotton famine" in England. Rhodes, iii. 502515; Hart, Contemp's, iv. 296-298; Watts, ch. viii., xii.; Lincoln, ii. $301-302$.

4. The Trent affair. - Capture of Mason and Slidell. Lothrop, ch. xviii.; Storey, ch. xiii.; Rhodes, iii. 520-543; Nicolay and Hay, v. ch. ii.; Battles and Leaders, ii. I35-I42; Paris, i. 464-472; Morse, Lincoln, i. 380-387; McPherson, 338-343; Hart, Contemp's, iv. 29S-30r.

5. Capture of important positions on the Atlantic coast. Ammen, ch. ii., viii.-ix.; Battles and Leaders, i. 632-69I, ii. I-I2; Nicolay and Hay, v. I I-20, 239-25I ; Paris, i. 443-464, 580-590, ii. 224-232 ; Ropes, Story, i. I84-185.

RESEARCH. - The financial condition and financial measures of the Confederacy. Paris, ii. 69I-703.

\section{First Breaks in the Confederate Line of Defence.}

Topics and References.

r. Coöperation of army and navy on western rivers. 2. Capture of forts Henry and Donelson. Grant, i. ch. xxi.-xxiii.; Mahan, The Gulf, II-I 8, 2I-28; Force, ch. ii.-iii.; Ropes, Story, i. I89-19I, 210-2I 2, ii. ch. i. ; Battles and Leaders, i. 338-346, 358372, 398-436: Paris, i. 473-474, 479-498; Rhodes, iii. 58I-598; Nicolay and Hay, v. iI I-I I 5 ; Morse, Lincoln. i. 353-355; Hart, Contemp's, iv. 32.4-328.

3. Resulting advance of Grant and Buell. 4. Battle of Shiloh. Grant, i. ch. xxiv.-xxv.; Sherman, ch. x.; Battles and Leaders, i. 465-610; Paris, i. 522-525, 531-560; Rhodes, iii. 61 7-628; Force, 
ch. v.-vii.; Nicolay and Hay, v. ch. xviii.; Morse, Lincoln, i. 359362: Hart, Contemp's, iv. 334-336.

5. General Mitchell's march southward. Battles and Leaders, ii. 701-708; Paris, ii. $184-188$.

6. General Thomas's success in eastern Kentucky. Coppée, 4273 ; Ropes, Story, i. 193-194, 200-210; Cist, ch. ii.; Battles and Leaders, i. 382-397: Paris, i. 474-479; Nicolay and Hay, v. II 5I 7 .

7. Commodore Foote and General Pope on the upper Mississippi. Mahan, The Gulf, 28-40; Force, ch. iv.: Paris. i. 525-53I ; Battles and Leaders, i. 439-446, 460-462.

8. Battle of Pea Ridge. Battles and Leaders, i. 314-334; Paris, i. 503-5 44: Nicolay and Hay, v. 288-293.

RESEARCH. - The thrilling episode of the "locomotive chase" connected with General Mitchell's expedition. Battles and Leaders, ii. 707-716; Pittenger.

\section{Inaction in Virginia.}

Topics AND References.

I. The army of the Potomac kept in camp. 2. The President's order for a movement (text in Lincoln, ii. I I9). 3. Evacuation of Manassas by the Confederates. 4. "Quaker guns." Rhodes, iii. 497-502, 578-581, 604-606; Nicolay and Hay, r. ch. ix. and I73179; Paris, i. 570-580, 608-61 5: Ropes. Story, i. 217-239, 257262 ; McClellan, ch. ix.-xiii. : Morse, Lincoln, i. 31S-345; Long, 150.

\section{The Merrimac and the Monitor.}

Topics AND REFERENCES.

I. Beginning of iron-clad ships of war. 2. The Confederate Merrimac. 3. Ericsson's Monitor. 4. Attack by the Merrimac on the blockading squadron in Hampton Roads. 5. Arrival of the Monitor and her combat with the Merrimac. 6. Ultimate fate of the Merrimac. Soley; 53-8I ; Battles and Leaders, i. 692-750; Nicolay and Hay, v. ch. xiii.; Morse, Lincoln, i. 356-357, ii. 4S49; Paris, i. 591-608; Rhodes, iii. 608-614; Hart, Contemp's, iv. 329-333; Ammen, ch. vi. 
318. Work of Congress. 1861-1862.

Topics AND ReFERENCES.

I. Financial situation. 2. Government expenditures. 3. The "legal tender" act. - Its provisions and the effect. 4. Tariff and internal taxes. Rhodes, iii. 558-572; Blaine, i. ch. xix.; McPherson, 356-373; Hart, Chase, 245-252; Spaulding.

5. Compensated emancipation proposed to the border slave States (text in Lincoln, ii. I29-I30). 6. Emancipation in the District of Columbia. Nicolay and Hay, v. ch. xii.; vi. 224-239; Rhodes, iii. 630-636; Morse, Lincoln, ii. I0-15, I8-29; Burgess, Civil War, ii. 78-82 ; Paris, ii. 739-74I ; Lincoln, ii. 132-135, 137-I38, 204205, 207, 270-277; McPherson, 209-227.

7. Conscription in the Confederacy. Paris, i. 565-570.

RESEARCH. - The "Homestead Act" of I 862, which introduced the policy of granting free homes to settlers on the public lands. Donaldson, ch. xxvii.

\section{Opening of the "Peninsular Campaign" against Richmond.}

Topics AND ReFERENCEs.

1. Line of movement chosen by McClellan. 2. Siege of Yorktown. Webb, ch. ii.-iii.; Paris, ii. I-I4; McClellan, ch. xv.-xviii.; Long, I 50-I 54; Nicolay and Hay, v. I 79-I 84, 358-375; Battles and Leaders, ii. I63-I72; Rhodes, iii. 606-608, 6i4-6I 7 ; Morse, Lincoln, ii. 31-47; Ropes, Story, i. 239-256; Lincoln, ii. I30-131, I37.

3. Advance to the Chickahominy. 4. Naval advance up the James. Paris, ii. I4-34; Battles and Leaders, ii. I72-I78; Nicolay and Hay, v. 376-386; Webb, ch. iv.-v.; Long, I 54-I 56 : Rhodes, iv. 5-II; McClellan, ch. xix.-xxii.; Morse, Lincoln, ii. $47-50$.

5. "Stonewall" Jackson's frustration of Union plans. Paris, ii. 35-51; Cooke, Jackson, roo-199; Nicolay and Hay, v. ch. xxii.; Battles and Leaders, ii. 282-3I3; Morse, Lincoln, ii. 5058 ; Rhodes, iii. 460-462, iv. I I-22. 


\section{Farragut's Capture of New Orleans and Opening of the Lower Mississippi.}

Topics AND ReFERENCES.

ז. Passage of the Confederate forts. 2. Occupation of New Orleans by General Butler. 3. Conquest of the Mississippi below and above Vicksburg. Mahan, The Gulf, ch. iii.; Paris, ii. 149I79, 199-203; Nicolay and Hay, v. ch. xv.-xvi., xix.; Battles and Leaders, ii. I3-102 ; Morse, Lincoln, i. 357-359; Rhodes, iii. 629630; Hart, Contemp's, iv. 336-33s; Greene, Mississippi, 14-28; Force, ch. viii.

\section{Failure of the Peninsular Campaign.}

TOPICS AND REFERENCES.

r. Battle of Seven Pines or Fair Oaks. 2. General Lee in command of the Confederate army. 3. Lee's attack and McClellan's retreat to the James. - The "Seven Days' Battles." Webb, ch.vi.viii.; Paris, ii. 5I-I48; McClellan, ch. xxiii.-xxvii.; Battles and Leaders, ii. I7S-IS7, 220-263, 313-43S; Long, 156-160, and ch. x. ; Cooke, Jackson, 200-249; Rhodes, iv. 23-5t; Nicolay and Hay, v. 3S6-39r, 413-454; Morse, Lincoln, ii. 5S-64; Hart, Contemp's, iv. 338-3+2; Lincoln, ii. IS9-202, 206.

4. Determination to withdraw from the peninsula. 5. Halleck made general-in-chief. - Pope called to Virginia. Rhodes, iv. 95I Io; Paris, ii. 242-249; McClellan, ch. xxviii.-xxix.; Nicolay and Hay, v. 454-460, vi. I-3; Morse, Lincoln, ii. 64-68; Ropes, Pope, 3-7; Lincoln, ii. 188-203. 


\section{CHAPTER XVI.}

THE WAR FOR THE UNION.

Its Second Period: Striking at Slavery. i862-i865.

322. Preparing to Strike. July, 1862. If the north was downcast, it was not discouraged, and its feeling was taking a sterner tone. Congress, since December, had been debating proposals for a general confiscation of the property and liberation of the slaves of all persons in arms against the government, and now, on the I Ith of July, it was persuaded to pass the Confiscaact. This was as far as Congress seemed authorized to go; but the President was believed to be empowered to proclaim, as a war measure, the absolute emancipation of all slaves within the rebellious States, and he now felt called upon to exercise that power. With one firm conviction and one faithful purpose in his mind, he had taken guidance from events in his whole dealing with slavery, from the beginning of the war. ${ }^{1}$

1 Two years later (April 4, 1864), writing of his action at this time, he described in a few words the course of thought and feeling which led him to decide that his official obligation to preserve the Constitution must be fulfilled by striking slavery down. "I am," he wrote, "naturally anti-slavery. If slavery is not wrong, nothing is wrong. I cannot remember when I did not so think and feel, and yet $I$ have never understood that the presidency conferred upon me an unrestricted right to act officially upon this judgment and feeling. It was in the oath I took that I would, to the best of my ability, preserve, protect, and defend the Constitution of the 
Having arrived at a clear conviction of duty on the

The Emanclpation Proclamation prepared, July 22,1862 . subject, President Lincoln prepared a proclamation of emancipation and submitted it to his cabinet on the 22d of July. All but Secretary Blair approved ; but Secretary Seward advised

United States. I could not take the office without taking the oath. Nor was it my view that I might take an oath to get power, and break the oath in using the power. I understood, too, that in ordinary civil administration this oath even forbade me to practically indulge my primary abstract judgment on the moral question of slavery. I had publicly declared this many times, and in many ways. And I aver that, to this day, I have done no official act in deference to my abstract judgment and feeling on slavery. I did understand, however, that my oath to preserve the Constitution to the best of my ability imposed upon me the duty of preserving, by every indispensable means, that government - that nation, of which that Constitution was the organic law. . . . I felt that measures otherwise unconstitutional might become lawful by becoming indispensable to the preservation of the Constitution through the preservation of the nation. Right or wrong. I assumed this ground, and now arow it. I could not feel that, to the best of my ability, I had even tried to preserve the Constitution. if, to save slavery or any minor matter, I should permit the wreck of government, country, and Constitution, all together. When, early in the war, General Frémont attempted military emancipation, I forbade it, because I did not then think it an indispensable necessity. When, a little later. General Cameron, then Secretary of War, suggested the arming of the blacks, I objected, because I did not yet think it an indispensable necessity. When, still later, General Hunter attempted military emancipation. I again forbade it. because I did not yet think the indispensable necessity had come. When, in March and May and July, IS62, I made earnest and successive appeals to the border States to faror compensated emancipation, I believed the indispensable necessity for military emancipation and arming the blacks would come unless averted by that measure. They declined the proposition. and I was, in my best judgment. driven to the alternative of either surrendering the Union, and with it the Constitution. or of laying a strong hand upon the colored element. I chose the latter." Lincoln, Iritings, ii. 50 S. 
that the great mandate be withheld until the military situation had been changed by some important success. Lincoln thought the advice good, and the proclamation was laid aside to await a brighter day.

Meantime, though an unwarranted order of emancipation, issued by General David Hunter, at Hilton Head, S. C., on the $9^{\text {th }}$ of May, had been re- arming the scinded by the President, General Hunter was blacks. permitted to begin organizing and arming the refugee colored men at Hilton Head, and henceforth negro soldiers were employed freely in the war.

323. Lee's Crushing Defeat of Pope and Invasion of Maryland. ${ }^{1}$ August-September, 1862. The brighter day was not near; the worst disasters were to come. Pope, preparing vigorously for a direct movement on Richmond, gave offence to his army by some unwise addresses and orders, and its feeling towards him was chilled. Lee, with his superior promptitude and daring, and Jackson, with the swift sureness of his sudden strokes, frustrated all the plans.

Second battle of Bull Run. While McClellan's army was coming in detachments from the James, to coöperate with Pope, the Confederates reached the rear of the latter's forces and broke them badly, in battles at Gainesville, Groveton, and Bull Run, August 2S, 29, and 30, throwing them back on Washington in almost as disordered a state as after the first Bull Run.

There was panic in Washington again; but Lee did not venture to attack the fortifications of the city. Instead of doing so, he moved by way of Leesburg into Maryland, and met little of the welcome he expected there. Most wisely, in the circumstances, President Lincoln gave McClellan command of all the forces that 
could be used against Lee, and that excellent organizer

Battles of South Mountain and Antietam, September, 1862. had them ready to start from Washington September 5. On the I4th he fought Lee at South Mountain, and on the 17 th at Antietam. The battles were not decisive, but they brought the invasion to an end.

324. Emancipation proclaimed by President Lincoln. September-January, 1862-1863. The situation was far from satisfying, but it had brightened, and President Lincoln, on the 22d of September, issued his great proclamation, - his First Proclamation of Emancipation, - declaring that on the Ist day of January, I $86_{3}$, "all persons held as slaves within any State, or designated part of a State, the people whereof shall then be in rebellion against the United States, shall be then, thenceforward and forever free." It will be proper to say now that at the appointed time, on the first day of $I 86_{3}$, the final proclamation was issued, declaring the freedom of all slaves in Arkansas, Texas, Louisiana (excepting thirteen designated parishes), Mississippi, Alabama, Florida, Georgia, South Carolina, North Carolina, and Virginia (excepting IVest Virginia, seven eastern counties, and the cities of Norfolk and Portsmouth).

325. Dark Days. 1862-1863. Some people expected that an immediate uplifting of the national cause would follow the proclaiming of emancipation, but it did not come. There were months of sore trial to be gone through yet. When Lee was in Maryland, threatening Pennsylvania, another Confederate army, under Braxton Bragg (successor to Beauregard in the west), was in Kentucky, and Ohio was alarmed. Bragg's invasion fared no better than Lee's; he was defeated by Buell at Perryville (October 8), and fell back to Chattanooga. Grant's 
Army of the Tennessee fought two battles with success, at Iuka, Miss., September I9, and at Corinth, October 3, 4, and 5 (see Map XIII.); but all the fighting of the time was defensive on the Union side, and seemed to show ill-managePerryville, Iuka, Cor-' inth, September-0cment of the greater forces on that side.

Foreign governments had no belief that the seceding Confederacy would be overcome, and the French emperor, Napoleon III., already engaged in The French an undertaking of conquest in Mexico, hoped in Mexico. to persuade England to join him in intervening to stop the war. The British government, although controlled by the unfriendly classes, would not go to that length, but it did little to prevent the giving of private aid to the Confederate States. Confederate agents were permitted to fit out cruisers in British ports and send them to sea. One, named the Florida, was set afloat at Liverpool in March. In July the more formidable Alabama was allowed to sail from Liver-

The Flor-

Ida and the Alabama. pool, though proof of her character had been given to the authorities by the American consul at that port. The ships and cargoes destroyed by these and other commerce-destroyers of British build amounted to many millions of dollars in value, and a heavy claim for indemnity on account of them was, brought against England when the war closed.

In the northern States, the united feeling that sustained the government at the outbreak of the war had disappeared. Party lines were drawn strictly again. While many former Democrats had left their party and joined the Republicans, a larger body, known as "War Democrats," supported the war for the Union in principle, but were sharply critical of the management of it. These were bitter in condemnation of many measures of 
530 SECESSION, CIVIL WAR, AND REUNION.

the government, - especially its military suspensions of the writ of habeas corpus, and its arbitrary military Democratic arrests. A smaller section of the Democratic opposition. party, composed of people whom the Republicans described as "Copperheads," were open in opposition to the war, demanding that it be stopped, and arowing sympathy with the secession cause. The free speech of these latter was suppressed in many instances by military authority, and that proceeding became a principal cause of opposition to the government in the Democratic party at large. Such opposition, strengthened by a general sickening of mind over the military failures, and sharpened in some quarters by dislike of the emancipation proclamation, worked strongly against the government in the fall elections of I \$62, and the Republican majority in the next Congress was much reduced.

326. More National Reverses. ${ }^{1}$ December-May, 1862-1863. After the battle of Antietam, Lee was allowed to retire slowly across the Potomac without being pursued, and dissatisfaction with $\mathrm{McClellan}$ revired. On the 5th of Norember he was remored, and General Ambrose E. Burnside, a good soldier and an admirable

Repulse of Fredericks. burg, Docomber 13, 1862. man, took his place. Under Burnside the army was moved to Fredericksburg, on the Rappahannock, and there, crossing the river (December I3), it assaulted the Confederates, who held fortified positions on the hills behind the town. The loss suffered was terrific, the repulse complete, and another disaster, worse than any before, was added to the painful record of the Army of the Potomac.

In the west there was more success, though incomplete. Buell's command had been giren to General Rosecrans, lately serving under Grant. In December 
Bragg started on another movement northward, from Chattanooga, and was met at Stone River, near Murfreesboro, by Rosecrans. They fought on the last day of the year, and the Union army came near to a dreadful defeat. It was saved by the Battle of
Stone River,
December 31,1862 . conspicuous ability and steadiness of General Thomas, who commanded a corps, and General Sheridan, who led a division under General McCook. The high quality of these soldiers began then to be understood.

Further west, in Grant's department, he and General William Tecumseh Sherman, his most trusted lieutenant and close friend, were beginning movements that aimed at the taking of Vicksburg.

On the $25^{\text {th }}$ of January, I 863 , General Burnside gave up the command of the Army of the Potomac, and it passed to General Joseph E. Hooker, whose fighting reputation as a corps commander raised great hopes. After staying in camp on the Rappahannock until April, the army started upon a movement which placed the main body at Chancellorsville, on the south side of the Rappahannock, and on the flank of Lee. There, on the Ist, $2 \mathrm{~d}$, and $3 \mathrm{~d}$ of May, it fought Battle of There, on the Ist, $2 \mathrm{~d}$, and $3 \mathrm{~d}$ of May, it fought Chancelanother losing battle, and was forced to an- May 1-3, other disheartening retreat. The success of the Confederates was costly to them, for Stonewall Jackson fell, mortally wounded by a mistake of his own men.

Even before this last reverse, the war spirit of the country had so ebbed, and enlistments had so fallen off, that Congress, in March, passed a conscription act, for the enrollment of all able-bodied male citizens between twenty and forty-five years

Conscription act, March, 1863. of age, making them subject, when needed, to draft. Another important measure of the session created the 


\section{SECESSION, CIVIL WAR, AND REUNION.}

existing system of national banks, which prored an invaluable aid to the government in managing its loans, and which has siren the country many of the adrantages, without the evils, of the single great national banking institution orer which parties fought so long.

Notwithstanding the sloomy circumstances of the winter and spring of $1 S \sigma_{3}$, the rast sums of money required by the gorernment were obtained with little difficuly; but the money of the time was the depreciated "legal tender" notes (called "greenbacks," from the color of the print on the back), and they doubled the cost of the war by doubling the price of everything bought. Great actirity, largely speculative, prevailed in business, and many fortunes were made in these days.

327. Lee in Pennsylvania. - Gettysburg. - Vicksburg. July, 1863. After Chancellorsville, Lee planned another attempt to carry the war into the northern States, and his army was set in motion on the $3 d$ of June. Before the end of the month he had passed up the Shenandoah, crossed the Potomac, marched through Maryland, and was in Pennsylvania, with about 75,000 men. Hooker had followed, on the eastern side of the Blue Ridge, but had disagreements with Halleck, and asked, on the 27th of June, to be relieved. His request was complied with, and General George G. Meade, of the Fifth Corps, receired the chief command. Four days later the two armies met at Gettysburg, in south. ern Pennsylrania, and fought, during three days, July Battle of I, 2, and 3, the most terrific battle of the Gettysburg, war. The killed and wounded of the Union
July 1-3, 1863.

93.000: those of the Confederate army exceeded I 5,000 out of 70,000 . The latter was more shattered than the 1 See Maps XII. and XIII. 
former ; its campaign of invasion was a failure, and Lee drew back in retreat. At last, a great victory for the Union had been won, and the country had the news of it on a memorable $4^{\text {th }}$ of July.

How doubly memorable that $4^{\text {th }}$ of July had been made was not known in the north until three days later, when news came from General Grant. He The taking had taken Vicksburg on the morning of Inde- of vickspendence Day, after more than five months 4,1863 . of labor, battle, and siege. From the end of January till the middle of April he had struggled with difficulties created by the surrounding bayous and swamps, trying to put his army on high ground behind the place. At length, with the help of Admiral Porter, who ran a fleet of gunboats and transports past the Vicksburg batteries, the army was placed at a point below Vicksburg on the east side of the river, and fought its way to the position desired. Failing, on the 22d of May, to carry the works by assault, he opened a siege, which ended in the surrender of the place on the $4^{\text {th }}$ of July.

On the 8th of July Port Hudson, a few miles above Baton Rouge, was surrendered to General Banks, whose forces, coöperating with Farragut's fleet, had been assailing its strong fortifications since the latter part of May. This was the last Confederate stronghold on the Mississippi, and

Surrender of Port Hudson, July 8, 1863. the great river was reopened throughout its length. The Confederacy was cut in twain; it lost the resources of the States west of the river, and the war in that region had little importance thereafter.

328. Draft Riot in New York. July, 1863. Gettysburg, Vicksburg, and the reopening of the Mississippi revived confidence in the final success of the Union arms; but they were not permitted to raise the spirits 
of the northern people to an exuberant height. The draft, just beginning to be enforced, was a dismal matter at the best, and it became an alarming one on the I $3^{\text {th }}$ of July, when the most ferocious and destructive riot that America has ever known broke out in the city of New York. For four days a wild mob fought militia and national troops, as well as the police, and was not suppressed until I000, at least, are believed to have been killed.

329. Operations against Charleston. - Quiet in Virginia. April-September, 1863. Military and naval undertakings against Charleston were not having suc-

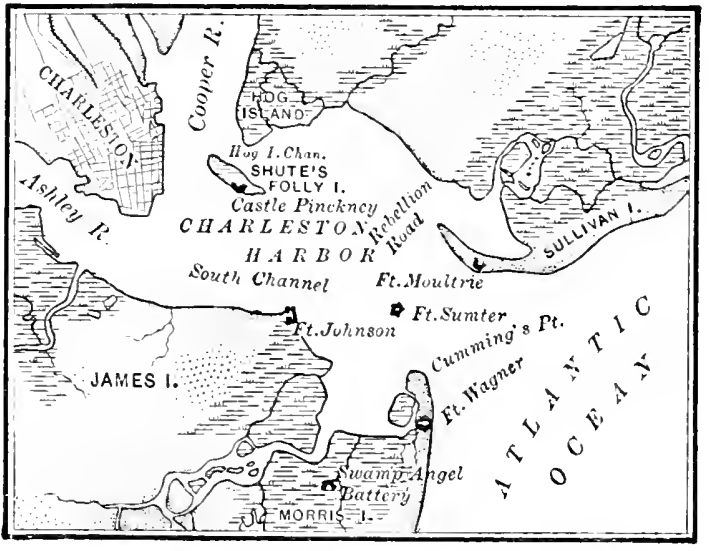

CHARLESTON HARBOR. cess. In April Admiral Dupont, with seven Ericsson monitors and two partially ironclad vessels, had attempted to enter the harbor and had been beaten off by the forts. Then a landing of forces on Morris Island, at the entrance to the harbor, was effected by General Gillmore, and on the I 8 th of July an assault on the Confederate

Assault

on Fort

Wagner, July 18, 1863 .

Fort Wagner was repulsed with grievous loss. The storming party was headed by a regiment of colored soldiers, who fought bravely, and their colonel, Robert G. Shaw, of Massachusetts, was among the slain. Some weeks later, in September, after long bombardment, the Confederates evacuated Fort Wagner, and guns were mounted in it which 
threw shells into Charleston, doing much damage to the city and bringing blockade-running to an end.

After the battle of Gettysburg Lee was again permitted to make an undisturbed retreat into Virginia, and his army and Meade's were back, before the end of July, on nearly their old ground. During the next few months there were frustrated movements on both sides, with no severe fighting. Large forces were drawn from both armies in September to reinforce Rosecrans and Bragg in Tennessee, one led by Hooker, the other under Longstreet's command.

330. Critical Situation in Tennessee. - Grant to the Rescue. ${ }^{1}$ August-December, 1863. The effort which President Lincoln had been urging since the war began, to occupy East Tennessee and liberate its loyal people, was about to be made. Burnside, transferred to eastern Kentucky, penetrated the valley which leads to Knoxville in August, and compelled the evacuation of that town. At about the same time, on the southern border of the State, Rosecrans forced Bragg out of Chattanooga and took possession (September 8) of what was considered the military key to the whole mountain region. Then, pursuing Bragg, he separated his forces unwisely, and paid dearly for the error on the Igth and 2oth, when the Confederate general, reinforced by Longstreet, turned upon him and routed all but the left wing of his army, commanded by Thomas, which held its ground

\section{Battle of}

Chickamauga, September 1920,1863 . against heavy odds. Saved by Thomas, "the Rock of Chickamaugua," as he has been called, the army retreated from the bloody field of Chickamauga to Chattanooga, and was practically in a state of siege for the next two months. 
536 SECESSION, CIVIL WAR, AND REUNION.

Command of the Army of the Cumberland was now transferred from Rosecrans to Thomas; Sherman was appointed to the command of the Army of the Tennessee; and both, with the Department of Ohio, were united in one military division, under General Grant. Grant, reaching Chattanooga on the 23d of October, began preparations to extricate the Army of the Cum-

Battles at

Chattaberland from its dangerous position. Reinnooga, November 24forced by Hooker with two corps from the 25,1863 .

Army of the Potomac, and by Sherman with one corps from Memphis, his plans were carried out on the $24^{\text {th }}$ and $25^{\text {th }}$ of November with perfect success. Sherman drove the Confederates from a neighboring height, called Missionary Ridge, while Hooker cleared them from Lookout Mountain, in a battle fought above the low-lying clouds of a misty day. As a dramatic spectacle, these battles at Chattanooga were among the most remarkable ever fought. They had important results, including the complete deliver-

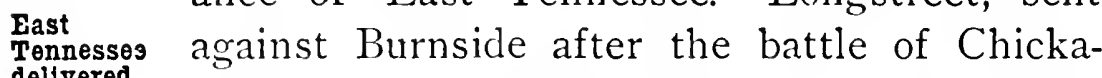
ance of East Tennessee. Longstreet, sent dellivered.

mauga, had shut the latter up in Knoxville, and that besieged town had been reduced to great distress. It was now relieved by Sherman; Longstreet retired, and East Tennessee was free.

A sadly interesting incident of the later weeks of

Lincoln's

Lincoin's address, November $19,1863$. the year was the dedication, at Gettysburg, November 19, of a cemetery for the many dead of the great battle, and the speaking there of a few words of address by President Lincoln, which are immortal in their tender eloquence.

331. Amnesty offered by President Lincoln. - His plan of "Reconstruction." December-July, 18631864. With his annual message to Congress, in De- 
cember, the President issued a proclamation of amnesty, which opened doors for the return of both individuals and States to the Union fold. Excepting certain classes of leaders and special offenclers, the proclamation offered full pardon, "with restoration of all rights of property except as to slaves," to every participant in the rebellion who would subscribe a given oath. The prescribed oath pledged fidelity to the Constitution and the Union, and support to what had been done by legislation and proclamation touching slavery, "so long and so far as not repealed, modified, or held void " by Congress or the Supreme Court. The proclamation then made known that whenever, in any State where rebellion had been prevailing, a number of qualified voters, not less than one tenth of the number of votes cast at the presidential election in I860, should, after taking the prescribed oath, reëstablish a republican state government, conforming to the oath,

President

Lincoln's plan of reconstruction. such government would be recognized as the true government of the State; but the admission to Congress of senators and representatives from such State would depend on the action of Congress itself. This, said the President, "is intended to present . . . a mode in and by which the national authority and loyal state governments may be reëstablished" in the States designated; but "it must not be understood that no other possible mode would be acceptable."

At first the proclamation and its suggested plan of "reconstruction" for the States at war with the Union was received with general satisfaction in Congress, as it was in the Union at large. But a few radicals took exception to its leniency, and declared that Congress only could determine the mode of dealing with the seceded States. According to the radical view, the rebellion of 
538 SECESSION, CIVIL WAR, AND REUNION.

those States had wrought a forfeiture of all their consti-

Radical tutional rights; it had destroyed their status opposition. as States, and reduced them to that of Territories, or subjugated provinces, whenever their rebellion should be overcome. In this view the President's plan of restoration was too simple and too mild in its terms. It was a view that gained ground in Congress, until it brought about the passage of an act in the last hours of the session (July 4, i 864) which embodied a different plan. The act in question required that a majority of congres- the white male citizens of a State in rebellion

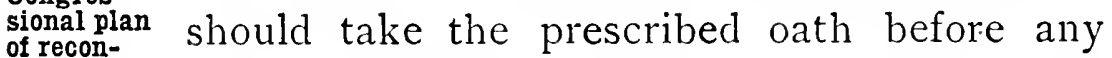
struction. "reconstruction" of state government could occur, and that the proceeding of reconstruction should be in one precisely defined mode. This would nullify action taken already under the President's proclamation in Louisiana and Arkansas, where state governments had been organized under constitutions which prohibited slavery forever. The bill came to the President an hour before Congress adjourned. He declined to sign it, but submitted it a few days later to the consideration of the President's people in a proclamation, saying: "While I proclama- am . . . unprepared, by a formal approval of tion. this bill, to be inflexibly committed to any single plan of restoration, and while I am also unprepared to declare that the free state constitutions and governments already adopted and installed in Arkansas and Louisiana shail be set aside and held for naught, thereby repelling and discouraging the loyal citizens who have set up the same as to further effort, . . . nevertheless I am fully satisfied with the system for restoration contained in the bill, as one very proper plan for the loyal people of any State choosing to adopt it." By taking this wise course President Lincoln avoided a mis- 
chievous issue between Congress and himself. Public opinion sustained his policy and his action, and when his radical opponents, at the next session of Congress, attempted new legislation to undo his measures, they could carry it through neither House. These are facts to be remembered when the "reconstruction" conflicts of a later period, after Lincoln's death, come into view.

332. Grant made Lieutenant-General, in Chief Command. March, 1864. Since his notable success at Chattanooga, following that at Vicksburg, the hopes of the nation were fixed on Grant. An act of Congress in February, I864, revived the rank of lieutenant-general, which none since Washington had held, and Grant was appointed to it on the $3 \mathrm{~d}$ of March. He was called to the capital at once and assumed the general command, taking personal direction of operations in Virginia at the President's request. Sherman succeeded him in the western command. And now the war entered its final stage.

General Meade retained command of the army of the Potomac, but Grant was with it in the subsequent campaign. Burnside's corps was brought east again to join it, and Sheridan came to take command of the cavalry corps. Grant's plan was to move directly across country upon Richmond, through the wilderness in which Hooker met defeat, fighting his General Grant's plan. way, wearing his antagonist down; while a coöperating army under Butler (who had returned from New Orleans to Fortress Monroe) moved up the James, and another under Sigel held the Shenandoah and broke Lee's communications with the west. At the same time Sherman was to advance from Chattanooga upon Atlanta, engaging an army commanded by General Joseph E. Johnston, who had succeeded Bragg; and General Banks, suc- 
cessor to Butler at New Orleans, was to move against Mobile. Sherman had about 100,000 men for his movement, against some 75,000; Grant started from the Rapidan with 122,000 , and Lee had about 62,000 ; but the advantage of the Confederates in making a defensive fight, and in holding the inner line of every movement, was very great.

333. Grant's Movement on Richmond. ${ }^{1}$ May-June, 1864. Grant crossed the Rapidan and opened the campaign on the $4^{\text {th }}$ of May. No details of the dreadful month of battles that followed can be given in this place.

The Wilderness, nia, North
Anna, May, 1864 .

Two days (May 6-7) of terrific fighting in the Wilderness ; two more (May Io and I2), and a week of less general fighting, at and near Spottsylvania Court House; a third hard encounter (May 23) on the North Anna River, with minor conflicts incessantly, brought what survived of the great Army of the Potomac to the vicinity of the Chickahominy (May 28), where McClellan had been two years before. There, on the ist and $3 \mathrm{~d}$ of June, the Confedcold Har- erate lines were attacked, at Cold Harbor, and bor, June 1 nearly 10,000 killed and wounded were the and 1864 .

cost of a vain assault. Almost if not quite 40,000 had fallen since the movement began, while the Confederate loss had been much less.

Meantime, General Butler, moving up the James to attack Richmond, had been met by forces brought from the Carolinas by Beauregard, and had been driven to an intrenched position at Bermuda Hundred, where, as Grant expressed it, he was "bottled up." Most of his force was then drawn away to the Potomac army.

334. Sherman's Movement on Atlanta.' May-July, 1864. Three days after Grant set out from the Rapi${ }^{1}$ See Map XII.

${ }^{2}$ See Map XIII. 
dan Sherman moved against Johnston, who retreated before him. There was no serious engagement until May 25-28, at New Hope Church, after which, as Sherman relates, "not a day, not New Hope an hour, not a minute, was there a cessation of fire." "And thus matters continued until June 27," when a general assault was made on Johnston's lines at Kenesaw. Three days afterward Johnston resumed his retreat, and the next battle occurred at Peach Tree Creek, July 20; but Johnston had then been superseded by General Hood. Hood

\section{Kenesaw,} June 27; Peach $\mathrm{Treek}$, July 20, 1864 . was driven into Atlanta with heavy loss, and a siege of the city was begun. Among those who fell on the Union side was General McPherson, who commanded Grant's and Sherman's old Army of the Tennessee, and who was rising to prominence among the best soldiers of the war.

335. Grant before Petersburg. - Sheridan in the Shenandoah Valley. ${ }^{1}$ June-October, 1864. After the bloody repulse at Cold Harbor, Grant changed his base of supplies to the James, crossed the river, and moved against Petersburg, attempting to take that city, south of Richmond, by a sudden stroke, which failed. From that time (the middle of June) until nearly the ending of the war, the Army of the Potomac remained in front of Petersburg, not carrying on a regular siege, though its work was so called, but making attacks on the forces there and at Richmond, and on Lee's communications with the south.

The more active campaigning of the summer and fall was in the Shenandoah, where the Confederate commander, Early, overmatched the Union generals, Sigel, Hunter, and Cooke, and invaded Maryland and Penn- 
sylvania in July, threatening Baltimore, and Washington itself. Troops from the Army of the Potomac were summoned hastily, and Sheridan was brought up to take command of a "Middle Military Division," embracing everything between Sherman's command and Meade's. Then a brilliant campaign in the Shenandoah valley was opened, and ran through a series of victories won Winchester, Fisher's by Sheridan, at Winchester, September I9, Hill, Cedar Creek, SeptemberOctober, 1864. at Fisher's Hill on the 22d, at Cedar Creek, October I9. Sheridan was absent from the field when the last-named battle began, and made a famous ride of twenty miles to reach it, and to snatch victory from defeat. The result of the campaign was to clear the valley of the Confederates and to lay it waste from end to end.

336. Naval Exploits, June-August, 1864. In this exciting summer of I 864 the navy had been doing important work. After a career of nearly two years, in

Sinking of the

Alabama, June 19, 1864 . which she had destroyed millions of dollars' worth of property, the Confederate cruiser Alabama was encountered (June I9) on the coast of France, near Cherbourg, by the United States steamer Kearsarge, and sunk in an engagement which lasted but an hour.

On the 5th of August Admiral Farragut almost surFarragut passed his feat at New Orleans, by enteringat Mobile,
August 5, the harbor of Mobile with his fleet, destroying 1864. the Confederate naval force there and capturing the forts. The city itself was not occupied till a later time.

337. Sherman's March to the Sea. SeptemberDecember, 1864. Sherman's siege of Atlanta ended on the $2 d$ of September, when Hood evacuated the town. Its few inhabitants were then removed, and it 
was made exclusively a military post. Hood withdrew for a short distance only, and, early in October, he moved suddenly northward, pushing for the rear of Sherman's army; but Sherman was not disturbed. General Thomas, with a large force, had been sent back to Nashville, and Hood was left to his care. The northward raid was rather favorable to a

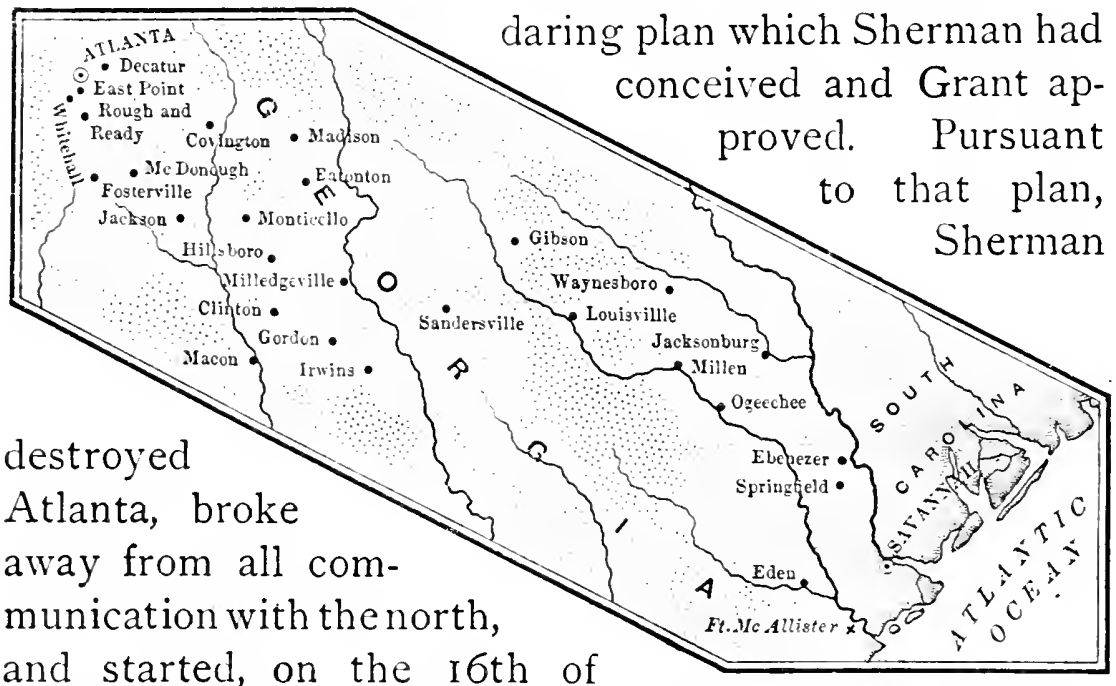

November, with 60,000 veteran troops, on his memorable "march

TRACK OF SHERMAN'S MARCH TO THE SEA.

to the sea," foraging for subsistence as he went, and leaving a widely desolated track. On the roth of December he reached Savannah; on the 2oth the Confederates evacuated that town.

Hood's army meantime had been shattered in two battles (see Map XIII.), first at Franklin, where he fought with General Schofield (November 30), and then Hood's at Nashville, where General Thomas, in two defeat. days of hard fighting (December $15-16$ ), completed his defeat. A remnant only of his force fell back through Tennessee.

338. Reëlection of President Lincoln. November, 
544 SECESSION, CIVIL WAR, AND REUNION.

1864. In the midst of these exciting events, which portended the exhaustion of the Confederacy, President Lincoln, in November, was reëlected by a large majority over General McClellan, the Democratic nominee. Republican radicals had opposed the nomination of Lincoln, making Chase and Frémont rival candidates; but the larger body of the people had faith in the great man whom they affectionately called "Father Abraham" and "Old Abe."

Mr. Chase, after many disagreements with the President, had resigned the Treasury Department in the previous June. In the following December he was appointed Chief Justice of the Supreme Court of the United States, succeeding Chief Justice Taney, who died October I 2.

339. Peace Conferences. Sherman moving northward. - Work of Congress. July-March, 1864-1865. Twice in July there had been unofficial peace conferences with Confederate officials by Horace Greeley, of the "New York Tribune," at Niagara Falls, and by two adventurous gentlemen who went to Richmond and interviewed President Davis in person. The only result had been to show that, without disunion, no peace could be made.

Fresh successes to the Union arms came early in the Fort Fisher, new year. Fort Fisher, at Wilmington, N. C., Fort Fisher, was taken on the I 5 th of January by military
1865.

forces under General Terry, with the help of Admiral Porter's fleet. On the ist of February Sherman started northward from Savannah, on another bold charleston march through hostile country, with no base of Ovacuated, supplies. His movement would isolate Charles17, 1866. ton, and it was evacuated by the Confederates on the 17 th. On the $22 \mathrm{~d}$ of February Wilmington was 
occupied by troops from the west under General Schofield, and General Cox moved soon afterward from New-

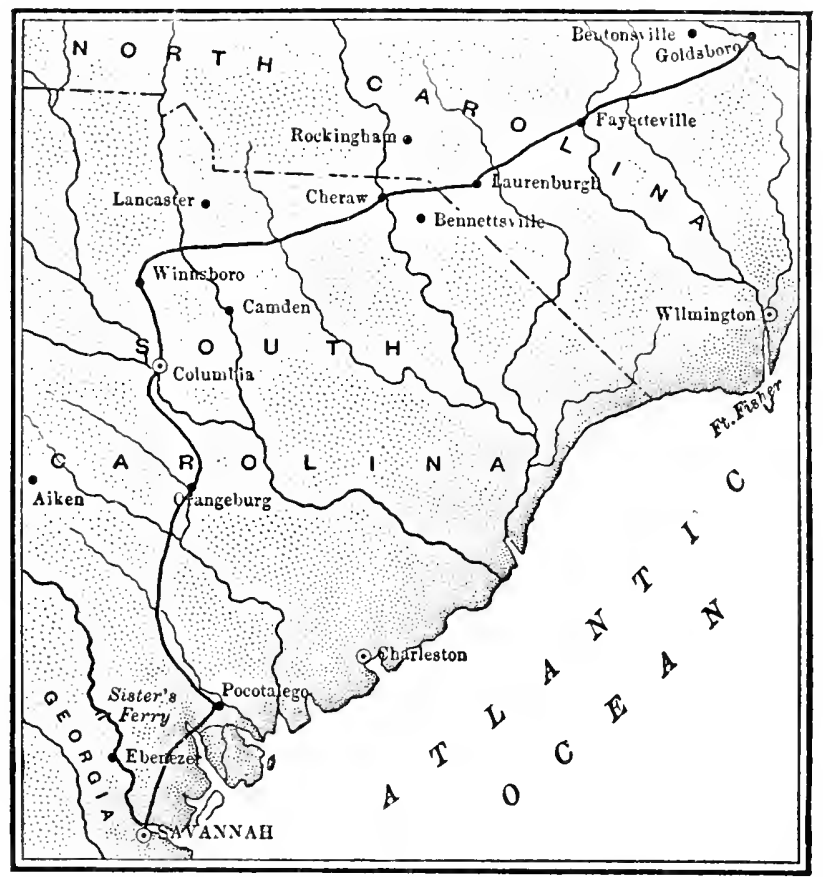

TRACK OF SHERMAN'S MARCH NORTHWARD FROM SAVANNAH.

berne with forces to meet Sherman at Goldsboro, where the latter arrived on the $22 \mathrm{~d}$ of March.

In these months Congress had been doing notable work. The Thirteenth Amendment to the Constitution of the United States, which prohibits slavery forever, was adopted by the House of Re- $\begin{gathered}\text { Thirteenth } \\ \text { Amend- }\end{gathered}$ presentatives on the last day of January, having ment. passed the Senate at the previous session, and it went then for ratification to the legislatures of the States. ${ }^{1}$

1 Already, before this action in Congress, Maryland and Missouri, the former by popular vote on a new constitution (October I2-13, I864), the latter by ordinance of a constitutional convention (Jan- 
546 SECESSION, CIVIL WAR, AND REUNION.

Both houses passed an act to free the wives and children of persons mustered into the service of the United States, - all negro soldiers having been declared free long before. Another act established what was named the Freedmen's Bureau, for the care and protection of the liberated blacks, and for the relief of impoverished white refugees in the south.

Renewed efforts to bring about some negotiation of peace were being made at this time by unofficial persons,

Renewed offorts for peace.

and the President was persuaded by them to meet Vice-President Stephens of the Confederacy and two others (February 3), for conference, on a steamer at Fortress Monroe. The meeting, in which Secretary Seward took part, had no result.

On the $4^{\text {th }}$ of March Mr. Lincoln entered on the second term of his presidency, and delivered an inau-

President Lincoln's second gural address in which, as Mr. Carl Schurz has said, "he poured out the whole devotion inaugural. and tenderness of his great soul. It had all the solemnity of a father's last admonition and blessing to his children before he lay down to die." "No American President," continues Mr. Schurz, "had ever spoken words like these to the American people. America never had a President who found such words in the depth of his heart."

340. The Ending of the War. ${ }^{1}$ March-May, 1865. Military events now moved rapidly toward the inevitable end of the exhausted Confederacy. Early in March Davis and Lee had determined to abandon Richmond, and they waited only for some drying of impassable uary 6, I 865), had abolished slavery. Two States reconstructed under President Lincoln's proclamation, Arkansas and Louisiana, had done the same; Tennessee followed in February, 1865.

1 See Map XII. 
roads before beginning a southwestward retreat. Grant anticipated their intention, and began a preventive movement on the 29th of March, with Sheridan (who had rejoined him ten days before) in advance. At Five Forks, on the ist of April, Sheridan broke Lee's line of defence, and exposed the works at Petersburg to an assault by which Five Forks, April 1, 1865. part of them were carried the next day. Both Petersburg and Richmond were evacuated that night, and nearly a third of the latter city was destroyed by a fire which started from the burning of public stores. With all that remained of his army, about 30,000 men, Lee began a retreat. Grant pursued with more than twice the number, and there was no escape. At Appomattox Court House, on the gth of April, Lee gave up Lee's the attempt, and surrendered the remnant of surrender, his little force. He and his worn veterans $\mathbf{1 8 6 5 .}$ could yield with no shame, for they had fought against tremendous odds as stubbornly, as bravely, and as skilfully as any army in the history of the world. It is a satisfaction to know that the terms of surrender were made generous by Grant.

The surrender of General Lee was practically the ending of the war. General Johnston surrendered his forces on the 26th of April ; President Davis was taken prisoner in Georgia on

End of the war, May, 1865. the IIth of May, and when that month closed there were no Confederates in arms.

341. Last Speech of Lincoln.-His Views of "Reconstruction" Policy. April 11, 1865. President Lincoln was with General Grant, at City Point, when Richmond was given up, and he visited the stricken city twice. On the gth of April he returned to Washington, and on the I Ith, responding to a serenade at 
548 SECESSION, CIVIL WAR, AND REUNION.

the White House, he made his last public speech. He spoke on the subject of the restoration or reconstruction of the States lately rebellious, reviewing the practical steps he had taken, and showing in his clear, plain way how useless and mischievous it would be to go into disputes as to "whether the seceded States, so called, are in the Union or out of it." "We all agree," he said, "that the seceded States, so called, are out of their proper practical relation with the Union, and that the sole object of the government, civil and military, in regard to those States, is to again get them into that proper practical relation. I believe that it is not only possible, but in fact easier, to do this without deciding or even considering whether these States have ever been out of the Union, than with it. Finding themselves safely at home, it would be utterly immaterial whether they had ever been abroad." I Alluding to the question of the suffrage for freedmen he said: "I would myself prefer that it were now conferred on the very intelligent, and on those who serve our cause as soldiers;" indicating that he would think it unwise to make a sudden gift of the ballot to the whole mass of emancipated slaves.

On the I 2 th an order was issued to stop drafting, recruiting, and the purchase of military supplies.

342. The Murder of President Lincoln. April 14, 1865. The i 4th of April brought the fourth anniversary of the surrender of Fort Sumter to Beauregard, and an impressive ceremony was performed at Charleston, in the ruins of the fort, that day. The flag lowered four years before was formally raised by General Anderson, and Henry Ward Beecher delivered an address.

1 The Supreme Court, in a case (Texas $z s$. White) that came before it in I872, decided that the seceded States were never out of the Union. 
At Washington the memorable day was more memorably closed, and macle an anniversary of national grief and horror for all time. That evening the careworn President sought an hour of relaxation by attending the theatre with his wife and a party of friends. As he sat in his box watching the play, an assassin, who had prepared for the opportunity, stole into the box from behind and shot him, leaping instantly to the stage and escaping before any one could realize what he had done. His bullet had entered the brain of the wisest and noblest man of his time, and extinguished consciousness, but not life. Borne to a neighboring house, the murdered President breathed until early morning, and then passed away. The feeling of the country that morning when the awful news burst upon it cannot be described. It seemed at the first shock as though chaos had come, - as though everything had been lost.

With the news of the murder of the President came intelligence of an attempt on the life of Secretary Seward, made at the same hour. Mr. Seward had been thrown from his carriage a few days before, and had received injuries that confined

Attempt to murder Mr. Seward. him to his bed. A man pretending to have been sent by his physician obtained access to his chamber and stabbed him three times, but not fatally, in the neck and cheek. Two sons of the Secretary and a nurse were wounded seriously in a struggle, unarmed, with the assassin, and he, too, escaped.

The President's murderer proved to be a well-known actor, John Wilkes Booth. He was tracked in his flight from the theatre and found, on the $25^{\text {th }}$ of April, in a barn, near Fredericksburg,

John

Wilkes

Booth.

Va. Refusing to surrender, he was shot. The attempt 
to kill Mr. Seward had been male by one Lewis Powell, alias Payne, from Florida, who had acted in concert with Booth. A third confederate, George Atzerodt, was to have killed the Vice-President, Andrew Johnson, but failed to perform his part. The three were found to have belonged to a small band of conspirators, of which Booth was the leader, and which met at the house of a Mrs. Surratt. Their original plot was for kidnapping the President and taking him to Richmond; but when the rebellion collapsed, Booth ordered an undertaking of murder, and his confederates obeyed. Except a son of Mrs. Surratt, who escaped from the country, all The plot were captured, and tried and convicted by a revealed. military court. Payne, Atzerodt, Mrs. Surratt, and a fourth, named Herold, were hanged ; several others were imprisoned. Surratt, who escaped, was caught two years afterward in Egypt and brought to trial; but the jury in his case disagreed.

The fear awakened in many minds, that a desperate, widespread conspiracy of defeated Confederates had been formed to destroy the heads of national authority, was proved very soon to have no ground. The first desire of many, for stern dealing with the leaders of the defeated Confecleracy, on charges of high treason, Jefferson yickled to wiser counsels, and no political Davis. prosccutions occurred. Mr. Daris was imprisoned at Fortress Monroc for two years, then admitted to bail, and shared in a general amnesty, proclaimed finally in December, is68.

343. Statistics of the War. The most stupendous of civil wars was at an end. More than 3,000,000 men had been enlisted in its armies, from first to last, 2,200,000 under the national flag, I, 000,000 under that of the Confederacy. Of those who fought for the 
Union, 360,000 had given their lives to the cause, I 10,000 in battle, or from wounds received in battle, 224,000 from disease, and the remainder from accidents and other causes of

Armles, battlos, deaths, wounds. various kinds. On the other side the deaths from all causes are estimated to have numbered 250,000 or 300,000 . In the four years of war there were 2265 engargements, large and small, in 330 of which the Union loss exceeded roo men.

The navy, insignificant when the war began, had grown to 700 ships when it closed, and 75 of The them were iron-clad. The Confederates had navies. put I I cruisers afloat, and the property they had destroyed was reckoned at nearly $\$ 18,000,000$.

The money cost of the war to the government was $\$ 3,250,000,000$, and it left a national debt of $\$ 2,808,549,000$. The Confederate expenditure

Money cost. was about $\$ 1,500,000,000$. Of the value of property destroyed in the war, no estimate can be made.

The grcat armies of the Union had been created with such speed that 60,000 and 80,000 men were sometimes put into the field in single months. Even more rapidly they were dissolved. By the middle of November, $1865,800,000$ men had been mustered from service and returned to their homes. Before

Dissolution of the armles. the dissolution of the two principal armies, the Army of the Potomac and the Army of Sherman, they were marched through Washington, on two successive days (May 23-24), passing in review before the President, affording a military spectacle of grand impressiveness, but such as this country will be happy if it has no opportunity to witness again.

Of Confederate soldiery, I 74,000 were formally surrendered at the close of the war, and 63,000 in the 
camps of the prisoners of war were set free. There is no account of the many who went from the lost field to their homes without formal leave.

\section{TOPICS AND SUGGESTED READING AND RESEARCH.}

\section{Preparing to strike at Slavery.}

\section{Topics AND ReFERENCES.}

I. Confiscation and liberation act of Congress. Nicolay and Hay, vi. 97-IoS; Burgess, Ciail th ar, ii. 75-76; McPherson, I96I 98 .

2. The President's power to emancipate slaves as a war measure. Whiting, ch. iii.

3. Lincoln's conviction of duty regarding the use of his power to strike down slavery. 4. His proclamation of emancipation prepared. 5. Reasons for deferring it. Lincoln, ii. 50S-509. 227228, 396-399, 479-4So: Carpenter, 20-24: Hart, Contemp's, iv. 397-402 ; Hart. Chase, 264-269: Nicolay and Hay, vi. ch. vi.: Tarbell. ii. I 13-120: Rhodes, iv. 67-76: Schurz, Lincoln. 7S-S6; Morse, Lincoln, ii. 99-IIG; Blaine, i. 435-440; Burgess, Cizil II ar. ii. $72-75 . S_{4}-87$.

6. The forming of negro regiments. Morse. Lincoln, ii. I5-I8; Nicolay and Hay, vi. cl. xx.

\section{Lee's Crushing Defeat of Pope and Invasion of Maryland.}

Topics AND ReFERENCES.

r. Pope's plans frustrated. 2. His army druven back to Washington. Ropes, Pope, ch. i.-xiii.: Paris, ii. 250-303: Long, ch. xi.; Cooke, Jackson. 249-307; McClellan. ch. xxx.-xxxi.: Rhodes, iv. I13-I3t; Nicolay and Hay, vi. ch. i.: Morse. Lincoln, ii. 73-So; Hart, Contemp's, ir. $3+2-3+6$.

3. Lee's invasion of Maryland. 4. McClellan against Lee in Maryland. - End of the invasion. Palfrey, ch. i.-iii.: Long, ch. xii.; McClellan. ch. xxxii.-xl.: Paris, ii. 303-359: Cooke, Jackson, 307-348: Rhodes, iv. 134-156: Morse. Lincoln, ii. So-92 ; Hart, Contempis, ir. 346-35I : Nicolay and Hay, vi. 20-29, 131-146: Lincoln, ii. $244,245-246,249-252$. 


\section{Emancipation proclaimed by President}

\section{Lincoln.}

TOPICS AND REFERENCES.

r. First proclamation, September 22, I862 (text in Lincoln, ii. 237-238). 2. Second proclamation, January I, 1863 (text in Lincoln, ii. 285, 287-288). Nicolay and Hay, vi. ch. viii., xix. ; Tarbell, ii. I20-126; Burgess, Civil War, ii. 97-101; Morse, Lincoln, ii. II6-I2I，I30-I33；McPherson, 227-233; Hart, Chase, 270-27I; Rhodes, iv. $157-163$.

\section{Dark Days.}

TOPICS AND REFERENCES.

1. Bragg in Kentucky. - His defeat at Perryville. Coppée, 7888; Paris, ii. 360-395; Cist, ch. v.; Rhodes, iv. 173-I8I ; Battles and Leaders, iii. $1-69,600-609$; Nicolay and Hay, vi. ch. xiii.

2. Battles of Grant's army. Battles and Leaders, ii. 717-759; Grant, i. 325-350 ; Sherman, i. 287-292 ; F. V. Greene, The Mississippi, ch. ii.; Cist, ch. vi. ; Paris, ii. 396-417.

3. Views of foreign governments. 4. The French in Mexico. 5. The Confederacy favored by the British government. 6 . The Alabama and other "commerce-destroyers." Nicolay and Hay, vi. ch. ii.-iv.; Rhodes, iv. 76-95, 337-394; McPherson, 348-354; Lothrop, 376-394; Burgess, Civil War, ii. 288-3I I J. Davis, ii. 245-252; Soley, ch. vii.

7. Party opposition in the north. 8. "War Democrats" and "Copperheads." 9. Military arrests and interference with free speech. Rhodes, iv. 224-226, I63-172, 245-255; Morse, Lincoln, ii. 95-99, 183-I94; Nicolay and Hay, vii. ch. xii.; Paris, iii. 404-406, 4I8-420; ii. 678-684; Burgess, i. 232-236; ii. 214-219, 222-223; Schurz, Lincoln, ro9-I I2; Blaine, i. 488-493; McPherson, I 52-194; Lincoln, ii. 123-1 25, 239, 345-352, 360-363, 406-407, $54 \mathrm{I}-543$.

ro. Elections in 1862. Blaine, i. 44I-444; Morse, Lincoln, ii. I $21-125$.

RESEARCH. - Disloyal secret societies and conspiracies in the north, and plots by Confederate agents in Canada. McPherson, 445-454; Nicolay and Hay, viii. ch. i. 


\section{More National Reverses.}

TOPICS AND REFERENCES.

I. Burnside's repulse at Fredericksburg. Palfrey, ch. iv.; Paris, ii. 559-605: Rhodes, iv. Ist-202: Battles and Leaders, iii. 70-I 42 ; Long. ch. xiii.: Cooke. Jackson, 365-3\$s ; Nicolay and Hay, vi. ch. ix.-x. : Hart. Contemp's, iv. $35 \mathrm{I}-356$.

2. Battle of Stone River. Cist, ch. riii.: Battles and Leaders, iii. 613-634: Paris, ii. 49S-535: Coppée, S9-117.

3. Grant and Sherman preparing to attack Vicksburg. Grant, i. ch. xxx.: Sherman, i. 307-331 : F. V. Greene, The Mississippi, ch. iii.; Paris, ii. $+43-472$; Mahan. The Gulf, I It-169.

4. Hooker's defeat at Chancellorsville. Paris, iii. I-I23: Doubleday, I-St: Nicolay and Hay, vii. ch. iv.: Long, ch. xiv.; Cooke, Jackson. 397-464; Battles and Liaders, iii. I52-233; Rhodes, iv. 256-267: Hart. Contemps, iv. 359-363: Lincoln, ii. 306-307. 322, $33^{6-337}$.

5. Passage of a conscription act. 6. Creation of the national bank system. 7. Effect of the "greenback currency" on the cost of the war. Rhodes, iv. 236-239: Nicolay and Hay, vi. 240-247, vii. 3-16; Paris. iii. 407-416: Hart, Chase, $274-2 S_{3}$ : Blaine, i. ch. xxii.; Morse, Lincoln, ii. I9t-19\$.

\section{Lee in Pennsylvania. - Gettysburg. - Vicksburg.}

TOPICS AND REFEREXCES.

1. Lee's second campaign of invasion. 2. Meade in command of the Army of the Potomac. 3. Battle of Gettysburg and retreat of Lee. Battles and Leaders, iii. 24+-433: Doubleday. \$7-210; Paris, iii. 451-694: Nicolay and Hay. vii. ch. viii.-ix.: Long, ch. xv. ; Rhodes, ir. 268-297: Morse. Lincoln, ii. I43-I 52: Lincoln. ii. 368-369: Hart. Contempis. iv. 372-376.

4. The doubly memorable th of July. 5. The taking of Vicksburg by Grant. 6. Surrender of Port Hudson to Banks. 7. The Mississippi reopened throughout. Battles and Leaders. iii. 46259S: F. V. Greene, The Mississippi, ch. iv.-viii.: Paris, iii. I7S402: Rhodes, iv. 299-319: Grant. i. ch. xxxi.-xxxviii.: Sherman, i. ch. xiii.: Lincoln, ii. 366-368; Morse, Lincoln, ii. 157-163: Nicolay and Hay, vii. ch. ri.-vii., ch. $x$. 


\section{Draft Riot in New York.}

TOPICS AND REFERENCES.

r. Four days of terror in the city of New York. Rhodes, iv. 320-332; Nicolay and Hay, vii. 16-26; Paris, iv. 2-7; Lincoln, ii. $381-382$; Hart, Contemp's, iv. $376-381$.

\section{Operations against Charleston. - Quiet in Virginia.}

TOPICS AND REFERENCES.

r. Admiral Dupont's repulse from Charleston harbor. 2. Landing on Morris Island. - Assault on Fort Wagner. 3. Final evacuation of Fort Wagner. 4. Bombardment of Charleston. Battles and Leaders, iv. I-74; Ammen, ch. v., vii.; Nicolay and Hay, vii. ch. iii., xv.; Paris, iii. 14r-I65, 349-380; Rhodes, iv. 332-336.

5. Ineffectual campaigning in Virginia. Paris, iii. 695-828; Long, ch. xvi.; Battles and Leaders, iv. 8I-96; Nicolay and Hay, viii. ch. ix.

\section{Critical Situation in Tennessee. - Grant to the Rescue.}

TOPICS AND REFERENCES.

r. Burnside reaches Knoxville. J. D. Cox, Atlanta, ch. ii.; Paris, iv. 45-53; Nicolay and Hay, viii. ${ }_{5} 8-170$.

2. Rosecrans in Chattanooga. 3. Battle of Chickamauga and the result. - Rosecrans besieged in Chattanooga. Cist, ch. ix.xii.; Coppée, 118-164; Battles and Leaders, iii. 635-67I ; Grant, i. ch. xl.; Paris, iv. 53-192 ; Nicolay and Hay, viii. ch. iii.-iv.; Rhodes, iv. 395-401 ; Morse, Lincoln, ii. I63-I66; Hart, Contemp's, iv. $38 \mathrm{I}-386$.

4. The shifting of western generals. - Grant's enlarged command. 5. Grant's operations at Chattanooga. - Battles of Missionary Ridge and Lookout Mountain. 6. Defeat of Bragg and Longstreet. - Deliverance of East Tennessee. Paris, iv. 193-330; Grant, i. ch. xl.-xlii.; ii. ch. i.-iii. ; Sherman, i. 374-396 ; Battles and Leaders, iii. 676-75I ; Cist, ch. xiii.-xiv.; Coppée, I65-198; Nicolay and Hay, viii. I 2 I-I 57, 170-I 88.

7. President Lincoln's Gettysburg address. Lincoln, ii. 439; Nicolay and Hay, viii. ch. vii.; Morse, Lincoln, ii. 214-216; Rhodes, iv. 297-298. 
331. Amnesty offered by President Lincoln. - His "Reconstruction" Plan.

TOPICS AND REFERENCES.

I. Terms of the President's proclamation (text in Lincoln. ii. 44-444). 2. His plans for the reëstablishment of loyal state gorernments. 3. Congressional riew of it. - Radical objections. 4. The radical theory. 5. Reconstruction act of Congress. - Not signed by the President. 6 . His proclamation submitting it to the country (text in Lincoln. ii. $5+5$ ). 7. His policy sustained by public opinion. Lincoln. ii. $45+456.504-505:$ Nicolay and Hay, ix. 104-127. 445-456: Norse. Limoln. ii. $217-237$. 295-29s; Blaine. ii. 37-46: Storey, $2 \$ z-2 \$ 9$ : Schurz, Limolm. $05-96$.

RESEARCH. - Reconstruction proceedings in Arkansas. Louisiana. and Tennessee. under President Lincoln's proclamation; and proceedings to abolish slavery in Maryland and Missouri. Nicolay and Hay, viii. ch. xri.-xx.

\section{Grant made Lieutenant-General, in Chief Command.}

TOPICS AND REFERENCES.

I. The revived rank. 2. Grant in general command. with personal direction in Tirginia. 3. Sherman in the western command. 4. Meade leading the Army of the Potomac. 5. Sheridan as cavalry commander. 6. The general plan of campaign. 7 . Strength of the main armies. Humphrers ch. i. : Nicolay and

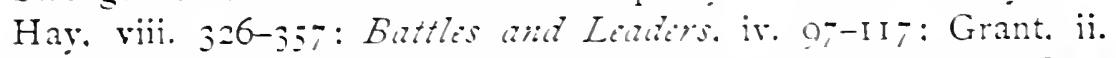
4+6z: Morse Lincoln. ii. 27-7-270: Rhodes, ir. $+33-439$ : I. D. Cox. Athata. ch. iii.

\section{Grant's Morement on Richmond.}

TOPICS AND REFEREXCES.

I. Battles from the Rapidan to the Chickahominy. 2. Repulse at Cold Harbor. 3. General Butler's morement. Grant. ii.ch.ri., viii-xiii.: Battles ara Leabirs, ir. I Is-2+6: Humphreys, ch. ii.vi.: Long. ch. xrii.: Nicolay and Hay, viii. ch. xir.-xr.: Rhodes, iv. Ho-4fs: Morse, Limoln. ii. 279-2S2: Hart, Contints. iv. +1 2415. 


\section{Sherman's Movement on Atlanta.}

Topics ANd References.

x. Battles of the campaign. - Siege of Atlanta. - Death of General McPherson. Sherman, ii. ch. xvi.-xviii.; J. D. Cox, Atlanta, ch. iv.-xiv.; Grant, ii. ch. vii.; Battles and Leaders, iv. 250-344; Nicolay and Hay, ix. ch. i., xii.; Rhodes, iv. 448-456, 5 I I $-5 \mathrm{I} 3$.

\section{Grant before Petersburg. - Sheridan in the Shenandoah Valley.}

Topics ANd References.

I. Operations of the Army of the Potomac. Grant, ii. I74-204; Humphreys, ch. vii.-xii.; Battles and Leaders, iv. 533-589; Long, 369-40I.

2. General Early in the Shenandoah and invading Maryland. 3. Sheridan's campaign against Early. - The valley laid waste. Pond, ch. iv.-xiv. ; Grant, ii. 204-224; Battles and Leaders, iv.492530 ; Long, ch. xviii.; Nicolay and Hay, ix. ch. vii., xiii.-xiv.; Hart, Contemp's, iv. 422-427; Morse, Lincoln, ii. 282-286.

\section{Naval Exploits.}

Topics AND References.

x. Destruction of the Alabama. Soley, 205-213; Battles and Leaders, iv. 600-625; Nicolay and Hay, ix. I42-157; Hart, Contemp's, iv. 4i6-4I8.

2. Farragut's victory in Mobile Bay. Mahan, The Gulf, ch. viii.; Battles and Leaders, iv. 379-4II ; Nicolay and Hay, ix. ch. x.; Hart, Contemp's, iv. 4I $8-42$ I.

RESEARCH. - The daring exploit of Lieutenant Cushing in destroying the Confederate ram Albemarle, at Plymouth, N. C., October 27, I864. Battles and Leaders, iv. 634-642 ; Soley, 97I05.

\section{Sherman's March to the Sea.}

Topics AND ReFerences.

x. The fate of Atlanta. 2. Hood's raid northward. 3. Sherman's march to Savannah. Sherman, ii. ch. xix.-xxi.; J. D. Cox, Atlanta, ch. xv.-xvii.; J. D. Cox, March to the Sea, ch. i.-iii. 
Battles and Leaders, iv. 663-68o; Grant, ii. ch. xvii.; Nicolay and Hay, ix. ch. xx.; Hart, Contemp's, iv. $42 S-432$.

4. Shattering of Hood's army in Tennessee. J. D. Cox, March to the Sea, ch. iv.-vii.; Grant, ii. ch. xviii.; Nicolay and Hay, x. ch. i.; Hart, Contemp's, iv. 432-436.

\section{Reëlection of President Lincoln.}

\section{TOPICS AND ReFerexces.}

I. President Lincoln's large majority over McClellan. 2. Radical Republican opposition to Lincoln. Rhodes, iv. 456-470, 475-4S7, 517-539; Blaine, i. ch. xxiv.; Tarbell, ii. ch. xxviii.; Morse, Lincoln, ii. 286-295; Schurz, Lincoln, 96-102; Nicolay and Hay, viii. ch. xii.; ix. ch. ii.-v., xi., xvi.; Hart, Chase, 307-3I2; Lincoln, ii. $59+-596$.

\section{Peace Conferences. - Sherman moving north- ward. - Work of Congress.}

TOPICS AND REFERENCES.

I. Efforts for peace. Nicolay and Hay, ix. ch. viii.-ix.; Rhodes, iv. $513-515$.

2. Union successes. - Capture of Fort Fisher. - Sherman in motion again. - Evacuation of Charleston. Sherman, ii. ch. xxii.xxiii.; Grant, ii. ch. xix.-xx; J. D. Cox, March to the Sea, ch. viii.xi.; Battles and Leaders, iv. 642-66I, 683-705; Ammen, 21 5-244: Nicolay and Hay, x. ch. iii.

3. Thirteenth Constitutional Amendment. Morse, Lincoln, ii. 316-328; Nicolay and Hay, x. ch. iv.; Blaine, i. 50+-507; Lincoln, ii. 633-634; Hart, Contemp's, iv. 465-467.

4. The Freedmen's Bureau. Barnes, ch. v.-viii., xii.; Williams, ii. pt. S, ch. xxi.-xxii.; Herbert, ch. i.

5. President Lincoln's meeting with Vice-President Stephens. Lincoln, ii. 640-65I ; Nicolay and Hay, x. ch. v.-vi.; Morse, Lincoln, ii. 302-3I I.

6. President Lincoln's second inaugural address (text in Lincoln, ii. 656-657). Nicolay and Hay, x. ch. vii.; Morse, Lincoln, ii. 31 I315 ; Schurz, Lincoln, 103-104. 
TOPICS, REFERENCES, AND RESEARCH. 559

\section{The Ending of the War.}

TOPICS AND References.

r. Lee and Davis preparing for retreat. 2. Lee's line of defences broken by Sheridan. 3. Evacuation of Petersburg and Richmond. 4. Lee's retreat and Grant's pursuit. - The surrender at Appomattox Court House. Grant, ii. ch. xxii.-xxv.; Long, 402427 ; Battles and Leaders, iv. 705-753; Humphreys, ch. xiii.-xiv.; Nicolay and Hay, x. ch. viii.-xi.; Morse, Lincoln, ii. 329-340; J. Davis, ii. 661-678; Hart, Contemp's, iv. 437-444.

5. Johnston's surrender. - Capture of Jefferson Davis. - End of the war. Sherman, ii. 342-373; Grant, ii. ch. xxvi.; J. Davis, ii. 678-705; Battles and Leaders, iv. 754-767; J. D. Cox, March to the Sea, ch. xiii.; Nicolay and Hay, x. ch. xii.-xiii., xvii.

\section{Last Speech of Lincoln. - His Views of Reconstruction Policy.}

Topics and References.

r. The President's visits to Richmond. 2. His speech at Washington, April I I. 3. His treatment of the question whether the seceded States are in or out of the Union. 4. His opinion as to giving the suffrage to the freedmen. Lincoln, ii. 672-675; Nicolay and Hay, ix. 456-463; Blaine, ii. 46-50; Hart, Contemp's, iv. $462-464$.

\section{The Murder of President Lincoln.}

TOPICS AND REFERENCES.

I. Anniversary of the surrender of Fort Sumter. 2. The murder of the President that evening. 3. Attempt on the life of Secretary Seward. 4. Pursuit, discovery, and death of the President's murderer. 5. The plot and the plotters of the crime.Their fate. Nicolay and Hay, x. ch. xiv.-xv.; Tarbell, ii. 232-244; Morse, Lincoln, ii. 342-354.

6. No political prosecutions after the war. 7. Imprisonment, release, and amnesty of Jefferson Davis. Hart, Chase, 35I-354; Nicolay and Hay, x. 274-276.

ReseARCH. - Estimates of Lincoln. Morse, Lincoln, ii. 355-358;

Nicolay and Hay, x. ch. xviii. ; Schurz, Lincoln, II 5-II 7. 


\section{Statistics of the War.}

TOPICS AND REFERENCES.

I. Number of men in arms. 2. Death-roll of the war. 3. Number of battles, large and small. 4. Federal navy of the war. 5. Confederate cruisers and their work. 6. Money cost of the war. 7. Creation and dissolution of armies. Blaine, i. 549-562, ii. 27-33; Nicolay and Hay, x. 329-330, 335-340; Phisterer, 62219; Battles and Leaders, iv. 767-768; Grant, ii. 35I-355.

8. Grand final review at Washington. Grant, ii. $378-380$; Sherman, ii. 375-3So; Blaine, ii. IS-2I ; Nicolay and Hay, x. 330335 .

Research. - The organized work of the United States Sanitary Commission and the United States Christian Commission, in assisting the government to supply the wants and to care for the soldiers. J. W. Draper, iii. ch. 87 ; Paris, iii. 432-438; Stillé ; Livermore; Wormeley ; E. P. Smith. 


\section{CHAPTER XVII.}

THE RESTORED UNION. I865-I880.

344. Vice-President Andrew Johnson becomes President. - His Conflict with Congress. AprilDecember, 1865. Andrew Johnson, of Tennessee, elected Vice-President in I 864, took the oath of office as President on the morning of April 15, 1865. He had been a senator from Tennessee when that State joined the Confederacy, but refused to recognize the secession, and kept his senatorial seat to the end of his term. After Nashville was occupied by the national forces, in I 862, he was appointed mili- 1861-1865. tary governor of the State. As a loyal southerner, the Republicans thought it good policy to make him VicePresident, though his political opinions had been those of a Democrat, and opposed on some points to their own. There was now a situation like that which occurred when Vice-President Tyler became President, and the result was much the same.

President Johnson retained the cabinet of his predecessor, and took up the work of reconstructing governments in the lately rebellious States on substantially the lines that President Lincoln had laid down. On the 29th of May he issued a proclamation of amnesty and pardon, differing little from Linculn's except in additions to the list of excluded classes. On the same day he issued the first of a series of proclamations which appointed provisional governors to conduct the prescribed 
562 SECESSION, CIVIL WAR, AND RELNION.

process of reconstruction in the sereral States. The Tho Pres1. Work was in progress everywhere by the middont's
Rocon- dle of July, and before Congress came tostruction measures, gether, in December, all the States except Texas had adopted constitutions prohibiting slavery; had organized state gorernments, and nine of them had ratified the Thirteenth Amendment to the Constitution of the United States (see sect. 339). Without some of these ratifications, that national prohibition of slavery could not have acquired force. ${ }^{1}$

In several of the States thus reconstructed, the legislatures had proceeded immediately to pass laws for regulating the labor of the freed negroes, with prorisions that seemed likely to take most of their lately given freedom away. Had President Lincoln lived, and had he found it impossible to secure proper protection for the freedmen by the methods of reconstruction that he first proposed, he would undoubtedly have modified his course: and he would without doubt have kept the confidence and support of the people in what he did. But Presiunpopu- dent Johnson had none of the qualities of mind larity of
President and temper that gave Lincoln his extraordiJohnson. nary power. His course tended from the beginning to alarm the ruling party and drive it into the extremely radical policy from which Lincoln had been holding it back.

345. Congressional Reconstruction. 1865-1871. In the bitter quarrel that ensued between Congress and the President, his reconstructive work was undone, and most of his executive authority was taken practically away. By majorities so large as to orercome his retoes, Congress passed a series of radical acts. A Civil Rights

1 The adoption of the Thirteenth Amendment by three fourths of the States was proclaimed December IS, I $\$ 65$ 
Bill, made law in April, I866, affirmed the citizenship of the freed negroes and gave them the protection of United states courts, and military and naval forces, to prevent state interference with their equal privileges and rights. In June a joint resolution recom- Fourteenth mended to the States a Fourteenth Constitu- Amendtional Amendment, embodying the principles ment, 1866 . of the Civil Rights Act $;^{1}$ providing, further, for a reduction of the congressional representation of any State that should deny the elective franchise to any male citizens of voting age; also excluding prominent officials of the late Confederacy from Federal offices until Congress should pardon them, and forbidding the payment of any debt incurred in aid of rebellion against the United States. The reconstructed legislature of Tennessee ratified this Fourteenth Amendment so promptly that Congress, in July, declared that State restored to its former relations to the Union.

The congressional elections of I 866 turned on the issue between Congress and the Presiclent, and the former was sustained. Rejection of the Fourteenth Amendment by all the lately Confederate States except Tennessee, and a serious riot in New Orleans, helped to array popular feeling against the President's reconstructive work. The result was the election of a new Congress (the Fortieth), more radical

Congress sustained in the elections, 1866. than the one whose contest with the Executive it would take up. That contest was reopened rigorously when the final session of the Thirty-ninth Congress began. By a

1 In what are known as the Louisiana "Slaughter House Cases," the Supreme Court decided in 1873 that citizenship of the State is distinct from citizenship of the United States, and that the right of a State to regulate the privileges of the former is not affected by this amendment. 
504 SECESSION, CIVIL WAR, AND REUNION.

law known as the Tenure of Office Act, the power of the President to make removals from office was rendered dependent on senatorial consent. Practical independence of the President was conferred on Lieutenant-General Grant. Universal manhood suffrage, without regard to color, was established in the District of Columbia and in the Territories. Nebraska was admitted to the Union.

Finally, on the next to the last day of its existence, this aggressive Congress passed a "Military Reconstruc-

\section{The Mill-} tion Act," which swept away the structures The Mill- tary- of state government raised by the President, struction Act, March, and divided all the late Confederate States (ex1867 .

cept Tennessee, now fully restored) into five military districts, each to be commanded by a general of the army, under whose direction a new reorganization of state governments was to take place. In the proceedings for that purpose the suffrage was to be exercised by blacks and whites on equal terms of sworn loyalty to the Constitution and the Union, with an extensive disfranchisement of those white people who had taken part in the rebellion. When any State so reorganized should have adopted a satisfactory constitution, and should have ratified the proposed Fourteenth Amendment (hitherto rejected by all but Tennessee), and said amendment should have become part of the Constitution of the United States, such State would be declared entitled to representation in Congress, and not before. By a supplementary act the new Congress, convened on the 4th of Narch, added more strictness to these provisions, and they were set in operation at once. Within little more than a year, compliance with the requirements of the act was secured in seven States, and they were admit. ted to representation in June, I $\$ 68 .{ }^{1}$ The process was

1 On the 2 Sth of July the Fourteenth Amendment was proclaimed to have been ratified by three fourths of the States. 
slower in Mississippi, Texas, and Virginia, the last named of which regained seats in Congress in January, I87 I.

The three laggard States were required to ratify not only the Fourteenth Amendment to the Constitution, but a Fifteenth, which Congress proposed in February, I869. This last of the reconstruction amendments forbids the United States or 1869-1870. any State to deny or abridge the right of citizens of the United States to vote "on account of race, color, or previous condition of servitude." It was ratified by the needed number of States, and added to the Constitution by proclamation on March 30, I 870 .

346. The Working of the "Reconstruction" Measures. 1866-1876. Serious evils attended the reorganization and working of state governments in the circumstances created by the Reconstruction Act. The negro vote, dominant for a time almost everywhere, was influenced and controlled to a great extent by political adventurers, many of whom went into the southern States from the north. Such northern workers in southern politics were called "carpet-baggers;" 1 others of the same class, branded as "scalawags," were a home product in the south. Between them they brought about, in several unfortunate "Carpet-"
baggers"
and scala-
wags." States, a scandalous reign of corruption, extravagance, and almost open plundering of the public, which went on for several years. Resistance by violent measures, to intimidate colored voters, keep them from the polls, and

1 The term "carpet-bagger" signified one who went into the south, not to settle permanently, but to use the opportunity for getting office and to engage in dishonest schemes. Large numbers of a very different class sought homes in the southern States with an enterprising eye to the development of their resources and the restoration of their prosperity. 
frighten them out of public offices, was resorted to by the whites. Secret societies for the purpose were formed, under different names, and these were all finally merged in one formidable organization known as the Ku-Klux Klan, which terrorized many regions of the south for half a dozen years after i 567 .

347. Impeachment of the President. 1868. The triumph of Congress in reconstruction did not end its conflict with the President. Several members of his cabinet, including Secretary Stanton, had disapproved his course, and all of those except Stanton resigned. At length the President attempted to remore Stanton,

Attempt to

remove

Stanton. in defiance of the Tenure of Office Act, which he deemed unconstitutional: whereupon, in February, I 68 , the representatives impeached him for trial before the Senate, exercising for the first time, against a President, the power conferred by the Constitution in Art. I. sect. ii. clause 5, sect. iii. clauses 6-7, and Art. II. sect. ir. This was a grare proceeding, new to the experience of the country, and it was anxiously watched. The trial of the impeachment, begun on the Traal and 5 th of March and ended on the 16 th of May, vote. resulted in a failure to conrict. by one less than the necessary two thirds of the senatorial rote.

348. Incidents of the Period. 1866-1867. After ten years of perserering effort and many costly Atlantic cable, 1866 . failures, the first successful telegraph cable was stretched across the Atlantic, from Newfoundland to the coast of Ireland, and opened for public use on the fth of August. I $\$ 66$.

The public was fumished with a brief excitement at the end of May, that year, by an Irish organization called the Fenian Brotherhood, formed with objects of hostility to the government of Great Britain. A body of about 900 
armed Fenians assembled at Buffalo, crossed the Niagara River on the 3 Ist of May, and invaded Canada, Fonlan with objects that were never made clear. After $\begin{gathered}\text { Invasion of } \\ \text { Canada, }\end{gathered}$ a slight skirmish with Canadian troops they re1866 . turned to American soil. The government of the United States was tardy in taking measures to prevent this breach of the peace.

In March, I867, the French emperor was warned out of Mexico, where he had been conducting an audacious war of conquest since I 862 . His troops had entered the country in coöperation with English and Spanish forces, to enforce a payment of debts. The English and Spanish governments drew out of the expedition when they found that Louis Napoleon

\section{French in}

Mexico, had further designs, and he proceeded alone to subjugate the Mexican people, regardless of remonstrances from the United States. He felt assured that the American Republic was going to pieces, and that he could establish himself in influence on this side of the world. He had succeeded so far as to overthrow the Mexican Republic and set up an empire, of which Archduke Maximilian, of Austria, was persuaded to accept the throne, - a throne supported by the bayonets of France. When the United States became free from domestic war, its government renewed expostulations on the subject, with such emphasis that the French army supporting Maximilian was withdrawn (March, I 867). Two months later the unfortunate Austrian prince was defeated by the Mexicans, taken prisoner, tried by court-martial, and shot.

What is proving to be a valuable as well as a large addition to the territory of the United States

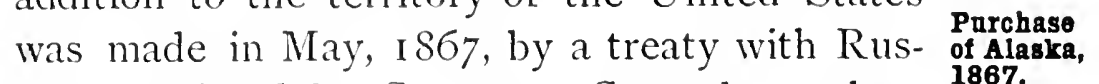
sia, negotiated by Secretary Seward, purchasing Alaska (see Map XV.) for the sum of $\$ 7,200,000$. 
349. Election of General Grant. - Conditions in the South. 1868-1872. The presidential election of I $56 S$ was carried by the Republican party electing General Grant over ex-Governor Horatio Seymour, of New York. The latter carried New York, New Jersey, and Oregon, of the northern States.

During most of the period of the presidency of General Grant a turbulent and deplorable condition of things Disorder existed in many of the southern States. Their In the local govermments were bad; a large part of 1868-1872. their white citizens were intensely hostile to the state authorities, to the negro roters, to the politicians who led the negroes, and generally to all who upheld the existing condition of things. Frequent conflicts and acts of riolence challenged Congress to sustain its previous measures by severe penal laws, known as "force bills." passed in IS 70 and $i S z I$. The Federal executive was called upon in several instances to interfere, in obedience to the fourth section of Article IV. of the Constitution; but President Grant seems to have aroided such intervention when he could. In IS/2 political violence had subsided so far that Congress, that year, modified its harshest legislation and restored the full franchises of citizenship to large classes by a general amnesty act. IVithin the next two or three years a change for the better, in the character of their legislatures and administrative officials, was brought about in all the southern States.

350. Rupture in the Republican Party. - Reëlection of President Grant. 1872. Beginning about is;o, considerable dissatisfaction with the conduct of the Administration and with the course of Congress in carrying out its reconstruction policy arose in the Republican party, and a positive rupture appeared in the presidential 
election of 1872 . The dissatisfied section of the party, taking the name of Liberal Republicans, formed a coalition with the main body of the Democratic party, and Horace Greeley, editor of the Liberal Republicans, 1872. "New York Tribune," was nominated for President as the candidate of both. Dissenting Democrats nominated Charles O'Conor, of New York. The regular Republicans renominated President Grant, and elected him by a majority much larger than in I 868 .

351. Incidents of the Period of President Grant. 1869-1876. Early in the administration of President Grant, an opportunity for the annexation of the Dominican Republic, in the island of San Domingo, or Hayti, was presented to him, and he

San

Domingo treaty, 1869 . thought it should be improved. Without the approval of his cabinet he negotiated an annexation treaty with the Dominican president then in power (1869), and pressed the acceptance of it on the Senate very earnestly, but without success. Opinion generally was against the measure.

From the beginning of the ravages committed by the Alabama and other Confederate cruisers fitted out in British ports, the American government had been claiming indemnity from England. Two conventions for a settlement of what were called the "Alabama Claims" had been negotiated in President Johnson's time, but neither was acceptable to the United States. In I87 I the British government proposed a Joint High Commission, to meet in Washington and devise a settlement of several questions in controversy between the two countries, including the Alabama Claims. The proposal was accepted, and resulted in an agreement styled the Treaty of Washington, which was signed on the 8th of May, I87I. Under this treaty

Settlement of Alabama Claims, 1871-1872. the claims in question were submitted to a tribunal of 
570 SECESSION, CIVIL WAR, AND REUNION.

arbitration, which had its sessions in Geneva, Switzerland, and which, in September, I 872, awarded \$ I 5,500,000 to the United States.

President Grant was very earnest in efforts to bring about some correction of notorious wrongs in the treatment of the red men on their reservations in the west, and he gave extensive powers to a commission of philanthropic citizens who tried to assist him to that end; but the "spoilsmen" of the public service and the lawless population of the frontier were too strong for him and them. The Indians were never worse treated, and several fierce outbreaks of different tribes were provoked.

Indian

wars,

There were bloody and costly wars with the 1871-1876.

Apaches of Arizona in $187 \mathrm{I}$, with the Moclocs of

Oregon and northern California in I873, and with the Sioux of South Dakota in 1876 . In the lastnamed conflict, five companies of a cavalry regiment, led by General Custer, one of the famous cavalry commanders of the Civil War, were overpowered by a great force of the Sioux warriors, commanded by an able chief named Sitting Bull, and were slain to the last man.

This period following the war was naturally one of demoralization in political and commercial affairs. Nar Demoraliz- tends always to derange the better order of ing conse- things, producing a moral laxity of conduct and war. feeling, in many ways. In this case it had intensified the vices of the "spoils system" in the public service, and raised dishonesties in it to a scandalous pitch. Then, too, the pernicious influence of the depreciated legal-tender paper money, which stimulated extravagance and cultivated the gambling spirit in business, was coming to its climax in the years that followed the war. The result was a state of things which brought unscrupulous boldness to the front in many fields of busi- 
ness and of public affairs. The administration of the government was beset by corrupting influences, as it had never been before. The country was outraged and shamed by frauds in the War Department, in the Custom House, and in the Indian Bureau, and by "whiskey rings" of dishonest distillers and conniving officials, who worked together to evade the excise. Plundering combinations got control of municipal governments, most notoriously that known Tweed as the "Tweed ring," in the city of New York. ring. took possession of great railway corporations, as in the case of the Erie Railway, and used them in au- Erie dacious schemes. Extensive frauds in the con- Railway. struction of the first line of rails from the Missouri to the Pacific, with corruption of men in public life, by a company of men styled the "Credit Mobilier," came to light in $1872-73$. Enterprise in railway build-

Credit Mobilier. ing ran wild in these years, to such a degree that no less than $\$ I, 700,000,000$ were estimated to have been expended upon it, between 1868 and 1873 . It was extravagantly overdone, and had much to do with bringing about a financial panic and crash in 1873 .

If demoralizing influences that arose from the circumstances of the Civil War reached their culmination in the period of the presidency of General Grant, they were generally checked before it closed. Vigorous movements of correction and reform, in various directions, were set on foot. It was then, on the recommendation of President Grant, in his message of 1870 , that the first act of Congress in the interest of "civil "civil service reform" was passed. From I 865 to reform." I870, a representative from Rhode Island, Mr. Jenckes, had striven annually to persuade Congress to begin some reform of the public service, without success. Now the 
572 SECESSION, CIVIL WAR, AND REUNION.

first step was taken toward introducing a "merit sys"Merit tem" of selection and appointment, by means system." of competitive examinations; but congressmen disliked it, and brought the new system nearly to a stop, at the end of three years, by with holding appropriations for the necessary work. Public opinion, however, was demanding the reform, and hostile politicians could not suppress it long.

The years $187 \mathrm{I}$ and 1872 were marked by two of the most calamitous fires that have been known in modern

Great times. By that of 187 I the city of Chicago, Grat
chlcago then containing a few more than 300,000 infire, 1871.

habitants, was nearly destroyed. The flames raged from Sunday evening, October 8 , until the Tuesday following, burning over more than three square miles of the densest business and resident section of the city, devouring the homes of almost 100,000 people, with a total destruction of about 17,000 buildings, and of property reckoned altogether at $\$ 200,000,000$. Boston was Boston fire, the sufferer in November, 1872 , from a fire 1872. which laid waste sixty-five acres in the commercial heart of the city. Nearly 800 buildings and $\$ 80,000,000$ worth of property were destroyed. In the same years there were widely destructive forest fires in Michigan and other parts of the northwest.

352. Preparation to resume "Specie Payments." Rise of the "Greenback Party." 1875-1879. In I 875 an act was passed by Congress which provided for the resumption of specie payments by the government on the Ist of January, I879. That is, the government pledged itself to redeem its legal tender notes, dollar for dollar, in gold, on and after that date ; and the pledge was duly fulfilled. The price of gold in greenbacks had been slowly declining since the end of the war, and continued 
to do so until "resumption" made the paper dollar and the gold dollar equal in worth. But the market price of all commodities went down, of course, toward the gold measure of values, in proportion as the depreciated greenback currency rose toward equivalence with gold, ${ }^{1}$ and many people were dissatisfied with that effect. Believing that inflated prices would stimulate industry and trade permanently, as well as temporarily, and that abundance of a "cheap money" would keep the country prosperous, these people were opposed to any opposittion abandonment of the system of legal-tender irre- to resumpdeemable paper money, which the country had created as a desperate expedient, under the stress of war. They formed what came to be known as the "Greenback party," and were a force of importance in the politics of the next few years.

353. The Centennial Year. - Disputed Presidential Election. 1876. In 1876 the centennial anniversary of American independence was celebrated in many modes, but most impressively by the holding, at Philadelphia, of a great International Expo-

Centennial

Exposition, 1876. sition of industries and arts. The educating effect of the exposition on the millions who flocked to it, from every part of the country, appeared notably afterward, in improvements of workmanship and refinements of taste.

The presidential election of that centennial year was the most agitating and critical in its outcome that has

1 Since the suspension of specie payments in 186 I (see sect. $3^{18}$ ), gold, whether coined or uncoined, had been only a commodity of the market, bought and sold for greenbacks at prices always fluctuating and generally rising. The highest greenback price of gold was reached on the IIth of July, IS64, when the gold dollar was priced at $\$ 2.85 \frac{1}{2}$ in greenbacks; at which rate the paper "dollar" (so called) was worth in reality but 35 cents. 


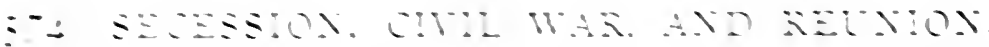

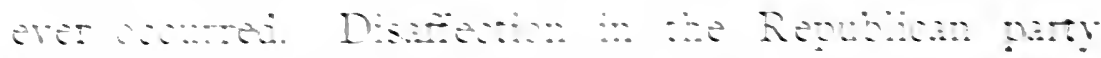

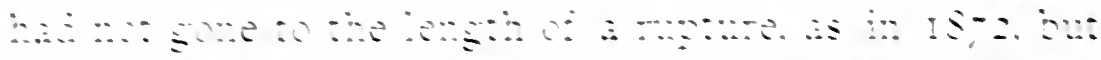

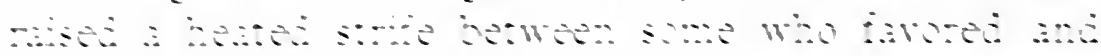

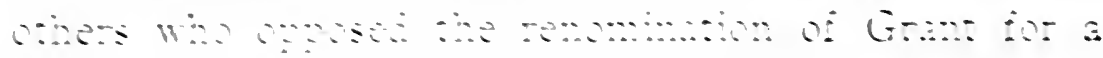

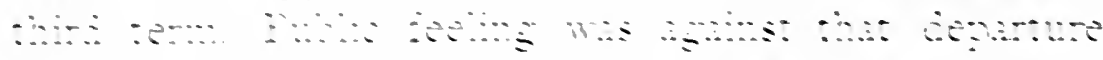

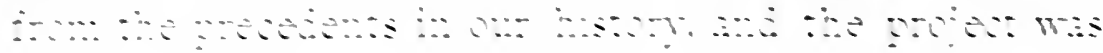

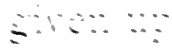

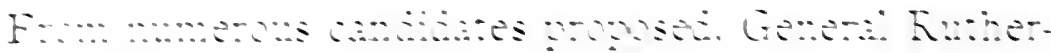

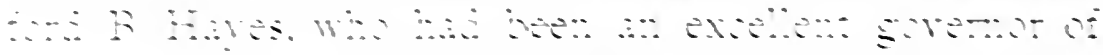

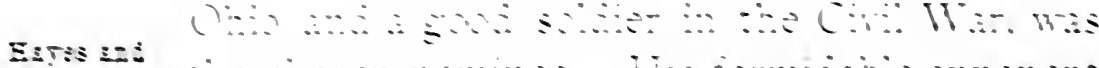

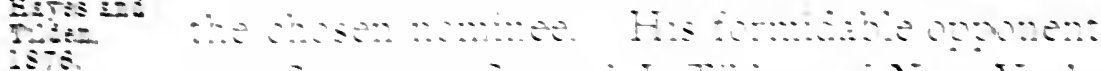
w.

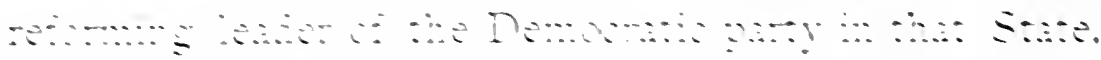

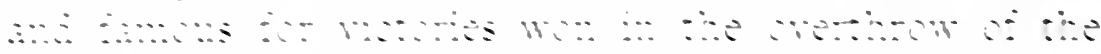

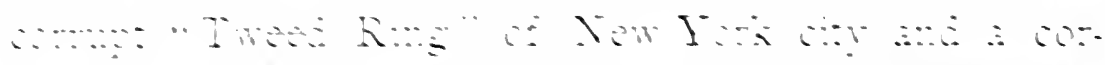
……ㄴ..

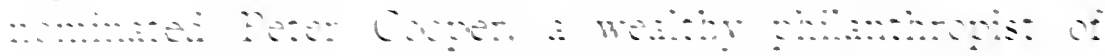

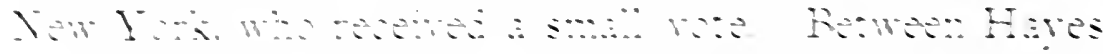

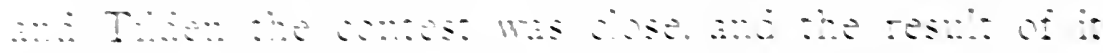

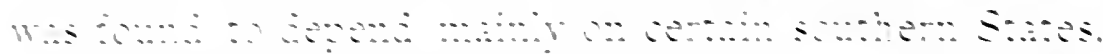

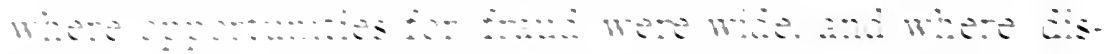
Ұ....

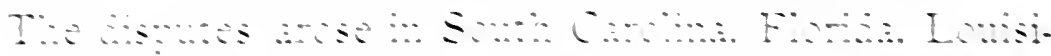
(1) ………… as ……

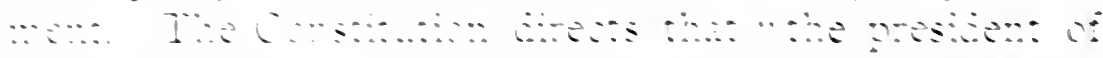

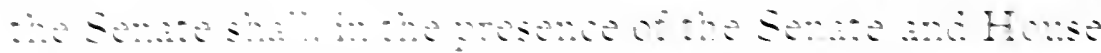
$\therefore$ А s.m.

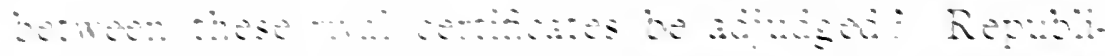

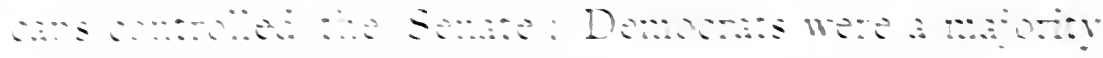

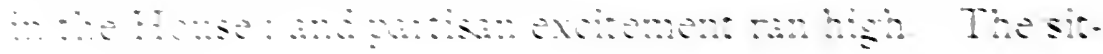


mation was so dangerous that leading men in the two partics were fored to arrive at some agreoment before the day of combing came. They united in creating an Electoral Commission of tive

The dan-

gerous questlan. 1876. semants, tive representatios, and tive justices of the suprome Court. to which all disputed rotes should be referred. (on this plan the count was conducted, and Mr. Hayes, on the moming of March 2 IST: was declared elected. by a majority of one electoral rote. Luhappily. crey question referred to the (ommission was decided by a partisan rote, of S Republicans against - Democrats. which cast a doube on the impartiality of the judgment of the case. There was no resistane to the decision t the submission to it was most admirable: but a larse part of the mation questioned the righttuhess of the election of Presiden Hayes.

354. Administration of President Hayes. 18771881. That any doub should shadw the election of

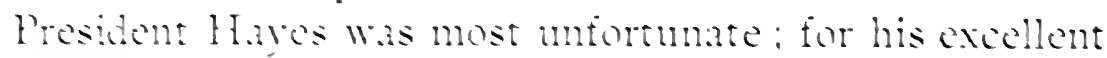
anmintration of the goremment marks distincty an epoch of reovery from the derangements of the Civil Mar. The temper of partisan politics lost much of its heat. and those leaders who clung to the bitter reconstruction issues found their inthence decline. Public feeling aproved the action of the President when. soon atter his inaugmation, he withdrew most of the Federal forces from the somth, and allowed state sorernments which military authorit had been upholding in South Carolina and Louisiana to be set aside by the courts and legislatures ot those siates. The white inhabitants regained polition control in all the reomstructed states. and have kept it by methods (of intimidation at first and afterward of law) White
ascendsucy
in the south. which anmul to a large extent the political rights that were 
576 SECESSION, CIVIL WAR, AND REUNION.

conferred on the freed slaves by the reconstruction acts. But experience had seemed to give clear proof of failure in the policy of force, employed for ten years to prevent that result, and public opinion settled slowly to the conclusion that the duty of the nation to the emancipated people must be performed in some other way.

Education, industrial training, encouragement to thrift, widening of opportunities, promotion of common interests Recent
progress in have appeared to be the most promising means and friendly relations between whites and blacks, the south.

for slowly bettering or curing the unhappy conditions of society which slavery brought about. A great work in those directions is in progress, with effects that show more plainly from year to year.

355. The Bland Silver Bill. - Resumption of Specie Payments. In 1878 the approaching resumption of specie payments, with the consequent full return to prices measured by the gold standard of values, led those who feared bad effects from that measure to combine with a strong silver-mining interest in pressing through Congress an act known as the Bland Silver Bill. Silver was Doclining losing value, compared with gold, from two value of
sllver,
causes. One cause was a vast increase in the production of silver, far exceeding the increase of gold production; the other was in the fact that many countries, where formerly both gold and silver coins were equally legal tender, at a ratio fixed by law (furnishing a double standard of value), had lately adopted the single gold standard, dropping silver coinage, except for purposes of "small change." By law the United States had done so in I873; but practically it had done the same, by not coining silver dollars, long before.

Three desires, then, actuated the pressure on Congress which brought about the passage of the Bland Silver 
Bill of I 878 : (I) to enlarge the market for silver; (2) to bring into use another and lower standard of value - a "cheaper money" - along with that of gold; and (3) to increase the quantity of money for circulation. The bill required the government to purchase, every month, not less than $\$ 2,000,000$ nor more than $\$ 4,000$,000 worth of silver bullion, and coin it into silver clollars at the rate of 4 I $21 / 2$ grains of standard silver, or $37 \mathrm{I} / 4$ grains of fine silver, for each dollar. It also authorized an issue of silver certificates on deposits of silver dollars in the treasury, thus creating a paper currency redeemable in that silver coin.

The resumption of specie payments was accomplished on the Ist of January, I879, with no shock of disturbance to the business world. The prepaResumption, 1879. rations for it made by the Secretary of the Treasury, John Sherman, were careful and complete.

TOPICS AND SUGGESTED READING AND RESEARCH.

\section{President Andrew Johnson. - His Conflict} with Congress.

Topics AND REFERENCES.

I. Antecedents of Vice-President Johnson. 2. His work of reconstruction in the lately seceded States. 3. Action of legislatures in those States. 4. Feeling produced in the north. Blaine, ii. I15, 56-1 54; Lothrop, 404-418; Storey, 290-301; Burgess, Reconstruction, 3I-6I ; Grant, ii. 359-36I ; Hart, Contemp's, iv. 468-475, $479-48 \mathrm{r}$.

\section{Congressional Reconstruction.}

TOPICS AND REFERENCES.

I. Undoing of the President's reconstructive work. 2. Civil Rights Act. 3. Fourteenth Constitutional Amendment. 4. Congress sustained in the elections. 5. Tenure of Office Act. 6. General Grant. - District of Columbia. - The Territories. - Ne- 
braska. 7. Military Reconstruction Act.-Seceded States restored. 8. Fifteenth Constitutional Amendment. Blaine, ii. ch. viii.-xii. ; Burgess, Reconstruction, ch. v.-vii., x.: Lothrop, 419-425; Storey, ch. xix.; Hart, Contemp's, iv. 48z-489. 49z-494; Barnes, ch. ix.-xxiv.

\section{The Working of the Reconstruction Measures.}

Topics AND References.

1. Serious evils created. 2. Political adventurers and the negro vote. 3. Scandalous state of things brought about. 4. Violent resistance by whites. 5. "Ku-Klux Klan" and other secret societies. Burgess, Reconstruction, 244-264; Blaine, ii. 463-474; S. S. Cox, ch. xxv.-xxvi.; Hart, Contemp's, iv. 475-478, 495-500; Herbert, ch. ii.-xiv.; B. T. Washington, ch. vi. ; Andrews, i. $36-40$.

\section{Impeachment of the President.}

Topics AND ReFERENCES.

r. The President's attempt to remove Secretary Stanton. 2. Impeachment proceedings and their failure. Burgess, Reconstruction, I 42-1 43, I 57-194; Storey, 346-35 I ; Hart, Chase, 357-361; McCulloch, ch. xxvi. ; Blaine, ii. ch. xiv. ; Hart, Contemp's, iv. 489492.

\section{Incidents of the Period.}

Topics and ReFERENCES.

r. The Atlantic Cable. Prescott, i. ch. xxvi.

2. Fenian invasion of Canada. Bourinot, 378 .

3. Undertakings of the French emperor in Mexico. 4. Maximilian of Austria made emperor. 5. Expostulations of the United States. 6. Withdrawal of the French. - Fate of Maximilian. H. H. Bancroft, ix. ch. i.-xiv.; Nicolay and Hay, vii. ch. xiv.

7. The Alaskan purchase. Blaine, ii. 333-339; Burgess, Reconstruction, 299-302; Hart, Contemp's, iv. 547-550.

349. Election of General Grant. - Conditions in the South.

Topics AND REFERENCES.

I. General Grant elected President. 2. Deplorable condition of many southern States. 3. Conflicts. - Acts of violence.- 
"Force bills." 4. Harsh measures modified in I 872. Stanwood, ch. xxiii.; Burgess, Reconstruction, 222-224, 267-276; Andrews, i. 40, 78-85, Ix 1 -167. (See, also, references under sect. 346.)

\section{Rupture in the Republican Party. - Reëlec-} tion of President Grant.

Topics AND ReFERENCES.

I. "Liberal Republicans." 2. Their coalition with Democrats. - Nomination of Horace Greeley for President. 3. Reëlection of Grant. Stanwood, ch. xxiv.; Burgess, Reconstruction, 264-267; Andrews, i. $30-36,57-78$.

\section{Incidents of the Administration of President Grant.}

TOPICS AND REFERENCES.

r. Treaty for annexation of the Dominican Republic. Storey, ch. xxiii.; Burgess, Reconstruction, 323-327; Andrews, i. 48-56.

2. Settlement of the "Alabama Claims." Blaine, ii. cl. xx.; Burgess, Reconstruction, 302-320; Andrews, i. 87-95; Hart, Contemp's, iv. $550-556$.

3. Indian wars. - Fate of General Custer and his command. Andrews, i. ch. vii.

4. Demoralization resulting from the recent state of war and the monetary inflation. 5. Frauds and corrupting influences. 6. The "Tweed Ring." - Erie Railway scandals. - "Credit Mobilier." 7. Excessive railway building. - Panic of i 873. 8. Movements of correction and reform. 9. First step in civil service reform.

I0. Great fires in Chicago and Boston. - Forest fires.

RESEARCH. - Insurrection in Cuba. - The affair of the Virginius.

Andrews, i. 47-48; Hart, Contemp's, iv. 557-56r.

352. Preparation to resume "Specie Payments." Rise of the Greenback Party.

Topics AND REFERENCES.

r. The resumption act. 2. Decline of inflated prices and consequent dissatisfaction. 3. Opposition to resumption. 4. Beliefs of the Greenback party. Bolles, iii. bk. I-2; Burgess, Reconstruction, 276-279; Johnston, Am. Politics, 242.

Research. - Gold speculation. - "Black Friday." Andrews,

i. $40-45$. 


\section{The Centennial Year. - Disputed Presidential Election.}

TOPICS AND ReFERENCES.

I. Centennial Exposition at Philadelphia. Andrews, i. 196-200.

2. Division in the Republican party. 3. Failure to renominate Grant for a third term. 4. The disputed presidential election. 5 . No provision of law for settling the dispute. 6. Agreement to create an Electoral Commission. 7. Decision electing President Hayes. - Doubts of its impartiality. Stanwood, 356-393; Burgess, Reconstruction, 2So--295; Hart, Contemp's, iv. 504-507 ; Andrews, i. 200-22I.

\section{Administration of President Hayes.}

Topics AND References.

I. An epoch of recovery. 2. Withdrawal of Federal forces from the south. 3. White ascendancy regained in the reconstructed States. 4. Political rights of the freedmen practically annulled. Burgess, Reconstruction, 295-29S; Bryce, ii. ch. xcii.; Herbert, ch. $\mathrm{xx}$.

5. Apparent failure of the policy of force. 6. Duty of the nation to the emancipated people: how shall it be performed? B. T. Washington ; Cable; Hart, Contemp's, iv. 663-665.

\section{The Bland Silver Bill. - Resumption of Specie Payments.}

Topics ANd References.

r. The combination which passed the Bland Silver Bill. 2. Silver losing value, and why. 3. The objects sought in the bill. 4. Provisions of the bill. Taussig, Silver Situation, I-Io.

5. Successful resumption of specie payments. Andrews, i. 264267; Hart, Contemp's, iv. 531-533. 


\section{THE NEW ERA.}

1880-1903.

\section{CHAPTER XVIII.}

RECENT YEARS.

356. General Garfield elected President. - His Murder. 1880-1881. As the presidential election of I 880 approached, a wing of the Republican party called "Stalwart,"'led by Senator Conkling, of New York, renewed the effort to nominate General Grant for a third term. One object of the movement was to defeat the nomination of James G. Blaine, of Maine, with whom Conkling was at feud. The defeat of Blaine was accomplished, but the nomination of Grant was not. The choice of the party fell upon General James A. Party Garfield, who had won distinction in the Civil division. War and in public life since. The Democratic nominee was General Winfield Scott Hancock, one of the notable corps commanders of the war. Other nominations were made by the Prohibitionists and by the Greenback party, so called. The latter party now demanded, not only the substitution of legal tender notes for the notes of the national banks, but also an unlimited coinage of silver to be legal tender money. It cast 308,000 votes. General Garfield was elected by small majorities in all of the northern States save three; but he led General Hancock by only 10,000 in the total popular vote.

By calling Mr. Blaine to his cabinet as Secretary of 
State, and by some appointments to office in New York, President Garfield incurred the wrath of the "Stalwarts" and their chief, and the first weeks of his administration saw the opening of a bitter factional feud. The passions excited by that quarrel worked on one weak-minded wretch, among the office-hunting swarms in Washington, The tragedy until, on the 2d of July, I 88 I, he shot the Presiof the
"spoils, dent, as the latter was about to enter a railway
system July 2, 1881. train for Long Branch. The wounded man lingered for more than eleven weeks, while the whole sympathizing world watched the slow agony of his death. On the Igth of September President Garfield breathed his last, and the Vice-President, Chester A. Arthur, succeeded to his place.

The new President had been most prominent as the close friend and political lieutenant of Senator Conkling; but he carried no spirit of faction into the great office to which he had been tragically called. His administration was one of dignity, of prudence, of not much eventfulness, but of quiet reputability in the annals of the United States.

The shock of the murder of President Garfield by a disappointed office-seeker, maddened by the excitements of a shameful quarrel over the parcelling out of public offices, roused the public to a sense of the hatefulness and the mischief of the "spoils system" as nothing else could have done. It incited a really resolute reform movement, which has gone steadily forward from that cuvil day. A National Civil Service Reform League, Service organized in I88 I, with George William Curtis 1881-1885. for its able and eloquent president, has given a strong lead to the influences that work for the reform. The first efficient law to establish a merit system of appointments in the national civil service (the Pendleton 
Act) was passed by Congress in I 883 , and faithfully administered by President Arthur. It has been supplemented since. In many States and cities the public service has undergone a like reform.

357. Change of Party in the Administration. - Election of President Cleveland. 1884-1885. In I 884 Mr. Blaine secured the Republican nomination for President, but failed in the election. A considerable body of "Independent Republicans" (called "Mugwumps" by their opponents) withdrew their support from him and gave it to Grover

Independonts or "Mugwumps," 1884. Cleveland, the Democratic nominee. Mr. Cleveland had attracted attention in recent years by conspicuously straightforward conduct in public life. As mayor of Buffalo he had dealt with corrupt politicians in a way that caused the people of the State of New York to make him governor; and as governor he had continued the exhibition of moral courage, sturdy uprightness, and sound sense. His election to the presidency gave fresh proof of the fact, which political managers are slow to understand, that no other candidate for important office is so "popular" as a single-minded, sound-minded, fearlessly straightforward man.

When Mr. Cleveland became President, no Democrat had held the reins of executive government at Washington for twenty-five years. To many good citizens the change of party in the administration was a untounded dreaded event, and it surprised them to find foars. that the country was disturbed no more than by the transfer of government from one Republican President to another. There may have been, on the whole, a little more shifting of officials and clerks; but it was slowly done, - too slowly to satisfy most of the politicians of the President's party, whose craving for the "spoils" of 
their victory, after twenty-five years of privation, was keen. Few Presidents have been so little moved by party influence and so firmly independent in their course, as Mr. Cleveland proved to be. He provoked hostility, as a consequence, in some influential circles of his party.

358. Controversies with Great Britain. 1885-1892. T,wo controversies with Great Britain gave some trouble to Mr. Cleveland's administration. One related to the privileges which American fishermen had been enjoying on the British-American coast, under the Treaty of Washington, concluded in I87 I (see sect. 351). A commission appointed to determine the compensation to be paid for those privileges, and which met at Halifax in I 877 , had made an award $(\$ 5,500,000)$ which

The Halifax award, 1877. caused dissatisfaction in the United States.

Consequently, by notice given in I883, the fishery articles of the treaty were annulled, and ceased to have effect July I, I885. This reopened troublesome old questions, and Congress was asked to authorize an arrangement with Great Britain for a joint commission to settle matters in dispute. Congress declined to do so, and a period of fishery quarrels ensued. At length, in I8S7, a joint commission of British and American statesmen was agreed upon, and it met in Washington late that year. A treaty which the Presicient approved was concluded in February, but the Senate rejected it after long debate. Fortunately, however, a change in modes of fishing had removed most of the causes of quarrel, and no further troubles of a serious kind occurred.

A graver difference sprang from the claim of the The United States to a right of jurisdiction over the Buring Sea "seal fisheries" (so called) of the Bering Sea. 1886-1892. The controversy became serious in President Cleveland's term, and the peace of the two countries 
was endangered by it for half a dozen years. Finally, in I 892 , the questions involved were submitted to a tribunal of arbitration, which had sessions in Paris during the following year. The decision was adverse to the claims of the United States, but regulations for the preservation of the fur seals were prescribed, which the governments of the United States and Great Britain were to enforce.

359. Legislation and Incidents of the Period. 18851887. In I 887 the repeal of the Tenure of Office Act, passed in I 867 to tie President Johnson's hands (see sect. 345), was brought about by a sharp refusal on the part of President Cleveland to

\section{Tenure of} Offlce Act repealod. report reasons to the Senate for his removal of a district attorney, and to submit papers relating to the case. $\mathrm{He}$ questioned the constitutionality of the act, and condemned it as a grave encroachment on the responsible powers of the executive. His argument was so convincing, and public opinion endorsed it so strongly, that Congress at its next session repealed the act.

Two other measures of great importance, touching the presidential office, were perfected in I 886 and I887. The first of these is a careful guard against the occurrence of a vacancy in the headship of government. It prescribes that, in case of the death,

Succession to the presidency, 1886-1887. resignation, or disability of both President and Vice-President, the executive office shall devolve on members of the cabinet in the following order: I, Secretary of State; 2, Secretary of the Treasury ; 3, Secretary of War ; 4, Attorney-General ; 5, Postmaster-General ; 6, Secretary of the Navy; 7 , Secretary of the Interior. The second act removed that dangerous question that arose in $\mathbf{1} 876$, relative to the counting of electoral votes. It provides for the determination by state 
courts, as far as possible, of all contests over electoral votes; but when Congress must decide such contests, in counting electoral votes, it shall do so by concurrent action of the two houses, acting separately; and if they disagree, the votes which are certified by the state executive shall be counted.

In exercise of the power conferred by the Constitution (Art. I. sect. viii. clause 3) "to regulate commerce ... among the several States," Congress passed an act of high importance in I 887. It placed all railroads that run in or through more than one State under the superInter-State vision of an Inter-State Commerce Commission, Commerce
Commis- which has large powers to prevent unfair disSommis- 1887 .

criminations between persons or places, in facilities for business or in transportation rates. Amendments from time to time have improved the working of the act, and made it effective for removing many causes of complaint.

The message of President Cleveland to Congress in I 887 was devoted to one subject, giving emphasis to the President fact that the taxation imposed by the existing Cleveland's tariff was piling up a dangerous surplus in the
taritf message, 1887. Treasury, draining money from the business of the country to an alarming extent. The time-honored principles of the Democratic party were against the collection of such a surplus of revenue, and against the high tariff that produced it; but a large section of the party had been helping of late to defeat all attempts to reduce tariff rates. The President's message was a summons to his party to renew allegiance to the principles it had always professed. The call was answered, and the tariff question, as a leading issue in politics, was raised again to its old place. Before Congress closed its session, the Democratic majority in the House of Repre- 
sentatives had passed a bill, known as the Mills Bill, for moderating duties, and the Republican Sen- mills ate had voted it down. The issue was made, Bill. and went to the people in the election of the next year. After a lingering and painful illness of several months, General Grant died on the 23d of July, I885, and was entombed at New York, on the 8th of August, with funeral honors the most elabo-

Death of

General

Grant, rate ever paid in America to a public man.

In the spring of I886 an extensive strike on one of the systems of southwestern railways was attended by violent rioting at St. Louis. This was followed by an outbreak of labor troubles at Chicago, connected with which a mass-meeting in the Haymarket was held on the evening of the $4^{\text {th }}$ of May. Speeches in the anarchist spirit, counselling criminal violence, were made, and one of the speakers was arrested by a body of the police. Thereupon a bomb, thrown from the crowd, exploded in the midst of the police, killing seven $\begin{gathered}\text { Chicago } \\ \text { anarchists, } \\ \mathbf{1 8 8 6} .\end{gathered}$ and wounding many more. Eight persons known as anarchists were arrested and brought to trial, as accessories to the crime, the throwing of the bomb being proved against none; but all were convicted, of whom four were hanged, three were sentenced to imprisonment, and one took his own life. The justice of the conviction of some of the accused was questioned by many people.

360. Election of President Harrison. 1888. Though President Cleveland had pleased few of the political managers of his party, they were forced to renominate him in I888. The Republicans named Benjamin Harrison, of Indiana, grandson of the former President Harrison, - a gentleman who had given excellent proofs of capacity in both civil and military life. Other candidates were put in nomination by several temporary organiza- 
tions, which cast few votes. So far as the election turned on the tariff question, which it may have done in the main, it had no decisive result. Of the popular vote, Cleveland received a majority of about I00,000, out of a total that exceeded I I,000,000 ; but Harrison's vote was more effective in carrying States, and the electoral vote secured for him was 233 against 168 .

The Republicans not only regained the presidency, but they won a majority of the House of Representatives, and controlled the whole government once more. In the Senate they were heavily reinforced during the Now States, next two years by the admission of six new 1889-1890. States, carved out of the great territory of the farther west and northwest. Washington, Montana, and the two Dakotas came into the Union in I 889, Idaho and Wyoming in I 890 .

At the same time, in I889, a portion of the Indian Territory, bought from the Indians and named Oklaoxlahoma, homa, "the beautiful land," was opened to white 1889. settlement. In anticipation of the opening, thousands of intending settlers had gathered on the border, and were held back by soldiers, until, on the $22 \mathrm{~d}$ of April, the signal of admission was given and they entered the land of promise with a rush. One town site, Guthrie, had 10,000 inhabitants camped on it that night. The Territory of Oklahoma was organized promptly, and has had a remarkably rapid growth.

361. The McKinley Tariff. 1890. The party restored to power seems to have had no doubt that its tariff policy was endorsed by the people ; for, instead of lowering the rates of duty, it proceeded at once to raise them Aim of the to a much higher scale. The aim of the new measure. measure, which became law October I, I890, was to prohibit, practically, the importation of many arti- 
cles, and reduce the excessive revenue by that means, while forcing the creation of manufactories to produce such excluded commodities in the United States. The act accomplishing this, known as the McKinley Tariff, from the name of the chairman, William McKinley, of the House Committee that framed it, was odious at home to the opponents of extreme "protection," and excited bitter feelings abroad.

362. The Sherman Act. 1890. Another act of the same period introduced a new experiment in finance. It is known as the Sherman Act, and it repealed the Bland Silver Act of I 878 (see sect. 355), but only to give further satisfaction to the demand for more Growing silver in monetary use. That demand was $\begin{gathered}\text { demand for } \\ \text { the use of }\end{gathered}$ spreading fast in the country, and politicians in both parties were turning toward it an attentive ear. An increasing number of people were persuaded that the need of the time was more money, and that the quantity of gold in the world was too limited to allow of a sufficient supply of money from that source alone. In the opinion of many there was need of no "standard of value," but all money could be created, as the greenbacks were created, by the "fiat" of government, making a " dollar," by calling it so, on a paper note. But, they would say, if we must have a precious metal standard, let it be the cheaper and more plentiful silver, or gold and silver together, at the ratio of value they once had, which was 16 to $\mathrm{I}$.

In 1890 these opinions in favor of silver money were spreading fast, and they were greatly promoted by the Sherman Act. It required the Secretary of the Treasury to buy $4,500,000$ ounces of silver every month at provithe market price, and to issue treasury notes in payment, which should be legal tender for all sions of the Sherman debts, and which should be redeemable in either gold or 
silver, at the discretion of the Secretary. The coining of $\$ 2,000,000$ worth of the silver every month was no longer required, as formerly by the Bland Act, but only so much as might be needed for redeeming the treasury notes. As it turned out, there was no demand for the silver coins, since the legal tender notes were worth just as much, and were more convenient for use.

363. Second Election of ex-President Cleveland. 1892. The monetary ideas described above were represented in a new political party that took form at this time,

The and which soon became formidable in the west. Populist It received the name of the People's or Popu-
party. list party, and, in the presidential election of I892, it cast I, I22,000 votes for James B. Weaver, its nominee. President Harrison and ex-President Cleveland were rival candidates again in this election, and the latter was chosen by a plurality of nearly 400,000 votes. The silver-mining States, and most of the other new States in the far west, were carried by the Populist party, or by a fusion of Democrats and Populists, and those two parties, together, gained control of both branches of Congress.

364. The Hawaiian Islands. ${ }^{1}$ - Columbian Exposition. 1893. On entering office, in March, I893, President Cleveland felt called upon to undo a recent act of his predecessor, which he disapproved. A revolution in the Hawaiian Islands had overturned the native government in the previous January, with the unconcealed approval of the American minister at Honolulu, and with something like protection given to the revolutionists by marines from a United States ship of war. The active parties in the revolution were mostly alien residents, and their purpose was to bring about the annexation of 
the islands to the United States. Having organized a provisional government, they sent commissioners to Washington, with whom President Harrison negotiated a treaty of annexation, which he

Annexation sent to the Senate, where it was under consideration when the change of executive took place. President Cleveland withdrew the treaty immediately, condemning the whole proceeding in strong terms.

The next important official act of President Cleveland was to preside, on the Ist of May, at the formal opening of a great international exposition, at Chicago, commemorative of the discovery of America by Columbus. The exact anniversary of the

Exposition at Chicago, 1893. discovery, October I2, I 892 , had been celebrated by a ceremonious dedication of buildings on the exposition ground, then unfinished. In their beauty, their extent, and their whole artistic arrangement, these buildings and the surrounding grounds surpassed those of all previous "world's fairs," and gave impressive evidence of the advance of the country in conceptions of art.

365. A Monetary Crisis. 1893. The working of the Sherman Silver Act of 1890 had produced by this time an alarming condition in the national Treasury and in the country at large. Silver had fallen in market value from $\$ 1.20$ per ounce in I 890 to 85 cents at the end of 1892 . As silver dropped in value, the demand for gold increased. It was hoarded, or it went abroad. People who carried United States notes, either greenbacks or silver certificates, to the United States Treasury and demanded gold for them must be given the gold, or the credit of the government would be impaired. The government must fulfil its promises to pay, Working of the Sherman Act. by payments in the money that was the standard money of the world. United States law might make silver money 
legal tender for debts in the United States, but could not make it so outside. Therefore, to preserve its credit in the world, it was compelled to keep its silver coin, its silver certificates, and its greenbacks up to the gold standard, by keeping them exchangeable for gold.

At the same time, by its own laws the government was compelled to accept the legal tender silver and paper Drain of money for customs dues and all taxes, and none gold
from the Treasury. it redeemed were paid out and might come back to it for re-redemption again and again, working like an endless chain, as was said aptly at the time, to draw gold from the Treasury. The only way in which gold could be obtained for satisfying this exhausting demand was by buying it with bonds, and the Treasury had no authority to do that with such bonds as would sell at a proper rate in gold.

In June, I 893 , this grave situation was made worse by a stoppage of the free coinage of silver in India, where silver money had been most in use. This caused a new depression in value of silver, a fresh increase of demand for gold, and a panic of alarm in the United States, lest our government should lose the ability to pay its obligations in gold. The President called Congress to an extra

Purchase of silver stopped. session in August, and urged that, at least, the requirement to buy silver should be repealed. A bill to that effect was passed by the House with no long delay, but the Senate, controlled by supporters of the silver policy, resisted all appeals from the alarmed business interests of the country until the end of October, when it passed the bill.

The monetary situation was still a cause of great anxiety, and the President appealed to Congress, at subsequent sessions, for measures to redeem finally and 
cancel all the legal tender notes and certificates of the government, and to require duties on imports to be paid in gold ; but it was not done.

366. The Wilson Tariff and the Income Tax. 1894. The subject of tariff revision was taken up in the House of Representatives during the special session of $1893-94$, and a bill called the Wilson Bill was framed, which reduced the rates of duty to an important extent. With it went an internal revenue bill, to make up the loss of tariff revenue, and the bill provided for an income tax. When the tariff bill reached the Senate, some protected interests, in sugar manufacture, coal and iron mining, etc., were strong enough there to procure changes which disgusted most of the advocates of tariff reform. President Cleveland was so dissatisfied that he refused to sign the act, but allowed it to become law. The income tax was extremely unpopular, and rejoicing occurred when, in the spring of 1895 , it was pronounced unconstitutional by the Supreme Court.

367. Venezuela Controversy with Great Britain. 1895-1897. On the I 7 th of December, I 895, President Cleveland startled the country by a message which complained sharply of the refusal of the British government to arbitrate a pending dispute with Venezuela, relative to the boundary between that country and British Guiana. He recommended the appointment of a commission to ascertain the true boundary, with a view to determining the future action of the United States. This was a menace to England that President's message, 1895. might easily bring on war. Congress acted with haste on the President's recommendation; the commission was appointed and proceeded to its task. In both England and the United States there was grievous surprise to find the two countries brought suddenly, as it seemed, 
to the verge of war, and great excitement prevailed for some weeks. Of really angry war feeling there was none, and before long a reopening of negotiations between the governments led to an arrangement for the arbitration of the dispute.

From the settlement of the Venezuela question the British and American governments went on to the framDefeated ing of a general treaty for the peaceful settlement arbltration
traaty, by arbitration of future questions between them. 1897.

That most important treaty, signed at Washington on the I Ith of January, I 897 , was approved with general joy in the country; notwithstanding which public approval, it was defeated by a faction in the Senate, large enough to prevent concurrence by the two-thirds vote which the Constitution requires.

368. The "Silver Question" in the Presidential Election. 1896. In the summer and fall of I $\$ 96$ the country passed through a presidential election as exciting as that of I 860 had been. One great body of the American people had come to believe that a free, unlimited coinage of legal tender silver money, with the quantity of silver in the silver dollar proportioned to the gold in a gold dollar in the old ratio of 16 to I (notParty divi- withstanding the lowered value of silver), sion in would give prosperity and plenty to everybody, and overthrow what they looked upon as a tyrannical money power, upheld by the existing single standard of value in gold. Another large body believed as firmly that what these silver advocates wished to do meant universal ruin, overwhelming and complete. The silver men won control of the Democratic national convention, held at Chicago, and nominated William J. Bryan, of Nebraska, for President. The nomination of Mr. Bryan was endorsed by the Populists, and by a body of Repub- 
licans organized as a National Silver party. It was repudiated by many Democrats, who held another convention and nominated General John M. Palmer, of Illinois. The controlling majority of the Republican party, in its national convention at St. Louis, declared itself " opposed to the free coinage of silver, except by international agreement with the leading commercial nations of the world ;" and it nominated William McKinley for President. There was never before such debating by a whole nation in speech and print, - such a "campaign of educa- The "camtion," as it was styled, - as that which ensued. 帒aign of edThe decision of the people was against the silver theory, by 7, I04,000 votes given to McKinley, 6,506,000 to Bryan, I34,000 for Palmer, and I8I,000 for Prohibition and Labor nominees.

369. The Dingley Tariff. - Adoption of the "Single Gold Standard." 1897-1900. One of the first acts of President McKinley, on taking office, was to call a special session of Congress for new tariff legislation, to increase the revenue of government, which he held to be the most imperative of needs. Congress met on the $15^{\text {th }}$ of March, 1897, and the House was so expeditious in acting on the President's recommendation that on the zoth of the same month it passed a bill, reported from Committee by Mr. Dingley, of Maine, and known as the Dingley Tariff Bill. The bill, which restored extreme protective cluties, higher than those of the McKinley Tariff, passed the Senate in July.

An effort to persuade the leading nations of Europe to join the United States in restoring the mone- monetary tary use of silver was made by the appointment commission. in April of a commission of three gentlemen, who visited France and England, but returned with a discouraging report. 
Efforts at home to deal with the incongruous and disturbing monetary system of the country were blocked by irreconcilable differences between the Senate, controlled by the silver parties, and the House of Representatives, where opposite opinions prevailed. Thus the situation remained until the spring of 1900 , when the sway of silver doctrines in the Senate was lost. A law was then enacted which makes 25.8 grains of coined gold, eighttenths fine, the standard "dollar," - the sole

The "standard, unit of value in the United States. "Dollars" "dostablished, represented in other forms, on paper or in 1900.

silver coins, must be kept to equivalence with that gold "dollar" by being exchangeable for it. Apparently that standard is now fixed by both public opinion and law.

In May, I 898, a convention with Great Britain provided for the creation of a Joint High Commission, to settle a number of troublesome questions between Canada and the United States, including a disputed boundary between Alaska and the Canadian Dominion. The

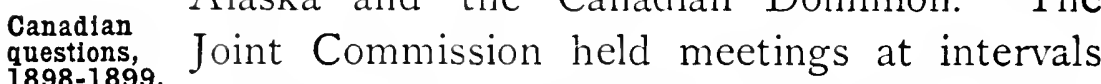
1898-1899. until February, I 899, when discouraging differences on the Alaska boundary question brought them to a close.

In July, I898, the annexation of the Hawaiian Islands was accomplished by a joint resolution of Congress.

370. The Spanish-American War. 1898. Since I 895 a revolt in Cuba, resisted with cruelty by the SpanDestruction ish government, had been appealing to the of the Maine, sympathy of the American people, and stirring February, an indignation that grew hotter from month to 1898. month. To that excitement of feeling another was added suddenly, on the I 5 th of February, I 898 , when the United States battleship Maine, while paying a visit of 
courtesy to Havana, was destroyed, with aimost her entire crew, by what seemed to be the explosion of a submarine mine. An American naval court of inquiry investigated the catastrophe, and decided that the explosion was exterior to the ship; while a Spanish inquiry. court concluded that it happened in the vessel's magazine. Whatever the fact, American feeling was hardened instantly to a determination that the war in Cuba must be stopped. After some fruitless negotiation to that end, the President was directed by Congress, on the I 8 th of April, to "demand that the government of Spain at once relinquish its authority and government in the island of Cuba." War followed immediately; the President, on the 23d of April, called for 125,000 volunteers, and for 75,000 more on the 25th of May. Cuban ports were blockaded, and naval forces were increased with rapidity by the purchase and adaptation of privately built ships.

A fleet from Spain, which reached the harbor of Santiago de Cuba, was blockaded there. Another Spanish fleet, guarding the Philippine Islands, - the only naval force of Spain in the Pacific, - was attacked in Manila Bay by the Asiatic squadron of the United States, under Commodore (afterward Admiral) George Dewey, and de-

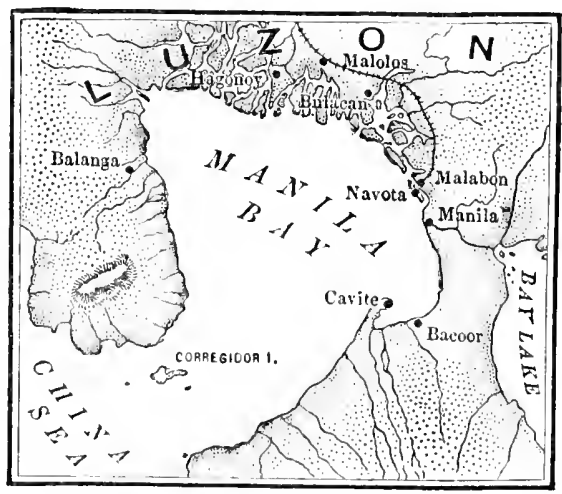

MANIIA BAY. stroyed, on the ist of May. On the I4th of June an expedition of 16,000 men, under General Shafter, sailed from Tampa, Florida, to Santiago de Cuba, to coöperate with the blockading fleet in the capture of that port and the Spanish fleet. Landed at a 
point near Santiago, the American army fought severe battles with the Spanish troops at San Juan Hill and El Caney, on the ist and $2 \mathrm{~d}$ of July, and gained positions Land and for an investment of the city. On the morning sea fights
at Santiago, of the $3 \mathrm{~d}$ Admiral Cervera, who commanded July 1-3. the Spanish fleet, foreseeing the capture of the port, attempted to run the blockade and escape ; but every

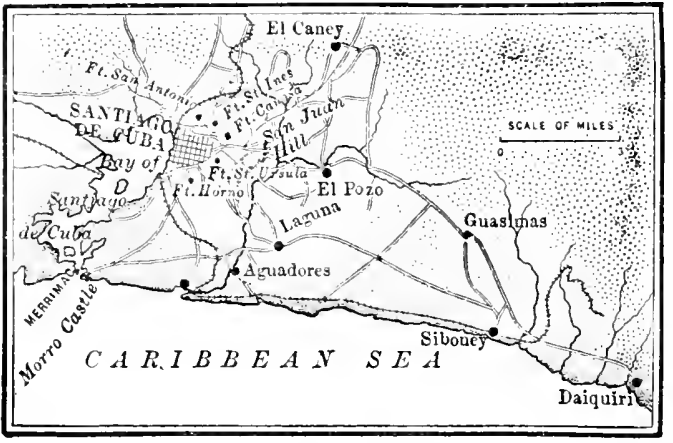

THE SANTIAGO CAMPAIGN. one of his ships was driven ashore or sunk. The honors of this victory have been kept in much dispute between friends of Admiral Sampson and Commodore Schley, who were first and second in command. Santiago and the Spanish army were surrendered on the I 7 th of July.

Before this occurred, troops sent from San Francisco were arriving at Manila, to assist Admiral Dewey in taking that city. Aguinaldo, exiled leader of an insurrection in the Philippines which had failed the year before, was brought back and raised a native force, between which and the Americans some degree of coöperation was mainAguinaldo tained for a few weeks. But Aguinaldo and his at Manila, followers were working for the independence of gust. the islands, while the government of the United States was yielding to a desire for their acquisition, as possessions of its own. Aguinaldo proclaimed a revolutionary government, with himself at its head, and began to take an attitude of hostility to the Americans before the capture of Manila, which occurred August I3. 
While the siege of Manila was in progress, another expedition from the United States, under General Miles, took possession of the island of Porto Rico, after a brief campaign of nineteen days, from July 25 till Porto Rico August I2. In that interval peace negotia- taken, tions with Spain had been in progress, and hosgust. tilities were suspended on the I2th of August, articles preliminary to a treaty having been signed that day. Peace commissioners from the two nations met at Paris in October, and the definite treaty was signed December io. Spain relinquished her claim to sovereignty over Cuba, and ceded to

\section{Treaty of} peace. Cesslons from Spain, December 10. the United States (see Map XVI.) the island of Porto Rico, the island of Guam in the Marianas or Ladrones, and the Philippine Islands, for which latter the United States agreed to pay the sum of $\$ 20,000,000$. The acquisition of the Philippines was opposed with deep feeling by many of the American people, who looked upon the policy of colonial empire, and the subjugation of native peoples, as a wrong and dangerous departure from the principles and precedents of the Republic.

371. Native Revolt in the Philippines. - Independence of Cuba. 1899-1902. The treaty was ratified, however; American authority was asserted in the Philippines, and Aguinaldo became the leader of a revolt against it, which came to an outbreak on the $4^{\text {th }}$ of February, I899. From that time until April, 1901, when Aguinaldo was captured by stratagem, and little of the . revolt was left, an army was maintained in the Islands which numbered $7 \mathrm{r}, 000$ officers and men in October, I900. Until July I, I90 I, the Islands were under military rule, with a civil commission, having legislative powers, acting in coöperation with the military authority during the last ten months. On the Ist of July, I90 I, 
civil government was established, pursuant to an act of Congress passed in the previous March. Judge Taft, who had been at the head of the previous commission, was appointed governor, and his wise administration appears to have created general content.

Civil government in Porto Rico, with a governor appointed by the President of the United States, and a legislative assembly elected by the Porto Ricans, was established in 1900 .

A military administration in Cuba was maintained by the United States, with General Leonard Wood as The governor, until the Cubans had framed a repub-

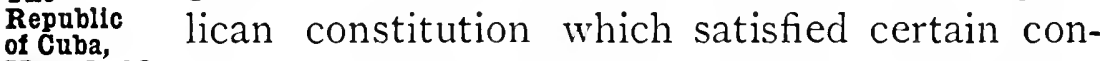
May, 1902. ditions imposed by the American Congress, and had elected a president and legislature. Then, on the 20th of May, 1902, the military forces of the United States were withdrawn, and the independent Republic of Cuba was recognized in due form.

372. In China. 1900. By the acquisition of the Philippine Islands the United States was led to take an active interest in the affairs of the Far East. The great empire of China appeared to be in a crumbling state, and European powers were taking advantage of the weakness of its government to extort cessions of ports and districts, and special trading, mining, and railway-building privileges, in a shamefully bullying way. The American government took no part in that scramble; but its Secretary of State, Mr. John Hay, pressed each of the powers in question for a pledge against any interference with equal rights of trade in China. Early in 1900 he secured such a guarantee of what was called the policy The "open
door,"
1900. of the "open door." In dealing with the dreadful "Boxer" rising against foreigners in China, which occurred that year, the American government took 
a creditable part, sending a considerable military force from the Philippines, under General Chaffee, to aid in the rescue of the besieged legations at Pekin. It exercised a potent influence in restraining the allies from extreme measures against the Chinese, who had been provoked by great wrongs.

373. Reëlection of President McKinley. 1900. The presidential election of 1900 brought the silver question up once more, and it pushed aside the issue that would otherwise have been supreme, between those who supported the government in its acquisition and subjugation of the Philippine Islands (called "imperialists "), and those (called "anti-imperialists") who opposed it. The silver forces again controlled the Democratic nominations, and again named Mr. Bryan, still demanding a free coinage of silver at 16 to I. President McKinley was renominated by the Republicans, and the canvass of 1896 was repeated, with less heat. The verdict of the country was more emphatic than before. Mr. McKinley was reelected by a majority of nearly a million over Mr. Bryan, and by half a million over all the candidates (Democratic, Prohibitionist, Labor party, etc.) in the field.

374. Murder of President McKinley. - Succession of Vice-President Roosevelt. 1901. President McKinley lived through but six months of his second term. On the 6th of September, I90I, while attending the PanAmerican Exposition ${ }^{1}$ at Buffalo, and receiving a throng of people in its Temple of Music, he was most treacherously murdered by an assassin, who approached him, in the passing line, with a pistol hidden by a handkerchief in his hand. For some days there was hope that the

1 The Pan-American Exposition was so called because limited to a representation of the resources, industries, and arts of North, South, and Central American countries. 
President would survive the dreadful wound he received, but the hope was delusive; he died on the I4th. The wretch who killed him, and who was seized on the spot, proved to be a Polish anarchist, who had no personal motive, but was actuated by the insane enmity of his kind to all authority and law. The murderer was tried, convicted, and executed within two months after his crime.

Vice-President Theodore Roosevelt, who succeeded to the presidency, had had large experience already in public life, though but forty-three years of age, and was Theodore distinguished for vigor and independence of Roosevelt. character, and for high political ideals. As a member of the national Civil Service Commission, as a police commissioner in the city of New York, and as governor of the State of New York, he had identified himself especially with civil service reform; and he had served with fine spirit in the Cuban campaign of the Spanish-American War. The cabinet of the late President was retained by Mr. Roosevelt, without change.

375. The Hay-Pauncefote Treaty. - The Interoceanic Canal. 1901-1903. In November Mr. Hay,

The Hayof the State Department, added to his successes Pauncetote in diplomacy by concluding with the British Treaty,
November, ambassador at Washington, Lord Pauncefote, 1901.

a new treaty, superseding the Clayton-Bulwer Treaty of 1850 , relative to the long-contemplated interoceanic canal. A similar treaty had been drawn and signed by the same negotiators in the previous year, but received amendments in the Senate which the British government declined to accept. The new Hay-Pauncefote Treaty proved acceptable in both countries, and was ratified without change. Like the Clayton-Bulwer Treaty, it guarantees the neutrality of any canal that may be opened through the Central American isthmus, but gives to the 
TOPICS, REFERENCES, AND RESEARCH. 603

United States rights of ownership, regulation, and defence, which the former treaty did not.

This arrangement with England was preparatory to the taking of definite measures for securing the construction of the canal at the cost and under the ownership of the United States. An act of Congress passed in June, I902, gives authority to the President to purchase, for the sum of $\$ 40,000,000$, the unfin- Canal Act, ished Panama Canal, begun in I 882 by a French June, 1902 . company which became bankrupt in $\mathrm{s} 888$; provided that the government of Colombia, in whose territory it lies, will transfer the franchise of that company to the United States, with proper rights and powers to protect and regulate the canal, and with control of a strip of ground on the margins of the canal, not less than six miles wide. A convention which satisfied those conditions was signed by the Colombian minister at Washington, on the 22 d of January, I903; but rejected by the Colombian government in the August following.

Rejected Colombian Treaty, 1903. If the arrangement for acquiring the Panama Canal should fail, the President is empowered to undertake the construction of a canal on what is known as the Nicaragua route.

\section{TOPICS AND SUGGESTED READING AND RESEARCH.}

\section{General Garfield elected President. - His} Murder.

TOPICS AND REFERENCES.

I. Strife over the Republican nomination. 2. Opposing candidates. - Demands of the Greenback party. - The election. 3. Factious hostility to President Garfield. 4. Effect on a disappointed office-seeker. - The President shot. Andrews, i. 307-336; Ridpath, ch. xii.-xiii.; Stanwood, ch. xxvi.

5. Vice-President Arthur as President. 6. Civil service reform quickened by the murder of President Garfield. Anclrews, i.336-347. 
357. Change of Party in the Administration. Election of President Cleveland.

Topics ANd References.

I. Action of "Independent Republicans." 2. Election of Mr. Cleveland, Democratic candidate, over Mr. Blaine. 3. The country undisturbed by the change of party in the government. 4. Independent course of President Cleveland. Andrews, ii. 62-95; Stanwood, ch. xxvii.

\section{Controversies with Great Britain.}

TOPICS AND REFERENCES.

I. Fishery disputes. - The Halifax award. - Fishery articles of the Treaty of Washington annulled. 2. New treaty rejected by the Senate. 3. Causes of dispute removed by changed modes of fishing. Andrews, ii. I I 8-I 25, 290-29I ; Burgess, Reconstruction, 319-322; Blaine, ii. ch. xxvii.; Hart, Contemp's, iv. 542-546.

4. Bering Sea controversy and its arbitration. Hart, Contemp's, iv. 564-567; Andrews, ii. 125-I 26.

\section{Legislation and Incidents of the Period.}

TOPICS AND REFERENCES.

I. Repeal of the Tenure of Office Act. Cleveland, 464-475; Atlantic Monthly, June-July, I900.

2. Provision against vacancies in the presidential office. 3. Act to regulate the counting of electoral votes. Stanwood. ch. xxviii.

4. Inter-State Commerce Commission.

5. President Cleveland's tariff message in $1887 .-$ The Mills Bill. Stanwood, 458-459; Andrews, ii. I I4-I I 7; Hart, Contemp's, iv. 5 I $8-520$.

6. Death of General Grant. Andrews, ii. I27-132.

7. Labor-strike riots. - Crime and execution of Chicago anarchists. Andrews, ii. 137-145.

\section{Election of President Harrison.}

Topics AND References.

I. Indecisive verdict of the election on the tariff question. 2. Republicans again in control of the government. 3. Adnission of 
TOPICS, REFERENCES, AND RESEARCH. 605

new States. - Creation and opening of Oklahoma Territory. Stanwood, 459-487; Andrews, ii. I 57-1 58, 195-200.

Research. - Difficulty of the United States with Chile. Hart, Practical Essays, v.

\section{The McKinley Tariff.}

Topics and References.

I. Plan of the new tariff. Stanwood, 489-490; Taussig, Tariff Hist., ch. v.

\section{The Sherman Act.}

TOPICS AND REFERENCES.

I. Object of the act. 2. Demand for more silver in monetary use. 3. Opinions which caused the demand. 4. Provisions of the act. Taussig, Silver Situation, pt. I, sect. vi.; White, ch. viii.

\section{Second election of ex-President Cleveland.}

Topics AND ReFERENCES.

I. The People's or Populist party. 2. Election of President Cleveland. 3. Fusion of Democrats and Populists in Congress. Stanwood, 490-5I8; Andrews, ii. 232-243.

\section{The Hawaiian Islands. - Columbian Expo- sition.}

Topics AND References.

I. The Hawaiian revolution. 2. Treaty of annexation withdrawn by President Cleveland. Andrews, ii. 310-310; Richardson, ix. $460-472$.

3. The Columbian Exposition at Chicago. Andrews, ii. 243-272.

\section{A Monetary Crisis.}

Topics And ReFerences.

I. Demand for gold, as silver declined in value. 2. Why the government must give gold in exchange for its notes. 3. The "endless chain" process, drawing gold from the treasury. 4. The situation in 1893. - Extra session of Congress. - Repeal of the requirement to buy silver. 5. Further measures urged without success. Stanwood, 522-525; Taussig, Silver Situation, ch. vi.; 
White, ch. viii.; Political Science Quarterly, December, I893; Hart, Contemp's, iv. 533-536; Richardson, ix. 40I-405.

\section{The Wilson Tariff and the Income Tax.} Topics AND REFERENCES.

r. Tariff reductions. - Internal revenue. - Income tax. 2. Senate action on the tariff bill. 3. Income tax pronounced unconstitutional. Andrews, ii. 303-307; Stanwood, 523-525.

RESEARCH. - Supreme Court decision against the constitutionality of the income tax. Larned, Ready Ref., vi. 554-557.

\section{Venezuela Controversy with Great Britain.}

Topics AND ReFERENCES.

I. President Cleveland's message on the Venezuela question. 2. Menace of war. - Feeling in the two countries. 3. Arrangement for arbitrating the dispute. Larned, Ready Ref., vi. 557-560, 684693; Hart, Contemp's, iv. 567-572.

4. General arbitration treaty rejected by the Senate. Larned, Ready Ref., vi. 577-5So.

\section{Silver Question in the Presidential Election.}

TOPICS AND REFERENCES.

r. Two conflicting opinions concerning money. 2. Excitement of the contest. - The "campaign of education." 3. The candidates and the popular vote. Stanwood, 525-569; Larned, Ready Ref., vi. 563-574; Hart, Contemp's, iv. 536-538.

\section{The Dingley Tariff. - Adoption of the Gold Standard.}

TOPICS AND REFERENCES.

I. Special session of Congress for tariff legislation. 2. Character of the Dingley tariff. Larned, Ready Ref., vi. $580-58 \mathbf{I}$.

3. Failure of negotiations for free silver coinage in Europe. Larned, Ready' Ref., vi. 3I 4-317.

4. Final adoption of a standard "dollar." defined in gold. Hart, Contemp's, iv. 539-5+1: Larned, Ready Ref., vi. 639-6+1.

5. Joint High Commission for settlement of questions with Canada. Larned, Ready' Ref., vi. 63-64. 


\section{The Spanish-American War.}

TOPICS AND REFERENCES.

r. American sympathy with revolt in Cuba. 2. Destruction of the Maine in Havana harbor. 3. Determination to stop the war in Cuba. - Demand addressed to Spain. 4. Consequent war. Calls for volunteers. - Blockade of Cuban ports. 5. Blockade of Spanish fleet at Santiago de Cuba. 6. Destruction of another in Manila Bay. 7. Military expedition to Santiago. - Battles of San Juan Hill and El Caney. 8. Attempted escape and destruction of Cervera's fleet. 9. Surrender of Santiago. Io. Siege and capture of Manila. - Relations between American army and a native force under Aguinaldo. ir. Revolutionary government proclaimed by Aguinaldo. 12. Conquest of Porto Rico. 13. Peace negotiations and treaty. - End of Spanish rule in Cuba.-Cessions to the United States. - Payment for the Philippine Islands. I4. Opposition to the acquisition of the Philippines, and its grounds. Larned, Ready Ref., vi. 583-63s, I 7I-I 82 ; Hart, Contemp's, iv. 579-58I, 586-590, 608-6r I.

\section{Native Revolt in the Philippines. - Independ- ence of Cuba.}

Topics AND ReFERENCES.

I. Revolt led by Aguinaldo, and its suppression. 2. Military rule, followed by a civil government. 3. Civil government in Porto Rico. 4. Creation of the independent Republic of Cuba. Larned, Ready Ref., vi. 37I-403, IS2-I90; Hart, Contemp's, iv. $601-603$.

\section{In China.}

TOPICS AND REFERENCES.

I. Condition of China. - Action of European powers. 2. Guarantee of the "open door" secured by Secretary Hay. 3. Part taken by American forces against the "Boxer" rising. Larned, Ready Ref., vi. So-r 4t; Hart, Contemp's, iv. 6r6-622.

\section{Reëlection of President McKinley.}

TOPICS AND REFERENCES.

I. The silver question revived. - The issue that it pushed aside. 2. The vote reëlecting President McKinley. Larned, Ready Ref., vi. $6+6-660$. 
608

RECENT YEARS.

374. Murder of President McKinley. - Succession of Vice-President Roosevelt.

Topics.

1. Circumstances of the murder of the President. 2. Antecedents and reputation of Vice-President Roosevelt.

\section{The Inter-oceanic Canal.}

Topics.

r. The Hay-Pauncefote treaty: - Isthmian Canal Act of Congress. - Rejected convention with Colombia. 


\section{EPOCHS OF PROGRESS AND CHANGE.}

Early Epochs in the Settlement of the United States. In the spreading of population over the great area of the United States there have been six epochs of movement, distinctly marked:-

The first morement planted settlements along the Atlantic margin of the continent and on the eastern slopes of the Appalachian Mountain system, which was the Coast setlimit of occupation, practically, till the end of the seventeenth century.

The second entered the valleys that lie between the ridges of the mountain system, stretching southwestwardly from Pennsylvania, where they come nearest to the coast, and where the movement into them began. Those valleys gave a direction to the most important ad- tains. vance of settlement in the first half of the eighteenth century.

Epochs of the Wateri'ays: Ricers, Canals, and Lakes. The third movement, passing the mountains, into the valley of the Ohio, was pioneered about the middle of the eighteenth century, and, during the next seren decades, carried most of the westward emigration In the
Talley of
the ofio, 1750 of the times to the borders of that river and its many tributary streams.

The fourth movement of population, started by the building of the Erie Canal $\left(\mathrm{I}_{17-25}\right)$, was into the basin of the Great Lakes. In I $\$ 20$ there were probably not Into the more than 100,000 people in the whole country that $\begin{gathered}\text { basin of } \\ \text { the Great }\end{gathered}$ has its drainage to the lakes, against a million, at Lakes, least, in the region whose waters run to the Ohio. 1850. From that time the westward migration on both courses, lake 
and river, went forward at an ever increasing rate, stimulated in both directions by the rapid development of steamboat navigation, and forwarded in both by an energetic construction of connecting canals. The quarter century between 1825 and $185^{\circ}$ was a period in which waterways, natural and artificial, were an agency of more importance than in any former or later time.

Epochs of the Railway. ${ }^{1}$ The fifth epoch opened when the new agency of the railway was added to the agency of the wateropening of ways, with substantial ability to double the rate of the rail- material progress. That came, as a fact, about way era.

I850; for railways, with steam locomotion, though they had their beginning in 1830 , did little for the western country in their first twenty years. In i $\delta_{50}$ only 9000 miles of the iron road had been constructed in the whole United States, and most of that was in the east. Then the real opening of the era of the rail and the locomotive, as the chief factors in our national development, may be said to have occurred. In that year lines of rail from Georgia and South Carolina passed the southern mountains to Chattanooga. In I 85 I the Erie Railway was finished from Lake Erie to New York; the Hudson River road was opened from New York to Albany; and the several linked roads (consolidated afterward in the New York Central) which had connected Albany with Buffalo since ${ }_{4}{ }_{42}$ were permitted for the first time to carry freight in free competition with the Erie Canal. It was in the same year that heavy iron rails began to displace thin strips of iron laid on wooden stringers, in the construction Westward of tracks. In 1852 two railways from Lake Erie to

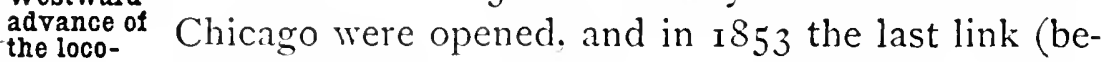
motive, motive, 1861. tween Cleveland and Toledo) needed to connect New York with Chicago by rail was filled up. In I 84 the Mississippi was reached by the chain of rails from the ocean, and the chain was stretched to the Missouri in 1859. By r860 the miles of railroad in the whole country

1 Poor, Manual of the Railroads of the United States. Interstate Commerce Commission. Annual Reports. 
had increased to 30,000 . 'Then came the check of the Civil War, during which only $5000^{\circ}$ miles of new road were built.

What we may fairly call a sixth epoch was opened almost simultaneously with the closing of the Civil War. Hitherto the railway had been either the ally or the rival of Beyond many mighty waterways of travel and trade. Now the great it ran beyond reach of their help or their competi- $\mathbf{1 8 6 5 .}$ tion, out of the great valley regions into the almost waterless high plateaus and mountains of the farther west. There it began the work of wonder which is peopling supposed deserts with millions, covering them with fruitful orchards and fertile fields, and filling the depths of their hills with wealthy towns. In 1860 there were 400,000 white inhabitants of California and Oregon, but less than 200,000 between them and the eastern settlements of Kansas and Nebraska, with little reason to suppose that the latter number could be much increased. Nevertheless, the building of a railroad From the from the Missouri to the Pacific, to span that wide Missouri solitude, was begun in 1865 and finished in 1869 . Pacific, It was an undertaking, not of commercial enter- $\mathbf{1 8 6 9}$. prise, but of public policy, projected by the government as a means of binding the Pacific States to the Union, and the building of it was induced by enormous grants of public lands. Nobody expected much settlement of population or creation of traffic along its line, but there was an The ambition to make it a route of trade with China and Farther Japan; yet the census of 1900 found nearly three $\mathbf{1 9 0 0 .}$ millions of people in five States through which it runs, and a recent historian of the road has written that ninety-five cents of every dollar it earns comes from its local trade. Instead of the one line of rail across the continent there are five lines to-day, inside of the limits of the United States, with a sixth in Canadian territory, at the north; and not less than ten millions of people are dwelling west of the meridian from which railway building took its new start in $\mathbf{r} 865$. 


\section{EPOCHS OF PROGRESS AND CHANGE.}

Irrigation of Arid Lands in the Farther West. ${ }^{1}$ In the recent history of American agriculture, the facts of most interest are connected with the beginnings of an artificial irrigation of lands, in those wide regions of the farther west which receive little rain. Not many years ago they were looked upon as wastes of desert, although it was known that much of their soil became fertile wherever watered by the smallest stream. Primitive Some artificial watering, by small canals and distribirrigation. uting ditches, from the limited lakes and rivers, had been practised from early times by the Pueblo Indian tribes of Arizona and New Mexico; and the Mormon settlers in Utah had applied such irrigation to considerable areas of land. In i870, at Greeley, Colorado, a colony was founded for the purpose of testing the possibility of profitable agriculture in that country, on lands artificially irrigated, and the experiment had success. Gradually from that time the conviction has been growing that a large part of the arid lands of the west are not only capable of reclamation, but richly worth being reclaimed, even at great cost for works to store and distribute the waters in a regulated way. Between 1880 Recent and I 889 nearly $\$ 68,000,000$ of private capital were works. invested in such works, and at the end of that period, as shown by the census report of 1900 , there were more than seven and a half millions of acres of far western land under irrigation, in 108,000 farms. In 1902 Congress was prevailed upon to make the undertakings of irrigation a national task, so far as to apply to them the proceeds of the sale of public lands in Arizona, California, Colorado, Idaho, Kansas, Nebraska, Nevada, New Mexico, North and South Dakota, Oklahoma, Oregon, Utah, Washington, and Wyoming. This was done by an act that became law in June of that year.

Expansion and Development in Thirty-five Years. ${ }^{2}$ In thirtyfive years, between the end of the Civil War and the end of

1 United States Census Reports: Tivelfth Census, I900, vol. vi. (Agriculture) pp. 797-880.

2 United States Census Reports: Twelfth Census, 1900, vol. ii. (Population), v.-vi. (Agriculture). vii.-x. (Manufactures). 
the century, our nation added more than forty millions to the number of its inhabitants, spread them to the remotest corners of its immense domain, and gave them busy employments of a thousand kinds. To accomplish that wonderful expansion of life and labor on the continent, many agencies have worked together, but the railway has led them ail. Its miles were lengthened from 35,000 in I 865 to 198,000 in I901. By facilitating and cheapening the transportation of commodities, it has opened illimitable markets for wheat grown on the great fields of the distant northwest, for meats fattened on the wide plains of Texas, Kansas, and Nebraska, for fruits ripened on the Pacific slope, and for every mineral unearthed in the rich rocky recesses of the land. A few examples will indicate how much that unlocking of the resources of the country has meant. In I 870 the improved farm lands of the United States measured I $88,000,000$ acres in extent; in I 900 the measure was 41 4,000,000. Of wheat grown there were $152,000,000$ bushels in 1867 , and $748,000,000$ in 1902 ; of corn, 868,000,000 bushels in 1867 , and $2,105,000,000$ in 1901 ; of cotton, $2,278,000$ bales in 1866 , and $10,768,000$ in 1902. The domestic animals of the country, were

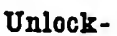
ing the of the country. valued at $\$ 1,229,000,000$ in 1870 , and at $\$ 2,981,000,000$ in 1900. The wool produced in 1866 weighed $150,000,000$ pounds, against $316,000,000$ in the product of 1902 . The tons of coal mined were $70,000,000$ in 1880 , and $261,000,000$ in r9or. Of iron and steel there were $3,26_{3}, 000$ tons produced in 1870 , and $29,507,000$ in 1900 ; but the nine-fold increase of quantity yielded only a four-fold increase in market value of product, showing that steel and iron have been cheapened more than half in the thirty years.

Cheapened Production of Iron and Steel. This cheapening of iron and steel, which has brought them nearly to the same level of low price, is the most important event in the industrial history of recent years. It gives the most useful form of the most useful metal to a thousand uses from which steel was barred formerly by its cost. It has been the result of 
scientific and mechanical improvements in the processes of manufacture, starting from a revolutionary discovery that was

Scientific and $\mathrm{me-}$ chanical improvements. perfected by Henry Bessemer in England, about 1859. The simple process of Bessemer for converting crude iron into hard and elastic steel, on a huge scale, at low cost, by forcing air through the molten metal to burn out an excess of carbon in it, was introduced in the United States about i 865 . From that date, slowly at first and rapidly at last, steel has been displacing, not only iron, but wood and other materials, for countless constructive purposes. The greatest of economies in railway transportation has resulted from the durability of steel tracks, superseding the old iron rail. The frames of important buildings, bridges, ships - nearly all considerable structures of every character - are now of steel ; while its use in machinery and utensils increases from day to day. By the more economical organization of their works, by the encouragement they give to labor-saving inventions, and by what seems to be a more efficient general management, the iron and steel manufacturers of the United States are now confessedly leading the world.

General Progress in Manufacturing Industries. ${ }^{1}$ Generally, the manufacturing industries of the country have been stimulated to a prodigious growth within the past thirty years, by their protection, on the one hand, from competition abroad. and, on the other hand, by the great area of their free trade at home, with multiplying millions of people. According to the census reports, $\$ 2,000,000,000$ invested in all branches of manufacture in 1870 had been increased to nearly $\$ 10,000$,000,000 in $1900 ; 2,000,000$ wage-earners in manufacturing establishments had been multiplied to more than 5.000,000; their earnings had risen from less than $\$ 800,000,000$ to more than \$2300,000,000; and the value of the total product of American manufactures had advanced from $\$ 4,000,000,000$ to

1 United States Census Reports: Truelfth Census, Igoo, vol. vii.-x. (Manufactures). 
$\$ 13,000,000,000$. Whether the country and the people, as a whole, have been bettered in condition, or otherwise, by the protective policy which helped to produce these results, is a question much disputed between those who favor that policy and those who are opposed.

No parts of the country have gained more from this development of manufacturing industry than those parts in which it was neglected most before the Civil War. There was a seven-fold increase of capital invested in manufactures in the southern States between

Progress in the south. 1870 and 1900, against five-fold in the United States at large; nearly five-fold increase of wage-earnings, against three-fold in the whole country; and a value of product four times greater in one case and but three times greater in the other.

Discovery and Invention. ${ }^{1}$ Since the beginning of the nineteenth century, scientific discovery and mechanical invention have wrought more change in the conditions of life on the globe than in all the ages that went before; and in no other country has the change been so great and so rapid as in the United States. Generally speaking, so far as human activities are affected by them, the important inventions of man have started from and been dependent on some capture of a natural force, subduing it to his use. At natural torces. first, and till not much more than a century ago, he merely caught those forces as he found them already in action around him, - already setting matter in motion, - in winds, waterfalls, and strong animals, like the horse. He borrowed, so to speak, the existing motions of the natural world, and made them directly helpful to himself. At last - late in history he began to get an inkling of the existence of an enormous store of locked-up force in the universe, prepared in motion-

1 Iles, Flame, Electricity, and the Camera; Mendenhall, Century of Electricity; Thurston, History of the Growth of the Steam Engine. 


\section{I6 EPOCHS OF PROGRESS AND CHANGE.}

less, imprisoned forms, ready to leap into activity for his serSteam and vice when he had learned how to set it free. Apthe stcam plying heat to water, he discovered the manageable engine.

energy in steam, invented the cylinder and piston, and acquired a new motor for every machine he might contrive. From the day of that grand achievement down to a time that seems only yesterday, invention was busy mainly with devices for perfecting and extending the service of the steam engine, - multiplying its labors as spinner, weaver, knitter, shoemaker, miller, sawyer, smith, printer, wagoner, galley-slave, - slave, in fact, for every task that the needs and desires of mankind can impose. For more than half a century after Watts, steam power was the sole form of force (except explosive and destructive force) that men had learned to generate and make useful for themselves. Then, having Electric come upon faint traces of that more mysterious The tele- form of force that we call electricity, they began to graph.

learn something of its hidden sources and strange workings, and to bring it into use; but only as an agile servant at first, swift of motion, but feeble, - fit for the messagebearing telegraph, and for nothing else. Electrical discovery reached that practical result in 1844 , and then halted for more than twenty years. It was not until about 1867 that The dy- the development of the dynamo began to disclose namo,
1867.

power. Since that time, the electric battery and the electric dynamo have taken the lead that the steam engine had held before, among the agencies of progress and change. The

The telo-

phone, electric lighting, electric railway, transmission of waterpower. 1876 . 1900. marvel of the telephone dates from about $1876-1878$; electric lighting was made practicable in the next decade ; the electric railway, which is transforming cities and revolutionizing rural life, had its beginning about $\mathrm{I} 88 \mathrm{I}$; the converting of power from great waterfalls, like that at Niagara, into electric energy, transmissible by wire for distant use, was accomplished in the last decade of the century; the employment of that energy in new processes of electro-metal- 
lurgy and electro-chemical manufacture, yielding valuable new products, arose simultaneously; and the latest grand achievement of electrical science, in wireless telegraphy, had just been reached when the century closed. That we are entering an era in which the new-found form of Nature's energy will work more change in the world and in the life of man than

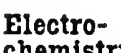
chemistry and metallurgy, Wtreless telegraphy, 1890 1900. all that has gone before seems a reasonable belief.

Social Effects of Economic Changes. The many and great economic changes of the past thirty years have acted upon the conditions of life in the country with profound social effects. The increase of wealth has surpassed the increase of population, which would mean a notable advance in general welfare if the increase had been shared in a general way; but that is a matter of some doubt. Probably there is, on the whole, a larger proportion of the people who enjoy what we call "easy circumstances" in life than there was a generation ago. Probably, too, those who live by hard labor earn generally the means of a more comfortable living than they did at the time in question. On all such points the comparisons are uncertain, because the scales of measurement have changed. Wages, salaries, incomes of every description, have mostly risen; but the cost of living has risen, too, in different particulars, at different places.

The one certain fact is that the inequalities of wealth in the country have been widening in these years to a startling degree. The mere millionaires, now common among us, were rarities in the last generation, while the huger fortunes of the present day, measured by hunWidening inequalt direds of millions, were unimaginable, even to the romancers of that age. On the other hand, there was much less of extreme poverty than has come to be familiar to us in the last thirty or forty years. There were few, if any, of the grave social problems that confront us in these days, on both sides of the scale of fortune, - on the side of poverty and on the side of wealth. Of unemployed labor there was seldom enough to raise questions in our minds. We knew nothing 
of the anarchist or the tramp. As for the great problem that now troubles the world, namely, how to keep peace between powerful combinations of workmen in one class and capitalists in another, and how to protect the general welfare against both, it had not come into view.

Combinations in industry on the vast scale of the corporations, the "trusts," so called, and the labor unions of the

\section{Opposing} tions of labor and capital. combina-

present time, were not possible until science and invention had done what they have done in recent years, with steam, electricity, and other forces, to overcome distance and time, widening and speeding the intercourse of people with one another. Such organizations have risen among us lately in a startling way, with immeasurable capabilities of good in all of them, if wisely directed and justly controlled; and with dreadful powers of mischief, if wantonly used. 'Their natural relation to each other is that of alliance and coöperation; but their present tendency is toward conflict, with deep injury to the very interests that have organized them, and still more injury to society at large. Struggles between employers and employed, in strikes and lockouts, have been growing more frequent, more bitter, and more extensive, from year to year. The most serious of such contests occurred in 1902 , when the production of anthracite coal was stopped for many months by a general strike of the miners engaged in it, and severe suffering in the whole country was caused. By the personal intervention of President Roosevelt, the mine-owners and the Peaceable miners were persuaded finally to submit the disarbitration
of disof dis-
putes.

in arbitration give hope that tribunals for a peaceful settlement of labor controversies may come into existence, and may acquire an authority that will remore most occasions of strife. One step of importance toward that result was taken in December, I90r, when action by a society called the "National Civic Federation" led to a conference in New York, at which eleven representatives of great corporations, twelve 
of the foremost leaders of labor organizations in the country, and thirteen distinguished gentlemen who are selected representatives of the public at large, organized an "Industrial Department" of the said "Civic Federation," having for its purpose "to promote industrial peace and prosperity," by using its influence and tendering its good offices "to obviate and prevent strikes and lockouts." The pacific influence of so broadly representative a body can hardly fail to be very great. Another influence to the same end seems likely to result from the creation, by act of Congress, in 1903, of a new department of admin-

Now Department of Commerco and Labor. istration in the national government, styled the Department of Commerce and Labor.

Hostilities more serious than those in the industrial field, because fiercer and more lawless, have grown alarmingly of late in the relations between white and black peo- Race ple, especially in those parts of the country where confllts. slavery left large numbers of the African race. The political suppression of the negro in those sections has not produced a friendlier attitude toward him on the part of the whites. Whole communities seem to go mad with rage when a black man commits or is suspected of the commission of some foul crime, and rise in furious mobs, to trample on civilization and law. This is one of the most sinister signs of the times.

Progress in Education. ${ }^{1}$ The hopeful remedy for all social disorders is in general education, and a noble share of the intense energy of American life and labor has always been directed to educational work, - more in late years than before. The foundations of a broad system of free common schools were laid early in most of the States; but not much beyond the establishing and improving of that elementary system had been accomplished at the outbreak of the Civil War. For an education above the rudiments of knowledge

1 United States Census Reports: Twelfth Cersus, rgoo, vol. ii. (Population); Butler, editor, Education in the United States; National Educational Association, Journal; Washington, Booker T., The Future of the Negro. 
the free opportunities were scant. Private academies and endowed colleges had risen only in limited numbers, as institutions for a favored few. Then, at about the middle of the last century, an expansion of the free public school sys-

The hlgh school development. tem to a higher and larger range was begun, by adding the "high school" and the "normal school;" and this has gone forward with a vigor so increasing that, in 1902, the number of high school pupils in the country was reported, at the annual meeting of the National Educational Association, to have doubled within the ten years last past. At the same time, the care for learning in still higher ranges has been stimulated in an equal degree. By munificent endowments from private benefactors, by large grants of public lands, by liberal appropriations of state aid, - often

Universities and schools of science and art. by united contributions from all three sources of support, - great universities and special schools of science and art have been multiplied extraordinarily within the past forty years. Nor has that upward pushing of educational forces caused any slackening of effort in the elementary field. The work of common teaching has been raised almost everywhere to a new efficiency, animated with a new spirit, and made resolutely searching, to reach all the youth in the land, by laws that restrict the industrial em-

The

United

States

Bureau of

Education.

ployments of the young and require their attendance at school. A systematic invigoration of all educational work has resulted from the organization at Washington, in 1867 , of a national Bureau of Education, which gathers stimulating and suggestive information from every part of the world.

The real fruits of education, in conduct and character, cannot be shown statistically : but a certain gross measure of the Rapid les- work of American schools during the last two desening of
iliteracy.

and 1900 , and it indicates a splendid advance. In ISSo no less than 77 per cent. of the total population of the United States, above ten years of age, was illiterate, - unable to read and write. In 1900 the illiterates had been reduced 
to 10.7 per cent. Of the white population of the country, 9.4 per cent. was illiterate in 1880 , and only 6.2 per cent. in 1900. Illiteracy among the native whites dropped from 8.7 per cent. in 1880 to 4.6 per cent. in 1900 ; but among the foreign-born white inhabitants it increased from 12 to 12.9 per cent. But the greater gain in elementary education appears among the people of color, 70 per cent. of whom had not learned to read or write in 1880 , while the census of 1900 found but 44.5 per cent. in that ignorant state.

Conditions in the former slave States were changed amazingly in those twenty years. In the two groups, of "South Atlantic" and "South Central," into which those In the States are divided in the census reports, 75 and $76 \underset{\text { former }}{\text { slave }}$ per cent. of the colored population was illiterate in States. I 880, against 47 and 48 per cent. in 1900 . Of the white population in the same two groups, 20 and 22 per cent. were unable to read and write in I880, and but i i per cent. in 1900. At this rate of diffusion, the rudiments of tucation will soon be given to all races in all regions, south and norih.

Possibly more important to the freed blacks than a knowledge of letters is the teaching of handicrafts, the training for industrial occupations, the cultivation of thrifty ambitions and well-ordered modes of living, on which $\begin{gathered}\text { Industrial } \\ \text { tralning of } \\ \text { freedmen. }\end{gathered}$ many devoted men and women are expending their lives in the south. That most practical mission work, begun by General Samuel C. Armstrong, the founder of Hampton Institute, in 1868 , has grown to fame and greatness in the hands of Booker T. Washington, the wise leader, who seems to be showing the way of uplift to his race.

As an instrument for producing enlightened judgment and action in our democratic country, the free public library, created wholly within the last half century, ranks nearly if not quite as high in importance as the free public school. The first library ever founded as a munici-

Free public libraries. pal institution, maintained at public cost, for supplying books freely to readers for use in their own homes, was opened in Boston in 1852 . From that seed of example, more than 5000 
public libraries, for the free lending of books. have sprung into existence since. within the Lnited States, nearly 3000 of Trarellng which exceed 1000 volumes in extent. These have ubraries. spread from cities to towns and rillages, in every: quarter of the land. Beyond the villages, too, out among the country farms. to the remotest settlements. streams of good literature are now flowing. in " travelling libraries." and by systems of rumal delivery. from centres of distribution already. organized in many states. Added to the free circulating libraries are some 2500 more that are free for the use of books by students and readers within their own rooms. Men

Library

endow-

ments.

of great wealth are promoting this free library movement by such endowments and gifts as never were bestowed on any public benefaction before. The gifts of Mr. Andrew Carnegie alone. to libraries in the United States. were reckoned at a total of $\$ 3 \$ .500 .000$ in 1903 . Among all the activities of the new era we have entered. this seems to be preeminent in the largeness of its spirit and its promise of beneficent fruits.

Amerian Litiratur. In the period following the Napoleonic wars and our second war with England. when the awakening of a new spirit in the country seemed to occur. we noted (see sect. 219) a very well-marked point of time from which American literature. in the higher meaning of the term. may be said to date. It appears late in the second decade Begin- of the nineteenth century. when Bryant (ISI $)$ pubnings. lished the poem "Thanatopsis." when Irving (ISIg) sare the first essays of the " Sketch Book" to the world, and when Cooper (ISzo) produced his first romance. Almost every name of high distinction in American letters - almost every uriting that appears to be marked for lasting preservation - has come from the generation that was young in those In its years. At the middle of the century that generaprime. tion was in its prime: its productive vigor was mostly: spent before the ending of the Civil IVar; and not much that is equal to the best of its work has been added to American literature since that time. if the critical judgment of our 
EPOCHS OF PROGRESS AND CHANGE. 623

own day is true. Let the reader make a list of the poems, romances, essays, histories, and other writings from American pens that class most assuredly high in 1870 . quality, as works of true literary art, arranging them by the dates of their first publication, and it will surprise him to see how they cluster in the middle decades of the nineteenth century, and how they drop away in its final thirty years.

The later period is more fertile than its predecessor, and the quality of its literary product is not mean. In fact, there was never a time before in any country when liter- ulterary ary gifts of a considerably high order were diffused fertility. so commonly, or cultivated so assiduously, yielding so much that is good; but the uplift of inspiration to great work seems wanting in nearly all that is done. Perhaps our age exhausts its genius so nearly in subduing the forces of nature and organizing the energies of mankind

Lack of high quality. that it has little to spare for the undertakings of art. The next generation may have more freedom from material tasks and be better prepared for the finer workings of imagination and thought. There are signs to indicate a trend that way in the swift and powerful currents of American life. 
$\bullet$ 


\section{APliNIIX A.}

\section{THE CONSTITUTION OF THE UNITED STATES.}

\section{P'RHAMHLE.}

We, the people of the United States, in order to form a more perfect union, establish justice, insure domestic trancfuillity, provide for the common defense; promote the general welfare, and secure the blessings of liberty to ourselves and our posterity, do ordain and establish this Constitution for the United States of America.

\section{Article I. Legislative Departalent.}

\section{Section 1. Congress in Gencral.}

All legislative powers herein granted shall be vested in a Congress of the United States, which shall consist of a Senate and House of Representatives.

Section II. Honse of Representatives.

1. The House of Representatives shall be composed of members chosen every second year by the people of the several States, and the electors in each State shall have the qualifications requisite for electors of the most numerous branch of the State legislature.

2. No person shall be a Representative who shall not have attained to the age of twenty-five years, and been seven years a citizen of the United States, and who shall not, when elected, be an inhabitant of that State in which he shall be chosen.

3. Representatives and direct taxes shall be apportioned among the several States which may be included within this Union, according to their respective numbers, which shall be determined by adding to the whole number of free persons, including those bound to service for a term of years, and excluding Indians not taxed, three fifths of all other persons. 'The actual enumeration shall be made within three years after the first meeting of the Congress of the United States, and within every subsequent term of ten years, in such manner as they shall by law direct. 'The number of Repre- 
sentatives shall not exceed one for every thirty thousand, but each State shall have at least one Representative; and until such enumeration shall be made, the state of New Hampshire shall be entitled to choose three, Massachusetts eight, Rhode Island and Providence Plantations one, Connecticut five, New York six, New Fersey four, Pennsyliania eight, Delaware one, Maryland six, Virginia ten, North Carolina five, South Carolina five, and Georgia three.

4. When vacancies happen in the representation from any State, the executive authority thereof shall issue writs of election to fill such vacancies.

5. The House of Representatives shall choose their Speaker and other officers, and shall have the sole power of impeachment.

\section{Section III. Senate.}

I. The Senate of the United States shall be composed of two Senators from each State, chosen by the legislature thereof, for six years; and each Senator shall have one vote.

2. Immediately after they shall be assembled in consequence of the first election, they shall be divided as equally as may be into three classes. The seats of the Senators of the first class shall be vacated at the expiration of the second year; of the second class, at the expiration of the fourth year, and of the third class, at the expiration of the sixth year, so that one third may be chosen every second year; and if vacancies happen by resignation or otherwise during the recess of the legislature of any State, the executive thereof may make temporary appointments until the next meeting of the legislature, which shall then fill such vacancies.

3. No person shall be a Senator who shall not have attained to the age of thirty years, and been nine years a citizen of the United States, and who shall not, when elected, be an inhabitant of that State for which he shall be chosen.

4. The Vice-President of the United States shall be President of the Senate, but shall have no vote, unless they be equally divided.

5. The Senate shall choose their other officers, and also a President pro tempore in the absence of the Vice-President, or when he shall exercise the office of President of the United States.

6. The Senate shall have the sole power to try all impeachments. When sitting for that purpose, they shall be on oath or affirmation. When the President of the United States is tried, the Chief Justice shall preside: and no person shall be convicted without the concurrence of two thirds of the members present. 
7. Judgment in cases of impeachment shall not extend further than to removal from office, and disqualification to hold and enjoy any office of honor, trust, or profit under the United States; but the party convicted shall, nevertheless, be liable and subject to indictment, trial, judgment, and punishment, according to law.

\section{Section IV. Both Houses.}

I. The times, places, and manner of holding elections for Senators and Representatives shall be prescribed in each State by the legislature thereof; but the Congress may at any time by law make or alter such regulations, except as to the places of choosing Senators.

2. The Congress shall assemble at least once in every year, and such meeting shall be on the first Monday in December, unless they shall by law appoint a different day.

\section{Section V. The Houses Separately.}

I. Each house shall be the judge of the elections, returns, and qualifications of its own members, and a majority of each shall constitute a quorum to do business; but a smaller number may adjourn from day to day, and may be authorized to compel the attendance of absent members, in such manner, and under such penalties, as each house may provide.

2. Each house may determine the rules of its proceedings, punish its members for disorderly behavior, and, with the concurrence of two thirds, expel a member.

3. Each house shall keep a journal of its proceedings, and from time to time publish the same, excepting such parts as may in their judgment require secrecy, and the yeas and nays of the members of either house on any question shall, at the desire of one fifth of those present, be entered on the journal.

4. Neither house, during the session of Congress, shall, without the consent of the other, adjourn for more than three days, nor to any other place than that in which the two houses shall be sitting.

\section{Section VI. Privileges and Disabilities of Members.}

I. The Senators and Representatives shall receive a compensation for their services, to be ascertained by law and paid out of the Treasury of the United States. They shall, in all cases except treason, felony, and breach of the peace, be privileged from arrest during their attendance at the session of therr respective houses, 
and in going to and returning from the same; and for any speech or debate in either house they shall not be questioned in any other place.

2. No Senator or Representative shall, during the time for which he was elected, be appointed to any civil office under the authority of the United States, which shall have been created, or the emoluments whereof shall have been increased during such time; and no person holding any office under the United States shall be a member of either house during his continuance in office.

\section{Section VII. Mode of Passing Laws.}

I. All bills for raising revenue shall originate in the House of Representatives; but the Senate may propose or concur with amendments as on other bills.

2. Every bill which shall have passed the House of Representatives and the Senate shall, before it become a law, be presented to the Presi lent of the United States; if he approve he shall sign it, but if not he shall return it, with his objections, to that house in which it shall have originated, who shall enter the objections at large on their journal and proceed to reconsider it. If after such reconsideration two thirds of that house shall agree to pass the bill, it shall be sent, together with the objections, to the other house, by which it shall likewise be reconsidered, and if approved by two thirds of that house it shall become a law. But in all such cases the votes of both houses shall be determined by yeas and nays, and the names of the persons voting for and against the bill shall be entered on the journal of each house respectively. If any bill shall not be returned by the President within ten days (Sundays excepted) after it shall have been presented to him, the same shall be a law, in like manner as if he had signed it, unless the Congress by their adjournment prevent its return, in which case it shall not be a law.

3. Every order, resolution, or vote to which the concurrence of the Senate and House of Representatives may be necessary (except on a question of adjournment) shall be presented to the President of the United States; and before the same shall take effect, shall be approved by him, or being disapproved by him, shall be repassed by two thirds of the Senate and House of Representatives, according to the rules and limitations prescribed in the case of a bill. 


\section{Section VIII. Powers granted to Congress.}

The Congress shall have power :

I. To lay and collect taxes, duties, imposts, and excises, to pay the debts and provide for the common defense and general welfare of the United States; but all duties, imposts, and excises shall be uniform throughout the United States;

2. To borrow money on the credit of the United States ;

3. To regulate commerce with foreign nations and among the several States, and with the Indian tribes;

4. To establish an uniform rule of naturalization, and uniform laws on the subject of bankruptcies throughout the United States;

5. To coin money, regulate the value thereof, and of foreign coin, and fix the standard of weights and measures;

6. To provide for the punishment of counterfeiting the securities and current coin of the United States;

7. To establish post-offices and post-roads;

8. To promote the progress of science and useful arts by securing for limited times to authors and inventors the exclusive right to their respective writings and discoveries;

9. To constitute tribunals inferior to the Supreme Court;

Io. To define and punish piracies and felonies committed on the high seas and offenses against the law of nations;

II. To declare war, grant letters of marque and reprisal, and make rules concerning captures on land and water;

I2. To raise and support armies, but no appropriation of money to that use shall be for a longer term than two years;

13. To provide and maintain a navy;

I4. To make rules for the government and regulation of the land and naval forces;

I 5. To provide for calling forth the militia to execute the laws of the Union, suppress insurrections, and repel invasions;

I6. To provide for organizing, arming, and disciplining the militia, and for governing such part of them as may be employed in the service of the United States, reserving to the States respectively the appointment of the officers, and the authority of training the militia according to the discipline prescribed by Congress;

I 7. To exercise exclusive legislation in all cases whatsoever over such district (not exceeding ten miles square) as may, by cession of particular States and the acceptance of Congress, become the seat of the Government of the United States, and to exercise like author- 


\section{APPENDIX A.}

ity over all places purchased by the consent of the legislature of the State in which the same shall be, for the erection of forts, magazines, arsenals, dockyards, and other needful buildings; and

I8. To make all laws which shall be necessary and proper for carrying into execution the foregoing powers, and all other powers vested by this Constitution in the Government of the United States, or in any department or officer thereof. 1

\section{Section IX. Powers denied to the United States.}

I. 'The migration or importation of such persons as any of the States now existing shall think proper to admit shall not be prohibited by the Congress prior to the year one thousand eight hundred and eight, but a tax or duty may be imposed on such importation, not exceeding ten dollars for each person.

2. The privilege of the writ of habeas corpus shall not be suspended, unless when in cases of rebellion or invasion the public safety may require it.

3. No bill of attainder or ex post facto law shall be passed.

4. No capitation or other direct tax shall be laid, unless in proportion to the census or enumeration hereinbefore directed to be taken.

5. No tax or duty shall be laid on articles exported from any State.

6. No preference shall be given by any regulation of commerce or revenue to the ports of one State over those of another; nor shall vessels bound to or from one State be obliged to enter, clear. or pay duties in another.

7. No money shall be drawn from the Treasury but in consequence of appropriations made by law; and a regular statement and account of the receipts and expenditures of all public money shall be published from time to time.

8. No title of nobility shall be granted by the United States; and no person holding any office of profit or trust under them shall, without the consent of the Congress, accept of any present, emolument, office, or title, of any kind whatever. from any king, prince, or foreign State.

\section{Section X. Powers denied to the States.}

I. No State shall enter into any treaty, alliance, or confederation; grant letters of marque and reprisal: coin money; emit bills of

1 This is the Elastic Clause in the interpretation of which arose the original and fundamental division of political parties. 
credit; make anything but gold and silver coin a tender in payment of debts; pass any bill of attainder, ex post facto law, or law impairing the obligation of contracts, or grant any title of nobility.

2. No State shall, without the consent of the Congress, lay any imposts or duties on imports or exports, except what may be absolutely necessary for executing its inspection laws; and the net produce of all duties and imposts, laid by any State on imports or exports, shall be for the use of the Treasury of the United States; and all such laws shall be subject to the revision and control of the Congress.

3. No State shall, without the consent of the Congress, lay any duty of tonnage, keep troops or ships of war in time of peace, enter into any agreement or compact with another State or with a foreign power, or engage in war, unless actually invaded or in such imminent danger as will not admit of delay.

\section{Article II. Executive Departant.}

\section{Section I. President and Vice-President.}

I. The executive power shall be vested in a President of the United States of America. He shall hold his office during the term of four years, and together with the Vice-President, chosen for the same term, be elected as follows:

2. Each State shall appoint, in such manner as the legislature thereof may direct, a number of electors, equal to the whole number of Senators and Representatives to which the State may be entitled in the Congress; but no Senator or Representative, or person holding an office of trust or profit under the United States, shall be appointed an elector.

3. [The electors shall meet in their respective States and vote by ballot for two persons, of whom one at least shall not be an inhabitant of the same State with themselves. And they shall make a list of all the persons voted for, and of the number of votes for each; which list they shall sign and certify, and transmit sealed to the seat of the government of the United States, directed to the President of the Senate. The President of the Senate shall, in the presence of the Senate and House of Representatives, open all the certificates, and the votes shall then be counted. The person having the greatest number of votes shall be the President, if such number be a majority of the whole number of electors appointed; and if there be more than one who have such majority, and have an equal 
number of rotes, then the House of Representatives shall immediately choose by ballot one of them for President; and if no person have a majority, then from the five highest on the list the said House shall in like manner choose the President. But in choosing the President the rotes shall be taken by States, the representation from each State having one rote; a quorum for this purpose shall consist of a member or members from two thirds of the States, and a majority of all the States shall be necessary to a choice. In every case. after the choice of the President, the person having the greatest number of rotes of the electors shall be the Vice-President. But if there should remain two or more who have equal votes, the Senate shall choose from them by ballot the Tice-President.] ${ }^{1}$

4. The Congress may determine the time of choosing the electors and the day on which they shall give their votes, which day shall be the same throughout the United States.

5. No person except a natural-born citizen, or a citizen of the Lnited States at the time of the adoption of this Constitution, shall be eligible to the office of President; neither shall any person be eligible to that office who shall not have attained to the age of thirty-five years, and been fourteen years a resident within the United States.

6. In case of the removal of the President from office, or of his death. resignation, or inability to discharge the powers and duties of the said office. the same shall devolve on the Vice-President, and the Congress may by law provide for the case of removal, death, resignation. or inability, both of the President and Vice-President, declaring what officer shall then act as President, and such officer shall act accordingly until the disability be removed or a President shall be elected.

7. The President shall. at stated times. receive for his services a compensation. which shall neither be increased nor diminished during the period for which he shall have been elected. and he shall not receive within that period any other emolument from the United States or any of them.

8. Before he enter on the execution of his office he shall take the following oath or affirmation:

. I do solemnly swear (or affirm) that I will faithfully execute the office of President of the L'nited States, and will to the best of my ability preserve. protect. and defend the Constitution of the United States."

1 This clause of the Constitution has been amended. See Amendments, Art. XII. 


\section{Section II. Powers of the President.}

I. The President shall be Commander-in-chief of the Army and Navy of the United States, and of the militia of the several States when called into the actual service of the United States; he may require the opinion, in writing, of the principal officer in each of the executive departments, upon any subject relating to the duties of their respective offices, and he shall have power to grant reprieves and pardons for offenses against the United States, except in cases of impeachment.

2. He shall have power, by and with the advice and consent of the Senate, to make treaties, provided two thirds of the Senators present concur; and he shall nominate, and, by and with the advice and consent of the Senate, shall appoint ambassadors, other public ministers and consuls, judges of the Supreme Court, and all other officers of the United States, whose appointments are not herein otherwise provided for, and which shall be established by law; but the Congress may by law vest the appointment of such inferior officers, as they think proper, in the President alone, in the courts of law, or in the heads of departments.

3. The President shall have power to fill up all vacancies that may happen during the recess of the Senate, by granting commissions which shall expire at the end of their next session.

\section{Section III. Duties of the President.}

He shall from time to time give to the Congress information of the state of the Union, and recommend to their consideration such measures as he shall judge necessary and expedient; he may, on extraordinary occasions, convene both houses, or either of them, and in case of disagreement between them with respect to the time of adjournment, he may adjourn them to such time as he shall think proper; he shall receive ambassadors and other public ministers; he shall take care that the laws be faithfully executed, and shall commission all the officers of the United States.

\section{Section IV. Impeachment.}

The President, Vice-President, and all civil officers of the United States shall be removed from office on impeachment for and conviction of treason, bribery, or other high crimes and misdemeanors. 
Article ill. Judicial Departaent.

\section{Section I. United States Courts.}

The judicial power of the United States shall be vested in one Supreme Court, and in such inferior courts as the Congress may from time to time ordain and establish. The judges, both of the supreme and inferior courts, shall hold their offices during good behavior, and shall, at stated times, receive for thcir services a compensation. which shall not be diminished during their continuance in office.

\section{Section II. Furisdiction of the United States Courts.}

I. The judicial power shall extend to all cases, in law and equity, arising under this Constitution, the laws of the United States, and treaties made, or which shall be made, under their authority; to all cases affecting ambassadors, other public ministers, and consuls; to all cases of admiralty and maritime jurisdiction; to controversies to which the United States shall be a party; to controversies between two or more States; between a State and citizens of another State; between citizens of different States; between citizens of the same State claiming lands under grants of different States, and between a State, or the citizens thereof, and foreign States, citizens, or subjects. ${ }^{1}$

2. In all cases affecting ambassadors, other public ministers and consuls, and those in which a State shall be a party, the Supreme Court shall have original jurisdiction. In all the other cases before mentioned, the Supreme Court shall have appellate jurisdiction, both as to law and fact, with such exceptions, and under such regulations as the Congress shall make.

3. The trial of all crimes, except in cases of impeachment, shall be by jury; and such trial shall be held in the State where the said crimes shall have been committed; but when not committed within any State, the trial shall be at such place or places as the Congress may by law have directed.

\section{Section III. Treason.}

I. Treason against the United States shall consist only in levying war against them, or in adhering to their enemies, giving them aid and comfort. No person shall be convicted of treason unless

1 This clause has been amended. See Amendments, Art. XI. 


\section{THE CONSTITUTION.}

on the testimony of two witnesses to the same overt act, or on confession in open court.

2. The Congress shall have power to declare the punishment of treason, but no attainder of treason shall work corruption of blood or forfeiture except during the life of the person attainted.

Article IV. - The States and the Federal GovernMENT.

Section I. State Records.

Full faith and credit shall be given in each State to the public acts, records, and judicial proceedings of every other State. And the Congress may by general laws prescribe the manner in which such acts, records, and proceedings shall be proved, and the effect thereof.

Section II. Privileges of Citizens, etc.

I. The citizens of each State shall be entitled to all privileges and immunities of citizens in the several States.

2. A person charged in any State with treason, felony, or other crime, who shall flee from justice, and be found in another State, shall, on demand of the executive authority of the State from which he fled, be delivered up, to be removed to the State having jurisdiction of the crime.

3. No person held to service or labor in one State, under the laws thereof, escaping into another, shall, in consequence of any law or regulation therein, be discharged from such service or labor, but shall be delivered up on claim of the party to whom such service or labor may be due. ${ }^{1}$

\section{Section III. New States and Territories.}

I. New States may be admitted by the Congress into this Union; but no new State shall be formed or erected within the jurisdiction of any other State; nor any State be formed by the junction of two or more States or parts of States, without the consent of the legislatures of the States concerned as well as of the Congress.

2. The Congress shall have power to dispose of and make all needful rules and regulations respecting the territory or other property belonging to the United States; and nothing in this Constitution shall be so construed as to prejudice any claims of the United States or of any particular State.

1 This clause has been canceled by Amendment XIII., which abolishes slavery. 


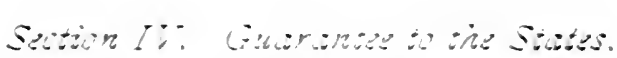

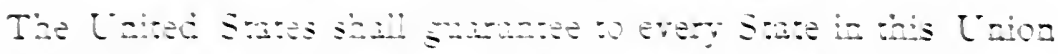

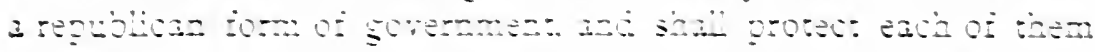

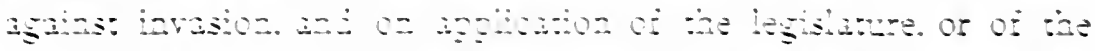

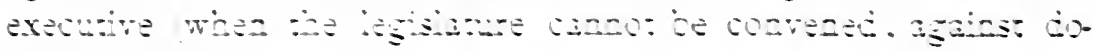

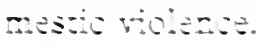

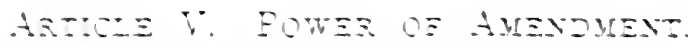

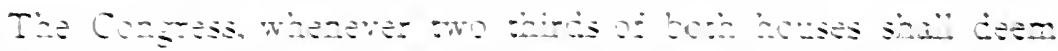

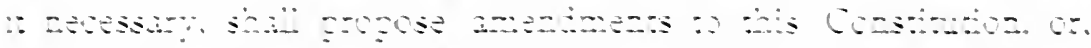

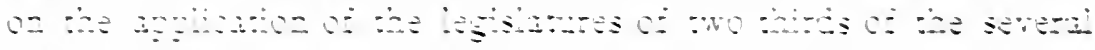

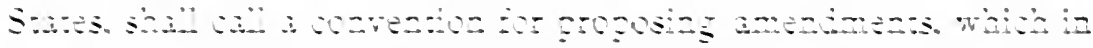

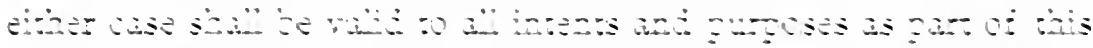

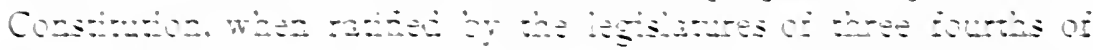

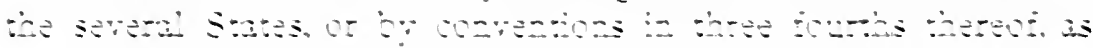
䗆

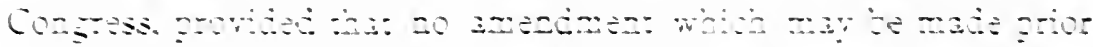

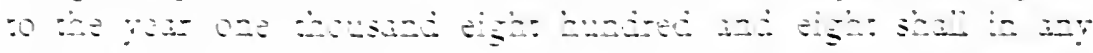

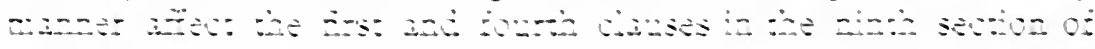

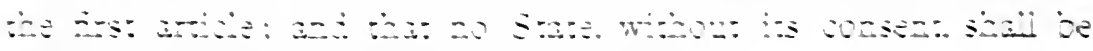

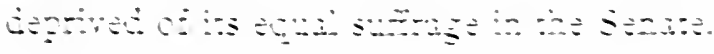

ARTRE 2.

๖. A. 수 a d

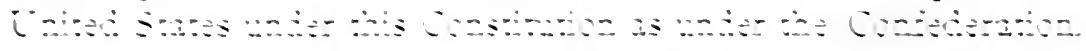

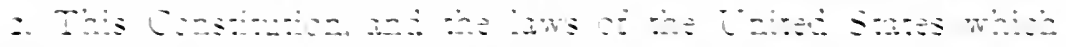
s."

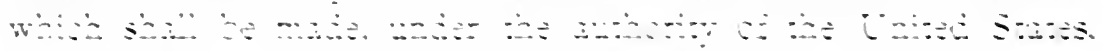

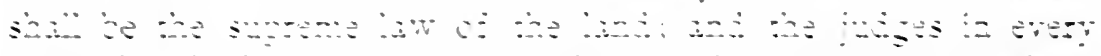
s.a.

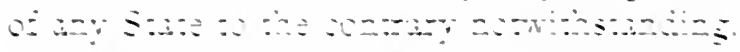

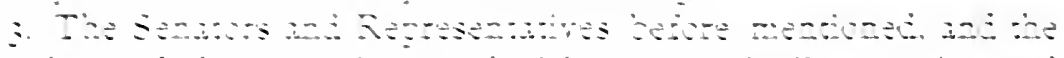

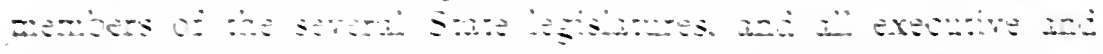
7. s.

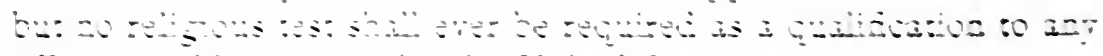

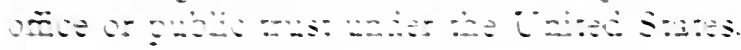


Akticle vil. Ratigicator of the Construtios.

The ratification of the comentions of nine stutes shall be suffoient for the establishment of this Constitution heween the States so ratifying the same.

Done in comention by the ummoms consent of the States present. the seventeden duy of Sepember. in the year of our Lord one thousund seven hunded and dighty-seren, and of the Independence of the L nited States of America the twelth. In witness whered, we have hereunto subseribed our names.

George Washington, President and Depury from Vikgixia. New Haursuke - John Langdon. Nicholas Giman.

Massachletrs - Nathubl Gorham. Rufus King. Coxiecrictr - William Samuel Johnson. Koger Sherman.

NEW YORK - Alexander Hamilon.

New Jensey - Willam Livingston, David Brearly. William Pat. terson. Jomathan Dayton.

Pexserbrasta - Benjamin Franklin. Thomas Miftin, Robert Morris, George Clymer. Thomas Fitsimons, Iared Ingersoll, James Wilson. Gourerneur Morris.

DELAWARE - George Read, Gumning Bedford. Ir. John Dichinson, Richard Bassett. Jacob Broom.

Makraxn - James MeHenry. Daniel of St. Thomas Jenifer, Daniel Carroll.

Vingivia - John Blair James Madison, Jr.

Cokтн Cakolna-William Blount. Richard Dobbs Spaight, Hugh Williamson.

Sotth CARolwa - John Kutledge. Charles Cotesworth Pinckney, Charles Pinckney, Pierce Butler.

Geokgla - Jilliam Few, Abraham Baldwin.

Attest William Jackion. Serretary.

I Rhode Island sent no delegates to the Federal Convention. 


\section{AMENDMENTS. ${ }^{1}$}

ARTicle 1 .

Congress shall make no law respecting an establishment of religion, or prohibiting the free exercise thereof: or abridging the freedom of speech or of the press: or the right of the people peaceably to assemble. and to petition the government for a redress of grievances.

\section{ARTICIE II.}

A well-regulated militia being necessary to the security of a free State. the right of the people to keep and bear arms shall not be infringed.

\section{Article III.}

No soldier shall. in time of peace. be quartered in any house without the consent of the owner. nor in time of war. but in a manner to be prescribed by law.

\section{ARTICLE IV:}

The right of the people to be secure in their persons. houses. papers. and effects. against unreasonable searches and seizures. shall not be violated. and no warrants shall issue but upon probable cause. supported by oath or affrmation, and particularly describing the place to be searched. and the persons or things to be seized.

\section{ARTICLE T:}

No person shall be held to answer for a capital or otherwise infamous crime. unless on a presentment or indictment of a grand jury. except in cases arising in the land or naval forces. or in the militia. when in actual service in time of war or public danger: nor shall any person be subject for the same offense to be twice put in jeopardy of life or limb: nor shali be compelled in any criminal case to be a witness against himself. nor be deprived of life. liberty or property, without due process of law: nor shall private property be taken for public use without just compensation.

\section{Article li.}

In all criminal prosecutions the accused shall enjoy the right to a speedy and public trial. by an impartial jury of the State and

1 Amerdments I. to X. were proposed by Congress. Sept. 25, I 7 \&g, and deDlarec in iorce Dec. 15,1591 . 
district wherein the crime shall have been committed, which district shall have been previously ascertained by law, and to be informed of the nature and cause of the accusation; to be confronted with the witnesses against him: to have compulsory process for obtaining witnesses in his favor, and to have the assistance of counsel for his defense.

\section{Article Vil.}

In suits at common law, where the value in controversy shall exceed twenty dollars, the right of trial by jury shall be preserved. and no fact tried by a jury shall be otherwise reëxamined in any court of the United States, than according to the rules of the com. mon law.

\section{Article VIII.}

Excessive bail shall not be required, nor excessive fines imposed, nor cruel and unusual punishments inflicted.

ARticle IX.

The enumeration in the Constitution of certain rights shall not be construed to deny or disparage others retained by the people.

\section{ARTiCle $X$.}

The powers not delegated to the Linited States by the Constitution, nor prohibited by it to the States, are reserved to the States respectively or to the people.

\section{ARticle NI.1}

The judicial power of the United States shall not be construed to extend to any suit in law or equity, commenced or prosecuted against one of the United States by citizens of another State, or by citizens or subjects of any foreign State.

\section{Article Xil.?}

I. The electors shall meet in their respective States and vote by ballot for President and Vice-President, one of whom, at least. shall not be an inhabitant of the same State with themselves; they shall name in their ballots the person voted for as President, and in distinct ballots the person roted for as Vice-President, and they

1 Proposed by Congress March 5, 1794, and declared in force Jan. S, 179S.

2 Proposed by Congress Dec. 12, $1 \mathrm{SO}_{3}$, and declared in force Sept. 25, $1 \mathrm{SO}_{4}$. 
shall make distinct lists of all persons roted for as President and of all persons roted for as Vice-President, and of the number of rotes for each; which lists they shall sign and certify, and transmit sealed to the seat of the government of the United States, directed to the President of the Senate. The President of the Senate shall, in the presence of the Senate and House of Representatives, open all the certificates and the rotes shall then be counted. The person having the greatest number of rotes for President shall be the President, if such number be a majority of the whole number of electors appointed: and if no person have such majority, then from the persons having the highest numbers not exceeding three on the list of those voted for as President, the House of Representatives shall choose immediately, by ballot, the President. But in choosing the President the rotes shall be taken by States, the representation from each State having one rote: a quorum for this purpose shall consist of a member or members from two thirds of the States, and a majority of all the States shall be necessary to a choice. And if the House of Representatives shall not choose a President whenever the right of choice shall devolve upon them, before the fourth day of March next following, then the Vice-President shall act as President. as in the case of the death or other constitutional disability of the President.

2. The person having the greatest number of rotes as Vice-President shall be the Vice-President, if such number be a majority of the whole number of electors appointed: and if no person have a majority, then from the two highest numbers on the list the Senate shall choose the Vice-President: a quorum for the purpose shall consist of two thirds of the whole number of Senators, and a majority of the whole number shall be necessary to a choice.

3. But no person constitutionally ineligible to the office of President shall be eligible to that of Vice-President of the Lnited States.

\section{Article Nill.}

I. Neither slavery nor involuntary servitude. except as a punishment for crime whereof the party shall have been duly convicted, shall exist within the United States or any place subject to their jurisdiction.

2. Congress shall have power to enforce this article by appropriate legislation.

1 Proposed by Congress Feb. I. IS65, and declared in force Dec. Is, 1865. 


\section{Article XIV.1}

I. All persons born or naturalized in the United States, and subject to the jurisdiction thereof, are citizens of the United States and of the State wherein they reside. No State shall make or enforce any law which shall abridge the privileges or immunities of citizens of the United States; nor shall any State deprive any person of life, liberty, or property, without due process of law; nor deny to any person within its jurisdiction the equal protection of the laws.

2. Representatives shall be apportioned among the several States according to their respective numbers, counting the whole number of persons in each State, excluding Indians not taxed. But when the right to vote at any election for the choice of electors for President and Vice-President of the United States, Representatives in Congress, the executive and judicial officers of a State, or the members of the legislature thereof, is denied to any of the male inhabitants of such State, being twenty-one years of age, and citizens of the United States, or in any way abridged, except for participation in rebellion, or other crime, the basis of representation therein shall be reduced in the proportion which the number of such male citizens shall bear to the whole number of male citizens twenty-one years of age in such State.

3. No person shall be a Senator or Representative in Congress, or elector of President and Vice-President, or hold any office, civil or military, under the United States or under any State, who, having previously taken an oath as a member of Congress, or as an officer of the United States, or as a member of any State legislature, or as an executive or judicial officer of any State, to support the Constitution of the United States, shall have engaged in insurrection or rebellion against the same, or given aid or comfort to the enemies thereof. But Congress may, by a vote of two thirds of each house, remove such disability.

4. The validity of the public debt of the United States, authorized by law, including debts incurred for payment of pensions and bounties for services in suppressing insurrection or rebellion, shall not be questioned. But neither the United States nor any State shall assume or pay any debt or obligation incurred in aid of insurrection or rebellion against the United States, or any claim for the loss or emancipation of any slave; but all such debts, obligations, and claims shall be held illegal and void.

1 Proposed by Congress June 16, 1866, and declared in force July 28, 1868. 


\section{A?IENDIX}

5. The Congess shall have puwe on eaforce by appropriate legidutur. the provisions ot his aride

$$
A \therefore: B=19:
$$

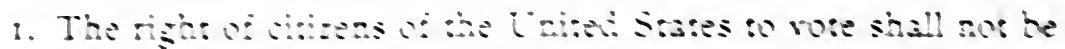

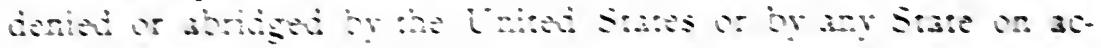

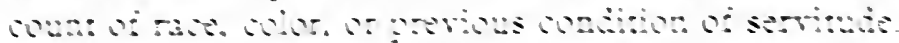

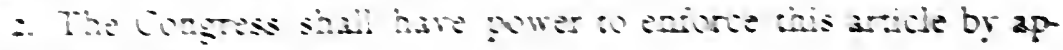

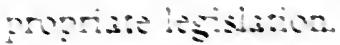

\section{APEENDIX B. \\ LIST OE STALE.}

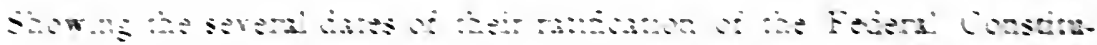

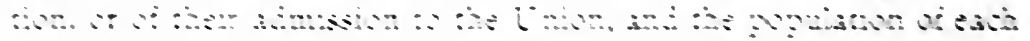

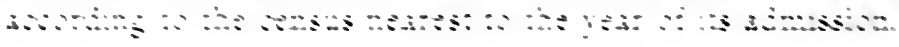

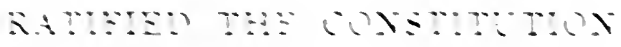

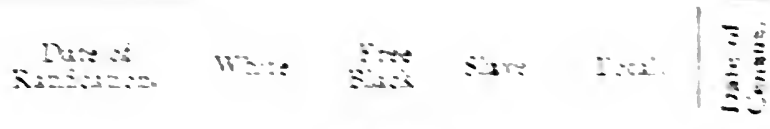

\begin{tabular}{|c|c|c|c|c|c|c|}
\hline$D_{-3}=8$ & ד: : : : & $\therefore:=$ & $\therefore \vdots$ & ミミ & $\therefore \therefore N$ & $:-3$ \\
\hline 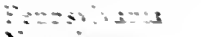 & $\therefore$ : : : : & $\therefore \therefore \therefore 2$ & $\therefore \vdots:$ & $\vdots \because-$ & 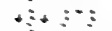 & \\
\hline Ninw & $\because+: \div:-3$ & $\therefore 心$ & $=\cdots$ & 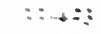 & 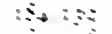 & $: 2$ \\
\hline$\left(\begin{array}{lll}3 \\
2\end{array}\right.$ & $\because 2=: \cdots$ & 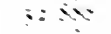 & 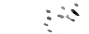 & $\therefore \therefore \therefore$ & 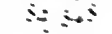 & $:=2$ \\
\hline 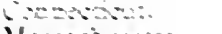 & 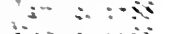 & $\because: \because:$ & $\therefore \therefore$ & $\therefore \because:$ & $\because \because \therefore:$ & $:-a$ \\
\hline$M$ math-y & $\because 2 \therefore=\cdots$ & 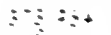 & 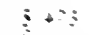 & - & $\therefore \because-:$ & 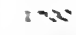 \\
\hline Ms-ine & 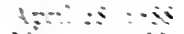 & $\therefore \therefore$ & $\therefore \therefore$ & $\therefore: \because:=$ & $\vdots \therefore \cdots$ & $: \cdots$ \\
\hline 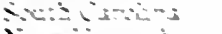 & 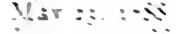 & $\therefore+: \because$ & $\therefore$ : & $\therefore \therefore$ & $\therefore \therefore: \div$ & $\because \because$ \\
\hline 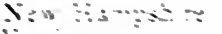 & $\therefore=08:-\because 3$ & $\therefore \therefore$ & $: \therefore$ & 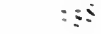 & $\therefore \therefore$ & $\because>$ \\
\hline$y=\infty$ & 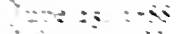 & +t: : : & $\therefore n$ & $\therefore \therefore$ & $\because 583^{2}$ & $:-3$ \\
\hline$\therefore=61 \because 2$ & 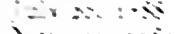 & $\therefore \& \therefore=$ & $+\therefore+$ & $\therefore \therefore$ & $\therefore \therefore \therefore s$ & 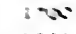 \\
\hline 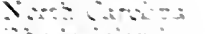 & $\because \because \because \because \cdots$ & $\therefore \because$ & •: & $\therefore \cdots:=$ & ミミ・: & $: \cdots$ \\
\hline 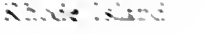 & $10: 2=2, \infty$ & $\therefore$ त & $\therefore+\infty$ & $\because:$ & $x-:=$ & \\
\hline
\end{tabular}

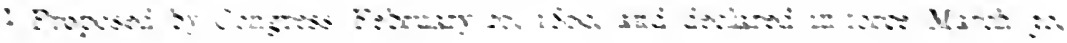
$\therefore \because+3$ 


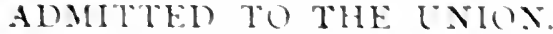

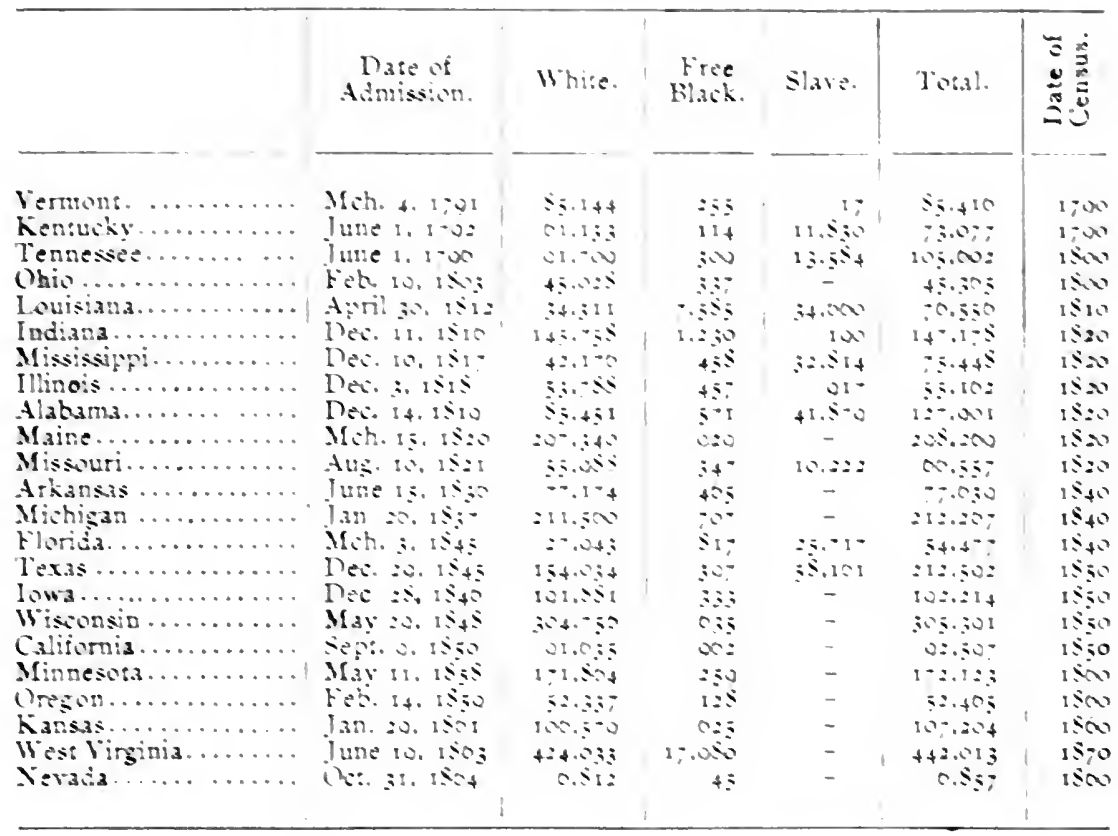

\section{ADMTTEI TO THE L'NION SINCE THE ABOLITION OF SIALEY.}

\begin{tabular}{|c|c|c|c|c|c|}
\hline & $\begin{array}{l}\text { Pate of } \\
\text { Admision. }\end{array}$ & White. & Black. & To:al. & 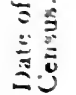 \\
\hline Xebrasisa............. & Moh. 1. IN- & $1: 211 ;$ & - & $1: 2.006$ & エミ: \\
\hline Coloraco............ & Ans. 1. IS- & 10101: & $2.4 \vdots 5$ & 303.351 & BO \\
\hline North Dako:3........ & Xำ. 2, & $152,12:$ & $3-3$ & 15.300 & 1 \&ou \\
\hline South Dakot..... & Now $=150$ & $\therefore=-200$ & $\vdots \$$ & $32-236$ & $1: 00$ \\
\hline Montana ............. & 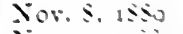 & $12=.2-1$ & 1.400 & $125 .-01$ & INo \\
\hline Washingion.......... & Xor.11,1心0 & $\vdots 40 \vdots \vdots 3$ & $1 . \infty 2$ & 342.615 & $1 \leqslant 0$ \\
\hline Idaho $\ldots \ldots \ldots \ldots \ldots$ & July: : : & \$2.0 & 2016 & 52.210 & $1 \leqslant 0$ \\
\hline Wyoming............. & Iuli: is. $15 x$ & 50,195 & $0:$ & a.to; & $1 \leqslant 0$ \\
\hline 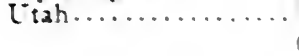 & $\operatorname{Tan}+150$ & $\therefore 5 N \infty$ & ミs: & $2 \times, 45 ;$ & $1 \leqslant 0$ \\
\hline
\end{tabular}


- DISTRICT OF COLUMBIA AND TERRITORIES.

\begin{tabular}{|c|c|c|c|c|c|}
\hline & $\begin{array}{c}\text { Date of } \\
\text { Organization. }\end{array}$ & White. & Colored.* & Total. & 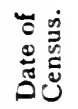 \\
\hline District of Columbia. & Mch. 3, 179 & 191,5 & 87,186 & 278,718 & 1900 \\
\hline Indian Territory ....... & June 30,1834 & 302,680 & $89,3 \mathrm{So}$ & 392.060 & 1900 \\
\hline New Mexico............ & Sept. 9, is 50 & 180,207 & 15,103 & 195,310 & 1000 \\
\hline Arizona ............. & Feb. 24,1363 & 92,903 & 30,028 & 122,931 & 1900 \\
\hline Alaska .................. & July 27, is 863 & 30,493 & 33.099 & 63,592 & 1900 \\
\hline Oklahoma ............. & April 22, 18S9 & 367,524 & 30,807 & $398,33 \mathrm{r}$ & 1900 \\
\hline
\end{tabular}

* Including Indians not taxed.

\section{APPENDIX C.}

\section{PRESIDENTIAL ELECTIONS.}

POLITICAL PARTIES, CANDIDATES, IETHODS, AND VOTES, FROMI 'THE FIRST ELECTION LNTIL 'IHE LATEST. ${ }^{1}$

The first four elections were conducted in accordance with the provisions of the Constitution as it was originally framed and adopted, the electors voting for two persons, with no indication of one to be President, the other Vice-President (see Constitution, Article 2, section 3). Subsequent elections have been regulated by the Eleventh Amendment to the Constitution, adopted in ISo4.

\section{First Election, 1789 : Washington and Adams.}

\section{Parties and Candidates.}

There was no definite contest between Federalists and AntiFederalists in the election, and no nomination of candidates. Washington was the choice of all for President, but many persons were suggested in different States for the second place.

States participating : $10 .^{2}$

1 Compiled mainly from Stanwood's History of the Presidency.

2 Rhode Island and North Carolina had not yet adopted the Constitution, and the vote of New York was lost in consequence of a disagreement between the two branches of its legislature. 
Mode of choosing Electors.

By legislature in Connecticut, New Jcrsey, Delaware, South Carolina, Georgia ; by vote of the people in Virginia, Maryland, and Pennsylvania; by selection in the legislature from persons named by popular vote in Massachusetts and New Hampshire.

\section{Electoral Vote.}

The ten States participating were entitled to 73 electoral votes, but four electors failed to perform their duty. Washington was named on all of the 69 votes that were cast. John Adams was elected Vice-President by 34 votes. Samuel Huntington received 2, John Jay 9, John Hancock 4, Robert H. Harrison 6, George Clinton 3, John Rutledge 6, John Milton 2, James Armstrong I, Edward Telfair I, Benjamin Lincoln I.

\section{Second Election, 1792: Washington and Adams.}

Parties and Candidates (nominations informal).

Federalist: George Washington, of Virginia, and John Adams, of Massachusetts.

Anti-Federalist (beginning to be styled Democratic-Republican, or simply Republican): George Washington, of Virginia, and George Clinton, of New York.

States participating: 15.

Mode of choosing Electors.

By vote of the people in Pennsylvania, Maryland, Virginia; by people and legislature in New Hampshire and Massachusetts; by members of the legislature, meeting for the purpose in districts, in North Carolina; by legislature in other States.

\section{Electoral Vote.}

For Washington, 132 (unanimous); for Adams, 77; for Clinton, 50; for Jefferson, 4; for Aaron Burr, I.

\section{Third Election, 1796: Adams and Jefferson.}

Parties and Candidates (nominations informal).

Federalist: John Adams, of Massachusetts, and Thomas Pinkney, of South Carolina.

Republican: Thomas Jefferson, of Virginia, and Aaron Burr, of New York. 


\section{APPENDIX C.}

States participating: 16.

Mode of choosing Electors.

By rote of the people in lennsyluania. Maryland. Tirginia. North Carolina: by people and legislature in New Hampshire and Massachusetis: by legislature in other states.

Electoral Vote.

For Adams. il for lef̈erson. Gs: for Thomas Pinkney, 30 : for Burr. so: for Samuel Adams. Is: for Oliver Ellsworth. II: for George Clinton, ; for lohn Jay, : : for James lredell $z$ : for George Washington, a for Samuel Johnson. z: for John Henry. 2 : for Charles C. Pinchner, I.

Fourth Election. 1800 : Jefferson and Burr.

Parties and Candidates (nominations informal

Republican: Thoma lefierson of Virgina and Aaron Burr, of New lork.

Federalist: John Adams of Massachusets, and Charles $C$. Pinckney, of Souh Carolma.

States participating : 16.

Mode of choosing Electors.

By rote of the people in Rhode Island. Maryland, Virginia. and North Carolina by legislature in other States.

Electoral Vote.

For Jefierson, in New lork. Fennsylunia. Maryland. Virginia. North Carolim. South Carolina. Georsia, Kentucky. Tennessee. total. 73.

For Burr. sume States, total. is.

For Adams, in New Hampshire. Vermont. Massachusetts. Rhode lsland. Connctian. New Jerseg. Pennsylunia. Delaware. Maryland. North Carolina total, os.

For Pinckner, in same states tomio of.

For John Jay. Khode Island. total. 1.

Jefferson and Burr haing received an equal rote. and that rote a majority of the whole, the election went to the House of Kepresentatives and was decided after 3 : unsuccessful ballots in favor of lefferson for President making Bur lice-President. Tefterson received 5a rotes. Burr 49. 
Fifth Election, 1804: Jefferson and Clinton.

Parties and Candidates.

Republican (nominations hy a caucus of Congressmen): Thomas Jefferson, of Virginia, and Cicorge Clinton, of New York.

Federalist (nominations informal): Charles C. Pinckney, of South Carolina, and kufus King, of New York.

States participating: 17 .

Mode of choosing Electors.

By legislature in Vermont, Connecticut, New York, Delaware, South Carolina, Ceorgia. Temessee: by vote of the people in districts in Maryland, North Carolina, Kentucky; by vote of the people on general tickets in other States.

Electoral Vote.

For Jefferson and Clinton in all States excepting Connecticut, Delaware, and Maryland, total, i6z.

For Pinckney and King, in the three States named, total, It.

\section{Sixth Election, 1808: Madison and Clinton.}

Parties and Candidates.

Republican ${ }^{1}$ (nominations by a caucus of Congressmen): James Madison, of Virginia, and George Clinton, of New York.

Federalist (nominations informal): Charles C. Pinckney, of South Carolina, and kufus King, of New York.

States participating: 17 .

Mode of choosing Electors.

By legislature in Vermont, Massachusetts, Connecticut, New York, Delaware, South Carolina, Georgia: by popular vote in districts in Maryland. North Carolina, Kentucky, Tennessee: by popular rote on general tickets in other States.

Electoral Vote for President.

For Madison, in Vermont, New York (13 out of 19), New Jer-

1 The party was divided by the nomination of Madison, James Monroe in Virginia taking the field as an independent candidate, and George Clinton in New York being supported by some Republicans for President instead of Vice-President. 
sey, Pennsylunia. Maryland, Virginia Norh Carolina, South

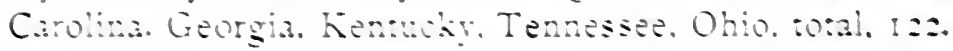

For Pincher. New Hamphire. Massachusets, Khode Island. Connecticu. Deiaware Maryland. Norh Carolina to:al. \&"

For Clinion. New lork.

Eiectoral Vote for Vice-President.

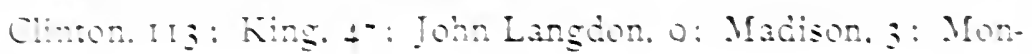
ㄱ․:

\section{Serenth Election. 1812 : Madison and Gerry.}

\section{Parties and Candidates.}

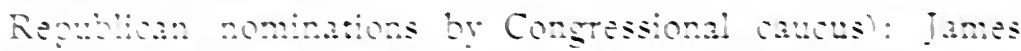
Mäson ot Virgnia and Elbritge Gery of Massachuset:s.

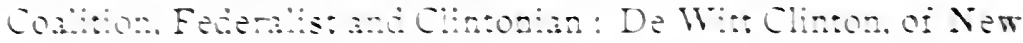

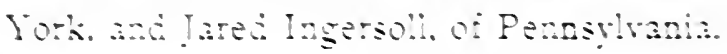

Siates garticisating is.

Mode ot choosing Eiectors.

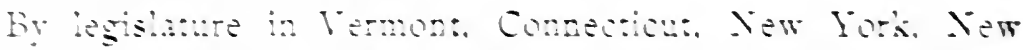

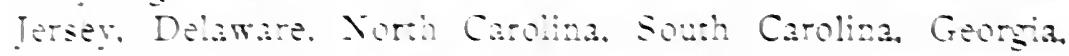
Loustana by rote ot the geoge in Estrics in Massachusetts. Maryan. Kenuchy. Tenessed by pupuar rute on genera?

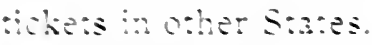

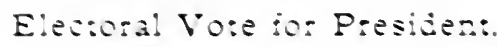

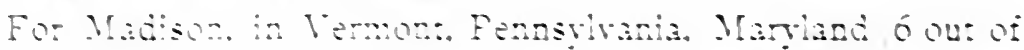

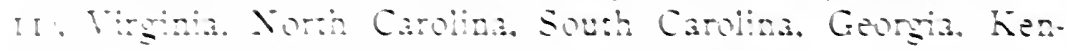

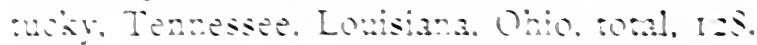

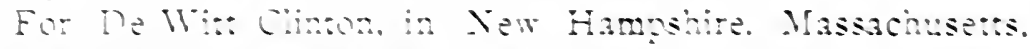

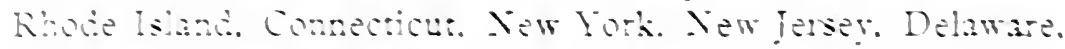

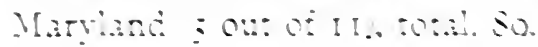

Eiecoral Vose tor Vice-Presiden:

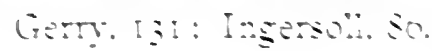

\section{Eighth Election. 1816: Monroe and Tompkins.}

Parties and Candidates.

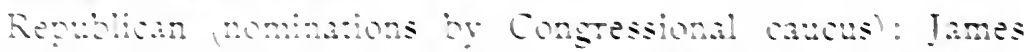

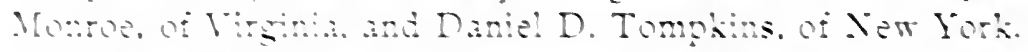

Feterals: no tomal nominaton' Kurus King of Xew losk. 
States participating: 19 .

Mode of choosing Electors.

Same as in the preceding clection.

Electoral Vote for President.

For Monror, in all States except Massachusetts. Connecticut, Delaware. total, IS;.

For King. in the three states named. total. 3t.

Electoral Vote for Vice-President.

Tompkins, Is3: John E. Howard of Maryland. 22 : scattering. 12 .

\section{Ninth Election, 1820 : Monroe and Tompkins.}

Parties and Candidates.

Republican (nominations informal): Iames Momroe of Yirginia. and Daniel D. Tompkins. of New lork.

Foderalist : no nomination.

States participating: 24 .

Mode of choosing Electors.

By legislature in Vermont. New York. Delaware. South Carolina, Georgia. Lousiana: by rote of the people in districts in Maine. Maryland. Illinois, Kentucky. Missouri : by rote of the people on general tickets in other States.

Electoral Vote for President.

For James Monroe. all votes except one. in New Hampshire. total. $23 \mathrm{I}$.

For John Quincy Adams. I.

Electoral Vote for Vice-President.

Tompkins, 2IS: Richard Stockton. S: scattering. 6.

\section{Tenth Election, 1824: Adams and Calhoun.}

Parties and Candidates.

Democratic-Republican (now called Democratic): William H. Crawford of Georgia, and Albert Gallatin. of Pennsylvania (nominated for President and Vice-President by Congressional caucus): John Quincy Adams of Massachusetts, Andrew Jackson. of Tennessee, and Henry Clay, of Kentucky (independently nomi- 


\section{APPENDIX C}

nated for Presicer): Iohn C. Calhoun, of South Carolina (independentiy nominared for Vice-President.

Siates participating: 24 .

Mode of choosing Electors.

Sane as in prececing election.

Electora: Vo:e jor Presidert.

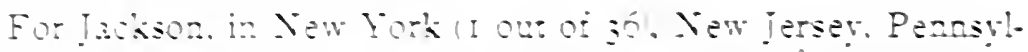

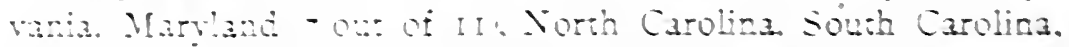

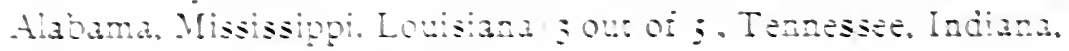

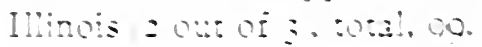

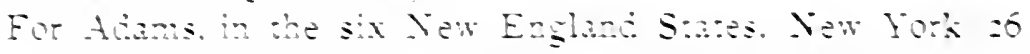

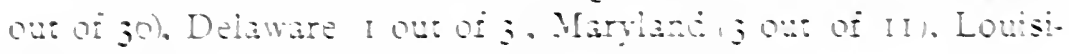

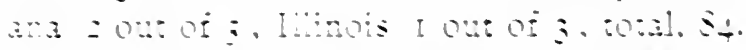

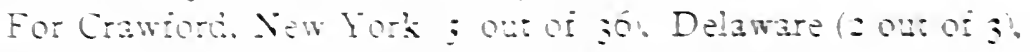
Maryland I out of I I l'rsina lieorgia to:al, II.

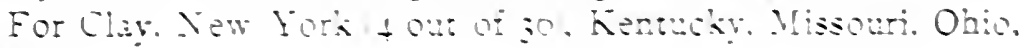
ivial :-

Electora: Vo:e jor Vine-Presigers

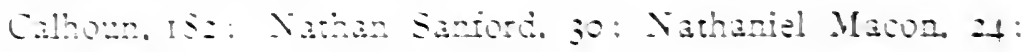
scizering :

None of the cancidares for Fresiden baving received a ma-

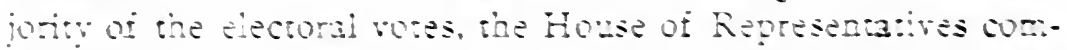

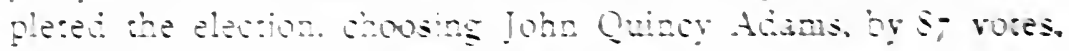

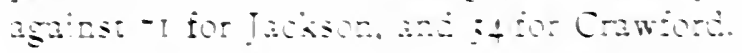

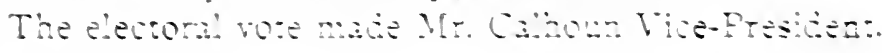

\section{Elerenth Election, 1828 : Jackson and Calhoun.}

\section{Paries an: Cansidizes}

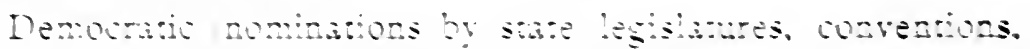

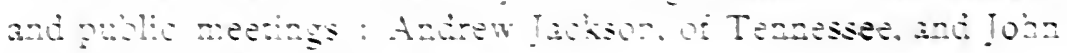

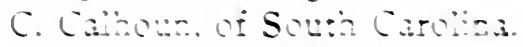

Xational Kequhlican cominations infomall fohn Quingy

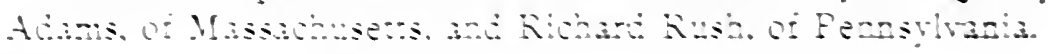

Siates faricigarizg: 24

Mode of choosing Eiecrors.

By legisianre in Delaware and Souh Carolina: by roie of the peogle in Ustros in Mane. New York. Maryand. Tenaesser: by rote of the people on general ticisess in other Sates. 


\section{Popular Majorities.}

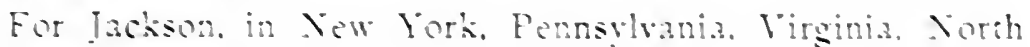

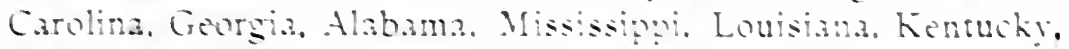
Tennessee, Missouri. Ohio, Indima Ilinois.

For thams, in Mane. Jew Hampsine. Vermont. Massachusetts. Khode Island. Connecticu. New Jersey, Maryland.

Total Popular Vo:e.

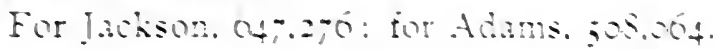

\section{Electora! Vo:e.}

For President, Tackson, 1-S: Adams. S:

For Vice-President. Calhoun 1-1: Kush. s: William Smith. 7

Twelfth Election. 1832: Jackson and Tan Buren.

\section{Parties and Candidates.}

Democratic mominations by national conventionl: Andrew Jakson of Tennesser and Martin lan Buren of New lork.

Xatomal-Kepublican (nominations by national convention):

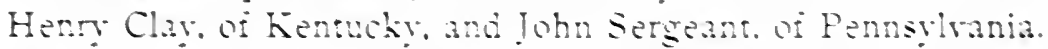

Anti-Masonic nominations by natomal comenton): Willam Wirt, of Maryland and Amos Elmaker of Eennsylunia.

\section{States participating: 24 .}

\section{Mode of choosing Electors.}

By legislature in South Carolina: by vote of the people in dis. tricts in Maryland: by vote of the people on general tickets in other States.

\section{Popular Majorities.}

For Jackson, in Mane. New Hampshire, New lork, New Ter. sey. Pennsylvania. Vinginia. Corth Carolina. Georgia. Mississippi. Louisiana. Tennessee. Missouri. Ohio. Indiana. IMinois.

For Clay, in Massachusetis. Khode Island. Connecticus. Delaware, Maryland. Kenucky.

Total Popular Vote.

For Jackson, 65;.joz: for Clay, 330.15o.

\section{Electoral Vote.}

For President. Jackson, 219: Clay, 40: Wirt. i: John Floyd. II. 


\section{APPENDIX C.}

For Vice-President. Van Buren. 1So: Sergeant. 49: Elmaker. 7 : William Milkins, 30 : Henry Lee. il.

\section{Thirteenth Election, 1836 : Van Buren and Johnson.}

\section{Parties and Candidaies.}

Democratic (nominations by convention): Martin Van Buren. of New York, and Richard M. Johnson. of Kentuchy.

Whig and Independent (nominations in various modes): for Fresident. William Henry Harrison. of Ohio. John McLean of Ohio. Hugh L. White of Tennessee. Daniel Mebster, of Massachusets: for Tice-President. Francis Granger, of New York, and John Tyler of Virginia.

States participating: 26 .

Mode of choosing Electors.

By legislature in South Carolina: by popular rote on general tickets in other States.1

Popular Majorities.

For Tan Buren. in Maine. New Hampshire. Rhode Island. Connecticut, New Jork. Pennsylrania. Virginia. North Carolina. Alabama Mississippi. Louisiana. Arkansas. Missouri. Mllinois. Michigan.

For the various opposing candidates, in Vermont. Massachusetts. New Terser. Delaware. Maryland. Georgia. Kentucky. Tennessee. Ohio. Indiana.

Total Popular Vote.

For Van Buren, -62.075: for opposition candidates, 736.230 .

\section{Electoral Vote.}

For President. Van Buren. I70: Harrison. 73 : White. 26 : Webster. Iq: Willie P. Mangum, i r.

For Tice-President. Tohnson. if : Granger. 37 : Tyler. 4i: William Smith. 23 .

1 From this time until rss the mode of choosing electors remained unchanged. the sole exception to their election by popular vote on general tickets being in South Caroina. 
Fourteenth Election, 1840 : Harrison and Tyler.

Parties and Candidates.

Whig (nominations by convention ${ }^{1}$ ): William H. Harrison, of Ohio, and John Tyler, of Virginia.

Democratic (nomination by convention): Martin Van Buren, of New York. (No nomination for Vice-P'resident made.)

Liberty Party (nominations by convention): James G. Birney, of New York, and Thomas Earl, of Pennsylvania.

States participating: 26 .

Popular Majorities.

For Harrison, in Maine, Vermont, Massachusetts, Rhode Island, Connecticut, New York, New Jersey, Pennsylvania, Delaware, Maryland, North Carolina, Georgia, Mississippi, Louisiana, Kentucky, Tennessee, Ohio, Indiana, Michigan.

For Van Buren, in New Hampshire, Virginia, Alabama, Missouri, Arkansas, Illinois.

\section{Total Popular Vote.}

For Harrison, 1,275,016; for Van Buren, I,129,102; for Birney, 7069 .

\section{Electoral Vote.}

For President, Harrison, 23t; Van Buren, 60.

For Vice-President, Tyler, 234; R. M. Johnson, 48; L. W. Tazewell, II ; James K. Polk, I.

\section{Fifteenth Election, 1844: Polk and Dallas.}

\section{Parties and Candidates.}

Democratic: James K. Polk, of Tennessee, and George M. Dallas, of Pennsylvania.

Whig: Henry Clay, of Kentucky, and Theodore Frelinghuysen, of New Jersey.

Liberty Party : James G. Birney, of New York, and Thomas Morris, of Ohio.

States participating : 26 .

1 From this time all party nominations for the presidency and vice-presidency were made by national conventions. 
Pepula: majozics.

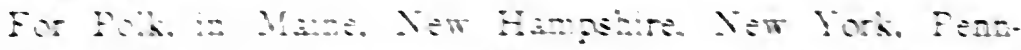

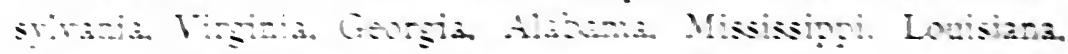

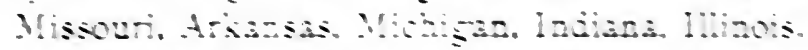

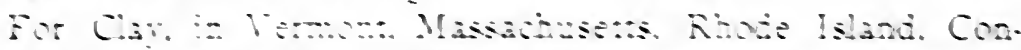

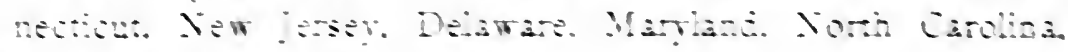

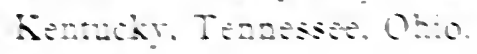

To:j: zosuis: ro:e

Fo:

Eis:cis:

For 药

Sisteenth Election, IStS: Isplor sad Fillmore.

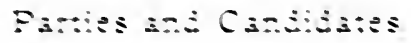

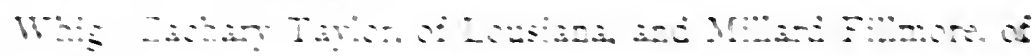

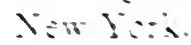

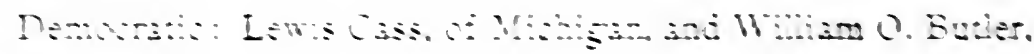

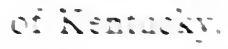

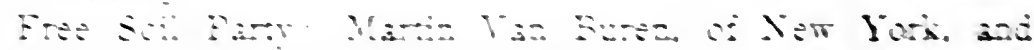

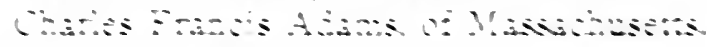

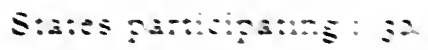

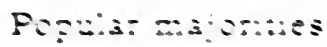

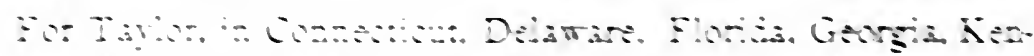

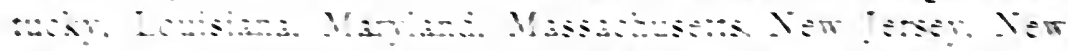

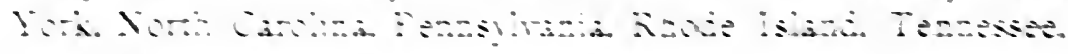

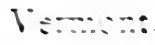

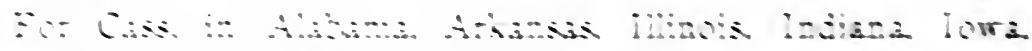

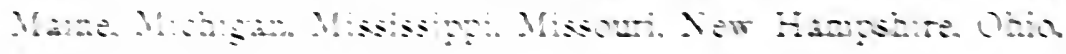

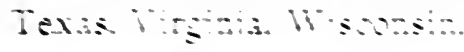

Toral sazia: ro:

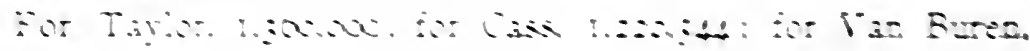
: 21.23

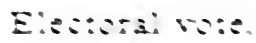

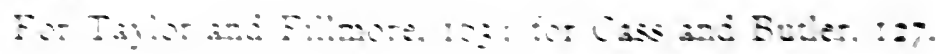




\section{Serenteenth Election, 1852: Pierce and King.}

\section{Parties and Candidates.}

Democratic: Franklin Heree, of New Hampshire, and William K. King of Alabom.

Whis: Winteld scout of dew Jersey and William $A$. Grahm, of Corth Corolina.

Free Soll Farty: Iohn H. Hale of New Hamphire, and Goorge W. Iulian. of lndiama.

States participaing : 3 s.

Popular majorities.

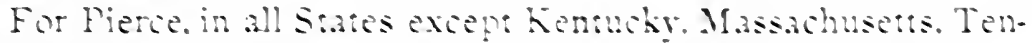

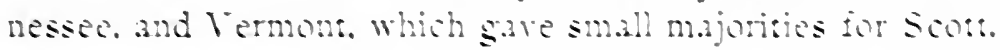

Total popular rote.

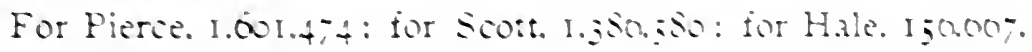
Electoral rote.

For Pierce and King, zit: for Scots and Graham. 42.

Eighteenth Election, 1856: Buchanan and Breckenridge.

Parties and Candidates.

Democratic: James Fuchaman, of Ponnsilvania, and John $C$. Brechenrigge. of kentuchy.

Kepublican: John C. Frémoni, of Califorma and Willam L. Dayton, of New Tersey.

American and Whig: Millard Filmore of New York and Andrew I. Donelson of Tenuessee.

States participating: $3 \mathrm{I}$.

Popular Majorities and Pluralities.

For Buchanan. in Alabama. Arkansas. Califorma. Delaware. Florida Georsia. Illinois. Indiana. Kenmoky Louisiana. Mississippi. Missouri. New Ierser. Norh Carolina, Fennsylyania. Tennessee. Texas Virginia.

For Frémont in Connecticut. Iowa. Maine. Massachusetts. Michigan. New Hampshire. New lork, Ohio, Rhode Island, Vermont. Wisconsin.

For Eillmore, in Maryland. 
Total Popular Vote.

For Buchanan, I, 838,169 ; for Frémont, I,341,264; for Fillmore, 574.534 .

Electoral Vote.

For Buchanan and Breckenridge, I74; for Frémont and Dayton, IIt; for Fillmore and Donelson, $S$.

\section{Nineteenth Election, 1860: Lincoln and Hamlin.}

Parties and Candidates.

Republican: Abraham Lincoln, of Illinois, and Hannibal Hamlin, of Maine.

Democratic (northern wing): Stephen A. Douglas, of Illinois, and Herschel V. Johnson, of Georgia.

Democratic (southern wing): John C. Breckenridge, of Kentucky, and Joseph Lane, of Oregon.

Constitutional Union Party: John Bell, of Tennessee, and Edward Everett, of Massachusetts.

States participating : 33 .

Popular Majorities and Pluralities.

For Lincoln, in California. Connecticut, Illinois, Indiana, Iowa, Maine, Massachusetts, Michigan, Minnesota. New Hampshire, New York, Ohio, Oregon, Pennsylvania, Rhode Island, Vermont. Wisconsin.

For Breckinridge, in Alabama, Arkansas, Delaware, Florida, Georgia, Louisiana, Maryland, Mississippi, North Carolina, Texas.

For Bell, in Kentucky, Tennessee, Virginia.

For Douglas, in Missouri and New Jersey.

Total Popular Vote.

For Lincoln, I.\$66.452; for Douglas, 1,376,957 ; for Breckenridge, $s_{49.7} S_{1}$; for Bell, $58 S \$_{79}$.

Electoral Vote.

For Lincoln and Hamlin, ISo; for Breckenridge and Lane, 72; for Bell and Everett, 39 ; for Douglas and Johnson, I 2. 


\section{PRESIDENTIAL ELECTIONS.}

Twentieth Election, 1864: Lincoln and Johnson.

\section{Parties and Candidates.}

Republican: Abraham Lincoln, of Illinois, and Andrew Johnson, of Tennessee.

Democratic: George B. McClellan, of New Jersey, and George H. Pendleton, of Ohio.

States participating: 25.

Popular Majorities.

For Lincoln, in all States except Delaware, Kentucky, and New Jersey, which gave majorities for McClellan.

\section{Total Popular Vote.}

For Lincoln, 2,330,552; for McClellan, I,835,985; soldiers' vote for Lincoln, I16,887; for McClellan, 33.748.

\section{Electoral Vote.}

For Lincoln and Johnson, 2I2; for McClellan and Pendleton, 21 .

Twenty-first Election, 1868: Grant and Colfax.

\section{Parties and Candidates.}

Republican: Ulysses S. Grant, of Illinois, and Schuyler Colfax, of Indiana.

Democratic: Horatio Seymour, of New York, and Francis P. Blair, Jr., of Missouri.

States participating: $33^{1}$

Mode of choosing Electors.

By legislature in Florida; by popular vote on general tickets in other States, including South Carolina.

Popular Majorities :

For Grant, in all States except Delaware, Georgia, Kentucky, Louisiana, Maryland, New Jersey, New York, and Oregon, which gave majorities for Seymour.

\section{Total Popular Vote.}

For Grant, 3,012,833; for Seymour, 2,703,249.

1 Virginia, Mississippi, and Texas had not yet been readmitted to representation in Congress, and did not take part in the election. 


\section{APPENDIX C.}

\section{Electoral Vote.}

For Cirnt and Colfax. 21+: for Sermour and Blair. B.

Twents-second Election, 1872: Grant and Wilson.

Parties and Candivates.

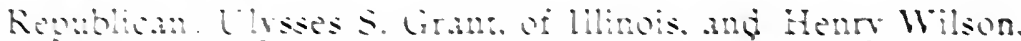
of Massichusuts.

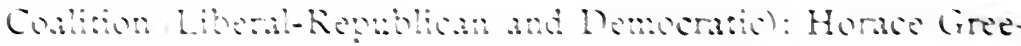

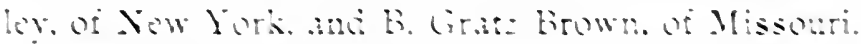

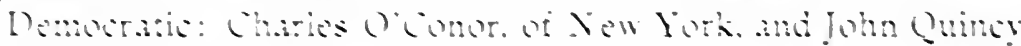
thoms. of Mtassobusents.

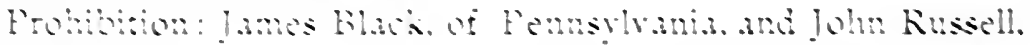
of 1 thethom

Siates participating: :-

Popular Majericies.

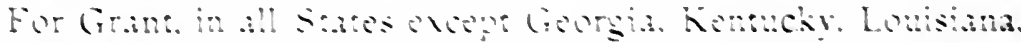

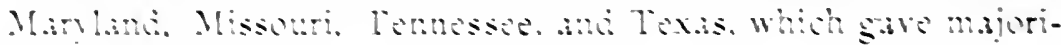
ides fut Gereler.

Total Populat Vose.

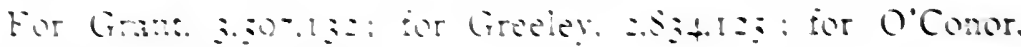

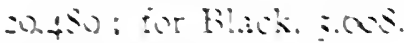

Electural Vote.

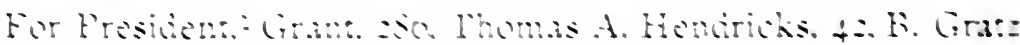

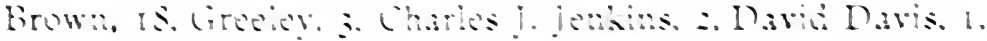

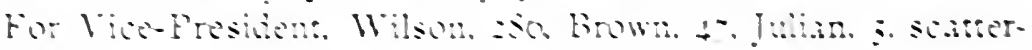
ins. 14 .

Twenty-Third Election. 1976: Hages and Wheeler.

Parties and Canivinies.

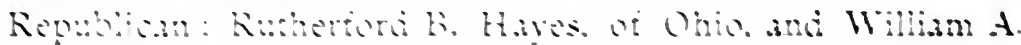
Whepler, of low los

I) Honticks of latima.

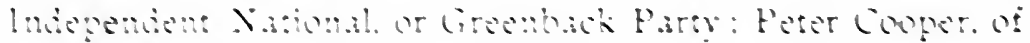
Now Vork and Samul b. Carr of ohio.

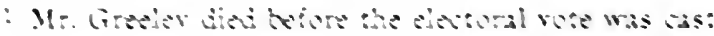


Prohibition: Green Clay Smith, of Kentucky, and (;. T. Stewart, of Ohio.

States participating : 38 .

Popular Majorities.

For Hayes, in California, Illinois, Iowa, Kansas, Maine, Massachusetts, Michigan, Minnesota, Nebraska, Nevala, New IJampshire, Ohio, Oregon, I'ennsylvania, Rhode Istand, Vermont, Wisconsin.

For Tilden, in Alabama, Arkansas, (onnecticut, J)laware, Georgia, Indiana, Kentucky, Maryland, Mississippi, Missouri, New Jersey, New York, North Carolina, Tennessee, Texas, Virginia, and West Virginia.

In South Carolina, librida, and Lonisiana there were disputed returns, and in oregon one Repuldican elector chosen was declared ineligrible by the grovernor, who gave a certificate to the highest candidate on the I emocratic list.

\section{Total Popular Vote.}

For Hayes, according to Republican returns from the States in dispute, 4,036,208, according to Democratic returns, 4,033,76,8; for Tilden, according to I emocratic returns, 4,300,590; according to Republican returns, $4,285,9) 2$; for Cooper, 8I,737; for Smith, 9522.

\section{Electoral Vote.}

As determined by the Electoral Commission, see p. 575; for Hayes and Wheeler, 185 ; for Tilden and Hendricks, 184.

\section{Twenty-fourth Election, 1880 : Garfield and Arthur.}

\section{Parties and Candidates.}

Republican: James A. Garfield, of Ohio, and Chester A. Arthur, of New York.

Democratic: Winfield S. Hancock, of l'emnsylvania, and William H. English, of Indiana.

Independent National or Creenback Party: James 13. Weaver, of Iowa, and 13. J. Chambers, of 'Texas.

Prohilbition: Neal I)ow, of Maine, and A. M. Thompson, of Ohio. 


\section{APPENDIA C.}

Siaies participating : js

\section{Poguiar Majorities.}

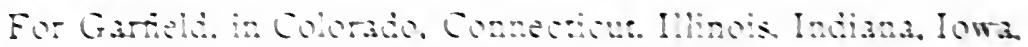

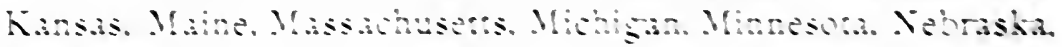

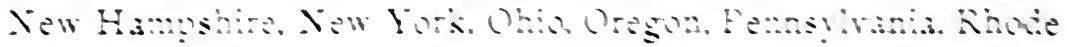

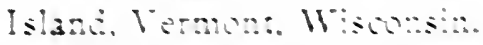

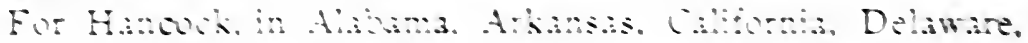

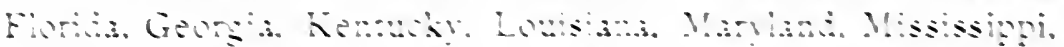

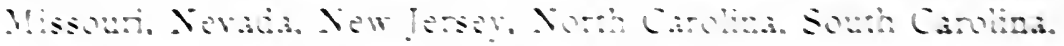

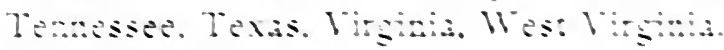

\section{To:al Populas Vote.}

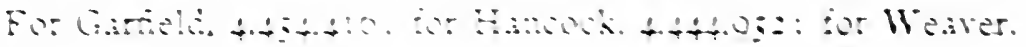
B.:-

Elestorai: Yote.

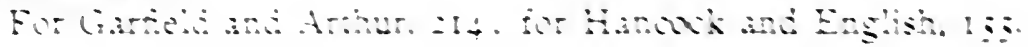

\section{Twentr-tift Election. 1SS4: Clerelsnd snt Heviricls.}

\section{Paries and Canjizines}

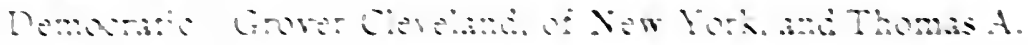

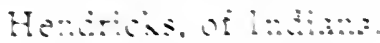

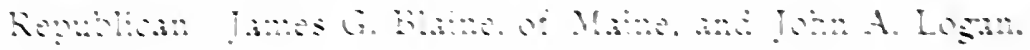
oflanos

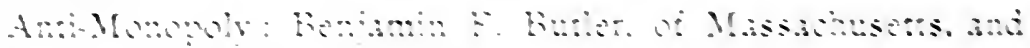

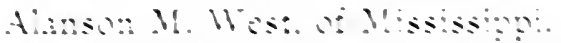

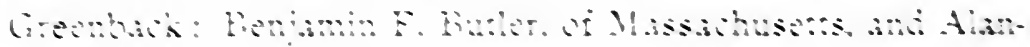

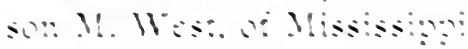

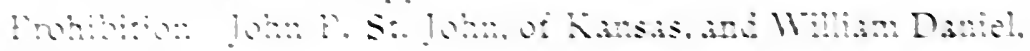
of Yartan:

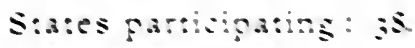

Pugular Majorites.

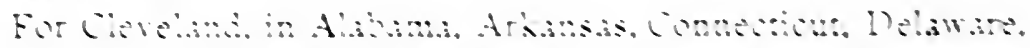

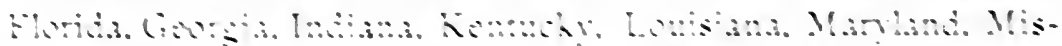

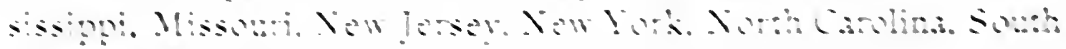

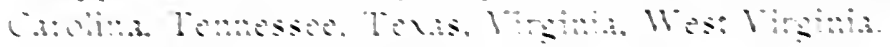

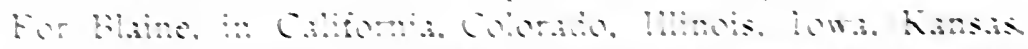

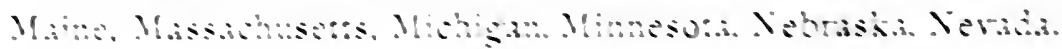


New Hampshire. Ohio. Oregon. Pennsylyania, Khode lsland.

Vermont. Wisconsin.

\section{Total Popular Vote.}

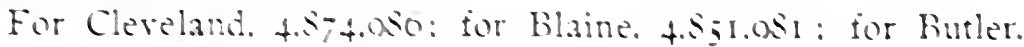
175.30 : St. Iohn $130.3(x)$.

\section{Electoral Vote.}

For Cleveland and Hendricks. zlo: for hlame and Logan. IS.

\section{Twentr-sixth Election, 1888: Harrison and Morton.}

Parties and Candidates.

Kepublican: Henjamin Harrison, of Indiana and Leri P. Moran. of Xew lork.

Demoratic: Grover Cleveland. of Xew lork and Allen G. Thuman. of (Ohis.

Datomal Probibiton Party: Clinon B. Fiske of Xew Ierser. and lohn A. krooks. of Missouri.

Union Lahor Farty: Alson I. Sireeter of Illinois. and Samuel Evans, of Texis.

Lnited Labor Pary: Kober H. Cowdrey of llbinois. and 11 . H. T. Makerield. of Kansas.

States participating : $3 S$.

Popular Majorities.

For Harrison. in California. Colorado. Illinois. Indiana. Iowa. Kansas. Maine. Massachusets. Michigan. Minnesota. Nebraska.

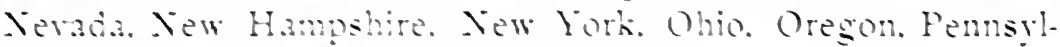
vania. Khoie Island. Vemont. Misconsin.

For Cleveland. in Alabma. Arkansas. Connecticut. Delaware. Florida. Georgia. Kenandy. Lousiama. Maryland. Mississippi. Missout. New Tersey. Xorth Carolina. Souh Carolina. Tennessee. Texas. Minginia. Mest Virginia.

\section{Total Popular Vo:e.}

For Hartison. : 4 : $2 .: 3$ : for Cleveland. : $: 40.320$ : for Fishe.

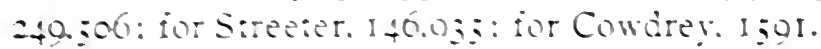

\section{Electoral Vo:e.}

For Hartison and Morton. 233: for Cleveland and Thurman. ICN. 


\section{Trentr-serenth Election, 1892 : Clerelsud and Sterenson.}

\section{Paziles and Canjiajes}

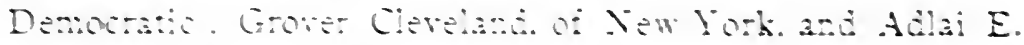

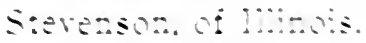

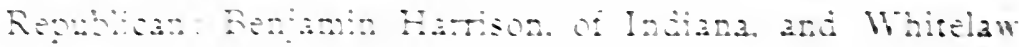

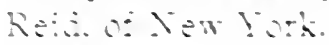

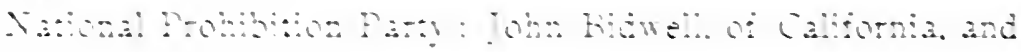

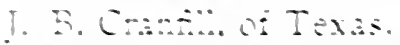

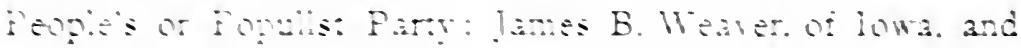

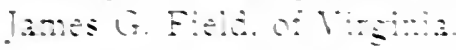

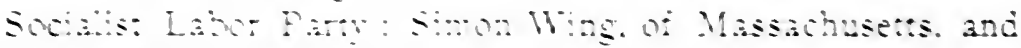
Chates H. Mather. ot lew yoth

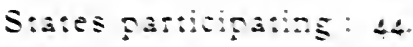

Pogula Magorites and Piuraties

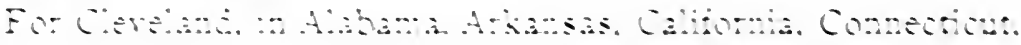

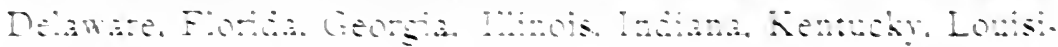

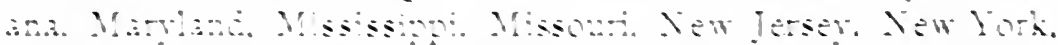

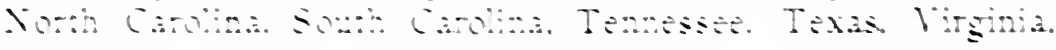
Wes: 1

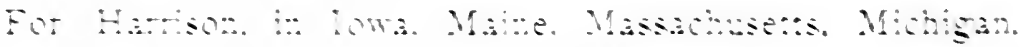

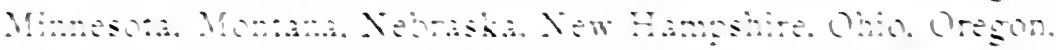

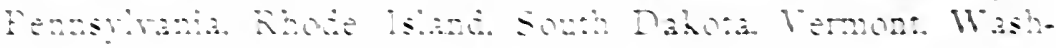
ingon. Wroming

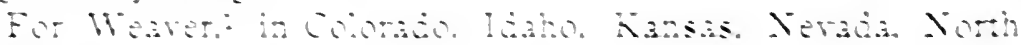
I) $\sin$ in.

To:a: Poguia: Vo:e.

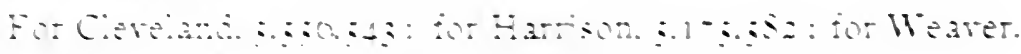

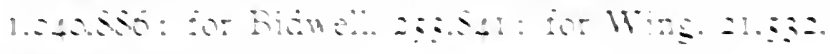

Elestorait Ve:e

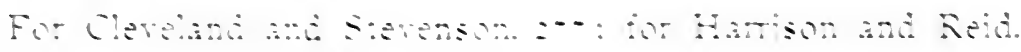

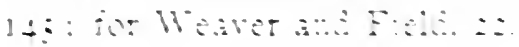

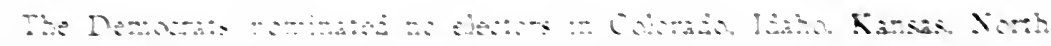

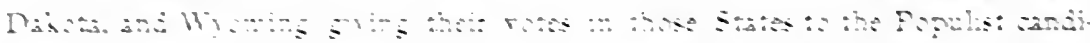

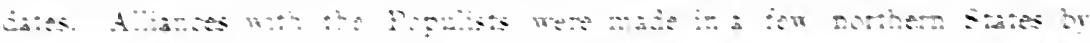

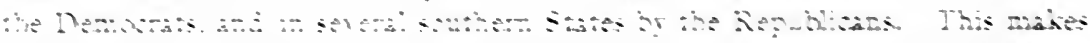

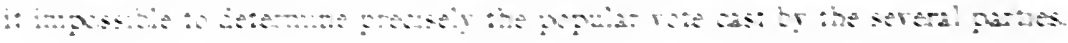




\section{Twenty-eighth Election, 1896: McKinley and Hobart.}

\section{Parties and Candidates.}

Republican: William McKinley, of Ohio, and (iarret A. Hobart, of New Jersey.

Democratic: William J. Bryan, of Nebraska, and Arthur Sewall, of Maine.

People's or Populist Party: William J. Bryan, of Nebraska. and Thomas E. Watson. of Cieorgia.

National Silver Party: William J. Bryan, of Nebraska, and Arthur Sewall, of Maine.

National Democratic: John M. I'almer, of Illinois, and Simon B. Buckner, of Kentucky.

Socialist Labor Party: Charles H. Matchett, of New York, and Matthew Maguire, of New Jersey.

Prohibition Party: Joshua Levering, of Maryland, and Hale Johnson, of Illinois.

National l'arty (a secession from the P'rohibition): Charles li. Bentley, of Nebraska, and James H. Southgate, of North Carolina.

States participating: 45.

Popular Majorities and Pluralities.

For McKinley, in California, Connecticut, Delaware, Illinois, Indiana, Iowa, Kentucky, Maine, Maryland, Massachusetts, Michigan, Minnesota, New Hampshire. New Jersey, New York, North Dikota, Ohio, Oregon, Pennsylvania, Rhode Island, Vermont. West Virginia, Wisconsin.

For Bryan, in Alabama, Arkansas, Colorado, Florida, Georgia, Idaho, Kansas. Louisiana. Mississippi, Missouri, Montana, Nebraska. Nevada, North Carolina, South Carolina, South Dakota, Tennessee, Texas, Utah, Virginia, Washington, Wyoming.

\section{Total Popular Vote.}

For McKinley, 7,111,607; for Bryan, 6,509.052: for Palmer, 134,645 ; for Levering, 131,312 ; for Matchett, 36,373 ; for Bentley, 13,968 .

\section{Electoral Vote.}

For President, McKinley, 271 , Bryan, 176.

For Vice-President, Hobart, 27I, Sewall, I 49, Watson, 27. 


\section{Twentr-ninth Election, 1900: McKinley and Rooserelt.}

Parties and Candidates.

Kepublicar: Willam Mckinler of Ohio, and Theotore Rooseveri, of lew lork.

Democrat: Whlliam I. Bryan of Nebrasia and Acha E. Sievenson, of Illinois

People's or Ponulis: Fary (dived) : Midile-of-he-Road

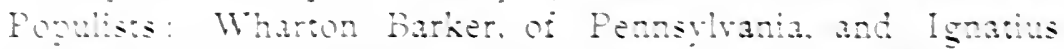
Donnely, of Minnesota: Fusion wing: Willam I. Bryan of Cérasta and Chares A. Towne of Minnesota.

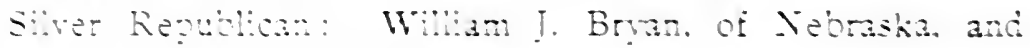

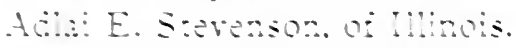

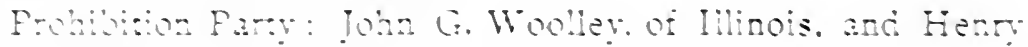

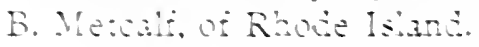

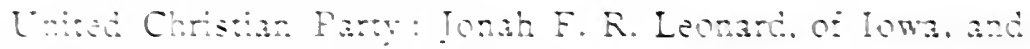

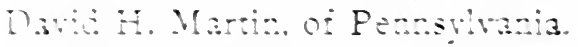

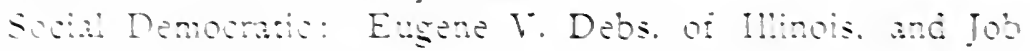

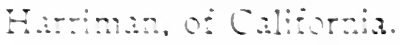

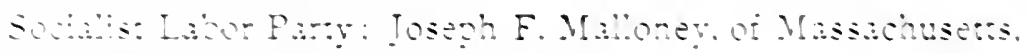

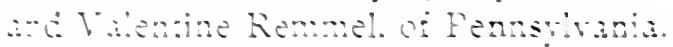

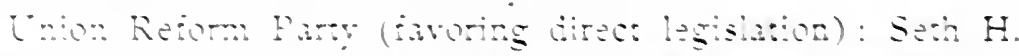

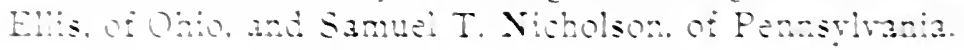

Siates paridizating 45

Popular Majorities and Pluralities.

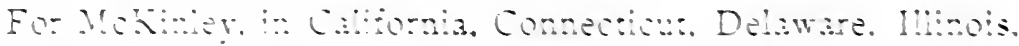

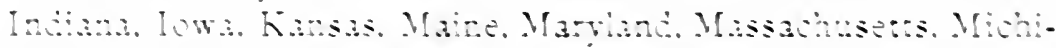

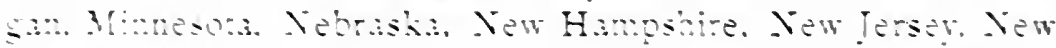

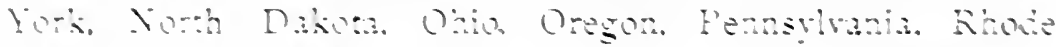

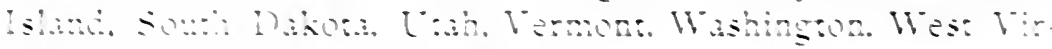

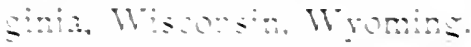

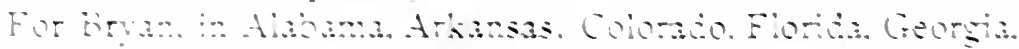

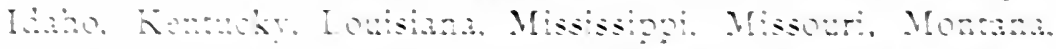

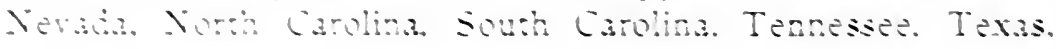
linginis.

Tosil Popular Vote.

For Whiniey -2060\%: for Bran. 6.7-30\% for Barker. 
IMPORTANT MEASURES OF THE GOVERNMENT.

50.373; for Woolley, 20\$,555; for Leonard, I060; for Debs, S4,003: for Malloney, 39.537: for Ellis, 5698 .

\section{Electoral Vote.}

For Mckinley and Roosevelt, 292: for Bryan and Stevenson. 155.

\section{APPENDIX D.}

\section{IMPORTANT MEASURES OF THE NATIONAL GOVERNMENT.}

\section{A CHRONOLOGICAL SUMMARY.}

\section{Administration of President Washington.}

1789. First tariff and tonnage acts. - Organization of the Federal Treasury, State, and War Departments. - Organization of a Federal judiciary system. - Confirmation of the Ordinance of $17 \delta_{7}$, relative to the Northwest Territory. - Proposal and adoption of the first ten Amendments to the Federal Constitution.

1790. Funding the foreign and domestic debt of the late Confederation. - Assumption and funding of the war debts of the States. - Acquisition and nationalization of the District of Columbia, for the location of a national capital. - Resolutions declaring the powerlessness of Congress to interfere with slavery in the States. - First Census Act. - First Patent Law. - First Copyright Law.

1791. Revision of the tariff. - Excise Law. - Act creating the first Bank of the United States. - Admission of Vermont and Kentucky to the Union.

1793. Proclamation of neutrality in the war between England and France. - Demand for the recall of "Citizen Genet," minister from France.

1794. Suppression of the "Whiskey Rebellion" in western Pennsylunia. - Negotiation and ratification of the Jay Treaty with England.

1795. Conclusion of treaty with Spain, freeing the navigation of the Mississippi.

1796. Admission of Tennessee to the Union. 


\section{Administration of President John Adams.}

I797. Pacificatory mission of three envoys extraordinary to France.

1798. War measures consequent on the "X. Y. Z. Correspondence." - Alien and Sedition Acts. - Organization of the Territory of Mississippi.

1800. New treaty with France, originating "French Spoliation claims." - Organization of the Territories of Ohio and Indiana.

I801. Appointment of John Marshall to be Chief Justice of the United States.

\section{Administration of President Jefferson.}

1801. Chastisement of the pirates of Tripoli. - Purchase of Louisiana from Napoleon I.

1802. Organization of the Territory of Orleans and the District of Louisiana.

1803. Expedition under Lewis and Clark sent to explore the Missouri, and beyond.

1805. Treaty with Tripoli. - Organization of the Territory of Michigan.

1806. Act prohibiting the importation of British goods.

1807. Enforcement of Non-Importation Act. - Passage of Enlbargo Act. - Act prohibiting the African slave trade.

1809. Enlargement of powers for enforcement of Embargo Act. - Repeal of Embargo Act. - Substitution of non-intercourse with Great Britain and France. - Organization of the Territory of Illinois.

\section{Administration of President Madison.}

1809. Suspension and renewal of Non-Intercourse Act, as it related to Great Britain.

1810. Provisional repeal of Non-Intercourse Act. - Commercial intercourse with Great Britain interdicted. - Occupation of West Florida. - Act authorizing the adoption of a state constitution in the Territory of Orleans.

18I. Dissolution of the United States Bank.

1812. Admission of the Territory of Orleans as a State, named Louisiana. - Annexation of West Florida in part to the new State 
and in part to the Territory of Mississippi. - Act ordering an embargo for ninety days. - Declaration of war with Great Britain.

1815. Treaty of Ghent, restoring peace with Great Britain. War, resulting in a treaty, with the Dey of Algiers.

1816. Charter of the second Bank of the United States. - Admission of Indiana to the Union. - Tariff Act, increasing protective duties. - Appropriation for "internal improvements."

\section{Administration of President Monroe.}

1817. War with the Seminole Indians of Florida. - Admission of Mississippi to the Union.

1818. Convention with Great Britain establishing part of northwestern boundary, with joint occupancy of Oregon. - Admission of Illinois to the Union.

r8rg. Purchase of West Florida from Spain, with a definition of Spanish boundary lines in the west. - Admission of Alabama to the Union.

1820. The Missouri Compromise Act. - Admission of Maine to the Union. - Act fixing a four years' term for many Federal offices.

1820. Admission of Missouri to the Union.

1823. Declaration by President Monroe of the principle of American policy known since as the "Monroe Doctrine."

i824. Tariff Act, increasing protective duties.

\section{Administration of President John Quincy Adams.}

1828. The "Tariff of Abominations."

\section{Administration of President Jackson.}

1830. Diplomatic arrangement with Great Britain, to reopen her West Indian trade to American shipping.

1832. Act to renew the charter of the United States Bank, vetoed by the President. - Tariff Act, more strictly protective than that. of $x$ 82S. - President Jackson's proclamation against the nullifying ordinance of South Carolina.

r833. "Force Bill." - "Compromise Tariff " Act. - Removal of government deposits from the United States Bank. - Censure of the President by Senate resolution.

1834. Creation of Indian Territory.

1835. Settlement of claims against France.

1836. Resolution of the House of Representatives directing all 


\section{APPENDIX D.}

petitions concerning slavery to be laid on the table, without action. - Act directing a distribution of surplus revenue among the States. - The President's "Specie Circular."

1837. Resolution to expunge the censure of President Jackson, passed in $1 \$_{33}$, from the journal of the Senate. - Recognition of the Republic of Texas.

\section{Administration of President Van Buren.}

1840. Act to establish the Independent Treasury System. Resolution of the House of Representatives refusing to receive petitions against slavery.

\section{Administration of President Tyler.}

1841. Repeal of the Independent Treasury Act. - Act to distribute proceeds of the sale of public lands among the States.

1842. Revision of the Compromise Tariff, annulling the Act to distribute land revenues. - Negotiation of the Ashburton Treaty.

1844. Texas annexation treaty rejected by the Senate.

1845. Annexation of Texas. - Admission of Florida and Iowa to the Lnion. - Rescinding of the rule of the House of Representatives against receiving anti-slavery petitions.

\section{Administration of President Polk.}

1846. Oregon Boundary Treaty with Great Britain. - Declaration of war with Mexico. - Walker Tariff Act. - Act to reëstablish the Independent Treasury.

1848. Treaty of Guadalupe Hidalgo with Mexico. - Territorial organization of Oregon with slavery excluded.

\section{Administration of President Fillmore.}

1850. The five measures of Compromise, admitting California to the Lnion, establishing territorial governments in New Mexico and Utah, purchasing the Texas claim on New Mexico, prohibiting the slave trade in the District of Columbia, and enacting a new Fugitive Slave Law. - Negotiation of the Clayton-Bulwer Treaty with Great Britain.

\section{Administration of President Pierce.}

1854. Kansas-Nebraska Act, organizing the Territories of Kan- 
sas and Nebraska, and repealing the Missouri Compromise. Treaty of Reciprocity with Canada.

\section{Administration of President Buchanan.}

1857. The Dred Scott decision by the Supreme Court.

r858. Act submitting the Lecompton Constitution to a vote of the people of Kansas. - Admission of Minnesota to the Union.

1859. Admission of Oregon to the Union.

186r. Admission of Kansas to the Union. - Morrill Tariff Act. - Territorial organization of Colorado, Nevada, and Dakota.

\section{Administration of President Lincoln.}

x86x. Call (April I 5) for 75,000 militia to suppress combinations against the laws. - Call (May 3 ) for 42,000 volunteers and 18,000 seamen. - Proclamation (April 19) of a blockade of southern ports. - Executive approval of the dictum that slaves are "contraband of war." - Congressional ratification of war measures of the President. - Authority given to raise 500,000 volunteers and make a loan of $\$ 250,000,000$. - Act to increase tariff rates and impose an income tax. - Act to confiscate property used for insurrectionary purposes, including slaves.

1862. First Legal 'Tender Act, authorizing an issue of $\$ 100,000$,ooo of legal tender treasury notes. - Revision of the tariff, increasing rates of duty. - Internal Revenue Act. - Resolution of Congress proffering aid to undertakings of compensated emancipation in slave States. - Act forbidding military officers to surrender fugitive slaves. - Compensated abolition of slavery in the District of Columbia. - Act to confiscate the property (including slaves) of all persons in arms against the government. -- Executive consent to the organizing and arming of refugee negroes for military service. - President Lincoln's first (warning) Proclamation of Emancipation. - Admission of West Virginia to the Union.

1863. The President's final Proclamation of Emancipation.Conscription Act. - National Banking Act. - President Lincoln's Proclamation of Amnesty and Reconstruction.

1864. Reconstruction of state governments in Louisiana and Arkansas. - Abolition of slavery by state action in Maryland.

1865. Adoption by Congress of the Thirteenth Amendment to the Constitution. - Act to establish the Freedmen's Bureau. Abolition of slavery by state action in Missouri, Tennessee, Ar- 


\section{APPENDIX D}

hansas, and Louisiana. - Executive order to stop drafting. recruiting. and the purchase of miliary supplies.

\section{Administration of President Johnson.}

Is65. President Johnson's Frodamation of Amnesty - Reconstruction of state governments in V"irginia. North Carolina, South Carolina. Ceorgia. Florida. Alabama and Mississippi. - Proclamainn of the ratication of the Thirtenth Amendment to the Constitution by three fourths of the States.

Is66. Civil Kights Aci - Joint resolution proposing the Fourienth Amendment io the Constantion. - Tennessee readmitied to regresentation in congress.

Isó-. Tenure of Orice Act - Act to establish universal man. hood sufrage in the District of Columbia and the Territories Admission of Vebrakta o the Unon - Military Keconsiruction Act - Suphlemenary Reconstruction Act - Diplomatic expostu lations cussing the whthawal of the French from Mexico - Pur. chase of Alaska from Kussia.

Is6S. Impeathent and wial of the President - North Carolina. south Carolina. Georsia. Florida. Alabama. Lousiana. and Arkansas, reconstructed under the Military Keconstruction Act. admitted o represemation in Congress. - Katincation of the Fourteenth Amendment prodaimed.

ss6g. Toint resolution proposing the Fifieenth Amendment to the Constitution.

\section{Administration of President Grant.}

IS6g. Treaty for the amexation of San Domingo rejected by the Sente.

Is;o. Ratitiation of the Fitteenth Amendment proclamed.Force Bill passed.

rs;o. Second Force Bill passed. - Treaty of Washington. First Civil Service Reform enactment.

Is 2 . Amuesty dci. restoring iranchises to large dasses in lately rebellious states - Settement of Alabama Chams by arbitration at lienera.

Is/3. Coingse At:

Is;5. Act to provide for a resumption of specie payments lanu3r. 1. ミ゚ー0.

sij. Act to create an Electoral Commission. 
IMPORTANT MEASURES OF THE GOVERNMENT.

Administration of President Hayes.

1877. Executive withdrawal of Federal forces from the south.

1878. Bland Silver Act.

1879. Resumption of specie payments.

Administration of President Arthur.

r883. Pendleton Civil Service Act. - Notice to annul the tishery articles of the Treaty of Washington.

First Administration of President Cleveland.

1886. Act to prevent a vacancy in the presidential office.

1887. Act to regulate the counting of electoral rotes. - Act to create an Inter-State Commerce Commission. - Repeal of the Tenure of Otfice Act.

1888. Fisheries Treaty with Great Britain rejected by the Senate.

\section{Administration of President Benjamin Harrison.}

r889. Admission to the Union of Washington. Montana, North Dakota, and South Dakota. - Opening of Oklahoma to white settlers.

1890. The Mchinley Tariff Act. - The Sherman Silver Act.Admission to the Union of Idaho and Wyoming.

1892. Agreement with Great Britain for the arbitration of the Bering Sea dispute.

1893. Treaty of annexation with the revolutionary government of the Hawaiian Islands.

Second Administration of President Cleveland.

1893. Hawaiian annexation treaty withdrawn from the Senate by the President. - Act stopping the purchase of silver by the government under the Sherman Act.

1894. The Wilson Tariff Act and Income Tax Act.

1895. Supreme Court decision against the constitutionality of the income tax.

1897. Arbitration Treaty with Great Britain rejected by the Senate. 


\section{Administration of President McKinley.}

IS97. The Dingley Tarifi Act.

Isgs. Declaration of War with Spain. - Treaty of peace with Spain, acquiring Porto Kico. Guam. and the Philippine Islands. and releasing Cuba from Spanish rule.

Igoo. Act establishing the standard "dollar," denned in gold. Establishment of a Civil Commission in the Philippine Islands. with legislative powers. to cooperate with the miliary authority. Erection of civil government in Porto Kico. - Diplomatic negutiation of the pledge of the "open door " to trade in China.

1900. Erection of civil gorernment in the Philippine Islands. Coopperation with other Powers in the suppression of the "Boxer" outbreak in China.

\section{Administration of President Roosevelt.}

Igoo. Negotiation and ratification of the Hay-Pauncefote Treaty with Great Britain, relative to an inieroceanic canal.

Igo2. Withdrawal of military forces from Cuba and recognition of Cuban independence. - Isthmian Camal Act.

I903. Isthmian Canal convention with Colombia, rejected by the Colombian Senate. 
INDEX. 



\section{INIDEX.}

Abercrombie, Gen. James, ${ }_{4} S$.

Abolitionism. See Slavery.

Acadia, Mos $l^{\circ}$. El:; graut to Sieur de Monts, 25 : ceded by France to England. and named Nova Scotia, i26: dispersion of Acadian French, $146-147$.

"Acts of Trade," English, 111-113: 125.

Adams, John, on James Utis, $\mathbf{6} 1$; leadership in Boston, 173: in the First Contimental Congress, 176 ; his political writings, rgo: in Second Continental Congress, r9s: in peace negotiation, 234: Vice-President of the Lnited States, 266 25r: President, 201-206: defeat by Jefferson, 296: death, $3 s_{3}$.

Adams, John Quincy, minister to Russia and commissioner to Ghent, 351 : Secre. tary of State and author of "Monroe Doctrine," 377: elected President, 3703 So: combination against his administration, $3 \mathbb{S}_{1-3} \mathbb{S}_{2}$; defeated by Jackson, $3 \$ 5-3 \$ 6$; high-minded treatment of officials who opposed him. 305: defence in Congress of the right of petition, fontho: attempt to censure, +24 : victory for the right of petition, 435 .

Adams, Samuel, his popular leadership in Massachusetts, I6S-I09: threatened with arrest and trial in England for treason, 169, 175. 194: demands the removal of the British regiments from Boston, izi: institutes committees of correspondence. 173: in the First Continental Congress, $176:$ his political writings, 190 : in second Continental Congress, igs; opposition to a strong federal government, 255: opposition to the Federal Constitution, 263

Agricultural development, 612-613.

Aguinaldo, 505,509 .

Aix-la-Chapelle, treaty of, 139.

Alabama, admission to the Union, 371 : secession declared, foo: enancipation proclaimed, $52 \mathrm{~S}$; restored to the Lnion, $564-565$.

Alabama, the Confederate cruiser, 529, $5+2$.

Alabama claims, $520,560-570$.

Alamance, the, battle, 171 : Morp $7 \%$. Cc.

Alamo, the, 4iा: Mas. II. Inc.

Alaska, 567,506 ; Mas $\mathrm{KI}$.

Albany, Map $1 \%$. Dc: Dutch Fort Orange built, ${ }_{4} 8$ : renamed by the Finglish, 87 : Colonial Congress, 1754, 143-144; npening of the Hudson River Railway, 610.
Albany Rerency, the, 304.

Albenirle, the ram, destruction by Lientenant (ushing. $55 \%$.

Albemarle Sound, thap $T^{\circ} I I$. Dc.

Alexander VI., Pope, bulls of, 5.

dlexandria. Va., tos: .Map . TIT. De.

Algerine wars (with map), 310-311, 31s, 353 .

Algonquian tribes, 20, 26: Mas $I I$. Fb, and 1). 26 .

Alien and sedition acts, 293-294.

Allen, Ethan, 10: 270 .

Altamaha River, Map $1 \%$ / . Bf.

Ambrister, Jackison's executinn of, 360 .

America, Miaf $1 /$. discovery by Northmen, 1: by Columbus, $3-6$ : name given to aborigines, 5: papal grants to Spain and Portugal, 5; Cabot s royge and English claim founded on it, $7-S$; named in honor of Americus Vespucius, 8 : early Spanish explorations and conquests, 9-i ; early French explontions, 10: effect of discovery on Europe, 12: state of native inhabitants when first kuown, 16-19: linguistic classification of aboriginal tribes, 22; phrsical features, 22-24.

Anerican ("Kunw Nothing") party, 46z$46_{3}, 464,4^{6} 5$.

"American system," Clay"s, 375-376, 401.

Amberst, Gen. Ieffrey, ifo.

Ammesty, President Lincoln's proclamation, 536-539; President Johnson's proclamation, 561: ammesty of 1S68, 550: general amnesty act, 1572,568 .

Anarchists, Chicagn, $5 \$ 7$.

Anderson, Major Robert, delence of Fort sumter, $457,4 \$ 8,490-401$; raising the restored flag ( 1565$), 548$.

André, Major John, 220-230.

Andros, sir Edmund, governor of $\mathrm{New}$ York, of-o6: captain-general and govermor of New England, ror-102; his rule extended, 102: expulsion from Massachusetts, mo.

Ammapolis, Md.. 237-23S, 256-257; Mfap -VII. Ed, and p. 493 .

Annapolis, N. S., 25: 14as T: Dc.

Anne, (lueen, 124.

Antietam, battle of, $525 ;$ Mas . YTI. Cc.

Anti-Federalist party, its formation and aims, - Jefferson's leadership, $2 S_{t}-2 \leqslant 4$.

Anti-imperialists, $60 t$

Anti-Masonic party, $3 S_{5}-3 \$ 6,400,402,414$

Antinonian controversy, $44^{-45}$. 


\section{INDEX.}

Anti-rent disturbances, $+30-+31$.

Anti-slavery movements: See slavery.

tpaches, war with the, 570: $11,2 \% .1 \%$ Eb.

Appalachian Mountain system, 22-24, '34. 135-136: 14.2p I.

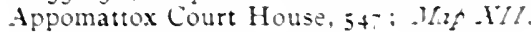
th.

Aquidneck, the first name of $K$ hode Island.

Arbitration, of Alabama claims. $5(x)-5 ; 0$; of Bering Sea controversy, $54_{4} 5 \mathrm{~s}$ : of Venezueh question, =3-57t; rejection of arbitration ireaty Mith Creat hritain. 504: arbitration of labor disputes, ors(c) 10.

Arbuthnot. Jackson's execution of. 300 .

Aristocratic tendencies. in coloni.l Virginia and Maryland, -3-7t: in New

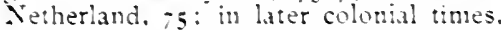
ISS-IẼ; in the Federalist party. ZN:.

"Aristocrats," the New lork faction of. 121 .

Arizona, acquistion by the United States. +42 .

Arkansas, admitted to the Lnion, Appendix B: secession declared, fos: emancipation proclaimed, szs: slutery abolished by state action, $5+5$ (foot-note) : restored :o the Union, $564-505$

Arkansas Rirer, 360 : MaA . H D D .

Arlington, Earl of go

Armies, Lnion and Confederate, statistics. $550-552$

Ainistrong, Gen. John, $2: 6-237,3+9$.

Armstrong. Gen. Samuel C., $0 \geq 1$.

Army of the Cumberland. 530 .

Army of the Potomac. formed under ML Dowell, - first battle of Bull Kun, - Mc Clellan called to command. 500-501: strength and condition in October, ISor, -inaction through fall and winter, so;504. 507: advance to Manassas, 50s: peninsular campaign, 511-5:2, 513-5is: recall to the Potomac, stt: cobperation with Pope, and campain asains! Lee in Maryland, $: 2-5: s ;$ reverse under Burnside. 30 , and again under Hooker. : is: Gettysburg campargn, \$3:-533: in Virgina again, 535: movement on Kichmond under Grant. 530.540: befure Petersburg. $5+1$; in pursuit of I.ee, - and of war. 5 fe$5+7$ : grand review at Washington, 55 .

Army of the Tennessee, $530,5+1$.

Arnold, Benedict, at the capture of Ticonderoga, ros: defence of I atie Champlain. zog: in campaign against burgoyne, 215 : .ttempted treason, 220-230.

Arthur, Chester A. S s.

Articles of Confederition, $2+\$-2 \$ 0,250-252$.

Ashburton treaty, $4: t$.

Asia, early trade of Europe with, 2-3.

Assassinations: of President Lincoln, 54s-

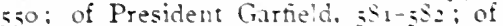
President McKinley, (ool-ixzz

Assemblies, colonial, established in Marrland, 3t; in Virginis, tiz: in Plymouth Colonit o5; in Massachusets Bay Colonv, io: in Commecticut, of-67: English orizin in all the colonies, to--o: in New Jersey, 87 ; in New lork, go: in Pennsvluania, 07-20: in Leorgia, 13t.

Assiento, the, r) 2 .

Assumption Bill, $24+275$

Assunpink Creek. Hâ, p. 2r 1 , Eg.

Assuria, 370; Dha .Y. da

Atherton gag." the. too.

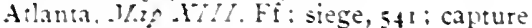
and destruction, $5+2-5+3$.

Bacon, Nathaniel, rebellion of, 90-92.

Babamas, 4. 504: . Was $I X$. Hd

Balboa. Vasco Nunez de, discovery of the Pacific Ocean br: 0 .

Bultmore. Burons of. See Calvert.

Baltimore, cits. Mat $\% /$. Db: British at. tack. Isit (with map), 340-350: secessionist attack on the oth Massachusetts Regiment, šor (with map), $492-493$.

Bancroft. Geored +35

Bank of the Lnited States. See United siates Rank.

Bunk questions, etc. See Monetary questions.

Bunks, Nathaniel P.. elected Speaker of the House of Representatives, $f_{4}$ : in military command. $=3: 530$.

Barbary Sures, medieval piracy of, 3 : wars with (with map). 310-31 3 Is, 353.

Bargain and corruption cry, is $24-25,3$ su:

"Barnburner" Democrats, 450-451.

Barré, Colonel Isaac, 104, 16:. 1 7 .

Bates, Elward. 400 .

Bawn Kouge, American seizure of Spanish

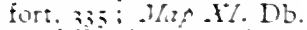

Ray of Fundy. Man l. Fb.

Beaturegard, Gen. Pierre G T., bombarcment and capture of Fort sumter, $+91:$ in command at first Bull Rur, sor: in battle of Shiloh, 506 : in the defence of Richmond. ifo.

Reecher, Henry Ward. its.

Bell. John, $4-5$

Bellingham, Richard, So.

Bellomont. Lord, 120 .

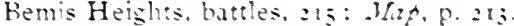

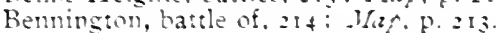

Benton, Thomas H. opinion of the Texas annexation treaiy, +3 .

Bering Sea controversy and arbitration.

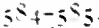

Rerkeley, Lord. :- 0 $5-00$.

Berkelev, Sir William, governor of Vir-

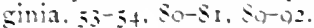

Berlin decree, the $: 21-92$. : 34

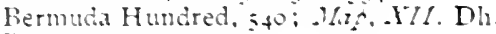

Ressemer process. 6it.

Beveriey, Kobert, io

Bienville. Celoron de, 1 to.

Rig Bethel, battle of. + s: : Mos. NII. Ei.

Billeting Act, the, 107 .

Firney. James G., $\$ 3+$.

Rlack, leremiah $5 ., 4$ -

Black Hawk War, st?

Bladensburs, battle. 3ts: . Mas, n. 34.

Elaine, James G., $5 \mathrm{Si}_{1}, 5 \mathrm{3}$. 
Blair, Francis P., 400 .

Blair, Francis P., Jr., 495-496.

Blair, Montgomery, 490, 527 .

Bland Silver Act, $576-577,589$.

Blennerhasset, Harman, $3 i s$.

Blockade of Confederate ports, 493, 504506, Mas, p. 505.

Blue Light Federalists, 350 .

Hlue Ridge, 532; Mlap . Fll. Be.

Board of Trade, British, 12S, $131,132,143^{-}$ $144,162,163$.

Bonaparte. See Napeleon Bonaparte.

Bon Honme Richard, the, 226-227.

Boone, Daniel, 223.

Booth, John Wilkes, 549-550.

"Border Ruffians," 463-464.

Boston, Map $l^{\circ}$. Bd; founded, 39-40; the mobbing of (iovernor Hutchinson, 165166: British regiments ordered to the city, 160: the "massacre" of citizens, 171 ; the "tea-party," I73-174; punishment by the Port Bill, 174-175; the British besieged in the city, 196; battle of Bunker Hill, 200-202; evacuation ly the British, 204-205: great fire, 572: founding of the first municipal free library, 628 .

Boston Public Latin School, 4 r.

Botetourt. Lord, 169-17o.

"Boxer" rising in (hina, 6on-6or.

liraddock's defeat, $144^{-146}$.

Bradford, William, governor of Plymouth colony, 64, I 55.

Bradford, William (early printer), 116, 137 . Bradstreet, Anne, ris.

Bragg, General Braxton, 52S-529, 53 ז, 535, $53^{6}, 539$.

Brandywine Creek, battle of, 216; Mas, p. 2 il $\mathrm{Ai}$.

Brant, Joseph, 222.

Breed's Hill, 200.

Brooke, 1,ord, 42 .

Brooklyn, battie of I ong Island. 208 ; Maf, 1). 209.

Brooks, Preston, 465

Brown, Gen. Jacob, 346,347 .

Brown, John, in Kansas, 454 ; attemnt at Harper's Ferry, 473-474.

Brunswick, the House of, 130 .

Bryan, William J., 594, 601.

Bryant. William Cullen, 365, 450, 622.

Buchanan, James, Secretary of State, 435 ; candidate for presidential nomination, 459 : signer of the "Ostend Manifesto," 460; elected President, 465-460: action sustaining the Lecompton fraud in Kansas, $468-470$; message to Congress on the Secession movement, $48_{4}-485$.

" Bucktails." 386.

Buell, Gen. Don Carlos, commanding l)epartment of the Ohio, 503 ; advarce to Nashville, - battle of Sliiloh, 506: defeat of Bragg, 52S-520; succeeded by Rosecrans, 530.

Buena Vista, battle of (with map), $440-441$

Buffalo, $\operatorname{lap} X$. Fa: burned by British and Indians, 346,347 ; first steamboat, 364 ; "Free Soil" convention, 1848 , 451; Fenian invasion of Canada, 566-
567 ; Grover Cleveland, mayor, $5 \$_{3}$; PanAmerican Exposition, - murder of President Mickinley, for-troz.

liull Kun, Map IT/. Ce; first battle, 501 : second battle, 527 .

liilwer, Sir Henry lytion, 457.

lituker Itill, battle of (with plan), 200202.

liurgesses, Virginia Jouse of, 63, 72 .

liurgogne, Cien. Jolun, his invasion and surrender (with map), 212-215.

burke, Edmund, opposition to British measures against the colonies, 169, 174, $178,100$.

Burnet, (iov. William, 135 .

Bumside, Gen. Ambrose F., in command of the Army of the Potomac, 530: succeeded by Giencral Hooker, 531; campaign in East Tennessee, 535, 536; rejoins the Army of the Potomac under Grant, 539.

Burr, Aaron, Vice-President, 206; intrigues, - ducl with Hamilton, 315316; conspiracy in the southwest, 316-318.

Butler, Benjamin F., in command at Fortress Mlonroe, - declares slaves contraband of war, 498-499; at New Orleans, 512; again at Fortress Monroe, movement up the James, 539, 540 .

Butler, John and Walter, 222.

Byrd, Ifilliam, rot.

Cabinet, the President's, 297.

Cabot, John, voyages to America, 7-8.

Caddoan tribes, $21 ; M a s I /$. Fc.

Calhoun, John C., entrance into Congress, 339; advocares protective tariff, and internal inprovements $(1 \& 16), 355$; clanged opinions, $3 s_{4}$; elected Vice-President, ins; chief agitator of the slavery question, $40 \mathrm{OS}-409$; Secretary of State under President Tyler, - negotiation of Texas annexation treaty, 432 ; new theory of slaveholding rights in the Territories, $445-446$; contempt for doctrine of "squatter sovereignty,' 461 .

California, acquisition by the United States, 439-440, 442; gold discovery, 443: mapped in 1840, Map $X$. : the question of exclud. ing slavery, - the " Wilmot proviso," $444-445$; fice-state constitution adopted, $45^{1}$; admitted to the Union, 454 ; development, $611-612$.

Calvert, Benedict, Lord Baltimore, proprietary goverument in Maryland restored to, 123.

Calvert, Cecilius, Baron of Baltimore, founder of Maryland, 33 ; troubles with Puritans, 54 .

Calvert, Charles, I,ord Baltimnre, deprived of the government of Maryland, 123.

Calvert, Leomard, 3.3-34.

Cambridge, Mass. (first named Newtown), Map, p. 195; migration from, to Connecticut, 4t-42, 66; Washington's headquarters, 202 .

Camden, battle, 228; Mlaf, p. 225 , Bf.

Camden, Earl, 166, 179 . 


\section{INDEX.}

Cameron, Simon, 490,526 .

Canada, aboriginal inhabitants, 20 ; French settlements, 25-28; state and character of early colonies, 116-117: French western exploration, Ir 7 -IS; strife of England and France, 123-126, $135-139,140-150$; cession to England, 150; English organization of government, 163; the Quebec Act, 175; address to the people by the Continental Congress, 177 ; in the war of American independence, 202-203, 209, 212-215: in the War of is $2,339-3+9$ : rebellion $(1837-1838)$, $18-419,431$ : reciprocity treaty with the United States, 460: Fenian invasion, 566-507: controversies with the $L_{\text {nited }}$ States, - joint high commission, 596 .

Canby, Gen. Edward R. S., 503.

Canning, George. 37\%.

Cape Breton Island, Wap I. Gb, and p. 13 S.

Cape Fear River, IKap $1 \% 11$. Cd.

Capitalists, combinations among, 6 I $7-6$ ig.

Caribbean Sea, 9 ; . Iap $I I$. He.

Carillon, Fort, $14^{6}$.

Carleton, Sir Guy, 209.

Carnegie, Andrew, 622.

Carolina colonies, founded as a palatinate (with map), $8_{4}-s_{5} ;$ Locke's constitution,

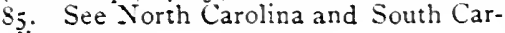
olina.

Caroline, burning of the, 4 IS + ro.

"Carpet-baggers," 565 .

Carrick's Ford, battle of, 500 ; .Map, p. 499 Ea.

Carteret, Sir George, 87, 95-96.

Cartier, Jacques, discovery of the St. Lawrence, ro: . Map $I I$. Hb.

Carver, John, 64

Casa II ata, battle of (with map), $4+4$.

Casco, I25; I I 2 p. Bd.

Cass, Lewis, $339,+51-+52,+53,+59,497$.

Catholic Church. See Roman Catholic.

Cavaliers, in the English civil war, +9: immigration to Virginia, 73 ; restored to power in England, So.

Cayugas, Map I. Bc. See Iroquois.

Cedar Creek, battle of, $5+2 ; .1 / 2 p .1 / 1$. Bd.

Census, the first, 276. See Population.

Centennial Exposition, 573.

Central America, discovery by Columbus, 6 .

Centreville, 5os: Map. III. De.

Cerro Gordo, battle of (with map), $4+\mathrm{r}$.

Cervera's tleet, destruction of, 598 .

Cessions of western territory by the States, 249-250;. Tap I"III.

Chaffee, Gen. Adna R.,6or.

Champlain, Samuel de, in New France, 2627 ; attack on the Iroquois, $26-27$.

Chancellorsville, batile of, 531 ; . Map $X I I$. Cf.

Channing, William Ellery, 366.

Chapultepec, battle of (with map), +4 .

Charles I., grant to Lord Baltimore, 33 ; oppressive rule in Enoland, 3s, 63; defeat in civil war and execution, 40-50.

Charles II., the colonies under, 80-roz; bad government in England, So-S1, 94, 100 : death, Ior.

Charles V., Enperor, I 2-13.

Charleston, S. C., .Map VII. Ce, and p. 225. Bh; founded, $8_{4}$ : treatment of tea-ships, $17+$; character and importance in late colonial times, 185: British refulse, 207208; surrender to the British, 225-226; nullifying movement (I832), 402-403; Democratic national convention (is6o), 475 ; Fort Sumter held by Major Anderson, $+97,{ }_{4} 98$ : Confederate siege and capture of Fort Sumter, $490-+91$; Union operations against the city (1563), 534-535; evacuated by the Confederates, $5+4$; restoration of the flag to Fort Sumter, $5+8$.

Charlestown, Mass., Hap $V$. Bd, and p. 195: first settlement, 39-40; battle of Bunker Hill (with map), 201.

"Charter Oak," 102.

Chase, Salmon P., Secretary of the Treasury under President Lincoln, 490 ; resignation, - appointed chief justice, 544.

Chatham, Earl of. See Pitt, William, the elder.

Chattanooga, 529, 531, 535.536, 610; .Hap XIII. Ee.

Chauncey, Commodore Isaac, $3+3$

Cherokee Indians, treatment by Georgia, ${ }_{3} s_{3}-3 s_{4}, 396 ;$. Tap X\%. Eb.

Cherry Valley, massacre, 222; Wap $I T .10 \mathrm{c}$

Cherubusco, battle of (with map), $44 \mathrm{~L}$.

Chesapeake, the frigate, attacked by the Leopard, 322-323; capture by the Shannon, $3+3-3+4$.

Chester, Pa.. Penn's first seat of government, 93, 99: Irap!I. Ce.

Chicago, Ihp $X^{-} I$. Ea ; great fire, 572; execution of anarchisis, $5 S_{7}$; Columbiau Exposition, 591 ; first connection by rail with the seaboard, 6 ro.

Chicheley, Col., 92.

Chickahominy River, military operations on the, 51 I-512.513-5It.540; Map $\dot{x} / 1$. Dh. Chichamauga, battle of, 535 : .Map $X I I I$. Ef. Chignecto Bay, Map I. Eb.

Chihuahua, I1, $+3 ;$. Iap $/ I$. Ed.

Chile, difficulty with, 605 .

China, pledge of the "open door " in trade, - the "Boxer" rising, 600-601.

Chowan River, .Map ITI. Dc.

Chrystler's Farm, battle of, 346; Map IX. Ec.

Church. Benjamin, $\mathbf{1} 9 \mathrm{I}$.

Cincinnati, founded, $265:$ Map $/ X . \mathrm{Cd}$.

Cincinnati, Order of the, 237.

Circular Letter of Massachuserts, 168-169.

Civic Federation, 618-6ig.

Civil Rights Act, $562-563$

Civil service reform, beginnings, 571-572; quickened by the murder of President Garfield, - formation of national league, - passage of Pendleton act, $5 \$_{2}$.

Clark, Gen. George Rogers, conquest of the northwest, $223-224,2+0$.

Class differences in colonial times, I\$SI 89 .

Clay, Henry, beginning of political career, 


\section{INDEX.}

- early leadership in Congress, - urgency for war with England, 33S-339; peace commissioner at Glient, $35 \mathrm{I}$; advocates protective tariff $(1816), 355$; brings about the Missouri Compromise, 374 ; champion of American system, 375-376; candidate for presidency (1824), 379-38o ; Secretary of State, $3 \mathrm{So}-3 \mathrm{~S}_{1}$; defeated in presidential election $\left(\mathbf{r}_{32}\right)$ on the U. S. Bank question, 400-402; leads Whig rupture with President Tyler, 42S-430; opposes the annexation of Texas, 432-433; nominated for the presidency $(1844)$, - defeated, $433^{-}$ 434 ; brings about the compromise of 1850,453 ; death, 459 .

Clayton-Bulwer treaty, 457, 602 .

Cleveland, city of, 610; Hap $X I$. Ea.

Cleveland, Grover, elected President, $5^{S_{3}}$; his administration, $58_{4}-58_{7}$; tariff message, i $\$ 87,586$; renominated, but not reelected, $587-5 S 3$; second election to the presidency, 590; action on Hawaiian treaty, 590-591; action on Wilson Tariff Act, 593; action on Venezuela question with Great Britain, 593-594.

Clinton, De Witt, candidate for presidency, 343 ; builder of the Erie Canal, 364 ; the "Clint onians," 386 .

Clinton, George, 316.

Clinton, Sir Henry, 205, 207-208, 220-221, $224-226,229,232$.

Cobb, Howell, 487 .

Coinage, the decimal system of, 254-255.

Coinage, silver. See Silver question.

Cold Harbor, battle of, 540 : N/ap XII. Dh.

Colden, Cadwalader, I66, 191.

Colombia, rejection of canal treaty, 603 .

Colonies, state of the : early, 62-76; at the end of the 17 th century, 108-118; at the beginning of the IV ar of Independence, 186-193.

Colorado, acquisition of western part from Mexico, 442; eastern part included in Nebraska Territory, 461 ; territoriai organization, 488 .

Columbia, District of. See District of Columbia.

Columbia River, 436; $\operatorname{Iap} X 1$. Aa.

Columbian exposition, $59 \mathrm{r}$.

Columbus, Christopher, merit and deserved fame, 1-2; four voyages to America, 36 ; death, 7 .

Comanches, $2 \mathrm{r} ; \operatorname{Map} I 1$. Dc.

Combinations of workmen and capitalists, 617-619.

Committee of Safety, Massachusetts, 179.

Committees of correspondence, 173 .

"Common Sense," Paine"s pamplilet, 204 .

Compromises, in the framing of the Constitution, 260-262; the Missouri Compromise (1820), 372-374; the Compromise Tariff (1833), 402-404; the compromise of $1850,452-454$; proposed Crittenden compromise (1860), 485 .

Concord, fight at (with map), 194-195.

Confederate States of America, organization of government, 489 ; war measures, - privateers and cruisers, 493-494; population and resources, - disadvantages and advantages in the Civil War, 496-497; effects of blockade, 504; map of blockaded coast, 505 ; constitution, $489,516$.

Confederation, Articles of, 248-249, 250252.

Confederation of New England colonies, 46.

Confiscation acts, 500, 525.

Cougress, Contineutal. See Continental Congress.

Congress, the frigate, 508-509.

Conkling, Roscoe, $5^{9}$.

Connecticut, founding of the colony (with map), 41-42; Pequot War, 42; New Haven settlement, 43; population in 1640,46 ; Dutch attempt to occupy, 48 ; "Fundamental Orders" of government, the first of written constitutions, 66-67 (foot-note), 69; "Fundamental Agreement " of New Haven, 67 ; local government, - town-meetings, 70-72; royal charter obtained, - New Haven absorbed, $8 \mathbf{z}-S_{3}$; disputed western boundary, 95; under Andros, - the hidden charter, 102; population, industries, and trade at end of 17 th century, 108-113; slavery and indentured servitude, 113114 ; education and literature, 114-116; state government formed, 207; cession of land claims to the Confederation, 249-250.

Conscription, in the south, 511; in the north, $531-534$.

Constitution, the English, its difference from written constitutions, 76 .

Constitution for the Carolinas, John Locke's, 85.

Constitution of the Confederate States, $489,516$.

Constitution of the United States, Articles of Confederation, 248-249, 250-252; the framing and adoption of the Constitution of $1787,256-264$; first ten amendments, 273 ; doctrine of "implied powers,"the "elastic clause," 277-278, 280 ; "strict construction" and "free construction," 278,2 So, 314, 354, 381-3S2; Jefferson's views, 309-310, 319-320; the Louisiana question, 313-314; early decisions by the Supreme Court, 296, 368; Dred Scott decision against the constitutionality of the Missouri Compromise, 466-467; Thirteentl Amendment, 545; Fourteenth Amendment, 563, 564 (footnote); Fifteenth Amendment, 565. See also Supreme Court. (Text in Appen. $\operatorname{dix}$ A.)

Constitution, the frigate, built, 293 ; battles with the Guerrière and the Java, $34^{2}$.

Constitutional Union party, 475.

Constitutions, the first written, $62-63$ (foot-note), 64, 66-67 (foot-note).

Continental army, formation, 198 ; dissolution, 236-237.

Continental Congress, the First, 175-179; 


\section{INDEX.}

the secund, called, 178 ; meeting and early action, 19\$-200: adjournment to Baltimore, 2 ro: lowered character, 2 i 7 : driven to Princeton, 237: in session at Annapolis, 238; weakness under the Articles of Confederation, $248-249,250-$ 252; adoption of the Ordinance of i $757,264-265:$ provision for elections under the new Federal Constitution, 265266 .

Continental currency, $218,228,253-254$.

Continental system, Napoleon's, 322, 333.

Contraband of war, slaves declared, $498-$ 429.

Contreras, battle of (with map), $44 \mathrm{r}$.

Comvention, Federal Constitutional, of $1787,256-262$.

Conway Cabal, $2 \mathrm{r} 7$.

Cooper, James Fenimore, 365, 622 .

Cooper, Peter, 574.

"Copperheads," 529-530.

Cordilleran mountain system, 22: Thap $I$.

Corinth. Miss., 506, 529; Map XI/I. Cf.

Cornstalk, chief, 172 .

Cornwallis, Charles, marquis, campaign against Washington in New Jersey, 2 ro212 ; in the Carolinas, $226,227-22 S, 231$; in Virginia. - surrender at Yorktown, $231-233$.

Coronado, Francisco de, expedition of, II.

Corporations, growth of, $617-618$.

Cortes, Hermando, conquest of Mexico by, 9 .

Cotion, Jolin, $\mathbf{1}_{5} 5$.

Cotton culture, Whitney's gin and its effect, 308-309: blockade in the Civil War, - cotton famine in Great Britain, 504505.

Cotton States, 309

Council for New England, 37, 40.

County, the, English origin, $; \mathrm{r}$; in colonial Virginia, 72.

Coureurs de bois, 27,117 .

Cowpeus, battle of the, $231 ; 1$ rap, p. 225, Ae.

Cox, General Jacob D., 545.

Crawford, William H., 379, 39o, 394-395.

Credit Mobilier, 57 ז.

Creek tribes, war, 346 : subsequent treat-

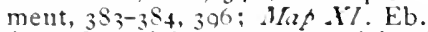

Crises, financial and commercial, of isio. 367-368; of $\mathrm{I}_{3} 37,4 \mathrm{II}-4 \mathrm{I}, 4 \mathrm{I} 5-4 \mathrm{I} S$; of 1857,$46 ;-465:$ of IS73, 57I; of IS93, $501-592$.

Critical period, the, 248 .

Crittenden Compromise, proposed, $45_{5}$ 486

Cromwell, Oliver, Lord Protector of England, 50; death, 54.

Crown colonies. See Royal provinces.

Crown Point. Wap $5 \%$. Db; in the wars with the French, $135,145,146,150$; in the War of Independence, 197-198.

Cuba, Map II. He: discovery by Colum. bus, 4; Anterican attempts to buy from Spain, - filibustering schemes, - Lopez expedition, 458; the "Ostend Manifesto." 460 ; revolt, I $\$ 95-9 \$,-$ subject of war between the United States and
Spain, 596; Spanish sovereignty relinquished, 599; independent republic established, 600 .

Culpeper, Lord Thomas, 90, 92.

Cumberland, $364 ;$ Map $X I$. Fb.

Cumberland Gap, 507 ; Map XIII. Fd.

Cumberland River, Map $\lambda^{\prime} / I /$. Cd.

Cumberland Ruad, 364 .

Cumberland, the frigate, 509.

Curtis, Gen., 507.

Curtis, George William, 582 .

Cushing, Iieut. William B., 557.

Custer, Gen. George A., 570 .

Cutler, Rev. Mamasseh, 264.

Dakota Territory, ${ }_{4}$ SE. See North Dakota and South Dakota.

Dakota tribes, 2 ; $M$ Lap II. Fb.

Dale, Commodore Richard, 3 I I

Davenport, John, $43, s_{3}$

Davis, Admiral Charles Henry, 513 .

Davis, Jefferson, new theory of slaveholding rights in the Territories, $445-446$; leader of southern extremists, 451 ; opposes the compromise of 1850,453 ; approves President Buchanan's message on the secession movement, $1 \$ 60,{ }_{4} S_{4}-4{ }_{5}$; elected President of the Confederate States, 4 So; commissioning privateers, 493-494; peace conference with, 544; abandonment of Richmond, $546-547$; capture, 547; amnesty, 550.

Deane, Silas, 2 r 2.

Dearborn, Gen. Henry, 345.

Debt, national, of the IVar of Independence, $273-274$; of the Civil War, $55 \mathrm{I}$.

Debtors, former treatment of, 133,254 .

Decatur, Stepljen, 342, 353.

Declaration of Independence, 206-207,

Declaration of Rights by the First Continental Congress, 177 : by Virginia, 206.

Deerfield, $125 ;$ Map $7^{\circ}$. Ad.

Delaware, granted by the Duke of York to William Penn. 98 : separation from Pennsylvania, roo; population, etc., at end of 17 th century, rog-1 i3; slavery. I $3_{3-1} 4$; state government formed, 207.

Delaware River, possession by the Dutch, $47-48$; Swedish settlements, 48 ; acquisition by the English, $s_{5}-S_{7}$; Washington's crossing (with map), $21 \mathrm{r}$.

Delawares, or Lenapes, 99.

Democracy, American, its full beginnings in Connecticut, 67 (foot-note): English origin of democratic institutions in the colonies, 60-70; democratic conditions in colonial New England, 74: class differences in late colonial times, ISS-ISO; democratic influences from the west, $3^{6} 3^{-}$ 364 .

Democratic party, formed from a wing of the Democratic-Republican party, in op. position to the administration of John Quincy Adams, $3 \$_{2-3} \$_{3}$; election of General Jackson. $3_{55-3} \$ 6$; election of Van Buren, $4 I_{4}$; defeat in 1540,4 r9-420; election of Polk, 433-434: division in New York, - "Barnburuers" and "Hunk. 


\section{INDEX.}

ers," - defeat in $1848,450-451$; election of Pierce, 458-459; weakened in the north by the Kansas-Nebraska act, 461 ; revolt led by Douglas against the Lecompton fraud in Kansas, $469-470$; split in national convention at Charleston (1860), - opposing nominations of Douglas and Breckenridge, 475 ; defeat, 476 ; support of the government at the beginning of the Civil War, 492, 500; later divisions, 529-530; in 1864,544 ; in 1868 , 568 ; in 1872,569 ; in $1876,574-575$; in 1880, 581; election of President Cleveland, 583 ; defeat in $1888,587-588$; second election of President Cleveland, 590 ; defeat in $1896,594-595$; defeat in r9oo, 6or.

Democratic-Republican party (called Republican). See Republican party, Democratic.

Deseret, the State of, $45 \mathrm{I}$.

Detroit, NIap p. 14 I Ec; Pontiac's siege, $15 x$; British use in War of Independence, 223-224; Hull's surrender, 340-341; recovery by Harrison, 345 .

Dewey, Admiral George, 597, 598 .

Diaz, Bartholomew, ?.

Dickinson, John, his " Famer's Letters," I68; in the First Continental Congress, 176 ; his writings, I9o; in Second Continental Congress, rg 8 ; in the Federal Constitutional Convention, 1787,258 .

Dieskau, Baron Ludwig A., 145, 146.

Dingley tariff, 595 .

Dinwiddie, Gov. Robert, r4o.

Discovery, scientific, 615 .

Disloyal secret societics, 553 .

District of Columbia, acquisition by the national government, 275 ; petitioning for emancipation in the District suppressed, 408-410; demand for abolition, 452 ; slave trade suppressed, 454 ; slavery abolished, $5 \mathrm{I}$; universal manhood suffrage, 564 .

Dix, John A., 450, $48_{7-4} 88$.

Dollar, the standard, established and defined in gold, 596 .

Dominican Republic, rejected treaty for annexation of the, 569 .

Donaldson, Fort, capture of, 506; Map $X I I I$. Dd.

Dongan, Sir Thomas, 96.

Doniphan, Col. Alexander W., 440.

Dorchester, Mass., Map, p. 39 and p. I95; nigration to Connecticut, 66 ; Washington's seizure of the heights, 204.

Dorr rebellion, 430 .

Douglas, Stephen A., advocates the compromise of $18_{50}, 453$; candidate for presidential nomination, 459; author of the Kansas-Nebraska bill, repealing the $\mathbf{M}$ issouri Compromise, $460-461$; doctrine of popular sovereignty, $46 \mathrm{r}$; revolt against the Lecompton fraud in Kansas, 469-470; debate with Abraham Jincoln, - reëlection to the Senate, 470-472; nomination for President by the northern wing of the Democratic party, 475 ; defeat, 476 ; loyal stand in 1861, - death, 492.
Dover, N. H., 45; Map $I^{\circ}$. Bc.

Draft. See Conscription.

Draft riot, New York, 533-534.

J)ed Scott decision, 466-467.

Duane, William J., 404-405.

Dudley, Thomas, 45 (foot-note).

Dulaney, Daniel, rgo.

Dunmore, Lord, 172, I97; 203-204

Dupont, Admiral Samuel F., 534.

Duquesne, Fort, 145, 148;Map VI. Ad.

Dutch settlements. See Holland, and New York.

Early, Gen. Jubal A., 541-542.

Eaton, John H., 394, 399.

Economic conditions, at end of 17 th century, ro9-114; at beginning of War of Independence, $186-188$; under the Articles of Confederation, 252-255; early in the 19th century, 306-308, 319 ; after the War of $\mathrm{I}_{12}, 364-3 \overline{6}_{5}, 67-368,609-6$ ro; preceding and following the "crisis" of $1837,411-414,415-418$; at the middle of the century, 456, 6ro; in $1846-57,467-$ 468 ; at the beginning of the Civil War, 496-497; during the war, 532 ; since the Civil War, 6ri-6ra.

Education, founding of public schools and Harvard College jn Massachusetts, 4i ; schools in the colonies at end of 17 th century, I14-116; provisions of the Ordinance of 1787 for northwest territory, 264 ; educational work among freedmen, 576,621 ; educational progress in the last half 'century, 619-622.

Edward, Fort, 146, 213; $M$ \% p, p. 145.

Edwards, Jonathan, Igo.

El Caney, battle of (with map), 597-598.

Elastic clause of the Constitution, $277-278$.

Elections, presidential, Appendix C.

Elective franchise, restricted to church members in colonial Massachusetts, $4 \mathbf{y}$, 65; qualifications in colonial Virginia, 63; restriction in New Haven colony, 67; unrestricted in Comnecticut colony, 67 (foot-note); religious limitation in colonial Pennsylvanja, 99; broadened democratically in new western States, 363 ; broadened in Rhode Island, 430; universal manhood suffrage in District of Columbia and the Territories, and in reconstructed States, $56_{4}$; practical suppression of the exercise of the franclise by blacks, $565-566,568,575-576$.

Electoral Commission, 575 .

Eilectoral votes, act to regulate the countjng of, $5^{8} 5-586$.

Electrical discovery and invention, 616 . See also Telegraph.

Elliott, Lieut. Jesse D., 343.

Ellsworth, Col. Ephraim E., 498.

Emancipation, compensated, offered to States, 510 ; enacted for District of Columbia, 511 .

Emancipation Proclamation, 525-527, 528.

Embargo Act (1 807 ), 323-326; (1812), 339340.

Emerson, Ralph Waldo, 365. 


\section{INDEX.}

Endicott, John, settlement at Salem, 39; governor of Massachusetts, 52 .

England, ground of claim for sovereignty over most of North America. 8; Protestant Reformation and rise of Puritans and Independents, 14 ; conflict with Spain and development of maritime power, $14-15$; first colonizing attempts in America, 15; founding of Virginia and Maryland colonies, 28-34; founding of New England colonies, $35-46$; struggle of the people with King Charles I., 3\$, 49-50; bestowal of representative government on the colonies, 69-72: restored monarchy under Charles II., So-8ı; bad government, So$81,94,100$ : conquest of New Netherland (New York), $8_{5}-87$; loss and recovery of New York, 94 ; death of Charles Il. and accession of James II., 10r; "glorious revolution" of 1688 , 102, ros; navigation acts and other "acts of trade," $\boldsymbol{I}_{1} \mathbf{I}_{1}-\mathbf{I}_{1} \mathbf{I}_{3}$; opening of struggle with France, 123-126; acquisition of Nova Scotia, Newfound land, and Hudson Bay, 126; colonial policy under William III.. Anne, and the first Georges, 126-135; final struggle with France in America, - the Seven Years' War, 139-150; acquisition of French possessions in North America east of the Mississippi, I 50; colonial policy of George III., 160-179; slavery in the colonies and the slave trade fostered by the government, I92-193; American War of Independence, 194-234; overtures for peace, - war with France and Spain, 2 r9: war with revolutionary France, - treatment of neutrals, - impressnent of American seamen, $23_{5}, 28_{7}-$ 2SS, $318,322-323$; Jay treaty, 2SS-29o; orders in council, 320-322; American embargo and non-intercourse with, 323-326, $332-335$; relations with the United States in 1S11, 337-339; second war with the United States, 339-353; convention of 1818 with the United States relative to boundaries, Oregon claims, and fisheries, 370; West India trade opened to American shipping, 415: Ashburton treaty, 431 ; settlement of the boundary dispute, $435-437$; proclamation of neutrality in the American Civil War, 493-494: attitude of different classes, - cotton famine, - the Trent affair, 504-505; cruisers furnished to Confederate States, 520: treaty. of Washington, - settlement of Alabama claims, 569-570; fishery and Bering Sea controversies $\left(1 S_{77}-92\right), 58_{4}-58_{5}$; Venezuela controversy, 503-504; joint high commission on ('anadian questions, 596.

Epochs of Progress and Change, 609-623.

"Era of Crood Feelings," 366.

Ericsson, John, 50 S.

Erie (Presque Isle), 1 40, 1 50; Map VI. Ac. Erie, Fort, $347-348 ;$ Ma $p, 34 \mathrm{I}$.

Erie Canal, historical importance, 24, 364365, 412,609.

Erie Railway, 571,6 ro.

Erskine, Mr., British minister, $332-333$.
Española (Hispaniola), 4 ; Mrap II. He.

Estaing, Charles Hector, Count d', 221 , $224-225$.

Europe, early trade with the East, 2-3, 7.

Eutaw Springs, battle, 231 ; Map, p. 225 $\mathrm{Bg}$.

Evangeline, source of Longfellow's tale of, I 46-147.

Evans, Oliver, 308 .

Everett, Edward, 475.

Excise taxes, 277, 288

Exeter, N. H., 45 ; Map $V$. Bc.

Expunging the Senate censure of President Jackson, 405.

Fair Oaks, battle of, 513;. Map XII. Dh. "Farmer's Letters," 168 .

Farragut, Admiral David G., capture of New Orleans, 512-513; operations on the Mississippi, 513, 533; against Mobile, $54^{2}$.

Federal Constitution. See Constitution of the United States.

"Federalist, The," 262-263.

Federalist party, its formation and aims, - Hamilton:s leadership, $28_{1-2} S_{4}$; election of John Adams, President, 29I; extreme party measures, - alien and sedition acts, 293-294; overthrow in $\mathrm{r} 800$, 295-296; inconsistency on the Louisiana question, 3r3-3r4: threatenings of secession in New England, - plotting with Burr, 3r4-3I 5 ; the party weakened, 316 ; John Henry intrigues, 324-325, 339; threatening opposition to admission of Louisiana, 336; English leanings, 338; opposition to the W War of $1812,-$ the Hartford Convention, 350-351; decay and dissolution, 353-354, 374 .

Federalists of $178_{7}-1788,262-263$.

Fenian invasion of Canada, 566.

Ferguson, Major, $227,231-232$.

Fifteenth Amendment, 565 .

Fifteenth century, geographical ideas in, 2.

"Fifty-four forty or fight," the cry, 436 .

Fillmore, Millard, elected Vice-President, 45I; becomes President and approves the compromise measures of 1850,453 ; American and Whig candidate for President, $465-466$.

Fisher. Fort, 544 ; Map. p. 545.

Fisheries, New England, early, 109: rights on British-American coast secured in $17 S_{3}, 234$; unsettled by War of $1 S_{12}$, and partially restored by convention of I 8 I8, 352, 370; privileges increased by Canadian reciprocity treaty (is54-66), 460 ; renewed by treaty of Washington, I 87 I, - Halifax award of compensation, $5 s_{4}$; annulled, $18 s_{5}$, - rejection of new treaty, - change in modes of fishing, 584 .

Fisher's Hill, battle of, 542 ; Map XII. Bd.

Fiske, John, on Captain John Smith, 30; on Thomas Hooker, 67 (foot-note).

Fitch, John, 308 .

Five Forks, battle of, 547 ; Map XII. Ci. 
Five Nations, 21. See Iroquois.

Flag, American, $2 \mathrm{I}_{4}$ (foot-note).

Florida, explored by Ponce de Leon, 9 ; by Fernando de Soto, I1; Huguenot colony, 16; cession by Spain to England, 150 ; English government organized, 163; West Florida claimed by the United States, 315; and occupied, $335-336$; first Seminole War, $368-369$; purchased from Spain, 369; admitted to the Union, 435; secession declared, 486; emancipation proclaimed, 528 ; restored to the Union, $564-565$; disputed electoral returns, $1876,574$.

Florida, the Confederate cruiser, 529.

Floyd, John, 402 .

Floyd, John B., 486.

Foote, Admiral Andrew H., 506, 507, 513.

"Force Bills" of 1833,403 ; of $1870-71$, 568.

Fort Orange. See Albany. Map, p. 47.

Fourteenth Amendment to the Constitution, 563,564 (foot-note).

Fox, Charles James, oplosition to British colonial policy, i 78 , 190.

Fox, George, 52 .

Frame of Government, Peun's, 98-99, 100.

France, early explorations and attempted settlements in America, 10 ; settlements in Canada and Acadia, 25-28; fur trade, and treatment of Indians, 27-28; state and character of early colonies, $116-117$; exploration of the interior, 117-118; beginning of strife with England for supremacy in America, 123-126; cession of Acadia, Newfoundland, and Hudson Bay to England, 126; "W ar of the Austrian Succession," 138-139: posts in the upper Mississippi valley and around the Great Lakes, Map, p. I4I ; final struggle with England in America and defeat, - the Seven Years' War, 140-150; cession of all American possessions to England and Spain, 150; assistance to the revolting British colonies, 212; alliance with the American States, and recognition of their independence, 219; military and naval aid to Americans, $221,224-225,228-229$, 232-233: French Revolution in American politics, $284-285$; claim of aid against England, - conduct of Citizen Genet, 285-286; hostility to the United States, - the X. Y. Z. affair, 20 $1-293$; peace treaty with the United States, 1800, 295206; recovery of Louisiana and sale of it to the United States, 312-313; settlement of United States claims (1835), 415; undertakings of Napoleon III. in Mexico, - attempts to intervene in American Civil War, 529; warned out of Mexico, 567 .

Franklin, Benjamin, arrival in Philadelphia, 137; plan of colonial union, 144; agent for colonies in England, 178; his political writings, r9o; his fame, r9o; in Second Continental Congress, $19^{8} ; \mathrm{com}-$ missioner to France, 212 ; in peace negotiation, 234; in the Federal Constitu- tional Convention, 1787,257 ; president of a society for promoting abolition of slavery, - death, 275-276.

Franklin, battle of, $543 ;$ Map XIII. De.

Frederick the Great, 147 .

Fredericksburg, battle of, 530 ; Map $X I I$. Cf.

Free Soil party, 450-451, 458, 459 .

Freedmen, President Lincoln on the question of suffrage, 548 ; labor laws of $1865-$ 66 in reconstructed States, 562; Civil Rights Act of Congress, and Fourteenth Amendment, 563, 564 (foot-note); suffrage to blacks and whites, 564 ; political rights annulled by intimidation or law, -educational work, 575-576, 621; race conflicts, 619 .

Freedmen's Bureau, 546.

Freedom of speech and the press, interferences with, in the colonies, 137; by the Sedition Act of 1798, 294; by the "slave power," 407-409; by military authority in the Civil War, 530.

Freedom, religious. See Iiberty.

Freeman's Farm, battles of, 215 .

Freeport, "Freeport doctrine:" 471-472; Map XIV. Ib.

Frémont, John C., explorations, 439; action in the seizure of California, 440: Republican candidate for President, ${ }^{6} 5^{-}$ 466; commanding Department of the West in the Civil War, - his Emancipation Proclamation, 502-503, 526; candidate for presidential nomination, 544 .

French and Indian War, 140-150.

French Creek, 140, 142; Map VI. Ad.

French in America. See France.

French spoliation claims, 296, 304 .

Friends. See Quakers.

Frontenac, Count Iouis De Buade de, $123-124$.

Frontenac, Fort, 148; Map $I \% \mathrm{Cb}$.

Fugitive Slave Law, $452,454^{-456 .}$

Fulton, Robert, 308, 364 .

Fundamental Agreement of New Haven Colony, 43, 67.

"Fundamental Orders" of Connecticut, 66-67 (foot-note).

Fur trade, 27-28, 48, 110-111.

Gadsden, Christopher, 176, 190, 198.

Gadsden Purchase, 442 ; Map XV. Dd.

Gage, General, 175-176, 194-196, 200.

Gaines's Mill, battle of, 514 ; Map XII. Dh.

Gainesville, battle of, 527 ; Map XII. Ce.

Gallatin, Albert, 31 I, 310, 336-337, 351 .

Gama, Vasco da, voyage round Africa to India, 7 .

Garfield, Gen. James A., clected President, $5^{81}$; murdered, $5^{8} 2$.

Garrison, William I,loyd, 406, 407.

Gaspée, burning of the, 172-173.

Gates, Horatio, credited with the capture of Burgoyne, - intrigues against Washington, 215, 217; campaign in the Carolinas, 227-228; promoter of discontent in the army, 236-237. 


\section{INDEX.}

Geary, John W., 464,468 .

General Court of Massachusetts, 66.

Genesee Kiver, .Hat l\% Bc.

Genet, "Citizen." 255-2\$6.

Genera tribunal, s-o.

Georse 1., 131.

George III.. beginning of his reign in Englan. - his character. 160-101; his treatment of the colonies, $101-1-5$.

George, Fort, 345, 346. 347; 142, p. 341 . Georeia, the founding, 133-1 34: war with the Spaniards, 13 : ready for independence, 205 : state govermment formed. 207 ; subjugation by the British, $224-225$; cession of land claims to the Confederation, 240-250: treatment of Creek and Cherokee Indiaus, $33_{3}-3+4.306$; secession declared, 4 \$6: emancipation proclaimed, 52S: restored to the Lnion, $564^{-}$ 565.

German immigration, $129, \mathbf{1}_{36} 6$.

Germantown, battle of, 210 ;. Maff, p. 211 .

Gerre, Elbridge, 202.

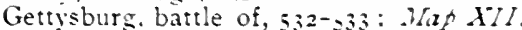
Db.

Gettysburg address, President Lincoln's, $5,36$.

Ghent, peace treaty of, 351-352

Gillmore, Gen. Quincy A.. 534 .

Gist, Christopher, I39.

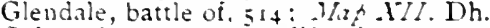

Gold, discovery in California, 4t3; sus. pends use as money tsee Specie payments): price in greenbacks during and after the Civil War, 5-3 (foot-note).

Goldsboro (with map). $5+5$.

Goliad, 41 ; Mas .1T. Uc.

Gookin, Damiel, I15.

Gos old, Bartholomew, $2 S$.

Grant. Gen. Lllisses S.. appointment to a district command. 502: capture of forts Henry and Donelson, - battle of Shiloh. 500: Iuka and Corinth, 520: operations against Yicksburg, 531,533 : at Chattanooga. 536: appointed lieutenant-general, in chief commund, - joins the army of the Potomac, - plan of campaign, $530-$ 540: movement on Richmond, 540: operations at Petersburg. 54l: surrender of Lee's armx, $540-54^{-}:$made practically independent of the President, 564: elected President, 56s: reëlected, 505500 : incidents of a ininistration, $560-5-2$ : question of a third term, $57,55 \mathrm{r}$; death. ミ゙ー.

Cirasse. Count françois de, 232-2.33

Great bridge, battle, 204: Vifs, P. $225, \mathrm{Fb}$.

Great liritain. See England.

Great Lakes. See Lakes.

Great Meadows. 1q2: Mas TI. Ae.

Great Salt Lake, $4+3:$. I 2 \& $17 . \mathrm{Bb}$

Greeley, Horace, 544 .

Greeler, Col., 6iz

Green, lifuf, 400

Green Mountain Bors, $105,2-0$

"Greenbacks," 532 .

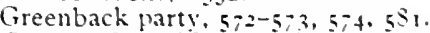

Greene, Cien. Nathanael, at siege of Bos- ton, 196; appointed brigadier-general, 199: campaign in the south (with . Mos. p. 225$), 227,228,231-232$.

Grenville, George, $162-167$

Goveton, battle of, 527 : iks . TII. Ce.

Guadalupe Hidalgo, ireaty of, +42 .

Guam, 599: . Wap $1 \%$ Cb.

Guerriere, the British frigate, 342 .

Guilford Court House, batile of, 231: Wugh. p. 225. Cc.

Gunboat policy, President Jefferson's, 323.

Gutlirie, O. K., 5 ss.

Habeas corpus, suspensions of the writ of, 530.

Hale, Joln P., 450

Halfway Covenant, 65.

Halifax, 205. Map $l^{-}$. Fc.

Halifax award. 5 t.

Halleck. Gen. Henry W., command in Missouri, 503: general-in-chief at W"ashington, 514 .

Hamilton, Alexander, early political writings, 190: on W'ashington's staff, 219; in the Federal Constitutional Convention, $1-8-25:$ : chief author of "The Federalist, " 262-203: Secretary of the Treasury, $272-286$ : report on public debt and public credit, $2-3-2-5:$ adrocacy of United States lank, - doctrine of "implied powers" in the Constitution, $276-2-s$, 2So: adrocacy of protective industrial system and internal improvements, aso; influence, - leader of Federal party, $2 \mathrm{~S}_{\mathrm{I}}-$ $2 \varepsilon_{;}$: at emmity with Jefferson, - retirement from Washington's cabinet, $2 \mathrm{SO}$; continued political intluence, 29r: appointed second in military command, 203: duel with Aaron Burr, and death, $315-310$

Hamilonian party. See Federalist party.

Hampton Roads, 50s; .Mos . III. Fi, and p. 500 .

Hancock, Gen. Winfield Scott, $5 S_{1}$.

Hancock, John, leadership in Boston, 173: attempt to arrest, 194: president of Second Continental Congress, r $9 \$$.

Hanoverian kings, 1;0-131.

Harmar's defeat. $2 \mathrm{SO}-2 \mathrm{~S}$.

Harper's Ferry, John Brown's seizure, 4i-4it: Mis X'C. C.

Harrison, Benjamin, elected President, 5:--5SS: administration, 5s- 590.

Harrison, Gen. Willam Henry, governor of Indiana Territory, - war with Tecumsel, 337 : operations in the War of 1912 , $343,345,340$ : candidate for presidency (Is36). tit: elected President (is40), $410-420$; death, $42 \mathrm{~S}$.

Hartford, $42,67:$ Mas 15 . Ad.

Hartford Convention, 350-351.

Harvard College, the founding of, $4 \mathrm{t}$.

Hatteras Inlet, 505-506: M/as . p. 505.

Hawailan Islands, Iap . IT. Ia annexation treaty withdrawn by President Cleveland. 500-501; annexation accomplished, 596 . 
Hawthorne, Nathaniel, 365 .

Hay, John, 600, 602.

Hay-Pauncefote treaty, 602.

Hayes, Rutherford B., elected President, 574-575; administration, 575-577.

Hayne and WVebster debate, 398 .

Hayti, 4: Map II. Hd.

Helper's “Impending Crisis," ${ }_{4} S_{2}$.

Henry, prince of Portugal, early exploration promoted by, 3 .

Henry, John, intrigues of, 324. 339.

Henry, Patrick, speech on Sitanp Act, 16 4$16_{5}$; action against the Townshend acts, r7o: in the First Continental Congress, 177 ; his speeches, 190 ; in Second Contimental Congress, 198 ; governor of Virginia, 217; opposition to the Federal Constitutional Convention, 257.

Heury, William, $3 \circ 8$.

Henry, Fort, capture of, 506; Map $\mathrm{X} / I$. De.

Herkimer, Col. Nicholas, 214.

Hessians, employment of, 203 .

Hiawatha, 2 I.

Higginson, Francis, 115.

Hillsborough, Map, p. $225, \mathrm{Cc}$.

Hilton Head, S. C., $527 ; M \operatorname{Lip} p$, p. 505.

Hispaniola. See Española.

Hobkirk's Hill, battle of, 23t; Map, p. $225, \mathrm{Be}$.

Holland, brought under Spanish rule, I2; revolt, independence, and rise to maritime greatness, 13; claims and possessions in America (with map), 46-49; their surrender to the English, $\mathrm{S}_{5}-\mathrm{S}_{7}$; recovery and second surrender, 94. See also New York.

Holmes, Oliver Wendell, 365-366.

Holst, Professor Hermam E. Von, on the Continental Congress, 200.

Holt, Joseph, $4{ }_{4} 7$.

Holy Alliance, the, $376-377$.

Homestead Act, 523 .

Honduras, $\mathrm{S}$; Map II. Ge.

Honolulu, 590; Map XVI. Ia.

Hood, Gen. John B., 541, 542-543.

Hooker, Gen. Joseph, in command of the Army of the Potomac, 531; succeeded by Meade, 5.32: in Tennessee, - battle on Lookout Mountain, 535,536 .

Hooker, Thomas, founder of Conuecticut, 4 I father of American democracy, 67 (foot-note); writer, 115 .

Houston, Gen. Sam, 4ti.

Howe, Admiral Richard, earl, 20 S.

Howe, George Augustus, Viscount, killed at Ticonderoga, 148 .

Howe, Gen. William, Viscount, at Bunker Hill, 201: in command of Britisb forces, 205; capture of New York, 208-209; failure to coöperate with Burgoyne, 2 I $5^{-}$ 216; occupation of Philadelphia, 216; superseded by Clinton, 220.

Hubbardstown, battle of (with map), 2r3.

Hudson Pay, ceded by France to England, $126 ;$ Map $I I$.

Hudson River, Map $/ 1$. Hb; and p. 209 ; plyysical importance, $23^{-24}$; discovery by
Henry Hudson, 47 ; Dutch possession, 47 ; surrender to the English, $8_{5}-8_{7}$; military importance in the War of Independence, 206.

Huguenots, i6, 129.

HuHl, Capt. I saac, 342 .

Hull, Gen. William, surrender of Detroit, $340-341$.

Hulsemann letter, Webster's, 457.

Hundred, the, in early England, 71 ; in Maryland and Virginia, 72.

" Hunker" Democrats, 450 .

Hunter, Gen. David, command in Kansas, 503 ; emancipation order, 526, 527; in the Shenandoab, 541 .

Huron-Iroquois, Map Ir. Ac. See Iroquois.

Hutchinson, Mrs. Anne, 44-45.

Hutchinson, Thomas, his bouse sacked by a mob, 165-166; action relative to the tea-ships, t74; superseded by General Gage, 175 : sincerity of his Toryism, $\mathrm{x}_{9}$; his history, 191 .

Iceland, early royages to America from, $x$. Idaho, admitted to the Union, $5 \& 8$.

lllinois, under the Ordinance of $17 S_{7}, 264-$ 265 ; territorial organization, 326 ; admission to the Union, 371 .

Illiteracy, decreasing, 620 .

Immigration, increase after $18_{45}, 443$.

Impeachment of President Jolnson, 566.

Imperialists, 601 .

Implied powers in the Constitution, the doctrine of, $277-27$, 2 So.

1 mpressment of seamen, British, $2 \mathrm{~S}_{7-2} \mathrm{SS}$, $289,31 S, 322-323$; cause of war, 340 ; unmentioned in the treaty of peace, 352 .

Income tax (IS61), 500: (1S94), 593 .

Indentured servitude, $75-76 ; 113-114$.

Inderiendence, ripening of public desire for, 203-204; demai ded, 205-206; declared, $206-207$; completer acquisition after the War of $1812,362-363$.

Independent Republicans, $5 \$_{3}$.

Independent spirit, in colonial Massachusetts, 50-51, $8_{1}-8_{2}$; increasing in the colonies generally, 126-128, 131-132.

Independent 'Treasury, or Sub-treasury system, 4i7; abolished by the Whigs, 428 ; restored, 444.

Independents, or Separatists, I4, 36-37.

India, early trade of Europe with, 2-3, 7 .

Indian Territory, set apart, 396 ; purchase and separation of Oklahoma, 588 .

Indiana, under the Ordinance of 1787 , 264-265; territorial organization, 307 , 314, 326; Tecumseh's conspiracy, 337; admission to the Union, 371 .

Indians, American, origin of the name, 5 ; earliest knowledge of, 16-19; linguistic grouping of tribes, 20-22; outbreak in Virginia, 1622, 32-33; Pequot War, 4243: purcliase of land from, in Massachusetts and at Providence, 44; war with the Dutch in New Netherland, 49; war in Virginia, go-9 I King Philip's War, 92-94; Penn's dealing with, 99 ; enslave- 


\section{INDEX.}

ment in the colonies, is : employed by French in colonial wars, 123-125, r 48 : Pontiac's War, I5I; western region assigned to them by George III., I03: Iroquois alliance with British in War of Independence, $206,213-21 \$, 221-223$ : northwestern war, 1-90-91, 250-2si: Tecumseh's war, 337; Creek war, 346: first Seminole war, $368-300$; treatment of Creeks and Cherokees in Georgia, $3 S_{3}-34,306$ : creation of the Indian Territory, soo: second Seminole war and "Black Hawk War," 306-397 ; wars with Apaches. Modocs, and Sioux, 570 .

Industrial conditions. See Economic conditions, and Protective policy.

Industrial contlicts, ș;, 6r;-6ro.

Intlation, monetary, $253-255,367,412-414$, $+15-410,510,532,570-5-1$.

Ingraham, Captain, 450 .

Intercolonial war, tirst. 123-124; second, 124: third, 13z-130.

Internal improvensents, Hamilton's policy, 2So: constitutional amendments to authorize, favored by Jefferson, 3ro-3zo: appropriation advocated by Calhoun and vetoed by Madison, $355:$ constitutionality denied by Monroe. 375 : reaction against the policy in the south, - upheld by the fational Republican party. $3 \mathbf{3}_{2}-3$ : opposed by President Jackson, 306.

Inter-oceanic canal, Clayton-Bulwer treaty. 456-45;: Hay-Pauncefote treaty, co2$\mathrm{Co}_{3}$ : Isthmian Canal Act, - rejected Columbian treaty, fos.

Inter-State Commerce Commission, $5 \$ 6$.

lntolerance, religious, in Puritan Miassachusets, 41,65 : in New Haven colony, $6-:$ of Puritans in Maryland, 5s: orisinating cause of early colonial settlements, oz: revival in Maryland, $122-123$.

Invention, $615-610$.

Iowa, admitted to the Lnion, 435.

Iron-clads, $50 s-5(n)$.

Iron manufacture, development and cheapening, $613-614$

Iroquois, the, .tan II. Hb: their tribes (Five Xations), their territory, and their political league, 20-21, X.zA. p. 26: hostility to Hurons, Alsonquins, and French. $26-27,1$ Is: friendshin with the Dutch. 4: a alliance with the English, 05: peace with the French, ras: declared to be subject to the dominion of England, 126 : the Five Sations become Six Xations, iso: treaty with English colonies at I ancaster, $174,140:$ intluence of Sir William Johnson, It5: alliance with the English in the llar of Independence, zot, $21 ;-$ $214,2=1-23:$ New lork land claims derived from their conquests, 240 .

Irrepressible contlici, Semator Seward's statement of the, $4: 2-473$.

lrrigation, (1).

Irving, Washington, 365, 622.

Isabella, queen of Castile. $:-4,6$.

Island Xo. 10, 50\%: Mâ. IIT Ce.
Isthmian Canal. See Inter-oceanic canal. Iuka, battle of, 5=9: .1/as . $17 / 7$. Cf.

Jackson, Andrew, in Congress from Tennessee, 200: in Creek 11.ar, 346 ; in the battle of New Orleans, 353 ; in the first Seminole War, $365-360$; candidate for presidency, $379-350$ : his belief that he was defrauded, - his character, $3 \mathrm{~S}$, . 393, 4 15: elected President by the Democratic party, $355-356$ : his "kitchen cabinet." 393-304: his introduction of the "spoils system" at Washington, 394-395: forecast of his policy, 395-396: dealing with Georgia and its Indian tribes, 306 , 39 : : attitude toward the protective tariff policy and the nullification doctrine, $307-30$ S; rupture with Calhoun, 390: reelection. 402: proclamation and action against the nullifying ordinance of South Carolina, $402-404$ : removal of deposits from the Enited States Bank, 404-405: the Senate censure expunged, 405; effects of the remom! of deposits, $+12-413$, $4+410$; intluence of President Jackson, $+1 t^{-415}$; favors annexation of Texas, +32 .

Jackson. (ien. Thomas J. ("Stonewall") at Bull Rum, sis (foot-note): raid into the Shen.mdoah. 5ız: in Seven Days' liattles. 513: in campaign against Pope. 527 : death, 53 i.

Jackson. Mr., British minister, 333

Jamaica. 6: ikas $1 /$. He.

James I., grants and charters to Virginia Company and London Company, 25-30: hostility to London Company, 62.

James Il.., treatment of Massachusetts and New England, tor-10z: expulsion from the English throne, roz.

Jamestown colony (with map), 3c-32.

Japan, Ferry's expedition to, 457.

Jay. John. in the First Continental Con. gress, $1-6$ : his writings, 100 ; in the Fecond Continental Congress, 10: : in New York constitutional convention. 217 ; in peace negotiation. 234; author of papersin "The Federalist," 263 : first chief justice of the Lnited States and acting Secretary of State, 273 ; special envoy to Fingland, 2 SS.

Tay treaty, 2S:-2So, 200.

Teferson. Thomas, action in Virginia Assembly against the Townshend acts, $1 ; 0$ : reply to Lord Xorth"s "olive branch" proposals, 170: early political writings, 100 : in the Second Continental Congress. 10S: author of the Declaration of Independence, $20^{-}$: in the Vircinia lecislature, 217 : mission to France, 257 : Secretary of State, $2,2,2,3 ;$ leadership of the Anti-Federalist party, $2 S_{1-2 S t}$ at enmity with Hamilton, - resignation from Washington's cabinet, $2 \$ 6$; elected VicePresident, 201: author of the Kentucky resolutions of $\tau ; 0 R, 205$ : elected President, 206: aims as Fresident and theory of national government, 300-310; his 
unbelief in the need of war, 310 ; purchase of Louisiana, 312-314; reëlected President, 316; broadened conceptions of the general govermment, 319-320; experiment in "peaceable coercion," 323326; death, $38_{3}$ : removals from office during his presidency, 394 .

Jeffersonian party. See Republican party, Democratic.

Jenckes, Thomas, 571-572.

Jesuit missions, 28 .

Johnson, Andrew, elected Vice-President, becomes President, - previous career, 561 ; rupture with the ruling party, 562565 ; impeachment, 566 .

Johnson, Edward, I I 5 .

Johnson, Fort, Map $V I I$. Ce.

Johnson, Sir Williain, 145, 146, I 51.

Johnston, Gen. Albert S., 506.

Johnston, Gen. Joseph 'E. . in the first battle of Bull Run, 50r ; commanding in Virginia, 504; evacuation of Manassas, 5o8; wolnded at Fair Oaks, $5^{13}$; succeeds Bragg in the west, against Sherman, 539, 540-54I ; superseded by Hood, $54 \mathrm{I}$ : surrender, 547 .

Joint High Commissions, $569,5 S_{4}, 590$.

Joliet, Louis, I $17-$ I 18 .

Jones, Paul, 226-227.

Josselyn, John, I 15 .

Judges, colonial, appointment at the king's pleasure, 162 ; salaried by the crown in Massachusetts, 173 .

Kahokia, 223; Map, p. 141, Be.

Kalb, Baron Johann de, 227-22S.

Kanawha River, the Great, Map, p. 141.

Kansas, territorial organization, by KansasNebraska Act, repealing the Missouri Compromise, $460-462$; pro-slavery and anti-slavery strife in the Territory, $463^{-}$ 464 ; the fraud of the Lecompton Constitution, and its defeat, $468-470$; admission to the Union, 488.

Kaskaskia, 223: Map, p. 141, Be.

Kearney, Gen. Philip, 439-440.

Kearsarge, the, 542 .

Kenesaw, battle of, $541:$ Mas XIII. Ff.

Kentucky, beginning of settlement, $13^{6}$, 223 ; demand for the right of navigation on the Mississippi, 256; admission to the Union, 279; effects of the cottongin on slavery, 308-309; detachment in interest from the east, 307; Iiurr's conspiracy, $316-318$; adherence to the Union (1861), 495 .

Kentucky resolutions, 1798, 294-295. See Nullification.

Key, Francis Scott, 350.

Kieft, William, 49 .

King, Rufus, 354 .

"King Creorge's War," $138-139$.

"King Philip"s War," 92-94.

"King William's War," 123; Mas, p. 125.

King's Mountain, battle of, 231-232; Map, p. 225 , Ae.

" Kitchen cabinet," President Jackson's, 393-394, 400, 405.
"Know Nothings." See American party.

Knox, Gen. Henry, 272 .

Knoxville, siege of, 535,$536 ; \operatorname{Map} \mathrm{XIII}$. Fe.

Kossuth, Louis, 457.

Koszta, Martin, 459.

Ku-Klux Klan, 566.

Labor combinations and conflicts. See Industrial conflicts.

Labor parties, 595, 601.

Labrador, 7; Map II. Ia.

Ladrones, 599.

Lafayette, Marquis de, services offered to the American colonies, 212; friendship with Washington, 218 ; in battle of Monmouth, 220 ; visit to France, 228 ; commanding in Virginia, - at Jorktown, 232-233; in the French Revolution, $28_{4}-$ 285 ; visit to the United States in 1824 , $37^{8}-379$.

Lake Frie, battle of, 344 ; Maf, p. 345 .

Lake of the Woods, 370; Map XI. Da.

Lakes, basin of the Great, historical importance of, 23; French exploration, I17-1 8 ; French possession (with map), - English conquest, 140-150; settlement prohibited by George II I., 363; added to the province of Quebec, 175 ; yielded to the United States by Great Britain, $234^{-235}$; cession of state claims, 249250 ; Ordinance of ${ }_{17} S_{7}, 26_{4}-26_{5}$; opened to settlement and trade by the Erie Canal, $364-365,412,609$; development, 1820$40,411-412$; development by the railway, 6 ro.

Lancaster, Mass., 125; Map $V$. Bc.

Lancaster, $\mathrm{Pa} ., 140 ; \mathrm{Map} l \% 1$. Cd.

Lands, public, cessions by the States to the United States, 249-250 (Mapl $V^{*} I I I$.); speculative buying (IS25-IS37), 4II-414; distribution of land revenue, 428-429; distribution annulled, 430; Homestead Act giving free homes to settlers, 523 .

La Salle, Robert Cavelier de, i 8 .

Laud, Archbishop, 40.

Laurel Hill, battle of, 500; Mas, p. 499, Eb.

Lawrence, Capt. James, 344 .

Lawrence, Kansas, $46_{4}$; Map XIV. Hc.

Le Bœuf, Fort, I40, I41, 150; Map $V I$. $\Lambda \mathrm{d}$, and p. $\mathrm{I}_{4} \mathrm{I}$.

Lecompton, IFp XIV. Hc ; Lecompton constitution, $468-470$.

Lee, Arthur, 212.

Lee, Charles, appointed najor-general, r99; command in the south, 208 ; disobedience to Washington, - capture by British, 209-2 ro; treachery while a prisoner, - conduct at Monmouth, 220221.

Lee, Gen, Henry, 231, 288.

Lee, Richard Henry, i76, r9o, igS.

Lee, Robert F.., in command against John Brown's party at Harper's Ferry, 473474 ; accepts the secescion of Virginia, 495: commanding Confederate forces in Virginia in peninsular campaign, 513$5 \times 4$; defeat of Pope, - invasion of Mary- 


\section{INDEX}

land. and retreas. $5:-5 z=$ repulse of

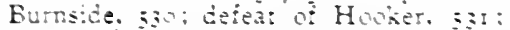
renewed invison ot the norh and reirea:

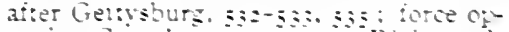
posing Cirant s movemen: on Kichmons. 5+0: controning Gran: a: Petersburs. 5+1: retreat from Kichmond and surender. $i 40-i 4^{-}$.

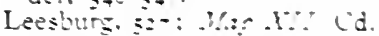

Lezal Tender Ac., isoz, in Rassage. 510 ;

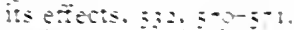

Legsinures. connial See Assembies. coivnial.

Leit Ericsorn. I

Lessier. Tacos. $120-121$.

Leisierians, is:

Lemanes see Deiawares

Levpard and Chesapeake, the, : : $2-3: 3$.

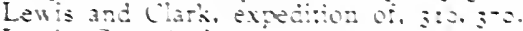

Lewis, lien. Andrew, : z.

Lexingion. excounter at with magl : :04 In:

Liberai Lhristanisy, 300

Liberal Kegulicans, 300 .

"Libera:or", "ha, 400"

Liber:y part. 4is.

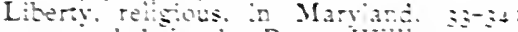
contended ior by Roger W'Mams. 4:

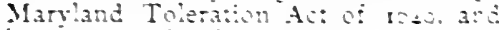
its treatmen: by the Purtans. :a-s; : es-

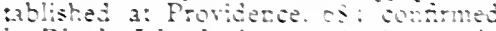
in Rhoü Isknz chazer. si-st esiah lished by charter in ihe Caro: :-as, $\$ 4$ : in Penrsylrania. w: acrances made

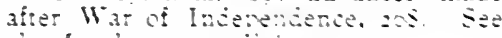
aiso lavierance reisious.

Libraties. tree pubi:o. oz:-?:2

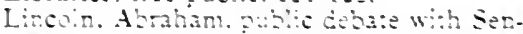

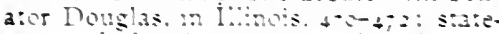
ment of the issue concerning starery.

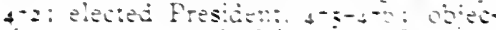
tions io proposed lizienden Comoro

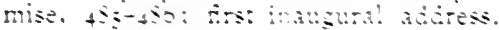

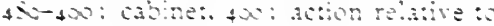
Fort Sumet, $4 x-40$ : 6.s: and second

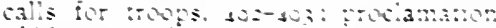
of hickade of souhern ports 403 . wise dealing wath borter stave Siatos tos frst message to longress. caton of Fremont srikiamanon. :50: order for a sereal advance ồ

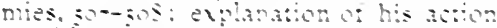

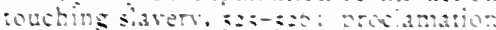

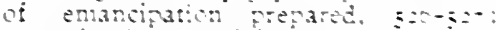
emancipation axcames.

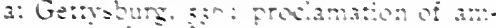

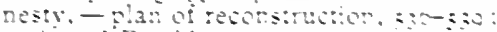
resiected President ins-zan peace conference with lice-Presicen Somhens.

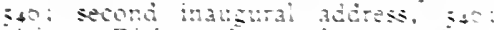
Visis o Richmond, it - las: speeth. -

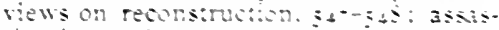

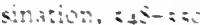

lincon, Gen kernimin, : : : :24-z:

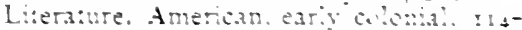

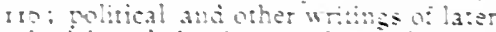

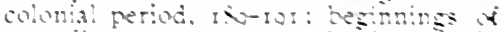

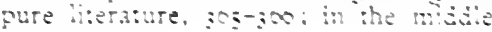

deraces of the loth century, and since. $0: 2-\infty: 3$

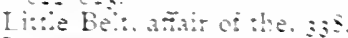

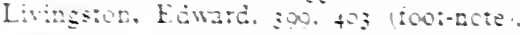
$4 \div 4$

Livirzs:on, Philiz, I, 2 , 105

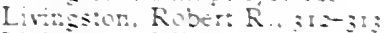

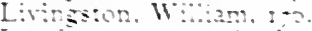

Lowi governmen: in the Engish coinnes

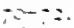

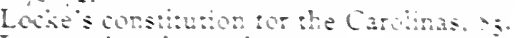

Lavomolve chase. the $: z=$

Lozan. he worns at.

London lomany charers tom Tames I , o: restandation, : : change in chat actor. : : verthrow. :

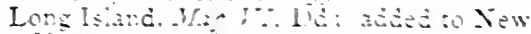

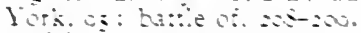

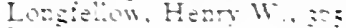

Longstresi. Ger. Iames.

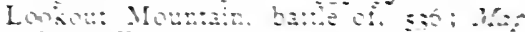
$1 \% \mathrm{ES}$

Lopez expez:nos: 0 Cuks, 458

Lores of Trabr. : :

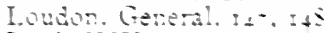

Lous XIT.. 1:

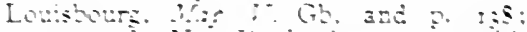

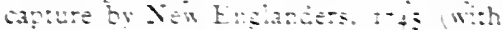

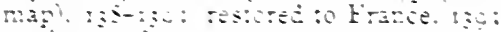
renisen, is

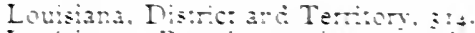

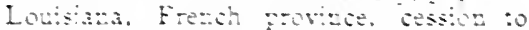

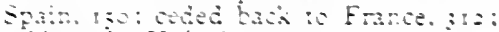

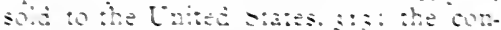

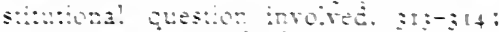

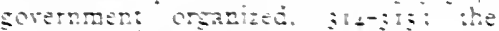

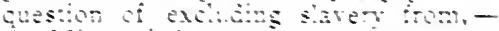
the Missont lompromise. :-i-z-4.

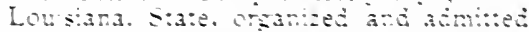

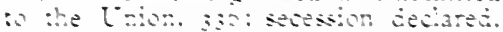

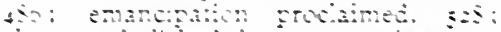
slavery abolshed by siate actios. =5

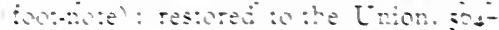

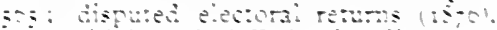

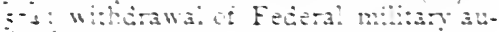

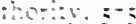

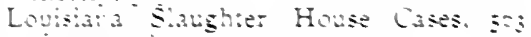
lion-avie).

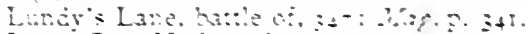

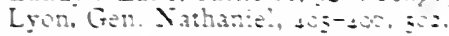

Mel a.ur. Gem. Geora E . campanon in Wes: Visina with man. $400-50$; callec :o the Amy ot he Poimas sor:

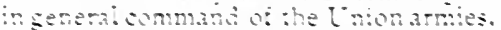

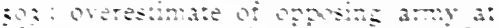

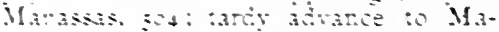

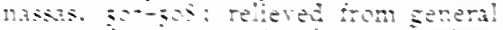
comman. sta pensusut campars.

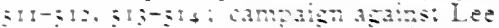

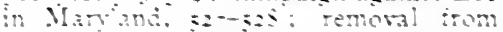

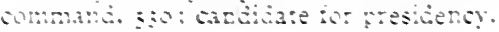
$5 \$ 4$.

Mecons. Gen. Alevander M sid

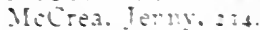

Mackorough, Commodote Thomas. st:

MeDowe... Gen. Irvin. cummasing Army of the lo:onace - batie of But Ruz. 


\section{INDEX.}

sox-5ur; during MaClellan's peninsular campaign. 512.

MeHemry, Fort, $3+9-3=0$.

McKinley, Willam, name connected with the ariff act of 1 Swo, sis-5so: elected President, 595: rëlection, - murder. wit.

Mclane. Loms, 300, to4.

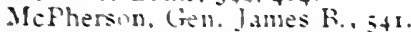

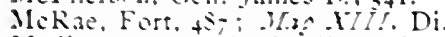

Madison. James, in the Fedenal Constitutional Convention, Iー iributor to "The Federalist." zo:-263: leader in First Congress, $2 ; 1$; becomes an Anti-Federalist, 2S: a athor of the Virginia resolutions of $1700.205:$ Secretary of State, in: elected President. 325; misled by the Kritish minister. 332: deceived by Xapoleon, 3:3-335: recommendation of war with Engiand. 330-3+0: recelected President, 3\$3.

Magellan, vorage of. o.

Mame, stanied to Sir Ferdinando Gurges. to: clamed by Massachusetts, so-wo: maier thdros, 102: population and condition in ross, nos-ro, annexed to Massachusetts, 120: sufferings in Queen Anne"s War (with map), 125: separation from Massachusetts and admisston to the Union, $32 z-373$.

Maine, batileship, $506-50 ;$.

Malvern Hill, bastle of, sit: Ma MII. Dh.

Manassas Iunction, 5or, sas: Who \$II. Ce.

Manlattan Island, settled by the Dutch (with map), 47-4s: taken by the English, s6-si.

Manila, naval battle, - siege and capture. $507,505:$ : $1200,507$.

Manors, New York, rss-1so, $+30-+31$.

Manufacturing induscries, forbidden or discouraged in English colonies. 125,132 133 : condition at the beginning of the Viar of Independence. 1 -IES: Hamilton's report on, 25o; progress since the Civil War,6r3-ors. See also Protective policy, industrial.

Marey. William L. . $+50-460$.

Mariana Islands, s00: M.zp $17 \%$ Cb.

Marietta, Ohio, 205 : .Mos T. Dd

Marion, Francis, 22\%.

Marlborough. Duke of, 120.

Marquette, Father Jacques, in-i is.

Marshall. Iohn, mission to France, 202: appointed chief justice, - his coustitutional decisions, $206,30 s$.

Maryland, founded as a "palatimate" by" patent to Lord Balsimore (with map), 33-34, 08, 60: religious and political liberty established, 34 : coleration act of 1640. 53-54: Puritan domination, st: local government, - the "hundreds," $70-72 ;$ social structure and character. 73-7t: population and industries at end of 17 th century, 10s-110, 111-113: slavery and indentured servitude, I 13 : revolution of $16 S 5$, - proprietary govern- ment aken away and restored, - intolerance revived, 12z-123: action upon the news of Lexington and concord, log10,: state government formed, 20; : action relative io western land claims of the States, 2fu-250: effects of the cotton-sin on slavery, jos-sco: suppression of secessionists ii isor, fos : invasion by Lee (rsoz). 5zby state action, 5t5 (foot-note).

Maskokitribes, a : Magh I/. (ic.

Masom, George, 100, 2:

Mason, John, tis.

Mason, John X.. $+\infty$.

Mason and Dixon's I.ine. Mas . HI: Ke: its origin, etc., 0\$, 270. 300.

Mason and slidell, capture of. 505.

Massachusets, the Crovernor and Company of Massachusetts hay, its charter. io-40: settlement of Boston and vicinity, to: hostility in Englond, to: Puritan exclusiveness. 4 : sccession of Connecticut settloments. $41-4 z$ : expulsion of Roger IV illiams. $+3-4+$ : bomishment of Mrs. Anne Hutchinson, 45 : decrease of Purian immigration, to: confederation of New England colonies, fo: theory of chartered rishts. and substantial independence, 50-5 r : establishment of a mint, so-si: persecution of Cuakers, $52-53$ : Folitical structure of the early colony, os-6t. oo: local soremment, town-meetings. 70-7z: assertion of "Liberties," - attitude towards the resiored English monarchy, \$1-s2: resistance to the hing's comnissioners. 1604 . Sz-So: annulment of the charier, roo101: treatment under Andros, 101-102: fopulatin and industries at end of roth century, ros-110, 11-113: slaves and slavery, $1_{3-1}+$ : education and literature. inflic: overthrow of Ancros. IIg: newly chartered as a royal province, 119-120: Plymouth and Maine annexed, rzo: participation and suffering in colonial wars with France, 124120; capture of Louisbourg, I $3-130$ : proposal of Stamp tat Congress. ios: circular letter to the colonies. 10s-rto: punishment by the " Kegulating Act" and the Foston Port Bill, r $7^{-175}$ : call for a Commental Congress, 1zs: provi. sional government formed. - "Conmittee of Safer." 170: social condition at the end of the colonial period, so: extiuction of slavery. 192: engagement in the shae trade, 103; opening of the 11 ar of Independence, $104-100$ : declares for independence, 200 : state sovernment formed, 207: cession of land claims :o the Confederation, $2+4-250$ : attitude in the llar of $\mathrm{x}$ s $2,350-35 \mathrm{I}$ : separation of Maine, 3-2-373: "Sixth Regiment attacked in Balimore, to2.

Massasnit, 37,03.

Matamoras, $43-439 ; .1 .2 \hat{s}, \mathrm{p} .+40$.

Mather, Cotton, 191 .

Mather. Increase, is 


\section{INDEX.}

Maumee River, Maf, p. 345.

Maximilian, Emperor, 567 .

Mayflower compact, 64 .

Maytlower, voyage of the, 36 .

Meade, Gen. George G., in command of the Army of the Potomac, 532-533, 535, 539.

Measures of the national government, $\mathrm{Ap}$ pendix $D$.

Mechanicsille, battle of, 5it: Map XII. Cg.

Mecklenburs County, resolutions of 1775 . 197: Hapl III. Bd.

Memphis, Tenn., 513: Map XIII. Bf.

Merit system. See Civil service reform.

Merrinac River, as named in the Massachusetts charter, 39. S9: Map $l$. Bc.

Merrimac, the iron-clad, 50\$-509, 512.

Mexico, ifaf II. Ed: conquest by Cortes, 9: expedition of Coronado, 11: Spanish plundering, 13: aboriginal inhabitants and their state of culture. I9: overthrow of Spanish rule. - independence, 335. 376 ; revolt and separation of Texas. $410-$ 4II: war with the United States, 437442: treaty of Guadalupe Hidalgo, cession of territory to the United States, 442: attempted French conquest, Maximilian's short-lived empire, 529 , 567.

Mexico, City of capture, $442:$ M $\mathrm{f}, \mathrm{p} .44 \mathrm{I}$

Mexico, Gulf of, 9 : Wap II. Gd.

Michigan, under the Ordinance of ${ }_{17} \mathrm{~S}_{7}$, $264-265$; territorial organization, 326 .

Milan decree, $322,334-335$.

Miles, Gen. Nelson A., 599.

Military arrests, 530.

Mill Spring, battle of, 507; Map XIII. $\mathrm{Fd}$.

Mills Bill, $5^{\mathrm{S}} 7$

Mims, Fort. $34^{6}$ : Wap I.X. Be.

Minnesota, admitted to the Union, $47^{\circ}$ (foot-note).

Mint, in colonial Massachusetts, 51-52: of the United States, $254^{-255}$.

Minute men, 179 .

Missionary Ridge, battle of, 536 ; Map XIII. Ee.

Missions to the Indians, Catholic, $2 S$, I 7 .

Mississippi River, Mas II. Fc: entered by Pineda, 9; reached by Narvaez, ı : crossed by Fernando de Soto, 1 : French exploration, iा7-is Spain of its navigation. 256 : treaty freeing the navigation, 290 ; first steanboat, 364 : operations in the Civil War to open navigation, $507,512-513,531,533$.

Mississippi, the State, territorial organization, 307,336 : admission to the Union. 371 : secession declared, 466 : emancipation proclaimed, 528: restored to the Union, $56_{4}-56_{5}$.

Mississippi Villey, great feature of the continent, 22: early exclusion of the English and introduction of the French, 23: historical influence, 23-24: early French exploration, I $7-1$ is: English neglect, 134-135: French and English struggle for (with map). 139-149: colonial indifference to French occupation, $x_{42-1}+3$; cession of French possessions to England and Spain, 150: English portion yielded to the United States, 234235: detachment in interest from the east, 307: Burr's conspiracy, 316-318: democratic conditions of society, $36_{3}-$ 364 : settlement promoted by steam navigation, 364, 412, 609-610; western Spanish boundaries defined, 360 : development (1 $\$ 20-1840), 411-412$ : later western development, $609-61_{11}, 61_{3}$.

Missouri, territorial organization, 314 ; proposed exclusion of slavery, - Compromise, - admission to the Union, 372374 ; invasions of Kansas, $463-464$; adherence to the Union (IS6I), 495-496: Frémont in command, 502-503; slavery abolished by State action, $5+5$ (foot-note).

IIssouri Compromise, $372-374$; its repeal, $460-462$; declared unconstitutional by the Dred Scott decision, $466-467$.

Mitchel, Gen. Ormsby M., 506-507.

Mobile, Farragut in the harbor, 542: Map XIII. Di.

Modocs, war with the, 570; Map XT. Aa.

Mohawks. See Iroquois.

Mohegans, neutral in King Philip's War, 94: Map I: Ad.

Molasses Act, 162.

Molino del Rey, battle of (with map), $44 \mathrm{I}$.

Monetary questions and measures, "continental currency," 218, 228, 253-254: first United States Bank charter, $276-278$; dissolution of the bank, 336-337 : bank inflation, - "wild-cat" banks ( $\left.\mathrm{S}_{11-21}\right)$, - second bank of the United States, $36 \%$. 365 ; overthrow of the bank by President Jackson, 305-396, 400-401, 404-405: "wild-cat" banks $\left(1 s_{33-37}\right), 412-414$, $415-416$ : President Van Buren's "independent treasury" system. $4^{17}$ : New York banking law of ${ }_{13} s_{3} s, 417-41 s$; suspension of specie payments, 1861 . 500-510; Legal Tender Act, IS62, 510; national bank system, 532: opposition to resumption, - Greenback party, 572573: the Bland Silver Bill, 576-577: resumption accomplished. 577 : the Sherman Act. $5 S_{9}-500$; crisis consequent on the Sherman Act, - partial repeal of the act, 591-59: monetary commission to Europe, 505: act defining the standard "dollar" in gold, 506 .

Monitor and Merrimac, battle of the (with map), $508-500$.

Monitor ironclads, $508-509,512,534$.

Monmouth Court House, battle of, 220 : Map, 2 I т Fg.

Monroe, James, minister to France, 29 I- $^{-}$ 292 ; special mission to France, 3r3; Secretary of State and Acting Secretary of War, 349: elected President, 354: the "era of good feelings," 366 : reëlected without opposition, 374-375: message embodring the "Monroe Doctrine," socalled, $376-37 \mathrm{~s}$. 


\section{INDEX.}

Monroe Doctrine, $376-378$.

Monroe, Fortress, 49S, 511, 539, 546; Map $X I I$. Fi, and p. 509 .

Montana, partly inciuded in Nebraska Territory, $46 \mathrm{r}$; admitted to the Union, $5 \mathrm{SS}$.

Montcalm, Marquis de, $147^{-149}$.

Monterey (with map), 440.

Montgomery, Ala., 489 .

Montgomery, Richard, 199.

Montreal, $M$ Iaf $V$. Ab; first settlement, I 7 ; colonial English expeditions against, 124; capture by General Montgomery, 202-203; expedition against in 1813,346 .

Monts, Sieur de, 25-26.

Moore's Creek, battle of, 205 ; Mapt, p. 225 . De.

Morgan, Abduction of, $3^{8} 5$.

Morgan, Gen. Daniel, 202, 203, 2 I 5, 23 r.

Mormons, $442-443,451,468,612$.

Morrill tariff, 488 .

Morris, Gouverneur, 254-255, 257.

Morris, Robert, 255, 257, 268.

Morris Isiand (with map), 534 .

Morristown (with nap), $211-212$.

Morton, Nathaniel, i 5.

Moultrie, Col. William, 20 S.

Mound-builders, $17-18$.

Mount Vernon, home of Washington, $23 \mathrm{~S}$; Miap XII. De.

"Mugwumps," $58_{3}$.

Murfreesboro, $53 \mathrm{I}$; Map XIII. Ee.

Muskingum River, Map, p. I4 I, Ed.

Muskogean tribes, 2 ; Map II. Gc.

Napoleon Bonaparte, in Egypt and Syria, 293; sale of Louisiana to the United States, 312-313; war with England,Berlin and Milan decrees, 320-322 ; trickery with the United States, 333-335; downfall, $346-347$.

Napoleon IIII., 529,567 .

Narragansett Bay, first settlements on (with map), 44 ; Nap I 5 . Bd.

Narragansetts, Irap $I$. Bd; in King Philip's War, 93.

Narvaez, expedition of, ro.

Nashville, Map XIII. De: occupied by General Buell, 506; defeat of Hood by Thomas, 543 .

Nassau, Fort, on the Delaware, Map, p. 47 .

Nassau, Fort, on the Hudson, $4 \mathrm{~S}$.

Nat Turner insurrection, 407 .

National bank system, 532 .

National Republican party, formed in support of the administration of John Quincy Adams, $38_{2-3} 8_{3}$; defeated in $1828,385-386$; and in $1832,400-401,402$; merged in Whig party, 414 .

National Silver party, 595

Naumkeag, 39 .

Nauvoo, 443 ; Map XI. Da.

Navigation acts, English, So, I I I-I 12 .

Navy, in the War of Independence, 226227 ; against the Parbary pirates, 3 Io$311,318,353$ : in the War of $1812,342-$ 344,348 ; in the Civil War, 504-506, 507 . $508-509,512-513,534,542,551$.
Nebraska, territorial organization by Kansas-Nebraska Act, repealing the Missouri Compromise, $460-462$; adnitted to the Union, 564 .

Necessity, Fort, $4_{4} 2$; Mas VI. Ae.

Netherlands, brought under Spanish rule, 12; revolt and independence, 13 . See also Holland.

Neutral rights, violation of, in the wars between England and France, 2S6-2 $S_{7}$, $318,320-322$.

Neutrality, British, in the American Civil War, 493-494.

Nevada, acquisition by the United States, 442 ; territorial organization, $4 \$ 8$; admission to the Union. Appendix B.

New Amsterdam. See New York City : Iaf, p. 47.

New Brunswick, N. J., 212; M/ap, p. 211, Ef.

New England, mapped, named, and described by Captain John Smith, 35; founding of first colonies, $36-45$; decrease of I'uritan imnigration, 46 ; confederation of four colonies, 46 ; substantial independence, 50-52; early political and social development, 62-76; local government, - town-meetings, $70-72$; attitude toward the restored king. Charles II., $8_{I}-8_{2}$; visit of king's commissioners, $87^{-S 9}$; under the rule of Andros, Io I02; population, industries, and trade at the end of the 17th century, 108-112; slavery and indentured servitude in the colonies, 113-114; education and literature, I I-I16; participation and suffering in colonial wars with the French, I23126 ; capture of Louisbourg, $138-139$; the revolutionary rising, 195-196; formation of state governments, 207; strength of Federalist party, 309 ; threatening opposition to the Louisiana Purchase, 3 I3 $^{-}$ 315 ; and to the embargo policy, 324-325; disaffection in the War of $1812,-$ the Hartford Convention, 350-351 ; opposed to protective tariff in 1816,355 ; divided on tariff of $18_{24}, 376$; supports tariff of I $828,{ }_{3} \mathrm{~S}_{4}$.

New France, 25-2S; cessions to England and Spain, I 50 .

New Hampshire, early settlements, 45 ; claimed by Captain John Mason, 46; claimed by Massachusetts, $S_{9-90}$; under Andros, ro2; population and condition in 1685, 108-116: suffering in "Queen Anne's War" (with map), 125; state government formed, 207.

New Hampshire grants, 197-19\$, 279.

New Haven, Conn., first settlement, 42, 43; "Fundamental Agreement," 67: joined to Connecticut colony, $\mathrm{s}_{3} ;$ Maf $V$. Ad.

New Hope Church, battle of, 54I; Maf XIII. Hif.

New Jersey, origin and name, 87 ; sale of West Jersey to Quakers, 95-96; sale of East Jersey to Penn and others, 96 ; under Andros, 102 ; population, industries, and 
trade at end of 17 th century, 108-1 13 ; slavery and indentured servitude, I13-1 14 ; becomes a royal province, 121 ; action upon the news of Lexington and Concord, 196: state government formed, 207 : attitude towards Continental Congress, 255.

New Madrid, 507: .Hap XIII. Cd.

New Mexico, . Map II. Ec: Coronado's expedition to, is : claim by Texas, $437^{-}$ $43 \mathrm{~S}$; acquisition by the Lnited States, $439-4+2:$ as occupied and known in is 49 , Map A:; the question of excluding slavery, - the "Wilmot Proviso," $444^{-}$ 445 ; purcliase of Texas claim, and territorial organization with no reference to slavery, 454 .

New Netherland. See New York.

New Orleans, IKap I.X. Bf; cession by France to Spain, 150: privileges conceded to American merchants, 290: ceded back to France, 312: sold to the United States, 313; discontent of people, plotting with Burr, 3 16-318: battle ( $\mathrm{IS}_{15}$ ). 352-353; first steamboat, 364 ; seizure of Federal property, - General Dix's message, $4 \mathrm{S7}-4 \$ 8$; capture by Farragut, $5 \mathrm{I2}$. New York Central Railway, 6 ro.

New York City, founded by the Dutch and named New Amsterdam, $4 \mathrm{~s}$ : taken by the English and re-named, $86-S_{7}:$ colonial Congress, 1690, 124: Stamp Act Congress, 165 ; mobbing of Governor Colden, 166; treatment of tea-ships, 174: action upon the news of Lexington and Concord, 196; Washington defending the city, 206, 208; taken by the British, 20S209; evacuation by the British, 236, $23 \mathrm{~S}$; progress in ISoo, 306 ; effects of the Erie Canal, 365 ; draft riot, 533-534; "Tweed Ring," 571, 574; early railway connections, 6 ro.

New York Colony and State, aboriginal inhabitants, 20; Dutch occupation and early settlement (with map), $46-45$ : ill-government, ${ }_{4} \mathrm{~S}-4 \mathrm{G}$ : Dutch patroon system, 75; conquest by the English, and grant to the Duke of York, $\mathrm{S}_{5}$ 87; Joss and recovery by the English, 94 ; under Andros, 94-96: Governor Dongan, 06 ; first representative assembly, 96 ; united with New England, under Andros, ro2; population, industries, and trade at end of $i_{7}$ th century, 103-1 13 ; slavery and indentured servitude, I I $;-I_{4}$ : education and literature, $14^{-1} 16$; the revolution of r68S and Jacob Leisler, r 20-12 I : quarrels with the governor, 139 : indifference to French occupation of western couniry, It2; resistance to Billeting Act, - suspension of assenubly, 167: social state at the end of the colonial period, $188-1 \mathrm{~s}$ : strength of Tory party, ISo, 206 ; gradual emancipation of slares, $191-192 ;$ state government formed, 207; Tory and Indian raids in the War of Independence, - Sullivan's expedition, 221-223: cession of land claims to the Confederation,
249-250; struggle over the ratification of the Federal Constitution, 263; claim to Vermont, 279; building of the Erie Canal, $364-36_{5}$ : political factions, "Clin. tonians," "Bucktails," and Anti-Masons, $3 S_{5-3} S 6:$ " spoils system," 395 ; banking law of $183 \mathrm{~S}, 417-41 \mathrm{~S}$; anti-rent disturbances, 430-431; "Barnburner" and "Hunker" Democrats, 450-451; Seventh Regiment at Washington (186r), 493 .

Newark, N. J., $s_{3}$ : Map $I \%$. Dd.

Newbern, N.C., 506; Map, p. 225 , Ed.

Newburgh, Newburgh Address, 236-237; Map !' I. Dd.

Newfoundland, Wap $I^{\circ}$. Ha: ceded by France to England, t26; French tishing rights, 150.

Newport, R. I., Map $I^{*}$. Bd: first settlement, $44^{-}+5$; held by the British, - attacked by Americans and French, 221: French fleet blockaded in harbor, 229.

Newspapers, the first American, rzo; others, early, 137.

Newtown, Mass. (afterward Cambridge), $41-42,66 ;$. Map, p. 39.

Newtown. X. Y. (Elmira), battle, 222 ; Map l. I. Cic.

Niagara, Fort, Ifap $I^{r} I . \mathrm{Bc}$, and p. I $4 \mathrm{Fb}$; in the wars with the French, 135, 145, 146,$150 ;$ in the War of Independence, 222, $22:$; in the War of $1 S_{12}, 346$.

Niagara frontier in $1 \$ 12-14$ (with map), $p$. $3+\mathrm{r}$.

Nicaragua canal route, 603.

Nicolet, I ean, ir 7 .

Nicolls, Col. Richard, governor of New lork and commissioner to New England, 86-87.

Niles, Samuel, rq.

Nipnucks. 93: .Map I'. Bd.

Nominating couventions, their beginning, $400-40$ r (foot-note).

Non-importation measures, colonial, 170, $172,17 S$; in Jefferson's administration, $323-326$.

Non-intercourse Act, 325-326, 332-335.

Norfolk, Va., 508, 509 (with map), 512.

North, Lord (Frederick, Earl of Guilford), head of the British ministry, 168: repeal of the Townshend Acts, 170: olive branch offered to the colonies, 178 ; overtures for peace, $219-220$; resignation, 233.

North Anma River, battle of, 540: Map XII. Cg.

North Carolina, early settlements, $s_{4}-s_{5}$ : proprietary government, $8_{5}$; population, industries, and trade at end of $i ;$ th century, 10S-113, 123; slavery and indentured servirude, 113-114; Indian War $(1 ; 11-13), 130$; became a royal province, 133; Scotch-Irish settlements, 136; the "Regulators," 171 ; first hostrlities with the royal govermment, 197; battle of Moore's Creek, - resolution for independ. ence, 205; state government formed, 207; Greene's campaign against Corn. 


\section{INDEX}

wallis, 230-231; cession of land claims to the Confederation, $249^{-250}$; tardy ratification of the Federal Constitution, 264,276 ; session declared, 494 ; emancipation proclaimed, $52 \mathrm{~S}$; restored to the Union, 564-565.

North Dakota, included in Nebraska Territory, 461 ; in Dakota Territory, 488 ; admitted to the Union, 588.

Northmen, discovery of America by the, $\mathbf{r}$.

Northwest passage, search for, $9-$ ro.

Northwestern territory, the old, claimed by Virginia, 20-30, I40; conquest by Clark, 223-224; yielded to the United States by Great Britain, 234 ; cession of state claims, $249^{-250}$; Ordinance of $1787,264-265$; reënacted in 1789,271 ; population in 1800,307 .

Nova Scotia, Map l. Fic; grant to Sieur de Monts, 25; ceded (as Acadia) by France to England, 126: dispersion of Acadian French, 146-1 47 .

Nueces River, 437,$438 ;$ Marh, p. 440 .

$\mathrm{Nullification,} \mathrm{the} \mathrm{doctrine} \mathrm{of,} \mathrm{first} \mathrm{formu-}$ lation, 294-295; revived in South Carolina, $397-398$; nullifying ordinance, 402404 .

O'Conor, Charles, 560.

Ogdensburg, 343 .

Oglethorpe, Gen. James, 133-134.

Ohio Company (of 1748), r39; (of 1787), $264-265$.

Ohio River and Valley, historical influence, 23-24; English neglect, 134-135; French and English struggle for (with map), I30149 ; colonial indifference to French occupation, 142-143; cession by France to England, 150; settlement prohibited by George III., I63; added to the province of Quebec, 175; beginnings of settlement, 136, 223; yielded by England to the United States, 234-235; cession of state claims, $249^{-250}$; inportance of a right to navigation of the Mississippi, 255; population in $\mathbf{s} 800,-$ detacliment in interest from the east, 307 ; Burr's conspiracy, 316-318; democratic conditions of society, $36_{3}-36_{4}$; settlement promoted by steam navigation, 364,412 , 609-610; development (1820-40), 411412.

Ohio, the State, under the Ordinance of ${ }_{7} 87,264-265$; territorial and state organization, 307 .

Oklahoma, 588 .

Oneidas. See Iroquois.

Onondagas. See l roquois.

Orange, Fort. 48 ; Map, p. 47.

Orders in Council, British, 320-322.

Ordinance of $1787,264-26_{5}$; reënacted by Congress in $1789,271$.

Oregon, Lewis and Clark's exploration, 319; American and English claims, joint occupancy arranged (1818), 370 ; settlement of the boundary dispute, 435437; as occupied and known in 1849 , $\Lambda \operatorname{Tap} X$. ; territorial organization, exclud- ing slavery, $444^{-445}$; admission to the Union, 470 (foot-note); disputed electoral returns, 1876,574

Orinoco River, $6 ; \operatorname{Map} 11$. If.

Oriskany, battle of, 214 ; Map, p. 145.

Orleans, territory of, 314,336 .

Ostend manifesto, 460 .

Oswald, Mr., 233-234.

Oswego, г 35, г 46,$147 ;$ Map VI. Cic.

Otis, James, $161,190$.

Pacific Ocean, discovery of, 9 .

Pacific railways, 6ri.

Pacific slope in 1849 , Nap $X$.

Paducah, 502; MIap XIII. Cd, and p. 503.

Paine, Thomas, I90, 204, 2 10.

Pakenham, Gen. Sir Edward M., 353

Palatinate, in Maryland, 33, 68; in the Carolinas, 84.

Palmer, John M., 594-595.

Palo Alto, battle of, $439 ;$ Map, p. 440

Panama, Map $I I$. Hf ; Congress (1825), $38_{3}$; Clayton-Pulwer canal treaty, 456457 ; Hay-Pauncefote treaty, - Isthmian canal act, 6o2-603.

Pan-American Exposition, 6or.

Panics, financial. See Crises.

Paper money, irredeemable, "Continental currency," 2I 8,228 ; after the War of Independence, 253-254; "wild-cat" banking, $367-368,412-413$; legal tender notes, - "greenbacks," 510, 532, 570$571,572-573$.

Parishes, 71-72.

Parkman, Francis, on French treatment of the Indians, 28.

Parsons, Gen. Samuel, 264.

Parties, Political. ${ }^{1}$ See Federalists of ${ }_{7} 8_{7}-$ 88; Federalist party ; Anti-Federalist party; Republican party (Democratic 1793-1825); National Republican party; Democratic party; Anti-Nlasonic party; Whig party; Liberty party; Free Soil party; Barnburner and Hunker Democrats: Republican party (Anti-slavery); American ("Know Notling") party"; Constiutional Union party ; War Democrats; Copperheads; Liberal Republicans; Greenback party ; Prohibition party; Independent Republicans (" Mugwumps "); People's (Populist) party; National Silver party; Labor parties. See also Appendix C.

Patriot war, Canadian, 4I8-4I9, 431.

Patroon system in New Netherland, 74$75,188,430-43 \mathrm{I}$.

Patterson, Gen. Robert, 501.

Patuxent River, Map, p. 349.

Pauncefote, Rt. Hon. Sir Julian, 6o2.

Pawnee tribes, 2 I.

Pea Ridge, battle of, 507; IIap, p. 503, Ab.

Peace conferences in the Civil War, 544, 546.

1 These parties are named in the chronological orler of their appearance in American politics. 


\section{INDEX.}

Peace Convention, 186I, $485-489$.

Peace treaty with Great Britain $\left(17 S_{3}\right), 234^{-}$ $235 ;\left(181_{4}\right), 351-352$.

Peaceable coercion, Jefferson's theory of, 310; its trial, 323-325.

Peach Tree Creek, battle of, 54I; Map XIII. Ff.

Peage money, $\mathrm{St}^{-52}$.

Pearl River, Map XI. Eb.

Pendleton, Edmund, 176.

Pendleton Act, 582 .

Penhallow, Samuel, igr.

Peninsular campaign, McClellan's, 5ir$512,513-514$.

Penn, William, in New Jersey affairs, 96 ; early life and character, 96-97; obtains grant of Peunsylvania, $97-98$, founding of colony, 97-99; "Frame of Government," 98 ; temporarily deprived of authority, 121-122; second visit to his colony, - "Charter of Privileges," r22 ; death, 136.

Pennsylvania, Dutch claims, $47-48$; founded by William Penn, 96-99; "Frame of Government," $9^{\$-99,}$ 100: population, industries, and trade at end of 17 th century, 103-113; slavery and indentured servitude, $\mathrm{II}_{3}-\mathrm{II}_{4}$; education and literature, 116 ; Penn temporarily deprived of authority, 121-122: "Charter of Privileges," I22; indifference to French encroachments in western parts, I $42-143$; ending of slavery, I92; state government formed, 207; Connecticut land claims, 249-250; whiskey rebellion, 288: prosperity in 1800,306 .

Pensacola, 369,487 ; . Hap XI. Eb.

People's (Populist) party, 590, 594.

Pepperel, Sir William, 139.

Pequots, 42-43; Map $V$. Bd.

Percy. George, I 6 .

Perdido River, Iap $\mathrm{X} T$. Eb.

Perry, Capt. Oliver H., 344-345.

Perry, Commodore Matthew C., expedition to Japan, 457.

Perryville, battle of, 52S-529; Map XIII. Ec.

Petersburg, Va, Map XII. Ci, and p. 225. Ea : military operations at, $54^{1}$; Confederate evacuation, 547 .

Petition, the right of, struggle in Congress over, $408-410,435$.

Philadelphia, Map $I T$. Ce ; founded, 99 ; rapid growth, 122; arrival of Benjamin Franklin, 137; treatment of tea-ships, 174, first Continental Congress, 175176; action upon the news of lexington and Concord, 196; second Continental Congress, I98-200: occupied by the British, 216; evacuated by the British, 220; flight of Congress to Princeton, 237 ; prosperity in 1800,306 ; Centennial Exposition, 573 .

Philippi, battle of, 500 ; Nhop, p. 499, Da.

Philippine Islands, Mop . $\mathrm{I}^{-1}$. Ab, Ac: discovery by Magellan, 9 ; naval and military operations, I $\$ Q S,-$ acquisition from Spain, 597-599; suppression of na- tive revolt, - establishment of civil government, 599-600.

Phips, Sir William, 124.

Physical features of North America, 22-24.

Pickens, Andrew, 227.

Pickens, Fort, $4^{S} 7$; Map XIII. Di.

Pierce, Franklin, election and administration, $45^{s-465}$.

Pilgrim fathers of New England, 36-37.

Pillow, Fort, 513 ; Map XIII. Be.

-Pinckney, Charles C., 292.

Pineda, Alvarez de, 9.

Pine-tree shillings, 52 .

Pinkney, Thomas, $29 \mathrm{r}$.

Pitt, Fort (Fort Duquesne, - Pittsburg), I Iap VI. Ad.

Pitt, William, the elder, Earl of Chatham, his conduct of the war with France, $14^{8}$; resignation of prime ministry, 160 ; opposition to the Stanup Act, 166: nominal premiership, - accepts peerage, 167 ; opposituon to king's colonial policy, 178 ; tribute to the Continental Congress, 190; opposition to American independence, death, 2 I9-220.

Pitsburg, Map $X I$. Fa; English and French fort building, 141; the French Fort Duquesne, 145: expulsion of French, $\mathrm{I} 47$; named Fort Pitt, - Indian siege in Pontiac's WVar, 151 ; first steam. boat (I8I I), 364 .

Pittsburg Landing, so6; Map XIII. Co.

Plattsburg, battles at, $34^{8}$.

Plymouth Colony, founded by the Mayflower Pilgrims, $3^{6-37}$; population in I640, 46; a self-constituted republic, 6465,69 ; under Andros, 102; population, etc., 1688, 108-116; annexed to Massachusetts, 120.

Plymouth Company, grant to, 29; failure of Popham colony, 3o: reorganized as The Council for New England, 37.

Point Pleasant, battle of, 172; Map, p. I41.

Pokanokets. See Wampanoags.

Polk, James K., elected President, 433434: programme of his administration, 435,444 ; war with Mexico, 437 .

Ponce de leon, Juan, 9.

Pontiac's War, i 51.

Pope, Gen. John, capture of New Madrid and lsland No. 10, 507: command of the Army of Virginia, 514; defeat by Lee, 527.

Popham colouy, $30 ;$ Map I. Cc.

Popular sovereignty, the doctrine of, $46 \mathrm{r}$, $467,47 \mathrm{I}$.

Population, of colonies (168\$), ro8-109; (1775), 1 86 ; of United States (1790), 276 ; (ISoo), 306-307; (1820-IS40), 411-412; ( 1560$) .496$; epochs of movement, 609$61 x, 612-613$.

Populist party. See People's party.

Port Bill, Boston, 174.

Port Hudson, 533; Map XIII. Ai.

Port Roval, N. S., 25; Map I'. Ec.

Port Royal, S. C. 506: Nap, p. 505.

Porter, Admiral David D., 533, 544. 


\section{INDEX.}

Porter, Gen, Fitz John, 514.

Porto Rico, $M$ Tap XVI. He; acquisition from Spain, 59\$-599; civil government established, 600 .

Portsmouth, R. I., 45 ; Nap, p. 44.

Portugal, early enterprise in maritime exploration, 3 ; first voyage round Africa, to India, 7 ; progress blighted by Spanish rule, $12-13$.

Pory, John, i16.

Postal system, early colonial, $\mathbf{3} 0$

Pottawotomie Creek, $464 ;$ Map XIV. Hc.

Prescott, Col. William, 200 .

Presidency, Act to prevent a vacancy in the, 585 .

Presidential Elections, Appendix C.

Presque Isle, I40. I50, 344; Map I'T. Ac, and p. $1_{4} \mathrm{I}, \mathrm{Fc}$.

Press, the. See Printing and Newspapers.

Pretender, the, rzo.

Prince, Thomas, ror.

Princeton, bat tle of (witl map), 211-212.

Pring, Martin, 28.

Printing, the first process in the colonies, 116.

Privateers, American, in the War of 1812 , $342,344,352$; Confederate, $1861-65,493^{-}$ 494 .

Progress and Change, Epochs of, 609-623.

Prohibition party, 5SI, 595 .

Proprietary provinces: Maryland, 69 ; the Carolinas, 84 ; New York, 86; New Jersev, 87 ; Pennsylvania, 96-98; changed to royal provinces: New York (by Duke of York becoming king), 101; Pennsylvania (temporarily), 121; New Jersey, 121; Maryland (temporarily), 122-123; the Carolinas, 133.

Protective policy, industrial, applied by England to the colonies, 128, 132-133; state protective tariffs under the Articles of Confederation, 253; first national tariff, 272; Hamilton's proposals, 280; tariff of $18_{1} 6,354-355$; tariff of 1824 , Clay's American system, $375-376$; reaction against the protective policy in the soutl, 382 ; upheld by the National Republican party, $382-383$; Massachusetts accepts protective policy, - the "tariff of abominations" ( 828 ), 384; doctrine favored by President Jackson, 397 ; nullification of tariff laws proposed in South Carolina, 397-398; tariff act of 1832,401 ; nullifving ordinance of South Carolina, the "compromise tariff" of $1832,402-$ 404 ; tariff of 1842,430 ; Walker tariff, 1846, 444; reciprocity treaty witl Canada, 460: Morrill tariff, I860, 488; Civil War tartff, 500, 510; tariff message of President Cleveland, I $88_{7}$, - the Mills Bill, 586 ; the McKinley tariff, $588-580$; the Wilson tariff, 593 ; the Dingley tariff, 595 ; stimulation of manufactures in recent years, 6i3-6i 5 .

Providence, R. I., Map $V$. Bd; the founding, 43-44; colony established by royal patent, 45 ; organization, $67-68$; religious liberty established, 68 ; chartered with Rhode Island, $83-84$. See Rhode Island.

Puebla, Mexico, Map, p. 44 I.

Pueblo tribes, irrigation by, 612 .

Pueblos of the Zuñis, 11, 19.

Pulaski, Count Casimir, 225.

Pulaski, Fort, 506.

Puritanism liberalized, 366.

Puritans, origin, 14; struggle in England with King Charles I., 38; extensive emigration to New England, 38-40; religious exclusiveness in Massachusetts, 4 i ; decrease of immigration to New England, 46: expulsion frcm Virginia and settle. ment in Maryland, 73 ; conduct in Maryland, 54 .

Putnam, Gen. Israel, 196, 199

Putnam, Gen. Rufus, 264.

"Quaker guus," 5o8.

Quakers (Friends), persecution in Massachusetts, 52-53; purchase of West Jersey, 95-96; Willian. Penn and Pennsylvania, 96-99; early opposition to slavery, 114, 192; and to military expenditure, 142 ; memorials against slavery, 275 .

Quebec, Map $V$. $\mathrm{Bb}$; city founded by Champlain, 26; colonial English expedition against, 124; capture by Wolfe (witl plan), 148-149; name given to eastern Canada, and English government organized, I63; enlargement of the province, - the Quebec Act, 175 ; addressed by the Continental Congress, 177; unsuccessful attack on the city by Arnold and Montgomery, 202-203.

"Queen Anne"s War" (with map), r24I 26.

Queenston Heights, battle of (with map), $34 \mathrm{I}-342$.

Quincy, Josiah, 336 .

Railways, beginnings, 412; development in the middle of the century, 456 ; excessive building, 1868-73, 571; Inter-State Commerce Commission, 586; epochs of the railway in the development of the country, 6io-6in, 6is.

Raisin River, battle of, 343 ; Map, p. 345 .

Raleigh, Sir Walter, 15 .

Rambouillet, decree of, 334 .

Randolph, Edmund, roo.

Randolph, Jolnn, 330, 3.39.

Randolph, Peyton, $176,190,198,257$.

Rapidan River, Mas $X I I$. Bf.

Reciprocity treaty with Canada, 460 .

Reconstruction, President Linco!n's plan, 536-5.39; last statement of his views, $547^{-}$ 548 ; President Johnson's measures, $56 \mathrm{I}-$ 562; Congressional action, - military reconstruction act, $562-565$; working of the measures of Congress, $565-566,568$; withdrawal of Federal forces by President Hayes, 575-576.

Redemptioners, 76 .

Red River, $360 ;$ Map XI. Db.

Reeder, Andrew H., 464. 


\section{INDEX}

Regicides, $s_{3}$.

Regulators, the Carolina, $r 7$.

Religious Liberty. See Liberty, religious.

Remorals from othice. See Spoils System, and C'vil Service Reform.

Representation, taxation without. See laxation.

Represemation, virtual, the theory of, 164 .

Representative govermment, established in Maryland, 34. os; in Virgmia, 62; in Plymouth Colon, 03: in Massachusetts Buy Colony, vo: English origin in all the colonies. 0q-jo: older Germanic origin, 7s: in Jew Jersey, 87: in N"ew lork. 96 : in Pennsyluania, 97-99: in the Union, $250-201$

Representatives, House of, proportionate representition and slave representation, 260-261: loss of ground by slaveholding States, 37 .

Republican party (Anti-Slavery), its rise. 4 2: election of Speaker Banks. $45+$ : momination of Frémont for President. $45-406$ : conviction and purpose stated by Lincoln and Seward, $+72-473$; election of Abraham Lincoln, President, +75475; in control of Congress, 4 s: reelection of Lincoln, 5+3-5t4: rupture with President Juhnson, 505-566: election of Grant, 565: reelection of Grant, 56S-500; election of Hayes, $57+-575$; election of Garfield, $5 S_{1}$; defeat in $15 S_{4}$, \$33: election of Harrison, $5 \$-5 \$ S$ : defeat in $18,2,50$ : election of Mchinley. 504-505: reelection of Mckinley, 601.

Republican party (Demucratic, 1-03-1 525 ), name assumed by the Anti-Federalists, 280: nullifving doctrines in Kentucky and Virgina resolutions, $294-275$ : electiun of Jefferson. President, 296 inconsistency on the Louisiana question, $3 \mathbf{1}_{3}-$ 34 : mopnosed in the period of Monroe $306.3+-3-5$; beginning of division, $3-0$ : division complete. forming the Democratic party and the Nation.l Republican party, :32-3:

Resaca de la Palma, battle of, +30 : . M.zs, p. 4 to.

Resumption of specie payments, See specie paymenis.

Revere, Paul, ras.

Revolution, the American, 194-234.

Revolution, the English, of $16+2-4$ ), 4950, 80-8t; of $168-102,105$.

Rerolusion, the French, $2 S_{4}-255$.

Rhett, R. Barnwell, $4+5,+5 t$.

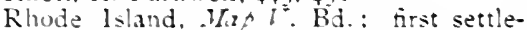
ments and naming (with map), $\$ 5-45$; self-organization of sovernment, $6=-68$, (a): royal charters nbtained, s; $-s_{4}$; under Andros, 102: population industries, and trade at the end of 1 -th century, ros-is slavery and bond service, $113-114$ : education and literature, Itf-1i6: engagement in the slave trade. r93: declares for independence, zo5-zo6: state sovernment formed, 20-: recall of delesates from the Continental Congress, 255 : re- fusal to send delegates to the Federal Constitutional Convention, 253 : tardy ratification of the Constitution, 264, 270; Dorr rebellion, +30 .

Rich Mountain, battle of, 500 ; . Wrzs, p. 499 Lb.

Richmond, Dean, +50 .

Richmond, Va., Has XII. Ch: capital of the southern Confederacy, 511: peninsular campaign against, $511-512,513-$ 5It: Grant's campaign against, $539-540$. 541: Confederate evacuation, - destructive fire, - visited by President Lincoln, $54 i$.

Rio Grande River, 371: . Mas . KI. Cc.

Roanoke lsland, 15, 506; Mip II. Hc, and p. 505.

Rochambeau, Count de, 22\$-229.

Rockingham, Marquis of, 166, 233.

Roman Catholic Church, French missions to the Indians, $2 s$ : refuge in Maryland from English persecution, 33-34; experience in Maryland, 53-54, $122-1=3$.

Roosevelt, 'Thecdore, on Commodore Macdonough, 34:; Vice-President, becomes President, tor $_{2}$ action relative to coal strike, 6 Is.

Rosecrans, Gen. William S., commanding in 11 est Virginia, 503: in command of the Army of the Cumberland, 530-531, 535: succeeded by Thomas, 530 .

Rotation in office, 305

Koyal provinces. or Crown colonies, Virginia subjected to the direct authority of the king, 33 : the proprietor of New lork becomes king, tol: Massachusetts loses its charter and becomes a royal province. 100-102, 110-120: New Jersey, 121: Pennsylvania (temporarily, 121 Mary. land (temporarily). $122-123$ : the Caroli. nas, 133 : Georgia, 134 .

Rumser, James, 30 .

Rush, Richard, $3 s_{5}$.

Russell. Jomathan, ist.

Russia, settlement of American boundary. 40 : sale of thaska, 560 .

Rutledge, Edward, $1-6$.

Rutledge, John, $1,6,217,25 \$$.

Ryswick, Treaty of, $12+$.

Sabine River, 360: M.xp . II. nb.

Sackett's Harbor, ift: . Mar I.X. Ec.

Saco, Me, rz5: ihat: Bc.

Sacramento, +43 : What . A t b.

Sacs and Foxes, 307; Mas, p. 141.

St. Clair, (ien. Arthur, $265,2 S_{1}$.

St. Lawrence Gulf and Kiver, discovery by Cartier, 10: .M/zh $I I$.

St. Lawrence river and lake system, Mas 1. ; historical influence, 23 : French exploration and occupation, i16-318, ito: English conquest, 140-150. See also Lakes, Basin of the Great.

St. I,eger, Col. Barry, zit.

St. Louis, Ma . I I B. Bc: Secessionists baftled ( $1 S 61$ ) , 405-406: labor riots, $5 \$ \%$ St. Marks, $360 ;$ M/2s . II. Eb

St. Mary's, Md., 3t: . Wh t'll. Db. 
Salem, Mass., Map $l^{r}$. Bd; the founding, 39; witchcraft maduess, 129 .

Samoset, 37 .

Sampson, Admiral William T., $59 \$$

San Antonio, battle of (with map), 44r.

Sand usky, (). ; Map, ए. $3+5$.

Sandys, Sir Edwin, 62 .

Sandys, George, I 16.

Sanitary Commission, United States, 560.

San Jacinto, battle of, 4 I i Map $\mathrm{A}^{\prime}$. Dc.

San Juan Hill, battle of (with map), 59759.3.

Santa Anna, $410-411,440-44$ I.

Santa Fé, $44^{\circ}$.

Santiago de Cuba, military and naval operations at (with map), 597-599.

Saratoga, 139, 2т5; Mhap IF. Dc, and p. 213.

Savage Station, battle of, 514; Map XII. Dls.

Savannal, Map VII Be, and p. 225, Ah; founded, 134; taken by the British, unsuccessful American siege, 224; reduction of Fort Pulaski in the Civil War, 506 ; reached by General Sherman, 543 .

Savannah River, II; Map II. Gc.

Say and Sele, Lord, 42.

Saybrook, 42; Miap $Y$. Ad.

"Scalawags," 565.

Scluenectady, 124; Mab $l \%$. Dc, and p. 125.

Schley, Admiral Winfield S., 59 S.

Schofield, Gen. John M., $5+3$.

Schools. See Education.

Schurz, Carl, on Lincoln's second iuaugural, 546.

Schuyler, Gen. Philip, ro9, $2 \times 5$.

Scientific discovery, 6r5

Scotch-Irish, the, $135^{-136,230,495 .}$

Scott, Gen. Winfield, in battle of Queenston Heights, 342: at I.undy's Lane, 347 ; in the Mexican War, $440-442$; nominated for President and defeated $\left(\mathrm{IS}_{52}\right), 45 \mathrm{~S}-459$; retirement from general conmand of the army, 503.

Scrooby Independents, 36 .

Seal-fishery dispute, $584-585$.

Search and impressment, British, 287-2 88 , $2 S_{9}, 318,322-323$; cause of war, 340; unnentioned in treaty of peace, 352 .

Secession, threats and suspected intentions of New England Federalists, in I $803^{-4}, 314,315-316$; in 1811, 336; in r8I2-r5, 350-35r; threats from the slaveholding interest, in $1820,372-374$; in I $\$ 32,402$; in $1850,452-454$; in 1856 , 466 ; in $1860,474:$ declared secession of seven States, December, $1 \$ 60-1 \mathrm{eb}$ ruary, IS6I, 4\$4-4\$6: further secession movement in four States, April-May, I86r, 494-495.

Second war with Fngland, 339-353.

Secret societies, disloyal, 553 .

Sectionalism, the northern and southern division, - slavery and wher causes, 309; effects of sectional differences in interest, 323,338 ; even balance in num- ber of free and slave States, 371. See Slavery.

Sedition Act, 293-294.

Seminole Indian wars, 368-369, 396-397; Map XI. Ec.

Senate, state representation in the, $259-$ 260; balance maintained between free and slave States, 37 .

Senecas, Map VI. Br. See Iroquois.

Separatists. See Independents.

Seven cities of Cibola, I r .

Seven Days' battles, $5 \mathrm{t}+$

Seven Pines, battle of, 5 13; Map XII. I) h.

Seven Years' War, 146-150.

Seward, William H., opposes the Compromise of 1850,453 ; allusion to a "higher law," 455 ; enters the Republican party, 463 ; statement of the "irrepressible conflict," $472-473$; Secretary of State under President Lincoln, 490; advice concerning emancipation proclamation, 527; at peace conference with VicePresident Stephens, 546; attempt to murder, $549^{-550 ;}$ purchase of Alaska, 567.

Seymour, Horatio, 568 .

Shackamaxon, 99 .

Shafter, Gen. William R., 597-598.

Shaw, Col. Robert G., 534.

Shelburne, Earl of, 233-234.

Shenandoah Valley, 135, 501, 512, 541-542; MIap XII. Bd.

Sheridan, Gen. Philip H., in battle of Stone River, 53I ; commanding cavalry of the Army of the Potomac, 539; campaign in the Shenandoah, 541-542; at Five Forks, 547.

Sherman, John, 577 .

Sherman, Roger, 176.

Sherman, Gen. William I'., in operations against Vicksburg, $53 \mathrm{I}, 533$; commanding the Army of the Tennessee, - at Chattanooga, 536; succeeds Grant in general western command, - plan of cainpaign, - forces, 539-540; movement on Atlanta, 540-541: march to the sea (with map), 542-543; northward movement from Savannal (with map), 544545: great review of army, $55 \mathrm{I}$.

Sherman Act, 580-590, 591-502.

Shiloh, battle of, 506, 513 , imp $X I I I$. Cf.

Shipping, American early, 1og-1 13 .

Shires, 7 I.

Shirley, Governor WVilliam, 145,146

Shoshonean tribes, $2 \mathrm{r} ;$ Map $/ 1$. Dc.

Sigel, Gen. Franz, 502, 530, 541 .

Silver question, its opening, - the Bland Act, 576-577; the Sherman Act, 5 S9-59o; monetary crisis produced by the Sherman Act, 591-592: partial repeal of Sherman Act, 592: the silver question in the election of $\mathrm{r} 806,594-595$; monetarv commission to Furope, 595; the standard "dollar" defined funally in gold, 596: silver question in the election of rooo, 6or.

Sionx, - Siouan tribes, 21, 570; Map II. $\mathrm{Fb}$, and $X I$. Ca.

Sitting Bull, 570. 


\section{INDEX.}

Six Nations, the, 130. See Iroquois.

Slavery, physical influences faroring, 24: beginnings in the colonies, 75; established in the Carolinas, 85 ; as existing in the colonies at end of inth century, 113-114; forced by English interests, I 13 ; earlv Quaker opposition, 114 ; futile prohibition in Georgia, 134; class distinctions caused by, IS5: in the States when they became independent, 191192; fostered in the colonies and forced on them by the English government, 192-r93: the slave tracte of England and New England, 192-193: compromises of the Constitution on slavery questions, 2tro-262; exclusion from the Northwest Territory by ordinance of $1757,264-265$; proposal to tax importation of slaves, 272 ; action of Congress on first abolition memorials, 275-276; slaves north and south in $1 \$ 00,306$; effects of the cottongin, 308-309; abolition of the African slave trade, 320; opening of the question of slavery extension in the Territories, 371-372: the Missouri (ompromise, 372374 : cause of reaction in the south toward extreme doctrines of State Rights and strict constructions of the Constitution, $3 \mathrm{~S}_{\mathrm{I}}-3 \mathrm{~S}_{2}$; beginning of aggressive anti-slavery agitation, - the abolitionists, 405-406: alarm and anger in the south, - differing effects in the north, 406-407; suppression in Congress of the right of petition, - attempts to exclude antislavery literature from the mails, 4os4ro; Calhoun as the leader of agitation, 4ro: slavery carried into Texas, - the Texas question opened, $410-411$ : expansion of slavery by annexation of Texas, $431-434$; the right of petition established, 435: intensifying of the question of slavery in the Territories by the conquests from Mexico and the Oregon treaty, - the "Wilmot Proviso," 444445 ; new theory of slaveholding rights. $445^{-4} 4^{6}$ : the question in the election of $184 \mathrm{~S}, 450-451$ : pro-slavery and antislavery demands, and the Compromise of $\mathrm{I} 50,45 \mathrm{I}-454$; the Fugitive Slave Law, 454-456: "personal liberty laws" and the "Underground Railway," $455^{-}$ 456: anti-slavery apathy in $1852,45^{\circ-}$ 450 ; repeal of the Missouri Conpromise by the Kansas-Nebraska act, $460-462$; rise of the Republican party, 462 : the strife for Kansas, $4^{6} 3-464$ : Dred Scott decision, 466-467; the Lecompton fraud in Kansas and its defeat, $468-470$; I incoln and Douglas dehate, 470-471: further claim of a slaveholding right to protection in the Territories, 472: Lincoln and Seward's statements of the issme concerning slavery, - purpose of the Republican party, 472-473: John Brown's attempt at Harper's Ferry, 47.3-474; election of Abraham Lincoln, 475-476; slavery a source of military strength in the Civil War. $48^{8}$; slaves declared con- traband of war, $498-499$; act to confiscate property for insurrectionary purposes, 500; Frémont's proclamation of emancipation, 502-503; compensated emancipation offered and urged, 5 ro; rendition of fugitive slaves by the army forbidden, - compensated emancipation in the District of Columbia, 51 1 ; principles that governed President Lincoln's dealing with slavery, 525-526; his proclamation of emancipation prepared, 526-527; emancipation proclaimed, 529; slavery prohibited by the Thirteenth Amendment, 545; abolished by state action in Maryland, Missouri, Arkansas, Louisiana, and Tennessee, 545 (footnote).

Slemmer, Lieut., $4 S_{7}$.

Sloat, Commodore Jolnu D., $44^{\circ}$.

Sloughter, Col., r 20 .

Smith, Caleb B., 490.

Smith, Capt. John, in Virginia, 30-31; naming and describing of New England, 35; writings, I16; Map of New England, IIap III.

Smith, Joseph, 443.

Smith, William, 116, 191.

Social development, early colonial, 73-76; later colonial, $188-1 S_{9}$; after the second war with England, 362-364; since the Civil War, 617-619.

Sonora, 19: Map II. Dc.

Sons of Liberty, $165-166$.

Soto, Fernando de, expedition of, 11 .

Soulé, Pierre, 460 .

South America, discovery by Columbus, 6: Spanish American revolutions, 335, $376-377$.

South Carolina, early settlements, $8_{4}-S_{5}$ : proprietary government, 85 ; population, industries, and trade at end of izth century, 10S-113, 123; slavery and indentured servitude, I 13-1 44 ; rice cultivation, 120 ; proprietary govermment overthrown, - becomes a roval province, 133 ; ScotchIrish setulements, 136 ; social state at the end of the colonial period, $t 88$; first hostilities with the royal government, 197; organization of a state government, 205; state government formed, 207: subjugation by British forces, 224-226, 227 ; deliverance by Greene, 231-232: cession of land clains to the Confederation, 249250: nullification movement, ${ }_{1} \mathrm{S2S}_{2} \mathbf{3 2}$, $397-399,401,402,404$ : ordinance of secession, is6o, $4 \$_{4}, 486$; emancipation proclaimed, $52 S$; restored to the Union, $564-565:$ disputed electoral returns, 1876 , 574 : withdrawal of Federal military authority, 575 .

South Dakota, included in Nebraska Territory, $461 ;$ in Dakota Territory, $4^{8 S}$; admitted to the Union, 588 .

South Mountain, battle of, 52S; Map XII. Cic.

"South Sea," early notion of the, 9-10.

Spain, clain to countries discovered by Columbus, 5 ; papal grant, 5 ; explorations and conquests in America, 9-11; 


\section{NDEX.}

decay of the nation, 12-13; war with England, 1739, 137-139; acquisition of Louisiana and New Orleans from France, and cession of Florida to England, 150 ; alliance with France against England, 219 ; treaty with United States, freeing the navigation of the Mississippi, 290; cession of Louisiana to France, 312 ; revolutions in American colonies, - American occupation of IV est Florida, 335, 336; sale of Florida to the United States, and definition of western boundaries, 369 ; revolution in Spain and in Spanish-American provinces ( $1 S_{20}-23$ ), 376 ; revolt in Cuba, -- war with the United States, 596599 ; cession of territory, 599.

Spanish-American War, 596-599.

Specie circular, President Jackson's, 413$4 \times 4,416$.

Specie payments, suspended, IS37, 416 ; resumed, $18_{3} 8,418$; suspended, 1861 , 509-510; preparation to resume, 572 ; opposition to resumption, 573 ; resumption accomplished, 577 .

"Spoils System," origin in state politics, -introduction in the national public service, 394-395; vices intensified, 570571 ; beginning of reform, $571-572$; cause of the murder of President Garfield, $5^{82}$; checked by President Cleveland, $5^{8} 3$.

Spotswood, Alexander, $134^{-1} 35$.

Spottsylvania Court House, battle of, $54^{\circ}$; Map XII. Cf.

Springfield, Mass., $46 ;$ Nap $V$. Ad.

"Squatter sovereignty," $461,467,471$.

"Stalwarts," $58 \mathrm{r}$.

Stamp Act, $164^{-167}$.

Standard of value, the question, 576-577, 589.

Stanton, Edwin M., 487, 490, 566.

Stanwix, Fort, $214 ;$ Map, p. 145.

Star of the West fired on at Charleston, 488.

Star Spangled Banner, the song of the, 349-35o.

Stark, John, 196, 214.

State Rights and State Sovereignty, the contention for, concession to it in the 'Tenth Amendment to the Constitution, 273 ; early issue between parties, $277-278$, $283-284$; state rights reaction in the south, $381-382$; nullification as a state right, 294-295, 397-398; secession as a state right, $494^{-495}$.

State Sovereignty. See State Rights.

Staten Island, M K p, p. 209.

States, list of, with dates of admission to the Union, etc., Appendix B.

Statistics of the Civil War, 550-552.

Steam-engines, number in the country in 1803, 307-308; development and effects, $615-616$.

Steam locomotion. See Railways.

Steam navigation, beginnings, 308 ; early development on American lakes and rivers, 364,412 ; supplanting sails on the ocean, 456 .

Steel manufacture, development and cheapening, 613-6r4.
Stephens, Alexander H., 484, 486, 489, 546.

Steuben, Baron Friedrich, 218-219, 232.

Stillwater, battles near, 215; Map, p. 213.

Stith, IVilliam, sor.

Stockton, Commodore Robert F., 440.

Stone, William, 53-54.

Stone River, battle of, 531 ; Map XIII. Ee.

Stony Creek, battle of, 345 .

Stony Point, 224 ; Map, p. 209.

Stowe, Harriet Beecher, 456 .

Strachey, William, I 6.

Strict constructionists, 278, 2So, 3 I 4, 354 $381-382$.

Stuyvesant, Peter, 49, 87 .

Sub-treasury system, 417 .

Suffolk County resolutions, 177 .

Suffrage, political. See Elective franchise.

Sugar Act, 162.

Sullivan, Gen. John, 199, 221-223.

Sullivan's Island, 208 ; Map, p. $225, \mathrm{Bl}$.

Sumner, Charles, on the effects of the Kansas-Nebraska Act, $4^{6} 3$; assaulted by Preston Brooks, 465 .

Sumter, Thomas, 227 .

Sumter, Fort, held by Major Anderson, 487,488 ; altacked and taken by the Confederates, 490-491; the flag restored, $54^{8}$; Map, p. 534 .

Supreme Court, Chief Justice Jay, 273 ; Chief Justice Marshall, 296; important early decisions, 308 ; Chief Justice Taney, - Dred Scott decision, 466-467; Chief Justice Chase, 544 ; decisions on the Legal 'Iender Act, 5 10; decision that the seceded States were never out of the Union, 548 (foot-note); decision concerning citizenship, national and state, 563 (foot-note); decision against constitutionality of the income tax, 593.

Surplus revenue, distribution of, $4^{13}-4^{1} 4$.

Surratt, Mrs. Mary E., $55^{\circ}$.

Suspension of specie payments. See Specie payments.

Swedish settlements, 48 .

Taft, William H., 599-600.

Talleyrand-Périgord, Prince, 292-293.

Tallmadge's amendment, 372 .

Tammany Society, 386 .

Tampico, $11 ; \operatorname{Map} 11 . \mathrm{Fd}$.

Taney, Roger B., Attorney-General under President Jackson, 399; transferred to Treasury Department, - removal of deposits from the United States Bank, 405; Chief Justice of the Supreme Court, Dred Scott decision, 467 : death, 544.

Tariffs. See Protective Policy, Industrial. Tarleton, Col. Sir Banastre, 227, 231.

Taxation without representation, the question of, its rise, 127, 131-132; English decision to tax colonies, 144; English theory of virtual representation, $164 ; \mathrm{de}$ claration of Continental Congress, 177 .

Taylor, Gen. Zachary, in the Mexican War, $43^{8}-439,440-44 x$; elected President, $450-451$; views of policy on the slavery question, 45I, 453 ; death, 453 . 
Tea, the tax nn, 167, 170, 17-3-174.

Tea Party, the lioston, 173-174.

lecumseb, 337, 34 1, 345.

Telegraph, electric, beginnings, 433 ; Atlantuc cable. 566 .

Temnessee, Scotch-Irish settements, i 6 : government framed under the "Articles of the Watauga Association," I I-1-1;2; admission to the Ĺnion, 200 ; detachment in interest from the east, 30-: Burr's conspiracy, 316-31s: secession declared, 494: secession resisted in East Tennessee, 495: slavery abolished by state acion, $5+5$ (foot-note): restored to the Union, 563 .

Tenure of Uffice Act, $564,566,5 \$ 5$

Terry, Gell. Alfred H.. 544 .

Texas, should have been included in the Louisiana Purchase, 315: orerthrow of Mexican authority, - achievement of independence, $+10-411$ : annexation proposals declined by President Van Buren, 4IS: President Tyler's anmexation treaty rejected by the Senate, $431-432$; the Texas question in the presidential election $(1940), 43-434$ : annexation accomplished, 434 ; cause of war with Mexico, $437-438$ : Mexican claim relinquished, $4+2$; secession declared, $+\$ 6$; emancipation proclained, $52 \mathrm{~S}$; restored to the Union, $564-565$

Thames, battle of the (with map), $3+5$.

Thirteenth Amendment to the Coustitution, 545 .

Thomas, Gen. George H., victory at Mill Spring, 507: in battle of sione River, $53 \mathrm{r}$; at (hickamauga, 535: commanding army of the Cumberland, 536 ; at Nashville, $5+3$.

Ticonderoga. Fort, .14as $\%$. 1) ; built by the French and called fort Carillon, 146 : British repulse at, Its: French evacuation, I+9-150: capture by Ethan Allen, 197-109: given up to Furgovne, 213.

Tilden, Samuel J., in the "Barnburner" wing of the Democratic party, 4 :0: Democratic nominee for President, sit.

Tippecanoe, battle of, 337 : Haf I.1. Hic.

Tobacco culture, beginnings in Virgmia, 31-32: social and economic effecis, $73^{-}$ 74 , ro: affected by the Navigation Acts, So, $111-115$.

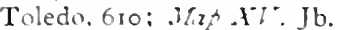

Toleration, religious. See I.iberty, religious.

'Topeka, tho: Mat All' Hc.

Tories, origin of the name, ion (foot-note); in the colonies, iso; during the Revolution, 221-223, 22\%, 230-231; treatment after the war, $234-23=2 ; 6$.

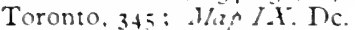

Toscanelli, Paolo del Pozzn, 2.

Town-meetings, New England, ro-zz.

Townshend. Charles, and the ". Townshend tots, "162,16;-168.

Trent affair, 505

Trenton, batile of (with map), 211 .

Trinidad, 6: Maf II. Ie.
Tripoil, war with (with map), 310-311, 3 IS.

Trist, Mr. 4t2.

Trusts, 6iz-6is.

Iun-scipes and tun-moots, early English, $7 \mathrm{I}$.

Turner, Nat, insurrection, $40 \%$.

Tuscaroras, driven from the Carolinas, r 30 ; Wap ITI. Ac.

Tuscumbia, 507: Map XIII. Df.

"lweed King," 571,574 .

Twiller, Wouter Van, 49 .

Tyler, John, elecied Vice-President, 4ro420: becomes President, 42.; rupture with the Whigs, 42\$-430: action on the Texas question, $431-432,434$.

" Encle Tom's Cabin," 456 .

"Lnderground Railway," $\$ 55-456$.

Lnion, colonial, early desires for, 126-127: plans of Franklin and the Board of Trade, $143-144$.

United Colonies of New England, 46.

United States, the frigate, built, 293 ; capiure of the Macedonia, $3+2$.

Lnited States Bank, the first, $276-278$; its dissolution, $336-337$; the second, 367 ; warning of President Jackson's hostility, 395-396; the bank question in the presicential canvass, - recharter retoed by the President, $400-402$ : goverrment deposits removed by President Jackson, 404-405: recharter by Pennsyluania, failure, 405: bill for a third charter vetoed by President Trler, 420.

United States Bureau of Education, 620 .

Cuited States Christian Commission, 560.

linited States Sanitary Commission, 560.

Lpland, 9 s.

Tpshur, Abel P.. +32.

Uiah, acquisition by the United States, 4t2: occupation by the Mormons, $4+2-$ $4+3$ : called the "State of Deseret." $4 \leq 1$ territorial orgarization, 454: Mormon rebellion, $465^{\circ}$; irrigation of arid lands, 612

Utes, 2 I : Map HII. Dc.

Utrecht, Treaty of, $126,192$.

Vaca, Cabeza de, II.

Valley Forge, 21z-210: Mas, p. $211, A$ h.

Van Buren, Martin, Secretary of State under President Jackson, 304, 300: elected Vice-President, 402: elected President, $\mathrm{I}_{4}$; wise and courageous dealing with the business crisis of $\mathbb{S}_{3}$, , with the Texas question, and with the Canadian rebellion, 416-419: defeat in election of 1s+o, +10-420: opposes annexation of Texas and loses Democratic nomination for the presidencr, 432,433 ; nominated for President by the Free Soil party, $4: 0-451$ : return to Democratic party, 458 .

Van Rensselaer. Gen. Solomon, 341 .

Van Rensselaer estate, 25.

Vane, Sir Harry, 45.

Venango, Fort, Ito, r5o: Map $I J$. Ad, and P. I +1 . 


\section{INDEX.}

Venezuela controversy with Great Britain, 593-594.

Vera Cruz, 440; Map, p. 44r

Veragua, 6; IIap II. Gf.

Vergennes, Count de, 234.

Vernont, action in the War of Independence, r97-ros; early history, - admission to the Union, 279.

Verrazano, voyage of, 10.

Vespucius, Americus, voyages to America and name given to the continents, 8 .

Vicksburg, 513, 531, 533; Hap XIII. Bh.

Vincennes, 223; Ma $\rho$, p. 141 .

Virginia, the name, and its first application, 15; grants to Virginia Company and London Company, 2S-3o; grounds of claim to northwestern territory (with map), 29-3o; Jamestown colony, 30-33 (Ma p , p. 31); London Company overthrown, 33: the colony during the English civil war, commonwealth and protectorate, 53 ; its early political development, $62-63,69$; local government, - the parish and the county, $70-72$; social structure and character, 73-74; introduction of slavery and indentured servitude, 75 ; under Charles II. and Governor Berkeley, 8o-81, 89-9o : Bacon's rebellion, $90-92$; population and industries at end of $17^{\text {th }}$ century, IosII3; slavery and indentured servitude, Ir3-II4; education and literature, II5116 ; revolution of 1688,123 ; assertion to the French of northwestern clains, I $_{40-}$ 141 ; declarations against the Townshend acts and non-importation measures, r69ro ; social state at the end of the colonial period, 189; conflicts with Governor Dunmore, 197, 203-204; declaration of rights, 206; state government formed, 207; theatre of the final campaign of the War of Independence, 232-233; cession of land claims to the Confederation, $249^{-}$ 250 ; action leading to the Federal Constitutional Convention, 256-257; nullifying resolutions, 1798, 294-295; effects of the cotton-gin on slavery, 308-309; secession declared, 494; secession resisted in West Virginia, 495; organization of a loval government, and final separation of West Virginia, 50o; emancipation proclaimed, 528; restored to the Union, 564-565.

Virginia Company, its charter and its two branches, 28-29.

Wagner, Fort (with map), 534.

Walker, Robert J., Secretary of the Treasury, 435 ; author of tariff of 1846,444 ; governor of Kansas, 464, 468-460.

Walker, William, filibustering schemes, 460.

Walpole, Sir Robert, his colonial policy, 131-132; loss of power, 137.

Wampanoags, or Pokanokets, 37, 92-93; Map $V$. Bd

Wampum, 5I-52.

War for the Union, 490-55I.

War of $1812-15,339-353$ : new spi:it in the country after the war, $362-366$.
War of Independence, 194-234.

War of the Austrian Succession, 138 .

War of the League of Augsburg, 123.

War of the Spanish Succession, 124.

War with Barbary States, 3ro-3 r 1 , 318, 353 .

War with Mexico, 437-442.

War with Spain, 596-599.

War Democrats, 529-530.

"War Hawks," 33\$-339.

Ward, General Artemas, 196, г99.

Ward, Nathaniel, i 5.

Warren, Dr. Joseph, leadership in Boston, 173, 177; chairman of Massachusetts "Committee of Safety," r79; his writings, $190 ;$ his vigilance, 194 ; his death at Bunker Hill, 202.

Warwick, R. I., 45 ; Map, p. 44 .

Washington, Booker T., 621.

Washington, George, mission to French commander in western Pennsylvania, I40-I4I; opening hostilities with the French, $141^{-142}$; on Braddock's staff, I 45; action in Virginia Assembly against the Townshend acts, 170 ; in the First Continental Congress, 176 ; in Second Con. tinental Congress, - appointment as commander-in-chief of Continental Army, 198-199; in command at Cambridge, 202203, 204-205; defending New York and the Hudson (with map), 206, 20S-209; hostile criticism, - retreat into Pennsylvania, 209-2 ro; recrossing the Delaware, - returning into New Jersey (with map), $210-212$; intrigues to supplant, 215,217 ; at the Brandywine and Germantown, 2 I6; at Valley Forge, 217-2 I9; at Monmouth, 220; guarding the Hudson, 221 ; Yorktown campaign, 232-233 : retirement from the army, 236-238; in the Constitutional Convention of $17 S_{7}, 256-258$; elected President of the United States, 265-266; inauguration, 271 ; reëlection, 281 ; attempted non-partisan administration, $28 \mathbf{I}$; proclamation of neutrality between France and England, $28_{5}$ : acceptance of the Jay Treaty, 2S6-288, 288-290; retirement from the presidency, - farewell address, 290291: appointed commander-in-chief, 293 ; death, 295.

Washington, city of, founded, 275 ; condition in 1 Soo, 306 ; capture by the British (with map), 348-349; peril in April, 1861 (with map), 493; slavery abolished, 5I I ; panic after second battle of Bull Run, 527; threatened by General Early, 541542 ; great review of Union armies, 551 .

Washiugton, Fort, Mixp, p. 200.

Washington, State of, admitted to the Union, $5 \times 8$.

Washington, Treaty of (187 ) , 569-570.

Watauga Association, Articles of the, 172.

Watertown, Mass., 66; M/ap, p. 39.

Waterways, importance in the development of the country, $364-365,600-610$.

Wayne, Gen. Anthony, 224, 281 .

Wealth, increasing inequalities in, 617-618. Weaver, James B., 590 . 
Webster, Iariel, first election to Congress, 343: opposed to protective tariff (isi6), 355 ; also to that of 1824,376 : change of attitude, $3_{4}$; speech in reply to Senator Hayne, 395 ; candidate for presidency $(1 \leqslant 30), 4+4$; Secretary of State in 'lyler's cabinet, 429-430; negntiation of Ashburton Treaty, 431 ; adrocates the Compromise of $1850,-$ seventh of March speech, $453-454$ : Secretary of State in Fillmore's cabinet, 454 ; Hulsemam letter, 457 : death, 459 .

Welles, Gideon, 490.

iVells, Me., 125; Map $I:$ Bc.

West, The. See Mississippi Valley, Ohio Valley: Iakes, The Basin of the Great: Northwest, The: Louisiana Purchase: and West, The Farther.

West. The Farther, its development since the Civil War, 61:-6r3.

West Point, 229; Matp. 200.

West Virginia, Scotch-Irish settlements, 136 : settlements beyond the mountains, 139: fidelity to the Union (1861), 495 ; NicClellan's campaign (with map), - organization of a loyal state government, and final separation from the Old Dominion, $409-500$.

Western forts, retention by the British of, $235,258,259,290$.

Western Reserve. 250.

Wethersfield, Conn. $+2,67 ;$. Map IT. Ad

Weymouth, George, $2 s$.

Wheeling, 364 ; N/as XI. Eb.

Whig party, American formation, $4^{4}$ : election of Harrison and Tyler, $410-420$ : rupture with Tyler, 42\$-430: defeat in is $4,+33^{-434}$ : election of Taylor and Fillmore, $+50-451$; defeat in $1852, .158-$ 459: absorption in the Republican and American parties, $461-463$.

Whig party, English, origin of the name, 100; attitude in England toward American colonies, 127 .

"Whisker Rebellion," zss.

"Whiskey Ring." 571 .

White, Hugh L.. 4 it.

Whitman. Marcus, $+36-437$ (foot-note).

Whitner, Eli, $3 \circ s$.

Whittaker, Alexander. I 16.

Whittier, John G.. 365.

"Wide Awake Clubs," 476

"Wild-cat" banks, $367,412-413$.

Wilderness, battles of the, $540 ;$ Map. TII. Cf.

Wilkinson, Gen. James, 317,346 .

William IJI. (Prince of Orange) and Marv, accession to Finglish throne; 102 : leader in Furopean resistance to Louis XIV., 123 .

William and Mary College, I 15

William Henry, Fort, If(6, 147: Mfap $1 \%$. Dc.

Williams, James, 227 .
Williams, Roger, founder of Providence, R. I.. and apostle of religious liberty, 43-45; writer, 115 .

Williamsburg, battle of, $511 ;$ Nap XII. Eh.

Wiimington, Del., Map, p. 47 .

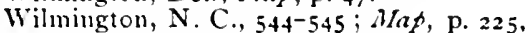
Ef.

"Wilmot Proviso," $4+4-445,+50,452$.

Wilson, James, 257 .

Wilson tariff, 593 .

Wilson's Creek, battle of, 502: Mas, p. $503, \mathrm{Ab}$.

Winchester, Gen., 343.

Wincliester, battle of, 5+2: Mas XII. Bd.

Windsor, Conn.. 42,67; Map $I^{\circ}$. Ad.

Winslow, Edward, 115 .

Winthrop. John, first governor of the colony of Massachusetts Bay, 40; succes. sive elections, 45 (foot-note): death, 52 ; writings, 115 .

Winthrop, John, the younger, agent for the grantees of Connecticut, 42 ; governor of Connecticut, $82-\$_{3}$.

Winthrop. Theodore, 498.

Wirt, William, 402.

Wisconsin, under the ordinance of ${ }_{17} S_{7}$, $264-265$ : admitted to the Union, Appendix $\mathrm{F}$.

Witcheraft, Salem, 129.

Wolfe, Gen. James, 14 S-149.

Wood, Gen. Leonard, 600 .

Wod, William, I 15.

Woodbury, Levi, 399 .

Wright, Silas, 417,450 .

Writs of Assistance, $16 t-162$.

IVyoming. massacre of, 222, 250 ; Map $l^{-} I$. Cd.

Wyoming. State of, acquisition of western part from Mexico, $4 \$ 2$; eastern part included in Nebraska Territory, 461; admitted to the Union, ss8.

X. Y. Z. correspondence, 292-293.

Yale College, 130.

Vazoo River, i : Map II. Fc.

York. James, Duke of, receives grant of New Netherland, etc., S6: sale of New Jersey, 87 : loss and recovery of province. $94-96$; grant of Delaware territory to William Penn, os ; becomes king, ror. See James II.

York (Toronto), Canada, 345: Mas IX. Dc.

Vork, Pa.. 216; Mfos I\%. Ce.

Vorktown, Maf, p. 225, Fa ; surrender of Cornwallis, 232-233; siege in Civil War, $5 \mathrm{II}$.

loung, Brigham, 44.3, 468 .

Zenger trial, 137 .

Zunis, pueblos of the, II, 19. 
Cbe thiluerside pregs

Electrotyped and printed by $H$. O. Houghton \&o Co.

Cambridge, Mass., U.S.A. 



- 


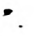


